BIBLIOTECA VIRTUAL DE CIÊNCIAS HUMANAS

\title{
DESTINO DO SINDICALISMO
}

\author{
Leôncio Martins Rodrigues
}




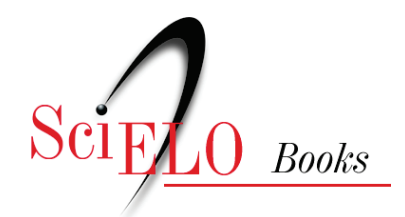

\title{
Destino do sindicalismo
}

\author{
Leôncio Martins Rodrigues
}

RODRIGUES, LM. Destino do sindicalismo [online]. Rio de Janeiro: Centro Edelstein de Pesquisas Sociais, 2009. pp. 344. ISBN: 978-85-7982-000-7. Available from SciELO Books $<$ http://books.scielo.org $>$.

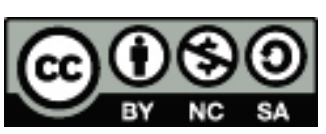

All the contents of this chapter, except where otherwise noted, is licensed under a Creative Commons Attribution-Non Commercial-ShareAlike 3.0 Unported.

Todo o conteúdo deste capítulo, exceto quando houver ressalva, é publicado sob a licença Creative Commons Atribuição Uso Não Comercial - Partilha nos Mesmos Termos 3.0 Não adaptada.

Todo el contenido de este capítulo, excepto donde se indique lo contrario, está bajo licencia de la licencia Creative Commons Reconocimento-NoComercial-CompartirIgual 3.0 Unported. 
Esta publicação é parte da Biblioteca Virtual de Ciências Humanas do Centro Edelstein de Pesquisas Sociais - www.bvce.org

\section{Destino do sindicalismo}

Copyright (c) 2009, Leôncio Martins Rodrigues

Copyright (c) 2009 desta edição on-line: Centro Edelstein de Pesquisas Sociais Ano da última edição: 1999, Edusp - Editora da Universidade de São Paulo

Nenhuma parte desta publicação pode ser reproduzida ou transmitida por qualquer meio de comunicação para uso comercial sem a permissão escrita dos proprietários dos direitos autorais. A publicação ou partes dela podem ser reproduzidas para propósito não comercial na medida em que a origem da publicação, assim como seus autores, seja reconhecida.

ISBN: 978-85-7982-000-7

Centro Edelstein de Pesquisas Sociais

www.centroedelstein.org.br

Rua Visconde de Pirajá, 330/1205

Ipanema - Rio de Janeiro - RJ

CEP: 22410-000. Brasil

Contato: bvce@centroedelstein.org.br 


\section{SUMÁrio}

INTRODUÇÃ̃o

Primeira Parte: O Declínio do Poder Sindical

1 A queda das taxas de sindicalização: a década dos 80 .................. 6

2 As diferenças nacionais: a situação norte-americana.................. 22

3 As diferenças nacionais: a situação europeia .............................. 32

$4 \mathrm{O}$ sindicalismo do setor público ................................................. 74

5 Greves, dessindicalização e poder sindical .............................. 112

\section{Segunda Parte: Os Fatores de Dessindicalização}

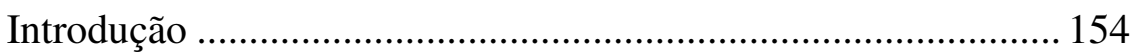

6 Os fatores socioeconômicos..................................................... 162

7 As mudanças nos sistemas de relações de trabalho .................. 194

8 Os efeitos das mudanças políticas............................................ 230

\section{Terceira Parte: Perspectivas do Sindicalismo}

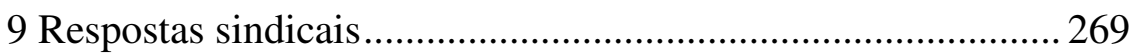

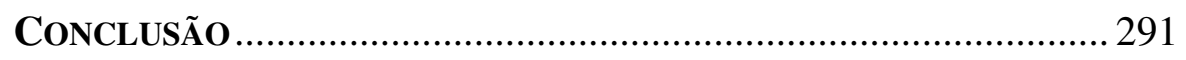

Anexos Metodológicos E Estatísticas ..................................302

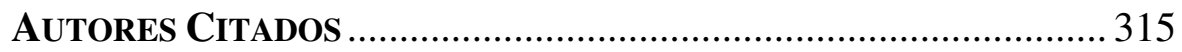




\section{INTRODUÇÃ̃o}

$\mathrm{O}$ sindicatos, em todo o mundo, vivem hoje uma situação muito difícil, expressada na queda do número e da proporção de trabalhadores filiados e no declínio das taxas de greve, dois fenômenos indicativos do enfraquecimento do sindicalismo como instituição e do poder sindical como ator político. O conjunto de mudanças políticas, econômicas, comerciais, tecnológicas e culturais dos últimos decênios, às vezes designadas pelo controvertido termo "globalização" (que não temos a intenção de discutir), atingiu duramente o sindicalismo. Em fins da década dos 80, Jelle Visser (1989), uma das maiores autoridades em todo o mundo nos estudos comparativos sobre taxas de sindicalização e em análises comparadas de sistemas de relações de trabalho, escrevia: "Nunca, durante esses últimos quatro decênios, o futuro do sindicalismo nos países ocidentais foi tão incerto" (p. 17). Em fins da década dos 80, em alguns países da Europa do Norte os sindicatos ainda conseguiam manter as mesmas taxas de filiação dos anos 70 e mesmo aumentar ligeiramente o número de filiados, como na Suécia, na Dinamarca, na Finlândia e na Alemanha. Mas, desde então, à medida que o século XX chegava ao seu término, foi se tornando cada vez mais claro que as dificuldades enfrentadas pelo sindicalismo não eram conjunturais e nem específicas de alguns países, e fatores estruturais mais duradouros e profundos minavam a força de uma das instituições mais características e importantes das democracias capitalistas do Ocidente.

Este trabalho visa oferecer ao público brasileiro uma descrição da situação atual do sindicalismo nos países em que os sindicatos haviam sido um ator político e econômico importante. Retomo um tema já tratado por mim de modo sumário em outros escritos (Rodrigues, 1992a, 1992b e 1992c). O presente livro não tem intenção de originalidade e se baseia, em larga medida, em fontes secundárias. Nesse aspecto, difere bastante de outras de minhas publicações, que tinham como objeto o sindicalismo e as classes trabalhadoras no Brasil e resultaram de pesquisas empíricas com a pretensão de trazer informações e dados novos. O tema central é a evolução das taxas de sindicalização nos países desenvolvidos, entendidas como o total de sindicalizados sobre o total de trabalhadores potencialmente sindicalizáveis. Trata-se de uma definição que, teoricamente simples, apresenta, na prática, muitos problemas de cálculo. Quero advertir que os números referentes às taxas de sindicalização, que Os americanos e britânicos referem-se algumas vezes como a "densidade sindical" (union density), devem ser vistos como aproximações indicativas de tendências e não como valores exatos. Há muitos problemas referentes à coleta de dados e à padronização das metodologias nacionais, aspecto que afeta principalmente as análises comparativas entre países.

Outros pontos relacionados com a história de cada movimento sindical nacional e de seus sistemas de relações de trabalho, que os autores anglo-saxões chamam de "relações industriais" (termo cada vez mais impróprio em virtude das mutações do mercado de trabalho), são focalizados de modo lateral, apesar de seus evidentes vínculos com as formas de ação e funções do sindicalismo ${ }^{1}$.

Ocorre que o objetivo principal - o fenômeno da redução dos índices de trabalhadores sindicalizados ou da "dessindicalização" e de suas causas já era por si só uma tarefa demasiadamente grande e até mesmo pretensiosa.

\footnotetext{
${ }^{1}$ Como nota Paul Edwards (1995), o termo "relações industriais" implica um viés em direção à indústria, fora do setor de serviços, privados Ou governamentais. O termo "relações de emprego" ou "relações de trabalho" seria mais apropriado para os dias de hoje. Apesar disso, uma vez que o termo "relações industriais" encontra-se bem implantado, Edwards não vê razões para abandoná-lo, desde "que seja corretamente entendido", isto é, como as relações entre empregados e empregadores juntamente com a influência das maiores instituições envolvidas: empresários, sindicatos e Estado (p. 4). O termo, na Grã-Bretanha e nos EUA, traz a marca das características do desenvolvimento econômico liberal, do peso da indústria na criação de novos padrões de relações entre empregados e empregadores, marcado mais fortemente por negociações diretas entre empresas e sindicatos, pelo envolvimento comparativamente baixo do Estado e da classe política no condito, enfim, pela ausência de uma legislação trabalhista, tal como existente nos países latinos. Por isso talvez, o termo "relações profissionais", comum na França, não é usado habitualmente nos países anglo-saxões. Mas, por outro lado, o termo "relações industriais" parece hoje ainda mais inadequado porque o sindicalismo e mesmo a barganha e a negociação estendeu-se não apenas ao setor de serviços mas também ao setor público. Stricto senso, nesses novos setores públicos e de serviços, não se têm relações industriais. No Brasil, o termo "relações industriais" não é usado, a não ser, algumas vezes, Couto resultado da influência anglosaxônica. Preterimos o termo "relações de trabalho", suficientemente ,amplo para apreender as relações, normais e informais, entre empregadores, empregados e sindicatos, quer as normas estejam formalizadas por uma ampla legislação de extensão nacional e, consequentemente, requeiram tribunais trabalhistas para dirimir conflitos, quer a regulamentação se dê por contratos coletivos estabelecidos mediante negociações diretas entre sindicatos de trabalhadores e empresas ou sindicatos patronais.
} 
Apesar disso, na medida do necessário para a compreensão de certos pontos, procurei também oferecer aos leitores brasileiros uma rápida visão dos vários modelos sindicais e dos sistemas de relações de trabalho de alguns dos países desenvolvidos cujas características são, às vezes, incompreensíveis para nós que nascemos e vivemos há mais de meio século num modelo corporativo estatal de relações de trabalho. Por isso, as notas colocadas ao final de cada capítulo são às vezes extensas - mais do que aquelas que normalmente se encontram em trabalhos acadêmicos. Apesar disso, entendo que se fazem necessárias porque, amiúde, trazem informações sobre aspectos que, em geral, não são conhecidos fora dos círculos mais restritos dos estudiosos do sindicalismo e dos sistemas de relações de trabalho.

Houve de minha parte um esforço para dar conta de uma vasta literatura internacional. Apesar de todo o empenho, porém, é altamente provável que trabalhos e autores importantes tenham sido deixados de lado. Em certos casos, por desconhecimento; em outros, por dificuldade de acesso à bibliografia; em outros ainda, pela impossibilidade de dar conta do imenso volume de escritos existentes na área. Tenho a impressão, contudo, de que a falta de referência a alguns estudos não invalida este texto. Acredito que, apesar das lacunas, ele será útil aos interessados nos assuntos do sindicalismo, a começar pelos próprios sindicalistas, e poderá talvez sugerir e estimular pesquisas de certas áreas relacionadas com $\mathrm{o}$ sindicalismo brasileiro ainda não suficientemente conhecidas.

No empenho pela obtenção de dados, exposição de hipóteses e teorias, não discriminei autores em virtude de posições políticas, ideológicas ou metodológicas, ou por seu status na hierarquia dos pesquisadores. Informações sobre as taxas de sindicalização em vários países foram procuradas em variadas fontes mas nem sempre foram tão atualizadas como eu desejaria. Especialmente difícil foi conseguir estatísticas sobre a sindicalização do setor público relativas aos últimos anos da década dos 90 . É provável que existam dados mais recentes do que os que encontrei. Mas, como este livro já estava correndo o risco de envelhecer antes de terminar (sua redação iniciou-se em dezembro de 1995), resolvi dar por terminada a tarefa de coleta de material, consolandome com a ideia de que alguma coisa é melhor do que nada, de que em algum momento a tarefa teria de terminar e de que, finalmente, em virtude da rapidez das mudanças da época contemporânea, livros como este sempre estariam atrasados diante delas e, quando postos à disposição dos leitores, já estariam ligeiramente defasados.

Mas, com relação aos problemas dos dados e estatísticas, quero observar que, independentemente de minhas falhas e das dificuldades que encontra um pesquisador situado fora dos países centrais, há um obstáculo geral para todos os estudiosos da evolução das taxas de sindicalização: o da inexistência de estatísticas com informações recentes sobre a situação sindical de muitos países, especialmente dos países da Europa latina. Mesmo em publicações bastante atuais da Organização Internacional do Trabalho (OIT), as séries referentes à sindicalização apresentam muitas lacunas ou estão defasadas, porque a OIT reproduz dados nacionais que não são coletados regularmente nos respectivos países. Trata-se de um obstáculo que mesmo os pesquisadores situados nos países desenvolvidos encontram, como se observa na leitura de seus últimos trabalhos. De todo jeito, utilizamos bastante a publicação da OIT, El Trabajo en el Mundo, 1997-1998, que, ao lado de uma avaliação geral das mudanças ocorridas nos sistemas de relações de trabalho, apresenta dados sistematizados sobre as taxas de sindicalização e sobre o volume de trabalhadores sindicalizados no inundo nos anos de 1985 e 1995.

No empenho de obtenção de informações mais atuais e detalhadas, fui ajudado desinteressadamente por várias pessoas, as quais quero nomear e agradecer: Maria Helena Gomes dos Santos, Secretária de Relações Internacionais do Ministério do Trabalho e Turismo; Franco Patrignani, Secretário Geral da Confederazione Italiana Sindacati Lavoratori (CISL) da região de Masserata, Itália; Achim Wachendorfer, diretor do Instituto Latino-Americano de Desenvolvimento Econômico e Social (ILDES) da Fundação Friedrich Ebert; e Maria Silvia Portella de Castro, assessora sindical da CUT nacional.

Durante a redação desse trabalho, beneficiei-me das discussões com alguns colegas e amigos e da leitura rigorosa e atenta do texto original, da correção de várias de suas falhas, de críticas francas e sugestões construtivas. A eles quero externar meus agradecimentos: Iram Jácome Rodrigues, professor da Faculdade de Economia e Administração da USP; Carlos Alberto Novaes, cientista político; Erickson Crivelli, advogado e assessor trabalhista da CUT; Glauco Arbix, professor da Faculdade de Filosofia, Letras e Ciências Humanas da USP. Nenhum deles, porém, tem qualquer 
responsabilidade pelas deficiências cio texto que foi à publicação nem pelas posições e ideias expostas, das quais, algumas vezes, discordaram.

Pela tradução de textos do idioma alemão, quero agradecer a Bruno Speck, colega do Departamento de Ciência Política da Unicamp. Nas tarefas de levantamento de dados, de localização de revistas e artigos, de transcrição de tabelas e especialmente de assessoria na parte de informática, muito devo a Gilvanilson Aparecido da Gama, presente durante todo o transcorrer do trabalho.

Last but not least, quero agradecer a Fapesp pelo financiamento dos custos de realização da pesquisa e publicação desse volume e o CNPq pela concessão de uma bolsa de produtividade em pesquisa.

\section{Primeira PARTe: O DECLÍNIO do PODER SindicAL}

\section{Capítulo 1 \\ A queda das taxas de sindicalização: a década dos 80}

Se a década de 1970, na maioria dos países desenvolvidos, pode ser $\checkmark$ considerada a dos sonhos dos sindicalistas, a de 1980 pode ser vista como a dos pesadelos. Nos anos 70, em praticamente todos os países da Europa Ocidental e da América do Norte, o movimento sindical expandiu-se em termos do número de trabalhadores sindicalizados, da sua capacidade de mobilização, pressão e participação nos vários níveis da economia e do sistema político. Os avanços efetuados pelo poder sindical nos vários países não foram equivalentes. Substanciais diferenças persistiram entre os movimentos nacionais. Mas, no conjunto, havia para o sindicalismo dos vários países, inclusive para aqueles em que se encontrava menos desenvolvido, uma perspectiva de crescimento, que dava a esperança aos "retardatários" (como os da Europa latina) de alcançar os mais "adiantados" (geralmente os da Europa do Norte), para ficarmos com duas situações polares.

Do ângulo das comparações nacionais, a hipótese de um desenvolvimento convergente das taxas de sindicalização não parecia descabida, como nota Ebbinghaus (1995). Mesmo com fortes diferenças nacionais, aumentavam os índices de filiação sindical em todas as democracias capitalistas. Mas o caminho em direção à convergência ficou confinado à época do "Velho capitalismo" (Visser, 1993b, p. 207)1. A França, na Europa, e os EUA, na América do Norte, foram dois países em que o fenômeno da crise ou decadência do sindicalismo se manifestou mais cedo e de modo mais visível. Contudo, no conjunto dos países, ainda havia lugar para a crença de que o caso americano e o francês seriam exceções e as quedas nos níveis de sindicalização dever-se-iam a fatores nacionais

${ }^{1}$ Visser localiza o ano de 1973 como ponto de referência a partir do qual, de modo geral, a
tendência à convergência foi revertida. Mas, antes dessa data, já havia sinais de queda da tendência à convergência foi revertida. Mas,
sindicalização em países como EUA e França. 
específicos dos sistemas de relações de trabalho, das características da organização sindical desses dois países e de outras variáveis que geralmente afetam o poder sindical. Finalmente, na década dos 80, na maioria dos países da Europa Ocidental e da América do Norte, começou-se a perceber que a dessindicalização era um movimento mais amplo e profundo e o futuro da instituição sindical enquanto tal parecia comprometido.

Entretanto, cabia ainda uma dúvida: tratar-se-ia de uma perturbação passageira, de uma mutação ou de um processo de decadência irreversível do sindicalismo, isto é, tratar-se-ia de crise ou de declínio? Conforme optemos por um ou por outro conceito, seremos levados a percepções diferentes dos problemas enfrentados pelo sindicalismo neste final de século. Crise e declínio, ainda que às vezes possam ser usados como sinônimos, não significam a mesma coisa. Crise é uma alteração súbita nos rumos de um processo, uma ruptura de uma situação de equilíbrio ou de um desenvolvimento que até então seguia rumos normais, quer dizer, previsíveis. No uso comum, o termo é utilizado com o significado de uma mudança negativa, indicando uma conjuntura perigosa, uma fase difícil de um sistema econômico, de um regime político, de uma instituição, de uma relação social.

Declínio é entrar em decadência, decair, perder vitalidade de modo inexorável, ainda que o ritmo possa ser mais lento ou mais rápido. É um processo mais do que um estado. Referido a uma dada instituição, declínio indica um enfraquecimento que não necessita acontecer súbita e rapidamente. No caso do sindicalismo, "crise" não é necessariamente sinônimo de agonia. O sindicalismo poderia estar passando por uma fase difícil mas passível de superação após algumas reformas. Já o termo "declínio" remete-nos a um processo de debilitamento do organismo (que pode ser mais rápido ou mais lento), mas que não deve forçosamente provocar alterações bruscas nas formas de organização, nas estratégias, nos valores da instituição sindical.

Teoricamente, a organização sindical pode ir declinando, extinguindose aos poucos, perdendo poder e espaço, como um organismo envelhecido que definha. Trata-se de algo diverso do que poderia acontecer com um organismo jovem que, subitamente, é afetado por alguma moléstia que pode levá-lo à morte mas também pode ser vencida. Das crises diz-se às vezes que podem trazer efeitos benéficos. Do declínio, nunca. Um organismo declinante não tem cura, ainda que não esteja em crise, tal como o processo de envelhecimento. $\mathrm{O}$ declínio pode ser apenas o desenvolvimento normal do organismo ou de uma entidade, de duração variável, mas pode, é verdade, acelerar-se e apressar uma crise terminal. Declínio pode gerar crises, quer dizer, alterações dramáticas, às vezes inesperadas, num padrão de desenvolvimento; crise pode levar a declínio que, continuado, implica o fim.

$\mathrm{O}$ quadro que parece caracterizar o sindicalismo neste final de século sugere mais declínio do que crise. De modo mais preciso: o que parecia na década dos 70 ser uma crise, que atingia o sindicalismo de alguns países e não o de outros, foi adquirindo, na década dos 80, o caráter de um declínio, à medida que o tempo corria e o sindicalismo, num número crescente de países, não encontrava respostas satisfatórias para pôr fim à persistente redução de seus filiados e dos espaços que havia conquistado após a Segunda Grande Guerra. No caso da instituição sindical, porém, o declínio deve-se mais a razões externas do que internas, isto é, mais a mudanças no ambiente no qual o sindicalismo vive do que a processos derivados do envelhecimento do sindicalismo como organização (esclerose burocrática, acomodação à ordem industrial, por exemplo), que resultariam de seu próprio crescimento num ambiente externo relativamente estável. $\mathrm{Na}$ realidade, na maioria dos casos, até que o hábitat que havia favorecido a expansão do poder sindical começasse a mudar, o sindicalismo (centrais, federações especialmente), ainda que institucionalizado e burocratizado, não mostrava sinais de senilidade. Estava bastante bem adaptado ao modelo fordista da produção mecanizada e de massas e à sua clientela preferida, que era o trabalhador manual da grande indústria e dos serviços coletivos. $\mathrm{O}$ declínio, como uma doença que atacou o organismo sindical, veio de fora, das mudanças ambientais e da criação de um novo hábitat ao qual o sindicalismo vem encontrando dificuldade para adaptar-se. É possível, como acentuam alguns autores, que o gigantismo de algumas organizações sindicais institucionalizadas e acomodadas ao ambiente anterior à economia globalizada tenha dificuldade de ajustar-se ao novo meio, se essa adaptação for possível. Mas não é aqui que parece estar a causa principal do declínio do sindicalismo no final do século XX, declínio que torna problemática sua sobrevivência no século XXI, pelo menos com a importância que chegou a ter em algumas democracias capitalistas. 


\section{A DESSINDICALIZAÇ̃̃O}

Apesar dos problemas metodológicos e conceituais, e das diferenças com relação à avaliação da profundidade do fenômeno da dessindicalização e ao futuro da instituição sindical, é consensual entre a grande maioria dos pesquisadores a tese da queda geral dos níveis de sindicalização nos países desenvolvidos durante a década dos 80. Excluindo desempregados, autônomos e aposentados, Jelle Visser (1991) nota que, durante a década dos 70; para a maioria dos países para os quais havia dados e não contando Grécia, Espanha e Portugal onde os trabalhadores tiveram bem mais tardiamente liberdade de organização, os sindicatos chegaram a ganhar 14 milhões de novos membros (p. 100). Porém, na década seguinte, perderam aproximadamente cinco milhões. Trata-se de uma cifra global mas que, numa primeira aproximação, serve para dar uma visão sintética das perdas sindicais nos anos 80 , perdas que se prolongaram pelos anos 90 .

Tomando como pontos de referência os anos de 1970 e 1988, a sindicalização caiu de $35 \%$ para $28 \%$ no conjunto dos países. De 1970 a 1975 , a proporção de trabalhadores sindicalizados ainda aumentou $2 \%$. A partir de então, começou a cair. No período considerado, tomando-se os países europeus (médias ponderadas) em conjunto, em 1988 o nível de sindicalização (38\%) era o mesmo existente em 1970. Em 1980, a sindicalização atingiu seu pico (44\%), passando a cair a partir desse ano. A evolução no interior desse período indica queda para todos os países tomados em conjunto. Note-se que as taxas de sindicalização tendem a ser mais elevadas na Europa do que em outros continentes. Entre 1975 e 1980, ainda houve ligeiro aumento da sindicalização entre os países europeus (43\% e 44\%, respectivamente). Porém, entre 1985 e 1988 em nenhum dos blocos a sindicalização cresceu (Quadro 1.1).

Tomando como pontos de referência os anos de 1970 e 1988, a sindicalização caiu de $35 \%$ para $28 \%$ no conjunto dos países. De 1970 a 1975, a proporção de trabalhadores sindicalizados ainda aumentou $2 \%$. A partir de então, começou a cair. No período considerado, tomando-se os países europeus (médias ponderadas) em conjunto, em 1988 o nível de sindicalização (38\%) era o mesmo existente em 1970. Em 1980, a sindicalização atingiu seu pico (44\%), passando a cair a partir desse ano. A evolução no interior desse período indica queda para todos os países tornados em conjunto. Note-se que as taxas de sindicalização tendem a ser mais elevadas na Europa do que em outros continentes. Entre 1975 e 1980, ainda houve ligeiro aumento da sindicalização entre os países europeus (43\% e 44\%, respectivamente). Porém, entre 1985 e 1988 em nenhum dos blocos a sindicalização cresceu (Quadro 1.1).

Quadro 1.1

Tendências gerais da sindicalização

\begin{tabular}{|lccccc|}
\hline \multicolumn{5}{|c|}{ Taxas de sindicalização ponderadas $^{\mathrm{a}}$} \\
\hline Grupo de países $^{\mathrm{a}}$ & 1970 & 1975 & 1980 & 1985 & 1988 \\
Todos os países $^{\mathrm{b}}$ & 35 & 37 & 35 & 30 & 28 \\
Europa $^{\mathrm{c}}$ & 38 & 43 & 44 & 40 & 38 \\
América do Norte $^{\mathrm{d}}$ & 30 & 30 & 26 & 19 & 18 \\
Outros países fora da OECD $^{\mathrm{e}}$ & 37 & 38 & 35 & 33 & 30 \\
Todos os países $^{\mathrm{b}}$ (médias não ponderadas) & 44 & 47 & 48 & 45 & 43 \\
\hline a
\end{tabular}

a As médias incluem estimativas para países para Os quais, com relação a alguns anos, não se têm informações.

${ }^{\mathrm{b}}$.Países indicados nas notas c e e.

'.Áustria, Bélgica, Dinamarca, Finlândia, Alemanha, Irlanda, Itália, Holanda, Noruega, Suécia, Suíça e Reino Unido

d.Canadá e EUA.

e.Austrália, Japão e Nova Zelândia.

Fonte: Visser (1991).

Obs.: O quadro apresentado por J. Visser é mais extenso. Dele tomamos apenas as informações que nos estavam interessando. Foram excluídos dados sobre pequenos e grandes países, sobre tipos de sistemas de relações de trabalho (de tipo "cooperativo" e "adversário") e outros que não julgamos necessários para a presente discussão.

Essas observações são muito gerais. Do Quadro 1.2 (abaixo) pode se perceber que a evolução das taxas de sindicalização teve comportamento muito variado. Em alguns países, a dessindicalização começou bem cedo: na França e no Japão em 1975 (embora até 1990 as perdas nesse último país tenham sido pequenas); na Holanda e no Reino Unido, em 1979; na Suíça, em 1978. Nos EUA, o pico do volume de trabalhadores sindicalizados foi alcançado em 1978, embora em termos proporcionais a porcentagem mais elevada tenha sido em 1953, quando $25,9 \%$ do total da força de trabalho estavam filiados a sindicatos (32,5\%, se excluirmos a agricultura) (Troy, 1986, p. 81). Nesses países, o recuo do sindicalismo não apenas começou mais cedo, mas também foi mais profundo. Mas, em outros, durante a década dos 80 , em termos absolutos, os sindicatos praticamente não tiveram perdas (Canadá, Austrália, Dinamarca, Alemanha, Itália e Suécia). 
Quadro 1.2

Número absoluto de membros de sindicatos (1955-1990) (em milhares)

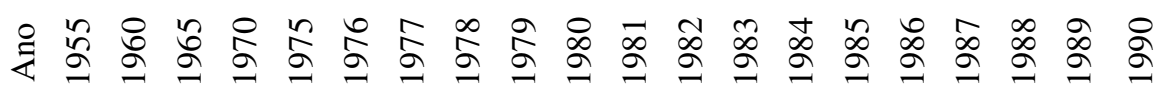

苛

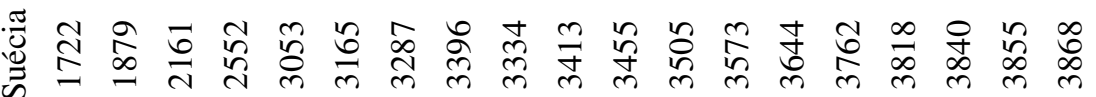

䒿

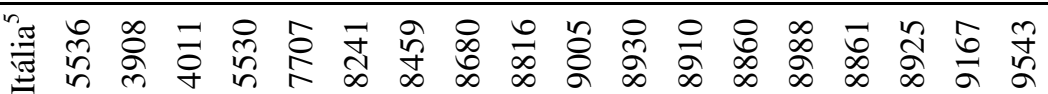

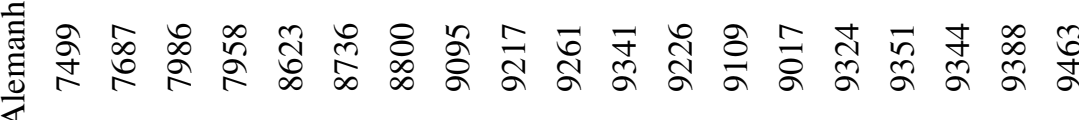

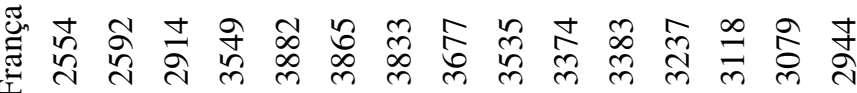
$\stackrel{?}{2}$ চ

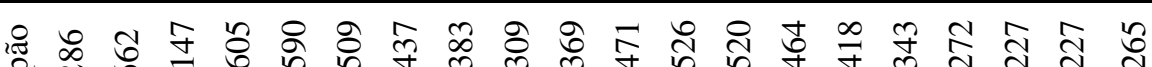
票

\begin{tabular}{|c|c|c|c|c|c|}
\hline 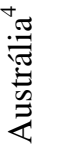 & $\frac{m}{n}$ & $\begin{array}{l}\infty \\
\stackrel{0}{ } \\
\end{array}$ & 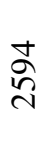 & $\begin{array}{l}0 \\
\tilde{n} \\
\end{array}$ & 8 \\
\hline
\end{tabular}

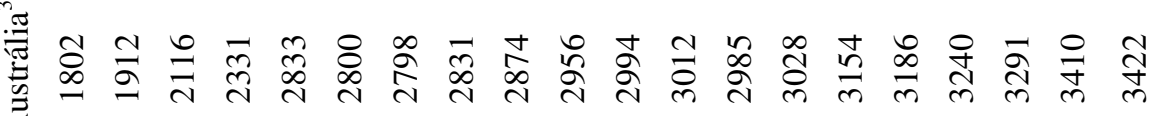

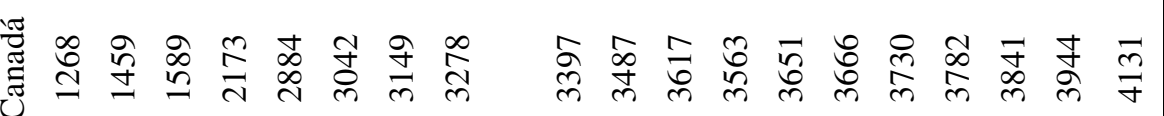

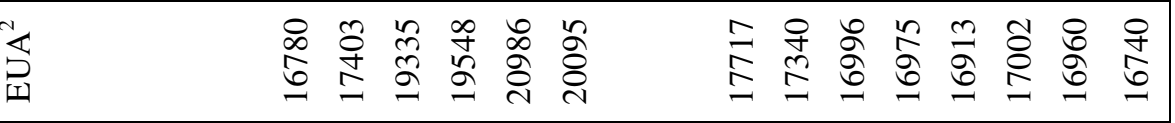
『

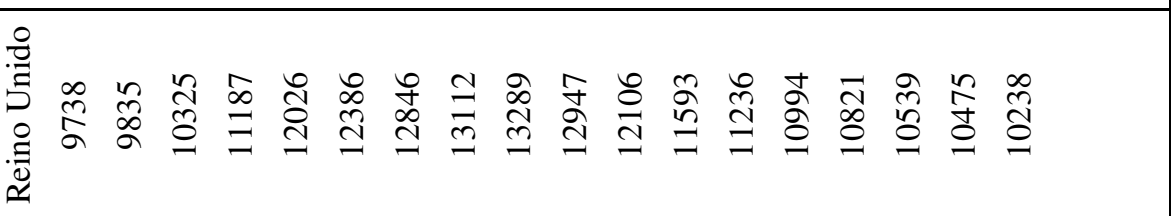

Notas do Quadro 1.2:

${ }^{1}$.Dados das amostragens bienais dos sindicatos e associações de empregados dos EUA. Para 1955, 1960 e 1965, os dados excluem membros das associações de empregados. Em 1970, excluindo as associações de empregados, a taxa de sindicalização como porcentagem dos trabalhadores que recebem salários e ordenados civis era de $27 \%$.

${ }^{2}$.Dados do Current Population Survey. Para 1975 e 1976, os dados excluem membros das associações de empregados. Para 1975-1980, os dados são de maio. Para todos os demais anos, os dados são médias anuais.

${ }^{3}$.Dados apresentados pelos sindicatos e confederações. Para 19551984, os dados são de 31 de dezembro. A representação (coverage) em alguns sindicatos refere-se aos que estavam com suas cotizações em dia enquanto em outros sindicatos representavam vários outros membros desempregados, aposentados, membros honorários e outros filiados em atraso com suas cotizações. Começando em 1985, os dados são 30 de junho e incluem todas as pessoas consideradas como associadas a sindicatos.

${ }^{4}$.Dados de amostragem domiciliar, incluindo apenas sindicalizados empregados e excluindo pessoas com 70 anos ou mais. Para 1976, os dados são de fevereiro; para 1982, os dados são de março-maio, e para 1986, 1988 e 1990, os dados são de agosto.

${ }^{5}$.Dados excluem sindicatos independentes, os quais representam uma estimativa de quatro milhões de membros (incluindo aposentados e autônomos e desempregados) em fins da década de 1980.

Fonte: Bureau of Labor Statistics, completado com diversas fontes nacionais. Para a França, os dados são de Jelle Visser, European Trade Unions in Figure (Boston, Kluwer Law and Taxation Publishers, 1989), pp. 5378. Os traços indicam dados não disponíveis.

Fonte: Chang \& Sorrentino (1991). 
Quadro 1.3

Proporção de sindicalizados em doze países (1955-1990) ( dados não ajustados) Empregados civis com ordenados e trabalhadores assalariados

\begin{tabular}{|c|c|c|c|c|c|c|c|c|c|c|c|c|c|c|c|c|c|c|c|c|}
\hline \& & $\stackrel{n}{2}$ & 융 & & $\stackrel{\circ}{2}$ & & $\frac{0}{2}$ & 슴 & $\stackrel{\infty}{\stackrel{2}{-}}$ & กิ & & 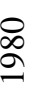 & $\stackrel{\infty}{\circ}$ & $\stackrel{\infty}{\infty}$ & $\stackrel{\infty}{\infty}$ & $\stackrel{+}{\stackrel{\infty}{\circ}}$ & $\begin{array}{l}\mathscr{\infty} \\
\stackrel{\infty}{=}\end{array}$ & 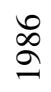 & $\stackrel{\infty}{\infty}$ & $\begin{array}{l}\infty \\
\infty \\
\infty\end{array}$ & $\stackrel{\infty}{2}$ \\
\hline 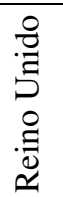 & ○ & $\stackrel{\curvearrowleft}{\forall}$ & $\stackrel{\wp}{\forall}$ & 으 & $n$ & $n$ & in & $\stackrel{\infty}{n}$ & is & & 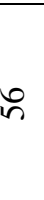 & $n$ & $\dot{n}$ & $n$ & กิ & $\bar{n}$ & $g$ & $\stackrel{q}{q}$ & 웅 & \\
\hline$\stackrel{\widetilde{v}}{\mathscr{\Xi}}$ & N & $m$ & $\stackrel{\sim}{n}$ & $\bar{m}$ & $n$ & $\hat{n}$ & e & r & लै & & $\dddot{m}$ & 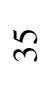 & $\ddot{n}$ & $n$ & $\ddot{n}$ & กี & ñ & กี & $\vec{m}$ & $\vec{m} \bar{m}$ \\
\hline 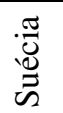 & สิ & ช్ & $\infty$ & $\stackrel{n}{r}$ & $\ddot{\infty}$ & $\mathscr{\infty}$ & $\infty$ & ஓ & $\hat{\alpha}$ & & $\infty$ & ஓे & $\bar{a}$ & สু & ๙ૂ & $\curvearrowleft$ & ๙ & ล́ & ஜ & $\curvearrowleft$ \\
\hline 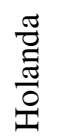 & 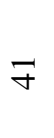 & $\stackrel{\mathcal{Y}}{f}$ & \& & $\stackrel{\infty}{m}$ & $\stackrel{\mathcal{Y}}{f}$ & $\stackrel{\mathcal{Y}}{\gamma}$ & $\mathscr{f}$ & $\mathscr{\vartheta}$ & $\vartheta$ & a & $\exists$ & ભે & ले & $\infty$ & m & mे & $\vec{m}$ & $m$ & $m$ & $m \stackrel{\alpha}{m}$ \\
\hline 潈 & in & mे & $m$ & $\stackrel{\vartheta}{\forall}$ & $i$ & 8 & ชิ & ชิ & 8 & a & ชู & ชె & ชู & ชู & $\widehat{6}$ & $\overline{6}$ & $\overline{6}$ & $\tilde{6}$ & 6 & \\
\hline 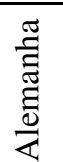 & 寸 & O & $\stackrel{\infty}{m}$ & $\hat{n}$ & ले & \& & 암 & $\overline{7}$ & 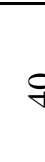 & t & \& & ㅇ & 우 & ㅇ & 우 & ㅇ & 우 & ㅇ & ले & ले \\
\hline 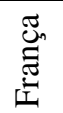 & $\vec{\sim}$ & ๙ิ & 오 & ป & $\overparen{\sim}$ & $N$ & ป & $\bar{\sim}$ & 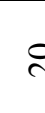 & & $\underline{2}$ & 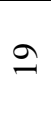 & $\infty$ & $\infty$ & 궁 & I & & & & $=$ \\
\hline 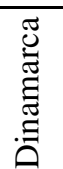 & in & $\widehat{6}$ & $\tilde{6}$ & ț & $N$ & $n$ & 2 & $\approx$ & $\vec{\alpha}$ & & $\infty$ & $\bar{a}$ & ন & ฉ̊ & ñ & สু & $\infty$ & $\bar{a}$ & $\infty$ & \& $\alpha$ \\
\hline 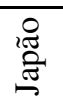 & in & $m$ & లి & $n$ & $n$ & $\dot{m}$ & $m$ & $m$ & त) & $\frac{N}{r}$ & $\bar{m}$ & $\bar{m}$ & $\bar{m}$ & in & ন & ฉે & $\stackrel{\infty}{\sim}$ & $\stackrel{\infty}{\sim}$ & $\hat{\sim}$ & $\stackrel{\circ}{N}$ \\
\hline
\end{tabular}

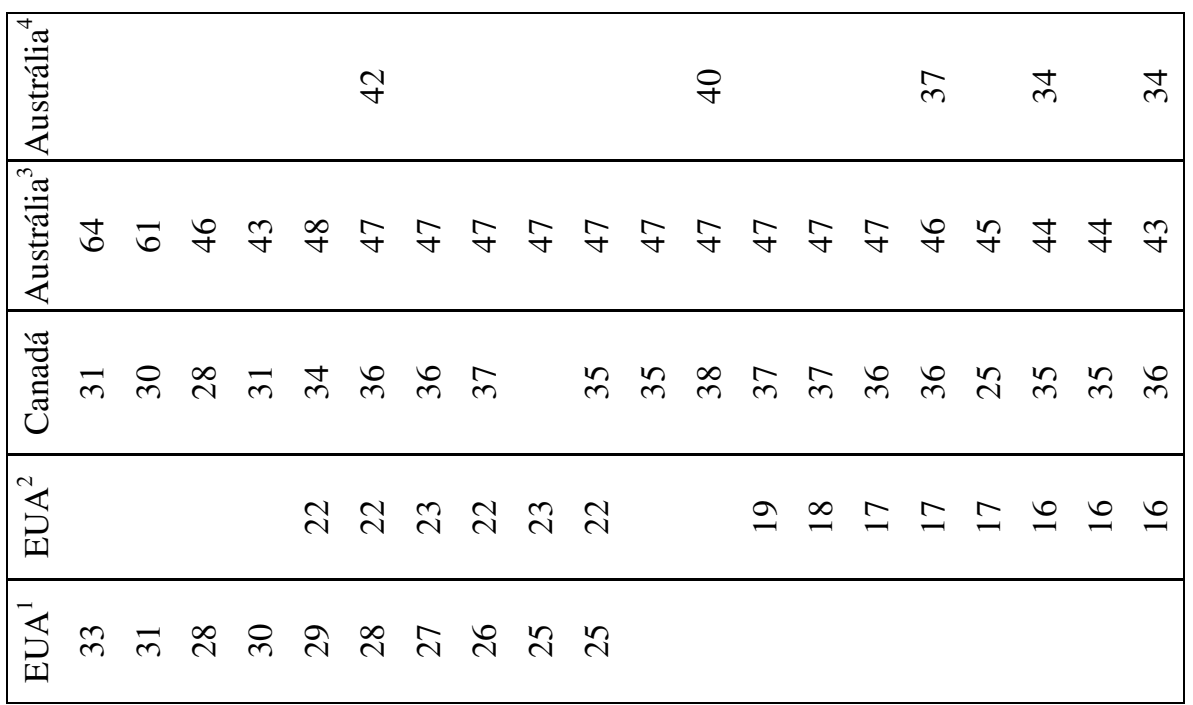

Notas do Quadro 1.3, na página ao lado:

${ }^{1}$ Dados dos surveys bienais dos sindicatos e associações de empregados dos EUA. Para 1955, 1960 e 1965, os dados excluem as associações de empregados. Em 1970, excluindo as associações de empregados, era de $27 \%$ a taxa de sindicalização dos assalariados civis e dos empregados com ordenado.

2 Dados do Current Population Survey. Para 1975 e 1976, os dados excluem membros das associações de empregados. Para 19751980, os dados são de maio. Para todos os outros anos, os dados são para as médias anuais.

${ }^{3}$ Dados de relatórios dos sindicatos e confederações. Para 1955-1984, os dados são para 31 de dezembro. Em alguns sindicatos, a representação (coverage) refere-se apenas aos trabalhadores com empregos e em dia com as mensalidades, enquanto, em outros sindicatos, abrangem vários outros tipos de membros, conto desempregados, aposentados, sócios honorários, assim como libados em atraso com as cotizações. Começando em 1985, os dados são de 30 de junho e incluem todas as pessoas consideradas como filiadas a sindicatos.

${ }^{4}$.Dados obtidos das pesquisas de amostragem domiciliar. Incluem apenas sindicalizados empregados e excluem pessoas com 70 anos ou mais. Para 1976, são para fevereiro; para 1982, os dados são para março-maio; e para 1986, 1988, e 1990, são de agosto.

${ }^{5}$ Dados excluem sindicatos independentes, os quais representam tona estimativa de quatro milhões de membros (inclusive aposentados e autônomos e desempregados inscritos em sindicatos) em fins de 1980.

Fonte: Bureau of Labor Statistics, com dados de várias fontes nacionais de estatística. Para a França, os dados são da Law and Taxation Publishers, 1989, pp. 53-78.Traços indicam dados não disponíveis.

Fonte: Chang \& Sorrentino (1991)

Outros dados mostram que também a Finlândia, a Bélgica, a Islândia, a Áustria não tiveram perdas absolutas de efetivos sindicais. Na maioria dos 
países, inclusive durante a década dos 80 , o número absoluto de trabalhadores sindicalizados aumentou ou sofreu queda muito pequena. Porém o aumento do número absoluto de trabalhadores sindicalizados pode esconder fortes perdas do sindicalismo em termos relativos, caso a força de trabalho tenha aumentado mais fortemente. Por isso, embora o número de trabalhadores sindicalizados tenha crescido em alguns países, as taxas de sindicalização declinaram ou estagnaram na maioria deles. Mas essa afirmação necessita ser matizada. Nos países nórdicos, na realidade, durante a "década maldita" os sindicatos conseguiram crescer. Aí, já atingiram um teto de sindicalização acima do qual chegar-se-ia perto de $100 \%$, o que significa dizer que, na melhor das hipóteses, o sindicalismo desses países só poderia registrar aumentos muito pequenos. Mas, além deles, países importantes, como o Canadá e a Alemanha, também mantiveram suas taxas de sindicalização ou as aumentaram um pouco durante os anos 80 .

Quando os cálculos se fazem a partir da proporção relativa de sindicalizados, aumenta o número de países em que houve decréscimo da proporção de sindicalizados e as perdas tendem a ser mais profundas. Acontece que o número de trabalhadores sindicalizados diminuiu em termos absolutos em alguns países e, em outros, aumentou mais lentamente do que o crescimento da força de trabalho. Consequentemente, a situação dos sindicatos, em maior número de países, é mais negativa do que parece quando se considera apenas a evolução do número absoluto de associados.

Mas os dados relacionados com o volume de sindicalizados escondem ainda outros elementos que, quando explicitados, mostram uma curva ainda mais negativa dos níveis de sindicalização durante os anos 80. As estatísticas relativas ao volume absoluto de membros, embora excluam os autônomos na maioria dos países europeus, incorporam desempregados e aposentados.

A inclusão desses segmentos entre associados dos sindicatos eleva as taxas de sindicalização. Isso ocorre particularmente nos países em que os sindicatos têm políticas de "segurar" os aposentados e desempregados em suas fileiras. Contudo, em nem todos os países os sindicatos adotam esse procedimento ou, quando o fazem, as proporções nacionais de aposentados e desempregados podem ser muito diferentes, o que introduz um viés nos cálculos comparativos. Desse modo, formalmente, pode-se estar lidando com um mesmo indicador. Porém, em cada país, ele expressa uma realidade diferente e induz a conclusões enganosas, especialmente quando dele se busca extrair elementos para a avaliação da força do sindicalismo. Entre 1970 e 1988-1989, a proporção de aposentados e desempregados no total de trabalhadores sindicalizados aumentou bastante (quase $40 \%$ no caso italiano). Com exceção do Canadá, em todos os países desenvolvidos, a proporção de trabalhadores inativos sindicalizados é superior a 10\%. E a tendência é para o crescimento. No mesmo período, na Bélgica, o aumento foi particularmente forte: $16,2 \%$ para 31,7\%; na Finlândia, de 12,6\% para 20,9\%; na Áustria, de $15,0 \%$ para 21,5\%. Na média, nos países considerados, a proporção de desempregados, aposentados (e estudantes) entre filiados a sindicatos subiu de $10,4 \%$ para $17,3 \%$. Relatório da OIT (1997-1998) que não especifica exatamente o ano mas que provavelmente se refere a 1995 oferece números aproximados um pouco mais elevados: $46 \%$ na Itália, $36 \%$ na Bélgica, $19 \%$ na Suécia, $18 \%$ na Holanda, Áustria e República Tcheca, 6\% na França e 5\% na Suíça.

Por outro lado, focalizando a questão de ângulo inverso, a proporção de sindicalizados entre desempregados, às vezes, pode ser muito elevada. Na Bélgica, 80\% de todos os desempregados são sindicalizados, proporção maior do que a encontrada entre os trabalhadores com emprego. Em outros, como na Itália, os desempregados são organizados em federações separadas (Visser, 1991, p. 99). A permanência de trabalhadores desempregados nos sindicatos está relacionada com o fato de, em países como Bélgica, Dinamarca, Finlândia e Suécia, os sindicatos administrarem os seguros de desemprego. É claro que esse procedimento favorece as taxas de sindicalização em comparação com as de países em que isso não acontece porque os desempregados não tendem a abandonar os sindicatos ${ }^{2}$.

\footnotetext{
${ }^{2}$ A tradição de os movimentos sindicais terem fundos de garantia contra o desemprego foi A tradição de os movimentos sindicais terem fundos de garantia contra o desemprego foi
comum nas fases iniciais do movimento associativo de trabalhadores artesãos. Inicialmente, Os fundos formavam-se de contribuições dos próprios associados. No caso da Bélgica, que ao lado do Reino Unido foi um dos países que mais cedo se industrializaram, as aposentadorias começaram a ser subsidiadas pela Prefeitura de Gand, centro da indústria têxtil da época e onde,já havia embutido uma tradição associativa. O sindicato dos tecelões, de 1857, é considerado um dos primeiros "verdadeiros" sindicatos europeus. O sindicalismo belga, no seu conjunto, estava avançado em relação ao de outros países do continente. No dobrar do século, minta conjuntura de forte recessão, a Prefeitura de Gand passou a subsidiar os fundos de desemprego. Mas esses continuaram a ser administrados pelo sindicato. $\mathrm{O}$ sistema de seguro desemprego controlado pelos sindicatos teve imitações em outros países da Europa mas a partir dos últimos cinquenta anos, em quase toda a parte, foi assumido pelo Estado. Somente nos quatro países citados, o sistema permaneceu sob controle sindical. Segundo o "modelo de
} 
Tal como Western (1994) concluiu de seu estudo comparado sobre a sindicalização em 16 países, o "sistema de Gand" (juntamente com modelos neocorporativos de barganha coletiva centralizada, como Suécia e Áustria) não apenas aumentaria as taxas de sindicalização por manter os desempregados filiados aos sindicatos, mas também por favorecer a sindicalização em geral, em especial entre os jovens e mulheres, setor em que a sindicalização costuma ser mais baixa.

Se os trabalhadores que estão fora da força de trabalho forem contabilizados como sindicalizados, as taxas nacionais de filiação sugerem uma força e uma estabilidade organizatória que os sindicatos não possuem, porque aposentados e desempregados, embora possam ter alguma capacidade de pressão eleitoral e mesmo política, não fazem greve, o que significa dizer que não elevam a força dos sindicatos diante das empresas (além de serem, de modo geral, mais dificilmente mobilizáveis). Mas, em cada país, há diferenças quanto ao peso dos aposentados e dos desempregados nas fileiras dos sindicatos. Os sindicatos americanos e britânicos praticamente não têm aposentados entre seus membros. $\mathrm{O}$ fato afeta as taxas nacionais de sindicalização. Em razão das diferenças de política dos sindicatos para com os aposentados e os desempregados, assim como das proporções variadas desses segmentos em cada país, Clara Chang e Constance Sorrentino, retrabalhando dados de Visser, buscaram padronizar as metodologias nacionais de modo a permitir cotejar mais adequadamente os níveis de sindicalização europeus com os dos EUA. A intenção foi verificar quanto efetivamente a sindicalização norte-americana era mais baixa do que a de outros países europeus quando a contagem de sindicalizados seguia os padrões dos EUA. Entre as correções efetuadas, não consideraram como membros dos sindicatos os aposentados, os autônomos, os militares (que podem se sindicalizar em muitos países europeus mas não nos EUA, no Canadá e no Japão).

O resultado foi classificar como membros de sindicatos apenas trabalhadores com emprego e assalariados do setor civil, urbano e rural, isto é, deixando de lado os autônomos, os aposentados, os desempregados, os militares, quer dizer, todos os grupos que não constituem a clientela

Gand", os funcionários sindicais definem as alternativas profissionais adequadas e as condições sob as quais o desemprego se torna "involuntário" (Vilrokx \& Leemput, 1993, pp. 359-360; Western, 1994, p. 502) habitual da ação sindical. Trata-se de um critério restritivo, reconhecem as autoras, mas que considera os membros de sindicatos mais diretamente atingidos pela ação sindical, pelo menos potencialmente ${ }^{3}$.

\section{Quadro 1.4}

Proporção de aposentados, desempregados e estudantes sindicalizados 1970/1988-1989

Aposentados, desempregados e estudantes como porcentagem da filiação total

\begin{tabular}{|c|c|c|}
\hline Países & 1970 & $1988-1989$ \\
\hline Alemanha & 13,1 & 15,3 \\
Austrália $^{\text {Áustria }}{ }^{a}$ & 15,0 & $12,4^{\mathrm{b}}$ \\
Bélgica $^{\text {Canadá }}$ & 16,2 & 21,5 \\
Dinamarca & 2,3 & 31,7 \\
Finlândia & 3,6 & 1,5 \\
Holanda & 12,6 & 14,9 \\
Itália & 8,5 & 20,9 \\
Noruega & 11,1 & 17,4 \\
Reino Unido & 13,0 & 39,2 \\
Suécia $^{\mathrm{c}}$ & 10,0 & 15,8 \\
Suíça $^{\text {Média }}{ }^{\mathrm{d}}$ & 8,7 & 10,0 \\
\hline
\end{tabular}

a. Sem emprego

b. Filiação gratuita.

c. As proporções para o Reino Unido são estimadas.

d. Média não ponderada.

Fonte: J. Visser (1991)

Os quadros reajustados por Chang \& Sorrentino resultam em taxas de sindicalização ainda mais baixas em todos os países analisados, com exceção, obviamente, do caso americano (16\%), em que a densidade média, em 1989, calculada por Visser, não muda, uma vez que os critérios de cálculo foram padronizados precisamente para permitir a comparação com os usados nos EUA. Utilizados para os demais países os critérios americanos de sindicalização, um dos efeitos foi a redução das diferenças entre os EUA e outros países, o que significa níveis de sindicalização mais

\footnotetext{
${ }^{3}$ Uma explicitação mais detalhada da metodologia adotada por Chang \& Sorrentino, que discutem os critérios para os vários países, afastar-nos-ia demasiadamente dos objetivos desse trabalho e só poderia interessar mais de perto aos especialistas em estudos de taxas de sindicalização. Para uma discussão da metodologia empregada, ver Chang \& Sorrentino (1991).
} 
baixos para todos eles, como se percebe especialmente nos casos da Austrália, da Alemanha e da Itália, quando se comparam as estatísticas ajustadas e as não ajustadas.

\section{Quadro 1.5}

Comparação entre as taxas de sindicalização ajustadas e as não ajustadas

\begin{tabular}{|c|cc|cc|cc|}
\hline & Taxa média 1989 & \multicolumn{2}{|c|}{$\begin{array}{c}\text { Percentual e } \\
\text { alteração na } \\
\text { sindicalização } \\
\text { 1980-1989 }\end{array}$} & $\begin{array}{c}\text { Percentual de } \\
\text { alteração na taxa } \\
\text { média 1980-1989 }\end{array}$ \\
\hline País & Ajustada & $\begin{array}{c}\text { Não } \\
\text { ajustada }\end{array}$ & Ajustada & $\begin{array}{c}\text { Não } \\
\text { ajustada }\end{array}$ & Ajustada $\begin{array}{c}\text { Não } \\
\text { ajustada }\end{array}$ \\
\hline Alemanha & 33 & 39 & 3,0 & 2,2 & 3 & 1 \\
Austrália & 34 & 44 & 1,2 & 9,3 & 6 & 3 \\
Canadá & 33 & 35 & & 16,1 & & 0 \\
Dinamarca & 75 & 88 & 9,2 & 13,4 & 1 & 2 \\
Estados Unidos & 16 & 16 & 15,6 & 15,6 & 6 & 6 \\
França & 11 & & 41,6 & & 8 & \\
Holanda & 28 & 33 & 12,2 & 10,2 & 7 & 8 \\
Itália & 47 & 65 & 9,4 & 6,0 & 6 & 3 \\
Japão & 26 & 26 & 1,1 & 1,1 & 5 & 5 \\
Reino Unido & 41 & 46 & 20,9 & 20,9 & 10 & 10 \\
Suécia & 84 & 95 & 9,6 & 13,3 & 4 & 7 \\
Suíça & 28 & 32 & 7,9 & 3,0 & 5 & 3 \\
\hline
\end{tabular}

Mas, apesar da diminuição das diferenças - porque as taxas europeias ficaram mais baixas e as americanas permanecem as mesmas - os EUA continuam sendo um dos países do Primeiro Mundo com os mais baixos índices de filiação a sindicatos (acompanhados de perto pela França), o único caso em que os níveis de sindicalização caíram continuamente desde meados da década dos 50 .

Os quadros anteriores permitem agora sintetizar a situação do sindicalismo nos países considerados. Três grandes blocos podem ser distinguidos: os de alta, os de média e os de baixa sindicalização. Tomando limites relativamente arbitrários, os blocos podem ficar assim compostos (em ordem decrescente) segundo os níveis de sindicalização de 1989, com exclusão dos aposentados e dos desempregados:
Baixa sindicalização (índice inferior a 30\%): Estados Unidos, França, Japão, Suíça e Holanda.

Média sindicalização (mais de 30\% e menos de 50\%): Alemanha, Áustria, Austrália, Canadá, Islândia, Itália, Luxemburgo, Reino Unido.

Alta sindicalização (acima de 50\%): Bélgica, Dinamarca, Finlândia, Islândia, Noruega, Suécia.

Examinando a curva de sindicalização desses países, vê-se que as quedas nas proporções de filiados tenderam a acompanhar os níveis nacionais de sindicalização no sentido de que, excetuando o Reino Unido, quanto mais fraco era o sindicalismo antes da "década maldita" dos anos 70 , maior foi a perda nos anos 80 .

Dos quadros anteriores, uma segunda observação pode ainda ser feita. Deixando de lado momentaneamente os países nórdicos (que constituem um caso à parte em virtude das elevadas e estáveis taxas de sindicalização durante os anos 80), percebe-se que as quedas nas taxas de sindicalização ocorreram em países bastante diferentes do prisma das características dos seus sistemas de relações de trabalho, do sistema político nacional e da própria organização sindical. A comparação entre os EUA e a França é paradigmática porque indica o declínio da sindicalização em contextos muito variados no que diz respeito aos respectivos sistemas de relações de trabalho, às tradições de mobilização, às ideologias predominantes no meio sindical, às táticas e estratégias do sindicalismo e suas relações com o sistema partidário e político.

Essas rápidas observações destinam-se a chamar a atenção para a importância relativa de variáveis nacionais na crise do sindicalismo. Em cada país, fatores específicos relacionados com a singularidade do modelo de relações de trabalhos entrosam-se com outros mais universais, como as mudanças na tecnologia, no mercado de trabalho, nos modos de gestão das empresas, tornando difícil formular hipóteses explicativas gerais. As dificuldades por que passam os movimentos sindicais nacionais são o resultado de combinações singulares de fatores que, em princípio e por si mesmos, são negativos para o movimento sindical mas cujo "grau de nocividade" é bastante diferente em cada país. Consequentemente, os "casos nacionais" requerem exames mais detalhados que possibilitem isolar, num contexto específico, a parcela de responsabilidade que cabe a 
cada fator. Urna avaliação do sindicalismo em todos os países para os quais anteriormente se ofereceram estatísticas tornaria esse trabalho excessivamente longo. Por isso, nos dois próximos capítulos, iremos examinar apenas alguns casos nacionais que, pela importância do país ou pelas peculiaridades da situação sindical, merecem o esforço de um exame mais acurado. Adiantemos, contudo, numa apreciação geral, que os dados mais recentes da OIT sobre as taxas de sindicalização dos países anteriormente citados indicam que, na comparação entre 1985 e 1995, em todos os países (com exceção da Noruega), houve queda dos níveis de sindicalização entre os trabalhadores (excluídos os desempregados e os aposentados) e no conjunto da população não agrícola (excluindo a Dinamarca) (ver Anexo 1.1).

\section{Capítulo 2 \\ As diferenças nacionais: a situação norte-americana}

s Estados Unidos estão entre os países em que os sindicatos sofreram as maiores perdas. O declínio, no entanto, começou há certo tempo, tendo as taxas de sindicalização decaído continuamente, em termos proporcionais, a partir dos anos 50. Percentualmente, o pico da sindicalização ocorreu por volta de 1953 . Nesse ano, 25,9\% da força de trabalho (32,5\% dos empregados, excluindo a agricultura) chegaram a estar sindicalizados ${ }^{1}$ (Galenson \& Smith, 1978, pp. 3031; Troy, 1986, p. 8083 ). Contudo, o número absoluto de sindicalizados continuou crescendo até fins da década dos 70. Entre 1933 e 1984, três períodos podem ser distinguidos no desenvolvimento do sindicalismo norte-americano. O primeiro, até 1953, seria o do crescimento contínuo tanto do número de membros como no de sindicalizados no conjunto da força de trabalho civil não agrícola. No segundo, a partir desse ano, houve a constante erosão da taxa de sindicalização, embora o número de membros dos sindicatos tenha continuado a crescer até o pico de 1975 (cerca de 22 milhões de membros). No terceiro, houve o declínio conjunto da taxa de sindicalização e do número de membros dos sindicatos (Troy, 1986).

Outra avaliação, incluindo o ocorrido entre 1985-1990, estabelece as seguintes etapas: (a) de começos de 1960 até 1979, o número de filiados a sindicatos, nos EUA, aumentou, mas a um ritmo mais baixo do que o do total do emprego; b) de 1979 a 1985 , o número de sindicalizados caiu enquanto o emprego subiu; e c) de 1985 a 1990, o número de trabalhadores sindicalizados declinou mais lentamente, enquanto o emprego continuou a subir (Labor Press Service, 17.02.1992).

Pelos dados do Current Population Survey, em números absolutos, o número de sindicalizados, em 1975, era de 16.780 mil, contra 16.740 mil em 1990, depois de ter chegado a 20.095 mil em 1980² (Chang \&

${ }^{1}$ Depois da Primeira Grande Guerra, como em outros países, o sindicalismo norte americano conheceu um período de expansão: em 1920, cinco milhões de trabalhadores chegaram a estar sindicalizados. Depois veio uma Lise de decréscimo cujo ponto mais baixo foi atingido em 1933 (Galenson \& Saia h, I 978, p. 29).

${ }^{2}$ Visser (1994, p.19) registra 21248 mil, em 1970; 20.095 mil em 1980 e 16960 mil em 1989. 
Sorrentino, 1991). De 1980 a 1993, os sindicatos americanos perderam 3,5 milhões de membros. Nesse ano, a taxa de sindicalização nacional estava em torno de 16\% dos empregados e trabalhadores assalariados. Em 1993, o número de trabalhadores sindicalizados caía para 16,6 milhões. A taxa de sindicalização do setor privado declinou para $11,2 \%$, seu nível mais baixo desde 1930 (Moody, 1995, p. 8). Em 1994, a proporção do total de sindicalizados na força de trabalho americana foi para $15,5 \%$ e, em 1995 , para 14,9\% (Monthly Labor Review, May 1996, p. 43); em 1996, para 14,5\% (Berstein, 1997, p. 57) em 1997, para 14,1\% (Employment and Earnings, January 1998, apud site da AFL-CIO de 19.07.98), isto é, pouco mais de 16 milhões sindicalizados.

Os dados apresentados pela publicação da OIT, El Trabajo en el Mundo, 1997-1998- daqui para frente referida apenas como OIT, 19971998 - indica 16.360 mil trabalhadores sindicalizados em 1995, 12,7\% da mão de obra não agrícola e $14,2 \%$ considerando apenas trabalhadores. A publicação da OIT inclui na categoria "trabalhadores" a totalidade da população trabalhadora, excluídos os trabalhadores por conta própria, os desempregados e os aposentados. A população não agrícola inclui os trabalhadores por conta própria e os familiares não remunerados, os empregados domésticos e os desempregados da indústria e dos serviços. Esse método tem a vantagem de permitir cálculos das taxas de sindicalização para a quase totalidade dos países, inclusive para os do Terceiro Mundo, onde as estatísticas são precárias. O inconveniente é que categorias não assalariadas entram como base de cálculo. (Para mais informações, ver "Apêndice Metodológico", no final.)

Em 1995, cerca de nove milhões dos sindicalizados estavam na indústria privada não agrícola; sete milhões nos governos federal, estaduais ou municipais (Monthly Labor Review, May 1996, p. 42). Projetando as perdas para o próximo século, Freeman cita estimativas pelas quais a taxa de sindicalização americana do setor privado estará em 5\% em começos dos anos 2000 (Freeman, 1995, p. 519). Boyer fala em 3\% para 2010 (Boyer, 1995, p.545).

Obviamente, a extensão das perdas foi diversa segundo os setores produtivos. Deixando de lado o fenômeno do sindicalismo do setor público (que será tratado posteriormente), os ramos mais atingidos pela dessindicalização foram os da indústria, justamente nos setores que haviam sido fortalezas do sindicalismo norte-americano: automóveis, minas, aço. O sindicato desse último setor, de um máximo de 1,1 milhão de membros em 1973, perdeu em dez anos 54\% de seus afiliados. Aproximadamente no mesmo período, o Sindicato dos Trabalhadores da Indústria Automobilística perdeu cerca de meio milhão de membros (Troy, 1986). A vazão entrou pela década dos 90: "No setor privado, os sindicatos foram quase dizimados", escreve Gary Chaison. De 1980 a 1993, 4,8 milhões de membros foram perdidos (Chaison, 1996, pp.1819). Em números absolutos, na mineração, 182 mil membros foram perdidos; na construção, 442 mil; 630 mil nos transportes, comunicações e utilidades públicas; e 379 mil no comércio por atacado e a varejo. Em volume de sindicalizados, os sindicatos só ganharam membros, em números absolutos, no setor de serviços, em expansão. Mas, ainda assim, a taxa de sindicalização desse setor baixou de 9\% para 6\% (Chaison, 1996, p.19).

Além das diferenças por setor de atividade, as taxas de sindicalização americanas variam fortemente segundo o grupo étnico, a idade, o gênero, o regime de trabalho etc. As diferenças nos níveis de sindicalização, ao que tudo indica, seguem um padrão estabelecido há certo tempo. Por exemplo: em 1977, 20\% dos assalariados brancos empregados e assalariados do setor privado pertenciam a um sindicato ou associação equivalente, contra $27 \%$ dos "não brancos" (Current Population Survey, 05.01.1977, apud Freeman \& Medoff, 1987, p. 41). Nos anos seguintes, essas tendências persistiram, embora com redução da sindicalização para todos os grupos: em 1988, $19,7 \%$ dos brancos estavam sindicalizados, contra $26,1 \%$ dos negros (Curme; Hirsch \& Macpherson, 1990, p. 13). Nesse ano, entre os trabalhadores de tempo integral a proporção de filiados a sindicatos era de $19,1 \%$ (21,5\% representados por sindicatos) enquanto entre os empregados em tempo parcial era de apenas 6,3\% (7,7\% representados por sindicatos). Em 1988, a taxa de sindicalização entre as mulheres brancas era de $11,4 \%$ contra $19,7 \%$ entre as mulheres negras. Entre as mulheres que trabalhavam em tempo parcial, a sindicalização era muito baixa: $6,3 \%(14,9 \%$ para as que trabalhavam em tempo integral) (Curme; Hirsch \& Macpherson, 1990).

Em 1991, no conjunto da força de trabalho em tempo integral e em tempo parcial, a proporção de sindicalizados entre os negros do sexo masculino, maiores de 16 anos, estava em 24,6\%. Entre os brancos, na mesma faixa de idade, a proporção caía para $18,8 \%$ e, entre os de origem hispânica, para $15,6 \%$. As diferenças no tocante à propensão a aderir a 
sindicatos são igualmente acentuadas quando se separam trabalhadores por gêneros: entre as mulheres com mais de 16 anos, a proporção de sindicalização era de $12,6 \%$, contra $21,3 \%$ entre os homens da mesma faixa etária (Labor Press Service, 17.02.92). Os dados para 1995 indicam a manutenção das mesmas tendências. Os homens negros mantêm a maior proporção de sindicalizados (cerca de $20 \%$ ) e as mulheres brancas a mais baixa (Monthly Labor Review, May 1995) ${ }^{3}$. Em 1996, a taxa nacional de sindicalização caía para 14,5\% (Bernstein, 1997, p. 62). O quadro seguinte indica a distribuição da sindicalização por etnia e por sexo, discriminando também a proporção de sindicalizados e dos que, embora não filiados a sindicatos, são cobertos pelos acordos coletivos.

\section{Quadro 2.1}

EUA 1980-1993 (em milhares)

Filiação sindical e taxa de sindicalização por setor ${ }^{\mathrm{a}}$

\begin{tabular}{|l|c|c|c|c|c|c|}
\hline & 1980 & 1993 & Diferença & 1980 & 1993 & Diferença \\
\hline Setor privado & 14283 & 9556 & 4727 & $20,1 \%$ & $11,2 \%$ & $8,9 \%$ \\
Mineração & 285 & 103 & 182 & 32,0 & 16,0 & 16,0 \\
Construção & 1371 & 929 & 442 & 30,9 & 20,0 & 10,9 \\
Indústria & 6726 & 3592 & 3134 & 32,3 & 19,2 & 13,1 \\
Transporte e serviços & 2554 & 1924 & 630 & 48,4 & 30,5 & 17,9 \\
públicos & & & & & & \\
Comércio (atacado e & 1746 & 1367 & 379 & 10,1 & 6,3 & 3,8 \\
varejo) & & & & & & \\
Finanças, seguros e & 162 & 131 & 3,1 & 3,2 & 1,9 & 1,3 \\
bens imóveis & 1439 & 1510 & +71 & 8,9 & 5,8 & 3,1 \\
Serviços & 5764 & 7018 & +1254 & 35,9 & 37,7 & $+1,8$ \\
Setor público & 20047 & 16547 & 3473 & 23,0 & 15,8 & 7,2 \\
\hline Total &
\end{tabular}

Fontes: Para 1980: Departamento de Trabalho dos EUA, 1981; para 1993: Behrmann (1994).

${ }^{2}$ Porcentagem de assalariados empregados e de trabalhadores assalariados filiados a sindicatos.

${ }^{\mathrm{b}}$ Agricultura excluída.

Essas tendências continuaram nos anos mais recentes. Em 1995, a porcentagem de trabalhadores cobertos por convênios coletivos havia caído para $11,2 \%$, o que significa dizer, de modo mais dramático, que quase $9 / 10$ têm contratos individuais (OIT, 1997-1998). Nesse ano, cerca de 20\% dos trabalhadores negros estavam sindicalizados contra $14 \%$ dos brancos e $13 \%$ ${ }^{3}$ Dados do Bureau of Labor Statistics. A publicação não indica a proporção de mulheres
sindicalizadas. dos "hispânicos". A proporção de sindicalizados entre os homens estava em torno de $17 \%$ e a das mulheres, em $14,5 \%$. Os empregados em tempo parcial registravam aproximadamente $17 \%$ de sindicalizados e os que trabalhavam em tempo parcial, 7\% (Monthly Labor Review, May 1996, p. 42). Em 1997, $16 \%$ dos empregados em jornada integral de trabalho pertenciam a sindicatos contra $7 \%$ dos que trabalhavam em jornada reduzida (Employment and Earnings, January 1998, site da AFL-CIO de 10.07.98).

\section{Quadro 2.2}

Trabalhadores sindicalizados e trabalhadores abrangidos por acordos por etnia e sexo nos EUA

\begin{tabular}{|c|c|c|}
\hline & Trabalhadores sindicalizados & Trabalhadores cobertos por acordos \\
\hline Homens & 19,3 & 21,3 \\
Mulheres & 12,6 & 14,8 \\
Brancos & 15,4 & 17,4 \\
Homens & 18,8 & 20,6 \\
Mulheres & 11,7 & 13,8 \\
Negros & 21,4 & 24,4 \\
Homens & 24,6 & 27,7 \\
Mulheres & 18,4 & 21,2 \\
"Hispânicos" & 15,6 & 17,7 \\
Homens & 16,9 & 18,6 \\
Mulheres & 13,5 & 16,2 \\
\hline Total & 16,1 & 18,2 \\
\hline \multicolumn{2}{|c|}{ Fonte: Labor Press Service, 17.02.92. Trabalhadores com 16 anos ou mais. }
\end{tabular}

Percebe-se que os homens tendem a sindicalizar-se mais do que as mulheres; os trabalhadores negros mais do que os brancos; os trabalhadores em tempo completo mais do que os de tempo parcial; os trabalhadores com idade entre 35-64 mais do que os das outras faixas etárias inferiores e superiores; os trabalhadores que têm apenas curso secundário (high school) mais do que os que têm curso superior.

As diferenças entre gêneros são influenciadas pelo regime e pelo tipo de trabalho que homens e mulheres realizam, assim como as diferentes etnias. Segundo Freeman \& Medoff, "mais de $80 \%$ da diferença entre homens e mulheres na sindicalização parecem dever-se à diferença nas características dos empregos ocupados pelos homens e pelas mulheres e nos interesses econômicos de cada grupo" e não a qualquer predisposição inata das mulheres a não se sindicalizar. O mesmo tipo de explicação serviria 
para a propensão, significativamente maior, dos negros à sindicalização em relação aos brancos. Ocorre que os negros tendem a ocupar, em maior proporção, empregos manuais e de outras atividades em que a proteção sindical é importante. Freeman \& Medoff consideram, ademais, que é especialmente provável que os avanços do sindicalismo beneficiem mais os negros. Com os trabalhadores jovens aconteceria o mesmo que com as mulheres. Os jovens frequentemente trabalham em empregos temporários ("mercado de trabalho secundário"), nos quais os empregados realizam tarefas que exigem aptidões pouco elevadas, rápido treinamento, por curtos períodos (Freeman \& Medoff, 1987, pp. 44-45) ${ }^{4}$.

Esse ponto, que tem repercussões sobre o sindicalismo nos EUA e em outros países, vincula-se a uma mudança em curso no mercado de trabalho: os setores em crescimento tendem a empregar relativamente mais jovens enquanto os setores em declínio costumam conservar os trabalhadores mais velhos (Freeman \& Medoff, 1987, p. 45).

O Quadro 2.2, apresentado anteriormente, traz a proporção de trabalhadores representados por sindicatos. Em vários países, tal como no Brasil, os trabalhadores podem estar representados por sindicatos ainda que não estejam sindicalizados. Nesse último caso, as proporções são sempre mais elevadas. Nos EUA, além do total de 16,6 milhões de sindicalizados, existiam em 1991 2,2 milhões de não sindicalizados, mas representados por sindicatos.

As taxas de sindicalização juntamente com as de trabalhadores cobertos por acordos coletivos nos EUA indicam que as porcentagens de sindicalização no setor privado tendem a ser de 45 pontos inferiores às de trabalhadores cobertos por contratos coletivos, proporção bastante mais baixa do que as existentes na Europa (Curme; Hirsch \& Macpherson, 1990, p. 8)

\footnotetext{
${ }^{4}$ Como um caso desse tipo, os autores citam a McDonald's, em que não existe sindicalismo: "Por trás de seus arcos dourados [a McDonald's] emprega mais jovens do que qualquer outra companhia dos Estados Unidos" (p. 45).

${ }^{5}$ Todos os dados são do Current Population Survey. A diferença de 45 apontada por Curme et alii deve-se em larga medida às características do sindicalismo nos EUA em que as negociações se fazem por empresas "sindicalizadas", quer dizer, em que há negociação com um sindicato reconhecido pelo empregador. Na Europa, onde o sindicato negocia em nome de todos os trabalhadores, filiados ou não, a discrepância entre os dois grupos tende a ser bastante forte. Por exemplo: na Alemanha, para uma taxa de sindicalização de 31\%, em 1990 a proporção de trabalhadores abrangidos pelos acordos era de $81 \%$; na França, os números
}

Em razão das características do sindicalismo americano (a negociação por empresa, a ausência de negociações centralizadas, a ideia predominante entre os dirigentes sindicais e trabalhadores de que os sindicatos só devem representar sindicalizados), a variável "número de trabalhadores abrangidos por contratos coletivos" pode, nos EUA mais do que em outros países, ser tomada como um indicador de poder sindical. Nesse sentido, ela é particularmente reveladora do declínio do sindicalismo norte-americano. Tal como acontece com a proporção de sindicalizados, a proporção de empregados cobertos por acordos coletivos vem declinando sistematicamente. Em 1989, cerca de $80 \%$ do total de trabalhadores dos EUA não estavam cobertos por acordos coletivos. No setor privado, a porcentagem de trabalhadores abrangidos por acordos coletivos que, em meados de 1955 , atingia $36 \%$ dos trabalhadores, baixou para $11,5 \% \mathrm{em}$ 1992 (Meyer \& Cooke, 1993, p. 532).

Do ponto de vista do Futuro do sindicalismo nos EUA, fato grave é o aumento do número de trabalhadores que não desejam ser representados por sindicatos. No caso americano, essa opção realiza-se por meio de eleições secretas realizadas nas empresas de acordo com as regras estabelecidas pela Lei Nacional de Relações Industriais (LNRI). Nos anos 50, os sindicatos

eram, respectivamente, $8 \%$ e $91 \%$; na Holanda, $19 \%$ e $71 \%$; na Espanha, 9\% e 68\%; no Reino Unido, 37\% e 47\% (cf. Vissem; 1994b, p. 99).

${ }^{6}$ A Lei Nacional de Relações Industriais foi aprovada pelo congresso norte-americano em julho de 1935 no âmbito da política do New Deal de recuperação econômica do governo Roosevelt e num contexto de alto desemprego. Ela garantiu aos empregados, entre outros direitos, o de criar sindicatos e de ser representados por eles. Para isso, os trabalhadores deveriam manifestar esse desejo em eleições organizadas pela Junta Nacional de Relações Industriais (JNRI) nas empresas, ou nos locais de trabalho. É necessário, para que tal aconteça, que um grupo de trabalhadores de uma empresa decida que deseja um sindicato e peça a uni sindicato existente que "organize" ("represente" seria linguagem brasileira) os empregados. Um terço dos trabalhadores do local deve assinar tini requerimento nesse sentido. Mas, de acordo com Freeman \& Medoff (1987, p. 270), a experiência mostra que, a menos que dois terços dos empregados assinem o requerimento, a instalação do sindicato "não terá a menor chance de vingar" em virtude das pressões patronais. Até agora, desde 1935, a Junta já patrocinou cerca de 345 mil eleições (Cravei, 1993, p. 127).

A JNRI, na década de 1930, encontrou muita oposição dos empregadores. A maioria dos observadores entendem que ela efetivamente ajudou a organização sindical e favoreceu a organização dos grupos de trabalhadores mais desprotegidos. Particularmente importante foi a aprovação, no congresso, da chamada Lei Wagner (do Senador Robert Wagner, principal arquiteto da nova legislação), que reintroduziu na Lei Nacional de Relações Industriais a chamada seção 7 , que garantia aos trabalhadores o direito de se organizar em sindicato e de 
foram vitoriosos em $65 \%$ a $70 \%$ das eleições realizadas em empresas, organizando cada ano aproximadamente $1 \%$ do total da força de trabalho por meio de eleições nos locais de trabalho patrocinadas pela JNRI (Junta Nacional de Relações Industriais). Porém, nos inícios dos anos 80, os sindicatos engajaram-se em poucas eleições e tiveram tão poucas vitórias que apenas $0,14 \%$ da força de trabalho que não estava organizada sindicalizou-se por meio das eleições da JNRI, porcentagem abaixo daquela necessária para os sindicatos manterem a proporção da força de trabalho sindicalizada e, mais ainda, para conseguirem crescer (Freeman \& Medoff, 1987, pp. 267-269).

De 1965 a 1975, o número de eleições realizadas em empresas subiu ligeiramente de 7.200 para 7.700 eleições anuais. Mas, entre 1975 e 1985, baixou para 6.600. Já em 1990, somente 3.623 eleições foram efetuadas, ou seja, um declínio de aproximadamente a metade com referência ao ano de 1965. Todavia, o número de eleições em que os trabalhadores se manifestaram a favor do sindicato foi de apenas 50\%. Em 1990, em 587

negociar coletivamente, protegidos contra toda interferência contrária ou intimidatória dos patrões. A nenhuma pessoa, como condição de emprego, seria exigido que se abstivesse de aderir a um sindicato. Posteriormente, houve uma reação contra o considerado excesso de poder conferido aos sindicatos pela Lei Wagner. Em 1944, a Lei Smith-Connally exigiu que um referendo patrocinado pelo governo fosse efetuado antes de cada greve. Em 1947, a Lei das Relações Industriais foi alterada - num sentido muito negativo para o poder sindical - pela lei "Taft-Hartley", votada no clima dos inícios da guerra fria. A nova lei impôs muitas restrições aos sindicatos como organização e como movimento. Os sindicatos ficaram obrigados a prestar informações sobre seus estatutos e gestão financeira. Para utilizar as vantagens da JNRI, os dirigentes dos sindicatos deveriam assinar um documento declarando que não pertenciam ao partido comunista ou a qualquer outra organização que pretendesse substituir o governo pela força e nem tinham quaisquer relações com essas organizações. Por outro lado, obrigava os sindicatos, em caso de intenção de greve, a informar as empresas com 60 dias de antecedência, proibia a cláusula da closed shop, tornava a direção dos sindicatos passível de sanções em caso de "greves selvagens" (quer dizer, de greves não declaradas pelo sindicato) (sobre a closed shop, e a union shop ver Cap. 6). Em 1959, a Lei Landrum-Griffin estabeleceu os direitos dos filiados ante as direções sindicais e deu às autoridades federais mais poderes de intervenção nos assuntos internos dos sindicatos. Essa lei passou sob o impacto de revelações sobre a corrupção no interior de sindicatos americanos e se destinou a aumentar o controle dos filiados sobre os assuntos internos dos sindicatos e "permitir sua reforma por dentro" (Benson, 1986, p. 350). Apesar das mudanças ocorridas na legislação, as relações de trabalho nos EUA são ainda hoje dominadas pelas normas introduzidas pela legislação de 1935. (Voltaremos a esse ponto quando, no Capítulo 4, mostrarmos os efeitos da legislação sobre a sindicalização dos empregados do setor público.) eleições de empresas em que os trabalhadores deveriam decidir se queriam ou não continuar a ser representados por sindicatos, a proporção de vitórias do sindicato foi de apenas 29\% (contra 31\% em 1965) (Meyer \& Cooke, 1993, pp. 532-533).

Os autores chamam a atenção, por outro lado, para o aumento das ações empresariais consideradas "desleais" adotadas contra os sindicatos (unfair labor practices) e proibidas pela Lei Nacional de Relações Industriais: dispensa de ativistas sindicais, tentativas de prejudicar as atividades de convencimento dos empregados por parte dos funcionários sindicais etc. O número de sindicalistas despedidos teria subido de 4.477, em 1965, para 34.532, em 1984, para em seguida cair e estabilizar-se entre 16 e 19 mil anualmente (Meyer \& Cooke, 1993, p. 533).

A obtenção de novos membros por meio das eleições da JNRI, calculada sobre a força de trabalho não agrícola empregada, caiu de 0,23\% em 1980 para $0,09 \%$ em 1986 e $0,07 \%$ em 1992 . Os sindicatos conseguiram porcentagens de êxito entre $40 \%$ e $50 \%$ mas apenas realizando eleições onde consideravam que teriam boas chances de vitória. Como resultado, a média do número de certificados por ano caiu de 3431 no período de 1975-1981 para 1595 no período de 1982-1992, uma queda de 54\% (Chaison, 1996, p. 19).

Declinou, pois, o número de trabalhadores do setor privado que os sindicatos poderiam representar por meio do que é chamado de eleições nos locais de trabalho (certificate elections). Entre 1975 e 1981, a média anual de trabalhadores que os sindicatos puderam representar foi de 157397. Entre 1982 e 1992, foi de 73992 trabalhadores, um número muito pequeno quando se considera a média de trabalhadores membros de sindicatos durante o período (de 10 a 12 milhões) (Rose \& Chaison, 1996, p. 82). Inversamente, os sindicatos foram derrotados em $77 \%$ das eleições em empresas ocorridas entre 1977 e 1981 supervisionadas pela Junta Nacional de Relações Industriais para os empregados decidirem sobre retirada (ou não) do sindicato na empresa (decertification elections) (Meyer \& Bain, 1994, p. 117).

O resultado geral é a continuação do declínio do sindicalismo nos EUA na década dos 90 . Mas cumpre notar que os aspectos mais negativos do quadro descrito anteriormente aplicam-se aos sindicatos do setor privado. No quadro geral de declínio, os sindicatos do setor público conseguiram manter posições e mesmo realizar certos ganhos durante as décadas dos 80 e dos 90, aspecto que analisaremos no Capítulo 4. 
A situação do sindicalismo no Canadá é particularmente interessante em razão de sua proximidade com os EUA, do elevado grau de conexão entre as duas economias, de um lado, e as diferenças nas taxas de sindicalização, de outro. Do ângulo do número absoluto de trabalhadores sindicalizados, no caso canadense, os efetivos sindicais quase dobraram entre 1970 e 1990: 2.173 mil contra 4.031 mil (Quadro 1.2 do capítulo anterior). Já a taxa de sindicalização não ajustada indica, no mesmo período, um aumento de $31 \%$ para $35 \%$, considerando somente trabalhadores com emprego, e de $29 \%$ e $32 \%$, se no cálculo forem incluídos desempregados (Quadro 1.3). Outros autores estimam que a sindicalização teria chegado a 37,5\% em 1993 (Rose \& Chaison, 1996, p. 81; OIT, 1997-1998). Pelos dados da OIT, considerando toda a mão de obra não agrícola, a taxa de sindicalização canadense seria de $31 \%$ em 1993 contra 31,3\% em 1985. Considerando apenas trabalhadores, seria de $37,4 \%$ contra $36,7 \%$ nos mesmos anos. Na comparação, em termos percentuais, entre 1985 e 1993, no total da mão de obra não agrícola, teria havido ligeira perda de $0,6 \%$ mas, entre trabalhadores, teria havido um ganho de 1,8\% (OIT, 1997-1998. Cf. Anexo estatístico).

Contudo, se houve ganhos em termos absolutos, em termos relativos a taxa de sindicalização nacional permaneceu praticamente a mesma entre 1980 e 1994: 37,0\% e 37,5\%, depois de ter declinado para 36,2\% em 1990 e 36,3\% em 1991 (Chaison, 1996, p. 53). O próprio Chaison alerta para o fato de que o ritmo de crescimento da sindicalização canadense declinou dramaticamente a partir da década dos 70: "A filiação a sindicatos aumentou $49 \%$ nos anos 60 e 56\% nos anos 70 mas somente $19 \%$ nos anos 80. A taxa de crescimento entre 1990 e 1994 foi de aproximadamente 1\%, um aumento de somente 47 mil novos membros em quatro anos" (Chaison, 1996, p. 53). (No cap. 6, voltaremos a discutir a situação canadense e as hipóteses relacionadas com a situação relativamente mais cômoda dos sindicatos nesse país em comparação com os EUA.)

\section{Capítulo 3 \\ As diferenças nacionais: a situação europeia}

Ta Europa, como os dados do Capítulo 1 indicaram, as perdas do sindicalismo não foram, de modo geral, da dimensão da verificada nos EUA. No entanto, três observações devem ser feitas, considerando especialmente a variedade de situações nacionais do sindicalismo na Europa Ocidental: a) em alguns países, as perdas foram muito elevadas já na década de 1980; b) nos primeiros anos de 1990, mesmo em países onde o sindicalismo havia conseguido evitar perdas (países nórdicos, Alemanha, Áustria), a continuidade das mudanças da economia internacionalizada e das novas tecnologias começou a ter efeitos negativos sobre as taxas de sindicalização; c) em razão dos sistemas europeus de relações de trabalho, as quedas nas porcentagens de sindicalização não tiveram efeitos significativos na proporção de trabalhadores cobertos por convenções coletivas. Com exceção do Reino Unido, onde, tal como nos EUA, os acordos coletivos geralmente não são extensivos aos trabalhadores não sindicalizados, as proporções de empregados protegidos por acordos continuaram elevadas ${ }^{1}$.

Nas páginas que se seguem, procuraremos apresentar algumas informações sobre a situação do sindicalismo europeu nos primeiros anos da década de 1990. Como advertimos anteriormente, apenas uma parte dos países mencionados nos quadros do Capítulo 1 será avaliada ${ }^{2}$.

\footnotetext{
1 As porcentagens de trabalhadores cobertos por convênios coletivos eram as seguintes: Alemanha, 90\%; Dinamarca, 55\%; Espanha, 82\%; Noruega, 66\%; Holanda, 80(.7( (dados de 1996); França, 90\%; Suécia, 85\% (dados de 1995); Irlanda, 90\%; Reino Unido, 25,6\% (dados de 1994) (OIT 1997-1998).

2 Também outros países desenvolvidos de fora da Europa foram deixados de lado pela impossibilidade, aqui, de um estudo mais abrangente. Os dados, no entanto, mostram, também nesses outros países, forte declínio da proporção de sindicalizados. Na Austrália, por exemplo, a taxa nacional de sindicalização, tomando como pontos de referência Os anos de 1985 e 1995, caiu de 40,6\% para 28,6\% no total da mão de obra não agrícola. Considerando apenas trabalhadores, o declínio foi de 50,0\% para $35,2 \%$. Na Nova Zelândia, entre 1986 e 1995 , de $47,1 \%$ para $23,2 \%$ (total da mão de obra não agrícola) e de $54,1 \%$ para $24,3 \%$ (para trabalhadores), uma das quedas mais fortes registradas no conjunto do mundo desenvolvido. No Japão, para o período entre 1986/1995, para a mão de obra não agrícola, a
} 
A Holanda, com um movimento sindical dividido entre católicos, protestantes e socialistas, pode ser colocada na classe dos países em que houve forte declínio da organização sindical ${ }^{3}$. Contudo, ao contrário dos países do sul da Europa, a Holanda apresenta a singularidade de ter possuído um movimento sindical forte nas décadas precedentes. Em 1950, a taxa de sindicalização holandesa atingia um pico elevado: $42,2 \%$ do total da força de trabalho nacional. Essa proporção era inferior à dos países escandinavos mas quase tão elevada como a do Reino Unido e a da Bélgica, superior à da Alemanha e muito mais elevada do que a da França. Mas, a partir daquele ano, bem antes dos demais países, a proporção de trabalhadores sindicalizados começou a baixar sistematicamente, para chegar a 23,4\% em 1989 (Visser, 1993a; Visser, 1993b).

Em dezembro de 1985, todos os sindicatos holandeses registravam um pouco mais de 1,5 milhão de sindicalizados contra 1,8 milhão em fins de 1978. Foi a maior perda desde os anos 20. Nem durante a Grande Depressão os sindicatos perderam tantos membros. A taxa de sindicalização, na década dos 80 , decaiu para $24 \%$ do total da força de trabalho ou $27 \%$ dos empregados com emprego. No setor privado, apenas um em cada cinco trabalhadores estava sindicalizado ${ }^{4}$ (Visser, 1992, p. 216). Os maiores prejuízos foram sentidos pela central FNV em razão da dessindicalização sofrida pelo maior sindicato filiado a essa central, o sindicato dos trabalhadores fabris (Industriebond FNV). Somente esse sindicato de trabalhadores industriais perdeu, na década dos 80 , mais de um terço de seus filiados, metade dos quais do setor metalúrgico. No total, metade da filiação perdida pela central FNV foi consequência das perdas da Industriebond FNV.

queda foi de 22,6\% para 18,6\% e de 28,8\% para 24,0\%, considerando apenas trabalhadores (OIT 1997-1998).

${ }^{3}$ 3.Existem três principais centrais sindicais na Holanda: a Confederação Sindical Holandesa (FNV), criada em 1981 pela fusão de sindicatos socialistas e católicos; a Federação dos Sindicatos Cristãos (CNV), majoritariamente protestante, e a Federação das Organizações dos Empregados da Administração Superior (MHP). Em 1986, a ENV possuía aproximadamente 891 mil membros; a CNV, 295 mil e a MHP, 108 mil. Outras pequenas organizações somavam 233 mil. No total, 1,5 milhões de trabalhadores estavam sindicalizados, dos quais 258 mil aposentados (Visser, 1992; Fechei \& Naumann, 1994; e Mielke, Rtitters \& Tudyka, 1994).

${ }^{4}$ Há diferença percentual de um ponto com relação aos dados do próprio Visser apresentados no Quadro 1.5.
Os dados veiculados pela OIT não são inteiramente coincidentes. A publicação da OIT (1997-1998) indica crescimento do número absoluto de sindicalizados na comparação entre 1985 e 1995: 1.290 mil e 1.540 mil, respectivamente. Do ângulo da proporção de sindicalizados, nesses mesmos anos, no total da força de trabalho (agricultura excluída) as proporções eram: $23,3 \%$ e $21,8 \%$ e, no que diz respeito apenas aos trabalhadores, $28,7 \%$ e $25,6 \%$. Nesse caso, teria ocorrido uma pequena queda. Mas outra publicação da OIT, com base NO ANUÁRIO HOLANDÊS DE ESTATÍSTICA, TRAZ UM VOLUME MAIS ELEVADO DE TRABALHADORES FILIADOS A sindicatos em 1995: 1.865 mil. Por esses dados, a taxa nacional de sindicalização estaria, em 1995, em 29\%, ou seja, 2,0\% mais alta do que em 1992 (ILO, 1996) (A publicação não traz as porcentagens anteriores a esse ano. Nos dados de 1995 da publicação OIT 1997-1998, não estão incluídos os trabalhadores por conta própria, os aposentados e os desempregados.)

Na França, as perdas sindicais foram tão acentuadas quanto nos EUA e na Holanda. Na verdade, tomando como ponto de referência os EUA, o declínio do sindicalismo francês começou antes mesmo que ocorressem certas mudanças estruturais tidas como causas da crise do sindicalismo norte-americano, tais como mudanças na estrutura de emprego, introdução de novas tecnologias e ascensão de governos hostis ao poder sindical.

O sistema sindical francês é visto algumas vezes como um caso de "excepcionalidade" na comparação com outros países industrializados de sindicalismo forte, como os dos países da Europa do Norte ${ }^{5}$. O caráter "atípico" do sistema francês viria: a) do fato de o conflito e o intervencionismo legal mais do que a negociação coletiva terem sido tradicionalmente o modo de estabelecimento de normas na esfera das relações de trabalho; b) do caráter altamente ideologizado das relações entre

5 É comum a distinção, no bloco dos países industrializados, dos seguintes tipos de sindicalismo: o da Europa do Norte; o da Europa do Sul e o dos EUA, com subdivisões no seu interior. Cf., por exemplo, Kassalow (1969) e Crozier (1962). Estudos mais detalhados e abrangentes, no entanto, fazem parecer "atípicos" muitos sistemas nacionais de relações de trabalho, de sindicalismo e de movimentos operários. Ocorre que, apesar da utilidade analítica da construção de "tipos", os movimentos sindicais apresentam, ao mesmo tempo, semelhanças e diversidades notáveis. No final, cada caso parece um caso que, concomitantemente, se assemelha e diferencia de outro. "Nada apresenta ao mesmo tempo mais contrastes e mais similitudes do que a história social", notaram há tempos Dolléans e Crozier (1950, p. VIII), na introdução à sua cronologia dos movimentos operários e socialistas da Inglaterra, França, Alemanha e Estados Unidos. 
as organizações de empregados e as de empregadores; c) da fraqueza histórica do sindicalismo de um país de antiga e relativamente alta industrialização; d) das divisões políticas e ideológicas que amiúde afetam a política das centrais sindicais em sua atuação diante dos governos e das empresas; e) do maior autoritarismo e intolerância do patronato com relação as organizações sindicais; f) do fato de ter sido o sindicalismo que mais declinou em termos de trabalhadores filiados em comparação com os de outros países da União Europeia.

O sindicalismo francês tem uma história especialmente conturbada, rachado por conflitos entre sindicatos ligados a diferentes correntes partidárias e ideológicas. Cinco organizações principais representam o sindicalismo francês: a Confederação Geral do Trabalho (CGT), comunista; a Força Operária (FO), moderadamente socialista; a Confederação Francesa Democrática do Trabalho (CFDT), originalmente católica e, posteriormente, socialista "gestionária"; a Confederação Francesa dos Trabalhadores Cristãos (CFTC), católica, da qual se originou a CFDT; e a Confederação Geral de Quadros (CGC), que agrupa engenheiros, técnicos, supervisores etc. Outras minúsculas entidades não são reconhecidas como representativas pelo governo francês: a pequena Confederação Nacional do Trabalho (CNT), de tendência sindicalista revolucionária; a Confederação Autônoma do Trabalho (CAT), que reúne sindicatos reformistas; a Confederação Nacional dos Assalariados da França (CNSF), implantada especialmente entre os caminhoneiros; e a Confederação dos Sindicatos Livres (CSL), gaullista (Mouriaux, 1983; Branciard, 1982; Reynaud, 1975).

Trata-se, hoje, do país de mais baixo índice de sindicalização de toda a Europa Ocidental, inferior inclusive aos de países como a Espanha e a Grécia. Segundo Rosanvallon, os sindicatos franceses, globalmente, perderam 59\% de seus filiados entre 1976 e 1988. A taxa nacional de sindicalização, que era de $20 \%$ em 1976, seria, em 1988, de $9 \%$ (Rosanvallon, 1988, p. 14). Em julho de 1989, um grupo de estudos sindicais de Lion estimava a proporção de sindicalizados em 7\% (Groux \& Mouriaux, 1990, p. 51).

O Quadro 3.1, construído a partir de dados baseados em informações divulgadas pelas próprias centrais, mostra a erosão de membros das principais organizações sindicais. $\mathrm{O}$ declínio seria especialmente acentuado entre 1983 e 1986-1987. A exceção seria a FO. (As frases estão no condicional em virtude da já mencionada dificuldade de avaliação dos efetivos sindicais franceses, dificuldade reconhecida por todos os autores. Voltaremos de modo mais detalhado ao assunto.)

\section{Quadro 3.1}

França: Número oficial de sindicalizados nas seis maiores organizações (1976 a 1986-1987)

\begin{tabular}{|c|c|c|c|}
\hline & 1976 & 1983 & $1986-1987$ \\
\hline CGT & 2074072 & 1622095 & $1030843(1987)$ \\
FO & 926324 & 1150000 & $1627500(1987)$ \\
CFDT & 829024 & 681300 & $600000(1988)$ \\
FEN & 525860 & 492900 & $394389(1988)$ \\
CFE-CGC & 325469 & 307383 & $240870(1986)$ \\
CFTC & 2223100 & 260000 & $250000(1987)$ \\
\hline
\end{tabular}

Fonte: Evalualion Liaisons Sociales, Documents W, 243, 28, dezembro, 1988 (apud Groux \& Mouriaux, 1990, p. 51)

O declínio da CGT. Pelos números do quadro acima, a Força Operária (FO), ou CGT-FO, teria superado a CGT, que do final da guerra até começos da década dos 80 era reconhecida, sem discussão, como a mais forte central sindical da França.

A CGT-FO (geralmente referida apenas como FO) surgiu da cisão entre socialistas e comunistas no meio sindical durante os inícios da Guerra Fria. A CGT, por sua vez, já passou por várias etapas ideológicas. Até a Primeira Guerra, foi majoritariamente sindicalista revolucionária. Depois da guerra, os comunistas; no cisma da esquerda ocasionado pelo aparecimento da Internacional Comunista (1919), criaram a CGT Unitária, ficando a CGT sob controle socialista. Em 1936, houve a reunificação das duas tendências. A CGT Unitária desapareceu; os comunistas entraram para a CGT, mas os socialistas permaneceram majoritários. Durante o Governo de Vichy, a CGT e outras organizações sindicais independentes foram dissolvidas. Após a Segunda Guerra, a CGT reapareceu, agrupando comunistas e socialistas. Mas, com o início da Guerra Fria, houve nova cisão. Dessa vez, os comunistas levaram a melhor, ficando com a CGT. Os socialistas por sua vez, criaram a CGT-FO (Mouriaux, 1982; Reynaud, 1975 e Branciard, 1982).

A CFDT, no Quadro 3.1, está em terceiro lugar. Outros dados, mais recentes, situam a CFDT ligeiramente à frente da FO. Contudo, a CGT, em outras estatísticas, aparece com mais filiados do que a FO, mas superada 
ligeiramente pela CFDT $^{6}$ (As cifras para a CFTC - que transpusemos literalmente de Groux \& Mouriaux (1990) - sugerem um erro de impressão. Pelo Quadro 3.1, a Confederação Francesa dos Trabalhadores Cristãos, com mais de dois milhões de filiados, teria, em 1976, mais membros do que a CGT, número que nenhuma outra fonte registra. Além disso, em cerca de sete anos, a CFDT teria perdido quase dois milhões de membros, o que dificilmente poderia ter acontecido. Provavelmente, o algarismo " 2 ", no quadro, foi acrescentado equivocadamente, sendo de 223.100 o número correto e não 2.223.100)

Quadro 3.2

França: Número de trabalhadores sindicalizados por entidade -1950-1994 (em milhares)

\begin{tabular}{|c|c|c|c|c|c|c|c|}
\hline & $C G C$ & $F E N$ & $C F T C$ & $F O$ & $C F D T$ & $C G T$ & TOTAL \\
\hline $1950-1959$ & 100 & 200 & 360 & 1000 & & 2046 & 3806 \\
$1960-1969$ & 200 & 300 & 150 & 800 & 507 & 1321 & 3278 \\
$1970-1979$ & 300 & 500 & 200 & 1000 & 684 & 1500 & 4184 \\
$1980-1989$ & 225 & 325 & 185 & 500 & 486 & 768 & 2489 \\
$1990-1994$ & 200 & 250 & 170 & 400 & 500 & 480 & 2000 \\
\hline
\end{tabular}

Fonte: Para a FO, a CGC e a FEN as informações das próprias entidades. Para a CGT e a CFDT, provêm de várias fontes. Apud Jefferys (1996a, p. 515).

Obs. No texto original não há indicação mas o número de sindicalizados para cada entidade deve referir-se à media no decênio.

Pelos dados do quadro acima, a CGT continuaria a superar a FO em número de membros. Mas as diferenças entre o Quadro 3.1 e o Quadro 3.2 são acentuadas. Ocorre que os autores encontram muitas dificuldades para saber os efetivos das organizações sindicais francesas. A divergência vem principalmente do uso de fontes diferentes. Como todos os quadros acima se baseiam em dados das próprias centrais, os efetivos estão provavelmente superestimados.

\footnotetext{
${ }^{6}$ Algumas entidades de cúpula do sindicalismo francês, as confederações, não são centrais sindicais no sentido brasileiro, quer dizer, organizações que abrangem trabalhadores de setores profissionais diferenciados, mas são organizações de grupos profissionais específicos. Por exemplo, a CGC (Confederação Geral de Quadros), como já dissemos, filia apenas técnicos de nível superior. A FEN (Federação da Educação Nacional) filia pessoal do setor do ensino. A FEN cindiu-se em 1993, com os professores cio ensino do magistério elementar criando uni associação própria, a FSU (Federação Sindical Unitária). No quadro acima, os membros das duas associações estão agregados (Jefferys, 1996, p. 515).
}

Os cálculos relativos aos índices de sindicalização franceses são dos menos seguros de toda a Europa, notadamente se comparados com as estatísticas britânicas, alemãs e dos países nórdicos. Rosanvallon alerta, tal como Visser e outros, para a dificuldade de medir as taxas de sindicalização na França, porque as informações fornecidas pelos sindicatos seriam "inverificáveis".., quando acontece de as centrais sindicais divulgá-las. A CFTC, por exemplo, não publicou nenhuma informação sobre os números de seus membros até 1982, quando a central declarou ter 250 mil trabalhadores.

As dificuldades de avaliação do número de associados são também fortes para as demais centrais (Mouriaux, 1983, pp. 6667). A FO seria a entidade cujos dados seriam menos confiáveis e mais secretos (Jefferys, 1996, p. 515). Para a CGT, Rosanvallon (1988) afirma que, entre 1980 e 1984, os números oferecidos por essa central estavam superestimados em $40 \%$ (p. 262). Em 1988, os efetivos da CGT seriam de $600 \mathrm{mil}$; os da CFDT, de 300 mil e os da FO, de 340 mil (Rosanvallon, 1988, pp. 14-15). Já Denis Segrestin, para apenas três anos antes (1985), estima os membros da CGT em aproximadamente um milhão (com uma perda de um quarto de seus membros em três anos); a CFDT teria 700 mil; a FO, 600 mil; a CGC, 150 mil (administradores e técnicos) e a CFTC, 200 mil (Segrestin, 1992, p. 106). De acordo com Durand (1996, p. 41), os efetivos da CGT caíram de 2,3 milhões em 1970 para 820 mil em 1990 (dos quais, respectivamente, 270 mil e 200 mil aposentados), chegando a 600 mil em 1994. As estatísticas divulgadas pela OIT, com base nos informes das principais centrais (que excluem os aposentados das cifras da CFTD e da CGT), registram uma queda de 2.555 mil afiliados em 1985 para 1.757 mil em 1995. Em termos percentuais, no total da mão de obra não agrícola, a taxa de sindicalização teria caído de 11,6\% em 1985 para 6,1\% em 1995. Entre o total de trabalhadores, teria caído de $14,5 \%$ para $9,1 \%$ nos mesmos anos.

Além da relutância das centrais sindicais a divulgar o número de filiados, a discrepância de dados vem da própria noção do que significa ser membro do sindicato. No caso da França, os critérios seriam bem mais fluidos do que em outros países (Rosanvallon, 1988, p. 261). Os sindicatos franceses distribuem cartas de associação sobre as quais selos das organizações sindicais, comprados pelos aderentes, devem ser colados, o que nem sempre acontece. Como afirma Rosanvallon, é costume considerar como aderente quem compra sete ou oito selos por ano. Uma federação que tiver vendido sete milhões de selos dirá que tem um milhão de associados. 
O sistema francês de definição de filiados, assim, tende a dificultar as avaliações precisas da força de cada central, federação ou sindicato. Mas, apesar das divergências sobre os números exatos, as análises confluem para a conclusão de que foi a CGT a central que mais perdeu aderentes num volume calculado em pelo menos um milhão de membros; cerca de um milhão entre 1976 e 19861988 (Groux \& Mouriaux, 1990, p. 51); 1,5 milhão entre 19501959 e 19901994 (Jefferys, 1996, p. 515), ou, segundo outros autores, decaindo de mais de dois milhões de membros em fins da década dos 1970 para cerca de 1,5 milhão em 1983 e um milhão em 1987, o que significaria, excluindo-se os sindicalizados aposentados, $50 \%$ de queda apenas nos anos 80 (Goetschy \& Rozenblatt, 1993, p. 410).

A CGT vangloriava-se de ser a central do trabalhador fabril, dos manuais, da classe operária enfim, o que, num país em que as ideologias comunistas e socialistas eram fortes, constituía um trunfo importante de legitimação, especialmente entre grande parte da intelectualidade. De fato, assim era. A CGT, mais disciplinada do que suas rivais, estava fortemente implantada nos setores da indústria em expansão no pós-guerra. Tendia, pois, proporcionalmente, a ser mais forte na "classe operária tradicional" e a ter mais apoio entre os trabalhadores qualificados do setor metalúrgico, químico, da construção, do aço, das minas, dos portos e também em serviços públicos como ferrovias, gás e eletricidade (Ruysseveldt \& Visser, 1996b, p. 95), quer dizer, justamente nos setores de atividade econômica que declinaram posteriormente em termos de absorção de mão de obra e de importância no $\mathrm{PIB}^{7}$. A CGT, como outras centrais francesas, está organizada, verticalmente, em amplas federações industriais e, horizontalmente, quer dizer, geograficamente, em sindicatos interprofissionais que organizam todos os trabalhadores em unidades por localidade, departamento ou região. Ao todo, existem 44 sindicatos industriais, 910 sindicatos locais, 95 sindicatos por departamento e 22 sindicatos por região (Ruysseveldt \& Visser, 1996b, p. 95).

${ }^{7}$ 7.Em 1975, um levantamento feito pela CGT indicava que os homens representavam 75\% dos membros dos sindicatos filiados a ela. Do total, $65 \%$ eram operários e $23 \%$ empregados; $57,3 \%$ eram do setor privado, $26,5 \%$ do setor público e $16,1 \%$ do setor nacionalizado. A Força Operária, por sua vez, estimava, em 1980, que 55\% dos seus membros estavam no setor privado; 30\% em funções públicas e 15\% no setor nacionalizado. A CFDT, em 1971, classificava seus cotizantes em duas grandes categorias: o privado, com 59,5\%, e o público, com 39,5\% (Mouriaux, 1986, p. 30).
Temos aqui a influência de um fator de tipo estrutural, ou seja, alterações no mercado de trabalho ocasionadas por mudanças tecnológicas e econômicas que afetam negativamente uma organização sindical. Mas esse é somente um dos fatores. A resposta das lideranças sindicais à nova situação (adversa) para suas organizações é um outro. No novo contexto da Europa globalizada, as perdas sindicais, ao que tudo indica, para o caso da França, tenderam a ser tanto mais fortes quanto mais a organização sindical se apoiava sobre uma cultura militante de oposição e de conflito, como era especialmente o caso da CGT (ligada ao PCF) e também, em menor medida, da $\mathrm{CFDT}^{8}$. As perdas da CGT foram particularmente fortes no setor metalúrgico. Segundo Reynaud, com base em dados da própria entidade, a Federação dos Metalúrgicos filiada à CGT, em 1974, tinha 420 mil filiados. Em 1982, havia baixado para 250 mil (Reynaud, 1984, p. 48). Em 1987, estava reduzida a 7.400 membros (Rosanvallon, 1988, p. 12). O pico de sindicalizados atingidos pela CGT, a partir das informações dessa confederação, foi de 3,2 milhões de membros, total atingido em 1978. Nesse ano, o número de aposentados nos quadros da CGT, que vinha aumentando sistematicamente, chegou a 302 mil (1964=187 mil) (Lasserre, 1986, p. 67). Os seguintes períodos de filiação teriam marcado a história da CGT no após-guerra: crescimento até 1947, ano a partir do qual declinou até 1958; entre 1959 e 1975, nova fase de crescimento; a partir daí, novo declínio (Goetschy \& Rozenblatt, 1993, p. 410).

O setor metalúrgico foi, como em toda a parte, um dos mais atingidos, a um ponto tal, como nota Denis Segrestin, que a associação patronal de metalurgia pôde declarar, em 1985, que a taxa de "efetiva" sindicalização no setor havia baixado de 25\% para 5\% (Segrestin, 1992, p. 106).

Outro fator que provavelmente contribuiu para o declínio da CGT, numa escala difícil de medir, foi o fim do socialismo no Leste Europeu e a crescente perda de força eleitoral do PCF, ao qual a CGT permanece ligada como "braço sindical" do partido. "Opondo-se à lógica do capital, escreve R. Mouriaux, a CGT recusa as dispensas, a 'precarização', a baixa do poder

8 "A CGT-FO se faz, pela palavra e pela prática, campeã da negociação e do espírito contratual. Para ela, o respeito ao compromisso assumido é o próprio fundamento da negociação, que é o principal meio de atuação do sindicalismo. [...] A CGT e a CFDT; pelo contrário, consideram como uni princípio que o acordo não é um contrato, mas um armistício, a constatação do resultado de uma relação de forças. Ligado a essa relação, o acordo pode, pois, mudar com ela" (Reynaud, 1975, p. 163). 
de compra. [...] A estratégia da CGT, que reivindica a noção de sindicato de esquerda, não é isolada da luta política levada pelo PCF, em primeiro lugar e, em menor medida, pelo PS. Desse ponto de vista, a central é diretamente afetada pelas alterações na esfera política e cuja autonomia relativa limita sua capacidade de influência" (Mouriaux, 1986, pp. 70-71).

Considerando as diferenças e as dificuldades de obtenção de informações seguras que possibilitem avaliar a força das centrais, os pesquisadores utilizam frequentemente, como indicação, os resultados das eleições para os "conselhos de empresas" que ocorrem a cada dois anos". Pelo Quadro 3.3 (abaixo), vê-se que, novamente, as perdas da CGT foram as maiores, caindo os votos a ela favoráveis de 32,3\%, em 1982, para 24,9\%, em 1990.

O aspecto dramático dos resultados acima para o sindicalismo francês como um todo reside no fato de que as perdas da CGT não beneficiaram as demais centrais e federações. $O$ grande aumento da proporção de votos foi para os delegados independentes (18,4\%, em 1982, para 26,6\% em 1990), fato indicativo da queda do prestígio e da influência de todas as organizações sindicais.

No final, malgrado as divergências quanto aos números de filiados e quanto à importância de cada central, todos os principais pesquisadores estão de acordo sobre a redução geral das taxas de sindicalização, sobre a dificuldade de recrutar jovens e sobre o enfraquecimento do poder sindical,

${ }^{9}$ Os comitês de empresa não foram tinia iniciativa da esquerda. Foram criados depois de 1945 por iniciativa de De Gaulle e regulamentados por uma lei de 1946, que outorgou direito de voto a todos os empregados. Os candidatos apresentam-se às vezes como representantes das confederações, às vezes concorrem como candidatos individuais. Em 1992-1993, existiam cerca de 25 mil comitês de empresa (Jefferys, 1996, p. 516). Seu objetivo é apresentar aos empregadores as reclamações dos empregados. Têm papel consultivo; o de barganha caberia aos sindicatos. Mouriaux observa, no entanto, que na prática, no âmbito das empresas, "comitês de empresa, delegados do pessoal, mandatários informais, negociam e assinam acordos de empresa" (Mouriaux, 1983, p. 166). Os comitês de empresa não devem ser confundidos com as seções sindicais, criadas também por lei em dezembro de 1968. Os delegados de seções não representam todo o pessoal mas os vários sindicatos diante da direção da empresa. Na prática, existe certa acumulação de funções entre membros dos comitês de empresa, representantes do pessoal eleitos pelos empregados e pelos representantes dos sindicatos. Uma pesquisa de 1992 mostrou que de cada cinco delegados sindicais um era também secretário do comitê de empresa (Cézard, Malan \& Bezançon, 1995, apud Jefferys, 1996) tendências refletidas no aumento da proporção de representantes independentes dos empregados vitoriosos nas eleições para os conselhos de empresas e para os Conseil de Prud'hommes (espécie de tribunal de trabalho composto por representantes dos empregados e dos empregadores para a avaliação de queixas individuais).

Quadro 3.3

França: Resultados das eleições para comitês dos trabalhadores (\% da votação) (1982-1990)

\begin{tabular}{|c|c|c|c|c|c|c|c|}
\hline & CGT & CFDT & FO & CFTC & CFECGC & Outras & Independentes \\
\hline 1982 & 32,3 & 22,8 & 11,7 & 2,9 & 7,0 & 4,4 & 18,4 \\
1984 & 29,3 & 21,0 & 13,9 & 3,8 & 7,1 & 4,8 & 19,7 \\
1986 & 27,1 & 21,2 & 14,4 & 3,8 & 7,5 & 5,0 & 21,1 \\
1988 & 26,7 & 20,7 & 13,7 & 3,7 & 6,8 & 4,8 & 23,5 \\
1990 & 24,9 & 19,9 & 12,8 & 3,6 & 6,5 & 5,6 & 26,6 \\
\hline
\end{tabular}

Nota: eleições para os conselhos de trabalhadores ocorrem a cada dois anos. Em algumas companhias, nos anos pares e, em outras, nos anos ímpares. Assim, a evolução dos padrões de votação tuim grupo particular de companhias pode ser vista como o resultado de anos pares ou impares.

Fonte: EIRR 211, agosto de 1995, apud Goetschy \& Rozenblatt, 1993, p. 415.

É interessante ressaltar que, no mesmo período em que a sindicalização caía, o número de contratos firmados diretamente entre empresas e sindicatos aumentava. No caso, deve-se ver aí a influência de fatores políticos, ou seja, da vitória eleitoral dos socialistas. A Lei Auroux, além de confirmar dispositivos pró-sindicais anteriores, obrigou as empresas, onde houvesse representação sindical, a abrir negociações anuais sobre salários e horas de trabalho, negociações que deveriam ocorrer no âmbito da empresa. A lei, editada por Jean Auroux em 1982, traz o nome do então ministro do Trabalho do governo socialista. Um dos seus objetivos era criar uma verdadeira "cidadania dentro da empresa". A mesma lei ampliava os direitos sindicais à obtenção de informações sobre a companhia e permitia aos comitês contarem com a assessoria de especialistas durante as negociações. Comitês de saúde e segurança no trabalho foram criados, mas apenas os sindicatos podiam negociar pelos empregados embora os comitês de saúde e segurança pudessem intervir nos assuntos internos das empresas.

Um dos objetivos da reforma introduzida pelo governo socialista foi a descentralização das negociações e o incentivo para negociações diretas entre empregados e empregadores no âmbito interno dos locais de trabalho (Goetschy \& Rozenblatt, 1993, pp. 429 e ss.; Tchobanian, 1995, pp. 128- 
129). Como resultado da Lei Auroux, nas empresas com mais de 50 empregados, o sistema de representação interna dos trabalhadores ficou composto por quatro corpos: a) delegados do pessoal; b) comitê de empresa; c) comitê de saúde e segurança no trabalho; d) delegado dos sindicatos (Tchobanian, 1995). No que diz respeito ao papel e importância desses organismos, as situações podem variar. Nas empresas em que o sindicato é fraco, os organismos eleitos pelos empregados aumentam de importância; quando o empregador é hostil ao sindicato, a tendência será a coordenação dos esforços dos sindicatos com os conselhos de trabalhadores e, finalmente, quando a presença do sindicato é forte e o empregador prefere um só interlocutor, o sindicato local é dominante (Martin, 1976, apud Tchobanian, 1995, p. 126). Mas, no geral, as relações entre os organismos locais, formalmente independentes, e os sindicatos sempre foram complicadas na França, em grande parte pelo conflito entre a ideologia conservadora dos empregadores e a tendência socialista do sindicalismo, notadamente da CGT.

$\mathrm{Na}$ França, a crise de um sindicalismo já fraco começou antes da vitória da esquerda e da ascensão de um "governo amigo" nas eleições de 1981 e continuou depois, durante os governos socialistas de Mitterrand. Trata-se, desse modo, de um declínio ocorrido numa situação política favorável, quando a maioria do eleitorado inclinava-se para a esquerda (até as eleições de março de 1993, quando a votação do PS caiu para cerca de $17 \%$ e a direita voltou ao poder, até ser novamente derrotada nas eleições parlamentares de maio/junho de 1997). Esse fato deve ser retido para as discussões dos capítulos posteriores sobre os motivos das quedas de sindicalização, especificamente para as interpretações que atribuem forte peso à natureza do partido no governo (mais à esquerda ou direita) no declínio do poder sindical.

No Reino Unido, a relação entre o desenvolvimento da política partidária e a dessindicalização efetuou-se num sentido inverso ao da França: a queda dos efetivos sindicais acompanhou mais de perto a perda de votos do Partido Trabalhista e foi bastante acentuada pela vitória do Partido Conservador e pelas leis aprovadas durante o governo Thatcher. No caso, os vínculos entre o TUC (Trade Union Congress, central sindical britânica) eram muito mais fortes com o Partido Trabalhista do que os dos sindicatos franceses com o Partido Socialista. Outro aspecto diferenciador diz respeito à situação do sindicalismo nos dois países. Ao contrário da França, de sindicalismo frágil, o do Reino Unido estava mais próximo do bloco dos países de sindicalismo forte, embora nos últimos decênios os níveis de sindicalização tenham caído bastante e o movimento sindical tenha sofrido fortes derrotas nas minas, nas docas e no setor de imprensa.

Mais precisamente, pelos dados de Visser (cf. Capítulo 1), o Reino Unido estaria, na década dos 70, no grupo dos países "intermediários", entre os países nórdicos, de alta sindicalização, e os da Europa latina, de baixa sindicalização (com exceção da Itália). Depois de ter chegado a um pico de 50\% de sindicalização no quinquênio 74/79, a taxa caiu para 37\% em 1990. Já entre 1979 e 1986, a porcentagem de sindicalizados havia declinado 25\%, ou seja, os sindicatos haviam perdido aproximadamente três milhões de associados (Visser, 1988). Em 1948, o número de trabalhadores no Reino Unido filiados a sindicatos era de 9.102.000 (taxa de sindicalização de $44,9 \%$ ), que subiu, em número de filiados, para 12.239.000 em 1979, ano em que mais trabalhadores estiveram sindicalizados. Desde então, a densidade sindical britânica declinou ininterruptamente. Três períodos distintos podem ser destacados: a) 1948-1968; b) 1969-1979; e c) 1980-1987.

a) Entre 1948 e 1968, o número absoluto de trabalhadores sindicalizados aumentou numa média de 32 mil por ano, embora a proporção de sindicalizados diminuísse. Isso significa que a sindicalização avançou a um ritmo mais lento do que o crescimento da força de trabalho.

b) No período de 1969-1979, a taxa de sindicalização aumentou e o número de membros cresceu em termos absolutos, numa média anual de 264 mil, até o pico de 12,6 milhões, em 1979. Foi a era de ouro do sindicalismo britânico. Nesse segundo período, houve aumento da força de trabalho em $10,5 \%$ e do emprego em $11,9 \%$, criando uma situação bastante propícia para a elevação do poder sindical. Mas, a partir de 1980, a situação inverteu-se e a maioria dos ganhos anteriores foram perdidos. Em 1987, a taxa de sindicalização e os níveis de emprego declinaram enquanto a participação da força de trabalho no total da população atingiu seu nível mais baixo desde 1948 (Waddington \& Whitston, 1995, p. 157).

c) Nos anos que vão de 1980 a 1987, a velocidade da queda dos efetivos sindicais variou. Entre 1980 e 1983, o número de filiados caiu a uma média anual de 468 mil. Em parte, isso aconteceu porque os sindicatos não conseguiram recrutar novos membros nas áreas de atividade econômica em que houve expansão do emprego, de modo a tentar compensar as perdas 
nos setores em que houve contração. O total de sindicalizados desceu para 9,6 milhões em fins de 1991, o menor número de trabalhadores sindicalizados desde 1954, 362 mil a menos do que em 1990 (Bird; Beatson \& Butcher, 1993, p. 190). Entre 1988 e 1992, a taxa de sindicalização continuou a decrescer a uma média de evasão de 537 mil por ano. Em 1992, os sindicatos perderam 5,6\% dos filiados. No outono de 1993, o número absoluto de trabalhadores sindicalizados declinou para 7682 mil. A taxa de sindicalização baixou de 32\%, em 1992, para 31\% em 1993 (Bird \& Corcoran, 1994). Contudo, outra publicação, citando dados do Departamento de Certificados das Associações de Sindicatos e de Empregadores, apontava, em dezembro de 1994, 8,3 milhões de sindicalizados $^{10}$. Pelos dados da OIT (1997-1998), no total da mão de obra não agrícola, a taxa de sindicalização era de $36 \%$ em 1985, tendo caído para $26,2 \%$ em 1995. Entre os trabalhadores, a taxa de sindicalização, que estava em 45,5\% em 1985, desceu para 26,2\% em 1995.

Os algarismos acima devem ser entendidos, convém repetir, como indicações com uma margem de erro difícil de estimar e com variações segundo as fontes e os critérios adotados. Mas servem para dar uma ideia geral do volume e do número de sindicalizados em cada país. Uma análise mais sofisticada, que não teríamos condições de fazer aqui, necessitaria considerar os vários setores da atividade econômica, especialmente o volume de trabalhadores nos variados locais de trabalho, onde os níveis de sindicalização mostram diferenças acentuadas. Assim, para ficarmos em apenas um exemplo: nos locais de trabalho com menos de 25 empregados, as estatísticas britânicas apontam taxas de sindicalização de $18 \%$, subindo

\footnotetext{
${ }^{10}$ Há variações nos índices de acordo com as fontes de informação. Os números acima foram retirados da Pesquisa por Amostragem sobre a Força de trabalho. 'trata-se de levantamento efetuado pelo Departamento de Emprego. Aproximadamente 65 mil domicílios privados foram entrevistados em todo o Reino Unido. Os períodos entre as pesquisas têm variado. Outra fonte de informação é o Relatório Anual dos Certificados, de março de 1994, que contém a relação dos sindicatos e entidades patronais, com a indicação do número de membros e orçamentos. Nesse caso, os números são significativamente mais elevados cio que os da Pesquisa sobre a Força de "trabalho. Por essa fonte, o número de sindicalizados chegava a cerca de 9 milhões em fins de 1992, ainda assim 537 mil (5,6\%) mais baixo do que em fins de 1991 (Bird \& Corcoran, 1994). Os dados da Pesquisa sobre a Força de Trabalho foram contestados pela revista Labour Research, que entende que a empresa que realizou a pesquisa exagerou a queda. O declínio entre as mulheres teria sido de apenas $1 \% \mathrm{e}$ não de $2 \%$ (32\% para 30\%, como afirma a pesquisa). Entre Os homens, o declínio teria ido de $39 \%$ para $38 \%$ e não para $36 \%$ (Labour Reseawh, 1994).
}

para $47 \%$ nos locais com mais de 50 empregados, embora haja exceções a essa regra (Bird \& Corcoran, 1994, p. 192). Porém, contrariamente aos EUA, as diferenças nos índices de sindicalização, no Reino Unido, não parecem tão pronunciadas entre as etnias. Em 1993, a taxa agregada de sindicalização entre os brancos com emprego era de $33 \%$ contra apenas $32 \%$ no conjunto das demais minorias étnicas; no total de empregados, era de $37 \%$ nos dois grupos. No tocante ao gênero, havia $36 \%$ de sindicalizados entre os homens e 30\% entre as mulheres (McIlroy, 1995, p. 34, dados da Employment Gazette, January 1993).

$\mathrm{Na}$ Itália, considerando o número de trabalhadores sindicalizados e as taxas de sindicalização, à primeira vista as perdas foram muito pequenas, permitindo até, no início da década dos 80, a interpretação de que, mais do que uma crise, estaria ocorrendo uma mutação do sindicalismo italiano ${ }^{11}$. As principais centrais sindicais, a Confederação Italiana do Trabalho (CGIL,), a Confederação Italiana dos Sindicatos de Trabalhadores (CISL) e União Italiana do Trabalho (UIL) ${ }^{12}$, conservaram seus efetivos ou registraram perdas insignificantes em termos do número total de trabalhadores sindicalizados (Codara, 1997; Ferner \& Hyman, 1993; Negrelli \& Santi, 1992; Visser, 1991).

Entre 1970 e 1989, em termos absolutos, o número de sindicalizados passou de cerca de 5,2 milhões para 9,5 milhões, com um ganho liquido, entre 1970 e 1988, de quase 4,5 milhões de novos membros (Visser, 1991, p. 101). A CGIL, ligada ao PCI e, durante todo o após guerra, a mais importante central sindical italiana, entre 1968 e 1978 dobrou seus efetivos, passando de 2,4 milhões para 4,5 milhões (Ferner Hyman, 1993b, p. 545).

\footnotetext{
${ }^{11}$ Por exemplo, Giusto Barisi, para quem, em fins da década dos 80, a crise atual [do sindicalismo na Itália] era só uma crise de mutação que "pôs em discussão a natureza, as modalidades de funcionamento, as estratégias do sindicalismo italiano". Embora acreditasse que "essas transformações provocaram unia crise nas organizações existentes entre militantes e quadros experientes, uma redução dos recursos técnicos e humanos à disposição dessas organizações, uma baixa das ambições e dos objetivos de reivindicação", Barisi considerava que se assistia também ao nascimento de novos movimentos de reivindicação e à sindicalização de novas camadas sociais (Barisi, 1989, p. 21).

12 Além das três grandes centrais sindicais (CGIL., CISL. e UIL.) existe ainda uma minúscula central neofascista, a Confederação Italiana dos Sindicatos Nacionais de Trabalhadores (CISNAL), com lima pequena representação no setor público.
} 
Na década dos 80, o melhor ano para as centrais sindicais foi o de 1988, quando, em comparação com 1987, houve um aumento de 4,2\% no número absoluto de sindicalizados. Para esse resultado, contou o extraordinário ganho da CISL $(6,8 \%)$, embora todas as centrais tivessem tido aumentos significativos. Entre 1980 e 1994, os sindicatos italianos acrescentaram aproximadamente mais 1,5 milhão de membros a suas fileiras. A central que mais avançou entre 1977 e 1994 foi a CISL, seguida da UIL e da CGIL, numa competição em que todas tiveram ganhos.

\section{Quadro 3.4 \\ Itália}

Total de sindicalizados na CGIL, CISL, e UIL

(trabalhadores ativos. desempregados e aposentados )

\begin{tabular}{|l|c|c|c|c|c|c|c|c|}
\hline & \multicolumn{3}{|c|}{ CGLI } & \multicolumn{2}{c|}{ CISL } & \multicolumn{2}{c|}{ UIL } & \multicolumn{2}{c|}{ Total } \\
\hline Ano & $\begin{array}{c}\text { Números } \\
\text { absolutos }\end{array}$ & $\begin{array}{c}\text { Var. } \\
\%\end{array}$ & $\begin{array}{c}\text { Números } \\
\text { absolutos }\end{array}$ & $\begin{array}{c}\text { Var. } \\
\%\end{array}$ & $\begin{array}{c}\text { Números } \\
\text { absolutos }\end{array}$ & $\begin{array}{c}\text { Var } \\
. \%\end{array}$ & $\begin{array}{c}\text { Números } \\
\text { absolutos }\end{array}$ & Var.\% \\
\hline 1977 & 4.490 .105 & & 2.809 .802 & & 1.160 .089 & & 8.459 .996 & \\
1978 & 4.527 .962 & 0,8 & 2.868 .737 & 2,1 & 1.284 .716 & 10,7 & 8.681 .415 & 2,6 \\
1979 & 4.583 .474 & 1,2 & 2.883 .097 & 0,5 & 1.326 .817 & 3,3 & 8.793 .388 & 1,3 \\
1980 & 4.599 .050 & 0,3 & 3.059 .845 & 6,1 & 1.346 .900 & 1,5 & 9.005 .795 & 2,4 \\
1981 & 4.595 .011 & 0,1 & 2.988 .813 & 2,3 & 1.357 .390 & 0,8 & 9.911 .111 & 0,7 \\
1982 & 4.576 .020 & 0,4 & 2.976 .880 & 0,4 & 1.358 .004 & 0,1 & 8.910 .104 & 0,3 \\
1983 & 4.556 .052 & 0,4 & 2.953 .411 & 0,8 & 1.361 .514 & 0,5 & 8.860 .977 & 0,6 \\
1984 & 4.546 .335 & 0,2 & 3.097 .231 & 4,9 & 1.344 .460 & 0,5 & 8.988 .026 & 1,4 \\
1985 & 4.592 .014 & 1,0 & 2.953 .095 & 4,7 & 1.306 .250 & 2,8 & 8.851 .159 & 1,5 \\
1986 & 4.647 .038 & 1,2 & 2.975 .482 & 0,8 & 1.305 .682 & 0,0 & 8.928 .202 & 0,9 \\
1987 & 4.743 .036 & 2,1 & 3.080 .019 & 3,5 & 1.343 .716 & 2,9 & 9.166 .771 & 2,7 \\
1988 & 4.867 .408 & 2,6 & 3.288 .279 & 6,8 & 1.398 .071 & 4,0 & 9.553 .756 & 4,2 \\
1989 & 5.026 .851 & 3,3 & 3.379 .028 & 2,8 & 1.439 .216 & 2,9 & 9.846 .095 & 3,0 \\
1990 & 5.160 .376 & 2,5 & 3.508 .391 & 3,8 & 1.486 .758 & 3,2 & 10.144 .525 & 3,0 \\
1991 & 5.221 .691 & 1,4 & 3.657 .116 & 4,2 & 1.524 .136 & 2,6 & 10.402 .943 & 2,5 \\
1992 & 5.231 .325 & 0,2 & 3.796 .986 & 3,8 & 1.571 .844 & 3,1 & 10.600 .155 & 1,9 \\
1993 & 5.236 .571 & 0,1 & 3.769 .242 & 0,7 & 1.588 .447 & 1,1 & 10.594 .260 & 0,1 \\
1994 & 5.247 .201 & 0,2 & 3.733 .007 & 1,0 & 1.594 .105 & 0,4 & 10.574 .313 & 0,2 \\
$80 / 94$ & 646.181 & 14,1 & 673.162 & 22 & 247.105 & 18,4 & 1.565 .518 & 17,4 \\
\hline
\end{tabular}

Um exame atento do Quadro 3.4, contudo, indica alguns problemas já na década dos 90 . O número de trabalhadores filiados às três principais central que havia chegado a 10,6 milhões em 1992 (o mais elevado até então), baixou para 10,5 milhões em fins de 1994. Contudo, foi uma perda muito pequena. Ainda em 1992, o volume de sindicalizados chegou a crescer um pouco. Mas, em 1993, houve uma pequena redução $(0,2 \%)$. Na verdade, no total das três principais centrais não houve perdas em número absoluto de sindicalizados até 1992 e depois, até 1994, o decréscimo no volume de sindicalizados foi muito pequeno $(0,2 \%)$ e limitado à CISL. Aparentemente, o sindicalismo italiano teria sido capaz de atravessar relativamente incólume a década dos 80 e, posteriormente, os primeiros anos da década dos 90 .

Mas o Quadro 3.4 não revela o problema maior do sindicalismo italiano num aspecto já mencionado: a baixa do nível de sindicalização dos trabalhadores empregados e o aumento da sindicalização dos aposentados e desempregados. Se contarmos apenas os trabalhadores sindicalizados com emprego, o declínio da taxa de sindicalização em todas as centrais aparece de modo muito nítido e a visão da situação do sindicalismo na Itália tornase mais sombria.

Assim, excluindo os inativos (aposentados e desempregados) do total de sindicalizados nas três centrais (10.574.313 em 1994), o número total de sindicalizados cai para 5.727.707, ou seja, para quase a metade (Quadros 3.5 e 3.6). A erosão de filiados atingiu a todas as centrais, embora com intensidade diferente. No total, com os aposentados excluídos, entre $1980 \mathrm{e}$ 1994, as três centrais perderam 22,3\% de filiados, ou seja, 1,6 milhão em números redondos.

Quadro 3.5

Itália: Trabalhadores em Atividade Inscritos na CGIL., na CISL. e na UIL (Aposentados excluídos)

\begin{tabular}{|c|c|c|c|c|c|c|c|c|}
\hline & \multicolumn{2}{|c|}{ CGLI } & \multicolumn{2}{c|}{ CISL } & \multicolumn{2}{c|}{ UIL } & \multicolumn{2}{c|}{ Total } \\
\hline Ano & Membros & $\begin{array}{c}\text { Var. } \\
\%\end{array}$ & Membros & $\begin{array}{c}\text { Var. } \\
\%\end{array}$ & Membros & $\begin{array}{c}\text { Var } \\
. \%\end{array}$ & Membros & $\begin{array}{c}\text { Var. } \\
\%\end{array}$ \\
\hline 1977 & 3.617 .387 & & 2.489 .513 & & 1.117 .754 & & 7.224 .654 & \\
1980 & 3.496 .537 & & 2.611 .710 & & 1.268 .823 & & 7.376 .070 & \\
1985 & 2.951 .342 & & 2.204 .060 & & 1.159 .519 & & 8.314 .921 & \\
1990 & 2.739 .700 & & 2.191 .977 & & 1.217 .682 & & 6.149 .359 & \\
1994 & 2.456 .463 & & 2.054 .462 & & 1.216 .782 & & 5.727 .707 & \\
$80-94$ & -1.036 .044 & $-29,7$ & -557.583 & $-21,3$ & -52.041 & $-4,1$ & -1.648 .363 & $-22,3$ \\
\hline
\end{tabular}

Em números absolutos, os inativos somavam, em 1994, aproximadamente 4,7 milhões num total de 10,5 milhões de inscritos nas três centrais. Na CGIL, 
o número de pensionati (2,7 milhões) supera o de assalariados (2,4 milhões) e é quase o dobro de trabalhadores do setor industrial. Na CISL, o número de assalariados é apenas ligeiramente maior do que o de aposentados (1,9 milhão contra 1,6 milhão). Deste ângulo, a UIL encontra-se numa situação melhor: 377 mil aposentados contra 1,1 milhão de assalariados em seus quadros. No total, nas três centrais, há 5,5 milhões de assalariados contra 4,7 milhões de aposentados.

\section{Quadro 3.6}

Itália: Total de sindicalizados na CGIL, na CISL. e na UIL. por setor

\begin{tabular}{|l|c|c|c|c|c|c|c|c|c|}
\hline & \multicolumn{2}{|c|}{ CGIL } & \multicolumn{2}{c|}{ CISL } & \multicolumn{2}{c|}{ UIL } & \multicolumn{2}{c|}{ TOTAL } \\
\hline Setor & $\begin{array}{c}\text { Números } \\
\text { absolutos }\end{array}$ & $\begin{array}{c}\text { Var. } \\
\%\end{array}$ & $\begin{array}{c}\text { Números } \\
\text { absolutos }\end{array}$ & $\begin{array}{c}\text { Var. } \\
\%\end{array}$ & $\begin{array}{c}\text { Números } \\
\text { absolutos }\end{array}$ & $\begin{array}{c}\text { Var. } \\
\%\end{array}$ & $\begin{array}{c}\text { Números } \\
\text { absolutos }\end{array}$ & $\begin{array}{c}\text { Var. } \\
\%\end{array}$ & $\begin{array}{c}\% \\
\text { de } \\
\text { sind. }\end{array}$ \\
\hline Agricultura & 303500 & 4,2 & 238263 & 7,2 & 139490 & 2,8 & 681253 & 3,9 & 93,5 \\
Indústria & 1180452 & 3,2 & 654066 & 4,6 & 382779 & 4,0 & 2217297 & 3,7 & 41,5 \\
Terciário & 500816 & 2,0 & 436749 & 5,3 & 268607 & 1,2 & 1206172 & 3,0 & 22,5 \\
Privado & & & & & & & & & \\
Terciário & 470862 & 2,2 & 580846 & 3,8 & 333067 & 0,2 & 1384775 & 2,3 & 46,1 \\
Público & 2455630 & 2,9 & 1909924 & 4,8 & 1123943 & 1,3 & 5489497 & 3,3 & 38,0 \\
Assalariados & 833 & 93,0 & 144538 & 7,9 & 92839 & 0,1 & 238210 & 5,9 & \\
Autônomos & 2759187 & 3,5 & 1613214 & 4,6 & 377323 & 5,6 & 4749724 & 4,0 & \\
Aposentados & 31551 & 6,3 & 65331 & 3,4 & & & 96882 & 4,4 & \\
Desempregados & 5247201 & 0,2 & 3733007 & 1,0 & 1594105 & 0,4 & 10574313 & 0,2 & \\
\hline Total geral & 524720 & \\
\hline
\end{tabular}

Fonte: Codara (1997).

Pelos dados da CGIL, entre os trabalhadores empregados, o número de filiados a essa central teria declinado de 2.747.013, em 1988, para 2.296.420, em 1997. O de aposentados, ao contrário, teria aumentado de 2.060.680 para 2.875.918, enquanto o de desempregados teria declinado de 59.713 para 36.123 , nos mesmos anos. Por isso, o total de inscritos teria passado de 4.867.406 para 5.208.461, entre 1988 e 1997, embora tivesse havido diminuição entre os sindicalizados com emprego (CGIL Nazionale, Departamento de Organização, fevereiro de 1998) $)^{13}$.

\footnotetext{
${ }^{13}$ Esse capítulo já estava escrito e o livro em fase de revisão quando recebi esses dados de Andrea Lanzi, do Instituto Della CGIL. no Brasil (Escritório do Rio de Janeiro), a quem agradeço a gentileza que me possibilitou oferecer aos leitores números mais recentes sobre a CGIL.
}

Quadro 3.7

Composição dos inscritos na CGIL., na CISL. e na UIL (1980-1994) \%

\begin{tabular}{|l|c|c|c|c|c|c|c|c|}
\hline & \multicolumn{2}{|c}{ CGIL } & \multicolumn{2}{c|}{ CISL } & \multicolumn{2}{c|}{ UIL } & \multicolumn{2}{c|}{ TOTAL } \\
\hline $\begin{array}{l}\text { Categoria de } \\
\text { sindicalizados }\end{array}$ & 1980 & 1994 & 1980 & 1994 & 1980 & 1994 & 1980 & 1994 \\
\hline Empregados & $76,0 \%$ & $46,8 \%$ & $85,4 \%$ & $55,0 \%$ & $94,2 \%$ & $76,3 \%$ & $81,9 \%$ & $54,2 \%$ \\
Assalariados & $75,8 \%$ & $46,8 \%$ & $82,0 \%$ & $51,1 \%$ & $85,1 \%$ & $70,5 \%$ & $79,3 \%$ & $51,9 \%$ \\
Autônomos & $0,2 \%$ & $0,0 \%$ & $3,4 \%$ & $3,9 \%$ & $9,1 \%$ & $5,8 \%$ & $2,6 \%$ & $2,3 \%$ \\
Aposentados & $24,0 \%$ & $52,6 \%$ & $14,6 \%$ & $43,2 \%$ & $5,8 \%$ & $23,7 \%$ & $18,1 \%$ & $44,9 \%$ \\
Desempregados & & $0,6 \%$ & & $1,8 \%$ & & $0,0 \%$ & & $0,9 \%$ \\
\hline & $100,0 \%$ & $100,0 \%$ & $100,0 \%$ & $100,0 \%$ & $100,0 \%$ & $100,0 \%$ & $100,0 \%$ & $100,0 \%$ \\
\hline
\end{tabular}

Fonte: Codara (1997).

Quando se examina a composição dos membros das centrais, percebe-se que o grupo dos aposentados foi o único no qual a sindicalização aumentou fortemente ao longo dos últimos anos. A comparação entre 1980 e 1994 é reveladora. Nesse intervalo, pelos dados de Codara, a porcentagem total de trabalhadores com emprego despencou de $81,9 \%$ para $54,2 \%$. O aumento da proporção de aposentados foi forte em todas as centrais, mas, em relação ao número de Filiados, UIL, seguida da CISL, foi a entidade em que houve maior aumento: na UIL, em 1980, os aposentados eram 5,8\%; em 1994, chegavam a $23,7 \%$; na CISL, no mesmo intervalo, foram de $14,6 \%$ para $43,2 \%$ e, na CGIL, de $24,0 \%$ para $52,6 \%$. O aumento da proporção de associados, segundo Codara, foi antes devido à queda da sindicalização dos trabalhadores com emprego do que ao aumento da sindicalização dos aposentados. A OIT estima, por volta de 1995, que desempregados e aposentados representariam 46\% do total de sindicalizados (OIT 1997-1998, p. 288).

Essa nova composição interna dos sindicatos muda o conjunto de recursos estratégicos de pressão à disposição do movimento sindical e afeta 0 poder sindical embora, em números absolutos, o total de sindicalizados continue grande. Aposentados, já ressaltamos, não têm força de pressão sindical, isto é, de atuação sobre os empregadores. É certo, contudo, que têm uma força eleitoral que poderia ser utilizada pelas centrais sindicais nessa conjuntura economicamente adversa. Nesse caso, a pressão dos aposentados teria que ser dirigida mais para o Estado do que para as empresas. Mas pode- 
se duvidar, se seguirmos o raciocínio de Thurow, que os aposentados possam ser mobilizados a favor dos trabalhadores com emprego ${ }^{14}$.

De modo sintético, deixando de lado os aposentados (e os desempregados, que não são percentualmente importantes) e considerando somente os assalariados, que constituem a base por excelência dos trabalhadores mais facilmente mobilizáveis pelos sindicatos, Codara traça o seguinte quadro da evolução das taxas nacionais de sindicalização italianas:

Quadro 3.8

Itália: Evolução da taxa nacional de sindicalização (Assalariados com emprego)

\begin{tabular}{|c|c|}
\hline Ano & Taxas \\
\hline 1980 & 40,0 \\
1981 & 47,6 \\
1982 & 48,2 \\
1983 & 45,2 \\
1984 & 44,9 \\
1985 & 42,0 \\
1986 & 40,3 \\
1987 & 39,9 \\
1988 & 40,0 \\
1989 & 39,4 \\
1990 & 39,3 \\
1991 & 39,1 \\
1992 & 39,1 \\
1993 & 38,6 \\
1994 & 38,0 \\
\hline
\end{tabular}

Fonte: ISTAT, Ocupazione e reddin da lavoro \& dipendente. Ano 19801994. Apud Codara (1997). Magistrados, militares e polícia foram excluídos dos cálculos ${ }^{15}$.

Esses cálculos estão próximos de outras avaliações. Considerando apenas os empregados, Visser calculou em $40 \%$ a taxa de sindicalização italiana em 1989 (Visser, 1994a, p. 19). O mesmo autor, em outro trabalho,

\footnotetext{
${ }^{14}$ De acordo com Thurow, seria difícil aos aposentados, que compõem a faixa dos idosos, juntarem-se às reivindicações de outros segmentos profissionais em atividade. Os aposentados seriam eleitores de um só objetivo, isto é, o de ampliar os benefícios sociais do Estado a seu favor. Avaliando as demandas dos idosos aposentados, Thurow chega mesmo a levantar a hipótese de que, nos próximos anos, a guerra de classes poderá não ser a dos pobres contra os ricos, mas dos jovens contra os idosos, que se apoderam da maior parte dos benefícios sociais à medida que aumenta proporcionalmente o seu número (Thurow, 1997, p. 141).

${ }^{15}$ A partir de 1993, houve mudança de metodologia de cálculo, que trouxe pequena alteração nos resultados. Assim, pela nova metodologia, a proporção de sindicalizados seria de $38,8 \%$ e, em 1994, de 38,2\% (Codara, 1997, Nota Metodológica).
}

focalizando apenas o setor privado, estima a média de $38 \%$ de sindicalizados no período de 1986-1991 e de 32\% em 1990 (contra 43\% em 1989) (Visser, 1994b, p. 82). Esses cálculos estão próximos aos que são apresentados na publicação da OIT (1997-1998). Nesta, 6.392 mil pessoas estariam sindicalizadas nas três principais centrais em 1994 contra 6.860 mil em 1985 . Esses números não incluem os desempregados e aposentados (45,5\% do total de sindicalizados). A eles deve-se acrescentar o de sindicalizados em outras entidades não filiadas às três grandes confederações, número estimado em aproximadamente um milhão. Lembremos que os dados da OIT para a categoria "trabalhadores" excluem autônomos, desempregados e aposentados. Em termos percentuais, há declínio nos dois grupos entre 1985 e 1995: 32,9\% para o total da mão de obra não agrícola contra 30,6\%, nas duas datas respectivamente. Considerando apenas os trabalhadores, as taxas são: 47,6\% e $44,1 \%$ nos mesmos anos.

Chegava, assim, o fim do que alguns autores denominaram de "decênio feliz" do movimento sindical italiano, durante o qual os trabalhadores teriam obtido um conjunto de vantagens mais elevado do que o de qualquer outro sindicalismo da Europa (redistribuição de renda a favor dos assalariados, redução dos ritmos e horas de trabalho e outros benefícios) (Accornero; Bibes \& Groppo, 1990, pp. 99102).

Também na Alemanha, se os anos 70 podem ser vistos como a década do sindicalismo, os de 80 tornaram-se a "década dos empregadores" (Jacobi \& Müller-Jentsch, 1996, p. 127). A central mais atingida pela queda da sindicalização foi a Federação Alemã dos Sindicatos (DGB), que agrupa $80 \%$ dos trabalhadores sindicalizados do país. A DGB é formalmente independente de todo partido político, mas os laços com o Partido Social-Democrata são fortes. A maioria dos seus dirigentes e funcionários é filiada a esse partido. Contudo, a DGB e a maioria dos demais sindicatos reservam uma pequena parte dos lugares nas suas executivas para membros e simpatizantes do Partido Democrata Cristão (CDU). Além da DGB, existem outras centrais ou organizações autônomas importantes. Os servidores públicos com garantia de emprego e outras vantagens (Beamte), que entre nós teriam o antigo status de "estatutários", quer dizer, regidos pelo Estatuto do Funcionalismo Público, estão representados pela Associação dos Funcionários Públicos (DBB), com aproximadamente um milhão de membros, mas não têm direito de negociação coletiva e de fazer greve. O Sindicato Alemão dos Empregados Públicos (DAG), com pouco mais de meio milhão de associados, negocia às vezes 
separadamente, às vezes em conjunto com a DGB. Além dessas entidades, existe uma central sindical de tendência democrata cristã, com apenas 315 mil membros (1992) (Mielke; Rütters \& Tudyka, 1996; Jacobi; Keller \& MüllerJentsch, 1993). A DBB teve um forte aumento no número de filiados entre 1991 e 1992 (cerca de 42 mil).

A DGB filia conjuntamente trabalhadores manuais (Arbeiter) e empregados não manuais (Angestelle) ${ }^{16}$. Em 1950, possuía 5,4 milhões de membros, representando $35,7 \%$ da força de trabalho. Em 1990, embora o número de filiados tivesse aumentado para 7,9 milhões, a proporção declinou para $29,0 \%$. No conjunto, considerando os filiados a todas as centrais, a taxa nacional de sindicalização estava em 39,5\%, em 1950. Em 1955, atingiu o pico de $39,7 \%$. No entanto, tal como aconteceu com os efetivos da DGB, no total de todas as confederações, houve um aumento do número absoluto de sindicalizados de seis milhões, em 1950, para 9,6 milhões em 1990. Em relação à década dos 50, o progresso foi forte. Mas acontece que, nos últimos anos de 1980, o aumento do número de trabalhadores sindicalizados foi extremamente pequeno e, finalmente, na década dos 90, começou a declinar Por exemplo: em 1980, havia 9,5 milhões de sindicalizados; em 1985, 9,3 milhões e, em 1990, 9,6 milhões (Jacobi; Keller \& Müller-Jentsch, 1993, p. 232). Em 1995, somando as duas Alemanhas, o volume de sindicalizados seria de 9.300 mil (OIT, 1997-1998).

Nos anos 90, a DGB, a mais importante das centrais sindicais alemãs, com mais de dez milhões de membros, foi a central que sofreu as maiores evasões. De 1991 para 1992, deixaram a central cerca de 785 mil membros (Mielke; Rütters \& Tudyka, 1994, p. 160). Em 1992, onze milhões de trabalhadores estavam filiados à DGB; em 1996, havia apenas nove milhões. (Deve-se considerar que, com a anexação do lado oriental, houve aumento da filiação nessa central.) Em comparação com o ano anterior, a DGB registrou uma perda de 3,7\% (IWD, 1997), ou seja, perdeu $350 \mathrm{mil}$ membros. Em 1997, os resultados mais negativos para a DGB foram registrados na ex-República Democrática Alemã. No caso, provavelmente o desemprego nessa parte da Alemanha tenha contribuído fortemente para o rebaixamento dos índices de sindicalização. As perdas, em 1996, foram da ordem de 273 mil. Em 1994, a taxa de sindicalização, calculada sobre o

\footnotetext{
${ }^{16}$ Um equivalente brasileiro seria, no interior das indústrias, a distinção entre "horistas" e "mensalistas".
}

total de assalariados, caiu para 30\% (OIT, 1996). Lembremos que Visser (1991) registrava 33,8\% em 1989 e que, pelas estatísticas ajustadas de Clara Chang e Constance Sorrentino, em 1980, a porcentagem era de 36\% (Chang \& Sorrentino, 1991, p. 50). Pela OIT (1997-1998), considerando apenas trabalhadores, a proporção teria caído de 35\% em 1991 para 28,9\% em 1995. Para o total da força de trabalho não agrícola, o declínio teria sido de $30,7 \%$ para $29,6 \%$ para os mesmos anos.

Como mencionamos, os cálculos para a Alemanha sobre o volume de sindicalizados foram afetados pela incorporação da antiga República Democrática Alemã. Antes da reunificação, os trabalhadores da Alemanha Oriental estavam representados pela Confederação dos Sindicatos Livres Alemães (FDGB), integrada ao aparelho do Estado e ao Partido Socialista Unificado, como se denominava o Partido Comunista na Alemanha Oriental. Os dirigentes da central habitualmente eram filiados ao partido. Seu papel era encorajar os aumentos de produção e distribuir benefícios sociais (facilidade de viagens, concessão de feriados e outras vantagens). Os sindicatos não tinham funções de negociação coletiva. Depois da reunificação de outubro de 1990, os trabalhadores do Leste europeu foram integrados aos sindicatos da DGB e os sindicatos da época comunista foram dissolvidos. A integração levou a um súbito e extraordinário aumento de cerca de $46 \%$ do número de trabalhadores filiados à DGB (Hyman, 1996b, p. 609).

A unificação colocou, também para os sindicatos, muitos problemas. A complexa legislação da República Federal Alemã foi estendida à exAlemanha Oriental anexada. A economia da Alemanha Oriental era de baixa produtividade, menos da metade da do lado ocidental. A jornada de trabalho do Leste era 43 3/4 horas semanais, contra 38,5 no lado ocidental. Aluguéis, transportes e bens de consumo eram fortemente subsidiados (Hyman, 1996b). No lado oriental, não havia experiência de negociação coletiva, nem por parte dos gerentes e administradores das empresas do Estado, nem dos diretores de sindicatos, muitos dos quais eram suspeitos de pertencer à polícia política (Stassi). Um trabalho de treinamento para funcionários dos ex-sindicatos comunistas, nem sempre bem sucedido, teve de ser empreendido pelos sindicalistas da DGB. (Em 19911992, os acordos coletivos levaram a reduzir a jornada para 40 horas salariais e a elevar, em alguns setores, os salários do lado oriental de $60 \%$ a $80 \%$ dos salários dos trabalhadores ocidentais [Hyman, 
1996b]). A desindustrialização subsequente e o desemprego levaram logo depois a uma forte queda do número de trabalhadores sindicalizados ${ }^{17}$.

Na DGB estão filiados 16 sindicatos nacionais de empregados de vários setores. O IG-Metall, que agrupa os trabalhadores do setor metalúrgico e mecânico (com aproximadamente 2,7 milhões de membros em 1996), é o mais importante. É seguido de perto pelo sindicato dos serviços públicos e transportes (1,7 milhão).

Na comparação entre 1996 e 1995, todos os sindicatos sofreram perdas. As maiores foram registrados nos segmentos econômicos mais atingidos pela reestruturação: têxtil e vestuário, móveis, plásticos e couros. $\mathrm{O}$ único sindicato que registrou um pequeno aumento no número de filiados (0,3\%) foi o da polícia (Die Quelle, Februar 1997). Os menores prejuízos foram sofridos pelos sindicatos ligados ao serviço público, como de servidores públicos e transporte, o sindicato de educação e ciência (dos professores). Perdas menores aconteceram no sindicato dos correios no de ferroviários. Esse último balanço refere-se às duas Alemanhas. $\mathrm{Na}$ Alemanha Ocidental, esses últimos sindicatos perderam 8,8\% e, com isso, menos que os $11,6 \%$ na média de todos os sindicatos no lado oriental. No Ocidente, as perdas nesses setores públicos somam apenas $0,4 \%$, menos que os 1,2\% na média dos quinze sindicatos (IWD, 1997).

Esses dados indicam que, também num dos países em que o sindicalismo havia conseguido evitar perdas graves durante a década dos 80 , movimento sindical no seu conjunto começou a sofrer as consequências negativas das mudanças tecnológicas e econômicas. É digno de menção que isso aconteceu com um movimento sindical solidamente implantado nas empresas, com fortes ligações políticas com o Partido Social-Democrata e sem ter tido de enfrentar uma oposição dura de parte do governo democratacristão. Para o futuro do sindicalismo alemão, é especialmente preocupante o fato de que, também em algumas áreas modernas da economia, em que os sindicatos já estavam consolidados, tenha havido erosão da sindicalização. Desse prisma, é significativo que, entre os sindicatos que registram mais perdas de associados, esteja um que deveria ter se aproveitado das transformações estruturais da economia em virtude do aumento da demanda de mão de obra: o Sindicato da Comunicação. Trata-se de um ramo em expansão mas, mesmo assim, o sindicato ficou, em 1996, com 5\% a menos de associados do que no ano anterior (IWD, 1997, p. 8).

\section{A EXCEÇÃO NÓRDICA}

No quadro geral de declínio das taxas de sindicalização, os países nórdicos constituem um caso excepcional de resistência às forças de desestabilização do sindicalismo. As perdas durante os anos 80 foram pequenas. No entanto, em todos os quatro países, o modelo de relações centralizadas, do estabelecimento de políticas salariais nacionais acompanhadas de negociação por empresas, políticas sociais, baixos índices de inflação e de emprego começou a ser atingido por mudanças que se davam na economia. Especialmente no caso sueco, houve fortes perdas em produtividade. $\mathrm{Na}$ área sindical, a expansão do sindicalismo do setor público e dos trabalhadores manuais levou ao fortalecimento de novas entidades sindicais, que se afastaram do controle das centrais de trabalhadores manuais. $\mathrm{O}$ processo levou a um enfraquecimento das relações entre os sindicatos e os partidos socialdemocratas, ao aumento dos votos dos partidos "burgueses" e a derrotas eleitorais da socialdemocracia.

A Suécia foi outro dos poucos países a registrar aumento dos níveis de sindicalização entre 1980 e 1990. Visser (1994b, p. 82), nos anos negros para o sindicalismo europeu da década dos 80 , registra aumentos pequenos na taxa total de sindicalização sueca ( $82 \%$ como média no período de $80-85$ e $84 \%$ 
no de 86-91). Mas acusa, nos últimos anos, pequeno declínio das taxas nacionais, pela primeira vez desde meados de 1920 . No caso, provavelmente o desemprego, que se aproximou dos $10 \%$ em 1993, tenha sido um dos fatores de queda num país onde, no setor industrial, a sindicalização havia chegado a $100 \%$ (Visser, 1994a, p. 27). Anders Kjellberg considera que o pico da sindicalização foi atingido em 1986, com 84\%. Em 1990, a taxa teria caído para $82 \%$ (Kjellberg, 1993, p. 118). A publicação da OIT, de 19971998, traz, para 1994 , uma taxa de $77,2 \%$ para o total da força de trabalho (agricultura excluída) e de 79,3\% em 1985, quer dizer, ligeiro declínio nesse grupo. Entre os trabalhadores, no entanto, ela teria passado de 83,8\% em 1985 para 91,1\% em 1995, quer dizer, uma situação em que a sindicalização praticamente atingiu seu ponto de saturação. Mas, no número total de sindicalizados, entre 1985 e 1995, teria havido uma diminuição de 4,8\%: 3 341 mil em 1985 e 3.180 mil em 1995 (OIT, 1997-1998).

Três confederações, ou "centrais", organizavam a quase totalidade da força de trabalho: a Confederação dos Sindicatos Suecos (LO), que agrupa os trabalhadores manuais, com 1,9 milhão de membros "ativos", isto é, excluindo os aposentados, estudantes e outras categorias muito inexpressivas de associados; a Organização Central dos Empregados Assalariados (TCO), que reúne os não manuais, com 1.440 mil filiados; e a Confederação das Associações Profissionais (SACO), que reúne os profissionais e técnicos, com 260 mil associados (dados de 1990). A divisão organizatória é indicativa da forte separação entre manuais e não manuais no interior do sindicalismo sueco (Visser, 1996b; Brulin, 1995; Martin, 1995; Kjellberg, 1994; Rehn \& Viklund, 1992).

A ligação com o Partido Social-Democrata (que havia permanecido ininterruptamente no poder de 1932 a 1976) e um sistema centralizado de negociações com um patronato bem organizado nacionalmente permitiram ao sindicalismo (e ao "socialismo sueco") atravessarem a difícil década dos 80 sem graves perdas, praticando um modelo de relações de trabalho que tem sido classificado de "corporativismo social", neocorporativismo ou simplesmente corporativismo (para a definição desses conceitos, ver Apêndice VI). Mas, desde então, o modelo sueco começou a sofrer as consequências da globalização, especificamente da concorrência internacional cada vez mais acirrada e da perda de competitividade das multinacionais suecas. Entre 1974 e 1977 e entre 1985 e 1989, de acordo com Kjellberg (1993, p. 93), a produtividade industrial do país tem ficado atrás da dos onze principais competidores e, desde 1974, abaixo da média dos países da OECD. Nos anos 60, no ranking de países altamente industrializados, a Suécia ocupava o terceiro lugar em nível de produtividade. Nas décadas dos 70 e dos 80 , despencou para o oitavo. A Suécia foi um dos países desenvolvidos que mais se "desindustrializaram". Entre 1966 e 1994, a queda da participação do emprego industrial no total do emprego civil declinou de $33 \%$, em meados dos anos 60, para $17 \%$ em 1994. Mais de $70 \%$ do emprego civil sueco está atualmente no setor de serviços (World Economic Outllook, "Meeting the Challenges of Globalization in the Advanced Economies", may 1997, p. 54).

No plano político, depois da derrota de 1976, os socialdemocratas voltaram ao poder por meio de um governo de coalizão (1976-1982). Conseguiram ainda três vitórias sucessivas na década dos 80. Mas, em inícios dos 90, sofreram forte derrota nas eleições de setembro de 1991, quando a socialdemocracia recebeu apenas $37,6 \%$ dos votos nacionais.

"Pela primeira vez desde 1928, o líder do Partido Conservador tornou se primeiro-ministro" (Pontusson, 1996, p. 199). As taxas de greve voltaram a aumentar. O longo período de paz social chegou ao fim em 1980 "com um gigantesco conflito" (Rehn \& Vicklund, 1992) e um forte aumento de dias perdidos por greves nos setores de educação, de saúde e de administração pública. Nesse ano, contra uma média de dois dias perdidos por greves em mil empregados em 1990, a Suécia teve 16 (Sweeney \& Davies, 1996).

$\mathrm{Na}$ área trabalhista, o sindicalismo sueco, ideologicamente unificado, fragmentou-se em quatro blocos de setores profissionais específicos, com força relativamente igual, representando separadamente, no setor privado, os manuais e os não manuais e, no setor público, também os manuais e os não manuais (Kjellberg, 1994; Clement, 1994; Goetschy, 1990). No Quadro 3.9, percebe-se que as quedas na taxa de sindicalização de todos os segmentos foram inexistentes ou muito pequenas. As maiores quedas foram no setor privado, entre os trabalhadores manuais. Nesse grupo, depois de um pico de sindicalização de $84 \%$ em 1986-1987, a taxa declinou para $77 \%$.

$\mathrm{Na}$ Finlândia, o sindicalismo avançou fortemente justamente nos anos em que, em quase toda a parte, tinha recuado. País de industrialização tardia, a Finlândia passou a integrar com atraso o "modelo nórdico". Durante largo período, o movimento sindical esteve dividido entre a 
socialdemocracia e os comunistas (esses também, após 1961, divididos entre si). A força da socialdemocracia nunca foi equivalente à atingida, por exemplo, na Suécia. O patronato, mais conservador e autoritário, aceitou com dificuldade um modelo centralizado de negociação coletiva. Talvez por isso as taxas de greve finlandesas tenham sido mais elevadas do que em outros países nórdicos.

Quadro 3.9

Suécia: Taxa de sindicalização 1975-1991

\begin{tabular}{|l|c|c|c|c|c|}
\hline & 1975 & $1980 / 1981$ & $1986 / 1987$ & 1990 & 1991 \\
\hline Trabalhadores manuais \\
\hline Homens & 84 & 86 & 87 & 82 & 80 \\
Mulheres & 67 & 80 & 87 & 81 & 81 \\
Total & 77 & 83 & 87 & 82 & 81 \\
Setor privado & 78 & 82 & 84 & 78 & 77 \\
Setor público & 76 & 86 & 92 & 87 & 87 \\
\hline Não manuais & 80 & 84 & 83 & 78 & 78 \\
\hline Homens & 78 & 84 & 85 & 83 & 83 \\
Mulheres & 79 & 84 & 84 & 80 & 80 \\
\hline Total
\end{tabular}

Fontes: LO 1989: AKU (Labor Force Surveys, SCB; opud Ferner \& Hyman (Kjellberg, 1993, p. 119).

Em meados de 1960, a porcentagem de trabalhadores sindicalizados era de cerca de $40 \%$ (Lilja, 1993, p. 200), proporção elevada, notadamente se comparada com a Europa latina, mas baixa se cotejada com os padrões nórdicos. Em 1970, os níveis de sindicalização finlandeses atingiam 58,8\%, porcentagem ainda inferior aos da Áustria $(70,4 \%)$, da Dinamarca $(62,2 \%)$ e da Suécia $(74,2 \%)$. Mas, em 1988, mesmo nos anos difíceis da década dos 80, a taxa de sindicalização da Finlândia alcançou 90,0\% (Visser, 1991, p.101). O aumento foi extremamente rápido, fazendo que esse país passasse a integrar o chamado "modelo nórdico": altas taxas de sindicalização, negociações centralizadas, organização sindical de local de trabalho, empregadores propensos - ainda que mais relutantemente do que nos outros países do bloco - à negociação com o setor sindical, neocorporativismo, partido Social-Democrata poderoso. O sindicalismo está organizado por indústria (industrial unions), não existindo sindicatos de ofício (craft unions). A principal organização sindical finlandesa é a Organização Finlandesa Central dos Sindicatos (SAK), de longe a mais importante, filiando, além dos trabalhadores manuais, cerca de $30 \%$ de white-collars. A
Confederação dos Empregados Assalariados (TVK) agrupa apenas sindicatos que representam empregados não manuais, majoritariamente do setor público, com muitos filiados do sexo feminino do setor privado e do público. Outras duas organizações menores representam técnicos e profissionais com formação acadêmica elevada (Lilja, 1993, p. 200).

Lilja registra, com base no Anuário Estatístico da Finlândia, um total de cerca de 1,8 milhões de trabalhadores inscritos nas principais organizações sindicais, o que corresponderia a uma taxa de sindicalização de 86\% em 1989 (Lilja, 1993, p. 201). Não temos dados percentuais para os anos seguintes, mas as estatísticas da OIT, que utiliza a mesma fonte (Anuário Estatístico da Finlândia), indicam 2,1 milhões de sindicalizados no país (OIT, 1996). Em comparação com 1989, teria havido um aumento bruto de 337,6 mil trabalhadores sindicalizados, o que permite supor que as taxas de sindicalização tenham aumentado. Os dados da OIT (1997-1998), dão, para $1995,59,7 \%$ de sindicalizados no setor não agrícola e 79,3\% para os trabalhadores. Em 1985, esses números eram, respectivamente, 61,4\% e $68,3 \%$, o que indicaria aumento de $1,7 \%$ para as taxas nacionais de sindicalização e declínio de $11,0 \%$ se considerarmos apenas os trabalhadores. No total, em números absolutos, houve declínio da sindicalização nos últimos dez anos: de 1.411 mil em 1985 para 1.377 mil, em 1995.

Na Dinamarca, onde contrariamente à Finlândia, os sindicatos organizados por ofício são importantes, a sindicalização não apenas cresceu durante a década dos 80 como se manteve estável nos anos 90. Em 1990, $15 \%$ do total de trabalhadores dinamarqueses estavam em sindicatos organizados por ofício; $36 \%$ em "sindicatos gerais"; $14 \%$ em sindicatos de profissionais e os demais em outros tipos de organização. Hoje, o maior sindicato, entre os 21 filiados à central LO, é um sindicato de serviços e escritórios, o Sindicato dos Empregados de Comércio e de Escritórios, com mais de 300 mil membros, que organiza tanto empregados do setor privado como público (Scheuer, 1993, p. 175).

O número de trabalhadores sindicalizados passou de $932 \mathrm{mil} \mathrm{em}$ 1960 para 1,1 milhão em 1970, chegando a 1,7 milhão em 1980 e a dois milhões em 1989, significando $79,4 \%$ da força de trabalho nacional sindicalizada (Scheuer, 1993, p. 177). Em 1994, aproximadamente 2,1 milhões de assalariados estavam filiados a sindicatos $(93,6 \%)$. Em 1994, as estatísticas registravam 2,162 milhões, isto é, 91,7\% do total de empregados 
assalariados do país (OIT. 1996), o que equivale a dizer que praticamente todos os empregados pertenceriam a algum tipo de associação.

Há algumas divergências entre esses dados e outros divulgados pela própria OIT e por outros pesquisadores. Para Visser, o total de membros sindicalizados em 1980 seria de 91,4\%, com declínio para 86,0\% em 1988. Considerando apenas assalariados com emprego, para os mesmos anos, as porcentagens respectivas seriam de $76,5 \%$ e $73,3 \%$. Nos dois casos, haveria queda durante a década dos 80 (Visser, 1991, p. 101).

Essas porcentagens, embora próximas, não conferem inteiramente com a publicação da OIT (1997-1998), que dá cifras menores para o volume de sindicalizados na Dinamarca. Por essa publicação, o número total de filiados a sindicatos seria de 1.730 mil em 1985 e 1.808 mil em 1994, abaixo dos dois milhões que apareceram anteriormente. Em termos percentuais, em 1985, 67,4\% do total da mão de obra não agrícola e 78,3\% dos trabalhadores estariam sindicalizados. Em 1994, para os mesmos anos, as porcentagens seriam, respectivamente, $68,2 \%$ e $80,1 \%$. Nesse caso, não teria havido declínio mas um pequeno aumento dos níveis de sindicalização. É possível que essas diferenças decorram de alguma alteração na metodologia. Visser (1991) indica problemas relacionados com a inclusão ou não dos aposentados nas estatísticas dinamarquesas. Nas organizações de não manuais, os aposentados não estão incluídos, mas entram nas estatísticas da central LO (cf. Anexo Metodológico).

Tal como nos outros países escandinavos, as mudanças ocorridas estão afetando a estrutura da barganha centralizada e o modelo anteriormente estabelecido pela socialdemocracia. Estão em curso mudanças em direção a formas de negociação coletiva mais pluralísticas e descentralizadas e em direção ao uso de estratégias patronais de implementação de formas de participação e envolvimento dos empregados com a companhia (Amoroso, 1992, p. 94). Os laços dos sindicatos com o Partido Social-Democrata enfraqueceram-se, ao mesmo tempo em que a esquerda se dividia; o aumento do número de empregados não manuais aumentou a segmentação do mercado de trabalho e fortaleceu as organizações sindicais dos empregados white-collars, com estratégias de negociação mais fragmentadas que punham em risco a chamada "estratégia solidária" (Amoroso, 1992; Scheuer, 1993). Em começos de 1980, a
Dinamarca possuía uma enorme dívida pública e o desemprego atingia $12 \%$ da força de trabalho (Christiansen, 1994).

$\mathrm{Na}$ Noruega, até começos da década dos 90, apesar da crescente internacionalização da economia e mutações da estrutura industrial e tensões no sistema político, as principais instituições do sistema de relações de trabalho haviam permanecido intactas (Dolvik \& Stockland, 1993, p. 143). Em 1935, tal como na Suécia, a central sindical LO e a central patronal NAF selaram um pacto de paz industrial e a socialdemocracia (Partido Trabalhista) foi ao poder com apoio do Partido Agrário. Um longo período de paz social abriu-se desde então. A partir do final da guerra, até 1964, o Partido Trabalhista não perdeu uma só eleição. Mas, a partir de 1966, o quadro começou a mudar. Em 1973, o Partido Trabalhista sofreu uma derrota histórica, baixando para $35 \%$ dos votos, a porcentagem mais baixa desde 1930. Apesar disso, em aliança com outros partidos, conseguiu voltar ao poder do qual estava afastado desde 1965, derrotado por uma coalizão dos partidos de centro (Liberal, Agrário e Cristão) (Mjoset; Cappelen; Fagerberg \& Tranoy, 1996, p. 240).

Depois de 1966, seguiu-se um período de alternância no poder entre a socialdemocracia e a coligação de outros partidos. Em 1990, os conservadores foram vitoriosos.

O declínio do Partido Trabalhista, além de refletir provavelmente as mudanças estruturais em curso que alteraram a composição do eleitorado, liga-se ao declínio de seu prestígio na sua própria clientela tradicional. $\mathrm{Na}$ década dos 80, o Partido Trabalhista perdeu sua hegemonia entre os eleitores das classes trabalhadoras. Em 1957, 76\% dos trabalhadores votavam por esse partido. Em 1989, a porcentagem correspondente era de 47\%; 12\% votaram por outro partido socialista de esquerda e $41 \%$ por partidos não socialistas. Em 1989, 33\% dos trabalhadores de sindicatos da LO votaram por partidos não socialistas (Dolvik \& Stockland, 1993, p. 158).

Na central sindical LO estavam filiados, em 1990, 29 sindicatos com um total de 785 mil membros, dos quais cerca de 600 mil com emprego: 340 mil no setor privado, 160 mil no setor municipal e 100 mil no setor público. As negociações coletivas se efetuam tanto no plano nacional como por local de trabalho. Os acordos nacionais devem ser aprovados em votação por todos os trabalhadores sindicalizados. Tal como em outros países, os sindicatos de trabalhadores fabris do setor de mercado 
começaram a declinar enquanto ascendiam outras organizações representativas dos empregados não manuais e do setor público. Na década dos 80, a LO perdeu 60 mil membros, enquanto as entidades do setor público ganharam aproximadamente 90 mil novos associados. O sindicato dos trabalhadores municipais (Kommuneforbundet) é hoje o maior sindicato norueguês.

Para os padrões nórdicos, a taxa nacional de sindicalização é bem mais baixa. Em termos porcentuais, em 1985, 50,7\% da mão de obra não agrícola pertenciam a sindicatos. Em 1995, houve um pequeno acréscimo: $51,7 \%$. Considerando apenas os trabalhadores, nesses mesmos anos, as taxas de sindicalização permaneceram as mesmas: 55,7\% (OIT, 1997 1998). Em números absolutos, a sindicalização passou de 971 mil, em 1985 , para 1.068 mil, em 1985.

\section{OS PAÍSES IBÉRICOS}

A Espanha e Portugal constituem casos em que a organização sindical, no sentido em que estamos usando o conceito, não teve tempo de se desenvolver. Em Portugal e na Espanha, após o fim do sistema corporativo do sindicato único, os anos favoráveis para a expansão do sindicalismo autônomo foram muito curtos ${ }^{18}$. Convém listar alguns dos problemas comuns que o sindicalismo recém-saído dos controles de um regime político autoritário conservador teve de enfrentar: a) o decréscimo das camadas de trabalhadores que tradicionalmente constituíram as bases de sustentação do sindicalismo, agravado pelos altos níveis de desemprego; b) a dificuldade, por parte dos três atores principais (sindicatos, empresas, governo), de institucionalizar um modelo de relações de trabalho em que os acordos coletivos constituem peça essencial; c) os problemas de superação da cultura corporativa, não apenas do patronato e das autoridades governamentais, mas dos próprios dirigentes sindicais.

A profundidade e o ritmo de destruição das estruturas corporativas foram diversos em Portugal e na Espanha. Para Fernandes (1985), em

\footnotetext{
${ }^{18}$ Referindo-se à Espanha, Estivill e Hoz (1992, p. 285) notam que a ironia da situação espanhola reside no fato de que o declínio do sindicalismo ocorreu interior de um sistema político legal favorável aos sindicatos, quando a democracia estava sendo consolidada e um partido de origem e programas pró-operário, o PSOE, foi ao poder.
}

Portugal, o direito sindical corporativo se manteve até 1976 e as estruturas corporativas permaneceram em pé pelo menos até 1985, com outros dirigentes e num contexto de semianomia. $\mathrm{O}$ sistema da contribuição obrigatória descontada pelo empregador em favor do sindicato (check-off) foi suprimido pelo governo socialista apenas em 1977 (Barreto, 1993, p. 466). Para Lima (1991), a institucionalização de um sistema de relações industriais e de uma democracia representativa, em Portugal, só teriam se completado em 1981.

Paradoxalmente, se fatores políticos, especificamente a constituição de um sistema democrático e a aproximação dos sindicatos com partidos de esquerda no governo, facilitaram a constituição de um novo modelo de relações de trabalho, as condições econômicas, marcadas por altíssimas taxas de desemprego, foram particularmente negativas para os trabalhadores ${ }^{19}$.

Para os objetivos deste texto, a colocação da Espanha e de Portugal num grupo separado vem do fato de se tratar de dois países cujo sindicalismo, enquanto organização autônoma dos trabalhadores começou a existir há muito pouco tempo, após o fim dos dois tipos de regimes autoritários, corporativos, antiliberais, nacionalistas e anticomunistas que haviam sobrevivido à Segunda Guerra. Todavia, embora o regime franquista e o salazarista sejam algumas vezes identificados, as diferenças são muitas. Para o período que segue o após-guerra, Tusell observa que a maior semelhança entre ambos se produziu entre os anos de 1945 e 1956 pela mútua reivindicação de uma herança comum, o "corporativismo católico" (Tusell, 1988, p. 278).

Também o modo de transição do autoritarismo para a democracia foi diferente nos dois países, o que provavelmente afetou as características do sistema de relações de trabalho e do sindicalismo que se seguiu: transição pacífica e controlada na Espanha, em certa medida preparada por medidas de liberalização progressiva; revolucionária e súbita, em Portugal.

\footnotetext{
${ }^{19}$ A proporção de desempregados, na Espanha, passou de 11,5\%, em 1980, para 21,2\% em 1986 (Estivill \& Hoz, 1992, p. 270). Em Portugal, a taxa de desemprego, que era de 2,1\% em 1974 (bastante baixa para os padrões ocidentais), subiu em 1976 para 6,5\%, elevando-se para 8,2\% em 1979; desceu ligeiramente em 1980, mas voltou em 1981 para os padrões de 1979. A partir desse ano, as taxas do desemprego feminino foram particularmente aumentadas, entre outros motivos pelo retorno da população das ex-colônias (Lima, 1991, p. 913).
} 
A construção de um sindicalismo autônomo liga-se à formação de uma sociedade democrática e pluralista, fato que implica, obviamente, alterações nas instituições, nas leis e nos costumes: o Estado precisa abrir mão dos controles autoritários sobre os grupos sociais; os empresários precisam aprender a aceitar as organizações dos trabalhadores e essas precisam aprender; por sua vez, a aceitar a legitimidade do lucro e dos interesses das empresas, ideia difícil de ser aceita pelas facções mais de esquerda, que geralmente têm papel importante no combate aos regimes autoritários de direita.

Como antes já havia acontecido com o fim da Itália fascista e da Alemanha nacional-socialista, a criação de um sindicalismo livre na Península Ibérica necessitou não apenas de uma ordem institucional democrática, liberal e pluralista como também de uma economia de mercado. A passagem, pois, de um modelo corporativo estatal para outro de autonomia e negociação é um processo relacionado com transformações globais da sociedade, da economia, do sistema político e também da cultura predominante nos meios empresariais e dos sindicatos de trabalhadores ${ }^{20}$.

Neste ponto, cumpriria abrir um parêntesis para uma observação lateral: embora estejamos nos referindo ao franquismo de modo geral, durante os longos anos da ditadura do General Franco, o modelo de relações de trabalho passou por mudanças que iriam repercutir posteriormente no sindicalismo sob regime democrático. Modesto Escobar, por exemplo, distingue uma primeira fase do franquismo (1939-1958) baseado nas corporações. Os sindicatos admitidos eram os oficiais, aos quais tanto os empregados como os empregadores deviam obrigatoriamente se filiar, num tipo de estrutura "vertical" fundada na concepção de que não havia nenhum conflito básico entre os interesses dos empregadores e os dos seus empregados. Os salários e as condições de trabalho eram estabelecidos por decreto governamental. Mas, entre 1958 e 1975, começou uma segunda fase, caracterizada pela liberalização econômica, aberta para os mercados internacionais, que substituiu a meta da autarquia econômica. Nessa segunda fase, os antigos jurados de empresa, a primeira forma de conselhos de trabalhadores estabelecidos logo após o final da Segunda Guerra, transformaram-se em comitês de empresa. Na fase de transição para a

\footnotetext{
${ }^{20}$ A Grécia constitui outro caso de transição que poderia ser colocado ao lado de Portugal e da Espanha, mas sobre o qual não temos condições de tentar nem mesmo uma análise sumária.
}

democracia, os mecanismos corporativos foram sendo substituídos. Aumentaram as possibilidades de eleição de delegados independentes para os comitês de empresa. Por essa razão, Escobar entende que a Espanha, desde 1930, teria passado por quatro tipos de relações de trabalho: sindicalismo livre sem conselhos de empresa durante a Segunda República (1931-1939); nem sindicalismo nem conselhos livres sob o franquismo (1939-1953); conselhos operários sem sindicalismo livre (1953-1977) e, finalmente, sindicalismo e conselhos livres a partir de 1977 (Escobar, 1995, p. 153).

Nas linhas que se seguem, tentaremos oferecer um resumo das vicissitudes da sindicalização em dois países que, sob a democracia, o movimento sindical reapareceu numa etapa do desenvolvimento econômico e tecnológico hostil à instituição sindical.

$\mathrm{Na}$ Espanha, o restabelecimento da democracia veio com um sindicalismo dividido, tal como no período anterior ao franquismo, um "sindicalismo politicamente dependente" de partidos, uma das características do sindicalismo espanhol, segundo Escobar (1995, p. 156). Duas principais organizações sindicais ideologicamente rivais filiam a maior parte dos trabalhadores:

a) as Comissões Operárias (CGOO), ligadas ao PC espanhol, surgidas de uma semiclandestinidade e que se aproveitaram de certas concessões outorgadas na década de 1960 pelo regime franquista: possibilidade de grupos de trabalhadores elegerem representantes para encaminhar reclamações à direção das companhias e apresentar candidatos para os sindicatos oficiais. Essas comissões de empresa estabeleceram posteriormente organismos de coordenação de nível superior;

b) a União Geral de Trabalhadores (UGT), de orientação socialista. A UGT foi fundada em 1888. Colocada fora da lei com a queda da República, ressurgiu depois do franquismo. Em 1986, nas eleições para os comitês operários, a UGT obteve 40,9\% e as CCOO, 34,5\%. Em 1978, a UGT tinha tido $21,7 \%$ e as CCOO, 34,5\%. Outra pequena central, influenciada pela doutrina social da Igreja, a União Sindical Operária (USO), em 1986, recebeu $3,8 \%$ dos votos. As cifras para 1985 indicam que as CCOO teriam 500 mil filiados, depois de ter chegado a mais de 700 mil em 1982. A UGT estaria estabilizada em torno de 660 mil (Lucio, 1993, p. 500). A antiga Confederação Nacional do Trabalho (CNT), de orientação anarquista, criada em 1910, 
reapareceu depois da democratização mas sem conseguir a mesma influência do passado (Escobar, 1995; Lucio, 1993; Estivill \& Hoz, 1992; OIT, 1983).

Mas, além dessas centrais sindicais mais importantes, a partir de 1977 foram reconhecidas outras organizações menores. Ocorre que sobre as diferenças ideológicas sobrepõem-se clivagens regionais que levam à existência de outras centrais de menor importância, ou de importância apenas regional, como a Solidariedade dos Operários Catalões (SOC), a Solidariedade dos Trabalhadores Vascos (ELASTV), a Intersindical Galega (INTG), a Confederação Geral do Trabalho (CGT), também de influência anarquista, a Confederação Canária de Trabalhadores (CCT), além de outras pequenas organizações que se formaram a partir de cisões ideológicas nas CCOO, como as Comissões Operárias Anticapitalistas (COA), impulsionadas pela Organização de Esquerda Comunista (OIC), com certa implantação na Valès em Barcelona, na Metal em Valência, na Fasa-Renault, em Valladolid; a Trabalhadores Auto-gestionários Independentes (TAI), existente em Alicante, e outras pequenas organizações de vida e influência incertas. Um relato das organizações sindicais surgidas depois da democratização encontra-se em Morcillo, Jiménez-Asenjo, Amorós e Torrecilla (1978), de onde tiramos essas informações.

Ao que tudo indica, desde o fim do regime franquista ${ }^{21}$, as taxas de sindicalização sofreram muitas oscilações. Em 1975, Visser registrava 30,4\% de trabalhadores sindicalizados e 16,0\% em 1985, uma queda impressionante dos efetivos sindicais (Visser, 1991, p. 101). Mas deve-se enfatizar a dificuldade de obtenção de informações seguras, reconhecida por todos os analistas. Já em fins de 1983, o relatório de uma comissão da OIT que visitou a Espanha, diante da ausência de estatísticas sobre os níveis de filiação, foi bastante vago no que diz respeito à porcentagem de trabalhadores sindicalizados, relatando que a taxa de sindicalização estaria entre $15 \%$ e $17 \%$, "segundo uns", ou de 25\%, "segundo outros" 22 (OIT, 1985, p. 29).

\footnotetext{
${ }^{21}$ O general e ditador Franco, convém relembrar, morreu em 1975 e o rei Juan Carlos I iniciou a liberalização rápida do regime. Em 1978, um referendo aprovou uma Nova Constituição. A Espanha tornou-se uma monarquia parlamentarista e, em 1982, um governo socialista foi formado após a vitória do Partido Socialista Operário Espanhol (PSOE). Em abril de 1977, uma lei que reconhecia a liberdade sindical foi aprovada e as Convenções 87 e $98 \mathrm{da}$ OIT foram ratificadas.

${ }^{22}$ Georges Couffignal, chamando a atenção para a ausência de estatísticas, relaciona o fato com as concepções franquistas sobre a sociedade: uma vez que o franquismo, seguindo a
}

No setor industrial, embora se julgue que a proporção de sindicalizados tenha alcançado a taxa expressiva de $40-45 \%$ após as mobilizações de fins da década dos 70, a sindicalização teria caído fortemente depois de 1982, "acreditando-se estar abaixo de 15\%, comparável com a da França” (Lucio, 1993, p. 500). Em 1983, o número de filiados a sindicatos era estimado em 1,7 milhão, mas, em 1985, todos os sindicatos não teriam mais do que 780 mil, ou seja, menos de $10 \%$ da força de trabalho (Estivill \& Hoz, 1991, p. 265). Em 1980, Visser (1961) indicava 1,703 milhão de sindicalizados e, em 1989, 1,163 milhão. Em termos percentuais, em 1981, o mesmo autor registrava $22 \%$ do total de trabalhadores, proporção que teria declinado para 16\% em 1985.

Dados da OIT (1997-1998), que se baseiam na pesquisa anual sobre os membros que cotizam a UGT, as CCOO, a ELASTV e sindicatos independentes, indicam 835 mil sindicalizados em 1985 e 1,606 milhão em 1994, um aumento, portanto, de 92\%, extremamente elevado num curtíssimo espaço de tempo. Em termos proporcionais, em 1985, no total da mão de obra não agrícola, 7,3\% estariam filiados e, considerando apenas os trabalhadores, 11,5\%. Em 1994, respectivamente, as porcentagens seriam 11,4\% e 18,6\%. Há, pois, discrepâncias fortes nos dados sobre a Espanha. Visser (1991) insiste em que não há dados confiáveis sobre os níveis de sindicalização e não se sabe quando a relação de sindicalizados inclui trabalhadores aposentados ou desempregados. Também não haveria informações disponíveis sobre a sindicalização feminina e nos vários ramos da indústria e no setor público (p. 127).

Em Portugal, até o movimento militar de 25 de abril de 1974 que pôs fim à ditadura, o modelo sindical e de relações de trabalho seguia o padrão corporativo estatal vigente em outros países (como o Brasil) que se inspiraram de algum modo no modelo fascista italiano. No modelo salazarista, de sindicatos únicos (sindicatos nacionais, de organização vertical), a sindicalização não era voluntária, mas todos os trabalhadores eram obrigados a pagar taxas (imposto sindical). Os sindicatos nacionais agrupavam os trabalhadores de acordo com a atividade profissional e por

ideologia fascista, negava o conflito entre o Capital e o Trabalho, o conflito não poderia existir e consequentemente não havia necessidade de estudá-lo. Nota o autor que, até setembro de 1979, não existia na Espanha uma revista sobre sociologia do trabalho (Couffignal, 1982, p. 135). 
distritos. A exigência para a formação de um sindicato nacional era de cem associados. Os profissionais liberais filiavam-se às Ordens. Não havia obrigatoriedade de filiação, mas todos deveriam pagar uma contribuição sindical (Paschkes, 1985). Embora, na teoria, os sindicatos nacionais devessem barganhar coletivamente, na prática a negociação coletiva era um processo dirigido pelo Estado. O Ministério das Corporações desempenhava um papel essencial na elaboração dos acordos coletivos, o que significa dizer que salários e condições de trabalho eram estabelecidos pelo governo. Aos sindicatos de empregados, como o dos bancários, eram outorgadas algumas vantagens, como a eleição de delegados sindicais. Esse fato teria facilitado a elevada organização e sindicalização dos bancários (Barreto, 1993, p. 543).

Apesar da queda do regime salazarista, a transformação do modelo e da cultura corporativa só teve maior impulso a partir da Constituição de abril de 1976, quando a pluralidade sindical começou a ser implantada de acordo com a Convenção 87 da OIT. Depois do levante militar de 1974, o Conselho Revolucionário pretendeu dar a Portugal uma orientação socialista. A Constituição de abril de 1976 estabeleceu que a economia portuguesa deveria ser baseada em relações socialistas mediante a apropriação coletiva dos principais meios de produção. $\mathrm{O}$ monopólio da representação sindical foi dado à Intersindical Nacional (IN), controlada pelos comunistas. As cotizações obrigatórias foram mantidas pelas novas autoridades militares por solicitação da Intersindical e abolidas em 1977 pelo governo socialista (Pinto, 1992; Barreto, 1993). Posteriormente, os princípios socialistas foram retirados da Constituição pelas revisões constitucionais de 1982 e 1989 e um processo de privatização das empresas nacionalizadas teve início. A Intersindical Nacional mudou seu nome para Confederação Geral do Trabalho Portuguesa-Intersindical Nacional (CGTPIN).

Em fins de 1978, foi criada uma segunda federação, a União Geral dos Trabalhadores, ligada ao partido socialista e ao partido socialdemocrático, tendo como um dos objetivos tentar eliminar o monopólio legal da representação que a Intersindical havia mantido até 1976. Com isso, duas centrais sindicais, a UGT, controlada pelos socialistas e socialdemocratas, e a CGTP, controlada pelos comunistas, passaram a reivindicar a representação dos trabalhadores. Mas calcula-se que cerca de $20 \%$ dos sindicatos portugueses não pertencem a nenhuma das duas centrais. A CGTP, em congresso de maio de 1986, afirmava possuir 1.350 mil de membros enquanto a UGT dizia ter 1.100 mil.
Tal como na Espanha, o sindicalismo em Portugal, após o período corporativo de unicidade obrigatória, reapareceu muito dividido. Além da CGTP e da UGT, existem outras tendências dentro e fora das duas principais centrais. Dentro da CGTP, havia correntes comunistas "albanesas", "socialistas gestionários", trotskistas do PSR, marxistasleninistas da UDP e outras menos expressivas (Castanheira, 1985).

Visser (1991, p. 101), em 1988, estimava em 30\% a taxa de sindicalização portuguesa. Pelos dados do pesquisador holandês, os níveis de sindicalização em Portugal teriam descido de 59,0\%, em 1970, para $52,4 \%$, em 1975; 58,8\% em 1980; 51,6\% em 1985 e, finalmente, para $30,0 \%$ em $1988^{23}$. Pela OIT (1997-1998), em 1995, o número estimado de filiados à CGTP e à UGT seria de 800 mil, o que representa uma forte baixa com relação aos 1434 mil sindicalizados em 1985. Esses números indicariam que $40,6 \%$ do total da força de trabalho (setor agrícola excluído) estariam sindicalizados em 1985, proporção que teria caído para 18,8\% em 1995. Calculando a porcentagem de sindicalizados apenas para os trabalhadores, 51,4\% estariam sindicalizados em 1985, proporção que teria baixado para $18,8 \%$ em $1995^{24}$.

Apesar da precariedade dos dados, eles indicam, de modo grosseiro, que Portugal estaria entre os países em que as taxas de sindicalização teriam sofrido declínio, aparentemente acentuado. Mas as variações parecem muito fortes nos diferentes setores econômicos. Nas empresas nacionalizadas, como geralmente acontece, a sindicalização seria bem mais elevada, oscilando de 40\% até quase 100\% (Pinto, 1993; Stoleroff \& Naumann, 1996). Nas indústrias metalúrgicas, do vidro e da tecelagem, onde existe uma tradição de militância sindical, a porcentagem seria "seguramente" superior a $40 \%$ (Pinto, 1992, p. 252). Outros autores calculam que a sindicalização seria de aproximadamente $30 \%$ do total (Barreto, 1993, p. 465) e que provavelmente teria sido inferior à do período final do regime corporativo quando (depois da introdução, em 1969, de algumas medidas liberalizantes) os sindicatos

\footnotetext{
${ }^{23}$ Tal como para a Espanha, as estatísticas portuguesas não são seguras. Visser baseia se no estudo "Sindicalização e Comportamento Sindical" do Ministério do Emprego e Segurança Social. Não fica claro se entre os associados estão incluídos aposentados, autônomos e desempregados. 'lambem não haveria dados sobre a sindicalização feminina.

${ }^{24}$ Os dados da OIT são estimativas do número de filiados à CGTP e à UGT. Os aposentados, os desempregados e os trabalhadores por conta própria estão excluídos.
} 
oficiais de empregados e empregadores obtiveram mais autonomia e legitimidade para negociar (Barreto, 1993; Fernandes, 1985).

\section{CONCLUSÃO}

Os dados indicam, em praticamente todos os países e com intensidade diferente, que o declínio das taxas nacionais de sindicalização verificado na década dos 80 continuou nos anos 90. Múltiplos fatores contribuíram para isso mas, antes de discuti-los, tentaremos verificar os efeitos do rebaixamento dos níveis de filiação sobre o poder sindical. É possível argumentar (embora não estejamos de acordo com a tese) que a redução da proporção de aderentes não tem relação, ou tem fraca relação, com a influência do sindicalismo na vida política e econômica das nações. A tese encontra apoio em fatos que a história do sindicalismo em vários países sugere: a diferenciação entre o sindicalismo como um movimento social e o sindicalismo como instituição.

No caso do sindicalismo como movimento social, a atenção desvia-se para o sindicalismo como força de mobilização (sindical, amiúde política) dos trabalhadores considerados como uma "classe", uma "totalidade", em que os elementos de coesão superam os de diferenciação. O fator "mobilização" significaria que a ação ligada a uma classe - ou a segmentos dessa classe ultrapassaria o campo de relações institucionalizadas dos sindicatos com governos e empresas. Há, nesse enfoque, a ideia mais ou menos explícita da existência de um potencial conflitivo, de envergadura diferenciada segundo os países, que oporia os trabalhadores ao patronato e os levaria permanentemente a colocar novas demandas ou a se situar como oposição a medidas que partem das empresas e/ou das autoridades governamentais, ou seja, dos que detêm o poder na esfera econômica e política. A ação operária, nesse enfoque, não necessariamente teria de passar pelas estruturas sindicais. O termo habitualmente usado para definir essas modalidades de ação, que, na maior parte dos casos, correspondem às fases iniciais da organização dos trabalhadores, é "movimento operário". O termo hoje soa arcaico e está cada vez mais em desuso. Ele corresponde à época de construção do sindicalismo em que a "classe operária" como segmento excluído, marginalizado, "explorado", "dominado" seria a força básica da transformação social. O foco da análise, portanto, desloca-se para o conflito (que não exclui negociações parciais e setoriais mas temporárias). O importante aqui seria a capacidade de mobilizar trabalhadores, exercer pressão sobre o patronato e sobre a classe política. Na ausência de estruturas mais sólidas e institucionalizadas, os elementos de identidade grupal, de oposição aos adversários (definidos como "inimigos"), contribuindo para a formação de uma "consciência de classe", são essenciais para fundar a ação dos trabalhadores e ampliar suas possibilidades de êxito.

Por outro lado, quando se analisa o sindicalismo como instituição, o foco da análise desloca-se para as estruturas, para o aparelho sindical, para seu funcionamento dentro da sociedade e do sistema político, para a negociação mais do que para o conflito, ainda que esses dois aspectos não estejam desligados. Pensar o sindicalismo como instituição significa considerar funcionários, recursos financeiros, direitos e deveres, lugar dentro da ordem, significa, enfim, apreender o sindicalismo como estrutura burocrática e como sistema de dominação. O conceito de "burocracia sindical" surge imediatamente. O termo pejorativo é usado amiúde pelas correntes sindicais de oposição, colocadas fora dos postos de direção. Numa hipótese generosa, o projeto radical seria conduzir a ação operária como movimento puro, sem estruturas, sem burocracia, "pela base". Numa hipótese menos generosa, mas talvez mais realista, o projeto oculto é a conquista do aparelho sindical. Contudo, sem estrutura organizatória, o sindicalismo não subsiste porque ele não pode ser puro movimento. "O sindicalismo nunca é inteiramente identificável a um movimento social" (Touraine; Wieviorka \& Dubet, 1984, p. 64). E não é nem poderá sê-lo porque as lideranças necessitam dar continuidade às suas posições de comando. Isso não pode ser alcançado sem organização, quer dizer, sem a institucionalização da dominação. O sindicalismo não poderia ficar eternamente como um movimento. Esse, no sindicalismo como em outros campos sociais, só tem sentido como meio para consolidação e perpetuação do poder de lideranças, o que exige organização e institucionalização.

Não é necessário ressaltar que ambos os lados do sindicalismo (o de movimento e o de instituição) estão entrelaçados, ainda quando determinadas situações levem à predominância de um deles. Os sindicatos, a partir do após-guerra até a crise da globalização, foram levados a ser, ao mesmo tempo, uma forma de movimento social (com variados coeficientes de anticapitalismo e antiliberalismo) e instituições integradas na ordem capitalista democrática, estabilizadoras do mundo industrial, capazes de introduzir 
maior grau de previsibilidade e racionalidade na produção capitalista, especialmente na sua fase da produção de massas padronizada.

Por isso, a redução das taxas de sindicalização pode ter efeitos diferenciados no sindicalismo enquanto instituição e enquanto movimento social. Teoricamente, a dessindicalização poderia atingir mais a instituição sindical, mas poderia não ter os mesmos efeitos sobre o movimento sindical. Essa face do sindicalismo - e é difícil agora deixar de evocar o termo "movimento operário" - seria menos dependente dos aparelhos que a face institucional do sindicalismo, que teria beneficiado sobretudo os burocratas sindicais. Ora, se o poder sindical depende mais de seu lado "movimento", ele não seria especialmente afetado pelo declínio dos níveis de sindicalização. Mas acontece que o poder sindical se realiza mediante sua capacidade de pressão, ou seja, sobre a possibilidade de infringir danos ao "outro lado", o que requer mobilização. A greve, nas democracias contemporâneas, é para isso o instrumento por excelência, ainda que não seja o único. É principalmente por meio dela que o sindicalismo assume sua forma de movimento social capaz, ao mesmo tempo, de pressionar o "outro lado" e, indiretamente, de reforçar o sindicalismo como instituição.

No Capítulo 5, procuraremos analisar em que medida as transformações ocorridas nessas últimas décadas afetaram os índices de conflito, o que indiretamente significa medir as consequências do declínio da filiação a sindicatos sobre o sindicalismo como movimento social e, desse modo, o poder sindical. Mas, antes, convém examinar a expansão do sindicalismo no setor público e suas consequências para o movimento sindical como um todo.

\section{Capítulo 4 \\ O sindicalismo do setor público}

declínio das taxas nacionais de sindicalização, de modo especial, e do poder sindical, em geral, teria sido mais acentuado se não tivesse havido a sindicalização dos empregados do setor público. Até então, o sindicalismo havia sido tipicamente um movimento associativo de trabalhadores manuais do setor privado, do setor manufatureiro, primeiro, e, logo em seguida, dos setores de serviços, como ferrovias, portos e trabalhos públicos urbanos. As chamadas "classes médias" mantinham-se, no conjunto, afastadas dos sindicatos. Havia, naturalmente, aqui e ali, dependendo do país, segmentos de classes médias assalariadas do setor privado em que tinham surgido algumas associações, como entre os jornalistas, professores, bancários, empregados de estradas de ferro etc. Uma delas, das mais antigas no mundo, foi a Associação dos Empregados de Estradas de Ferro no Reino Unido. Criada em 1887, filiou-se ao TUC em 1909, quando chegou a organizar a maioria dos empregados das estradas de ferro ${ }^{1}$ (Lockwood, 1962, p. 156).

Nos EUA, alguns grupos de trabalhadores manuais do setor público chegaram a se organizar bastante cedo. Já por volta de 1800, artesãos dos estaleiros da marinha filiaram-se a sindicatos que representavam seus companheiros do setor privado. No século XIX, o sindicalismo avançou entre os tipógrafos de estabelecimentos governamentais e entre os carteiros, primeiro como associações beneficentes e depois efetuando trabalhos de lobby junto ao Congresso, embora não agissem ainda como verdadeiros sindicatos e não fizessem greves (Herman \& Kuhn, 1981, pp. 85-86).

Apesar desses e de outros exemplos que se poderiam encontrai; inclusive no Brasil (caso dos trabalhadores dos estaleiros navais e de empresas do Estado $)^{2}$, no conjunto do movimento sindical, os sindicatos e 
associações de classe média tinham pouco peso, embora crescessem continuamente. Em 1951, os cinco sindicatos mais importantes de empregados de escritório tinham em conjunto cerca de 450 mil membros (Lockwood, 1962, p. 135).

O exemplo do Reino Unido é ilustrativo das etapas pelas quais atravessou o sindicalismo. Em 1985, numa lista dos dez maiores sindicatos britânicos organizada por Hobsbawm (1987, cf. especialmente o cap. "O 'Novo Sindicalismo' em Perspectiva”), todos eram organizações de trabalhadores manuais do setor manufatureiro e privado: mecânicos, caldeireiros, mineiros, marceneiros e carpinteiros, tecelões, alfaiates, forja dores, pedreiros e sapateiros. A lista indica o peso dos sindicatos de ofício, de trabalhadores qualificados e expressa a composição profissional da classe operária da época. Mas, em 1963, entre os dez maiores sindicatos, quatro eram sindicatos de empregados não manuais, a maior parte do setor público: o sindicato dos comerciários, o sindicato dos funcionários municipais, o sindicato nacional dos funcionários públicos e o sindicato nacional dos professores. Entre os sindicatos de trabalhadores manuais, três estavam no setor de serviços coletivos (transportes, ferrovias e serviços municipais). Os outros três eram o dos metalúrgicos, o dos mineiros e o dos eletricistas.

As alterações na lista dos maiores sindicatos refletem as mudanças desses últimos cem anos no mercado de trabalho e no sistema produtivo: indicam a supremacia dos grandes sindicatos de trabalhadores fabris e serviços coletivos e o início da expansão do sindicalismo dos não manuais. De modo esquemático, três grandes etapas poderiam ser distinguidas na história do sindicalismo: a) a do sindicalismo de ofício; b) a do sindicalismo de trabalhadores industriais ${ }^{3}$; c) a do sindicalismo do setor público. $\mathrm{Na}$ primeira fase, as organizações sindicais reuniram a nata da classe operária da época, os trabalhadores qualificados, profissionais com formação artesanal polivalente num período em que as máquinas ainda não haviam substituído o uso manual das ferramentas. Muitos desses sindicatos, em certos aspectos,

Cap. III: “República e Cidadanias”) e Fausto (1976, Cap. I da II Parte: “A Classe Operária e seu Movimento").

$3 \mathrm{Na}$ Inglaterra, durante o movimento do "novo sindicalismo" do final do século, a organização dos trabalhadores de baixa qualificação em "sindicatos gerais", abrangendo muitas categorias profissionais, dificultou a formação de típicos "sindicatos industriais", quer dizei; de trabalhadores fabris. Os "sindicatos gerais" foram, nesse país, o equivalente dos "sindicatos industriais" de outros lugares. foram bastante conservadores, especialmente nos EUA: eram organizações de trabalhadores brancos, qualificados, do sexo masculino, nas quais as mulheres, os aprendizes e todos os trabalhadores de baixa qualificação não eram admitidos. Nos EUA, negros e chineses (especialmente na costa do Pacífico) não tinham acesso aos sindicatos. Posteriormente, o surgimento da produção em série e em massa, a extensão dos princípios tayloristas-fordistas, propiciaram o aparecimento de novo tipo de sindicalismo, destinado a abranger os operários não qualificados. Aos poucos, esses sindicatos, filiados ao CIO, acabaram por receber os trabalhadores negros que emigravam do Sul para os estados do Norte; por outro lado, a escassez de mão de obra durante a Segunda Guerra facilitou a entrada das mulheres nas fábricas e nos sindicatos. Na América do Norte, a criação do CIO e dos "sindicatos industriais" durante o New Deal deu novo impulso ao movimento sindical em declínio e significou uma profunda renovação do sindicalismo. Finalmente, na década dos 60 , a sindicalização do setor público pode ser equiparável à superação dos sindicatos de ofício pelo sindicalismo dos operários fabris, ou seja, uma nova etapa do sindicalismo ${ }^{4}$.

Inicialmente, o sindicalismo dos empregados de escritório, dos setores de serviços, foi tratado como um sindicalismo de classe média, um white-collar unionism, na terminologia anglo-americana (cf., por exemplo, Lockwood, 1962; Kassalow, 1969, Cap. X, "O Desenvolvimento do

\footnotetext{
${ }^{4} \mathrm{O}$ esquema que oferecemos acima é muito geral. Em países onde a industrialização ocorreu com mais atraso, já na fase da produção em série, as associações de trabalhadores tenderam a adotar desde logo a organização por indústria. Porém, além das características técnicas do processo produtivo, outras variáveis influenciaram as formas das estruturas sindicais. No Reino Unido, o peso dos sindicatos de oficio levou a um "multissindicalismo" em que os sindicatos de ofício e os sindicatos gerais estabeleceram-se nas mesmas indústrias. O "sindicalismo industrial" nunca existiu na sua forma mais comum de representar todos os trabalhadores manuais de uma fábrica ou de um ramo. O grande número de sindicatos ainda hoje existente no Reino Unido pode ser explicado em razão da força da organização sindical por ofício. Já na Holanda, os sindicatos, tipicamente, estruturaram-se por amplos setores econômicos, abrangendo muitas indústrias, mas estiveram divididos por clivagens religiosas. Na Suécia, Os sindicatos diferenciaram-se por indústria e categoria ocupacional (cf. Visser \& Waddington, 1996). Três teses tentam explicar, segundo os autores, os modelos de estrutura sindical: a) a da "industrialização", relacionada com períodos de maior ou menor agitação operária, à qual acrescentaríamos o tipo de tecnologia dominante no momento do impulso industrial; $b$ ) a da "institucionalização", que considera o modo como os sindicatos foram incorporados à sociedade; e $c$ ) a tese "política", uma variante da segunda, que acentua Os efeitos das clivagens políticas e culturais sobre a organização sindical.
} 
Sindicalismo de Colarinho Branco"; Allen, 1971, especialmente Cap. 8: "A Revolta dos Colarinhos-Brancos" e Cap. 9: "O Crescimento do Sindicalismo no Setor Bancário, 1914-1927” e Carter, 1985).

O uso do termo "trabalhador de colarinho branco", para designar o empregado de escritório, o comerciário, o bancário, o professor, etc. que usava gravata, símbolo de distinção, é indicativo de que, então, preocupavase mais com o tipo de tarefa, isto é, tarefas não braçais, não manuais, do que com o setor de atividade, se público ou privado, se ligado ao mercado ou ao Estado, em que se localizava o empregado.

Parte da discussão travava-se ainda em termos da "consciência de classe" do empregado de classe média, pressionado entre o "grande capital" e o "proletariado". As discussões recaíam amiúde sobre as possibilidades de ação sindical da "classe média", isto é, porque esses segmentos "prensados entre a burguesia e o proletariado", finalmente, estavam começando a sindicalizar-se. Entre os motivos levantados, dois eram especialmente relevantes na determinação de outras condutas:

a) Perda de renda, de status e do estilo de vida aos quais estariam habituadas as classes médias, perda sentida de modo mais doloroso diante das vantagens salariais e de benefícios obtidos pelos trabalhadores manuais sindicalizados. O declínio desses segmentos das classes médias, sem sindicatos e sem direito de greve, seria especialmente acentuado nos períodos de inflação.

b) Burocratização dos procedimentos de seleção, racionalização dos serviços e mecanização de tarefas de escritórios, procedimentos que teriam levado a uma simplificação do trabalho e possibilitado o acesso dos filhos de operários a empregos de escritório e do comércio, anteriormente ocupados geralmente pelos filhos das famílias de classe média.

Muitas das análises faziam-se, nesse período - começos ou meados da década dos 60 -, em termos psicossociais, com inspirações nos esquemas interpretativos marxistas referentes às condutas das classes médias, aos assalariados de colarinho branco: vacilação, conservadorismo, insegurança, apoliticismo, temor do descenso social e da identificação com os trabalhadores manuais. Um exemplo é a frase de Allen (1971): "Com pequenas exceções, todos os grupos de empregados (white-collar groups) tentam evitar alinhamentos políticos partidários, tanto no parlamento como fora dele". Nesse aspecto, eles refletiriam a atitude política dominante dos empregados de classe média em geral. Esses trabalhadores, diria o autor, "no Reino Unido, são sucessores políticos dos pequenos empresários autônomos do século XIX mas eles não possuem nem coerência política nem objetivos políticos nítidos [dos seus antepassados...]. A hostilidade [ao sindicalismo de trabalhadores manuais] é uma barreira para a assimilação ao movimento sindical que pode persistir muito tempo depois que os empregados não manuais perceberem a necessidade da ação política (pp. 97-98)".

Lockwood, por sua vez, acentuava o "caráter ambíguo de classe média" dos empregados de escritório, por lhes faltar independência e renda, o que daria a esse tipo de empregado um caráter "marginal". Essa situação ambígua o faria agarrar-se mais fortemente à defesa de seu status, tentando diferenciar-se dos trabalhadores manuais. O declínio social dos empregados de escritório pareceria mais acentuado em razão do aumento da escolaridade dos trabalhadores manuais, do crescente recrutamento para empregos de escritórios em camadas sociais inferiores e da utilização cada vez maior de mulheres em tarefas anteriormente efetuadas por homens. $\mathrm{O}$ descenso social, pois, seria uma das chaves explicativas da sindicalização dos empregados de escritório.

Não pretendemos discutir essas hipóteses que, em si mesmas, podem explicar, pelo menos em parte, a sindicalização dos empregados de colarinho branco. Mas o ponto que nos parece central é a mudança de foco do empregado de escritório, de não manual para empregado do setor público. Os trabalhos mais recentes não mais falam, ou falam cada vez menos, na sindicalização das "classes médias" e sim na sindicalização do setor público. Nesse sentido, é digno de nota que Kassalow (1969), no seu conhecido estudo comparativo do sindicalismo, embora conservando o termo "sindicalismo de classe média", concentre sua atenção basicamente no desenvolvimento do sindicalismo do setor público, cujo avanço nos EUA e na Europa percebeu cedo.

$\mathrm{Na}$ verdade, o termo "sindicalismo de classe média" ou dos empregados não manuais não reflete adequadamente os recentes desenvolvimentos vinculados à ampliação da participação do Estado para outros setores de atividade econômica e social, a emergência de novos segmentos profissionais e seus movimentos associativos. Nesse aspecto, do ponto de vista das probabilidades de sindicalização, quando se combina o 
tipo de tarefa e da qualificação com a natureza do empregador (público, privado ou misto) e da relação empregatícia, pelo menos quatro grandes setores podem ser distinguidos.

a) O setor dos segmentos "de classe média" assalariada não manuais do setor privado. Trata-se de um segmento amplo e heterogêneo, que envolve empregados de baixa e média qualificação do comércio e escritórios (bancários, escriturários, balconistas, datilógrafos, digitadores, vendedores, calculistas, contadores, telefonistas, recepcionistas, enfermeiros, atendentes de hospitais etc.) e assalariados de qualificação elevada (médicos, advogados, engenheiros, arquitetos, professores universitários, cientistas, técnicos de alta qualificação etc.), que trabalham para as empresas privadas;

b) O setor de funcionários públicos tradicionais, os servidores do Estado, em geral empregados não manuais, cujas atividades e categorias profissionais (com exceção da segurança pública) podem ser muito semelhantes à do setor anterior, com a diferença de que a fonte pagadora (ou o "patrão") seria o Estado, não importando se se trata da administração central ou local. Nesse setor, poderíamos encontrar a alta burocracia do Estado, como promotores, juízes, procuradores, fiscais de renda etc., as chamadas "carreiras típicas do funcionalismo".

c) O setor de operários braçais do serviço público, como lixeiros, coveiros, garis, motoristas e empregados do setor de transporte municipal, e várias outras categorias, que poderiam gozar, do ponto de vista não salarial, de alguns dos benefícios concedidos às categorias não manuais dos funcionários públicos tradicionais (férias, aposentadoria, estabilidade no emprego etc.). Muitos desses serviços, atualmente, estão sendo terceirizados, o que faz com que esses segmentos das classes trabalhadoras passem para o setor privado.

d) O setor dos empregados das empresas estatais, como siderurgias, petroquímicas, ferrovias, usinas elétricas, minas, transportes públicos,cujas atividades e qualificações, em princípio, não diferem das existentes nos mesmos ramos de atividade de empresas do setor privado. Aí podem estar engenheiros, técnicos, telefonistas, escriturários, operários e outras categorias profissionais e ocupacionais equivalentes às que existem no funcionalismo e no setor privado. A diferença, no caso, viria do tipo de empregador (público ou privado), diferença que pode acarretar discrepâncias fortes no que toca a salários e benefícios ao fazer com que o empregado pertença a um setor "protegido" ou um a setor sujeito à concorrência. (Também aqui, as privatizações tendem a reduzir a parcela de trabalhadores "protegidos".)

Do ponto de vista da organização sindical, o quadro pode resultar bastante complexo. Sindicatos de profissionais liberais (como de médicos, advogados, professores) podem incluir tanto o pessoal do setor privado como o do setor público e até mesmo autônomos. Do mesmo modo, alguns sindicatos de trabalhadores manuais podem filiar tanto os trabalhadores do segmento privado como os do estatal. Essa possibilidade gera associações mistas, que reúnem empregados de funções semelhantes com relações empregatícias e status profissional discrepantes em termos de salários, benefícios, direitos e condições de trabalho, como é o caso de professores, dos bancários e outros grupos profissionais de estabelecimentos privados ou públicos. A negociação coletiva torna-se também mais complicada quando o sindicato que representa trabalhadores do setor privado e do setor público tem de negociar com o Estado (frequentemente personificado num político que ocupa função de comando no setor) e com empregadores privados, sendo que, algumas vezes, a negociação pode ocorrer ao mesmo tempo. De modo geral - como mostram, por exemplo, os casos dos professores, dos bancários, do pessoal da saúde -, o Estado é um empregador mais tolerante com o movimento associativo do que o patronato privado, o que não indica necessariamente que os salários do setor público sejam mais elevados.

Os segmentos das categorias profissionais denominadas de "classe média" ou de "não manuais" que mais se sindicalizaram em todo o mundo ocidental foram os que tinham como empregadores as várias instâncias da administração pública (federal, estadual ou municipal, conforme a organização institucional do país). Assim, no setor da saúde, os grupos mais ativos sindicalmente não são os dos empregados dos estabelecimentos hospitalares privados mas os do setor público. Consequentemente, o uso do termo "sindicalismo de classe média" não expressa adequadamente o que aconteceu, porque a "classe média" que se sindicalizou maciçamente foi a "classe média estatal". Não houve uma explosão do sindicalismo de classe média em geral, mas do sindicalismo dos trabalhadores e empregados do setor público, onde estão tanto os trabalhadores manuais como os não 
manuais, de "classe média", os blue-collars e os white-collars, os de "colarinho branco" e os de "colarinho azul", quer dizer, os de macacão".

Nesse sentido, uma observação de McIlroy parece-nos pertinente. Referindo-se ao processo de fusão em curso entre os sindicatos britânicos, à prática de ultrapassar as fronteiras da jurisdição sindical original mediante essas fusões, McIlroy indaga da utilidade do uso do termo white-collar. Esse termo teria sido adequado no período em que o sindicalismo era amplamente produto da ação de trabalhadores manuais. Mas as transformações tecnológicas têm atuado no sentido de borrar as divisões entre manuais e não manuais. $\mathrm{O}$ resultado seria, no plano do sindicalismo, o aparecimento de "organizações híbridas". Do mesmo modo, mais recentemente, ante as privatizações, o sindicalismo do setor público seria também outra categoria em mutação (McIlroy, 1995, p. 13). Esse crescimento do sindicalismo dos empregados do Estado, que assistimos também no Brasil, aconteceu em toda a parte e perturbou as relações tradicionais de poder no interior dos movimentos sindicais.

Nas páginas seguintes, faremos um rápido balanço da expansão do sindicalismo dos empregados do setor público. Às vezes, as estatísticas de cada país, usadas pelos pesquisadores, distinguem simplesmente manuais e não manuais (white-collars e blue-collars); outras vezes separam empregados do setor público e do setor privado. A mudança de critério dificulta uma avaliação comparativa mais precisa da evolução do sindicalismo do setor público, porque, como vimos, nem sempre todos os manuais estão no setor de mercado e todos os não manuais estão no setor público e, frequentemente, os sindicatos agrupam empregados de ambos os setores. De todo jeito, as tendências gerais são discerníveis e não se prestam a interpretações divergentes.

\footnotetext{
${ }^{5}$ Num artigo sobre a sindicalização das classes médias nos países desenvolvidos, cometi o mesmo equívoco ao falar na "sindicalização das classes médias" quando seria mais adequado ter me referido à sindicalização do setor público. Na realidade, na época do artigo, a maioria dos autores que tomei como fonte (alguns dos quais citados acima) estavam se referindo ao fenômeno da sindicalização da classe média. De todo jeito, já era relativamente claro que a variável principal não era o tipo de tarefa ou de função, se manual ou não manual, mas a natureza do vínculo empregatício (Rodrigues, 1992c).
}

\section{A AMÉRICA O NORTE}

Nos Estados Unidos, o número de empregados do setor público filiados a sindicatos, em 1953, estava entre três a quatro milhões. A partir especialmente de 1962, começou a crescer acentuadamente, atingindo seis milhões em 1976, o que representa cerca de 40\% do emprego governamental (Troy, 1986, p. 81). Entre 1960 e 1975, havia progredido a uma média anual de aproximadamente $5 \%$, duas vezes mais do que o crescimento do emprego no setor privado (Lewin, 1986, p. 243).

No total de sindicalizados, a participação dos trabalhadores manuais (blue-collars) que, em 1959, era de 79,5\%, caiu para 49,6\% em 1985 , enquanto a dos empregados (white-collars) passava de 19,1\%, em 1959, para $38,5 \%$, em 1985. Nesse ano, pela primeira vez na história do sindicalismo americano, no conjunto de trabalhadores sindicalizados, os trabalhadores manuais (blue-collars), com 49,6\% do total, deixavam de ser a maioria entre os sindicalizados (Troy, 1986, p. 86) ${ }^{6}$. Em 1983, a taxa de sindicalização entre empregados do setor público chegava a 34,4\% contra 17,8\% do setor privado (Troy, 1986, p. 82). Em 1985, a proporção de empregados do setor público no total de sindicalizados era de 33,8\%; em 1990, passou para 39\% e, em 1995, atingiu 42\% (Government Union Review, 1996, p. 43), proporção que se mantinha em 1997 (Employment and Earnings, January 1997, site da AFL-CIO de 8.8.98).

A expansão da sindicalização foi mais elevada entre os funcionários do governo federal. Em 1976, 47,6\% de todos os empregados estavam filiados a sindicatos, contra 14,0\% nos governos estaduais e municipais (Aaron; Grodin \& Stern, 1979, apud Herman \& Kuhn, 1981, p. 88). Em 1991, entre os funcionários estaduais e municipais, as taxas de sindicalização mais altas estavam entre os bombeiros (65\%), os professores do ensino secundário e elementar (58\%), a polícia (54\%) e os empregados do setor de saúde pública (50\%). Em 1980, mais da metade dos técnicos e profissionais do setor público era representada por sindicatos em negociações coletivas:

\footnotetext{
${ }^{6}$ Troy utilizada dados do Current Population Survey. No quadro de onde retiramos os dados, além das categorias white-collar e blue-collar, está a de serviços e outras que compreenderiam categorias como empregados de hotéis, serviços pessoais, oficinas de automóveis, cinema, diversão, saúde e serviços educacionais privados (p. 89). Mas, aqui, blue-collars e white-collars não estão discriminados. Em 1959, Serviços e Outros compunham apenas $1,4 \%$ do total de sindicalizados; em 1985, representavam 11,9\%.
} 
bibliotecários, enfermeiras, advogados, dentistas, médicos, professores e cientistas (exceto os das instituições consideradas de alto nível). Em 1976, 3/4 dos professores do ensino elementar e médio estavam representados por sindicatos, o que não significa dizer que o direito à negociação coletiva implicasse legalmente o direito à greve (Aronson, 1985, p. 352).

Por volta de 1993, os maiores sindicatos norte-americanos já não estavam no setor dos trabalhadores braçais. O Sindicato Nacional dos Professores, em número de membros, ultrapassou os Teamsters (caminhoneiros e trabalhadores de transportes), que até então era o maior sindicato dos EUA em número de associados. Os Teamsters perderam, entre 1974 e 1983, aproximadamente 400 mil filiados (Troy, 1986, pp. 9293). A eleição de John Sweeney, em 1995, para a presidência da AFL-CIO é marco significativo das mudanças que ocorreram na composição da classe trabalhadora norte-americana e do aumento da força dos sindicatos de trabalhadores não industriais. Sweeney havia sido, por quinze anos, presidente do Sindicato Internacional dos Empregados em Serviços. Esse sindicato organiza tanto empregados do setor privado como do setor governamental, sendo esses últimos majoritários (Troy, 1996, pp. 23).

\section{Quadro 4.1}

Maiores Sindicatos dos EUA

\begin{tabular}{|l|c|}
\hline & Total de membros \\
\hline NEA(professores) & 2.000 .000 \\
Teamsters (trabalhadores em transportes) & 1.300 .000 \\
AFSCME (servidores públicos) & 1.191 .000 \\
UFCW (trabalhadores em alimentação e comércio) & 997.000 \\
SEIU (empregados no setor de serviço) & 881.000 \\
UAW (trabalhadores na indústria automobilística) & 800.000 \\
CWA (trabalhadores em telecomunicação) & 600.000 \\
IAM (engenheiros) & 534.000 \\
USWA (siderúrgico) & 459.000 \\
APWU (empregados do correio público) & 228.000 \\
NALC (empregados do correio público) & 210.000 \\
UPIU (trabalhadores na indústria de papel) & 202.000 \\
OCAW (químicos) & 90.000 \\
UMWA (mineiros) & 82.000 \\
\hline
\end{tabular}

Fonte: Moody, 1995

No Canadá, a linha de desenvolvimento seguiu aproximadamente a dos EUA. Como em outras partes, o avanço do sindicalismo de funcionários começou nos inícios dos anos 60. De 1962 a 1977, a sindicalização dessa categoria cresceu 150\% (Huxley; Kettler \& Struthers, 1986, p. 128). Entre 1975 e 1985, o número de filiados a sindicatos do setor público passou de 1,1 milhão para dois milhões, com um aumento de aproximadamente $70 \%$. A taxa de sindicalização agregada no setor, no mesmo período, passou de $48 \%$ para $66 \%$. Em 1975, os filiados a sindicatos do setor privado representavam $58 \%$ do total de sindicalizados canadenses, mas em 1985 os do setor público tornaram-se majoritários, com 56\% do total (Troy, 1990, p. 132). Mas, tendo em vista a existência de empresas e de serviços dos mesmos tipos de atividade nos dois setores, a comparação dos níveis de sindicalização entre eles ajuda a perceber a influência da variável "tipo de empregador" em relação com a "tipo de tarefa", "qualificação dos empregados" ou outras relacionadas com as características de mão de obra de ambos os setores. No setor público de serviços, como educação, saúde, administração pública, o índice de sindicalização, em 1985, era de 67,7\% contra somente $6,3 \%$ no setor privado. No setor público, no item indicado como "bens" (compreendendo manufatura, mineração, transporte, comunicação e outras utilidades), 58,3\% estavam sindicalizados, contra $38,5 \%$ no setor privado (Troy, 1990, p. 127).

\section{A EUROPA OCIDENTAL}

Também nos vários países europeus, enquanto o sindicalismo do setor privado recuava em quase toda a parte na década dos 80, o sindicalismo dos funcionários públicos e dos empregados das estatais avançou entre 1960 e 1980. O progresso do movimento sindical nessas camadas e segmentos das classes trabalhadoras, no caso europeu, foi muito variado em virtude das fortes diferenças anteriormente existentes nos índices nacionais de sindicalização, nos modelos de relações de trabalho e no sistema político. Mas, de modo geral, a sindicalização dos empregados do setor público e estatal tendeu a ser tanto mais forte quanto mais elevados eram os índices nacionais de sindicalização. Nos anos 70, o setor público foi responsável por $2 / 3$ do total do crescimento do número total de sindicalizados na Noruega, na Suécia e na Áustria, pela metade do crescimento na Dinamarca e no Reino Unido e por um 1/3 na República Federal Alemã e na Itália. Em 1985, na Alemanha, entre os funcionários públicos com estabilidade e outras vantagens típicas dos servidores públicos, denominados Beamten, 68\% estariam sindicalizados contra $20 \%$ 
dos empregados do Estado, sem estabilidade, os Angestellten (Visser, 1988, p. 137). No interior da DGB, em 1990, 51,3\% dos filiados são servidores públicos (Jacobi; Keller \& Müller-Jentsch, 1993, p. 235).

Na Suécia, a proporção de sindicalizados do setor privado, em 1975, ainda era ligeiramente mais elevada do que a do setor público: $78 \%$ contra 76\%. Porém, em 19861987, a sindicalização dos funcionários e empregados da área estatal subiu para $92 \%$, enquanto na área privada o aumento foi menor: $84 \%$. Se o critério for o de empregados não manuais contra trabalhadores manuais, esses últimos, em 1991, mantinham pequena vantagem sobre os primeiros: $81 \%$ contra $80 \%$ (Kjellberg, 1993, p. 119).

No Reino Unido, enquanto o número absoluto de trabalhadores manuais filiados a sindicatos caía de sete milhões, em 1951, para 5,1 milhões em 1987, o de white-collars, no mesmo período, passava de 2,1 milhões para 4,7 milhões (Edwards; Hall; Hyman; Marginson; Sisson; Waddington \& Winchester, 1993, p. 34). O Sindicato Nacional dos Servidores Públicos (NUPE) passou de 200 mil membros em 1960 para 700 mil em 1979. A Associação dos Funcionários do Governo Nacional e Locais (NALGO) tinha 274 mil membros em 1960; em 1979 chegava a 753 mil. Em 1967, no Serviço Nacional da Saúde, havia 370 mil empregados sindicalizados e, em 1979, 1,3 milhão. Em 1993, o maior sindicato britânico em números de membros era o UNISON, com cerca de 1,5 milhão de membros, superando o Sindicato do Transporte e Trabalhadores Gerais, até então o maior sindicato de manuais, com 1.036.000 filiados (McIlroy, 1995, p. 15). O UNISON, formado em julho de 1993, resultou da fusão de três sindicatos de empregados do setor público: Confederação dos Empregados nos Serviços de Saúde, Associação dos Funcionários dos Governos Nacional e Locais e o Sindicato Nacional dos Servidores Públicos. Organiza funcionários de governos locais mas também trabalhadores dos serviços de saúde, do gás, da eletricidade, do transporte, do abastecimento de água e do ensino superior. Em razão das privatizações, o UNISON filia atualmente tanto os empregados do setor público como do privado (McIlroy, 1995, pp. 14-15; Visser \& Ruysseveldt, 1996a, pp. 70-78; IRS Employment Review, 1996, p. 11).
Quadro 4.2

Sindicalização no setor público (1970-1988)

\begin{tabular}{|c|c|c|c|c|}
\hline \multirow[b]{2}{*}{ Países } & \multicolumn{2}{|c|}{ Sindicalizados (milhões) } & \multicolumn{2}{|c|}{$\begin{array}{l}\text { \% no total de } \\
\text { sindicalizados }\end{array}$} \\
\hline & 1970 & 1988 & 1970 & 1988 \\
\hline Alemanha & 2414,5 & 2728,0 & 33,6 & 33,4 \\
\hline $\begin{array}{l}\text { Austrália } \\
\text { Survey domiciliar }\end{array}$ & - & 1146,6 & - & 45,2 \\
\hline Áustria & 379,5 & 462,6 & 29,4 & 35,9 \\
\hline $\begin{array}{l}\text { Canadá } \\
\text { Estatísticas Sindicais }\end{array}$ & 503,9 & - & 23,2 & \\
\hline Survey domiciliar & - & $1550,4^{\mathrm{g}}$ & - & 44,6 \\
\hline Dinamarca & 300,1 & 622,6 & 27,2 & 35,7 \\
\hline $\begin{array}{l}\text { EUA } \\
\text { Estatísticas sindicais }\end{array}$ & 4080,0 & - & 18,1 & - \\
\hline Survey domiciliar & - & 6422,0 & - & 37,9 \\
\hline Finlândia & - & $627,0^{j}$ & - & 39,9 \\
\hline França & $2043,0^{c}$ & 1300,0 & 52,6 & 61,9 \\
\hline Holanda & 550,5 & $638,3^{\mathrm{j}}$ & 38,0 & 50,3 \\
\hline Itália & $1170,0^{\mathrm{a}}$ & 1928,7 & 23,2 & 33,2 \\
\hline Japão $^{1}$ & 3278,8 & 2743,2 & 28,6 & 22,6 \\
\hline Luxemburgo & - & $23,0^{\mathrm{j}}$ & - & 30,7 \\
\hline Noruega & 235,1 & 522,8 & 35,9 & 53,0 \\
\hline Nova Zelândia & - & $174,2^{\mathrm{k}}$ & - & 28,4 \\
\hline Reino Unido & $3236,4^{\mathrm{a}}$ & $3386,0^{\mathrm{j}}$ & 33,7 & 39,4 \\
\hline Suécia & 631,3 & 1438,7 & 26,9 & 41,9 \\
\hline Suíça & 211,2 & $244,0^{\mathrm{i}}$ & 27,9 & 31,2 \\
\hline
\end{tabular}

a)1971; b)1974; c)1975; d)1979; e)1981; f)1982; g)1984; h)1986; i)1987; j)1989; k)março 1990; 1) setor público baseado em dados do Ministério do Trabalho japonês, Survey Básico dos Sindicatos, nos quais os professores estão incluídos no setor de mercado de serviços.

Fonte: Visser (1991, p. 113).

No Quadro 4.2, dois anos são apresentados (1970 e 1988) com dados sobre o número absoluto de sindicalizados no setor público e sua porcentagem no total de trabalhadores filiados a sindicatos. Em termos absolutos, em somente dois países (França e Japão) houve redução do volume de sindicalizados, na verdade, em ambos redução bastante forte. $\mathrm{Na}$ Alemanha, no Reino Unido, na Holanda, na Suíça e na Áustria, houve pequenos aumentos. Em troca, nos EUA, Canadá, Suécia, Dinamarca, Noruega e Itália houve forte crescimento. No Canadá e nos três países nórdicos, os sindicatos do setor público dobraram o número de membros. É 
preciso contar, no entanto, com um possível viés no caso dos EUA e do Canadá porque, nesses casos, os dados para 1970 são estatísticas fornecidas pelos sindicatos enquanto, para 1988, vêm de surveys domiciliares. Mas o fato não chega a prejudicar a análise da tendência do aumento, especialmente porque as estatísticas sindicais, como já vimos, geralmente são mais elevadas do que as dos surveys.

Ainda no Quadro 4.2, vê-se que a proporção de membros de sindicatos do setor público no total de trabalhadores sindicalizados cresceu em quase todos os países. Em alguns (Canadá, EUA, Noruega, Suécia e Holanda), o aumento dá participação foi de mais de dez pontos percentuais. As exceções foram a Alemanha ( 0,2\%) e o Japão ( 6\%). Na França, onde houve declínio do número absoluto de sindicalizados no setor público, a participação dos empregados do Estado no total de sindicalizados aumentou 9,3\%, fato que, por si só, é sinal de acentuada queda da sindicalização no setor privado.

Não teríamos condições de examinar as razões dos aumentos em cada país mas é possível assinalar os dois fatores principais que se combinaram para determinar, em quase toda a parte, o aumento da proporção de empregados do Estado no total de sindicalizados: de um lado, a própria elevação da sindicalização do setor público; de outro lado, a diminuição da taxa de sindicalização do setor privado. Uma análise nacional mais detalhada obrigaria a levar em conta os segmentos da população assalariada incluídos em cada setor e as mudanças no mercado de trabalho que afetaram esses segmentos em cada país. Além disso, seria preciso não esquecer as diferenças de metodologia usada nas estatísticas nacionais (Quadro 4.2).

\section{AS CAUSAS DA EXPANSÃO}

Há mais concordância com relação às razões que trouxeram os sindicatos para dentro do Estado do que com relação às que acarretaram a dessindicalização do setor privado. Duas linhas de explicação parecem centrais:

1) as relacionadas com as mudanças na legislação de modo a estender o direito de sindicalização aos funcionários do Estado, ponto que envolve a reversão das atitudes do poder público ante o direito dos seus empregados de atuarem organizada e coletivamente para mudar suas condições de trabalho, quer dizer, direito de negociação coletiva e, menos frequentemente, de greve. Há, aqui, um aspecto político que analisaremos mais adiante.

2) as relacionadas com as transformações no mercado de trabalho, na estrutura do emprego, levando ao crescimento da massa de empregados e assalariados do Estado.

A primeira linha de explicação encaixa-se no bloco das hipóteses de cunho políticos-institucionais; a segunda, no das hipóteses socioeconômicas. Ambas as linhas explicativas estão inter-relacionadas e não necessariamente eliminam outras hipóteses que foram mais comuns nas primeiras análises do sindicalismo de "classe média", tais como a racionalização dos serviços públicos, ligada à perda de status dos funcionários etc.

1. Fatores políticos: as transformações na legislação

As alterações na legislação, estendendo direitos de representação e de barganha às anteriores associações de empregados do setor público, foram um dos principais estimuladores da expansão do sindicalismo. As consequências favoráveis das mudanças, ou às vezes, mais precisamente, da eliminação de dispositivos que proibiam a sindicalização de empregados do governo parecem fora de discussão. Especialmente para o caso dos EUA, sobre o qual falaremos mais demoradamente em razão da importância do país e das características específicas do seu sindicalismo, fica muito visível a influência das reformas de dispositivos legais que favorecem a sindicalização e a negociação do Estado com seus empregados, ainda que o direito de greve não tenha sido legalizado.

Mas ocorre que, se a reforma da legislação pode ser o elemento diretamente deflagrador da sindicalização, as alterações nas leis não vieram por acaso, sendo necessário analisá-las junto com novas tendências políticas e axiológicas das sociedades ocidentais na década dos 60. De modo mais preciso: a ascensão do sindicalismo no setor público veio junto com o avanço dos partidos de esquerda, com o aumento geral das taxas de sindicalização no setor privado, com o aparecimento de novos movimentos sociais, com o avanço das ideologias de tipo socialista, com o recuo dos valores individualistas, com a ampliação do papel do Estado. Nos EUA (e Europa Ocidental), além propriamente da expansão do sindicalismo, houve a emergência dos movimentos dos direitos civis, da libertação feminina, do movimento estudantil, de rejeição, enfim, de antigas normas conservadoras na 
cultura e na política. Entendemos que as alterações na legislação que favoreceram a explosão do sindicalismo não podem ser desligadas dessa onda de democratização do sistema político e social, de rebeldia, de "participacionismo", que marcaram, em toda a parte, a década dos 60 e dos 70.

Por outro lado, o desenvolvimento dos Estados de Bem Estar Social teve efeitos cumulativos porque os novos serviços estatais aumentaram o número de funcionários, especialmente o de mulheres, o que por sua vez ampliou o peso eleitoral e a influência política dos funcionários. A consolidação dos Estados de Bem Estar, que começaram a ser construídos bem antes dos anos 60, não veio apenas da onda política democrática, mas também de pressões mais antigas dos movimentos sindicais, ligados geralmente à socialdemocracia ${ }^{7}$.

\section{A evolução da legislação nos EUA}

No caso americano, somente nos inícios dos anos 60, os servidores públicos conseguiram o direito de filiar-se a sindicatos e de discutir condições de trabalho com seus empregadores estatais. Esse resultado, como geralmente acontece, foi fruto de mobilizações anteriores, da

${ }^{7}$ As forças sindicais não foram as únicas forças a pressionar a favor da extensão de medidas de proteção social. Examinando as relações entre o sindicalismo e a formação dos Estados de Bem-Estar; Esping-Andersen (1994) nota que os primeiros movimentos operários, reformistas ou revolucionários, não tinham como meta o que hoje chamamos de Estado de Bem-Estar. As correntes que se orientavam estritamente por uma estratégia revolucionária entendiam que o problema social seria resolvido automaticamente nas sociedades póscapitalistas; as correntes comprometidas com reformas imediatas estavam voltadas mais para soluções trazidas por sociedades de auxílio mútuo do que pelo Estado. Porém, no período entre as duas guerras mundiais, o esforço dos partidos socialdemocratas para, através do parlamento, ampliar a democracia e os direitos sociais teria transformado a socialdemocracia em social-estatismo. Viria daí a tese da identificação entre socialdemocracia e Estado de Bem Estar Social (pp. 133-134). Mas Esping-Andersen, como base em outros autores e pesquisas, vê um quadro mais complexo de formação das políticas sociais, dos quais a socialdemocracia dos países nórdicos seria um modelo apoiado em partidos de esquerda e sindicatos fortes. Mas existiria um segundo modelo, o dos países do centro-sul da Europa, resultado de uma mistura de políticas autoritárias e conservadoras, influências católicas e movimentos sindicais variados. Por fim, haveria um modelo de tipo norte-americano e britânico (e das nações anglo-saxônicas, em geral), em que as obrigações e deveres do Estado seriam residuais. No final, a conclusão do autor é de que a influência dos sindicatos é uma das variáveis e que, especialmente nos EUA, outras forças atuaram, inclusive do lado dos empresários, interessados em desviar as pressões dos trabalhadores por maior proteção social para fora da empresa e de contar com recursos dos fundos de pensão e poupança. obtenção de pequenas conquistas, inicialmente limitadas a algumas categorias profissionais. $\mathrm{O}$ caso dos empregados do correio federal é paradigmático. Foi sob pressão dessa categoria que o congresso norteamericano, em 1912, votou a lei Loyd-LaFollete que garante aos servidores do Correio Federal o direito de apresentar petições ao Congresso e, mais importante ainda, garante lhes o direito de filiar-se a um sindicato. Posteriormente, em 1917, a Federação Nacional dos Empregados Federais (NFFE) foi credenciada pela AFL. Esse sindicato cresceu rapidamente: em 1920, tinha 38 mil membros; em 1935, 65 mil; em 1939, 75 mil $^{8}$ (Levine \& Hagburg, 1979, p. 14).

Um dos fatores que prejudicaram a sindicalização dos servidores públicos foi o fato de não terem sido beneficiados pela Lei Nacional de Relações Industriais de 1935. A Lei Wagner, especificamente, excluiu o governo federal da definição de empregador. Além disso, mais tarde, a Lei Taft-Hartley, de 1947, incluiu um dispositivo que proibia os servidores federais de realizar greves. As penalidades incluíam a dispensa imediata e três anos de proibição de recontratação. Em 1955, outra lei (Public Law 330) tornou ainda mais duras as penas contra funcionários federais que fizessem greve, defendessem o direito de fazer greve ou se filiassem a organizações que praticassem tais ações. Se tal acontecesse, tornavam-se passíveis de ação processual, pagamento de multa (na época, mil dólares) e prisão por um ano e um dia. Todo servidor federal deveria fazer uma declaração em que renunciava ao direito de greve contra o governo e de filiação a uma organização que defendesse esse direito (Levine \& Hagburg, 1979, p. 15).

Mas, por volta de 1961, já existiam 40 associações de empregados do governo federal, com aproximadamente 760 mil membros. A imensa maioria era de empregados dos correios, onde o nível de sindicalização chegava a $84 \%$, comparados a $16 \%$ para o resto do governo.

Os efeitos da onda democrática da década dos anos 60 podem ser percebidos na eleição de John Kennedy para a Presidência dos EUA. Durante sua campanha, em 1960, Kennedy defendeu o direito dos empregados federais de negociar com as repartições e agências governamentais. Em junho de 1961, nomeou uma comissão destinada a apresentar uma proposta sobre o

${ }^{8}$ Em 1931, o NFFE saiu da AFI,, a qual, então, para substituir o NFFE, concedeu carta de reconhecimento à Federação Americana dos Empregados do Governo. 90 
assunto. A comissão: a) reconheceu o direito dos empregados federais e de suas associações de participar nas políticas de melhoria das condições de trabalho dos empregados e das políticas de pessoal; b) recomendou que as associações de empregados fossem consultadas pelas administrações que poderiam, em certas condições, firmar acordos com os sindicatos; c) defendeu a regulamentação dos procedimentos de arbitragem individuais de queixas dos empregados; d) solicitou uma legislação para permitir descontos voluntários de cotização nas folhas de pagamento. Mas, ao mesmo tempo, foi recomendado que os funcionários públicos não tivessem direito de greve, que a cláusula da union shop e a da closed shop não eram adequadas para o governo federal e que salários e condições de emprego fixados pelo congresso não seriam objeto de negociação. Em janeiro de 1962, o Presidente Kennedy assinou dois decretos (Executive Orders 10.987 e 10.988) ${ }^{9}$, que, na frase de Troy, "liberou o gênio do Novo Sindicalismo" (Troy, 1994, p. 157), sobre o qual falaremos mais adiante.

A nova legislação estabeleceu três formas de reconhecimento dos sindicatos:

a) reconhecimento informal, concedido a todo sindicato, independentemente de tamanho ou status. Para ser credenciado, bastava ao sindicato solicitar o reconhecimento e demonstrar que representava alguns empregados de um órgão governamental. Esse sindicato tinha o direito de apresentar suas opiniões em matérias que interessassem a seus membros, mas a administração não era obrigada a seguir suas sugestões. Essa prática atendia a uma tradição longamente estabelecida de que os empregados poderiam apresentar suas opiniões, mas o empregador tinha o direito unilateral de aceitá-las ou não.

b) reconhecimento formal era concedido quando pelo menos $10 \%$ dos empregados de uma "unidade de negociação" eram membros de um sindicato e nenhuma outra organização estava qualificada formalmente para representá-los. No entanto, o reconhecimento formal poderia ser concedido a mais de um sindicato quando, na "unidade de negociação", não existisse outro com a exclusividade da representação. Nesse caso, os sindicatos tinham o direito de ser consultados de tempos em tempos pela

${ }^{9}$ Uma Ordem Executiva, que resolvemos traduzir por decreto, é emitida diretamente pela Presidência e tem força de lei. Não necessita passar pelo Congresso, mas pode ser por ele emendada ou rejeitada. Também o próprio presidente, ou seu sucessor, pode revogá-la. administração sobre questões de pessoal e outras matérias referentes às condições de trabalho. A qualquer momento, os sindicatos poderiam apresentar suas opiniões a respeito. A administração não tinha outra obrigação além de "afirmar seu desejo de um satisfatório entendimento da matéria em questão".

Finalmente, um sindicato passava a ter exclusivo reconhecimento se fosse votado pela maioria dos empregados da "unidade de negociação" como seu representante exclusivo. Mais de $60 \%$ dos empregados da unidade deveriam participar da votação. Nesse caso, fosse o sindicato escolhido, nenhum outro poderia existir na mesma unidade. O reconhecimento exclusivo ampliava os direitos de intervenção do sindicato nas questões locais, podendo discutir com a chefia questões de política de pessoal e de trabalho. A essência do reconhecimento exclusivo estava no fato de os representantes da administração local e do sindicato poderem negociar acordos coletivos com cláusulas extensivas a todos os empregados da unidade. Ademais, o sindicato teria o direito de enviar representantes a todas as reuniões relativas a queixas dos empregados e a todas as matérias relativas às condições de emprego (Levine \& Hagburg, 1979, p. 19).

Um dos problemas que surgiram, como era previsível (e existiu no setor privado e se expressou constantemente nos chamados "conflitos de jurisdição"), é o da definição do que constituiria uma "unidade de negociação". Nesse ponto, a regulamentação do setor público seguiu as diretrizes do setor privado, definindo uma "comunidade de barganha como uma comunidade de interesses claramente identificável entre os trabalhadores envolvidos". Essas comunidades poderiam ser estabelecidas a partir de qualquer local de trabalho, de ofício ou de uma função ou ainda em outras situações que criassem uma "comunidade". Algumas categorias profissionais, como as dos empregados que tinham funções de direção (como supervisores e empregados de profissões liberais), estavam excluídas. Por outro lado, o sindicato que tinha a exclusividade da representação não poderia recusar a filiação de um empregado que quisesse pagar a mensalidade e que preenchesse as condiçõos de filiação a sindicatos.

Apesar de alterações ocorridas durante o governo Nixon e posteriormente durante o governo Ford, as mudanças não impediram a continuidade da sindicalização no setor público. Em 1975, pela primeira vez o número de empregados cobertos por acordos coletivos no governo 
federal superou um milhão. Nesse ano, 670.029 empregados estavam representados na maior das associações, a Federação Americana dos Empregados do Governo (AFGE); 1.724 unidades de barganha haviam sido reconhecidas, das quais 1.223 estavam funcionando sob acordos coletivos, cobrindo 589.613 empregados (Levine \& Hagburg, 1979, p. 25).

No modelo estabelecido pela legislação, o avanço do sindicalismo no setor público resultou em três tipos básicos de associações de empregados do governo federal que não necessitavam ser compostas exclusivamente por funcionários governamentais:

a) sindicatos com todos ou com a proporção majoritária de filiados que são funcionários do governo federal;

b) sindicatos com a maior proporção de seus membros no setor privado, mas com um número substancial de funcionários federais. Um exemplo seria o Sindicato dos Empregados de Serviços, com aproximadamente 450 mil membros (dados de 1975), dos quais $30 \%$ de empregados públicos;

c) associações ou sindicatos independentes cujos membros são frequentemente "profissionais" em suas orientações e limitados a um ofício ou a uma instituição, como o Sindicato dos Empregados do Tesouro Nacional (NTEU), a Associação dos Controladores do Tráfico Aéreo (PATCO) (Levine Hagburg, 1979, p. 25).

Os decretos do Executivo que favoreceram, inegavelmente, o avanço da sindicalização no setor público não garantiram, contudo, o direito de greve, nem de formação de piquetes, operações-tartaruga ou outros atos destinados a prejudicar o andamento normal do trabalho. Apesar disso, entre 1962 e 1974, houve 18 greves envolvendo 164.300 empregados federais, entre as quais podemos citar a greve dos carteiros, em 1970, como uma das maiores, e as várias paralisações promovidas pela Associação dos Controladores do Tráfico Aéreo (PATCO) (Levine \& Hagburg, 1979, p. 32). (A PATCO acabou posteriormente dissolvida, sob o governo Reagan, num dos conflitos trabalhistas mais famosos dos EUA.)

Detivemo-nos, talvez excessivamente, na descrição da legislação americana para mostrar a relação entre o fator político (a vitória de Kennedy), o clima ideológico existente no período e a expansão do sindicalismo do setor público, relação que fortalece a tese da importância de "governos amigos" para a expansão do sindicalismo. Na verdade, em toda a parte, os elementos políticos - mesmo que, por sua vez, sejam influenciados por transformações na sociedade e na economia - foram sempre, como já foi discutido, uma variável altamente correlacionada com as características e a extensão do movimento sindical. Mudanças de regimes políticos muitas vezes alteraram a legislação sobre os sindicatos e sobre os sistemas de relações de trabalho. As consequências sobre o sindicalismo como movimento social e como estrutura organizatória podem ser muito grandes. Desse ângulo, o fim de dispositivos legais que impediam a sindicalização dos funcionários teve efeitos equivalentes a mudanças na legislação que, nos vários países e em momentos diferentes, afetaram negativa ou positivamente o desenvolvimento do sindicalismo do setor privado.

Mas, no caso do setor público, o fator político desempenhou papel de natureza diferente, relacionado mais diretamente com as disputas pela conservação do poder que passam pela busca do voto. Os empregadores governamentais tenderam a ceder mais facilmente, às vezes a se adiantar, às demandas das associações dos funcionários. Mais exatamente, nos anos 60 e 70, os partidos no governo, diante das pressões do movimento dos servidores, ficaram divididos entre duas tendências contraditórias: de um lado, as compensações eleitorais da concessão de vantagens aos empregados (que de todo modo não seriam pagas por eles) e, de outro, as possíveis repercussões negativas em parcelas do eleitorado "privado" e o enfraquecimento do poder público diante do movimento sindical dos funcionários. De modo geral, enquanto as vantagens concedidas apareciam como elementos de políticas sociais (criação de mais escolas, hospitais, aumentos salariais etc.), não oneravam demasiadamente o orçamento público e não exigiam aumentos de impostos eleitoralmente impopulares, os benefícios das concessões compensavam as desvantagens.

Ao contrário do setor privado, em que a diminuição de custos é um objetivo permanente da administração, o aumento de custos no setor público - como se sabe - significa geralmente aumento de poder da parcela da classe política que controla o Estado ou parte dele. Uma das vias pelas quais passa esse aumento é a ampliação do emprego, mediante novas contratações que aumentam o apoio aos grupos que controlam o Estado. Esse foi um procedimento seguido pela classe política ao longo da década dos 60 e dos 70 . 
Do ponto de vista das facções políticas no poder, a prática ideal seria a das concessões paternalistas que parecessem como dádivas de políticos preocupados com o bem-estar de seus funcionários. A crise dos Estados de Bem-estar Social, a falência das políticas intervencionistas e socializantes no novo contexto neoliberal elevou os custos eleitorais do clientelismo enquanto a racionalização crescente dos serviços públicos e a democratização da sociedade tornavam mais difíceis as práticas da patronagem política. Em todo o mundo, os governos foram surpreendidos pelo aparecimento de um novo tipo de movimento sindical que se organizava dentro deles mesmos, que punha em questão a sua autoridade e os princípios da soberania do Estado, cada vez mais incapaz de atender às demandas dos seus empregados e de reagir autoritariamente às pressões desse novo tipo de sindicalismo. Para alguns autores, foi justamente esse declínio do poder político que teria propiciado a rápida e fulminante expansão do sindicalismo de funcionários públicos (Nisbet, 1983; Dilts \& Deitsch, 1983; Herman \& Kuhn, 1981). Por volta de 1980 e 1990, a doutrina da soberania do Estado entrou também em crise em praticamente todos os países europeus, notadamente na França, na Itália, na Holanda e na Espanha (Ferner, 1994, p. 61).

Nessa linha de interpretação, a tese mais radical é de R. Nisbet (1983) que contém, no conjunto das análises, uma interpretação singular. $\mathrm{Na}$ medida em que as instituições e serviços públicos se teriam tornado mais impessoais, dominados por comissões e regulamentos, as relações informais tenderiam a enfraquecer-se e a dar lugar às carreiras burocráticas, aos concursos de admissão, às normas mais estritas e formais de trabalho. Com isso, ter-se-iam enfraquecido o clientelismo e o protecionismo que em toda a parte haviam marcado, com maior ou menor intensidade, o serviço público. O desaparecimento dos padrinhos e das máquinas políticas que ofereciam proteção e segurança para os funcionários públicos e criavam uma relação de fidelidade dos empregados ante as chefias e as diques políticas abriria espaço para a atuação sindical, destinada a dar aos funcionários a segurança e a proteção que o antigo esquema clientelístico não mais podia conceder. Os sindicatos seriam, deste modo, os sucessores das velhas máquinas políticas e dos esquemas clientelísticos (pp. 30-33) ${ }^{10}$.

${ }^{10}$ As considerações de Nisbet estão fundadas numa visão pessimista e conservadora do processo político e civilizatório em geral, no transcorrer do qual estaria ocorrendo a perda da confiança e respeito diante da autoridade estatal. Nesse contexto, em que sua autoridade se esvaneceria, o
Acompanhando ou não a tese de Nisbet, o peso do fator político no desenvolvimento do sindicalismo do setor público - e também, inversamente, a amplitude de seus reflexos no campo das disputas pelo poder - como salientamos, foram mais diretos e talvez mais fortes do que os que tiveram sobre o do setor privado porque a organização sindical dos funcionários invade e abala as estruturas do Estado. Já a ação sindical do setor de mercado, ainda que possa ter repercussões políticas e institucionais fortes, efetua-se no campo privado e, ao menos teoricamente, não necessita entrar no domínio dos assuntos que são da soberania da autoridade pública (se a ação sindical for legal). A atuação dos sindicatos dos funcionários ao mudar (ou tentar mudar) padrões, normas de trabalho, distribuição de recursos, planos governamentais etc., de alçada do poder executivo ou legislativo, significa alguma forma de intromissão externa em instâncias que representam o poder público. A obtenção de melhorias salariais e outros benefícios para categorias de empregados do Estado, e.g., sempre afetam orçamentos propostos pelo Poder Executivo e, nas democracias, geralmente apreciados pelo Poder Legislativo ${ }^{11}$.

Essas observações, às quais outras poderiam ser acrescentadas, indicam diferenças no movimento dos funcionários do setor público com relação ao do setor privado. Sob esse aspecto, não é difícil o consenso. A questão é saber quanto as duas formas de sindicalismo diferem e, assim, em que medida a condição comum de assalariado é suficiente para unificá-los ou aproximá-los ou, pelo contrário, se o surgimento do sindicalismo público não ajudaria a aumentar a fragmentação dos interesses das camadas assalariadas.

Estado apenas saberia agir repressivamente, o que leva a Nisbet a antever a possibilidade de um desenvolvimento - que os acontecimentos posteriores não confirmaram - da democracia americana em direção a alguma forma de Estado militar, tipo soviético, cubano ou chinês. Apesar disso, entendemos que a hipótese da relação entre a expansão do sindicalismo entre os funcionários públicos e o fim do clientelismo e paternalismo político merece atenção.

${ }^{11}$ Com base em várias pesquisas, Feuille (1991) entende que os sindicatos do setor público, especialmente em nível local, quando negociam sob a proteção da legislação, efetivamente conseguem vantagens para seus membros: "No conjunto, os dados mostram que os servidores públicos obtêm substanciais vantagens por estarem sindicalizados. Não somente Os ordenados, Os benefícios e o total de vantagens são mais elevados quando existem sindicatos mas Os empregados também gozam de proteções que seus colegas não sindicalizados não têm. Talvez, melhor do que tudo (pelo menos do ponto de vista dos funcionários), é que parece não haver correspondente declínio do emprego nas administrações públicas locais quando o preço a ser pago por um maior custo de uma unidade de trabalho se eleva" (p. 358). 
Cabem, a propósito do sindicalismo do setor público, várias indagações: em que medida temos um fenômeno que significaria uma nova etapa do movimento sindical como um todo? Em que medida ele ajuda a democratização das relações de trabalho dentro do Estado? Ou, em que medida se trata de um movimento de defesa de um segmento das classes assalariadas que se faz em detrimento de outros do próprio setor público ou do setor privado? Em que medida é um movimento na aparência contestador do autoritarismo das administrações públicas, de defesa dos "explorados" e "dominados", mas no fundo defensor de vantagens, ou mesmo de privilégios de categorias "protegidas"?

Não há respostas genéricas para essas indagações porque a atuação do sindicalismo do setor público não é igual nos vários países. No interior de um mesmo país, as posições ideológicas e políticas não são as mesmas entre as organizações das diversas categorias profissionais (sindicatos da polícia tendem a ser mais conservadores do que os sindicatos dos professores, por exemplo). Além disso, as leis e regulamentos do emprego público de cada país diferem entre si; o espaço que os sistemas políticos nacionais oferecem para a participação dos movimentos de seus empregados pode ser mais amplo ou mais exíguo. Esses aspectos afetam a conduta das organizações dos funcionários e empregados do Estado diante do resto do sindicalismo, fazendo-as mais cooperativas ou mais hostis ante os sindicatos e federações dos trabalhadores manuais do setor de mercado, que geralmente são mais antigos e menos "radicais" que muitas das novas associações de empregados públicos não manuais. Por isso, as avaliações do sindicalismo dos funcionários podem ser muito diversas, além de serem afetadas pela posição pessoal, mais positiva ou mais negativa, dos pesquisadores diante do sindicalismo.

Uma avaliação que vê no movimento dos funcionários um fenômeno novo é a de Troy (1994). O autor - que restringe sua interpretação basicamente aos EUA, com algumas referências ao Reino Unido e ao Canadá - entende que o sindicalismo do setor público é um "novo sindicalismo" (New Unionism), em muitos aspectos essencialmente diferente do sindicalismo do setor de mercado, o qual denomina de "velho sindicalismo"12.

${ }^{12}$ O conceito de Novo Sindicalismo, tal como definido por Troy, nada tem a ver com o do
livro homônimo de Heckscher (1996), que tem como referência o setor privado e imagina livro homônimo de Heckscher (1996), que tem como referência o setor privado e imagina
um "sindicalismo associativo" (associational unionism) menos conflitivo diante das
O Novo Sindicalismo seria a forma de organização sindical adequada para as mudanças ambientais ocorridas nos últimos tempos, especificamente a ampliação do setor de serviços e o encolhimento do emprego no setor industrial. Em começos de 1960, nos EUA, 94\% dos trabalhadores sindicalizados estariam no setor privado e apenas $6 \%$ no setor público. Por volta de $1994,40 \%$ de todos os sindicalizados estariam em organizações do setor público. O fato seria ainda mais significativo se tivéssemos em conta que o emprego público norte-americano, de acordo com Troy, representa somente $16 \%$ do total da força de trabalho. As razões da ascensão do sindicalismo dos funcionários, ou do "Novo Sindicalismo", nos termos do autor, são relativamente fáceis de explicar e já foram mencionadas anteriormente: avanço do processo de democratização, da política de massas e da expansão dos serviços oferecidos pelo Estado, às quais se deve acrescentar a nacionalização de serviços e setores produtivos anteriormente de caráter privado. Esses desenvolvimentos ocorridos a partir da década dos 60 fizeram-se mais facilmente sob governos socialdemocratas, socialistas ou trabalhistas, na Europa, ou governos do Partido Democrático, nos EUA.

Troy entende (tal como outros autores) que, no caso norte-americano, o ponto de partida do Novo Sindicalismo teria sido o Decreto 10988 (a Executive Order) do Presidente Kennedy, de 1961. A tese é de que o decreto teria permitido que as associações de funcionários já existentes se transformassem em sindicatos e aumentassem o número de membros e sua força de pressão. O Novo Sindicalismo, ao contrário do anterior, teria surgido basicamente da conversão de associações já existentes (protossindicatos) em sindicatos e não da criação de novas entidades, como no setor de mercado. Nesse aspecto, ao contrário do "velho sindicalismo", que se teria lançado a organizar os não organizados, o Novo Sindicalismo teria significado a "organização dos já organizados". Por isso, os ganhos do Novo Sindicalismo, ao contrário do anterior, não teriam exigido "sangue, suor e lágrimas" (p. 66).

O Novo Sindicalismo relacionar-se-ia com o que Troy denomina de "Novo Socialismo". Seu objetivo básico não seria a socialização dos meios de produção, mas a ampliação crescente da parte do governo na renda nacional, ou a "socialização da renda". As antigas reivindicações do "velho

empresas, que o autor julga mais capaz de fazer frente às mudanças técnicas e econômicas que estão ocorrendo nos EUA e que estariam levando ao declínio do sindicalismo norteamericano na sua forma atual. 
socialismo", de nacionalização da propriedade privada, estariam há certo tempo desmoralizadas. O capitalismo ter-se-ia mostrado mais competente no aumento da produção e distribuição da renda. Consequentemente, esse objetivo não mais interessaria ao Novo Socialismo. "As mudanças econômicas fizeram da socialização dos meios de produção uma relíquia do passado" (p. 9). Já o Novo Socialismo, dirigindo-se diretamente para a redistribuição da renda e não para a destruição da propriedade privada, estaria mais atualizado. Esse Novo Socialismo, diferentemente do velho (que se fundava sobre a classe operária), apoiar-se-ia sobre a classe média para a qual orienta a maior parte de seus programas (p. 15). Um estudo de 1984 teria mostrado que $70 \%$ dos "novos sindicalistas" eram empregados não manuais (white-collars), contra 23\% no antigo; $53 \%$ eram de categorias profissionais qualificadas, entre as quais a dos professores teria grande peso. As mulheres, por sua vez, representariam 53\% do Novo Sindicalismo contra $27 \%$ do velho (p. 42). Apesar disso, Troy entende que nem toda a classe média seria simpática ao Novo Socialismo porque é ela quem paga parte dos impostos que servem para aumentar os salários e benefícios dos empregados do Estado.

Sendo um sindicalismo de empregados do setor público, a estratégia do Novo Sindicalismo estaria dirigida para o aumento do âmbito das matérias envolvidas na barganha com o Estado, especialmente a ampliação do direito de greve nos serviços públicos. $\mathrm{O}$ sindicalismo do setor privado buscava fundamentalmente obter uma melhor redistribuição da renda dos empregadores privados para os empregados do setor privado, do Capital para o Trabalho. O Novo Sindicalismo visaria aumentar a contribuição da renda do setor privado para o setor público, ou seja, para os funcionários.

Mesmo entendendo, em trabalho posterior (Troy, 1996), que a sindicalização do setor público estaria, na segunda metade da década dos 90, atingindo seu teto, Troy considera que o Novo Sindicalismo terminará por assumir as posições de liderança no conjunto do movimento sindical, superando os grandes sindicatos de trabalhadores manuais do velho sindicalismo. Nos EUA, um indicador desse processo seria a superação dos Teamsters pelo Sindicato dos Professores (como maior sindicato do país); no Reino Unido, a superação do Sindicato Geral de Trabalhadores do Transporte e Outras Categorias (TGWU) pelo UNISON; na Suécia, em 1977, pela superação do Sindicato dos Metalúrgicos pela Komunal (Sindicato dos Trabalhadores Municipais), do setor público.
A tese de que o futuro do sindicalismo está representado pelo sindicalismo do setor público ou de empregados das estatais, em si mesma, parecia plausível, tendo em conta o constante recuo do emprego no setor industrial e a expansão do setor de serviços estatais e o correlato crescimento dos sindicatos do setor público. Contudo, a tese do autor de que "o futuro do Novo Sindicalismo [pelo qual tem pouca simpatia] parece assegurado" (p. 158) é mais difícil de ser defendida diante de um conjunto de mudanças ocorridas no papel do Estado a partir dos anos 80 e, assim, nas possibilidades de expansão do "Novo Sindicalismo", que reúne categorias profissionais muito heterogêneas, unidas apenas pelo fato de terem um mesmo empregador.

\section{Fatores econômicos: a expansão das atividades do estado}

No exame da expansão do sindicalismo do setor público, a influência dos elementos políticos deve ser examinada em associação com as alterações na distribuição do emprego. Uma delas, obviamente, é a elevação da oferta de trabalho no setor público durante os anos 60 e 70. Independentemente de outros elementos, como notam Dilts e Deitsch (1983), o próprio crescimento econômico, ao ampliar as "deseconomias externas" (aumento da criminalidade, dos problemas urbanos, etc.), levou à maior participação do Estado na busca de soluções que, aparentemente, não poderiam ser alcançadas por meio do mercado. Por outro lado, nas décadas anteriores à globalização, as pressões democráticas e igualitárias estimularam a passagem de serviços anteriormente privados para a esfera do governo, como serviços médicos, educacionais, pensões e aposentadorias. $\mathrm{O}$ resultado foi a enorme expansão do setor público. $\mathrm{Na}$ Itália, o emprego no governo cresceu $27 \%$ entre 1970 e 1980 e $19 \%$ entre 1980 e 1990; na Espanha, o emprego público cresceu mais de 50\% do total do emprego entre 1976 e 1989 (Ferner, 1994, pp. 68-69). Os reflexos na atuação sindical e política são evidentes. Na Alemanha, informa ainda Ferner, $40 \%$ dos deputados do Bundestag têm emprego público (p. 72). Como nota Visser (1988, p. 136), por volta da década de 20, a extensão do setor industrial era um dos melhores indicadores das taxas de sindicalização em cada país. Em outros termos, quanto maior a proporção da força de trabalho empregada na indústria, mais altos tendiam a ser os níveis de sindicalização. Em 1985, essa relação deixou de existir. O melhor indicador de sindicalização é a proporção da força de trabalho no setor público. 
Suécia e Dinamarca, em começos da década dos 90, tinham o maior setor público dos países europeus desenvolvidos, com aproximadamente um 1/3 de todos os assalariados com emprego no governo ou em instituições financiadas pelo Estado (p. 136). Aliás, já em 1985, o peso do setor público era bastante elevado nos países escandinavos. Em fins da década, também a Noruega aproximava-se dos $30 \%$. Significativamente, eram esses os países que possuíam as maiores taxas de sindicalização. Entre 1985 e 1989, somente no Reino Unido, na Irlanda, na Holanda e na Suécia houve uma diminuição, mesmo que pequena, no emprego público.

\section{Quadro 4.3}

Participação do setor público no total do emprego (Europa 1979-1990)

\begin{tabular}{|c|c|c|c|c|c|}
\hline & 1970 & 1975 & 1979 & 1985 & 1989 \\
\hline Áustria & 13,2 & 16,3 & 17,6 & 19,1 & 21,1 \\
\hline Bélgica $^{b}$ & 13,6 & 15,6 & 18,3 & 19,9 & 19,9 \\
\hline Dinamarca $^{a}$ & 17,2 & 23,6 & 26,9 & 30,2 & 30,1 \\
\hline Finlândia & 12,1 & 14,8 & 17,2 & 18,9 & 20,6 \\
\hline França & 17,6 & 19,0 & 19,9 & 22,1 & 22,8 \\
\hline Alemanha $^{a}$ & 11,1 & 13,8 & 14,7 & 15,5 & 15,6 \\
\hline Grécia $^{b}$ & 7,4 & 8,2 & 9,1 & 9,4 & 10,1 \\
\hline Irlanda & 12,0 & 14,4 & 16,1 & 18,3 & 17,9 \\
\hline Itália & 12,3 & 14,6 & 15,8 & 16,6 & 17,4 \\
\hline Luxemburgo & 9,4 & 9,7 & 10,6 & 11,3 & 11,4 \\
\hline Holanda & 12,2 & 13,6 & 14,7 & 16,1 & 15,1 \\
\hline Noruega $^{b}$ & 17,9 & 21,7 & 24,3 & 28,1 & 29,3 \\
\hline Portugal & 7,9 & 8,5 & 10,5 & 13,3 & 14,6 \\
\hline Espanha $^{\mathrm{c}}$ & 5,5 & 7,8 & 10,0 & 12,8 & 13,7 \\
\hline Suécia $^{b}$ & 20,9 & 25,7 & 29,9 & 32,9 & 31,8 \\
\hline Suíça ${ }^{b}$ & 7,5 & 9,0 & 10,1 & 10,2 & 10,5 \\
\hline Reino Unido & 18,1 & 20,9 & 21,2 & 21,8 & 19,6 \\
\hline
\end{tabular}

${ }^{a}$.Último ano com dados disponíveis: 1990.

b Último ano com dados disponíveis: 1988.

${ }^{\mathrm{c}}$ Último ano com dados disponíveis: 1987.

Fonte: Oxley \& Martin (1991).

Na década dos 80 , o ritmo de crescimento do setor público diminuiu em todos os países, com exceção da Áustria. A redução da expansão foi geral e atingiu todos os países europeus, qualquer que fosse o nível de desenvolvimento econômico e o tipo de governo. $\mathrm{O}$ fato tem importância para os prognósticos sobre o desenvolvimento do sindicalismo do setor público, uma vez que, como vimos, a expansão do emprego no setor havia sido um elemento importante para a explosão do movimento associativo entre funcionários e empregados do Estado.

Quadro 4.4

Média Anual de Expansão do Setor Público no Total do Emprego

(Europa: 1979-1990)

\begin{tabular}{|c|c|c|c|c|}
\hline & $1970-1975$ & $1975-1979$ & 1979-1984 & $1984-1990$ \\
\hline Áustria & 4,1 & 3,0 & 1,9 & 2,7 \\
\hline Bélgicab $^{b}$ & 3,0 & 4,1 & 0,9 & 0,7 \\
\hline Dinamarca $^{a}$ & 6,5 & 4,6 & 2,5 & 0,7 \\
\hline Finlândia & 5,0 & 4,3 & 3,2 & 2,2 \\
\hline França & 2,0 & 1,7 & 1,8 & 1,0 \\
\hline Alemanha $^{a}$ & 3,8 & 1,9 & 1,0 & 1,5 \\
\hline Grécia $^{b}$ & 2,6 & 3,3 & 2,2 & 2,5 \\
\hline Irlanda & 4,1 & 4,5 & 1,9 & $-0,8$ \\
\hline Itália & 3,8 & 2,6 & 1,4 & 1,3 \\
\hline Luxemburgo & 3,0 & 2,2 & 1,5 & 3,0 \\
\hline Holanda & 2,1 & 2,5 & 0,7 & 0,3 \\
\hline Noruega $^{\mathrm{b}}$ & 5,0 & 5,3 & 3,7 & 2,8 \\
\hline Portugal & 4,0 & 6,5 & 6,2 & 3,4 \\
\hline Espanha $^{c}$ & 7,6 & 5,0 & 2,9 & 4,0 \\
\hline Suécia ${ }^{b}$ & 5,3 & 4,6 & 2,2 & 0,0 \\
\hline Suíçab & 3,7 & 2,7 & 1,4 & 0,9 \\
\hline Reino Unido & 3,1 & 0,8 & $-0,3$ & -0 \\
\hline
\end{tabular}

${ }^{a}$ Ultimo ano com dados disponíveis: 1990

b Ultimo ano com dados disponíveis: 1988.

c Último ano com dados disponíveis: 1987.

Fonte: Oxley \& Martin (1991).

\section{EFEITOS DA SindiCALIZAÇÃo DO SETOR PÚBLICO SOBRE O SINDICALISMO}

A sindicalização dos funcionários e empregados do governo, em toda a parte, afetou fortemente as estruturas sindicais preexistentes: até então, o movimento sindical estava associado a trabalhadores manuais do sexo masculino, de mãos calejadas, que perfaziam tarefas árduas e penosas que, amiúde, exigiam força física, tal como aparecia habitualmente na iconografia do movimento operário. Hoje, a presença proporcionalmente maior desses novos segmentos de assalariados, de empregados de escritórios, dos laboratórios, das salas de aula, das repartições públicas, efetuando tarefas "limpas", teve efeitos complexos no movimento sindical, ajudando a mudar suas feições clássicas. Uma nova iconografia das 
mobilizações sindicais deveria deixar de lado as imagens habituais do operário, forte e rude (quando retratado em situações de mobilização), ou do trabalhador esquálido das oficinas (quando retratado nas situações de trabalho). Em seu lugar entrariam os empregados e empregadas, de mãos menos calejadas, já não tão andrajosos e famélicos. Mas nem por isso, necessariamente, seu sindicalismo seria menos radical.

Do ponto de vista qualitativo, da composição de gênero da massa de associados, a sindicalização do setor público aumentou a proporção de mulheres e elevou os níveis de escolaridade do movimento sindical. Do ponto de vista quantitativo, ajudou a segurar as taxas globais de sindicalização e a manter o sindicalismo na ordem do dia da política nacional. $\mathrm{O}$ sindicalismo dos funcionários salvou o movimento sindical de um declínio ainda mais profundo que seu enfraquecimento no setor privado vinha provocando. Em muitos sentidos, portanto, significou uma reativação do sindicalismo enquanto movimento, introduzindo dinamismo em estruturas sindicais consolidadas e acomodadas.

Mas a organização dos empregados públicos e empresas estatais trouxe também novos problemas para o movimento sindical no seu conjunto. Uma das consequências, no plano organizatório, foi a ampliação das divergências internas no campo sindical no que diz respeito às táticas de atuação, às ideologias e ao relacionamento com os "partidos da classe operária". A liderança tradicional, habitualmente recrutada dos sindicatos de trabalhadores manuais da indústria, especialmente do ramo metalmecânico, começou a ser contestada pelos novos dirigentes das associações de funcionários. O comando nos órgãos de cúpula, especialmente nas centrais sindicais, cabe sempre aos maiores sindicatos, aos que têm mais filiados, maiores recursos e maior força de pressão. Esses sindicatos eram até o grande avanço do sindicalismo do setor público e o recuo do sindicalismo do setor privado - o dos trabalhadores manuais das indústrias e o dos serviços coletivos ${ }^{13}$.

\footnotetext{
${ }^{13}$ Um exemplo é a composição atual, no Reino Unido, do Conselho Geral, órgão máximo da central TUC, com aproximadamente 40 membros.

Secção A. Sindicatos com 200 mil ou mais membros têm a seguinte representação:

200.000 a 399.999: dois lugares;

400.000 a 649.999: três lugares;

650.000 a 899.999: quatro lugares;
}

Na Suécia, o modelo centralizado de barganha, que selava o compromisso entre a central sindical $\mathrm{LO}$ e a associação patronal SAF, foi desafiado pelo crescimento de federações de empregados, manuais e não manuais, do setor público (funcionalismo tradicional e empresas estatais). $\mathrm{O}$ modelo neocorporativo de negociação centralizada entrou em crise com o aumento do poder de outra central, a TCO (Organização Central de Empregados Assalariados). Fundada em 1944 pela fusão de duas organizações, uma do setor privado e outra do setor público para empregados não manuais (white-collars), a TCO cresceu vigorosamente: em 1945, tinha cerca de 200 mil membros; em 1990, subiu para 1,2 milhões. Metade dos seus membros é de empregados e funcionários do Estado. Ao contrário da LO, a TCO não é ligada ao Partido Social-Democrata e possui um fundo de greve próprio, o que lhe permite desafiar a autoridade da $\mathrm{LO}^{14}$.

Na década dos 70, as organizações filiadas à TCO adquiriram o pleno direito de negociação independente e tinham sua própria política, marcada frequentemente por conflitos internos e pela fragmentação das negociações (Visser, 1996b). A LO perdeu, na década dos 80, sua posição dominante enquanto aumentavam as divergências entre os sindicatos de empregados e os de trabalhadores manuais. Em 1990, a taxa de sindicalização do setor público (88\%) superava a do setor privado (81\%). Na própria LO, tradicionalmente uma central de operários que reunia sindicatos organizados por indústria, a proporção de filiados com emprego público subia de 16,2\% em 1950 para 30,9\% em 1985, enquanto a proporção de sindicalizados do setor privado caía de $48,0 \%$ para $40,0 \%$ nos mesmos anos. Atualmente, entre os cinco maiores sindicatos suecos, há apenas dois

900.000 a 1.199.999: cinco lugares;

1.200 .000 a 1.499 .999 seis lugares.

Sindicatos com cem mil ou mais mulheres associadas devem eleger no mínimo uma representante.

Secção B. Sindicatos entre 100.000 e 199.999 membros têm direito a um lugar.

Secção C. Sindicatos com menos de cem mil associados elegem coletivamente oito membros.

Secção D. Sindicatos com menos de 200 mil membros elegem coletivamente quatro mulheres como representantes (McIlroy, 1995, pp. 4546).

${ }^{14}$ Os sindicatos filiados à LO, para entrar em greve, necessitam da prévia aprovação da central, caso o movimento atinja mais de 3\% dos empregados. Se a greve é aprovada, a LO, que controla os fundos de greve, reembolsa $75 \%$ dos salários perdidos pelos grevistas. "O sindicato que vá contra a LO corre o risco de perder muito dinheiro e de ser expulso. Mas isso nunca aconteceu" (Visser, 1996b, p. 184). 
de trabalhadores manuais: o dos metalúrgicos e o da construção civil (Visser, 1996b, pp. 182-183). O sistema centralizado de negociação foi quebrado em virtude do surgimento de outras entidades fora do controle da LO, da recusa crescente do patronato de manter o antigo sistema e da fragmentação dos interesses dos grupos de assalariados privados e públicos e do declínio político do Partido Social-Democrata (Rehn \& Viklund, 1992; Kjellberg, 1993; Pontusson, 1996; Visser, 1996b; Ferner, 1994).

O caso da Suécia - significativo porque se trata de um país no qual o movimento sindical havia atingido um avanço sem paralelo no resto do mundo - ilustra um desenvolvimento que aconteceu em toda a parte, com maior ou menor intensidade. A expansão do sindicalismo do setor público gerou novas lideranças de organizações poderosas, com reivindicações específicas, que foram adquirindo confiança e legitimidade para desafiar os dirigentes dos sindicatos do setor privado que até então, pela sua importância, dominavam as centrais sindicais. Por isso, o movimento associativo do setor público, ao mesmo tempo, deu novo impulso ao conjunto do sindicalismo, que decaía no setor de mercado, mas lhe trouxe novos problemas ao abalar a autoridade das centrais sindicais tradicionais, reduzir a legitimidade de suas lideranças, minar sua capacidade de representação ampla da massa de assalariados. Assim, direta ou indiretamente, ao enfraquecer a capacidade das centrais tradicionais diante do governo e das associações patronais, reforçaram as tendências ao enfraquecimento das negociações centralizadas e unificadas em favor de maior fragmentação dos acordos coletivos.

\section{As Perspectivas do Sindicalismo do Setor Público}

Considerando o impulso trazido pela expansão da organização sindical entre os empregados do Estado no momento em que o sindicalismo recuava no setor de mercado, cabe indagar em que medida esse desenvolvimento tem possibilidades de persistir para as próximas décadas. Se tal acontecer, estaríamos não diante de um declínio geral do sindicalismo, mas de uma transformação equivalente à que ocorreu no passado com a transição do sindicalismo de ofício para o sindicalismo da grande indústria. Para avaliar essas probabilidades, tentaremos nas páginas seguintes examinar a evolução do sindicalismo do setor público ${ }^{15}$ em anos mais recentes.

Quadro 4.5

Taxas de sindicalização no setor público (1970-1990)

\begin{tabular}{|c|c|c|c|c|c|c|}
\hline Países & 1970 & 1975 & 1980 & 1985 & 1988 & 1990 \\
\hline Alemanha & 61,0 & 56,6 & 52,6 & 50,4 & 44,9 & 44,0 \\
\hline Austrália & & & & & & \\
\hline Survey domiciliar & _- & - & $73,0^{\mathrm{e}}$ & $71,0^{\mathrm{g}}$ & 68,0 & - \\
\hline Áustria & 77,7 & 72,5 & 68,1 & 60,5 & 56,9 & - \\
\hline Canadá & & & & & & \\
\hline Estatísticas sindicais & - & - & - & - & - & 64,3 \\
\hline Survey domiciliar & - & - & - & $63,0^{\mathrm{f}}$ & - & - \\
\hline Dinamarca & 67,5 & 64,4 & 69,2 & 74,9 & 70,0 & - \\
\hline EUA & & & & & & \\
\hline Estatísticas sindicais & - & - & - & - & - & 36,9 \\
\hline Survey domiciliar & - & $29,4^{\mathrm{b}}$ & 36,7 & 35,8 & 36,7 & - \\
\hline Finlândia & - & - & - & - & $85,7^{\mathrm{h}}$ & - \\
\hline França & - & - & $44,0^{\mathrm{d}}$ & - & 26,0 & 23,0 \\
\hline Holanda & 64,4 & 63,7 & 59,7 & 49,0 & - & 45,0 \\
\hline Itália & $46,8^{\mathrm{a}}$ & 56,3 & 59,6 & 55,6 & 54,1 & 54,0 \\
\hline Japão & - & $77,5^{\mathrm{i}}$ & 74,5 & 61,7 & 55,8 & - \\
\hline Luxemburgo & - & - & - & - & $74,3^{\mathrm{h}}$ & - \\
\hline Noruega & 67,5 & 69,2 & 74,3 & 76,6 & 75,1 & - \\
\hline Reino Unido & $60,2^{\mathrm{a}}$ & $64,2^{\mathrm{b}}$ & $68,8^{\mathrm{c}}$ & $69,3^{\mathrm{f}}$ & $55,4^{\mathrm{h}}$ & 60,0 \\
\hline Suécia & - & - & 81,1 & 87,5 & 81,3 & 88,0 \\
\hline Suíça & 74,8 & - & 70,7 & $70,6^{\mathrm{f}}$ & - & - \\
\hline
\end{tabular}

a) 1971 ; b) 1974 ; c) 1979 ; d) $1981 ;$ e) $1982 ; 1$ 1) 1984 ; g) 1986 ; h) 1989 ; i) $1975 ;$ com relação ao Japão, os dados do setor público estão baseados em informações do Ministério do Trabalho japonês, nos surveys sobre sindicatos nos quais Os professores são contados como membros de

15 Foram incluídos no setor público: polícia; educação; transporte e serviços anexos; distribuição de energia e correios. Membros de indústrias nacionalizadas e de produção de energia não foram incluídos. Em algumas das atividades constantes do setor público nem todos os trabalhadores são diretamente empregados do governo mas, nesse caso, as atividades são de regulamentação governamental. Nos casos dos EUA, do Canadá e da Austrália, Visser incluiu informações obtidas nas pesquisas domiciliares. Para os demais países, os dados furam retiradas de publicações governamentais e de outros documentos que trabalham com estatísticas fornecidas pelos sindicatos. Mas várias fontes foram usadas. Nem sempre, para todos os países, há dados disponíveis para os anos indicados no quadro. Nesse caso, os anos estão assinalados. Não seria possível incluir aqui toda a parte referente à metodologia utilizada e as fontes para cada país. Para informações mais detalhadas, cf. Visser (1991, Anexo 4a). 
serviços no setor de mercado mas são dados estimados. Sobre as atividades incluídas no setor público, cf. nota 15, no fim do capítulo. Somente assalariados com emprego.

Fontes: Visser (1991, p. 113), para dados até 1988; Ruysseveldt \& Visser (1996, p. 387) para países europeus em 1990; Meltz e Verba para dados sobre os EUA e o Canadá em 1990.

Infelizmente, as estatísticas que obtivemos não foram tão amplas como gostaríamos e amiúde os dados também não são tão recentes, o que impede respostas concludentes. Porém, as indicações obtidas sugerem, na década dos 90 - ou mesmo antes, dependendo do país -, a paralisação do crescimento, ou mesmo um retrocesso, da sindicalização dos funcionários e empregados do governo.

Como indicado no Quadro 4.5, nos EUA, na Dinamarca, na Noruega e na Suécia as taxas de sindicalização aumentaram entre o pessoal dos serviços públicos. Desses quatro casos de aumento entre 1970 e 1988 ou 1990, três são de países nórdicos. Em outros, tomando como base o ano de 1970, houve persistente e significativo declínio (Alemanha, Áustria, França, Holanda, Japão). No Reino Unido houve movimentos de ascensão e queda. Nesse país, depois de 1985, a sindicalização subiu para 68,8\% em 1980 mas voltou a cair em 1988 para subir para 60,0\% em 1990. A Itália apresenta uma situação de queda depois de 1985.

Considerando a fortíssima diminuição dos níveis de filiação no setor privado nos EUA, a estabilidade da sindicalização no setor público americano não deixa de ser surpreendente. Nesse país, pelos surveys domiciliares, a porcentagem de sindicalizados subiu de 29,4\% em 1970 para 36,7\% em 1988 (Quadro 4.5). (Lembremos que as estatísticas para esse país foram elaboradas com informações colhidas nos surveys domiciliares, que são geralmente de $7 \%$ a $15 \%$ mais baixas do que as estatísticas fornecidas pelos sindicatos [Visser, 1991, p. 128] ${ }^{16}$.)

Mas os dados e análises dos autores não são totalmente coincidentes. De acordo com Troy (1996), a taxa de sindicalização do setor público norteamericano teria estacionado em torno de $38 \%$, o que representaria, em

\footnotetext{
${ }^{16}$ Nos exames das estatísticas sobre a sindicalização do setor público é preciso estar atento também às parcelas do funcionalismo que estão sendo levadas em conta para os cálculos. Nos EUA, por exemplo, dados referentes apenas aos funcionários dos governos estaduais e locais, em tempo integral, apontavam 48,8\% de sindicalizados em 1980, utilizando como fontes censos do Bureau of Labor Statistics (Lewin, 1983, p. 244). Cálculos de Visser (Quadro 4.5), usando os surveys domiciliares, para todo o funcionalismo davam, para o mesmo ano, $36,7 \%$.
}

números absolutos, cerca de 6,9 milhões de trabalhadores. Entre $1990 \mathrm{e}$ 1991, os sindicatos do setor público teriam ganho 147 mil novos membros, mas, entre 1991 e 1992, incorporaram somente mais 21 mil (p. 29). Segundo Troy, com base nas informações do Bureau of Labor Statistics, o setor público, entre 1994 e 1995, teria perdido 164 mil membros e a proporção de sindicalizados baixado de $39 \%$ para $38 \%$ (p. 30). As maiores perdas teriam ocorrido entre os empregados dos governos estaduais (65 mil) e depois no governo federal (50 mil). Dois terços, aproximadamente, das perdas, no nível federal, teriam vindo do fechamento de bases militares (dispensa de pessoal civil nelas empregado) enquanto outras teriam vindo da dispensa de empregados em regime de meio período ou de emprego temporário. As perdas no setor federal teriam sido compensadas pelo aumento de cerca de 200 mil novos postos de trabalho nos governos estaduais e locais (p. 30) ${ }^{17}$. Lipset (1986) já apontava, para 1983, declínio da taxa agregada de sindicalização em todo o setor público. Para esse ano, ela seria de 34,4\%, depois de ter atingido um pico de 40,2\% em 1976 (p. 82).

Na Suécia, Kjellberg (1993) indica também declínio da taxa de sindicalização do setor público. Esse, que havia chegado a 92\% nos anos 1986-1987, teria baixado para 87\% em 1990-1991. O prejuízo foi menor do que no setor privado, onde, de $84 \%$ em 1998-1987, a proporção de sindicalizados foi de 78\% em 1990 para 77\% em 1991. No Reino Unido, o UNISON, dos servidores públicos e da saúde pública, perdeu $10 \%$ dos seus filiados entre 1979 e 1992. Mas os prejuízos foram maiores em outros sindicatos. No período, o Sindicato Nacional dos Professores (NUT) perdeu 44\% dos membros (Visser \& Ruysseveldt, 1996a, p. 65).

Com relação ao Canadá, Chaison considera que não é mais possível pressupor que o setor público e o semipúblico possam continuar a ser a principal fonte de recrutamento de novos membros para o sindicalismo. As taxas de sindicalização estão próximas do ponto de saturação na administração pública (81\%, em 1990), atividades educacionais (77\%) e saúde e serviços sociais $(51 \%)$. Os esforços governamentais para reduzir

\footnotetext{
${ }^{17}$ Dados de revista do sindicato de empregados do governo registram pequeno aumento do número de associados entre 1990 e 1995, embora indiquem declínio do ritmo de crescimento. Assim, em 1990, haveria 6.485.000 sindicalizados, contra 6.927.400 em 1995 , ou seja, aumento de 442 mil. já, entre 1985 (5.743.100) e 1990, o incremento teria sido de 742 mil, aproximadamente (Government Union Review, 1996, p. 43)
} 
gastos têm levado ao congelamento de salários e benefícios e ao corte de empregos, tanto no governo federal como nos governos das províncias. A partir daí, a capacidade de barganha dos sindicatos diminuiu em razão da terceirização de serviços, da subcontratação e da introdução de métodos administrativos das empresas privadas (Chaison, 1996, pp. 53-54).

As causas apontadas para o Canadá valem para outros países. O declínio, ou estancamento da expansão da sindicalização no setor público, deve-se às políticas de privatização, de enxugamento do Estado, de introdução de procedimentos administrativos de tipo empresarial nas várias esferas das atividades de governo, entre as quais escolas e hospitais, onde a sindicalização era forte: racionalização, descentralização, enxugamento de pessoal e/ou terceirização. A capacidade competitiva dos países é vista como relacionada com a eficiência não só de suas empresas privadas mas também da atuação do Estado. Contudo, se as pressões de reforma do Estado tenderam a ser gerais, seus efeitos não foram iguais, tal como as tendências universais de mudanças no setor de mercado tiveram aplicação e resultados variados. De modo geral, onde a organização sindical era muito poderosa, a tradição de participação dos sindicatos estava institucionalizada e a pressão do mercado para a elevação dos coeficientes de competitividade não foi muito acentuada, o sindicalismo do setor público sofreu menos, como nos países nórdicos. Mas a tendência, enfrentando resistências que variam nacionalmente, tem sido a mesma em todos os países, especialmente na medida em que a integração europeia avança e o modelo anglo-saxônico tende a se espalhar por toda a Europa. Na Suécia, por exemplo, o governo está - desde a década dos 80 - devolvendo responsabilidade empresarial para cerca de 200 agências governamentais.

Como nota Anthony Ferner, no esforço para a introdução de elementos de mercado em serviços públicos não comercializáveis, o Reino Unido lidera a corrida europeia nas reformas do setor de saúde e de educação. As escolas, por exemplo, podem agora escapar das autoridades locais e ter mais autonomia sobre seus recursos, inclusive no que diz respeito à administração das relações de trabalho (Ferner, 1994, pp. 54 55). No conjunto do setor público, de aproximadamente cinco milhões de empregados no setor, por volta de 1990 somente um milhão tinham seus salários estabelecidos por negociações coletivas (Marsh, 1992, p. 185).
Em decorrência desse avanço em direção à adoção de modelos de administração do setor privado, o sindicalismo do setor público e estatal britânico experimentou grandes perdas de filiados devido à diminuição do número de empregados e funcionários governamentais. Em 1992, todo o setor público britânico tinha aproximadamente seis milhões de empregados, meio milhão a menos do que em 1979, embora o emprego direto no Estado tivesse se mantido estável, em torno de cinco milhões. Grande parte do declínio é explicado pela política de privatização de serviços e companhias anteriormente nacionalizadas. As empresas industriais estatais empregavam mais de dois milhões de pessoas e dominavam os setores de transporte, energia, comunicações, aço e construção naval. Cláusulas da closed shop prevaleciam nessas indústrias nacionalizadas. Em fins de 1989, cerca de 800 mil empregos haviam sido transferidos para a indústria privada pela privatização de 29 das maiores empresas e suas subsidiárias (Dibden \& Millward, 1991, p. 7). Somente a privatização da estatal de comunicações Telecom passou para o setor privado 300 mil empregados (Visser \& Ruysseveldt, 1996a, p. 76). Em 1992, apenas 600 mil pessoas estavam empregadas nas corporações públicas contra dois milhões em 1979.

A redução do número de funcionários e empregados do governo e das empresas estatais, juntamente com outras mudanças já salientadas, está minando as bases do sindicalismo nesses segmentos. Desse ângulo, o prognóstico de Troy de que o Novo Sindicalismo poderia ser o modelo sindical do próximo século parece que não se realizará porque também o sindicalismo do setor público está sendo atingido por alguns dos fatores que levaram ao declínio do sindicalismo do setor privado. Por isso, se persistirem para os próximos anos as atuais tendências, o avanço do movimento sindical ocorrido a partir dos anos 60 no setor público não será suficiente para contrabalançar o declínio do sindicalismo em geral e as taxas nacionais de sindicalização continuarão a cair, como aliás indicam as várias estatísticas nacionais.

Dois tipos de desdobramento parecem-nos decisivos para o futuro do sindicalismo do setor público. O primeiro deles diz respeito à evolução do emprego no setor estatal. O encolhimento do Estado resulta na diminuição da oferta de emprego e, Consequentemente, do enfraquecimento da base de sustentação do sindicalismo. Aqui estamos diante de uma variável de natureza socioeconômica. Mas outras variáveis, de natureza políticoinstitucionais, também devem ser consideradas. Como vimos inicialmente, 
razões políticas tiveram forte influência na entrada do sindicalismo no interior das estruturas estatais. Ora, o comportamento das elites políticas e dos governos diante do movimento sindical do setor público é grandemente dependente da apreciação da opinião do eleitorado. Nesse ponto, em comparação com o sindicalismo dos trabalhadores da indústria privada, o movimento reivindicatório dos funcionários, especialmente da administração direta, desperta menos simpatia do que greves e movimentos de trabalhadores do setor privado que enfrentam o poder das grandes companhias, especialmente das multinacionais. Geralmente, a maioria da população não é atingida e, muitas vezes, é simpática às ações sindicais que desafiam o poderio do grande capital. Não é o caso de greves no setor público que prejudicam os consumidores e usuários de bens e serviços fornecidos pelo Estado. Naturalmente, aqui o aspecto essencial é o tipo de atividade que é afetada e a extensão em que a população se vê prejudicada. Mas, na medida em que muitos serviços coletivos em que a organização sindical é forte (saúde, educação, especialmente) continuam a ser de responsabilidade governamental, o sindicalismo do setor público encontra limitações em sua ação, pois é muito dependente da atitude do governo, a qual depende, por sua vez, da simpatia que o movimento dos funcionários e servidores do Estado encontra entre os usuários, quer dizer, os eleitores. $\mathrm{O}$ apoio da população às mobilizações de empregados governamentais depende muito da avaliação da "justeza" das reivindicações em correlação com as áreas de atividades que são afetadas por paralisações e outras ações. Por isso, o aumento do poder sindical tende a ser avaliado pelos eleitores de modo mais negativo do que o aumento do poder sindical na área de mercado.

Por essas razões, parece-nos difícil que continue a existir, nos próximos anos, a mesma conjunção de elementos favoráveis que possibilitaram, na década dos 60 , a emergência e o desenvolvimento rápido do sindicalismo do setor público.

\section{Capítulo 5 \\ Greves, dessindicalização e poder sindical}

- sse capítulo trata da evolução das curvas de greve a partir da década dos anos 70. A intenção é verificar em que medida o declínio das taxas de sindicalização acompanhou-se do rebaixamento dos níveis de conflito. A intensidade da correlação entre os dois fenômenos pode indicar até que ponto as taxas de sindicalização são um bom indicador do declínio do poder sindical. O melhor e mais comum, mas não o único, instrumento de efetivação da força do sindicalismo está na capacidade de as lideranças sindicais causarem algum tipo de prejuízo aos empregadores (e também ao governo). Nas democracias, o instrumento por excelência para alcançar esse objetivo é a paralisação de atividades econômicas ou de outro tipo de atividade (quando se trata da administração pública), ou seja, cortar o fornecimento da força de trabalho para as empresas ou para o governo.

Mas é possível argumentar que a dimensão do poder sindical seria mais adequadamente avaliada por outras formas de mobilização capazes de produzir danos no campo adversário (ou de ameaçar produzir) e, desse modo, obterem resultados equivalentes ou melhores do que a deflagração de greves. Essas, para ocorrerem, não precisariam de altos níveis de filiação. Nessa linha de raciocínio, declínios nas taxas de sindicalização não indicariam redução do poder sindical e tampouco seriam sinônimo de decadência do sindicalismo ${ }^{1}$.

No caso, estamos entendendo o poder sindical como a capacidade de as elites sindicais imporem decisões (geralmente na forma de obtenção de reivindicações), vetarem decisões ou - alternativa menos favorável modificarem decisões que partam do governo, das empresas ou de outras

${ }^{1}$ Obviamente, a paralisação do funcionamento de setores de atividades não constitui a única forma de pressão dos sindicatos. Outras formas existem e são usadas, com maior ou menor intensidade: manifestações de rua, sabotagem, boicote, ocupação dos locais de trabalho, sequestro e detenção de dirigentes das empresas ou de autoridades públicas, pressões diretas sobre instâncias do poder, como ocupação de instalações governamentais, bloqueio de estradas e vias públicas, quebra-quebras e ações destinadas a influenciar a opinião pública. Não seria preciso dizer que as variações entre os países são grandes e que, quanto mais forte o sindicalismo, menor a tendência a ações mais violentas. 
elites. De um ângulo estritamente formal, a taxa de sindicalização só tem interesse político na medida em que se relaciona com a força do sindicalismo. Se o aumento das taxas de sindicalização não resultasse na elevação do poder sindical e não fosse capaz a fortiori de trazer vantagens (reais, simbólicas ou imaginárias) para as classes trabalhadoras, não haveria razão para a existência de sindicatos na forma como existem nas democracias capitalistas. Consequentemente, a pergunta que se coloca é: Até que ponto a queda nos índices de sindicalização reduz o poder sindical? Ou, de modo um pouco mais preciso: Até que ponto a dessindicalização enfraquece um dos mais importantes instrumentos de pressão do sindicalismo (a greve) e, assim, diminui a força política das lideranças sindicais no trato com outras elites políticas, econômicas e governamentais?

Nas democracias de massa, o poder sindical se expressa basicamente por duas vias: a política e a econômica. Pela primeira, os sindicatos podem aumentar ou diminuir as pretensões eleitorais dos políticos e partidos, ou seja, influenciar a escolha dos governantes; pela segunda, podem atingir o lucro das empresas (privadas ou estatais), paralisar atividades governamentais e o desempenho da economia nacional.

Embora geralmente os sindicatos estejam atentos à problemática política, é a segunda via que, notadamente nos regimes capitalistas democráticos, constitui o instrumento típico de pressão do sindicalismo e dos trabalhadores: a paralisação, ou a ameaça de paralisação, do trabalho. Para as correntes socialistas, especialmente para o marxismo, a greve seria a comprovação do antagonismo de classes que, de forma latente ou manifesta, existiria em todas as sociedades capitalistas. Porém a greve pode ser considerada, de modo mais sociológico e menos ideológico, como manifestação de conflitos de interesses, que pode ser mais aguda ou menos aguda, sem que pressuponha, inevitavelmente, uma oposição irreconciliável entre o Capital e o Trabalho (aceitemos a reificação habitual).

Em outras palavras: a intensidade do conflito é uma dimensão da ordem social e política contemporânea que varia histórica e geograficamente, cuja dimensão e importância podem ser medidas e, em alguns casos, podem ser muito altas ou muito baixas. Reforça essa posição o fato de que, empiricamente, são comprovadas significativas diferenças nos índices de greves entre países capitalistas. Na Suíça, por exemplo, as estatísticas mostram anos em que nenhuma greve ocorreu, o que poderia significar que não houve conflito entre o Capital e o Trabalho e que os interesses não são irreconciliáveis, mas dependentes também de uma dada cultura e de muitas outras variáveis. A interpretação da greve como sendo essencialmente a expressão do antagonismo entre proprietários dos meios de produção e trabalhadores forçados a "vender" (mais correto seria "alugar") a sua força de trabalho tornou-se mais problemática nos últimos decênios em virtude da expansão das paralisações no setor público, em que os funcionários não se opõem ao Capital, mas ao Estado, que, nas democracias de massas, está muito longe de ser o "comitê executivo da burguesia".

Mas a questão que nos interessa é até que ponto a dessindicalização tende a reduzir as taxas de greve e, Consequentemente, o poder sindical, tanto no plano político como no econômico. Com relação ao aspecto político, a redução do número de associados seguramente diminui a legitimidade das lideranças sindicais nas transações políticas com os partidos e governos, uma vez que elas não teriam legitimidade para falar em nome do conjunto ou de amplos segmentos das classes trabalhadoras e o apoio dos sindicatos não seria eleitoralmente importante para a classe política. Além disso, sindicatos com poucos membros teriam menos recursos financeiros e de outra natureza para o financiamento de partidos e de campanhas eleitorais, como acontece em vários países.

No entanto, no plano econômico, a ligação entre greve e taxa de sindicalização é mais complicada. Se aceitarmos que a greve é um dos instrumentos de efetivação do poder das lideranças sindicais, retorna a indagação já sugerida: quanto a queda dos índices de sindicalização enfraquece o sindicalismo? É claro que, se a dessindicalização não tiver efeitos negativos nos índices de greve, isto é, se eles permanecerem os mesmos ou aumentarem, a força das direções sindicais diante de outras elites não será afetada negativamente pela diminuição dos níveis de adesão dos trabalhadores a sindicatos. No limite, uma conclusão se imporia: altas taxas de sindicalização não seriam sinônimo de força do sindicalismo.

Há alguma base teórica para a defesa da tese que desvincula índices de sindicalização, por um lado, e poder sindical, por outro. Alta sindicalização associa-se necessariamente a organizações de massa e maior burocratização ${ }^{2}$.

${ }^{2}$ Sobre a relação crescimento-burocratização (ou institucionalização), as análises de Angelo Panebianco referida aos partidos políticos parecem-nos aplicáveis também às organizações 
Há, pois, em face do fenômeno das quedas dos coeficientes de filiação sindical, dois pontos interligados: A) o das relações entre sindicalização e poder sindical, de modo mais direto, e poder das classes trabalhadoras, de modo mais indireto; B) o das relações entre as taxas de sindicalização e conflito, expresso geralmente, mas não unicamente, em paralisações do trabalho. Vejamos sumariamente esses dois pontos.

\section{A) sindicalização e poder sindical}

Os estudos sobre a história do movimento sindical e as variedades de suas formas e manifestações mostram que as relações entre níveis de sindicalização e força do sindicalismo devem ser avaliadas com prudência em razão da variedade de tipos de sindicalismo. Visser (1994a), por exemplo, alerta que não se pode pensar que as taxas de sindicalização fornecem um indicador pronto e acabado da força do sindicato. Para que os vínculos entre os dois fenômenos sejam mais adequadamente interpretados, seria preciso ter mais informações sobre a composição do quadro de filiados, a estrutura e o modo de administração dos sindicatos, seus recursos, o compromisso que os associados têm com sua entidade e outros traços do sindicato. "Não podemos estabelecer a equação 'taxa de sindicalização = poder sindical' sem estudar a legislação sobre o trabalho e as associações, as práticas de negociação coletiva, os organogramas das organizações sindicais, o papel público do sindicalismo e entender como os membros são recrutados, como são convencidos a permanecer sindicalizados, a pagar as cotizações e, se necessário, a agir” (p. 22).

O significado do ato da sindicalização, o sentido que adquire para o trabalhador é uma variável importante. A sindicalização, para as diversas categorias profissionais, não significa a mesma coisa. O sentido da adesão depende do tipo de sindicato ao qual se adere, formal ou informalmente, quer dizer, como associado e cotizante regular, ou ideologicamente, como simpatizante mobilizado apenas em circunstâncias especiais. Além disso,

sindicais que constituem entidades de representação. Panebianco reduz o automatismo da relação crescimento-burocratização ao destacar, entre outros pontos, que o tamanho da organização, quando ela se encontra mais além do limite da sobrevivência e aquém do limite de esclerose, é objeto de manipulação por partes das suas elites para defender a estabilidade da organização em condições ambientais variáveis. Além dos dois extremos, o que decidiria a dinâmica organizatória seria a configuração da coalizão dominante, quer dizer, dos grupos que controlam o poder na organização (Panebianco, 1992, p. 367). singularidades nacionais, conectadas a variáveis mais amplas, de natureza econômica e política, produzem diferenças quantitativas e qualitativas nas taxas de adesão e na motivação da filiação sindical. Mas, igualmente, o sentido da adesão varia segundo o tipo de associação, das mais politizadas associações de mobilização do Sul da Europa até as orientações sindicais mais institucionalizadas e voltadas para o local de trabalho da Europa do Norte. O Colégio Real das Enfermeiras e o Sindicato dos Mineiros, de um lado, assim como a CGT francesa e o IG Metal alemão (o sindicato dos metalúrgicos), de outro, são organizações sindicais mas à sua maneira (Ackers; Smith \& Smith, 1996, p. 2).

Em relação com o tipo de sindicato, outra variável importante para o sentido que a sindicalização assume para os trabalhadores é o momento da adesão. Aderir a sindicatos em processo de formação, ou seja, nas "fases heroicas", tem sentido diferente do de tornar-se sócio quando o sindicato se encontra institucionalizado e aceito pela sociedade e, mais ainda, quando ele está de algum modo associado ao poder político, seja através das formas socialdemocratas (em economias predominantemente de mercado), seja nos regimes de tipo fascista ou comunista (em economias de mercado reguladas ou em economias estatizadas). A adesão a sindicatos de uma dada corrente ideológica na sua etapa "de movimento" é diferente da adesão em sua fase "institucionalizada", em que as filiações, especialmente as mais tardias, não implicam grandes riscos e, às vezes, podem ser forçadas pelo sindicato, sob pena de perda do emprego, por meio das cláusulas da closed shop (oficina fechada) ou da union shop (oficina sindicalizada) (ver Cap. 6).

Por isso, em muitos casos, o poder de fogo de cada sindicato pode ter fraca relação com a proporção de filiados. Alguns sindicatos com proporcionalmente poucos trabalhadores inscritos podem ser muito agressivos e pressionar constante e vigorosamente "o outro lado" (empresas ou Estado). E, embora agressividade não seja necessariamente sinônimo de força, não é excluído que reivindicações importantes sejam alcançadas por movimentos sindicais agressivos em países onde as taxas de sindicalização são baixas. Nesses casos, certas conquistas podem advir de conjunturas de crise política e/ou de perturbações sociais graves. Tipicamente, esse é o caso da França. A força do sindicalismo parece estar desvinculada, ou relativamente desvinculada, da proporção e do número de trabalhadores inscritos. Mas cabe também uma interpretação inversa: sindicatos fracos em termos de trabalhadores filiados têm baixa capacidade de mobilização e 
necessitam esperar contextos de crises extrassindicais para conseguir vantagens significativas

Um dos problemas envolvidos no estudo da relação "poder sindical" e "taxas de sindicalização" vem do fato de que o aumento da sindicalização pode ter efeitos contraditórios. Esse aumento, especialmente se for relevante e se acontecer em curto espaço de tempo, implica consequências variadas sobre o sindicalismo como organização e como movimento. Aumentar a taxa de sindicalização significa geralmente fortalecer algumas das facções sindicais em detrimento de outras. Pode enfraquecer facções moderadas em detrimento das radicais, ou vice-versa, conforme uma multiplicidade de situações que exigiriam uma análise específica. Paradoxalmente, o crescimento dos efetivos sindicais pode aumentar conflitos internos dentro do sindicalismo e, no limite, levar a cisões que deem origem a organizações rivais, congelando divergências e, no final, dividindo o sindicalismo e tornando-o, no conjunto, mais fraco. Por isso, as taxas de sindicalização agregadas, em si mesmas, no interior de um sindicalismo muito dividido não significam necessariamente aumento do poder sindical.

Finalmente, o poder sindical não é algo independente de sua "base", quer dizer, das características dos trabalhadores que aderem (ou não aderem) ao sindicato, de suas expectativas e disposições. Nos sindicatos, como nos partidos e em outras instituições de representação, há sempre algum tipo de relação entre "base", isto é, segmentos representados, e direção composta pelos que assumem a responsabilidade, os custos e os benefícios da representação. É possível a existência de bases mais agressivas, mais dispostas a certos tipos de mobilização e de pressão, e de bases mais acomodadas, que são geralmente as das organizações institucionalizadas. São possíveis situações em que os sindicatos têm elevados índices de "adesão burocrática", numericamente muito extensas mas de empregados pouco inclinados a participar de ações antipatronais. Portanto, o número de sindicalizados e a taxa de sindicalização podem não medir a capacidade de mobilização das lideranças, ou seja, sua força no trato com outras elites políticas e econômicas. Os adversários (ou os "inimigos") geralmente sabem disso, isto é, sabem quando o poder de fogo das lideranças é pequeno, mesmo quando elas afirmam representar a "grande maioria" dos trabalhadores.
De tudo o foi que dito dever-se-ia concluir que índices (maiores ou menores) de sindicalização nada significam do ângulo do estudo do poder sindical? Comparações internacionais das taxas de sindicalização nada diriam sobre a força do sindicalismo nos vários países? Mas, se assim fosse, do mesmo modo, as comparações históricas dos níveis de sindicalização setoriais ou nacionais - também deveriam ser postas de lado. Não é o que, de fato, ocorre nos estudos sobre o sindicalismo e a classe operária, inclusive entre os que são fundados em teorias mais radicalmente anticapitalistas. Para tomarmos um exemplo: o crescimento da sindicalização do primeiro pósguerra é habitualmente entendido como um avanço da "combatividade da classe operária" e não como um retrocesso. Aliás, é como geralmente se interpretam determinadas conjunturas, como crises políticas e econômicas, que levam a maciças adesões dos trabalhadores aos sindicatos, mesmo quando se trata de sindicatos "reformistas".

Essa digressão destina-se a defender a tese de que as taxas de sindicalização são um indicador importante (ainda que outros existam) da força do sindicalismo no interior do sistema político e econômico, ou seja, diante do Estado (ou do governo, se quisermos) e do patronato. Uma indicação forte de que as taxas de sindicalização, ceteris paribus, elevam a legitimidade dos sindicatos e o poder dos seus dirigentes é que as lideranças sindicais, especialmente as mais militantes, procuram aumentar o número de sindicalizados e não diminuí-lo. Seria difícil defender a tese de que a queda maciça da sindicalização de um sindicato de uma dada corrente política em favor de outra, ou que quedas gerais dos níveis de adesão querem dizer pouca coisa. As taxas de sindicalização são como termômetros que medem a temperatura e podem indicar que algo não vai bem, embora não possam indicar as causas e tampouco prescrever diagnósticos. O significado e as consequências da sindicalização não são expressos nas estatísticas mas servem, como nota Visser ( 1992a), "como um útil ponto de partida para o estudo do sindicalismo. Na comparação entre países, as taxas de sindicalização oferecem uma percepção rápida, embora incompleta, da força global dos sindicatos" (p. 24). Entendemos, com Visser e outros, que as taxas de sindicalização querem, sim, dizer alguma coisa. Mas seu significado não é dado apenas por números de associados.

A importância dos índices de sindicalização no tocante ao poder sindical pode ser melhor apreciada se focalizarmos a relação direção base de modo mais esquemático. Três hipóteses mutuamente excludentes podem 
ser formuladas: a) quedas nas taxas de sindicalização enfraquecem o poder sindical, qualquer que seja a natureza do sindicalismo; b) quedas nas taxas de sindicalização constituem um fator irrelevante para o poder sindical; c) quedas nas taxas de sindicalização fortalecem o sindicalismo. Intuitivamente, as duas últimas parecem absurdas. Aceitá-las implicaria julgar que o fator "organização", valorizado por todas as tendências políticas que atuam entre as classes trabalhadoras, é irrelevante. A fortiori, dever-se-ia também concluir que a organização é desnecessária para o exercício do poder sindical. Mas isso contraria toda a história do sindicalismo, embora não se deva daí inferir que todas as facções atribuem a mesma importância à construção de aparelhos administrativos.

Preferimos, assim, ficar com a primeira hipótese: o sindicalismo perde força à medida em que caem os índices de sindicalização, isto é, à medida em que os trabalhadores abandonam a organização. Note-se que não estamos tratando de deslocamentos da preferência de uma corrente sindical para outra, mas, sim, do pressuposto de que cada organização sindical, qualquer que seja a sua natureza e ideologia, debilita-se quando diminui o número de seus seguidores (se todos os demais fatores permanecerem os mesmos, é claro).

Mas a aceitação da primeira hipótese nada diz sobre as perspectivas do sindicalismo nem indica a dimensão de perda do poder sindical em relação com o declínio do número de filiados. Ela apenas sinaliza que organizações com mais filiados, mais recursos, mais influência tendem a ser mais poderosas, desde que sejam capazes de utilizar esses trunfos. A aceitação dessa hipótese não implica também que, em países de baixas taxas de sindicalização, os sindicatos sejam atores políticos desprezíveis. $O$ poder sindical depende da capacidade de mobilização das bases pelas lideranças, cuja relação com os índices de filiação, como insistimos anteriormente, não é automática. O que tende a ocorrer, fato que às vezes confunde os observadores, é que, nas situações de baixa sindicalização, as mobilizações são mais dependentes de um "clima" emocional, de uma "conjuntura", o que significa dizer que as explosões relativamente espontâneas de mobilização das "bases" tendem a ter mais importância e as lideranças têm menos autonomia de decisão por terem menos controle dos representados. Maior dependência de um dado "clima" é sempre sinal de fraqueza de um sindicalismo que enquadra uma parcela relativamente pequena de camadas e grupos de trabalhadores que, em princípio, deve representar.
Por isso, os argumentos que explícita ou implicitamente defendem a ideia de que as quedas das taxas de sindicalização em nada afetam (ou afetam muito pouco) o poder sindical e a capacidade de mobilização dos trabalhadores parecem-nos dificilmente sustentáveis, destinados amiúde a tentar reduzir (ou esconder) o declínio do poder sindical na economia globalizada. Se as quedas nos níveis de sindicalização nada significassem, raciocinando pelo absurdo, deveríamos aceitar que, quanto mais baixa a sindicalização, quer dizer, mais desorganizados os trabalhadores, mais forte seria o poder sindical. Se assim fosse, ab absurdo, as lideranças (quaisquer que fossem suas ideologias) deveriam agir no sentido de procurar desorganizar os trabalhadores para aumentar sua capacidade de mobilização e pressão. No limite, os sindicatos não existiriam, se não se supusesse que eles têm alguma função positiva na obtenção das reivindicações dos trabalhadores.

Mas não há sindicatos sem associados ${ }^{3}$. Quanto mais elevadas as taxas de sindicalização, maiores parcelas da classe trabalhadora estão organizadas. O fato serve também para indicar o coeficiente de poder das lideranças sindicais. Se assim é, cumpre aceitar também que quedas nos níveis de adesão a sindicatos são indicativas de debilitamento do sindicalismo, de que "algo não vai bem". Certamente, se a diminuição nas taxas de sindicalização não afetasse negativamente a capacidade das lideranças de mobilizar trabalhadores, ou se os trabalhadores não precisassem de sindicatos para suas mobilizações, o termo "declínio do sindicalismo" não teria sentido porque, em princípio, a dessindicalização não afetaria o poder sindical. Os sindicatos, ou seus dirigentes, continuariam a ser capazes de mobilizar os trabalhadores para pressionar empresas e governo, quaisquer que fossem os índices de filiação, ou seja, qualquer que fosse o grau de organização das classes trabalhadoras.

Essas considerações destinam-se a reforçar a hipótese de que a proporção de trabalhadores sindicalizados é um termômetro bom da saúde do sindicalismo. Nos casos de redução da filiação, a aceitação da hipótese não exclui, mas, ao contrário, supõe, que os efeitos das quedas dos níveis de sindicalização devam ser relacionados com a evolução das taxas de conflito. $\mathrm{Se}$, porventura, se comprovasse que os índices de conflito aumentaram

${ }^{3}$ Não é preciso dizer que estamos excluindo situações como a brasileira, em que Os sindicatos, uma vez que detêm o monopólio da representação e contam com rendas obtidas sem esforço, podem existir com um mínimo de trabalhadores sindicalizados. 
apesar da diminuição das taxas de sindicalização, uma conclusão se imporia: o poder sindical, medido por sua capacidade de causar dano ao lado contrário, não é afetado pelo enfraquecimento do sindicato enquanto organização, o que permitiria também concluir pela separação ainda mais forte entre o sindicato como movimento e o sindicato como instituição ${ }^{4}$. Com essas considerações sobre as relações entre poder sindical e sindicalização, passemos ao outro ponto com ele relacionado.

\section{B) quedas nos índices de sindicalização e conflito}

Nas democracias capitalistas, a forma clássica de impor prejuízo às empresas - e Consequentemente aumentar o poder dos dirigentes sindicais - é a greve. Ela é a medida por excelência dos índices de conflitos trabalhistas (e sociais, em menor medida) e um indicador das disposições dos sindicatos e das classes trabalhadoras com relação à sua situação como empregado e como consumidor. Para os pesquisadores, essa forma de conflito tem a vantagem de poder ser quantificável e, portanto, de oferecer a possibilidade de estabelecer correlações com outras variáveis políticas, econômicas, tecnológicas e outras que podem afetar os índices de greve. Possibilita, assim, análises ao longo de períodos num mesmo país, entre setores de atividades econômicas, entre categorias profissionais e também comparações entre países.

Desse modo, é um instrumento analítico útil mas que encontra uma limitação no fato de que nem sempre as estatísticas estão disponíveis, são confiáveis ou permitem, em razão de possíveis diferenças nas metodologias usadas, comparações setoriais ou nacionais. Para a temática do poder sindical em relação às taxas de sindicalização, o exame da curva de greves

\footnotetext{
${ }^{4}$ Outras variáveis, numa complicada relação de causa e efeito, necessitariam ser consideradas, como as divisões ideológicas do sindicalismo, seu grau de centralização e suas relações com partidos políticos. Na Segunda Parte discutiremos esses aspectos. No momento, queremos salientar brevemente a relação entre índice de centralização, unidade do movimento operário, força das organizações centrais nas negociações coletivas, conselhos operários e participação na gestão. Utilizando indicadores para essas características de vários sindicalismos nacionais de países desenvolvidos, Cameron (1984) definiu o poder organizatório do sindicalismo como dependente da unidade, do poder de barganha e da porcentagem da força de trabalho sindicalizada. A partir desses indicadores, estabeleceu uma hierarquia dos sindicalismos nacionais segundo seu grau de poder. Muito poder: Suécia, Noruega, Áustria, Bélgica, Finlândia, Dinamarca. Médio poder: Holanda, Alemanha, Austrália, Reino Unido, Irlanda. Fraco poder: Suíça, Itália, EUA, Canadá, França, Espanha, Japão (p. 167)
}

permite uma apreciação dos efeitos das quedas nas taxas de sindicalização sobre a força do sindicalismo. Se os sindicatos nunca pudessem fazer greves, como já notamos, o poder das lideranças sindicais ficaria consideravelmente rebaixado. Desse modo, uma queda na evolução das taxas de greve pode ser tomada também como um indicador do declínio do sindicalismo nas sociedades globalizadas. Se mais não for - considerando que na maior parte dos casos as paralisações não são decididas pelos trabalhadores autonomamente, mas pelos sindicatos - a diminuição da curva de greves é um indicador da redução do espaço ocupado pelas lideranças sindicais na vida política.

Mas objeções similares ao uso dos índices de sindicalização na avaliação do poder sindical podem ser levantadas no tocante às greves. De fato, a única conclusão a que se pode chegar, sem dar margem à discussão do aumento (ou declínio) dos níveis de paralisação (supondo-se uma mensuração segura), é a de que o conflito está aumentando ou diminuindo... De fato, nada mais se pode extrair dos exames dos índices de greves tomados isoladamente, isto é, sem que sejam conectados a outros fatores que dão substâncias aos dados quantitativos: conteúdo das demandas e tipos de paralisações (violentas, pacíficas, sob controle de sindicatos ou "selvagens", vinculadas a movimentos políticos mais amplos ou não). Esses aspectos, em si mesmos, não são graves porque as análises dos movimentos grevistas raramente se limitam à simples contagem dos conflitos, do número de dias de trabalho perdidos ou do volume de trabalhadores envolvidos. O ponto mais importante, para os nossos propósitos, é o da correlação entre níveis de sindicalização e a ocorrência de greves. Em que medida uma eventual diminuição dos índices de greve pode ser atribuída ao fenômeno da "dessindicalização", sendo pois reveladora da redução do poder sindical?

As correlações entre grau de adesão ao sindicato e índices de greve são variadas e contraditórias. A história do sindicalismo e a das interações entre sindicalização, de um lado, e o nível e intensidade do conflito, de outro, mostram que muitas vezes altos índices de sindicalização estão ligados a índices baixos de ocorrência de greves. Esse é o caso, particularmente, da Suécia, da Alemanha, da Noruega e da Áustria. Poderse-ia concluir que as baixas taxas de greves nos países de alta densidade sindical vêm precisamente da força do sindicalismo, que torna o patronato $\mathrm{e}$, às vezes, o governo mais predispostos a negociar seriamente com as 
organizações sindicais e a ceder em pontos que habitualmente não cederiam diante de um sindicalismo mais fraco.

Nesse caso, elevadas taxas de sindicalização significam precisamente maior poder sindical e coeficientes mais baixos de conflito. Por outro lado, a força do sindicalismo, em alguns países, tende a fazer com que ele se torne mais moderado porque as elites sindicais se associam, de algum modo, ao sistema decisório e passam a partilhar com empresas e governo uma parcela da responsabilidade pelos rumos da economia e do país. Esse é um cenário tipificado especialmente pelo sindicalismo dos países nórdicos e da Alemanha, cenário no qual o aumento do poder sindical aparece como causa do declínio do conflito e das tensões sociais.

A conclusão poderia ser a de que o sindicalismo forte, que seria um sindicalismo burocrático de massas, levaria à acomodação e à "colaboração de classes". Essa tese é aventada, às vezes, por tendências mais radicais diante de um cenário sindical mais "conservador". Mas ela não resiste a uma análise mais séria dos fatos e da teoria. Do ângulo dos fatos, sindicatos considerados pelas facções mais radicais como ideologicamente "de direita" podem ser bastante agressivos e ser bastante propensos à greve. Esse foi, durante longos anos, o caso dos sindicatos "contratualistas" norteamericanos que, num passado recente, fizeram dos EUA, ao lado da Itália, um dos países de mais elevada frequência de greves, ou, ainda, do sindicalismo "reformista" do Reino Unido, que não se notabilizou pela passividade. Além disso, na história do sindicalismo, há muita oscilação nas taxas de greve, que pode marcar um mesmo movimento sindical durante sua vida. Do ângulo da teoria, é difícil explicar, especialmente a partir de teorias de tipo marxista - e há várias - por que as "bases", que seriam naturalmente propensas às alternativas radicais e revolucionárias, aceitam direções que, "podendo ir mais longe", preferem as alternativas da acomodação. Na verdade, sem reduzir o papel que diferentes tipos de lideranças podem exercer no aumento ou diminuição do conflito, o que dificulta e torna mais complexo o estudo dos vínculos entre sindicalização e greves vem do fato de que as lideranças não podem fazer greves ou agudizar conflitos sempre que desejam. Essa afirmação parece-nos válida para qualquer tipo de liderança. Não importa aqui sua orientação ideológica e política, ainda que, indiscutivelmente, haja algumas lideranças mais propensas a aproveitar determinadas conjunturas para elevar os coeficientes de conflito, seja para "conscientizar a massa", seja para obter "vantagens imediatas". Na realidade, um objetivo não exclui o outro, embora a ênfase num ou noutro possa variar.

Mas o que tende a acontecer é que a ampliação do poder sindical, e frequentemente $\mathrm{o}$ aumento de suas responsabilidades nos rumos da economia e do sistema político, reduz o sentimento de oposição à ordem vigente e a vontade de alterá-la radicalmente. Mas, aqui, é preciso considerar que o crescimento do sindicalismo (e a integração dos sindicatos na ordem capitalista) não acontece sem que haja mudanças democráticas na economia e na política. Os sindicatos não se acomodaram a uma ordem mais excludente e fechada, mas a uma ordem mais democrática $e$ igualitária. $\mathrm{O}$ esforço reformista do meio econômico e político transforma ao mesmo tempo o sistema econômico, o peso das elites políticas e o próprio sindicato. No caso das elites políticas, a "integração dos sindicatos" (que significa, de fato, a participação das lideranças sindicais em determinados níveis das instâncias decisórias) geralmente vem junto com a diminuição da influência e poder das elites agrárias e o aumento da influência de novas elites empresariais e o declínio do capitalismo familiar. $\mathrm{Na}$ área sindical, um desenvolvimento desse tipo fortalece as lideranças moderadas em detrimento das mais radicais.

Os sindicatos, nas situações de normalidade social e política, não têm alternativas contrárias a esse processo integrativo nas economias capitalistas avançadas. A rejeição à integração significa rejeição à participação e, Consequentemente, implica deixar o sistema decisório em mãos do patronato e/ou dos políticos. Mas a obtenção de posições nas estruturas de poder do capitalismo acarreta normalmente a redução das aspirações de destruí-las e aumenta as de reformá-las de modo favorável ao sindicalismo. O resultado é que, geralmente depois de uma fase intermediária em que os conflitos (e seus custos) aumentam para todos, os "inimigos" começam a se ver como "adversários" e depois como "parceiros". No plano do conflito, o resultado é a tendência à diminuição das taxas de greves verificadas em países de altas taxas de sindicalização ${ }^{5}$.

\footnotetext{
${ }^{5}$ Seria ocioso ressaltar que esse tipo de desenvolvimento é mais fácil de ocorrer num contexto de crescimento econômico que possa beneficiar todas as partes. Seria necessário, além disso, existirem elites dispostas a entender as disputas não como um jogo de soma zero. Mas pode acontecer que, depois de tragédias nacionais que arruínem a economia do país e de outros eventos que ocasionem graves consequências negativas para todas as camadas sociais,
} 
Mas o que torna a análise das taxas de greve e de seus vínculos com o sindicalismo mais complicada é que não necessariamente um sindicalismo fraco (de pequenas minorias militantes) é capaz de "fazer mais greve" do que um sindicalismo forte, e vice-versa. As situações que envolvem sindicalização-poder sindical-greves são muito variadas. É difícil formular uma lei geral sobre as relações entre a força do sindicalismo e as suas consequências sobre os coeficientes de conflito trabalhista. Baixos índices de greve podem existir em situações de alta ou baixa taxa de sindicalização. Ocorre que os índices de sindicalização constituem apenas um fator que influencia a ocorrência de greves ao lado de muitos outros que amiúde estão fora do controle das lideranças dos trabalhadores e que podem levá-las a assumir posturas mais radicais, especialmente quando há risco de serem substituídas por outras "mais a esquerda".

A premissa aqui é a de que a participação das elites sindicais, passada uma fase de forte turbulência, consolida-se e acaba por ser admitida, ainda que a contragosto, pelas demais elites. Por isso, sistemas sindicais mais centralizados e unificados, com negociações nacionais abrangentes (neocorporativos) e organizações de trabalhadores com maior poder de fogo, constituem uma das variáveis mais importantes para a redução dos níveis de conflito. Nesses casos de predominância de negociações centralizadas, de nível nacional, as taxas de sindicalização são muito altas, fato indicativo de que o poder e influência das lideranças sindicais tende a atingir patamares mais elevados nas instâncias decisórias quanto mais forte for a proporção de trabalhadores sindicalizados, quer dizer, organizados.

A evolução das taxas de greves, nesse sentido, é um indicador das consequências do declínio dos níveis de filiação na capacidade de mobilização sindical. Se, no transcurso dos anos de queda na sindicalização, a atividade grevista se tivesse mantido em alta, uma conclusão a que se poderia chegar é a de que a diminuição do número de trabalhadores sindicalizados ao longo do período não foi um fator significativo para reduzir a capacidade de mobilização dos trabalhadores. Derivaria daí que organizações sindicais de massa não são - ou não seriam - instrumentos essenciais, ou importantes, para a obtenção de reivindicações e a imposição de políticas.

Capital e Trabalho revelem maior disposição para cooperação a fim de obter a reconstrução nacional. A Alemanha e o Japão dos anos do pós-guerra ilustram uma situação desse tipo.
Mas não foi o que aconteceu na maioria dos países desenvolvidos. Ao longo dos anos 80, as taxas de greve acompanharam as quedas nos índices de sindicalização, embora a manifestação do fenômeno, como se verá, tenha sido variada nos diferentes países e a relação com o declínio da densidade sindical esteja longe de ser linear. Cumpre, pois, examinar como se comportaram as taxas de greve nos últimos decênios. Tal como procedemos no exame da sindicalização, interessam-nos aqui os dados globais sobre as curvas de greves nas últimas décadas. Não se tentará, portanto, uma apreciação mais detalhada que envolva as diferenças por setor, os tipos de greve, as reivindicações, as estratégias e táticas dos sindicatos. O objetivo é tentar verificar, num enfoque agregado, as relações entre a diminuição dos efetivos sindicais e os movimentos grevistas. Com esse propósito, apresentaremos primeiro dados referentes aos vários países, de modo a permitir comparações nacionais. Em seguida, faremos uma breve apreciação das taxas de greves em alguns países tomados isoladamente.

\section{A EVOLUÇÃO DOS MOVIMENTOS GREVISTAS}

A avaliação das dimensões dos movimentos grevistas podem permitir resultados diferentes segundo o indicador adotado para a mensuração do fenômeno "greve"". Mas, no geral, tendem a coincidir. Os indicadores habitualmente utilizados são o número de greves deflagradas, o número de trabalhadores envolvidos, o número de homens-horas, ou de jornadas perdidas por paralisações do trabalho, ou a proporção de grevistas no total de força de trabalho, calculada geralmente por mil trabalhadores.

O número absoluto de greves ocorridas, de trabalhadores envolvidos em movimentos grevistas ou de horas ou jornadas perdidas por paralisações é um instrumento útil para comparações da intensidade do conflito no interior

\footnotetext{
${ }^{6}$ Segundo a definição adotada na $15^{\text {a }}$ Conferência Internacional sobre Estatísticas do Trabalho, realizada em Genebra em 1993 (OIT, Anuário de Estatísticas do Trabalho, p. 1009), a greve é "uma paralisação temporária realizada por um ou mais grupos de trabalhadores a fim de impor demandas, ou resistir a elas, expressar queixas ou apoiar outros trabalhadores em suas reivindicações ou queixas". Por sua vez, o lockout, que juntamente com as greves integra as estatísticas da OIT sobre conflitos de trabalho, é definido como "o fechamento temporário, total ou parcial de um ou mais locais de emprego, ou a obstrução das atividades normais de trabalho dos empregados por parte de um ou mais empregadores com o objetivo de impor ou resistir a reivindicações dos empregados, ou apoiar reivindicações ou queixas de outros empregadores" (OIT, 55. ed., 1996, p. 1009).
} 
de um mesmo país ao longo do tempo. Já não é tão útil para comparações internacionais em virtude das dimensões diferenciadas das respectivas forças de trabalho. É intuitivo que países com maior população de trabalhadores têm mais probabilidade de apresentar números mais elevados de paralisações, de trabalhadores envolvidos e de jornadas perdidas.

Análises mais precisas de movimentos grevistas necessitam operar com vários indicadores. Uma greve muito prolongada, embora possa entrar nas estatísticas como apenas uma greve, se atingir muitos trabalhadores, pode elevar extraordinariamente o número de jornadas perdidas. É possível haver, portanto, de um lado, diminuição do número de greves efetuadas, de trabalhadores envolvidos e, de outro, aumento das jornadas ou horas de trabalho perdidas. Por outro lado, avaliações do movimento grevista que utilizem a quantidade de greves deflagradas, se essas forem de curta duração, podem sugerir aumentos da atividade grevista ainda que ocorra decréscimo do número de trabalhadores participantes e de jornadas perdidas. Contudo, as discrepâncias entre os vários métodos não constituem a situação mais comum quando se comparam séries mais longas em vários países.

A análise dos movimentos grevistas, especialmente quando se utilizam conjuntamente as metodologias acima, oferece elementos não somente para a avaliação dos coeficientes de conflito no interior da sociedade, das disposições dos trabalhadores com relação à economia e à política, como também para compreender as características das organizações sindicais e dos sistemas de relações de trabalho nos vários países. Para ficarmos em alguns poucos exemplos: sindicatos que não dispõem de fundos de greves, ou sindicatos organizatoriamente fracos, com poucos associados, têm dificuldades para sustentar greves prolongadas. Por essa razão, tendem a preferir greves de curta duração, de preferência movimentos que envolvam muitos trabalhadores (geralmente não sindicalizados), mas que terminem rapidamente. Precisam contar mais com um "clima" que eleve a disposição de participação entre os trabalhadores. O grau de racionalidade do movimento tende, pois, a diminuir e geralmente a liderança tem menos controle sobre a massa de participantes. Sem dispor de muitos recursos organizatórios, o sindicato é mais dependente do apoio da opinião pública, de parcelas da classe política ou mesmo das autoridades públicas (quando o movimento está dirigido contra empresas privadas) ou quando o governo está em mãos de "partidos amigos" do sindicalismo. A melhor estratégia para sindicatos organizatoriamente débeis é evitar conflitos prolongados. Essa opção não exclui necessariamente atos mais radicais, como, por exemplo, a sabotagem dos equipamentos, a danificação da produção e das instalações das empresas, o uso da violência física contra empregados que furem o movimento.

Já organizações sindicais mais poderosas, especialmente as que dispõem de maiores fundos de greve e maior controle sobre sua base, podem dar maior racionalidade às suas mobilizações. Em situações mais difíceis, como as de desemprego e outras que favoreçam as empresas, podem preferir paralisações que envolvam número pequeno de trabalhadores, de modo a evitar exaurir seus recursos com a sustentação de um volume muito elevado de trabalhadores em greve. Paralisações por empresa isolada, nesse caso, são mais adequadas. De outro ângulo, movimentos sindicais mais centralizados e mais poderosos tendem a fazer menos greve e a moderar as exigências. Estudar os movimentos grevistas constitui, pois, uma maneira de conhecer mais adequadamente as singularidades do sindicalismo de cada nação ou setor de atividade econômica.

As dificuldades para a análise das greves não se limitam às que derivam da metodologia a ser adotada e da obtenção de informações fidedignas. $\mathrm{Na}$ verdade, os problemas não vêm tanto da descrição das manifestações do fenômeno, mas de sua explicação, ou seja, dos fatores que podem esclarecer oscilações da curva de greve dentro de um mesmo país em diferentes momentos, bem como a fantástica diversidade dos índices de conflitos na comparação entre países.

Muitos e variados fatores conjugam-se para aumentar ou diminuir a frequência, a extensão e as características dos movimentos grevistas. Pelo menos desde o detalhado estudo de Knowles (1952) sobre a ocorrência de greves no Reino Unido (1911-1947) sabe-se que múltiplos fatores influenciam as variações nas taxas de greve. Mas não é fácil o estabelecimento de correlações significativas entre o fenômeno greve e as suas causas, no caso consideradas como variáveis independentes. Dificuldades ainda maiores advêm quando se procuram correlações que possam ser estendidas para vários países em períodos de longa ou curta duração ${ }^{7}$.

\footnotetext{
${ }^{7}$ Knowles não conseguiu estabelecer nenhuma relação estatística significante capaz de explicar as variações nas taxas de greve entre os fatores que considerou, então, "incontáveis". Nessa época, Knowles distinguiu as seguintes variáveis: idade da indústria, "incontáveis". Nua expansão ou retração, a rapidez das mudanças tecnológicas, o tamanho e a eficiência das firmas, a prosperidade de seus empregados; os níveis salariais; a propensão ao desemprego; a
} 
Não é nossa intenção tentar aprofundar o tema. Queremos ressaltar, apenas, que as estatísticas não oferecem elementos que permitam concluir que o declínio nas taxas de sindicalização é "compensado" por algum aumento da "combatividade espontânea" dos trabalhadores correndo por fora das estruturas sindicais "burocratizadas", indicativa do renascimento próximo de um novo movimento operário mais combativo e autêntico. Pelo contrário: tendo em conta os dados agregados por país, as estatísticas sugerem que, apesar de alguns casos desviantes, o declínio da sindicalização está vindo junto com a diminuição dos movimentos grevistas, quer dizer, do enfraquecimento das organizações sindicais e do poder sindical.

Esse aspecto será avaliado por meio de dados sobre a frequência e extensão dos conflitos trabalhistas oferecidos nos quadros abaixo, retirados de estatísticas da OIT que não distinguem entre greves e lockouts, ou seja, as paralisações do trabalho que são de iniciativa dos sindicatos e as que são dos empregadores. Trata-se de uma limitação para avaliações mais refinadas, embora os dados agregados deem uma visão do estado das relações entre empregados e empregadores e, em si, sejam indicativos das variações nos conflitos $^{8}$. Como se verá, Trata-se de estatísticas nacionais agregadas, sem

periculosidade da natureza da tarefa; as formas dominantes de remuneração do trabalho, as diferenças e a proporção em que acarretam, por sua vez, diferenças dentro de grupos de empresas e empresas individuais; a proporção de mulheres e menores, de funcionários de escritório; a influência da organização sindical; a capacidade da liderança sindical, os acordos coletivos e a sua eficiência; o êxito de greves anteriores; a política econômica do governo (p. 163). Um dos problemas desse tipo de análise, que busca correlações capazes de explicar as oscilações nas taxas de greve, vem da dificuldade de isolar as variáveis econômicas, políticas, sindicais e outras para o estabelecimento de correlações estatísticas. Ocorre que, muitas vezes, as greves vêm em ondas. Os eventos nacionais são frequentemente influenciados por um "clima internacional", por um efeito de propagação por contágio, imitação ou estímulo externo.

Torna-se, assim, mais problemático encontrar correlações com fatores internos a cada país, como situação do mercado de trabalho, tipo de governo, organização sindical.

${ }^{8}$ As publicações da OIT tratam agregadamente dos dois fenômenos porque as estatísticas nacionais, de onde retira os dados, não fazem a distinção entre greve e lockout. É verdade que o número de lockouts, em geral, tende a ser baixo porque os empresários não gostam de fechar suas fábricas e, em alguns países, eles são proibidos de fazê-lo. Os lockouts normalmente acontecem diante de ações de iniciativa dos sindicatos ou dos empregados, quer dizer, de reivindicações e/ou greves. No caso de greve, no tocante aos cálculos de homens-horas perdidos ou de trabalhadores atingidos, quando também ocorre lockout, tende a haver coincidência entre o número de empregados afetados pela greve e pelo lockout, porque um eventual fechamento da empresa tende a atingir trabalhadores já em greve. Assim, o viés distinção por setor. Servem apenas para uma avaliação global e comparativa. Análises mais detalhadas seriam necessárias para distinguir os tipos de greve, os setores econômicos mais afetados, as relações entre as características do sindicalismo e os movimentos grevistas, para ficarmos apenas em algumas correlações mais evidentes. Mas, para os nossos fins, entendemos que os dados que usamos são suficientes. Considerando as discrepâncias que advêm do uso dos três principais critérios de mensuração da intensidade das ações trabalhistas, e mesmo correndo o risco de cansar o leitor, os dados serão analisados segundo os dias de trabalho perdidos, o número de grevistas por mil trabalhadores e o número de greves deflagradas. A intenção final é poder esboçar as tendências principais 9 .

O Quadro 5.1 mostra inicialmente uma forte variação de situações, no sentido de que, no cotejo entre os vários quinquênios por dias de trabalho perdidos na Europa Ocidental ${ }^{10}$, as perdas diminuíram, enquanto em outros aumentaram. A proporção do aumento também foi variável. Por exemplo:

decorrente da não separação entre greves e lockouts não parece afetar mais gravemente a interpretação dos números. Mas, quando se trabalha com números absolutos de paralisações, o viés parece mais acentuado porque, do ponto de vista formal, a proporção de lockouts pode ser superior à de greves. Se os algarismos indicam declínio ou aumento, de um modo estrito, podese inferir apenas que se tem declínio ou aumento de paralisações decretadas pelos sindicatos.., ou pelos empregadores. De todo jeito, se OS dados registram uma ou duas paralisações, como ocorreu em alguns anos na Suíça, por exemplo, seguramente pode-se concluir que não houve um número superior de greves nesses anos e que o índice de conflito é baixo. Mesmo assim, a não ser em alguns países onde as estatísticas se referem exclusivamente a greves, como em Portugal e na Espanha, não se tem certeza sobre as proporções de paralisações decorrentes de greves e de lockouts, ainda que a probabilidade maior seja de greves porque Os lockouts habitualmente são uma resposta patronal a uma iniciativa dos sindicatos ou dos empregados. Porém, na Alemanha, por exemplo, o número de trabalhadores atingidos por lockouts pode ser muito alto. Cumpre observar ainda que, nas estatísticas sobre greves, os critérios de registro não são os mesmos em cada país. Mas, para efeitos deste trabalho, eles serão ignorados. (Ver Anexo Metodológico e Estatístico no final do livro.)

${ }^{9}$ Os últimos dados que obtivemos vão até 1995. Como já dissemos na Introdução, a atualidade dos dados foi um dos problemas que enfrentamos. Mesmo as publicações mais recentes (digamos, de 1997) trabalham com dados mais "atrasados" (geralmente de 1995), em razão do tempo necessário para a coleta, o processamento de informações e a publicação. Porém, de modo geral, apesar de algumas greves importantes que eclodiram na Europa e nos EUA, não há indicações de reversão do quadro que transcrevemos, isto é, de um súbito reaparecimento dos movimentos grevistas em larga escala, fenômeno que não convém confundir com outros movimentos políticos e sociais.

${ }^{10}$ Esse quadro não traz dados relativos à América do Norte, que serão examinados a partir de outras fontes. 
tomando os dois quinquênios da década dos 60 (1961-1965 e 1966-1970), do primeiro quinquênio para o segundo e fazendo abstração da dimensão de aumento ou diminuição do fenômeno, houve elevação de conflito em oito países (Bélgica, Espanha, Grécia, Holanda, Irlanda, Itália, Suécia e Reino Unido) e diminuição em sete (Alemanha, Áustria, Dinamarca, Finlândia, França, Noruega e Suíça). Assim, independentemente da importância de cada país e das dimensões do fenômeno, o número de países em que o conflito aumentou superou ligeiramente o daqueles em que diminuiu. De 1966-1970 para 1971-1975, houve elevação em onze países de um total de quinze. Em alguns deles, o aumento dos dias de trabalho perdidos foi forte, embora as dimensões tenham sido muito diferentes (Reino Unido, Dinamarca, Finlândia e Suécia). De 1971-1975 para 1966-1980, as tendências começam a alterarse. Somente em quatro países (Espanha, Irlanda, Suécia e Suíça) houve aumento de paralisações. $\mathrm{O}$ aspecto a salientar é a entrada da Espanha nos países de alta taxa de greve, com um salto de 95,6 para 1.089,8 dias de trabalho perdidos, fenômeno explicável em larga medida pela democratização. Guardadas as proporções, o caso da Suécia é também digno de menção: 65,5 para 220,3. Apesar da diminuição do número de países em que houve aumento, as perdas continuaram altas na Finlândia e no Reino Unido, onde o declínio foi muito pequeno.

A entrada na "década maldita" acentuou as tendências ao declínio: de 1976-1980 para 1981-1985, somente na Dinamarca houve aumento. Nos demais países houve quedas, em alguns bastante acentuadas, como na Espanha (1.089,8 para 400,9), Itália (940,0 para 536,8) e Suécia (220,3 para 36,7). Na segunda metade da década, o número de países em que houve aumento passou para cinco. Mas um exame mais atento do quadro indica uma estabilização do declínio, porque, mesmo entre os países em que houve aumento de paralisações, ele foi pequeno e não voltou a atingir os índices elevados de outros quinquênios. Além disso, nos países em que houve queda, essa foi muito acentuada. Tal foi o caso da Itália $(536,8$ para 218,2$)$ e do Reino Unido (387,4 para 117,5). A grande exceção foi a Suécia, onde a média de dias perdidos pulou de 36,7 para 121,2.

Considerando os quinze países do Quadro 5.1 e comparando períodos mais longos, isto é, indo para as duas pontas do período (1961 1965 e 19981990) nos países analisados (faltam dados para a Bélgica), houve aumento em seis, justamente em países que não se notabilizam anteriormente por índices elevados de movimentos grevistas: Finlândia, Grécia, Holanda,
Noruega, Espanha e Suécia. Em contrapartida, houve redução na Áustria, na Dinamarca, na França, na Alemanha, na Irlanda, na Itália, na Suíça e no Reino Unido, ou seja, nos países de maior PIB.

\section{Quadro 5.1}

Europa: Dias de trabalho perdidos por conflitos trabalhistas por mil empregados (médias anuais)

\begin{tabular}{|l|c|c|c|c|c|c|}
\hline País $^{a}$ & $1961-$ & $1966-$ & $1971-$ & $1976-$ & $1981-$ & $1986-$ \\
& 1965 & 1970 & 1975 & 1980 & 1985 & 1990 \\
\hline Alemanha & 18,3 & 6,0 & 47,7 & 44,1 & 43,3 & 4,1 \\
Áustria & 85,4 & 11,9 & 14,7 & 2,1 & 1,8 & 1,2 \\
Bélgica & 63,0 & 144,8 & 195,8 & 183,2 & - & - \\
Dinamarca & 107,6 & 42,7 & 354,5 & 75,9 & 262,3 & 79,6 \\
Espanha & $14,1^{\mathrm{e}}$ & 37,1 & 95,6 & 1089,8 & 400,9 & 433,6 \\
Finlândia & 143,7 & 104,8 & 595,5 & 520,7 & 271,2 & 343,2 \\
França & 146,3 & $134,0^{\mathrm{b}}$ & 186,7 & 154,2 & 65,8 & 34,6 \\
Grécia & 32,1 & $48,0^{\mathrm{c}}$ & - & - & 36,0 & $126,4^{\mathrm{d}}$ \\
Holanda & 8,0 & 14,0 & 36,1 & 27,8 & 18,7 & 11,2 \\
Irlanda & 337,5 & 625,6 & 292,7 & 716,1 & 360,6 & 183,7 \\
Itália & 648,4 & 933,6 & 1063,9 & 940,0 & 536,8 & 218,2 \\
Noruega & 104,7 & 12,4 & 9,3 & 36,3 & 49,7 & 123,3 \\
Reino Unido & 127,0 & 222,6 & 538,6 & 521,7 & 387,4 & 117,5 \\
Suécia & 3,8 & 33,0 & 65,5 & 220,3 & 36,7 & 121,2 \\
Suíça & 2,7 & 0,2 & 0,9 & 2,6 & 0,4 & 0,3 \\
\hline
\end{tabular}

${ }^{\mathrm{a}}$ Luxemburgo e Portugal excluídos.

b 1968 excluído.

c 1966-1967 somente.

d 1986-1988 somente.

e 1963-1965 somente.

Fonte: OIT; Yearbook of labour Statistics, apud Ferner \& Hyman, 1993, p. XLIX.

Outras anotações podem ser feitas sobre o Quadro 5.1. No conjunto, percebem-se variações relevantes na incidência de greve entre os países. Até 1981-1985, a Itália registrou, desde 1961-1965, elevado volume de dias perdidos por disputas trabalhistas. No último quinquênio da década dos 80 , foi superada pela Finlândia e pela Espanha. Esse último país conheceu um fantástico salto na ocorrência de greves entre o quinquênio de 1971-1975 e o de 1976-1980: 95,6 mil para 1.089,8 mil. As perdas de horas de trabalho por greves, embora com um declínio forte, continuaram elevadas na década dos 80 e nos primeiros anos da década dos 90 . 
A Suécia é um caso de súbito e oscilatório surto de conflitos, embora o nível, qualquer que seja o indicador, ainda seja baixo diante de quase todos os demais países industrializados. Depois do lustro 1976-1980, as elevações e quedas conheceram forte oscilação, como ocorreu também na Dinamarca, dados que refletem a crise do modelo neocorporativo de ambos os países ${ }^{11}$.

Do quadro anterior, percebem-se elementos de continuidade e de mudança. Com relação ao primeiro, em alguns países, como a Itália, as taxas de conflito tenderam a permanecer altas desde os anos 60, de fato, bem mais elevadas do que em outros países. A Espanha foi outro caso de elevada ocorrência de greves, que aumentaram extraordinariamente a partir de meados da década dos 70 (quer dizer, após a democratização e o fim do sistema corporativo de relações de trabalho). Em outros países, como na Suíça, os índices de paralisação foram muito baixos durante todos os anos examinados. Mas o quadro mostra também variações num padrão, em que picos de greves sucederam a longas fases de calmaria, como nos países escandinavos ou, ao contrário, como no Reino Unido, onde, depois da intensa agitação na década dos 70, o declínio foi muito forte na dos 80 . Nesse caso, provavelmente tivemos o efeito do governo Thatcher e das novas leis trabalhistas (que serão examinadas na Segunda Parte). A segunda observação geral que se poderia extrair é a de que, apesar das variações, a tendência geral caminhou na direção da diminuição das taxas de conflito.

No Quadro 5.2, o mesmo fenômeno será avaliado, não mais por jornadas perdidas, mas por trabalhadores envolvidos em conflitos. São dados mais recentes da OIT, que chegam até 1996 mas que, em contrapartida, começam mais tarde ${ }^{12}$.

De outro lado, o Quadro 5.2 confirma as tendências a quedas, com oscilações, nos grandes países industriais: Alemanha, Reino Unido, Itália e França ${ }^{13}$. Chama ainda a atenção a situação da Áustria, onde o ano de 1991

\footnotetext{
11 Scheuer (1993) adverte, no entanto, que na Dinamarca o movimento em direção à descentralização significou antes um deslocamento da negociação nacional centralizada multi-industrial para negociações nacionais por indústria do que uma mudança de negociações nacionais por indústria para negociações por empresas.

12 Não encontramos publicação da OIT com dados recentes relativos a dias de trabalho perdidos por mil empregados, tal como Os analisados no Quadro 5.1. Obviamente, isso não significa dizer que não existam.

${ }^{13}$ Os dados para a França são um pouco mais complicados de ser avaliados, em razão da metodologia utilizada nesse país. Faltam dados para 1994 e 1995. Nesse último ano e em
}

registrou uma enorme elevação do número de grevistas, que contrasta com a baixa incidência de paralisações nos anos anteriores e posteriores. Os EUA e o Reino Unido, por outro lado, por esse indicador, continuaram com tendências acentuadamente decrescentes.

Quadro 5.2

Trabalhadores envolvidos em greves e lockouts (em milhares)

\begin{tabular}{|l|c|c|c|c|c|c|c|c|c|c|}
\hline País & 1986 & 1987 & 1988 & 1989 & 1990 & 1991 & 1992 & 1993 & 1994 & 1995 \\
\hline Alemanha & 115,5 & 155,0 & 33,5 & 44,9 & 258,1 & 208,1 & 593,3 & 132,5 & 400,7 & 183,3 \\
Áustria & 3,2 & 7,3 & 24,3 & 3,7 & 5,3 & 92,7 & 18,0 & 6,9 & 0,0 & 0,1 \\
Bélgica & - & - & 23,2 & 20,0 & 9,8 & 11,2 & 21,9 & 8,5 & 5,9 & 12,8 \\
Canadá & 484,3 & 581,9 & 206,8 & 444,7 & 270,5 & 253,3 & 149,9 & 101,8 & 80,9 & 124,4 \\
Dinamarca & 56,7 & 56,9 & 29,6 & 27,2 & 37,4 & 37,9 & 32,9 & 58,8 & 36,8 & 124,5 \\
Espanha & 857,9 & 1881,2 & 6692,2 & 1382,1 & 977,0 & 1983,8 & 5192,1 & 1076,8 & 5437,4 & 573,5 \\
EUA & 533,2 & 174,3 & 118,3 & 452,1 & 184,9 & 392,0 & 363,8 & 181,9 & 322,0 & 191,5 \\
Finlândia & 589,0 & 99,0 & 172,4 & 157,2 & 207,0 & 128,0 & 102,6 & 23,2 & 70,5 & 127,0 \\
França a & 21,8 & 18,6 & 27,2 & 20,3 & 18,5 & 18,5 & 16,3 & 19,9 & - & - \\
França & 194,4 & 135,3 & 76,8 & 54,9 & 55,8 & 183,0 & 123,1 & 18,4 & - & - \\
Grécia & 1106,3 & 1270,6 & 449,5 & 796,6 & 1304,2 & 476,6 & 243,2 & 181,7 & 73,8 & 52,1 \\
Holanda & 17,0 & 12,6 & 5,2 & 15,5 & 25,0 & 42,1 & 52,4 & 20,7 & 21,8 & 55,0 \\
Irlanda & 50,2 & 26,2 & 10,2 & 3,7 & 10,3 & 18,0 & 13,1 & 12,8 & 5,0 & 31,7 \\
Itália & 3067 & 4273 & 2712 & 4452 & 1634 & 2952 & 3178 & 4384 & 2614 & 445 \\
Noruega & 165,7 & 2,4 & 8,3 & 11,3 & 60,7 & 0,40 & 38,9 & 6,6 & 14,7 & 10,2 \\
Portugal & 231,5 & 81,3 & 155,5 & 296,1 & 128,9 & 119,0 & 131,9 & 83,1 & 94,4 & - \\
Reino Unido & 720,2 & 887,4 & 790,3 & 727,0 & 298,2 & 176,0 & 148,0 & 385,0 & 107,0 & 174,0 \\
Suécia & 66,3 & 10,5 & 95,2 & 34,1 & 73,2 & 2,5 & 18,0 & 29,3 & 22,0 & 125,9 \\
Suíça & 0,04 & 0,000 & 0,1 & 0,2 & 0,6 & 0,1 & 0,2 & 0,000 & 6,9 & 0,1 \\
\hline
\end{tabular}

a.Inclui greves localizadas (a ordem de greve é interna a um estabelecimento); média mensal de trabalhadores envolvidos em greve em curso em cada mês. As paralisações na agricultura e administração pública não estão registradas.

b.Greves generalizadas (a ordem de greve se estende a várias empresas); agricultura e administração pública não incluídas.

Fonte: ILO, 1996 e 1997, Yearbook of Labour Statistics.

Essas observações baseiam-se no critério do volume de trabalhadores afetados por paralisações decorrentes de greves ou de lockouts. No quadro seguinte, tem-se o número bruto de paralisações. Entendemos que a utilização desse indicador é capaz, em termos comparativos, de oferecer um quadro mais representativo do estado das relações entre os sindicatos, o governo e as empresas e das disposições dos trabalhadores em relação ao

1996, a explosão grevista dos funcionários públicos aumentou consideravelmente o número de grevistas e de homens-horas perdidos. As estatísticas da OIT registram duas séries de dados, segundo critérios indicados no Quadro 5.2. 
conflito. Em outras palavras: uma alta proporção de homens horas ou de jornadas perdidas por disputas trabalhistas, como no Quadro 5.2, pode ser devida a uma situação de agitação trabalhista de caráter setorial, restrito às vezes a uma categoria - como o caso da greve dos mineiros no Reino Unido ilustra de modo paradigmático - mas que pode não afetar outros grupos de trabalhadores ou a maioria dos assalariados. Assim, no conjunto, a situação pode ser de relativa paz trabalhista, estando a área de conflito circunscrita a uma parcela da classe trabalhadora de um setor de atividade econômica.

As estatísticas do número de trabalhadores envolvidos, de jornadas perdidas, analisadas em combinação com a do número de conflitos trabalhistas, podem dar indicações sobre as estratégias do movimento sindical. Desse modo, uma forte elevação do número de paralisações, correlacionada com um pequeno aumento do número de jornadas perdidas e/ou de grevistas envolvidos, indica uma estratégia de combates rápidos, de greves curtas, na qual o sindicalismo evita atirar-se em batalhas de grandes proporções, de custo elevado em termos financeiros e políticos, que possam resultar em derrotas graves, difíceis de ser absorvidas.

\section{Quadro 5.3}

Número de ocorrência de greves e lockouts em 17 países (19801996)

\begin{tabular}{|l|c|c|c|c|c|c|c|c|c|}
\hline País & 1980 & 1985 & 1990 & 1991 & 1992 & 1993 & 1994 & 1995 & 1996 \\
\hline Áustria & 9 & 4 & 9 & 9 & 3 & 3 & 0 & 1 & 0 \\
Bélgica & - & - & 33 & 62 & 49 & 28 & 30 & 46 & - \\
Canadá & 1028 & 829 & 579 & 463 & 404 & 381 & 375 & 326 & 327 \\
Dinamarca & 225 & 820 & 232 & 203 & 151 & 218 & 240 & 424 & 930 \\
Espanha & 2103 & 1092 & 1312 & 1645 & 1360 & 1209 & 908 & 883 & 830 \\
EUA & 187 & 54 & 44 & 40 & 35 & 35 & 45 & 31 & 37 \\
Finlândia & 2182 & 833 & 450 & 270 & 165 & 125 & 171 & 112 & 94 \\
França a & - & 78 & 29 & 12 & 15 & 10 & - & - & - \\
França & 2118 & 1901 & 1529 & 1318 & 1330 & 1351 & 1671 & - & - \\
Grécia & 726 & 453 & 480 & 161 & 824 & 596 & 215 & 110 & - \\
Holanda & 22 & 45 & 29 & 28 & 23 & 12 & 17 & 14 & 12 \\
Irlanda & 130 & 116 & 49 & 54 & 38 & 46 & 28 & 34 & 32 \\
Itália & 2238 & 1341 & 1094 & 791 & 903 & 1054 & 861 & 545 & 791 \\
Noruega & 35 & 11 & 15 & 4 & 16 & 12 & 20 & 11 & 18 \\
Portugal & 269 & 476 & 271 & 262 & 409 & 230 & 300 & 282 & 274 \\
Reino Unido & - & - & 630 & 369 & 253 & 211 & 205 & 235 & 244 \\
Suécia & 212 & 160 & 126 & 23 & 20 & 33 & 13 & 36 & 9 \\
Suíça & 5 & 3 & 2 & 1 & 3 & 0 & 8 & 2 & - \\
\hline
\end{tabular}

${ }^{\mathrm{a}} \mathrm{e}^{\mathrm{b}}$ Para França as mesmas observações do quadro anterior.

${ }^{\mathrm{c}}$ Inclui somente greves.
Fonte: Para 19801995: OIT, 1997-1998. Ver metodologia no Anexo Metodológico e Estatístico. Para 1996: OIT; 1997, Yearbook of Labour Slalistics.

Em termos do número absoluto de greves, o exame do Quadro 5.3 permite as seguintes observações:

a) As diferenças na ocorrência de conflitos trabalhistas entre os países é extremamente acentuada. Considerando apenas o ano de 1996, há países que não registraram paralisações (Áustria) ou apenas duas greves (Suíça). No polo oposto, houve 930 greves na Dinamarca, 830 na Espanha e 791 na Itália.

b) Dentro de cada país são possíveis fortes oscilações das frequências de disputas trabalhistas, tanto naqueles em que o número de paralisações é alto como naqueles em que é relativamente baixo. Eis alguns exemplos, considerando os anos de 1980 e de 1996. Para países com alta frequência: Espanha: 2.103 e 830; Finlândia: 2.182 e 94; Itália, 2.238 e 791; Canadá, 1 025 e 327. Para países com ocorrência mais baixa: Áustria, 9 e zero; Suécia, 212 e 9; Irlanda, 130 e 32.

c) Países com elevada frequência de paralisações, apesar das oscilações ocorridas no período, tenderam, em termos comparativos, a manter a posição. Assim, durante os anos considerados, a Espanha e a Itália conservaram o título de países com maior frequência de conflitos. A mesma observação, em sentido contrário, é válida para países com números extremamente baixos de ocorrências, como a Suíça e a Áustria.

d) Em todos os países, o número bruto de disputas tendeu a diminuir, na década dos 90, quer se tratasse de países onde o número de conflitos era elevado, quer se tratasse de países onde era baixo. Comparando $1980 \mathrm{com}$ 1996, na Itália, o número de paralisações despencou de 2.238 para 791; na Espanha, de 2.103 para 830; nos EUA, de 187 para 37; na Suécia, de 212 para 9; na Suíça, de 5 para 2 (1995). Para o Reino Unido, os anos de 1980 e 1985 não constam, mas, considerando 1990, o número de paralisações reduziu-se de 630 para 244 em 1995. (No caso do Reino Unido, outra publicação da OIT registrou 1.074 disputas em 1986 [ILO, 1996].) Comparando os números dos anos de 1980 e 1995, somente em três países - Bélgica, Dinamarca e Portugal (1994) - houve aumento do número de greves, mas, em 1996, em comparação com 1995, houve pequeno aumento em alguns países importantes: Reino Unido, Itália e Estados Unidos. 
O caso da França é mais difícil de analisar em razão da metodologia adotada, que não segue o padrão internacional. Esse recomenda, segundo a Off, que toda paralisação do trabalho devida a uma disputa trabalhista deva ser contada como uma greve ou um lockout, quando o período entre duas paralisações não exceda dois meses. No caso da França ${ }^{\mathrm{b}}$, as estatísticas do Quadro 5.3 contam como uma greve cada estabelecimento atingido por um mesmo movimento grevista, o que eleva substancialmente o número de greves (ILO, 1996, p. 1009). Usando a metodologia internacional, o número de conflitos trabalhistas na França caiu fortemente: apenas 10 em 1993 contra 78 em 1986 (ILO, 1996), números que situam a França entre os países de baixa ocorrência de disputas trabalhistas.

As oscilações interpaíses e intrapaíses requerem cuidados nos prognósticos sobre a tendência a um declínio constante dos movimentos grevistas. Avaliações mais seguras podem ser obtidas examinando as médias de períodos mais amplos e não de cada ano individualmente, mas não seria possível, aqui, uma discussão dos fatores associados à ocorrência de greves, tema que exigiria um tratamento mais extenso e que nos desviaria da temática central desse estudo. Queremos apenas chamar a atenção para o fato de que - além de fatores sociais (como a inflação e o desemprego), políticos, sindicais e culturais _ dois pontos específicos mereceriam especial atenção num estudo sobre greves:

a)as alterações ocorridas na estrutura do emprego que podem afetar segmentos da classe trabalhadora mais propensos a greves (como os mineiros, os doqueiros, os operários industriais) e

b)o modelo de relações de trabalho e o grau de centralização do movimento sindical. Sistemas mais centralizados tendem a ser menos propensos a greves. A existência de fundos de greves e o controle que as organizações nacionais (centrais sindicais, confederações e federações, sindicatos, regionais ou nacionais) podem ter sobre eles é relevante para explicar as variações nacionais nas taxas de greve (Visser, 1988, pp. 156159 especialmente). As greves francesas tendem a ser curtas pela inexistência de fundos de greve capazes de sustentar os trabalhadores em paralisações mais longas. Entre 1962 e 1971, a duração máxima das greves francesas foi de apenas 2,3 dias, em 1963, e a mínima, de 0,8 dias, em 1966 (Reynaud, 1975, p. 159) ${ }^{14}$.

Quadro 5.4

Médias de greves em 17 países em três períodos

\begin{tabular}{|l|c|c|c|}
\hline País & $1986-1990$ & $1990-1995$ & $1986-1995$ \\
\hline Áustria & 7,6 & 3,2 & 5,4 \\
Bélgica & 59,3 & 43,0 & 51,15 \\
Canadá & 634,0 & 389,8 & 511,9 \\
Dinamarca & 187,6 & 247,2 & 217,4 \\
Espanha $^{\mathrm{a}}$ & 1192,6 & 1201,1 & 1196,8 \\
EUA & 50,0 & 37,2 & 43,6 \\
Finlândia & 882,0 & 168,6 & 525,3 \\
Françab & 51,4 & 12,3 & 31,85 \\
França & 1581,6 & 1417,5 & 1508,4 \\
Grécia & 386,6 & 381,2 & 382,4 \\
Holanda & 31,4 & 18,8 & 13,3 \\
Irlanda & 66,8 & 40,0 & 53,4 \\
Itália & 1355,6 & 830,8 & 1093,2 \\
Noruega & 14,0 & 12,6 & 13,3 \\
Portugal & 820,6 & 300,3 & 560,4 \\
Reino Unido & 840,4 & 254,6 & 547,5 \\
Suécia & 111,2 & 25,0 & 68,1 \\
Suíça & 1,8 & 2,8 & 2,3 \\
\hline áté 1990,8 & &
\end{tabular}

${ }^{a}$ Até 1990, somente greves; Países Bascos excluídos.

${ }^{\mathrm{b}} \mathrm{e}^{\mathrm{c}}$ Mesmas observações referentes aos quadros anteriores. Fonte: ILO, 1996.

Na média do período 1986-1995, novamente dois países se destacam: a Espanha e a Itália, com mais de mil paralisações, o que significa, na comparação com outros, um número muito elevado. Em seguida, vêm

\footnotetext{
${ }^{14}$ Para uma avaliação monográfica que compara o "estilo" francês e o britânico de greve, a pesquisa de Gallie (1978) oferece um bom exemplo. O autor estuda o comportamento dos sindicatos de uma mesma empresa, a BP, com unidades no Reino Unido e na França. As greves do lado francês continham um forte componente ideológico, eram curtas e marcadas pelas divisões políticas do sindicalismo em três centrais, apesar de, então, a CGT ser de longe, na empresa em questão, mais poderosa do que a FO e a CFDT: No Reino Unido, as greves eram raras porém mais longas e mais capazes de provocar graves danos para a empresa e para as atividades econômicas a ela associadas. Unido ideologicamente, o sindicalismo britânico estava, no entanto, dividido pela presença de vários sindicatos de profissões dentro da empresa.
} 
Portugal, o Reino Unido, a Finlândia e o Canadá, com cerca de 500 conflitos. Seguem-se a Grécia e a Dinamarca, que registraram, na média, entre 200 e 400. Cinco países (EUA, França", Irlanda, Suécia e Bélgica) tiveram entre 40 e menos de 100 paralisações. Finalmente, em quatro países (Áustria, Holanda, Noruega e Suíça) a média de paralisações foi muito baixa, de menos de 20. Considerando esses dados, os países examinados poderiam ser classificados da seguinte maneira segundo a frequência de paralisações:

1. Muito alta (mais de mil paralisações): Espanha e Itália;

2. Alta (entre 500 e 1.000 paralisações): Portugal, Reino Unido, Finlândia e Canadá;

3. Média (entre 100 e 500): Grécia e Dinamarca;

4. Baixa (entre 20 e 100): EUA, França, Irlanda, Suécia e Bélgica;

5. Muito baixa (menos de 20): Áustria, Holanda, Noruega e Suíça.

Essa classificação foi construída considerando as médias do período 1986-1995. Para a evolução das frequências, convém confrontar o quinquênio de 1986-1990 com o de 1991-1995. A comparação indica que, entre os 17 países, somente em três (Espanha, Dinamarca e Suíça) houve aumento da média de greves. No caso da Espanha e da Suíça, os aumentos foram muito pequenos. Mas nesse bloco de países nos quais houve elevação da média de disputas, as situações foram muito diferenciadas, pois o bloco contém um país com elevadíssimo número de paralisações, a Espanha; outro com um número que poderíamos classificar de médio, a Dinamarca; e outro de frequência muito baixa, a Suíça. No caso suíço, o aumento médio foi de 1,8 para 2,8 greves.

Não obstante a dimensão absoluta da força de trabalho tenda, em princípio, a fazer com que o número absoluto de paralisações (e de jornadas perdidas) seja maior nos países de grande população trabalhadora, chamam a atenção as acentuadas discrepâncias nas mobilizações grevistas entre países de dimensão populacional (e da força de trabalho) muito diferentes. Os dados indicam alto volume de paralisações (qualquer que seja o indicador) em países de pequena população em comparação com outros, com uma força de trabalho consideravelmente mais elevada. Um exemplo é o que existe entre Portugal (560,4 conflitos em média no período) e os EUA $(43,6)$. O fato sugere, nesses pequenos países marcados por um volume elevado de conflitos, um quadro trabalhista bastante agitado, muito mais do que se os mesmos números se referissem a um país com grande população.

Outro ponto que chama a atenção é a variedade de situações nacionais, o que dificulta generalizações e o estabelecimento de padrões extensivos para vários países, e dá alguma base para sugerir que "cada caso é um caso". Assim, houve países, como a Espanha e Portugal, em que a propensão para a greve manteve-se alta em todo o período que estamos examinando. Aqui, certamente, uma variável política (a democratização) merece ser levada em conta (além da mudança de metodologia, como foi, para o caso da Espanha, a inclusão dos Países Bascos nas estatísticas). Mas houve países em que os índices de conflitos, na grande maioria dos anos, foram baixos, mas com momentos de explosões grevistas que afetaram suas médias: é o caso da Finlândia, com dois anos de fortes picos (1985 e 1988), seguidos de uma sequencia de anos com poucas greves. Na Suécia, registraram-se três picos grevistas (1988-1989 1990), que alteraram o padrão anterior de baixo conflito. Houve também países que durante todo o pós-guerra registram índices elevados de disputas trabalhistas, como a Itália, mas que conheceram, a partir dos primeiros anos da década dos 90, forte declínio.

Nos quadros que acabamos de comentar, os índices referem-se ao número absoluto de greves contadas individualmente. Mas a comparação com outras metodologias (número de jornadas perdidas, de trabalhadores envolvidos em greves), no geral, não indica divergência relevante entre os três indicadores. Em outras palavras: o número absoluto de conflitos, o volume de trabalhadores envolvidos e o de jornadas perdidas por greves ou lockouts tenderam a ser coincidentes na maioria dos casos. Tomemos alguns exemplos. No Canadá, do prisma de trabalhadores envolvidos em disputas trabalhistas, 1987 foi um ano de pico (entre 1986 e 1996). Mas esse ano, em números absolutos de paralisações (668) (cf. Anexo 2.1), foi o segundo, apenas superado pelo de 1986 (748), que foi também o segundo ano em termos de número de trabalhadores. No Reino Unido, o maior número de trabalhadores envolvidos em paralisações ocorreu em 1987, ano que foi também o segundo em números absolutos de conflitos. Na Suécia, o ano de 1988 foi o segundo maior em volume de trabalhadores e o primeiro em número de ocorrências. Seria inútil multiplicar os exemplos destinados a mostrar a correlação positiva entre os três principais indicadores. Entretanto, há algumas situações de discrepâncias entre os resultados segundo a metodologia adotada. Na Suécia, 1995 foi o ano em que ocorreu 
a maior participação de trabalhadores em conflitos embora somente 36 paralisações tivessem ocorrido ${ }^{15}$.

Os números dos quadros anteriores não possibilitam muitas inferências sobre a evolução do conflito trabalhista entre os países desenvolvidos, além daquelas que salientamos. Seria desnecessário insistir na necessidade, em termos explicativos das ocorrências e de suas variações, de examinar mais pormenorizadamente as situações nacionais a fim de detectar os fatores de conjuntura que favorecem (ou dificultam) as paralisações de trabalho e explicar por que, em alguns países, os sindicatos e/ ou os trabalhadores são mais propensos a fazer greve.

Como mencionamos, os fatores são muitos e se combinam de modo diferenciado. As variáveis mais habitualmente salientadas pelos não especialistas geralmente não resistem a um exame mais detalhado como causas de índices maiores ou menores de greve, tais como: sindicatos mais poderosos, força dos partidos de esquerda, níveis salariais dos trabalhadores, patronato mais democrático (ou mais autoritário).

Não queremos afirmar que os fatores apontados acima sejam irrelevantes. Mas as situações que "fogem da regra" são numerosas, tais como: altas curvas de disputas em países de baixa taxa de sindicalização ou de desemprego alto (Espanha); ou baixos índices de greve em países de sindicalismo forte e unificado (países escandinavos, Áustria e Alemanha); baixas (ou elevadas) taxas de greves em países de sindicalismo dividido ideologicamente: França, no primeiro caso; Itália, no segundo.

Uma investigação mais circunstanciada escapa de longe aos objetivos deste trabalho. A bibliografia disponível é imensa e não temos nem de longe a possibilidade de avaliá-la e de discutir as teorias sobre os ciclos de mobilização dos trabalhadores. Uma tentativa de aprofundamento do tema exigiria a distinção dos tipos de ação sindical, das suas variações por ramo nos vários países, das variações dos ciclos econômicos e muitos outros elementos. Para tanto, especialmente, cumpriria ter em conta períodos mais longos, quer dizer, anteriores a 1985, períodos que os quadros anteriores não mostram.

\footnotetext{
${ }^{15}$ Não comentamos as eventuais discrepâncias entre as metodologias adotadas para o caso da Alemanha, porque suas estatísticas não registram o número de paralisações ocorridas. Por essa razão, nos quadros 4.3 e 4.4, a Alemanha não aparece.
}

Para suprir, ainda que ligeiramente, as deficiências das análises anteriores, especialmente a evolução da curva de greve no período anterior à década dos 80 , e oferecer mais elementos para um prognóstico sobre as tendências futuras, apresentamos alguns dados extraídos do estudo de Shalev (1994) sobre a ocorrência de greves a partir de 1960 em 18 países da Organização Econômica para a Cooperação e para o Desenvolvimento (OECD). Cito as principais conclusões para chamar a atenção para as variedades de situações relacionadas com as formas de greve e as dimensões das mobilizações dos trabalhadores.

Embora salientando as tendências divergentes, o autor conclui que haveria, no cômputo geral, durante a década dos 80 , tendência ao declínio da atividade grevista nas economias capitalistas de regime democrático. Mas essa conclusão não conduz ao vaticínio do desaparecimento do conflito trabalhista. Para tanto, haveria que considerar, de um lado, mudanças de suas formas e dos setores em que a propensão para a greve é (ou era) mais forte e, de outro, a existência de muitos casos nacionais desviantes. "A verdade é que não sabemos, e não podemos saber, qual é o futuro reservado para a greve", conclui Shalev (1994, p. 126).

O estudo citado, comparando os movimentos grevistas entre países, mostra que a redução da atividade grevista não foi uniforme e geral e o declínio, que aparece como a tendência principal, não é linear na comparação do fenômeno em vários países ao longo do tempo, tal como as estatísticas dos quadros anteriores mostraram para as décadas mais recentes. Tomando 1960 como ano-base e indo até 1989, Shalev encontrou quatro períodos diferenciados de atividade grevista: 1960-1967; 1968-1973; 19741979 e 1980-1989.

Primeiro período (1960-1967). Teria sido marcado por baixo desemprego e rápido crescimento econômico. Mas o fenômeno grevista teria tido dimensões diferentes, caracterizando quatro tipos de situação:

a)Baixa participação do número de trabalhadores em greves. Seria a situação da Suíça e dos países nórdicos de governos socialdemocratas. Também na Alemanha e na Holanda, a participação do número absoluto de grevistas teria sido muito baixa, com greves de curta duração (aproximadamente três dias); 
b)Participação maciça em greves curtas. Seriam especialmente os casos da França, da Itália e da Áustria, onde $10 \%$ a $20 \%$ dos trabalhadores teriam participado em greves de um a dois dias;

c)Conflitos prolongados mas limitados. Casos dos EUA e da Irlanda, onde as greves teriam atingido parte pequena da classe trabalhadora ( $2 \%$ a $3 \%$ ), mas, na média, teriam sido de longa duração;

d)Níveis médios de atividade grevista. Nesse grupo, entre $1 \%$ a $4 \%$ dos assalariados teriam participado em greves que duraram em média três dias. Os países nessa situação foram: Japão, Reino Unido e Bélgica e, num plano mais baixo, Nova Zelândia, Finlândia, Áustria e Dinamarca.

Segundo período (1968-1973). Tratar-se-ia de um período extremamente turbulento. O padrão anterior ter-se-ia mantido aproximadamente o mesmo. França, Noruega e Japão teriam tido aumentos mínimos de greves. As duas grandes exceções teriam sido a Áustria (forte queda de greves) e a Finlândia (forte aumento).

Terceiro período (1974-1979). Teria sido marcado por estagflação, desemprego crescente na maioria dos países. Apesar disso, em comparação com o período anterior, teria havido pequena mudança na duração típica dos conflitos, com exceção dos EUA, onde as greves, apesar de poucas, tornaram-se mais prolongadas. Tratar-se-ia de subperíodo de transição que fixou o padrão do período subsequente.

Quarto período (1980-1989). As tendências mais notáveis teriam sido a acentuada diminuição da taxa de greve no Japão, na Suíça, nos EUA e na França e, num outro extremo, em termos da participação de trabalhadores, o forte aumento na Suécia, na Noruega e na Nova Zelândia. Como consequência, teria havido forte desvio com relação aos padrões internacionais existentes há cerca de duas décadas. Especialmente, teria havido "troca" de posição entre os países no que diz respeito aos padrões de greve. Por exemplo: enquanto, na década dos 80 , as greves decaíram no Japão, elas aumentaram fortemente na Suécia (Shalev, 1994, p. 104).

$\mathrm{O}$ aumento da atividade grevista na Suécia introduziu um viés nas linhas de desenvolvimento anterior. A média sueca anual de greves, nos anos 60, era de cerca de mil trabalhadores; nos anos 70, subiu para perto de 20 mil e, na década dos 80, para 40 mil (Shalev, 1994, p. 110). A média de dias por greve, que em 1961-1965 era baixíssima (3,8), alcançou 220,3 em
1976-1980, declinou depois para 36,7 em 1981-1985 e tornou a subir para 121,2 ao se aproximar do final da década (1986-1990). (Esses últimos dados foram retirados por mim de Ferner e Hyman, 1993, p. XLIX.)

Mesmo acentuando as variações nas tendências dentro de países e entre países, Shalev entende que, de modo geral, nos anos 80, “a atividade grevista foi menor (ou não foi maior) do que no período anterior” (p. 109). Considerando a perspectiva de longo prazo, quer dizer, de 1960 a 1989, as tendências teriam sido mais complexas. Ocorre que, em nove dos trezes países nos quais, nos anos 80 , decaiu o índice de greves calculado pelo número de grevistas por mil trabalhadores, o índice ainda seria mais elevado do que no período 1960-1967. Por isso, Shalev ressalta que os dados entre 1960 e 1989 não autorizam conclusões no sentido do declínio geral dos movimentos grevistas. Mas o autor levanta também a possibilidade de que o padrão possa ter mudado na década dos 90 , em virtude da continuidade, no ano de 1990, das tendências de declínio (Shalev, 1994, p. 110). Essas foram, na verdade, as tendências mostradas pelas estatísticas da OIT, que transcrevemos e analisamos anteriormente.

Os resultados das análises de Shalev, que acentuam o movimento em direção ao declínio do conflito trabalhista, são minimizados por Edwards e Hyman (1994). Esses pesquisadores julgam equivocada a comparação da década dos 80 com a dos 70, porque os anos 70 teriam sido dos mais elevados em termos de greves e, desse modo, seriam "normais" quedas nos anos seguintes (aceitando-se a teoria dos ciclos de greve). Entendendo que as mobilizações grevistas se propagam por ondas, Edwards Hyman argumentam que, depois do pico da década dos 70, os anos 80 poderiam expressar uma baixa que não significaria declínio secular.

Efetivamente, na maioria dos países da OECD, qualquer que seja o indicador, o movimento grevista foi mais intenso na década dos 70 do que na dos 50, com as exceções que sempre existem. Porém, utilizando os mesmos dados de Edwards e Hyman, a queda dos índices de greve na maior parte dos países continuou no biênio 1990-1991 ${ }^{16}$. Se, por exemplo, a comparação se fizer com o quinquênio de 1985-1989, que foi de declínio do movimento grevista em todos os países, com algumas exceções que

\footnotetext{
${ }^{16}$ Os autores, utilizando dados da OIT; estão considerando como greves os dias perdidos em
} razão de paralisações provocadas pelos sindicatos e pelos empregadores. 
dependem do indicador utilizado, houve declínio acentuado do movimento grevista. Cumpre notar que não se trata apenas do declínio quantitativo das mobilizações dos trabalhadores. Mais significativo foi o fato de que a maioria das greves foram desencadeadas, não para a obtenção de novas conquistas, mas para tentar manter as existentes, como foi o caso da grande greve de 1995-1996, na França ${ }^{17}$.

Vejamos os dados segundo as metodologias habituais. Medido o fenômeno pela proporção de empregados que participaram de greves, comparando o mesmo quinquênio de 1985-1989 e o biênio de 1990 1991, houve declínio em todos os nove países (não contando a Áustria e a Alemanha para os quais faltam dados) (cf. Anexo 2.3). Pela proporção de grevistas por mil empregados, em onze países, houve queda em oito e aumento em três (Áustria, Alemanha e Holanda). E, finalmente, se a comparação for feita por dias de trabalho perdidos por mil empregados, houve aumento em cinco (Áustria, Alemanha, Itália, Holanda e Noruega) e declínio em sete (Anexo 2.4). Mas desses sete, a partir de 1992, os movimentos grevistas, medidos por número de trabalhadores envolvidos, continuaram elevados na Holanda mas caíram acentuadamente na Áustria e na Itália. Na Alemanha, declinaram em 1993 e em 1995, mas os números em 1994 foram elevados ${ }^{18}$. Os dados apresentados pelos autores e as estatísticas da OIT não parecem suficientes para comprovar aumento dos índices de conflito trabalhista ou mesmo para rejeitar a tese do declínio da greve a partir de meados da década dos 80 .

Cumpre levar em conta que o artigo de Edwards e Hyman lida com dados que vão até 1991. O Quadro 4.2 e o Quadro 4.3, que apresentamos anteriormente, com estatísticas que chegam até 1996, indicam continuidade do declínio da taxa de greves em quase todos os países, qualquer que seja a

\footnotetext{
${ }^{17}$ Colin Crouch (1992a) observa que, "em lugar de greves curtas, ocorridas em locais de trabalho (shop-floor strikes), por melhores salários e condições de trabalho ou para resolver reclamações trabalhistas, que foram dominantes nas décadas dos 60 e 70, as greves agora [nos anos 80] tendem a ser lutas defensivas conduzidas por um sindicato, frequentemente para evitar perdas de emprego. Houve algumas greves surpreendentemente longas, embora a média de duração das paralisações tenha diminuído recentemente - não porque os trabalhadores tenham atingido seus objetivos rapidamente mas porque aceitaram a derrota" (p. 338).

${ }^{18}$ A situação da Alemanha é atípica em razão dos problemas da reunificação e do fato de que as estatísticas, até 3.10.90, se referem apenas à República Federal. A partir dessa data, incluem a ex-República Democrática Alemã, complicando assim a comparação com outros países e com a evolução do fenômeno na própria Alemanha.
}

metodologia adotada para medi-la. Seguramente, a tendência geral não exclui "desvios", envolvendo países que num passado ainda recente eram conhecidos por elevados índices de "paz social". Nas linhas seguintes, examinaremos alguns casos nacionais de explosão e declínio de movimentos grevistas e de rompimento de padrões que pareciam bem estabelecidos antes do terremoto das mudanças acentuadas a partir de meados da década dos 70 .

A Suécia e a Finlândia ilustram bem um contexto de relações de trabalho "pacíficas", em que, subitamente, houve acentuado aumento das taxas de conflito e da tensão social. O súbito desvio do padrão relaciona-se com a deterioração do modelo corporativo escandinavo de relações de trabalho e com as mudanças ocorridas na economia, que pressionam por um reajustamento das relações entre empregados e empregadores, privados ou estatais.

Já o Reino Unido retrata uma situação inversa, na qual as taxas de greve eram relativamente elevadas, mas sofreram queda constante ao longo dos anos 80 e no primeiro quinquênio da década dos 90. Em 1991, os dias perdidos por paralisações do trabalho haviam chegado a seu ponto mais baixo desde 1945. Aqui, é preciso ter em conta, além das mudanças no mercado de trabalho e no setor produtivo, os impactos da vitória do Partido Conservador sobre o sindicalismo (que discutiremos na Segunda Parte). A longa greve dos mineiros em 1984-1985 teve fortes consequências sobre o volume de homens-horas perdidos, tal como teria toda greve de longa duração que envolvesse número grande de grevistas. Em 1984, de um total de 27.135 jornadas perdidas, 22.483 foram devidas ao setor mineiro. É certo que a greve de 1984-1985 foi de duração excepcional, mas as mobilizações no setor mineiro sempre contribuíram para elevar os índices de greves do Reino Unido. Assim, em 1957, cerca de três quartos de todas as greves britânicas eclodiram nesse setor (Edwards; Hall; Hyman; Marginson; Sisson; Waddington \& Winchester, 1993, p. 54). Os autores concluem que "o declínio dos setores mais propensos para a greve torna muito improvável que a taxa de greve alcance algum dia os níveis de começo dos anos 70"19. Entre esses setores conviria incluir o das docas. Nesse último, entre 1963 e 1968,

\footnotetext{
${ }^{19}$ A greve dos mineiros durou aproximadamente um ano; 26 milhões de dias de trabalho foram perdidos (Church; Outram \& Smith, 1991). Segundo esses autores, até aproximadamente $1950,70 \%$ de todas as greves ocorridas no Reino Unido eclodiram no setor da mineração (p. 52).
} 
teria havido, em média, seis vezes mais greves do que nas minas (Turnbull, 1992, p. 295). Porém, também aí, a taxa de greve caiu de modo acentuado. Entre 1980 e 1989, a média anual de paralisações nas docas ficou em 50, contra 250 em 1967-1972. O volume total de dias perdidos decaiu de 2,6 milhões para 727 mil, nos mesmos períodos (Turnbull; Morris \& Sapsford, $1996)^{20}$. No caso, conta, obviamente, o declínio numérico da categoria profissional: o número de doqueiros com empregos registrados caiu de aproximadamente 60 mil em 1967 para somente 32 mil em fins de 1975. Pelos inícios de 1980, havia somente 23 mil doqueiros registrados e seu número havia caído para baixo de 10 mil pouco antes da greve de 1989 (Turnbull, 1992, p. 304). Com relação aos mineiros, em 1947, as minas de carvão do Reino Unido empregavam 704 mil mineiros. Em 1994, apenas 9 mil (Beynon, 1995, p. 8). Desenvolvimento equivalente ocorreu também nos EUA. Os mineiros e seu sindicato, que no passado haviam se notabilizado por agressiva militância, formavam em 1944 um poderoso contingente de aproximadamente 600 mil pessoas. Atualmente, seu número está entre 30 e 40 mil (Troy, 1996, p. 3)

De modo geral, as alterações no sistema produtivo tiveram forte reflexo nos movimentos grevistas, embora não expliquem tudo. Por exemplo,

\footnotetext{
${ }^{20}$ Todos os últimos trabalhos citados estão, na verdade, dirigidos para uma revisão crítica do estudo de Kerr e Siegel (1954), que teve grande repercussão nos meios acadêmicos. com base em estatísticas internacionais, os autores apontavam os mineiros e doqueiros como as categorias mais propensas à greve. Um dos pontos mais enfatizados por Kerr e Siegel como elemento explicativo dos diferenciais de greve seria a situação de "comunidade isolada" dessas categorias. Sobre as hipóteses de Kerr e Siegel, muitos estudos foram realizados, que mostraram um quadro mais complexo de fatores relacionados com a incidência de greves entre os mineiros do Reino Unido. Por exemplo, Church, Outram e Smith (1991a) julgam que as hipóteses de Kerr e Siegel "de fato ajudam a explicar as variações na ocorrência de movimentos grevistas, mas de modo algum garantem, por si sós, altos níveis de paralisações" (p. 76). Em outro estudo, os mesmos autores chamam a atenção para o fato de que, apesar de, até $1950,70 \%$ de todas as greves do Reino Unido terem ocorrido no setor mineiro, elas se encontravam concentradas em algumas minas. Excetuando as grandes greves nacionais de 1921 e 1926, entre as duas guerras, 24\% das disputas ocorreram em apenas $4 \%$ das minas (Church; Outram \& Smith, 1991b). A ideia não é desqualificar as hipóteses de Kerr e Siegel, mas chamar a atenção, nas variações da intensidade dos movimentos grevistas nos vários segmentos de atividade econômica, para outras variáveis. No tocante aos doqueiros, outro estudo mostrou que o fator decisivo é o tamanho do porto e que o fator a ser explicado nas greves de doqueiros é a "dicotomia entre a persistente militância numa minoria de portos e a relativa tranquilidade na maioria dos outros"(Turnbull; Morris \& Sapsford, 1996, p. 706).
}

na Alemanha Federal, que depois do após-guerra teve um dos mais baixos níveis de conflito dos países examinados, a redução da importância das atividades mineiras, da tecelagem, do aço e da construção tendeu a jogar para baixo as taxas de greve (medidas nacionalmente). O declínio da importância do setor industrial, notadamente, teve reflexos no movimento sindical, mas não impediu que a atividade grevista tivesse crescido (na comparação entre os decênios 1950-1959, 1960-1969, 1970-1979 e 1980-1989) no setor de impressão, do papel e da metalurgia, qualquer que seja a metodologia adotada. Na realidade, no que diz respeito ao peso sobre as mobilizações sindicais, o setor metalúrgico ainda é, de longe, o mais importante (Jacobi; Keller \& Müller-Jentsch, 1993, pp. 254-255) ${ }^{21}$.

Os mesmos autores chamam a atenção para a mudança no padrão de greve. Os sindicatos estão hoje procurando paralisar pontos estratégicos das empresas que, embora tenham poucos trabalhadores, podem prejudicar toda a cadeia produtiva. Mas, nesse país, os lockouts, que não são proibidos, afetam mais o volume de empregados paralisados do que as greves decretadas pelos sindicatos. Os lockouts patronais são geralmente utilizados de forma defensiva pelas empresas, depois do início de uma greve, a fim de pressionar financeiramente os sindicatos que devem sustentar os grevistas durante o movimento. Daí a razão de os sindicatos procurarem reduzir o número de trabalhadores formalmente paralisa dos. Um exemplo significativo, tanto do peso dos lockouts nas estatísticas sobre conflito, quanto dos custos para os sindicatos em greves prolongadas e das estratégias utilizadas, foi a greve de 1984 dirigida pelo sindicato dos metalúrgicos, o IG Metall, que pretendia uma redução na jornada de trabalho. A greve durou nove semanas. Segundo Baethge e Wolf (1995), 450 mil trabalhadores foram afetados pelo movimento: 58 mil oficialmente em greve; 147 mil em consequência de lockouts e 250 mil parados em decorrência da paralisação das entregas e falta de estoques. Para o sindicato, a greve custou 500 milhões de marcos, ou seja, um terço do total de suas

${ }^{21}$ Por exemplo, em termos do total de trabalhadores envolvidos em greve, 77,8\% estavam no setor metalúrgico (Jacobi; Keller \& Müller-Jentsch, 1993, pp. 254255). Mas, provavelmente, a continuidade das transformações técnicas e econômicas acabe por afetar o setor metalúrgico e enfraquecer significativamente o sindicato e a sua capacidade de mobilização. Por exemplo: entre 1992 e 1993, o IG Metall, o sindicato dos metalúrgicos, perdeu cerca de 20 mil membros a cada mês, refletindo a diminuição do emprego no setor (Visser \& Van Ruysseveldt, 1966, p. 144). 
reservas; para a federação dos empregadores, o custo chegou a 800 milhões. No final, um acordo foi alcançado: a média semanal de trabalho foi reduzida para 38,5 horas mas os empregadores ganharam aumento de flexibilidade no tocante às horas trabalhadas (p. 240). Os custos desses combates fazem com que a decisão de recorrer a greve seja ponderada muito seriamente, o que leva à tentativa de esgotar todos os recursos na mesa de negociação antes que o início do movimento seja ordenado.

Também na Suíça, depois de um pico de greves em 1976 o movimento grevista declinou acentuadamente. Mas Trata-se de um país em que a ocorrência de greve é fato raro. Entre 1971 e 1990, houve dois anos em que nenhuma paralisação aconteceu. Em 1989 e em 1990, houve apenas duas greves. Paralisações do trabalho continuaram fato raro na Suíça durante a década dos 90. Em 1993, não houve nenhuma greve. Em 1994, houve um forte aumento: oito greves. Em 1995, tornou a baixar para duas (Hortz-Hart, 1993; OIT, 1996).

Na França, o número de dias perdidos por greves entre 1979 e 1988 era um terço do número registrado entre 1970 e 1979 (Goetschy \& Rozenblatt, 1993). A queda das taxas de greve na França continuou na década dos 90, ou, mais precisamente, na média do período 1990-1994 em comparação com 19801984. Tomando 19751981 como referência, no setor de mercado, o número de dias perdidos por cem empregados caiu de 23,7 para 3,5. No setor público, o declínio foi significativamente menor. Na média do período de 1982-1989, o índice de dias parados declinou de 14,9 para 5,7 em 1990-1994 (Jefferys, 1996a, p. 521). É provável, como adverte o autor, que o número de greves do setor público seja bem maior do que o indicado nas fontes que utilizou. Por exemplo: nas cifras sobre o setor público, estão computadas as paralisações do funcionalismo público, dos professores, dos correios e comunicações, mas não as dos governos locais ou dos empregados dos hospitais públicos, de modo que a longa greve das enfermeiras de 1988 não foi contabilizada. Além disso, as greves dos transportes e das empresas nacionalizadas, nas estatísticas de greve, onde a ocorrência de greves é elevada, foram computadas no setor de mercado (Jefferys, 1996, p. 521). A explosão da greve dos funcionários em fins de 1995, ainda não incluída nas fontes utilizadas por Jefferys, seguramente fez subir ainda mais os índices de paralisação no setor público.
O caso da Espanha é singular porque o movimento grevista se manteve elevado com baixas taxas de sindicalização. Apesar disso e do desemprego, o país registrou as mais elevadas taxas de greve da Europa, tendo o movimento grevista atingido o pico em 1979, quando 5,7 milhões de trabalhadores realizaram 2.680 greves. A partir daí, com a única exceção de 1988, os movimentos grevistas começaram a declinar. Em 1985, houve 1.275 paralisações (Estivill \& Hoz, 1992, p. 84) ${ }^{22}$. O movimento grevista continuou nos primeiros anos da década dos 90. Em número de ocorrências, em 1991, houve 1.645 greves; em 1992, 1.360 e, em 1993, 1.209. Todavia, a partir daí houve um declínio forte: 908 em 1994, 883 em 1995 e 830 em 1996 (OIT, 1997). São números ainda altos para os padrões europeus, mas que, nacionalmente, indicam declínio.

Em Portugal, o cálculo dos movimentos grevistas oferece resultado diverso conforme o indicador utilizado. Em números de paralisação, o pico foi atingido em 1981, com 756 greves (Lima, 1991; Pinto, 1992). Mas, em termos do número médio de grevistas, o pico foi em 1980 (1.066), ano em que ocorreu também o maior número médio de dias de trabalho perdidos por greves. A partir daí, o volume de paralisações (qualquer que seja o indicador) foi decrescendo, embora com oscilações. Assim, em 1988 ocorreram 181 paralisações, havendo ascensão em 1989 (307 greves), com aumento do número médio de grevistas (964) e do número médio de dias parados (1.164), ainda inferior aos anos 1977-1982 (a única exceção foi a do ano 1982 quando o número de horas perdidos foi ligeiramente inferior). Do prisma do volume de paralisações, os dados não permitem afirmar uma tendência ao aumento, mas tampouco oferecem base sólida para demonstrar o contrário em razão das oscilações nas ocorrências. Em 1990, houve 271 greves; em 1991, 262; em 1992, 409; em 1993, 230; em 1994, 300; em 1995, 282; e, em 1996, 274 (OIT, 1997).

$\mathrm{Na}$ Itália, que ao lado da Espanha esteve entre os países com mais greves, depois de 13 milhões de trabalhadores envolvidos em movimentos grevistas em 1980, seguiu-se um período de declínio, mas com muitas oscilações: em 1993, 4,3 milhões de empregados participaram de greves; em 1995, 445 mil. Em números absolutos, no ano quente de 1980, houve 2.238

${ }^{22}$ Estatísticas de Ruysseveldt e Visser, com base em dados da OIT, indicam um número ligeiramente menor de paralisações em 1985: 1.511. Mas a diferença pode estar na não inclusão da Catalunha para o período de 19801985 (Ruysseveldt \& Visser, 1996, p. 389). 
paralisações, que foram se reduzindo, entre altos e baixos, até chegarem a 545 em 1995 (OIT, 1997-1998), subindo, contudo, para 791 em 1996.

\section{CONCLUSÃO}

Os principais resultados já foram adiantados. Tentemos agora sintetizar os aspectos que nos parecem mais importantes:

a)Todos os indicadores sugerem, nos principais países industrializados, o declínio da taxa de greves como a tendência principal na área dos conflitos trabalhistas.

b)Esse declínio não é linear nem atinge ao mesmo tempo e com a mesma intensidade todos os países. Apesar disso, não estão à vista sinais de um próximo desaparecimento do conflito na maioria dos países, ainda que em alguns deles a redução das taxas de greve tenha sido muito forte.

c)Em certos casos, as quedas nacionais nas taxas de sindicalização e de greve, quer dizer, a redução da força do sindicalismo como instituição e como movimento, parecem fortemente influenciadas por uma mesma causa: o declínio da importância de segmentos da classe trabalhadora mais propensos à greve. Os exemplos citados dos mineiros e doqueiros, no Reino Unido, e dos metalúrgicos, em toda a parte, são particularmente ilustrativos de efeitos provocados por uma mesma causa, aspecto que se liga, na verdade, à desindustrialização em curso na América do Norte e na Europa Ocidental.

d)Em alguns países, provavelmente (mas não temos dados a respeito) as taxas de greve foram influenciadas pelas mobilizações do setor público. A greve dos funcionários franceses, em novembro e dezembro de 1995, é paradigmática tanto da mobilização dos funcionários e empregados das empresas estatais como de súbitas mobilizações que alteram tendências estatísticas. Ela é também indicativa do "modelo francês" de luta reivindicativa: explosão e propagação relativamente espontânea do movimento, papel secundário dos sindicatos, intromissão, ou tentativa de intromissão, de outros atores no desenvolvimento das mobilizações: estudantes, intelectuais, políticos e grupos de esquerda (cf. Touraine; Dubet; Lapeyronnie; Khosrokhavar \& Wieviorka, 1996). É verdade que o movimento de 1995 escapa dos contextos habituais de conflitos trabalhistas ${ }^{23}$ Mas, como quer que seja classificada a mobilização, o resultado seguramente foi o grande aumento dos índices de greve, avaliados por jornadas perdidas e número de grevistas. No auge da mobilização, em 12 de dezembro, o volume de manifestantes estimado pelo Ministério do Interior em toda a França era de 985 mil. Não está indicado o números dos que estavam efetivamente em greve (Touraine et alii, 1996, p. 315). É claro que aqui estamos diante de uma situação de mobilização geral de outras categorias (os empregados do Estado), diferente das que habitualmente lideravam os movimentos grevistas na França (e em outros países), ou seja, os trabalhadores manuais.

e) Independentemente de outras variáveis, há indicações de que certas elevações súbitas dos coeficientes de conflito tendem a acontecer em duas situações tipificadas, de um lado, pelos países ibéricos e, de outro, pelos países nórdicos, especialmente Suécia. $\mathrm{Na}$ primeira, o aumento da taxa de greve relaciona-se com a transição de um sistema político autoritário para outro liberal-democrático e pluralista, com os inevitáveis reflexos no sistema de relações de trabalho: desembaraçados dos controles autoritários, os trabalhadores elevam sua pressão para ocupar espaço no interior do sistema político e econômico e chocam-se com um patronato e outras elites não habituadas a partilhar poder e a negociar. Nessa situação, as taxas de conflito aumentam em razão de ações sindicais ofensivas. $\mathrm{Na}$ segunda, o aumento das taxas de greve vem das tentativas empresariais de imposição de padrões neoliberais e de desmantelamento (ou debilitamento) de um modelo neocorporativo longamente estabelecido, no interior do qual um espaço de influência relativamente grande (dentro e fora das empresas) estava reservado para os sindicatos. Aqui, o aumento do conflito vem de ações defensivas do sindicalismo que busca o retorno ao status quo ante. $\mathrm{Na}$ verdade, também em outros países, objetivos defensivos parecem estar na raiz da maioria das greves deflagradas a partir de meados de 1985.

f) As estatísticas sobre as frequências do conflito, comparadas com as relativas ao declínio da proporção de sindicalizados, não provam que os declínios nos níveis de sindicalização sejam responsáveis pelas quedas nas taxas de greve. Uma afirmação da existência de relação causal entre os dois

23 Tal como Touraine, Khosrokhavar entende taxativamente que a greve foi "um não movimento social, sem projeto, sem utopia, sem ator central, não político, heterogêneo e sem expressão própria ..." (Khosrokhavar, 1966, p. 204). 
fenômenos teria de resultar de cálculos de correlação sofisticados. Para começar, não bastariam dados nacionais agregados. Seria preciso estudar também as taxas de sindicalização e de greve por setor nos vários países. Os dados anteriores, porém, não mostram um movimento inverso entre as curvas de sindicalização e as curvas de greve, quer dizer, que indicasse que, à medida que a sindicalização caísse, tenderiam a aumentar os conflitos trabalhistas. Por isso, julgamos que o cotejo entre os dois fenômenos sugere (mas não prova) que a dessindicalização favoreceu mais a diminuição do conflito do que sua elevação. Os dados disponíveis, ainda que incompletos, vão no sentido de respaldar a hipótese de que o enfraquecimento da organização sindical, medido pela proporção de trabalhadores filiados, tende a reduzir as taxas de greve. Nos países onde a sindicalização declinou fortemente (Reino Unido) ou onde sempre foi fraca (EUA, França) houve também forte recuo dos movimentos grevistas. De outro lado, em países onde os níveis de sindicalização permaneceram altos (Suécia, Dinamarca, Finlândia, Canadá) as taxas de paralisação na década dos anos 80 mantiveram-se elevadas e, às vezes, aumentaram. Há, pois, indicações de que, onde os níveis de sindicalização são elevados, os sindicatos tiveram mais capacidade de reação, sendo a greve uma expressão dessa capacidade.

g)Queremos com essa afirmação extrair a conclusão de que o volume e a proporção de trabalhadores filiados são indicadores relevantes da força do sindicalismo e do poder sindical, que tem, como um de seus principais instrumentos de efetivação, a capacidade de fazer greve.

h)Não está contida nessa conclusão a tese de que, sem organizações sindicais fortes, greves não possam eclodir. Também não está sendo defendida a ideia de que novas formas de conflito social estejam descartadas e de que as sociedades deste final de século serão "sociedades harmoniosas", tal como os marxistas imaginavam que seria a sociedade socialista. Mas está contida em nossa apreciação da evolução da curva de greve a hipótese de que a dessindicalização diminui a força dos sindicatos e tende a reduzir os índices de conflito trabalhista, a afetar negativamente o poder sindical, em especial porque os movimentos de trabalhadores, para sua continuidade e consolidação, necessitam de organização, mesmo com o risco da sua burocratização e acomodação às estruturas da ordem capitalista democrática.

\section{Segunda Parte: \\ OS FATORES DE DESSINDICALIZAÇÃo}

\section{Introdução}

Va primeira parte, preocupamo-nos em tentar descrever o declínio das taxas de sindicalização e a evolução do conflito nos países desenvolvidos da Europa Ocidental e na América do Norte. Não houve, contudo, uma análise de tipo causal que tentasse explicar os motivos do recuo do sindicalismo. Não seria preciso enfatizar que um fenômeno dessa magnitude vincula-se a um conjunto de mutações nas sociedades contemporâneas e nas formas de organização do trabalho, que começaram a operar de modo mais intenso, mas nacionalmente variado, a partir da década dos 70. Essas mudanças têm sido catalogadas em diferentes classes de fatores explicativos. As divergências, entre os pesquisadores, na taxinomia dos fatores, embora existam, não são muito acentuadas. Mais fortes, no entanto, são as divergências relativas à avaliação da extensão dos efeitos causais particulares. De modo mais específico: há razoável concordância no que tange ao arrolamento dos diferentes fatores que tendem a levar à dessindicalização e boa dose de divergência quanto à dimensão dos estragos que ocasionaram individualmente. Algumas diferenças, mais do que divergências propriamente ditas, existem também quanto à classificação desses "fatores de dessindicalização", aspecto que se liga, como veremos adiante, aos prognósticos sobre o futuro do sindicalismo. Vejamos alguns exemplos:

Colin Crouch, numa avaliação de vários estudos comparativos sobre os problemas enfrentados hoje pelo sindicalismo dos países desenvolvidos, distingue três tipos de explicação: a conjuntural, relacionada com a recessão dos anos 80; a estrutural, concernente às mudanças na força de trabalho e no sistema produtivo; e a política, relativa à balança de poder nas economias nacionais no final de século (Crouch, 1992a). Note-se que não estão mencionadas as políticas sindicais e empresariais, mas elas aparecem no interior dos tipos principais de explicação causais. 
De outro ângulo, Kane e Marsden (1988) separam dois grandes conjuntos de hipóteses explicativas: as ambientais e as institucionais ${ }^{1}$. Entre as primeiras colocam:

a)mudanças estruturais e econômicas: perda da posição estratégica das grandes unidades de produção, que agrupavam conjuntos mais homogêneos de trabalhadores; aumento do emprego feminino, especialmente de mulheres casadas;

b) "globalização": abertura de mercados, aumento da concorrência, diminuição das margens de benefícios a serem concedidos aos empregados; maior fluidez financeira e transferência de propriedade e consequente alteração da política de pessoal tradicional;

c)aumento da heterogeneidade da mão de obra, decorrente das novas formas não padronizadas de emprego e ocupação, que tornam a "representação sindical" mais complexa diante da necessidade de atender a demandas mais diferenciadas;

d)novas tecnologias: introdução de procedimentos eletrônicos e de informatização, que ocasionam maior descentralização das organizações com consequências quantitativas e qualitativas acentuadas sobre o emprego;

e)mudanças legais e políticas: restrições ao direito de greve, endurecimento dos governos com relação a ações sindicais, nova legislação etc.

Entre as segundas, incluem:

a)as estratégias empresariais que podem implicar, de um lado, mudanças de atividades, de produtos, de localização, de política de venda e, de outro, a capacidade dos sindicatos de influenciar essas estratégias;

b)as novas políticas de relações humanas para os empregados, destinadas geralmente a tornar desnecessário o recurso aos sindicatos e à representação sindical.

Green (1992), focalizando especificamente o declínio do sindicalismo britânico, entende que as hipóteses explicativas envolvem três grandes conjuntos de temas: a) mudanças no ambiente externo em que

${ }^{1}$ Os autores resumem os resultados de um seminário, realizado em dezembro de 1987 pelo Instituto Internacional de Estudos do Trabalho, que reuniu 25 especialistas de vários países. atuam os sindicatos; b) alterações no quadro legal das relações industriais; e c) mudanças na composição do emprego.

Metcalf, por sua vez, distingue cinco elementos que contribuíram para o declínio do sindicalismo: a) fatores macroeconômicos; b) composição do emprego; c) legislação governamental; d) reações dos empregadores em face das organizações sindicais (reconhecimento ou desreconhecimento); e e) conduta dos sindicatos (Metcalf, 1989, apud Disney, 1990, p. 166).

Por seu lado, Visser (1991, p. 103) agrupa as hipóteses explicativas do declínio sindical em classes mais abrangentes:

a)características da estrutura econômica: tamanho do setor agrícola ou industrial; desemprego e outras características do mercado de trabalho; concentração do emprego e papel das pequenas firmas no setor; empresas estrangeiras e nacionais e competição internacional;

b)fatores políticos e institucionais: hostilidade ou apoio dos governos para com os sindicatos; desenvolvimento do setor público; legislação trabalhista; políticas de desregulamentação e problemas de acesso dos sindicatos aos partidos e ao governo;

c)política e organização dos empresários;

d)sistema de valores da sociedade, e em particular os valores dos empregados com relação às ações e organizações coletivas.

Para Kochan (1988), que focaliza especificamente o sindicalismo norte-americano, quatro tipos de explicação podem ser distinguidos:

a)mudanças políticas e estruturais no ambiente em que atuam os sindicatos;

b)alterações nas estratégias das empresas em busca de maior flexibilidade, maior esforço por rebaixamento de custos e procura de novos mercados, o que levaria os empresários a ser mais agressivos diante do sindicalismo;

c)mudanças nos valores, atitudes e expectativas dos trabalhadores, que iriam no sentido de diminuir o interesse pelo sindicato. Essas alterações nos sistemas de valores estariam relacionadas com o enfraquecimento da solidariedade da classe trabalhadora; 
d)finalmente, o quarto tipo de explicação abrangeria os três anteriores como componentes inter-relacionados de uma teoria mais sistemática de transformação das relações industriais. $\mathrm{O}$ declínio da sindicalização seria somente uma peça no conjunto de amplas mudanças na estrutura institucional das relações de trabalho, que viriam em respostas a processos de longo prazo no mercado, na tecnologia, nos contextos políticos das relações de emprego, nas alterações das estratégias de negócios e recursos humanos dos empregadores: "A implicação central [...] é de que nenhuma estratégia única ou melhoria das estratégias organizatórias dos sindicatos ou mudanças nas condições políticas e econômicas podem levar a uma significativa recuperação da representação operária. Ao contrário, novos papéis para os sindicatos ou outras organizações de trabalhadores deveriam ser criados para oferecer uma melhor adequação entre as necessidades dos empregados e as do seu meio" (p. 187) $)^{2}$.

A ênfase nos fatores estruturais aparece, entre outros, em Jefferys (1995), para quem cinco tipos de mudança desestabilizaram o meio em que os sindicatos atuavam: a) mudanças estruturais no peso do setor manufatureiro e extrativo em benefício dos serviços; b) mercado mundial de produtos, levando a gestão das empresas a ser mais profissional; c) mercado de trabalho marcado pelo desemprego; d) novos processos de produção; e) nova visão da política, mais liberal e individualista, acompanhada pela diminuição do papel do Estado e dos partidos políticos.

De modo mais sintético, o sociólogo e cientista político S. M. Lipset (1986b) distingue três amplas categorias para explicar o declínio do sindicalismo norte-americano: a) as que integram as mutações estruturais da economia; b) as que dizem respeito a alterações na legislação; e c) as que se referem a mudanças nos valores básicos da sociedade.

\footnotetext{
${ }^{2}$ Kochan acredita, apesar disso, que alterações políticas, nova legislação sobre o sistema de negociações coletivas e medidas de proteção ao direito de organização dos trabalhadores poderiam produzir uma mudança, tal como na década de 1930. O autor pensa no exemplo ocorrido quando da introdução do New Deal. Então, sob leis mais favoráveis e com a adoção de novas formas de organização (por indústria), o sindicalismo conseguiu se recuperar, como aconteceu quando da formação do Congresso para a Organização Industrial (CIO) e de "sindicatos industriais" (de trabalhadores fabris) em lugar dos sindicatos de oficio, geralmente filiados à Federação Americana do Trabalho (AFL.). Do mesmo modo, Kochan crê que seria necessária a ligação dos sindicatos com um partido político forte, tal como existe em alguns países da Europa. Mas essas recomendações, diante dos problemas apontados pelo próprio autor, parecem cair mais no campo do wishfull thinking.
}

Como vimos, os motivos da dessindicalização às vezes se repetem ao mesmo tempo em que sua classificação varia. Seria tentador separá-los em dois grandes blocos: os "estruturais" e os "conjunturais". Entre os primeiros poder-se-ia colocar os eventos e processos de natureza mais estável, de efeitos de médio ou longo prazos e (ao menos aparentemente) menos sujeitos ao controle e intervenção deliberada dos vários atores do campo político e sindical (partidos, sindicatos, associações patronais, governo). Na classe das causas estruturais da dessindicalização estariam as mudanças tecnológicas e nos modos de fabricação, as transformações no mercado de trabalho e na estratificação social, custos e facilidades de transporte, alterações na disponibilidade de matérias-primas, facilidades de comunicação, novas tendências de consumo; alterações na estrutura etária dos consumidores etc.

Entre as causas de tipo conjuntural, mais sujeitas à reversão, estariam as alterações no campo do jogo político-partidário, das leis trabalhistas, dos modelos de relações de trabalho, das estruturas sindicais, das modalidades de negociação e de relações dos sindicatos com as empresas e com os governos. Aí estariam as situações que podem ser alteradas bruscamente ou a curto prazo, como mudanças na legislação trabalhista, nas estratégias dos sindicatos e das empresas, na relação de forças entre os partidos e outras da mesma natureza.

Em alguns casos, não há muita dificuldade para inserir um dado fenômeno na classe dos fatores estruturais ou conjunturais. Eventos políticos geralmente são de natureza conjuntural, tal como as alternâncias de partidos no governo. Uma vitória eleitoral de partidos conservadores ou liberais, que substitua no governo partidos socialdemocratas ou de esquerda, pode ter reflexos negativos consideráveis sobre o sindicalismo. Uma porcentagem significativa da perda de filiados pode ser decorrente desse fato, se a vitória "conservadora" implicar leis prejudiciais para o poder sindical. Alterações e rodízios na chefia de governos costumam acontecer. Mudanças políticas são eventos com probabilidade relativamente elevada de reversão, ao contrário do que acontece com a introdução de novas tecnologias que aumentam a produtividade: equipamentos obsoletos podem ser enviados para a periferia do sistema econômico, ou ser simplesmente sucateados, mas não tendem a retornar; forças políticas derrotadas eleitoralmente podem voltar ao governo embora nem sempre com os mesmos programas. 
No entanto, outras vezes, a classificação do que é "estrutural" e do que é "conjuntural" pode ser complicada. Esse é o caso do desemprego. Sem discutir se se trata de algo econômico ou social (uma solução seria classificá-lo de "socioeconômico"...), há dificuldades em entendê-lo hoje como algo estrutural ou conjuntural. No passado, o desemprego aparecia ligado a crises cíclicas do capitalismo e estava associado a quedas nos níveis de produção. A expectativa era de que diminuísse quando a economia recuperasse seu nível "normal" de atividade diante de uma retomada espontânea ou induzida da demanda. As taxas de desemprego poderiam ser vistas, assim, como um fator conjuntural, de natureza cíclica, que estaria afetando negativamente o movimento sindical, mas a partir do qual não se poderia vaticinar o declínio futuro do sindicalismo. Contudo, se entendido como uma característica estrutural, permanente, das economias globalizadas (embora talvez fosse cedo para uma afirmação dessa natureza), tenderia a ocasionar para o sindicalismo perdas não recuperáveis.

Citamos o exemplo do desemprego para ressaltar o caráter esquemático, e algumas vezes arbitrário, da classificação dos fatores, tanto quando consideramos a sua natureza (econômica, tecnológica, política) como quando os consideramos do ângulo de sua permanência (conjunturais ou estruturais). Mas, apesar disso, alguma taxionomia parece necessária e não só para fins didáticos e para pôr alguma ordem na exposição.

A separação analítica entre grandes conjuntos de variáveis, assim como o espaço que se concede a eles nas explicações das causas das quedas nos níveis de sindicalização, têm consequências mais profundas no que tange às interpretações sobre o futuro dos sindicatos. Se localizarmos as principais razões do encolhimento do sindicalismo em fatores de natureza político-institucionais (como estratégias empresariais antissindicais, burocratização das organizações dos trabalhadores e incompetência de lideranças sindicais, ascensão de governos hostis, legislação antissindical), boa parte das perdas nas taxas de sindicalização pode ser vista como recuperável, dependendo especialmente da capacidade das lideranças sindicais (e dos partidos de esquerda) de desenvolverem novas estratégias capazes de enfrentar o poder empresarial.

Se, pelo contrário, localizarmos as causas principais do declínio do sindicalismo em alterações da economia, da tecnologia, do mercado de trabalho, da estrutura social, da passagem de uma sociedade industrial para outra de serviços ${ }^{3}$, enfim, em fatores sociais e econômicos "estruturais", os prognósticos sobre as perspectivas da instituição sindical tenderão a ser mais negativos, porque a difícil situação atual do sindicalismo teria raízes mais profundas e dificilmente poderia haver políticas capazes de levar o sindicalismo a um retorno aos anos dourados, mesmo que paliativos possam ser achados. De modo geral, estudos que enfatizam o peso de fatores conjunturais ou político-institucionais são mais propensos a considerar que o sindicalismo poderia encontrar uma saída, dependendo especialmente de uma mudança no contexto político, da reorganização nas orientações e táticas dos sindicatos, de novas legislações do trabalho, da vitória de governos "amigos" etc. Consequentemente, o sindicalismo não seria uma instituição condenada pela sociedade pós-industrial deste final de século.

Por outro lado, as análises calcadas principalmente sobre variáveis estruturais (que enfatizem as transformações do ambiente no interior do qual a instituição sindical se insere) levam a prognósticos pessimistas. Assim, não estaríamos diante de uma situação de crise, mas de declínio da instituição sindical. No limite, não haveria espaço para o movimento sindical nas sociedades de serviço do próximo século. No quadro mundial do sindicalismo, a Suécia e os países escandinavos é que seriam a exceção que retrataria o passado enquanto os EUA indicariam o futuro. $O$ sindicalismo teria de aceitai; na melhor das alternativas, o papel de uma instituição de segunda classe.

Mas, como tentamos mostrar, a separação das hipóteses explicativas em "estruturais" e "conjunturais", em muitos casos, pode ser demasiadamente arbitrária. Por isso, para fins de exposição, preferimos agrupar os fatores que estão minando as bases do sindicalismo em dois grandes blocos: os de natureza socioeconômica (que tendem a ser fenômenos estruturais de mais longa duração e relativamente menos sujeitos à reversão) e os de natureza político-institucionais (que tendem a

${ }^{3}$ No que toca à classificação das empresas, a separação entre "indústria" e "serviços" tende hoje a ficar mais complicada. Nas "empresas de alto valor", para usarmos o termo de Reich (1994), a distinção que se costumava fazer entre "bens" e "serviços" perde significado. Empresas classificadas como "industriais" (nos EUA), como a IBM, são, de fato, empresas de serviços. "Menos de 20 mil dos 400 mil funcionários da IBM - diz Reich - estavam classificados como 'operários de produção', engajados em fabricação convencional” (p. 79). A desindustrialização, pois, pode ser mais acentuada do que sugerem as estatísticas que utilizam critérios tradicionais. 
ser de mais curta duração e mais sujeitos à intervenção deliberada dos principais atores da área trabalhista: governo, empresários e sindicatos). Um terceiro bloco poderia incluir as hipóteses que realçam o papel das mudanças culturais e valorativas. Entretanto, como as mudanças que se operam nessa área somente atingem o sindicalismo quando passam pelo jogo político e afetam as relações de força e de alianças entre grupos de interesses - quer dizer, os partidos no governo, a disposição das autoridades com relação ao sindicato, a legislação trabalhista -, as mudanças nos sistemas de valores foram inseridas no rol dos fatores institucionais e políticos.

\section{Capítulo 6 Os fatores socioeconômicos}

campo dos fatores sociais e econômicos não apenas é muito amplo como de fronteiras não muito claras. No seu interior, cabem fenômenos de natureza variada: formas de organização da produção, mudanças tecnológicas, desemprego, deslocamento de indústrias, declínio de atividades econômicas, mudanças na composição profissional da mão de obra e sua distribuição por ramos, dimensão de empresas, mercado internacional etc. Pode-se mesmo, com certo esforço, incluir neles até certas áreas relacionadas mais propriamente com a administração de empresas, como práticas gerenciais, técnicas de marketing etc. Alguns fenômenos de natureza econômica (ou mercadológica, mais exatamente) não parecem ter muita relação com a situação sindical, tal como, por exemplo, técnicas de venda. Outras variáveis tecnológicas, administrativas e mercadológicas, que poderiam ser inseridas na classe dos fatores econômicos - como a automação, o estilo de gerenciamento e de relacionamento com os empregados, as demandas de novos tipos de produtos por parte do mercado consumidor - podem ter relação mais forte com as taxas de sindicalização, na medida em que levam ao surgimento de novos postos de trabalho, de funções e de novos tipos de profissionais e, consequentemente, afetam as atitudes dos empregados perante os sindicatos e o número de trabalhadores potencialmente sindicalizáveis ${ }^{1}$.

\section{As NoVAS TECNOLOGIAS E A REORGANIZAÇÃO DA PRODUÇ̃̃o}

$\mathrm{Na}$ categoria dos efeitos tecnológicos, a introdução da automação e da informatização constitui um dos principais elementos que prejudicaram o

${ }^{1}$ Especialmente nocivo para a sindicalização é o surgimento de um novo tipo de empregado precário, móvel, instável no emprego, de trabalho temporário, subcontratado por meio de agências de emprego. Em lugar de ligar-se a uma firma e de procurar um emprego vitalício, ou de longo prazo, numa companhia, esses trabalhadores possuiriam um elevado e amplo leque de qualificações, de enfermeiros e programadores de computadores, na cúpula, a porteiros a trabalhadores diaristas, na base. Cobble (1995, apud Strauss, 1995, p. 337) estimou esses empregados "fora de padrão" em $25 \%$ da força de trabalho do setor privado dos Estados Unidos. 
sindicalismo, ao reduzir o número de trabalhadores manuais, alterando o mercado de trabalho, causando desemprego setorial e, algumas vezes, segundo sua dimensão, rebaixando os níveis nacionais de ocupação. As mudanças, que haviam se iniciado há certo tempo, aceleraram-se a partir de meados da década dos 70, ocasionando forte redução do emprego, notadamente nas camadas da classe trabalhadora em que os sindicatos estavam bem implantados e possuíam grande capacidade de mobilização e de paralisação de atividades vitais para a economia nacional. Nesse sentido, como já notamos, os setores de minas e portos foram muito afetados pelas transformações econômicas e técnicas. Uma vez que, em cada país, o espaço desses ramos na economia nacional é diferente, as consequências para os níveis de sindicalização não foram as mesmas. Para países em que a mineração não era (ou nunca fora) importante, a introdução de outras fontes de energia que levaram à crise desse setor - e ao desaparecimento de um dos segmentos das classes trabalhadoras onde o sindicalismo era forte - não poderia ter reflexos significativos nos índices de sindicalização. Nesse ponto, cumpre ver que os sindicatos penetram desigualmente em determinados segmentos das classes assalariadas e que as diferenças nos índices setoriais de sindicalização tendem a permanecer relativamente constantes, o que permite dizer que há (ou havia) padrões diferenciados de comportamento dos grupos de assalariados ante as organizações sindicais ${ }^{2}$.

O fenômeno da queda do emprego no setor industrial é tão conhecido que não vale a pena alongar-se nesse ponto. Limitemo-nos a dizer que, em 1960, em 17 países da OECD, o emprego industrial ultrapassava 40\% do total do emprego civil em oito países. No Reino Unido, representava 47,7\%; na República Federal Alemã, 47\%; na Bélgica, 45\%, para citar apenas alguns países onde o emprego industrial absorvia mais trabalhadores.

\footnotetext{
${ }^{2}$ Considerando o Reino Unido, Price e Bain distinguem quatro grandes setores do emprego com padrões diferentes de sindicalização: a) agricultura, silvicultura, pesca e b) serviços privados, nos quais a sindicalização é baixa; c) indústria e d) setor público, onde a sindicalização é elevada (Price \& Bain, 1976). Em 1974, os dois setores de alta sindicalização representavam aproximadamente $60 \%$ do total do emprego e mais de $84 \%$ do total de sindicalizados. A tese sustentada pelos autores é que as mudanças na distribuição do emprego trabalharam contra a taxa nacional de sindicalização do Reino Unido: “A proporção do total da força de trabalho empregada e de indústrias cuja longa tradição de sindicalismo e alta proporção de sindicalização - estradas de ferro, mineração de carvão, tecelagem de algodão e serviços governamentais - declinaram de 11,5\% para 5,5\% entre 1948 e 1974" (p. 341 ), tese que milita a favor das explicações "estruturalistas", que discutiremos mais tarde.
}

Em 1989, em nenhum deles a proporção da força de trabalho no setor ultrapassou $40 \%$ e somente em quatro deles foi um pouco além dos $35 \%$ : Áustria, França, Portugal e Suíça. No Reino Unido, caiu para $29,4 \%$ (OECD, 1991, apud Ferner \& Hyman, 1993a).

Nos EUA, foram perdidos 2,8 milhões de postos de trabalhos industriais entre 1979 e maio de 1992. As perdas maiores corresponderam aos seguintes subsetores: metais primários (548 mil); fabricação de produtos metálicos (375 mil); máquinas não elétricas (567 mil). A exceção foi o subsetor de máquinas de precisão, onde foram criados 260 mil novos postos de trabalho. Na França, o emprego na indústria manufatureira minguou entre 1982 e 1991 em cerca de $13 \%$ enquanto o emprego total cresceu 2,3\% (OIT, Informe I, 1994, p. 53) . $^{3}$.

No quadro geral da tendência ao declínio do emprego no ramo industrial, o setor metalúrgico, onde se localizava há muitas décadas uma das partes mais avançadas do sindicalismo, foi dos mais atingidos pelo progresso tecnológico. Para dar mais dramaticidade à dimensão da mudança, citamos alguns casos particulares. (Obviamente, a lista de situações equivalentes é imensa e tem sido tratada pela literatura especializada, de modo que não parece necessário estender-se sobre $o$ assunto.) Na Itália, nos anos 80, a Fiat produzia cerca de 1,5 milhão de carros por ano com 150 mil funcionários. Em 1996, produziu 1,6 milhão de carros com apenas 75 mil empregados. A indústria de geladeiras, que produzia 600 mil unidades com 2.200 pessoas, agora produz 1,2 milhão com 1.800 trabalhadores (Boletim do Dieese, 1997, p. 17). Nos EUA, em 1973, 49 mil trabalhadores estavam empregados na indústria de geladeira e freezers. Em 1991, o número havia caído para 25.700, uma queda média anual de 3,5\% (Rifkin, 1995, p. 150). Entre 1979 e 1990, o emprego na indústria metalúrgica americana diminuiu a uma média de $1,7 \%$ ao ano (Rifkin, 1995, p. 146).

A United State Steel, a maior companhia siderúrgica integrada dos EUA, em 1980, empregava 120 mil trabalhadores. Em 1990, produzia a mesma tonelagem com apenas 20 mil. Em dez anos, a produtividade dos

\footnotetext{
${ }^{3}$ A queda, no período, não foi geral. O mesmo informe da OIT indica que, na Alemanha, o emprego industrial chegou a crescer 5,8\% entre 1982 e 1990, diante de $9,6 \%$ da economia alemã no seu conjunto (p. 53). O fato explica provavelmente as perdas menores registradas pelo sindicalismo alemão na década dos 80 em cotejo com outros países.
} 
trabalhadores manuais havia crescido sete vezes (Drucker, 1993, p. 46). Drucker acentua que a maior parte do crescimento foi obtida pelo fechamento de usinas obsoletas e pelo investimento em novos equipamentos, mas que a maior parte do salto em produtividade veio do replanejamento do fluxo de trabalho e tarefas. Na União Europeia, o número total de postos de trabalho no setor siderúrgico se reduziu mais de 65\% entre 1975 e 1995, baixando de 991 mil para 326 mil. Na França e no Reino Unido reduziu-se $75 \%$ e $80 \%$, respectivamente. Nos EUA e no Japão, no mesmo período, houve redução de $51 \%$ e $48 \%$ dos postos de trabalho, respectivamente (Trabajo, Genebra, OIT, n 22, dezembro de 1997, p. 11).

Para os trabalhadores qualificados, a queda do emprego deverá ser de $14 \%$ até a primeira década do próximo século (Boletim 2409, Departamento do Trabalho dos EUA, apud Rifkin, 1996, pp. 146147). Segundo dados da União Internacional dos Trabalhadores das Indústrias Mecânicas, durante o período de 1992-1993, em todo o mundo, foram despedidos cerca de 90 mil trabalhadores da indústria siderúrgica; 200 mil da indústria automotriz; 126 mil da indústria aeroespacial; 170 mil do subsetor de informática e de outros subsetores da indústria eletrônica; 14 mil da indústria de fabricação de eletrodomésticos; 7 mil da construção naval e 75 mil trabalhadores de outros subsetores das indústrias mecânicas (OIT, Informe 1, 1994, p. 9).

O fim da Guerra Fria, com a redução da corrida armamentista, levou à queda brusca do emprego no setor metalúrgico e siderúrgico, aspecto que nem sempre tem sido acentuado nas análises sobre o desemprego. Nos EUA, a Comissão Nacional para a Reconversão Econômica e Desarmamento estimou que, entre 1990 e 1991, quase 300 mil empregos haviam sido suprimidos na indústria de defesa. Em princípios de 1993, haviam desaparecido outros cem mil. Na França, a redução do pessoal do setor de armamentos começou em 1958. Para 1997, estimava-se que 57 mil postos de trabalho deveriam ter desaparecido do total dos 250 mil empregados nas indústrias militares (OIT, Informe 1, 1994, pp. 31-32). O fim da Guerra Fria afetou também a sindicalização do setor público, com a diminuição do pessoal civil empregado em organismos de defesa. Na realidade, não se trata apenas da diminuição do emprego nesses setores industriais, mas de um movimento mais amplo de desindustrialização: para o conjunto dos países desenvolvidos, a parte da indústria no emprego declinou de cerca de $28 \%$ em 1970 para cerca de $18 \%$ em 1994. Entre as economias avançadas, é nos EUA que o processo se encontra mais adiantado, com o setor de serviços representando atualmente $73 \%$ do total do emprego (World Economic Outlook, "Meeting the Challenges of Globalization in the Advanced Economies", May 1997, pp. 47 e 48) ${ }^{4}$.

As previsões catastróficas de Rifkin sobre o futuro do emprego (que não se limitam à avaliação da situação no setor industrial, lembremos) podem ser discutidas ${ }^{5}$. Mas é difícil contestar o fato do declínio absoluto e relativo dos trabalhadores industriais, a não ser mudando o conteúdo do conceito, de modo a incluir na "classe operária" outras categorias profissionais assalariadas que nunca foram entendidas como "operárias", como os engenheiros e outros trabalhadores intelectuais. Com esse procedimento, Lojkine (1990) concluiu que a "classe operária" não estaria diminuindo, mas mudando de natureza. Segundo o autor, o que estaria prestes a desaparecer "não é a classe operária, mas a secular divisão entre a classe dos trabalhadores manuais (os 'colarinhos-azuis') e a dos 'colarinhos-brancos' [...]. A revolução informacional não significa o dobrar dos sinos pela classe operária: significa o fim de uma concepção estreita da classe operária" (p. 20). Lojkine entende que a classe operária ampliou se com as novas camadas de trabalhadores intelectuais que, entretanto, não se reconhecem como operários (p. 15).

Os efeitos das novas tecnologias, dos ganhos de produtividade e da diminuição do emprego industrial (e notadamente do declínio numérico e das mudanças internas da classe operária) têm efeitos sobre a teoria sociológica e política relacionada com a interpretação dos conflitos e seu desdobramento na sociedade contemporânea. No plano teórico, a ênfase na

\footnotetext{
${ }^{4}$ A publicação adverte que a desindustrialização não deve ser vista como um resultado da globalização. Ela refletiria principalmente Os impactos desiguais do crescimento das taxas de produtividade na indústria e nos serviços. No que se refere às relações de trabalho, a mesma publicação chama a atenção para o fato de que, em economias predominantemente baseadas em serviços, a negociação coletiva centralizada está ameaçada. Nessas economias, serão cada vez mais necessários acordos salariais que não somente contemplem as enormes diferenças em qualificação e produtividade mas também ofereçam incentivos para a acumulação de capital humano (p. 53).

${ }^{5} \mathrm{O}$ ex-secretário de Trabalho dos EUA, Robert B. Reich, professor de Política Social e Economia da Brandeis University, estima que nos seis anos da atual recuperação econômica americana foram criados 13 milhões de empregos e que, desde o final da década dos 70, vêm sendo criados uma média de dois milhões de emprego por ano. A taxa de desemprego estaria em torno de 5\%, a mais baixa nos últimos 24 anos. Em troca, a concentração da renda aumentou e o salário médio, ajustado pela inflação, é $5 \%$ menor do que era em 1989 (Reich, 1998).
} 
diminuição, ou mesmo transformação da classe operária conduz à conclusão de uma sociedade pós-capitalista mas não socialista ${ }^{6}$.

A industrialização da produção em série favorecia a homogeneização interna da classe trabalhadora, onde se sobressaíam os operadores de máquinas e os montadores das linhas de montagem, retratados de modo muito vivo pelos sociólogos do trabalho dos anos 50, 60 e mesmo 70, que pesquisaram o que hoje se tornou a "velha classe operária". Um tema comum desses estudos era a denúncia do trabalho repetitivo, maçante, alienado. Nesse contexto, as tarefas em si mesmas seriam incapazes de motivar os operários, a não ser pelas vantagens pecuniárias e materiais que o emprego poderia oferecer. O resultado seria, entre esses grupos de trabalhadores, a predominância das orientações "instrumentais". Tarefas repetitivas e salários altos levariam à colocação em primeiro plano de reivindicações econômicas e materiais como modo de compensar a alienação, a monotonia e o desinteresse pelo "trabalho em migalhas", ao contrário do que aconteceria (ou deveria acontecer) com o trabalho das fases artesanais... ${ }^{8}$

Além dos aspectos profissionais propriamente ditos, outros elementos sociais, culturais e geográficos favoreciam a maior coesão e homogeneidade

\footnotetext{
${ }^{6}$ Escreve Drucker: “Algumas décadas atrás, todos 'sabiam' que uma sociedade póscapitalista seria certamente marxista. Hoje, sabemos que marxista é a única coisa que a próxima sociedade não será". O fator de produção absolutamente decisivo, de acordo com o autor, não será o capital, a terra ou mão de obra mas o conhecimento. "Ao invés de capitalistas e proletários, as classes da sociedade pós-capitalista são os trabalhadores do conhecimento e os trabalhadores em serviços" (1994, pp. XIV e XV). Drucker, um pioneiro nesse tipo de abordagem das sociedades ocidentais contemporâneas, enfatiza a importância dos fundos de pensão no controle dos investimentos: "Nos Estados Unidos, esses fundos possuíam, em 1992, a metade do capital acionário) das maiores empresas e outro tanto de suas dívidas a longo prazo. Os proprietários e beneficiários dos fundos de pensão são, é claro, os trabalhadores do país. [...] Os fundos de pensão são dirigidos por uma nova espécie de capitalistas: empregados anônimos assalariados, os analistas de investimentos e gerentes de carteiras dos fundos de pensão" (p. XV). No Brasil, a opinião pública tomou consciência da força desses fundos por ocasião dos leilões das privatizações das estatais quando nomes como Petrus, Previ e de outros fundos de pensão se tornaram familiares.

O termo é de uma obra de G. Friedmann, O trabalho em Migalhas (junto com P. Naville, um dos pais da sociologia industrial e do trabalho na França).

${ }^{8}$ Ilustrativos desses estudos são as pesquisas de Friedmann (1958) na França; de Walker e Guest (1951) e de Chinoy (1955), nos EUA; de Goldthorper, Lockwood, Bechhofer e Platt (1970) e Beynon (1975), no Reino Unido, e a minha própria pesquisa em São Paulo com trabalhadores de uma indústria automobilística (Rodrigues, 1970).
}

da classe operária da fase da produção em série. A proximidade dos locais de trabalho (os bairros e vilas operárias), as semelhanças nas modalidades de consumo, dos níveis (baixos) de instrução, de valores, convergiam para a formação de uma subcultura de classe que favorecia os partidos ligados às camadas de trabalhadores e as teorias coletivistas.

É certo que, olhando mais de perto, apesar de todos os elementos que favoreciam a coesão e a unificação dos interesses, a classe operária como um bloco homogêneo existiu somente nos discursos e na literatura política. Sempre persistiram elementos de clivagem interna "da classe", que não decorriam somente da existência de uma "aristocracia operária". Muitos elementos de diversificação profissional subsistiam no interior dos grupos de trabalhadores de um mesmo ramo (operadores, montadores, trabalhadores de manutenção e reparação, aprendizes etc.), além daqueles que existiam entre ramos diferentes (por exemplo, portuários, empregados de serviços, operários industriais).

Além disso, o modelo taylorista-fordista nunca eliminou inteiramente a produção de tipo artesanal e as pequenas empresas, o que permitia a continuidade dos trabalhadores de formação profissional da fase préindustrial ${ }^{9}$. Mas, considerando a hegemonia da produção em série das grandes

\footnotetext{
${ }^{9}$ Usamos o termo taylorista-fordista, por facilidade de expressão, para indicar um sistema de trabalho fundado na especialização e repetição das tarefas, na supressão da iniciativa operária, na hegemonia dos escritórios de planejamento, na produção em massa padronizada. Porém, taylorismo e fordismo não são a mesma coisa. A aplicação de técnicas tayloristas não requer a mecanização, como aliás mostra o exemplo citado pelo próprio Taylor do trabalhador com a pá de carregar carvão, ao contrário das técnicas fordistas de fabricação em série. Estamos também deixando de lado, nessa caracterização sumária, o contexto macrossocial em que ambos os sistemas se inserem, como as formas de relação salário/trabalho e os métodos de regulação, ou seja, os modos de adaptação entre a produção e a demanda social no interior de uma dada configuração de formas institucionais, isto é num contexto muito mais amplo, que regula o funcionamento da produção. Segundo Boyer, as relações salário/trabalho compreendem outros componentes, que não se resumem à organização do processo do trabalho mas incluem a estratificação das qualificações, a mobilidade operária (intrafirmas e interfirmas), o princípio da formação direta e indireta do salário; etc. Dessa perspectiva, apesar do prolongamento dos métodos tayloristas mediante a mecanização, a passagem do taylorismo para o fordismo significa uma mudança radical na maneira como o mercado de trabalho funciona e no seu papel no processo de crescimento e na determinação da atividade econômica (Boyer, 1988, pp. 101 1). Nesse tipo de enfoque, a ênfase recai no estudo das mutações nos sistemas de relações de trabalho que incluem todos os processos envolvidos, ou refletidos, nos aspectos legais e institucionais e não apenas nos
} 
concentrações de trabalhadores, a diversificação interna das camadas operárias não era tão acentuada como hoje, em termos dos níveis salariais, dos tipos de reivindicação, da predominância absoluta em certas atividades do trabalhador masculino. Todos esses elementos de similitude não somente favoreciam a coesão e a consciência de classe, como permitiam a padronização das reivindicações, dos contratos, da representação e a unificação dos sindicatos em grandes federações e/ou centrais, que podiam "falar em nome da classe" (ou pelo menos das parcelas da classe trabalhadora que partilhavam da mesma ideologia, no caso de um sindicalismo dividido politicamente). Em muitos países, a formação dos grandes partidos de base social predominantemente operária (partidos socialdemocratas, trabalhistas e socialistas), o fortalecimento da representação sindical e partidária favoreceu leis (às vezes, uma legislação trabalhista bastante ampla) de cunho geral, padronizadoras de situações de trabalho as mais variadas. Elas serviram, ao mesmo tempo, de proteção ao trabalhador, de regulamentação dos conflitos e de integração dos sindicatos a patamares diversos dos níveis decisórios na política nacional e nas empresas.

Nos países onde a tradição "legalista", ou "intervencionista", não era forte (como nos EUA e no Reino Unido), a barganha coletiva institucionalizada cumpriu o mesmo papel. Desse modo, nas fases de préflexibilização do contrato, a legislação padronizada tornava-se, por sua vez, um elemento de unificação de direitos, vantagens, horários e jornadas. De um lado, antes da globalização, elementos de similitude e coesão facilitavam a agregação dos interesses dos trabalhadores e, assim, sua representação pelas grandes entidades sindicais e, de outro lado, tornavam mais fácil "botar ordem" nas relações entre empregadores e empregados, aumentar a previsibilidade dos investimentos, tranquilizar governantes e empresas, ao mesmo tempo em que aumentavam o poder político dos dirigentes sindicais, tornavam mais estáveis suas posições de comando nos sindicatos, mais previsíveis seus deveres, mais prescritível o que deveriam fazer.

sistemas de produção. Mas, apesar da importância dos meios sociais e políticos mais amplos que envolvem as relações de trabalho, diferenciam e regulamentam o taylorismo e o fordismo, é impossível deixar de considerar a relevância e a autonomia das tecnologias produtivas com relação às formas dos sistemas econômicos. É essa autonomia que explica a utilização de técnicas tayloristas e fordistas nos ex-regimes socialistas, quer dizer, em contextos de regulamentação geral da economia muito diferentes das ocidentais.
As tecnologias da era da informatização e da produção flexível, com o aparecimento de novas atividades profissionais, novas carreiras que exigem alta e flexível qualificação, tendem a ser mais difíceis de ser regulamentadas nacional ou setorialmente, de modo a facilitar a padronização da jornada, salários, normas de promoção, hierarquia e vantagens trabalhistas adicionais. O resultado do avanço tecnológico, em especial da robotização e informatização, foi a perturbação de todos os sistemas de classificação profissional, das escalas salariais e de distribuição de benefícios, sobre os quais, em larga medida, se apoiava a reivindicação sindical unificada, que justificava e facilitava a ação de representação coletiva e facilitava às lideranças preencher seus papéis.

Três séries de efeitos resultantes das inovações tecnológicas e administrativas, de acordo com Coriat (1992), podem ser distinguidos: a) um efeito de deslocamento; b) um efeito de reclassificação, que se refere ao modo como as diferentes categorias socioprofissionais são valorizadas, ou, pelo contrário, são desvalorizadas pela desqualificação de suas habilidades anteriores; e c) um efeito de reorganização, cujo resultado é levar ao aparecimento de "figuras" renovadas ou inéditas no sistema produtivo póstaylorista (p. 180). O resultado seria um novo modelo de trabalho.

Para o autor francês, três categorias de mão de obra seriam as "vítimas privilegiadas" pelas mutações em curso: os operários semiqualificados (no sentido francês do O.S., ouvrier spécialisé), de baixo nível de escolaridade; os jovens originários de ensino técnico de nível pouco elevado; e os operários donos de um ofício (p. 188, e especialmente o cap. "Metamorfoses da Divisão do Trabalho"). Seguramente, nem todas as categorias perdem com a automação e a reorganização do trabalho. Coriat aponta, entre as que ganham, os operadores das máquinas automatizadas e os técnicos da produção.

O ponto que vale salientar aqui é que, se nem todos os empregados perdem com a automação e alguns podem ser beneficiados, para as lideranças sindicais os resultados da introdução de novas tecnologias tendem geralmente a ser negativos. Não se trata somente da redução do volume da "sua base" tradicional, isto é, da classe operária manual. Ao elevar a qualificação (e salários) dos trabalhadores que conservam seus empregos nas indústrias automatizadas, ao melhorar o ambiente de trabalho quando eles eram especialmente agressivos (como nas seções de pintura), 
cansativos ou maçantes (como nas linhas de montagem), a produção automatizada tende também a tornar os trabalhadores que conservam seus empregos menos propensos a aderir a sindicatos. No final, a automação aumenta as diferenças internas entre os empregados. Os sindicatos passam a ser obrigados a desenvolver estratégias de defesa tanto dos segmentos altamente qualificados de profissionais e técnicos - geralmente não atraídos pelas formas tradicionais de negociação coletiva - com políticas e modos de atuação capazes de atrair os de baixa qualificação, especialmente do setor de serviços. Segundo informe da DGB (a central sindical alemã), a maioria dos empregados altamente qualificados, embora não sejam hostis aos sindicatos e entendam que, em princípio, eles são necessários, acham, apesar disso, que pode se defender sem eles (Olney, 1996). Esses profissionais tendem a acreditar que podem lidar melhor de modo individual do que coletivo com os problemas do local de trabalho e com os empregadores (pp. 910) ${ }^{10}$.

Obviamente, muitas variáveis estão relacionadas com a sindicalização. Salários e benefícios, que são quase sempre dependentes da qualificação do empregado, são apenas uma delas. Empregados de qualificação acima da média, que acreditam ter trunfos que lhe possibilitem negociar individualmente com o patronato, provavelmente não se interessarão pelo sindicato. Salários e benefícios coletivos padronizados podem não lhes ser vantajosos, mesmo quando faixas diferenciais possam ser contempladas nos acordos coletivos negociados pelos sindicatos.

Acontece que os diferenciais de salários têm relações com a propensão à sindicalização, o que significa dizer que tipos diferentes de empregados têm disposições diferentes perante o sindicato. A curva de sindicalização cruzada com salário tem a forma de um U invertido. Tende a subir com o aumento do salário até certo ponto; pela pesquisa de Bain e Elias, até aproximadamente 3.640 libras anuais (valores de 1975-1976). (A

\footnotetext{
${ }^{10} \mathrm{O}$ trabalho de Olney baseia-se em relatórios apresentados por treze centrais sindicais de oito países desenvolvidos, as quais apontam problemas que afetaram negativamente os sindicatos em começos da década dos 90 . No tocante a esses profissionais de alta qualificação, a central sindical holandesa (CNV) considerou que esse pessoal "é mais individualista e virtualmente sem nenhuma afinidade com os sindicatos" (p. 9). (As centrais que enviaram relatórios à OIT foram: a ACTU, da Austrália; a DGB, da Alemanha; a CGIL, a CISI. e a U II,, da Itália; a RENGO, do Japão; a CNV e a FNV, da Holanda; a LO, da Suécia; o "FUC, do Reino Unido, e a AFL-CIO, dos EUA.)
}

pesquisa foi feita com uma amostra de homens entre 16 e 64 anos e mulheres entre 16 e 59 anos, incluindo empregados e desempregados.) Os autores assumem a hipótese de que a variável que mais afeta a probabilidade de o empregado ser sindicalizado é o salário. A explicação é que os empregados nos níveis inferiores da escala salarial são os que mais interesses têm na sindicalização, enquanto os que estão no topo têm menos vantagens e são menos beneficiados, ou são mesmo prejudicados, pela substituição de critérios pessoais de atribuição de vantagens por regras padronizadas negociadas pelos sindicatos (Bain \& Elias, 1985). As taxas mais elevadas de sindicalização entre negros nos EUA constituem uma evidência de que, para os salários baixos, na relação custos-benefícios da sindicalização, os benefícios tendem a predominar. Já a partir de certo nível hierárquico com funções de comando, especialmente no setor de mercado, o fator "hostilidade patronal" praticamente elimina quaisquer vantagens da sindicalização para o pessoal mais qualificado e de salários mais altos, pois deles se espera maior lealdade à empresa e a sindicalização não é tolerada.

\section{A FRAGMENTAÇ̃̃O DOS INTERESSES DOS TRABALHADORES}

O efeito das novas tecnologias integra o campo dos fatores que vêm levando ao que tem sido denominado de "fragmentação dos interesses das classes trabalhadoras". Na realidade, a fragmentação não vem apenas de mutações tecnológicas, mas de um conjunto de alterações na área produtiva e no mercado de trabalho que aumentam as diferenciações no interior das classes trabalhadoras, dificultam a unificação de suas demandas e, consequentemente, diminuem sua coesão e solidariedade e fazem com que os sindicatos encontrem muita dificuldade para exercer o seu papel tradicional de representação. Entre os fatores de debilitamento da solidariedade dos trabalhadores estão a dispersão da produção (às vezes por países diferentes e distantes), a redução da dimensão das unidades de fabricação e o aumento da produção em pequenas empresas; a maior mobilidade do capital internacional; a tendência em direção a acordos por empresas e locais de fabricação; a flexibilização da produção, das normas e regulamentos que regiam tarefas, hierarquias e carreiras dos empregados, a maior heterogeneidade da força de trabalho em virtude do aparecimento de novas profissões, da maior presença da mulher e dos imigrantes no conjunto da mão de obra. O resultado desses novos desenvolvimentos não é apenas o fim (ou o começo do fim) do velho modelo taylorista-fordista, mas também, 
como dificilmente poderia deixar de ser, da velha classe operária sobre a qual se apoiara o sindicalismo como fenômeno de massa.

Hyman (1996c) associa quatro processos principais ligados ao conceito da fragmentação: a) um desvio do coletivismo em direção ao individualismo, refletido nas baixas das taxas de sindicalização, na menor receptividade, entre os empregados, das políticas e normas determinadas coletivamente; b) a polarização dentro da classe trabalhadora que pode coincidir com a divisão entre sindicalizados e não sindicalizados, divisão que muitos autores caracterizam do ângulo das relações entre centro e periferia ou entre os que estão dentro e os que estão fora; c) crescente particularismo das identidades e projetos das empresas, das ocupações e do setor econômico ou industrial; d) fragmentação dentro do sindicalismo, que se expressa em conflitos intrassindicais e intersindicais e no debilitamento da autoridade das lideranças nacionais, confederações e centrais (p. 10).

\section{A desconcentração da produção fabril}

Essa tendência já havia sido detectada há certo tempo por Piore e Sabei (1983). A redução das dimensões dos locais de produção continuou na década dos 80, impulsionada também pelos esforços de flexibilização da produção e de outras medidas destinadas a reduzir custos. Visando aumentar a flexibilização, as grandes empresas passaram a terceirizar parte de sua produção, repassando tarefas para pequenas e médias empresas, onde justamente a sindicalização tende a ser significativamente mais baixa.

No Reino Unido, por exemplo, os estabelecimentos que empregavam de um a 49 empregados, no setor manufatureiro, em 1951 representavam $11,4 \%$ do total de empregados; em 1979, $13,5 \%$ e, em 1990, 19,8\%. No outro extremo, os estabelecimentos com 1500 ou mais empregados, em 1951, eram 23,6\% do total; em 1979, subiram para 32\%, mas, em 1990, caíram para 21,7\% (Sisson \& Marginson,1995,p.101). "quanto menor a parcela dos empregados que trabalham em pequenas firmas (até nove empregados), maior tende a ser o nível de sindicalização. A expansão de pequenas firmas num setor é geralmente considerada uma ameaça para o sindicato.[...] De acordo com uma pesquisa de 1977-1978, na República Federal Alemã, a sindicalização subia sistematicamente com o aumento do tamanho do estabelecimento: de 7\% nas menores unidades com menos de dez empregados para 56\% nas que tinham dois mil ou mais. Na Noruega, a taxa de sindicalização variava de $18 \%$ para estabelecimentos com menos de cinco empregados para mais de $67 \%$ em estabelecimentos com 200 ou mais"(Bosch, 1985, apud Visser, 1998, p.140). Mas a relação entre o tamanho do estabelecimento (medido em número de empregados) e a probabilidade de sindicalização não é unilinear. A pesquisa de G.S Bain e P. Elias mostrou que, até aproximadamente 200-300 empregados, a probabilidade de aumento da taxa de sindicalização sobe acentuadamente. A partir de aproximadamente 800 empregados, a curva se estabiliza, ou seja: o aumento do número de trabalhadores por local de trabalho não eleva a proporção de sindicalizados (Bain \& Elias, 1985). Muitos outros exemplos poderiam ser citados, embora a dimensão medida pelo número de empregados não seja a única variável significativa para explicar as diferenças nos índices de sindicalização. Entre outros fatores que dificultam a sindicalização nos pequenos estabelecimentos (paternalismo, possibilidade de tratar diretamente com o proprietário, relações informais, etc.), há o fato de que sindicatos, na relação custo-benefício da sindicalização, preferem investir nas grandes empresas, em que podem ganhar mais em termos de número de trabalhadores que aderem ao sindicato. Os resultados dos esforços para aumentar a sindicalização em pequenas empresas geralmente não são compensadores, precisamente porque o número de empregados é baixo e as empresas estão mais dispersas, fato que aumenta aos custos de cada trabalhador sindicalizado.

A fase das grandes concentrações industriais acabou ou está em vias de acabar. Galenson (1994) nota que os grandes sindicatos industriais aumentavam a solidariedade operária e tinham seu poder de barganha reforçado. Mas essa forma organizatória poderia ter sido válida na época das grandes unidades de produção. Agora, ela poderia ser contraproducente. "Os interesses dos vários grupos profissionais podem divergir e entrar em agudo conflito em várias questões" (p.152).

Para tornar mais difícil a tarefa de representação dos sindicatos, a diminuição da concentração dos trabalhadores por estabelecimentos, ou por local de trabalho, mencionada acima, não se acompanhou das companhias, e consequentemente da unidade de comando empresarial. Pelo contrário. As corporações multinacionais continuaram como as grandes empregadoras, apesar da dispersão dos processos de produção dentro e fora dos paísessede. Em 1986, mais de 13 mil empresas da Comunidade Europeia empregavam, cada uma, ao menos 500 pessoas. Essa proporção representava 
0,1\% do total de empresas da CE, mas $28 \%$ de todo o emprego. Em 1991, foram identificadas mais de oito mil companhias que empregavam pelo menos mil trabalhadores nos países-membros. Mais de 900 grupos multinacionais com base na CE têm ao menos mil empregados em dois ou mais países. Além disso, existem pelo menos 280 multinacionais de fora da CE com mais de mil empregados (Ferner \& Hyman, 1993a, p.xviii).

A dispersão industrial e a desconcentração de trabalhadores por unidade de produção não significou, assim, a divisão da unidade de comando empresarial, o que significa dizer que grupos mais segmentados de trabalhadores passaram a ter pela frente companhias mais poderosas, com comandos e estratégias mais unificadas, com mais poder de fogo antissindical.

\section{Consequências da dispersão industrial}

Além do aumento da proporção do volume de trabalhadores nas pequenas empresas- seja pelo enxugamento da produção das grandes unidades, seja pelas subcontratações e terceirizações - há o deslocamento de fábricas para outras regiões dentro de um mesmo país ou para outros onde os salários são mais baixos, a pressão sindical mais fraca e as condições gerais de fabricação melhores, para não citar os benefícios que as autoridades locais, cada vez mais e especialmente nas áreas menos industrializadas, tendem a oferecer para atrair novos investimentos. No caso, não há somente a redução do volume de trabalhadores empregados mas as ameaças contidas na própria transferência ${ }^{11}$. Acontece que as transferências fabris constituem uma ameaça ao emprego local e, desse modo, reduzem a capacidade de reação dos trabalhadores diante das pressões patronais, tanto mais que os sindicatos tendem a encontrar menos apoio de parte dos trabalhadores que mantêm seus empregos nas novas unidades fabris enxugadas e modernizadas. A ameaça de transferir a produção, caso haja uma excessiva pressão sindical, constitui um poderoso instrumento do patronato para a contenção das reivindicações trabalhistas. Uma pesquisa que estudou as estratégias de atuação sindical de 600

\footnotetext{
${ }^{11} \mathrm{O}$ esforço para escapar das áreas de concentração operária que favorecem um sindicalismo mais agressivo e geram relações de trabalho mais turbulentas não é, obviamente, a única razão para a desconcentração industrial. Outros motivos devem ser considerados: preço dos terrenos, facilidades de transporte e obtenção de matéria prima, vantagens fiscais oferecidas pelos governos, oferta de energia, facilidades hidráulicas etc. Porém, quaisquer que sejam os motivos, os efeitos da dispersão das indústrias raramente são positivos para os sindicatos.
}

empresas norte-americanas revelou que, em cerca da metade dos casos, o empregador ameaçou os sindicatos que pretendiam representar o pessoal com o fechamento das empresas (em $10 \%$ dos casos, de transladar a empresa para o México). Em 12\% dos casos, em que o sindicato ganhou a eleição para a representação, o estabelecimento foi efetivamente fechado. $\mathrm{O}$ estudo chega à conclusão de que os riscos de translado pareciam ser bastante reais, a ponto de influenciar os resultados das eleições, ou seja, para fazer que o medo de perda de emprego fosse mais forte do que o desejo de ter um sindicato (Bronfenbrenner, 1997) ${ }^{12}$.

Diante do risco de diminuição do emprego, os sindicatos tendem a moderar as demandas e, assim, a se mostrarem menos úteis para os empregados. Consequentemente, os custos (pagamento de mensalidades e outras medidas de represália patronal) passam a não compensar as vantagens que a sindicalização possa eventualmente trazer.

\section{A mobilidade acrescida do capital}

A juízo da maior parte dos autores, as transformações no mercado financeiro internacional e a amplitude dos investimentos transnacionais resultaram muito negativas para o sindicalismo, "A mobilidade do capital desestabiliza a estrutura protegida dos salários na qual desembocavam os sistemas nacionais de relações de trabalho quando a competição se dava essencialmente dentro das fronteiras [nacionais]" (OIT, 1997-1998, p. 80). As eurocompanhias representam um desafio para os sistemas de relações de trabalho que são essencialmente de âmbito nacional. Constituem também uma ameaça para a representação dos trabalhadores, pois os sindicatos continuam organizados em bases nacionais, enquanto as eurocompanhias têm possibilidade de coordenar e controlar as relações industriais de um país para outro. Em fins dos anos 80, de acordo com Marginson e Sisson (1994, p. 18), existiam 880 eurocompanhias com sede na Europa, que empregavam 13,6 milhões de pessoas. As eurocompanhias dispõem de um arsenal antissindical bem mais poderoso do que tiveram as empresas nacionais. O avanço do sistema de informática e da tecnologia do computador facilitou os controles financeiros e de outros indicadores

${ }^{12}$ Trata-se de um estudo intitulado "Fechamento de Fábricas e Direitos Trabalhistas", feito a pedido da Comissão para a Cooperação Trabalhista encarregada de fiscalizar o cumprimento das disposições relativas aos trabalhadores contidas no Tratado de Livre Comércio Norteamericano. 
econômicos. Num mercado europeu unificado, as eurocompanhias podem coordenar e controlar os resultados de suas políticas nacionais de relações trabalhistas, possuindo a capacidade de aplicar políticas europeias e criar novas estruturas de relações em nível continental. $O$ fato atinge os sistemas de negociações nacionais e setoriais de cada país, forçados a se enquadrar nos esquemas internacionais (Hyman, 1994c, e Marginson \& Sisson, 1994).

Os efeitos da fragmentação sobre o sindicalismo

Quanto mais heterogêneos os grupos de trabalhadores, maiores as dificuldades de unificação organizatória, isto é, de seu enquadramento em entidades de cúpula destinadas a representar todos os trabalhadores (sindicatos nacionais, federações, confederações, centrais, dependendo do modelo organizatório do sindicalismo de cada país). Um dos desenvolvimentos das últimas décadas, relacionado com a maior diversidade das classes trabalhadoras, foi o aparecimento de novas entidades sindicais, novas formas de associação e movimentos que passaram a desafiar a autoridade das grandes organizações, frequentemente recusando-se a se filiar às centrais tradicionais, tais como as associações de funcionários públicos, cooperativas, comissões de base e outros tipos de organização (Hyman, 1998; 1994b; 1994c; Waddington \& Whiston, 1995; Gall, 1995; Visser, 1994a e 1988; Kern \& Sabel, 1994; Burgi, 1990) ${ }^{13}$.

\footnotetext{
${ }^{13}$ Segundo Hyman (1994c, pp. 111-112), cinco tipos de tensões introduzidas no interior do sindicalismo pelas mudanças estruturais das últimas décadas teriam enfraquecido a coesão interna e desencadeado várias pressões centrífugas no movimento sindical: a) desestabilização da balança tradicional de poder entre as confederações, frequentemente associadas com a perda da autoridade sindical confederal; b) nos países onde os empregados não manuais estavam habitualmente sindicalizados separadamente, a dominação numérica dos sindicatos de trabalhadores foi posta em xeque. A Suécia seria um bom exemplo para esses dois casos; c) confusão entre as "fronteiras jurisdicionais" da representação dos sindicatos (quem organiza quem?), criando competição entre eles, mesmo em países onde essas fronteiras estavam bem delimitadas. Seria o caso, na Alemanha, da rivalidade dentro da DGB entre sindicatos de trabalhadores industriais; disputas, na Suécia, entre sindicatos de trabalhadores manuais e sindicatos de não manuais do setor metalúrgico sobre a filiação das novas categorias de empregados altamente qualificados do setor da produção; d) enfraquecimento da autoridade de muitos sindicatos pelo alimento interno da diferenciação de interesses e pelas tendências em direção à descentralização da barganha coletiva; e) aparecimento de novas divisões de interesses entre empregados e desempregados, entre empregados do setor protegido e os do setor exposto à competição externa, entre setores com formas "típicas" e formas "atípicas" de
}

Assim, por muitos caminhos, as transformações mais recentes do setor produtivo vêm atuando no sentido de aumentar a heterogeneidade das camadas assalariadas, a tornar mais complexa a unificação das suas demandas e interesses, a fazer mais difícil a criação de formas unitárias de ação. No limite, as mutações do sistema produtivo levam à destruição da velha classe operária e de seu "sindicalismo solidário", para utilizarmos um expressão de Hyman (1996c) .

Para as empresas, num mercado cada vez mais competitivo, a inovação, a agilidade na criação e/ou atendimento de novas demandas (condutas cada vez mais rapidamente imitadas pelos competidores) tornaramse essenciais já não apenas para aumentar as margens de lucro mas para permitir a sobrevivência. A flexibilização de procedimentos na produção e desregulamentação das relações de trabalho daí decorrentes vem também da necessidade de atendimento de um mercado mais exigente em matéria de qualidade e de oferta de novos produtos. O abandono de normas rígidas não é uma opção livre das empresas individuais, mas de algo que lhes foi imposto em virtude de um ambiente muitas vezes mais turbulento do que em épocas anteriores. A flexibilização das normas de trabalho precisa acompanhar a flexibilização da produção. $\mathrm{O}$ resultado é a maior divisão e heterogeneidade interna das classes trabalhadoras. Independentemente das intenções das empresas ante os sindicatos, esses processos são muito negativos para o sindicalismo, notadamente para o do setor privado das atividades mais expostas à competição e dos ramos menos protegidos da economia nacional.

Os sindicatos, portanto, necessitam opor-se à flexibilização das normas de trabalho e esforçar-se para manter a padronização a fim de conservarem suas funções de representação e sobreviverem como instituições. No entanto, em toda a parte, sofrem derrotas. Mais cedo ou mais tarde, a flexibilização impõe-se porque está ligada à sobrevivência das empresas e, portanto, para os trabalhadores, do seu emprego. Seria muito difícil que as decisões de flexibilização (e desregulamentação), que se dão no plano da produção e da demanda, não tivessem consequências equivalentes no que diz respeito às jornadas de trabalho, benefícios, remuneração e todas as normas que regem as relações dos empregados com os empregadores. A manterem uma conduta de oposição rígida, de tentativas de manutenção do status quo, ao se

emprego, entre trabalhadores com novas qualificações e trabalhadores com qualificações superadas pelo desenvolvimento tecnológico e trabalhadores sem nenhuma qualificação. 
agarrarem as normas rígidas e gerais de regulamentação das tarefas, benefícios, direitos e deveres dos empregados da época da hegemonia da produção em massa e de bens padronizados, o sindicalismo arrisca-se a se transformar em força conservadora, de defesa de um passado que não mais voltará. Assim, precisaria encontrar respostas mais inovadoras, que provavelmente teriam de passar por um difícil equilíbrio entre as necessidades do aumento da produtividade que as empresas necessitam para se manterem competitivas e a defesa dos empregados, especialmente dos ameaçados de perda de emprego.

No tocante à flexibilização defendida pelas empresas, os sindicatos teriam de encontrar respostas capazes de conjugar os interesses das empresas com o ponto de vista dos empregados. Para isso, necessitam conservar algum poder de barganha. Hyman (1998b), por exemplo, julga que as questões ligadas à flexibilização podem ser focalizadas e discutidas pelos sindicatos de um prisma diferente, de modo a integrar e unir tipos bem diversos dos grupos de trabalhadores numa situação de mais acentuada diferenciação interna e de consequente maior fragmentação de interesses dos empregados. O autor acredita que, na medida em que certos traços característicos do modelo taylorista-fordista perderam sua força de atração sobre os empregadores, um espaço abre-se para os sindicatos conseguirem arregimentar os trabalhadores por alternativas mais radicais que transcendam certas divisões da classe operária (p. 146).

A dificuldade para a mobilização dos trabalhadores e, portanto, para que os sindicatos conservem seu papel tradicional de representação de interesses mais amplos vem do fato de que nem todas as mudanças foram desfavoráveis aos empregados, embora possam ter sido negativas para o sindicalismo, ou para o poder sindical. Na área das relações de trabalho, essas mudanças foram assim resumidas por Locke, Kochan e Piore (1995), três importantes pesquisadores das relações de trabalho: estabelecimento muito mais flexível de normas de trabalho e de demarcação de tarefas para os empregados; maior envolvimento da força de trabalho nas decisões de produção e consequentemente redução da autoridade da administração com relação ao empregado; sistemas de recompensas destacados das tarefas e mais ligados às características individuais do empregado, tais como nível de qualificação e avaliação da realização; níveis gerais de salário separados da antiga fórmula que havia se imposto no setor automobilístico, que inclui, às vezes, participação nos lucros e/ou bonificações como modos de recompensas opostas a taxas de aumentos anuais nos salários; ampliação de garantias contra desemprego em troca de maior comprometimento com a companhia e maior flexibilidade nos compromissos de trabalho (p. xxii).

Os autores observam que, nos EUA, essas medidas foram inicialmente aplicadas em empresas não sindicalizadas e depois levadas para as demais. Um ponto importante na alteração das normas de regulamentação dos trabalhos é que as companhias frequentemente concebiam e aplicavam os novos arranjos apenas para um grupo central de empregados. A flexibilidade para fazer face às incertezas do mercado era aplicada a uma parcela periférica da força de trabalho, mais facilmente empregada e despedida. "Geralmente, os novos arranjos estavam associados com aumentos nos requisitos de qualificação, escolaridade mais elevada e treinamento mais amplo, pelo menos para os empregados do núcleo central" (p. xxiii).

Trabalho em meio período e participação feminina

$\mathrm{O}$ aumento da heterogeneidade das camadas assalariadas e a fragmentação dos interesses de suas partes relacionam-se também com a maior proporção de trabalhadores em regime de tempo parcial. O resultado é a maior diferenciação interna entre os empregados não apenas por razões de novas tarefas ou ocupações, mas também pela existência de tipos diferentes de regime de trabalho nos quais alguns estão mais envolvidos pela situação de emprego e outros menos. $\mathrm{O}$ aumento do trabalho em tempo parcial está ligado em especial (mas não unicamente) à extensão quantitativa e qualitativa da participação feminina na força de trabalho. "O trabalho em meio período é principalmente trabalho feminino", conclui um estudo sobre o tempo de trabalho em 14 países industrializados (Bosch; Dawkins \& Michon, 1994, p. 19) ${ }^{14}$.

A porcentagem de trabalhadores em meio período e de mulheres nessa situação é comparativamente muito elevada em países como a Noruega, a Suécia e o Reino Unido. Nesses três países, pelo estudo citado, mais de $20 \%$ dos empregados estavam em regime de tempo parcial, dos quais cerca de $3 / 4$ mulheres. Já na Itália, na Áustria, na Finlândia e na

\footnotetext{
${ }^{14}$ Os países incluídos no estudo foram: Austrália, Áustria, Bélgica, Canadá, República Federal Alemã, França, Hungria, Itália, Japão, Holanda, Suécia, Reino Unido, Estados Unidos, União Soviética. Os estudos nacionais, realizados por vários autores, cobrem o período de 1985 a 1990.
} 
Bélgica, a proporção de trabalhadores em tempo parcial, na época do estudo, estava abaixo de $10 \%$, mas, na sua maioria, era trabalho feminino (Bosch; Dawkins \& Michon, 1994, p. 20). O fenômeno da "feminilização" do trabalho relaciona-se também com a expansão do emprego no setor de serviços. Esse processo favoreceu as mulheres, prejudicou o emprego masculino e introduziu mais diferenças no interior das classes trabalhadoras. A expansão do emprego feminino tem forte relação com a flexibilização dos contratos de trabalho. Um procedimento habitual, especialmente no setor de comércio, é a utilização de mulheres mais idosas, empregadas em meio período mediante contratos de trabalho diferenciados.

Um exemplo desse tipo de redução da jornada de trabalho, já na década dos 80, foi o acordo (1986) estabelecido no Grands Magasins du Printemps, de Paris, que ofereceu a 600 vendedores e vendedoras de mais de 50 anos a possibilidade de trabalhar 32 horas por semana (em lugar das 39 horas habituais), divididas em quatro ou cinco dias, por um salário correspondente a $35 \mathrm{~h} 30 \mathrm{~m}$, à condição de trabalharem todos os sábados (Sarfati \& Kobrin, 1987, p. 107). Muitos outros exemplos equivalentes poderiam ser citados. No que tange ao aumento da participação das mulheres no mercado de trabalho, o caráter novo dessa participação é a crescente presença feminina em tarefas que exigem qualificação mais elevada e em funções e postos importantes em todas as áreas de atividade. O exemplo do Grands Magasins du Printemps ilustra apenas um tipo de flexibilização da jornada. No conjunto, como chamam a atenção Rubery e Fagan (1994, pp. 142-143), os vínculos entre feminização, flexibilidade e organização da oferta de emprego devem ser considerados em relação com o conjunto de outras mudanças sociais referentes às novas regulamentações do mercado de trabalho, à reprodução social (apoio às famílias, aos desempregados) e a transformações nos sistemas produtivos.
Quadro 6.1

Proporção do emprego da população feminina e masculina em idade ativa (1960 e 1985) - (dos 15 aos 64 anos)

\begin{tabular}{|c|c|c|c|c|c|c|}
\hline País & $\begin{array}{c}\text { Índice de } \\
\text { ocupação } \\
\quad \text { das } \\
\text { mulheres } \\
1960\end{array}$ & $\begin{array}{c}\text { Índice de } \\
\text { ocupação } \\
\text { dos } \\
\text { homens } \\
1960\end{array}$ & $\begin{array}{c}\text { Índice de } \\
\text { ocupação } \\
\quad \text { das } \\
\text { mulheres } \\
1985\end{array}$ & $\begin{array}{c}\text { Índice de } \\
\text { ocupação } \\
\text { dos } \\
\text { homens } \\
1985\end{array}$ & $\begin{array}{l}\text { Indice de } \\
\text { ocupação } \\
\quad \text { das } \\
\text { mulheres } \\
\text { 1960-1985 }\end{array}$ & $\begin{array}{c}\text { Índice de } \\
\text { ocupação } \\
\text { dos } \\
\text { homens } \\
\text { 1960-1985 }\end{array}$ \\
\hline Alemanha Federal & 49,2 & 94,4 & 50,3 & 80,0 & 1,1 & $-14,4$ \\
\hline Austrália & 34,1 & 97,2 & 54,1 & 85,2 & 20,0 & $-12,0$ \\
\hline Áustria & 52,1 & 92,0 & 51,0 & 81,2 & $-1,1$ & $-10,8$ \\
\hline Bélgica & 36,4 & 85,5 & 50,5 & 75,9 & 14,1 & $-9,6$ \\
\hline Canadá & 33,7 & 91,1 & 62,4 & 84,9 & 28,7 & $-6,2$ \\
\hline Dinamarca & 43,5 & 99,5 & 74,5 & 87,4 & 31,0 & $-12,1$ \\
\hline EUA & 42,6 & 90,5 & 63,8 & 84,6 & 21,2 & $-5,9$ \\
\hline Finlândia & 65,6 & 91,4 & 73,7 & 81,8 & 8,1 & $-9,6$ \\
\hline França & 46,6 & 94,6 & 54,9 & 76,7 & 8,3 & $-17,9$ \\
\hline Reino Unido & 46,1 & 99,1 & 60,2 & 88,4 & 14,1 & $-10,7$ \\
\hline Holanda & 26,2 & 97,8 & 40,9 & 75,8 & 14,7 & $-22,0$ \\
\hline Irlanda & 34,8 & 99,0 & 36,6 & 85,5 & 1,8 & $-13,5$ \\
\hline Itália & 39,6 & 95,3 & 41,0 & 79,3 & 1,4 & $-16,0$ \\
\hline Japão & 60,1 & 92,2 & 57,2 & 87,8 & $-2,9$ & $-4,4$ \\
\hline Noruega & 36,3 & 92,2 & 68,0 & 86,6 & 31,7 & $-5,6$ \\
\hline Nova Zelândia & 31,3 & 93,8 & 47,6 & 83,2 & 16,3 & $-10,6$ \\
\hline Suécia & 50,1 & 98,5 & 77,6 & 84,2 & 27,5 & $-14,3$ \\
\hline Suíça & 51,0 & 100,4 & 53,2 & 89,4 & 2,2 & $-11,0$ \\
\hline Média & 43,3 & 94,7 & 56,6 & 83,2 & 13,2 & $-11,5$ \\
\hline
\end{tabular}

Fonte: EOCD Labour Force Statistics, Paris, OECD: Employment Outlook, Paris, apud Schimidt (1995).

O Quadro 6.1, copiado de Schmidt (1995), traz dados sobre a participação feminina no mercado de trabalho dos principais países desenvolvidos que indicam essas tendências. Nele se destacam os seguintes aspectos:

a) a proporção, na década dos 60 , bastante inferior de mulheres na força de trabalho comparativamente aos homens. Na média dos países considerados, o índice de ocupação feminina era de 43,3\% em 1960, enquanto a masculina era de 94,7\%. Em 1985, o índice de ocupação feminina subiu para $56,6 \%$, enquanto a masculina caiu para $83,3 \%$. $\mathrm{Na}$ 
comparação entre os dois anos citados, o índice de ocupação das mulheres subiu $13,2 \%$, enquanto o dos homens baixou $11,5 \%$;

b) as fortes diferenças nacionais. Em 1960, somente em cinco países (Áustria, Finlândia, Japão, Suécia e Suíça) a presença das mulheres superava 50\%, enquanto, com exceção da Bélgica, em todos os demais, os índices de participação masculina eram superiores a 90\%;

c) o aumento, já em 1985, dos índices femininos de participação e o declínio dos masculinos em todos os países. Esses índices mostram forte crescimento, inclusive em países onde, em 1960, a participação das mulheres era baixa, como a Holanda, a Austrália, o Canadá, a Nova Zelândia e a Itália.

Manfred Schmidt destaca três grupos de países no que diz respeito à atividade feminina: o grupo que inclui todos os países do norte da Europa, além de todos os países industrializados de língua inglesa, com exceção da Irlanda; o grupo de países industrializados de língua alemã (Alemanha, Áustria e Suíça) e mais a Itália, a Irlanda e o Japão; o grupo de países em situação intermediária, entre os quais se destacavam a França e a Holanda (1995, p. 3). Ajudam a explicar a crescente participação das mulheres, além do aumento das ofertas de trabalho em tempo parcial, a queda dos níveis de emprego no setor industrial, as taxas de natalidade decrescente, a expansão das redes de creches para crianças em idade pré-escolar e o aumento da procura de trabalho no setor de serviços, especialmente no setor público (Schmidt, 1995, p. 24).

Para a Suécia, país onde a porcentagem de mulheres na força de trabalho era a mais elevada $(77,6 \%)$ entre os países estudados, Schmidt (1995) apresenta as seguintes razões favoráveis: a) diminuição relativamente fraca da cota de participação do setor primário (um processo de encolhimento vagaroso, portanto, de um setor em que o nível de ocupação das mulheres é tradicionalmente alto); o encolhimento relativamente acentuado da taxa de ocupação no setor industrial (onde costuma haver grande predomínio de mão de obra masculina); b) paralelamente, um aumento incomum do nível de ocupação no setor estatal; c) o crescimento expressivo da oferta de vagas em instituições de abrigo para crianças; d) uma grande oferta de empregos de tempo parcial; e) sistema tributário que oferece incentivo à participação econômica das mulheres, notadamente das casadas; f) aumento incomum de mulheres eleitas deputadas; g) tradição de participação política das mulheres e maior influência das reivindicações feministas; h) força dos partidos de esquerda, o que favoreceu uma legislação de proteção da família e do mercado de trabalho; i) política de pleno emprego para todos defendida pelos sindicatos; j) secularização da sociedade e influência do protestantismo (p. 17).

A expansão dos serviços sociais foi também um importante fator de crescimento do emprego feminino. Na Suécia, nos quadros de um Estado de Bem-estar extremamente desenvolvido, os serviços sociais respondem por $85 \%$ da ocupação das mulheres (Esping-Andersen, 1994, p. 141). Esse é um dos motivos pelos quais o emprego feminino cresceu mais nos países escandinavos do que em outros países industrializados. Esping-Andersen chama a atenção para os efeitos que o desenvolvimento dos Estados de Bem-estar teve sobre o mercado de trabalho, especialmente no emprego público e nos serviços não manuais.

Mais de 4/5 dos trabalhadores que entrarão no mercado de trabalho, de meados da década dos 80 até o ano 2000, serão do sexo feminino, de minorias ou de imigrantes (Johnston \& Parker, 1987, apud Kochan \& Wever, 1991). No Reino Unido, um estudo de 1994 do Departamento de Emprego previa que, por volta do ano 2006, quase $90 \%$ do aumento da força de trabalho será creditado às mulheres (Wrench \& Virdee, 1996). Isso obriga os sindicatos (que até então eram instituições basicamente masculinas) a desenvolver políticas destinadas a incorporar esses novos segmentos que têm problemas e demandas específicas. A presença feminina nos sindicatos vem crescendo sistematicamente em todos os países estudados. Na Finlândia e na Suécia, as taxas de sindicalização feminina superaram as dos homens. De modo geral, essas taxas tendiam a ser mais baixas porque geralmente o emprego feminino se encontrava em atividades em que a sindicalização era baixa: serviços pessoais, agricultura, comércio a varejo (Visser, 1991, p. 115). No Reino Unido, o número de mulheres sindicalizadas entre 1993 e 1994 subiu 1\% (35 mil, aproximadamente), chegando a 3,5 milhões, enquanto o volume da sindicalização masculina declinou 9\% (456 mil). As maiores quedas da filiação masculina ocorreram principalmente nos grandes sindicatos (com pelo menos 250 mil membros). A proporção de mulheres sindicalizadas superou a dos homens em cinco dos dez maiores sindicatos. Somente no UNISON, do setor público, há 966 mil mulheres sindicalizadas (IRS Employment Review, 1996, p. 2). Na Holanda, 60\% dos novos membros da CNV (Confederação Cristã dos Sindicatos) são mulheres. Na outra central holandesa, a mais importante, a 
FNV (Confederação dos Sindicatos), mais de $80 \%$ dos novos membros no setor públicos são mulheres (Olney, 1996, p. 16) ${ }^{15}$.

Mas as taxas de sindicalização masculinas ainda são mais elevadas do que as das mulheres, inclusive entre trabalhadores (masculinos e femininos) em regime de tempo parcial (Rubery \& Fagan, 1994). Na Alemanha, por exemplo, $47 \%$ do total de trabalhadores estavam sindicalizados em 1991 contra 21,6\% das trabalhadoras. Na Holanda, 35\% dos homens estavam sindicalizados contra $13 \%$ das mulheres. A Suécia é exceção: a proporção de mulheres sindicalizadas é maior do que a dos homens (Wrench \& Coleman, 1992, apud Olney, 1996).

Um aspecto inesperado (e, em certo sentido, perturbador da ampliação do trabalho profissional feminino porque relacionado com as pressões pela "libertação feminina") foi o acirramento da luta pelos empregos na conjuntura atual de renovação tecnológica e desocupação. Como indica o Quadro 6.1, enquanto no período entre 1960 e 1985 apenas em dois casos (Áustria e Japão) houve ligeiro declínio do emprego feminino, no tocante aos homens houve queda em todos os países considerados, bastante acentuada em alguns como a Holanda (22\%), a França $(17,9 \%)$ e a República Federal Alemã $(14,4 \%)$. O desemprego atingiu, portanto, basicamente a força de trabalho masculina, em que a militância sindical era mais intensa. Entre 1960 e 1990, nos países da Comunidade Europeia, a força de trabalho aumentou aproximadamente 29 milhões, dos quais mais de 20 milhões de mulheres (Rubery \& Fagan, 1994, p. 146).

\section{A presença do trabalhador imigrante}

Ao lado da entrada da mulher no mercado de trabalho, o outro fenômeno que afetou a composição da mão de obra (e a clientela habitual dos sindicatos) e contribuiu para a fragmentação dos interesses foi a chegada dos imigrantes, de origem étnica e cultural diferente da dos trabalhadores que compunham os "núcleos duros" do sindicalismo, quer dizer, trabalhadores

\footnotetext{
${ }^{15} \mathrm{O}$ aumento da participação feminina na força de trabalho deve levar os sindicatos a colocar novas questões suscetíveis de atrair as mulheres, tais como: a discriminação feminina no emprego, creches, licença-maternidade, assédio sexual etc. Um indicador das mudanças que estão acontecendo foi a eleição, em 1995, para a vice-presidência da AFLCIO, de Linda Chavez-Thompson, a primeira mulher (e negra) a ocupar esse posto na história da entidade. Contudo, ainda na imensa maioria das centrais sindicais, os homens ocupam a maioria dos postos (Olney, 1996).
}

brancos, de certa qualificação, de famílias que tinham tradição de militância sindical e política. A influência do imigrante não foi igual em toda a parte, mas, de modo geral, tornou a classe trabalhadora mais diferenciada internamente. Em muitos países europeus, como a França, o Reino Unido, a Alemanha, não se trata apenas de migrantes com projetos de retorno ao país de origem, mas de trabalhadores de ex-colônias e de seus descendentes, que adquirem a nacionalidade do país de chegada e se tornam parte permanente da força de trabalho nacional. Os sindicatos, numa conjuntura difícil de desemprego e mudança tecnológica, foram sobrecarregados por uma nova tarefa: a de tentar organizar os novos membros das classes trabalhadoras, muitos dos quais sem tradição de participação sindical e com menos defesas contra as represálias patronais a empregados que se filiam a sindicatos. Nem sempre, de parte das lideranças sindicais, um esforço de arregimentação é empreendido ou, quando ocorre, geralmente dá magros resultados porque, mesmo deixando de lado preconceito e racismo eventuais dos trabalhadores brancos, essa nova parcela da força de trabalho tem tradições e valores diferentes daqueles dos núcleos tradicionais da classe operária que impulsionaram e consolidaram o movimento sindical.

Os sindicatos, formados tradicionalmente por trabalhadores nacionais, brancos, foram lentos na aplicação de uma política orientada para os grupos de imigrantes, especialmente quando se tratava dos mais desprotegidos, como as mulheres de baixa qualificação e com domínio precário do idioma do país. No Reino Unido, a preocupação com a temática específica do trabalhador imigrante começou tarde. Em muitas indústrias, nos anos 50, sindicalistas brancos insistiam numa cota (5\% geralmente) para empregados negros. Trabalhadores do transporte chegaram a começar uma greve em protesto contra o emprego de negros (Wrench \& Virdee, 1996, p. 242).

Em 1970, numa indicação indireta da existência de racismo, o secretário-geral do TUC, a central sindical britânica, Vic Feather, declarou que não havia diferença entre trabalhadores brancos e negros e que todos deveriam ter os mesmos direitos, sem necessidade de consideração especial para alguma etnia (Wrench \& Virdee, 1996, p. 245). Somente em fins dos anos 70 e começos dos 80, o TUC começou a adotar uma política contra o racismo. Mesmo assim, em 1984, um ramo do TGWU, o sindicato dos trabalhadores do transporte e de outras categorias, do aeroporto de Heathrow, de Londres, foi acusado de cúmplice do empregador na discriminação racial de mulheres asiáticas do serviço de limpeza (Wrench \& Virdee, 1996, p. 250). 
Procedimentos de discriminação racial como esses, de aliança dos sindicatos com os empresários contra trabalhadores imigrantes, não constituem eventos raros. Muitos sindicatos, nos EUA e na Europa, viram os efeitos da concorrência da imigração como favoráveis ao patronato e como um fator de rebaixamento de seus salários. Assim, frequentemente, defendiam políticas de restrição ou de cotas para a entrada de trabalhadores estrangeiros. No caso britânico, Wrench e Virdee veem três etapas históricas do comportamento do trabalhador branco sindicalizado com relação aos imigrantes ou minorias étnicas:

a)exclusão racista, consistente na tentativa, primeiro, de manter o imigrante fora do mercado de trabalho; depois, de mantê-lo fora do sindicato e, quando isso não era possível, mantê-lo fora dos benefícios alcançados pelos sindicatos;

b)incorporação do imigrante, primeiro como trabalhador sem nenhuma medida especial no sentido de considerar a diferença étnica política que seria consistente com a orientação tradicional de classe do sindicato - e, depois, como trabalhador com a característica especial de ser imigrante ou de pertencer a uma minoria étnica ou religiosa, o que implicava, de parte das lideranças sindicais, a adoção de certas medidas que tivessem em conta esses dados;

c) autonomia parcial, defendida por alguns grupos no sentido da criação de seções especiais do sindicato para os imigrantes (p. 265). No entanto, os êxitos no sentido da incorporação dos trabalhadores imigrantes têm sido pequenos e a presença de minorias étnicas atua no sentido de aumentar a fragmentação das classes trabalhadoras e tem favorecido o sentimento racista, especialmente na massa de trabalhadores de mais baixa qualificação e entre os jovens brancos, com mais dificuldade de entrar no mercado de trabalho.

A fragmentação dos interesses internos dos grupos de trabalhadores e a dificuldade de homogeneizar as reivindicações são acentuadas também pelo aumento da proporção de assalariados com empregos precários, especialmente nas pequenas firmas industriais e de serviços, pelo aumento das formas de trabalho atípicas, como as de tempo parcial, pelos contratos a prazos definidos e pelos contratos de aperfeiçoamento profissional que se relacionam com os esforços de aumentar a flexibilização do trabalho (cf. Baglioni, 1992; Baglioni \& Crouch, 1992, entre outros).
Desemprego e inflação

Para terminarmos o arrolamento dos fatores de natureza social e econômica que foram prejudiciais para o sindicalismo na década dos $80 \mathrm{e}$ dos 90, cumpre uma rápida menção a uma combinação muito negativa para o movimento sindical: alto desemprego e inflação baixa, combinação que se tornou uma constante das economias europeias a partir da década dos 80 . Visser, realizando comparações nacionais entre índices de desemprego e índices de sindicalização, encontrou correlação negativa entre desemprego e sindicalização nos anos de 1977-1979 e 1983-1985 (a Bélgica, a Dinamarca, a Finlândia e a Suécia foram excluídas da pesquisa porque, nesses países, os sindicatos estão envolvidos com a distribuição dos fundos de auxílio aos desempregados). Contudo, considerando as alterações nas médias de desemprego de 18 países da OECD durante todo o período entre a segunda metade da década de 1970 e 1985, o autor entende que, após 1980, o desemprego explica 44\% do declínio da sindicalização (Visser, 1994b, p. 90, e Visser, 1991, p. 106).

A ação prejudicial de taxas elevadas de desemprego expressa-se especialmente na diminuição das mobilizações, sobretudo deflagração de greves, efeito bem conhecido. Mas o desemprego atinge também os sindicatos como organização, pela redução do volume de trabalhadores empregados e, por essa via, tende a rebaixar as taxas nacionais de sindicalização. Com isso, as finanças sindicais ficam também abaladas. Além desses efeitos mais quantificáveis, o desemprego pode ter consequências negativas difusas mais difíceis de detectar, de ordem psicológica, como, por exemplo, tornar os trabalhadores mais temerosos de aderir a sindicatos e participar de greves. Mas esses fatores têm consequências diferentes segundo o país. Onde os desempregados continuam filiados, como já vimos, os reflexos sobre os níveis de sindicalização podem não ser muito acentuados, ainda que atuem no sentido de reduzir a capacidade de pressão dos sindicatos. Do mesmo modo, se o desemprego se concentra em setores em que a sindicalização já era baixa, ou ocupava parcelas reduzidas da força de trabalho, provavelmente seus reflexos não serão significativos. Mas, na verdade, é justamente o contrário o que tem acontecido: as áreas de atividade econômica onde a oferta de emprego é maior são justamente aquelas em que os trabalhadores são menos inclinados à participação sindical, quer dizer, os setores de serviços. 
A elevação dos níveis de desemprego veio junto com baixas taxas de inflação. A queda da inflação ajudou a tornar mais complexas as funções de representação dos sindicatos e, de certo modo, a favorecer a segmentação das reivindicações e contratos. Numa conjuntura inflacionária, a luta pela reposição dos salários reais servia de elemento de unificação dos interesses de todos os assalariados. Sem inflação (ou com inflação muito baixa), o aumento salarial adquire menor espaço no rol das reivindicações enquanto aumenta a importância de outras questões, como defesa do emprego, pensões, tempo de trabalho, flexibilização... Alguns desses pontos requerem ações políticas de nível nacional, mas outros pedem mais intervenção sindical no âmbito da empresa e da fábrica, o que reduz a importância das negociações trabalhistas no âmbito do ramo industrial, que era o foco principal da ação sindical em países como a Bélgica, a Holanda, a França e, em certa medida, a República Federal Alemã: "Esse debilitamento das relações de negociação no plano do ramo industrial levou à fragmentação do poder sindical em razão da brecha criada entre a ação no plano político e no plano da empresa" (Kane \& Marsden, 1988, p. 113).

O bom momento para os sindicatos, na década dos 60 , provavelmente deveu-se ao baixo desemprego combinado com inflação. Apesar das diferenças nacionais, os índices de desemprego permaneceram bastante baixos entre 1968 e 1973 em praticamente todos os países, com a exceção da Itália, que registrou 5,7\%. A década dos 80 , de começos da crise do sindicalismo, coincide com a expansão do desemprego em toda a parte.

O Quadro 6.2, embora incluindo dados de 1964 para cálculos das médias, não traz a situação de outros países desenvolvidos. Mas o Quadro 6.3, que apresenta dados a partir de 1976, inclui outros países, inclusive de fora da Europa, como os EUA, o Japão e a Austrália. Entre os grandes países desenvolvidos, apenas nos EUA houve declínio do desemprego na comparação entre $1976(7,6 \%)$ e $1995(5,5 \%)$
Quadro 6.2

Médias quinquenais padronizadas das taxas de desemprego em alguns países europeus (porcentagem do total da força de trabalho - 1965-1990)

\begin{tabular}{|l|c|c|c|c|c|}
\hline Médias & $1964-1967$ & $1968-1973$ & $1974-1979$ & $1980-1989$ & $1964-1989$ \\
\hline Alemanha & 0,6 & 1,0 & 3,2 & 5,9 & 3,3 \\
Bélgica & 2,0 & 2,5 & 6,3 & 10,8 & 6,5 \\
Espanha & 2,4 & 2,8 & 5,2 & 17,5 & 8,9 \\
Finlândia & 1,8 & 2,6 & 4,4 & 4,9 & 3,8 \\
França & 1,7 & 2,6 & 4,5 & 9,0 & 5,4 \\
Holanda & 0,8 & 1,5 & 4,9 & 9,7 & 5,3 \\
Itália & 5,1 & 5,7 & 6,6 & 9,5 & 7,3 \\
Noruega & 1,7 & 1,7 & 1,8 & 2,8 & 2,1 \\
Reino Unido & 2,5 & 3,3 & 5,0 & 10,0 & 6,1 \\
Suécia & 1,6 & 2,2 & 1,9 & 2,4 & 2,1 \\
\hline
\end{tabular}

Fonte: Economic Outlook, OECD , 1991.

No Japão, a proporção de desempregados continuou baixa, mas registrou pequeno aumento: de $2,0 \%$ para $3,1 \%$ nos mesmos anos. A Nova Zelândia mostra também pequena queda, mas não se têm os dados para 1976. A mesma observação vale para Portugal.

Tal como ocorreu no exame de outros fenômenos (como dos sistemas de relações de trabalho, das taxas de sindicalização, de participação feminina no mercado), as variações são também acentuadas entre países, aparecendo a Espanha como a campeã do desemprego (22,7\%) em 1995, superando de longe todos os demais. Deve-se notar, por outro lado, que a Suécia e a Alemanha, que até recentemente integravam o grupo dos países de baixo desemprego, tiveram forte elevação em seus índices, que ficaram pouco abaixo de $10 \%$ do total da força de trabalho. Esse crescimento é ainda mais chocante se recordarmos que, em 1980, a taxa de desemprego da Alemanha era de 2,9 e a da Suécia, de 2,0\% (Quadro 6.3).

Para o final do século, na maioria dos países europeus, as indicações apontam na direção da persistência dessa combinação de alto desemprego e baixa inflação, o que não favorece prognósticos otimistas para o movimento sindical. 
Quadro 6.3

Taxas de desemprego 1976-1998

\begin{tabular}{|l|c|c|c|c|c|}
\hline Países & 1976 & 1980 & 1985 & 1990 & 1995 \\
\hline Alemanha $^{\mathrm{a}}$ & 3,7 & 2,9 & 7,1 & 4,8 & 8,2 \\
Austrália & 4,7 & 6,0 & 8,2 & 6,9 & 8,5 \\
Bélgica & 6,4 & 8,8 & 11,3 & 7,2 & 9,5 \\
Canadá & 7,1 & 7,5 & 10,5 & 8,1 & 9,5 \\
Espanha & 4,5 & 11,1 & 21,1 & 15,9 & 22,7 \\
Estados Unidos & 7,6 & 7,0 & 7,1 & 5,6 & 5,5 \\
Finlândia & 3,8 & 4,6 & 5,0 & 3,4 & 17,1 \\
França & 4,4 & 6,2 & 10,2 & 8,9 & 11,6 \\
Holanda & 5,5 & 6,0 & 10,6 & 7,5 & 6,5 \\
Irlanda & - & - & 17,0 & 13,3 & 12,9 \\
Itália & 6,6 & 7,5 & 9,6 & 10,3 & 12,2 \\
Japão & 2,0 & 2,0 & 2,6 & 2,1 & 3,1 \\
Noruega & 1,7 & 1,6 & 2,6 & 5,2 & 4,9 \\
Nova Zelândia & - & - & - & 7,7 & 6,3 \\
Portugal & - & - & 8,5 & 4,6 & 7,1 \\
Reino Unido & 5,6 & 6,4 & 11,2 & 6,9 & 8,7 \\
Suécia & 1,6 & 2,0 & 3,0 & 1,8 & 9,2 \\
\hline Total da OCDE & 5,4 & 5,8 & 7,8 & 6,1 & 7,5 \\
\hline Total dos países acima & 5,4 & 5,5 & 7,2 & 5,7 & 6,8 \\
\hline União Europeia ${ }^{b}$ & 5,0 & 6,4 & 10,5 & 8,1 & 11,0 \\
\hline
\end{tabular}

Taxas de desemprego 1976-1998

${ }^{a}$ A partir de 1992 (inclusive) os dados concernem a toda a Alemanha.

b União Europeia: somente os países indicados: Alemanha, França, Itália, Reino Unido, Bélgica, Finlândia, Irlanda, Holanda, Portugal, Espanha e Suécia estão incluídos na área total.

Fonte: OECD Economic Outlook, nº6, December 1996.

\section{Quadro 6.4}

\section{Inflação 1997-1999}

\begin{tabular}{|l|c|c|c|}
\hline & 1997 & $1998^{*}$ & $1999 *$ \\
\hline Alemanha & 0,6 & 0,9 & 1,3 \\
EUA & 2,0 & 1,6 & 1,8 \\
Japão & 0,6 & 0,5 & 0,0 \\
\hline Total da OECD & 3,7 & 3,4 & 3,1 \\
\hline União Europeia & 1,8 & 1,8 & 1,9 \\
\hline
\end{tabular}

* Os dados referentes a 1998 e 1999 são projeções.

Fonte: OECD Economic Outlook 63, June 1998.
Quadro 6.5

Desempregados 1997-1999

\begin{tabular}{|l|c|c|c|}
\hline & 1997 & $1998^{*}$ & $1999^{*}$ \\
\hline Alemanha & 11,4 & 11,5 & 11,1 \\
EUA & 4,9 & 4,8 & 5,0 \\
Japão & 3,4 & 3,5 & 3,6 \\
\hline Total da OECD & 7,2 & 7,1 & 7,0 \\
\hline União Europeia & 11,2 & 10,9 & 10,5 \\
\hline
\end{tabular}

* Os dados referentes a 1998 e 1999 são projeções. Fonte: OECD Economic Outlook 63 , June 1998.

Parece-nos equivocado, no entanto, exagerar as consequências do fator desemprego no recuo do sindicalismo. Os exemplos da Alemanha, de um lado, com altas taxas de desemprego e taxas relativamente altas de sindicalização, e o dos EUA, de outro, com taxas baixas de desemprego e de inflação e baixos índices de sindicalização, sugerem, como procuramos mostrar ao longo deste trabalho, que múltiplos fatores estão correlacionados com os problemas que o sindicalismo enfrenta atualmente e que os efeitos individuais de cada um deles podem ser muito diferentes, segundo cada país.

\section{CONCLUSÃO}

No conjunto, e para dizer de modo sintético, no período que estamos examinando, as mudanças no campo da economia prejudicaram os sindicatos e favoreceram as empresas privadas. Essas transformaram-se no centro principal de desenvolvimento na própria medida em que o Estado reduzia seu papel estimulador e regulamentador da economia. Cada privatização aumenta o poder empresarial privado e reduz o poder da tecnocracia estatal e do poder sindical que tende a estar a ela associado. Os empresários, e especialmente as grandes empresas multinacionais, antes do que o Estado e a classe política, tornaram-se o ator central no processo de desenvolvimento, recuperaram a iniciativa, a legitimidade e a autoridade que tinham perdido progressivamente no após guerra e que de modo geral vinham perdendo à medida que se expandia a massificação do processo político e se fortaleciam os partidos que se apoiavam sobre as camadas populares ${ }^{16}$.

${ }^{16}$ Deve-se ter em conta, ponto que não há condição de desenvolver aqui mas que queremos deixar assinalado, que a recuperação do poder empresarial das últimas décadas tem pouco a ver com o fortalecimento da classe burguesa tradicional, dos proprietários individuais, das 
Mas não foram apenas as mutações na área da economia que abalaram os sindicatos. Outras tantas mudanças no plano político e institucional vieram a enfraquecer o sindicalismo diante dos empresários. As alterações nos anteriores padrões de relacionamento entre sindicatos e empresas derivaram do esforço de readaptação dos sistemas de relações de trabalho ao novo contexto da competição acirrada, da rapidez da mudança tecnológica, das novas demandas do mercado, da ampliação do espaço ocupado pelas companhias multinacionais. Os efeitos sobre o sindicalismo da readaptação das empresas a mercados mais competitivos foram muito diferenciados. $\mathrm{O}$ quadro mais negativo para o sindicalismo aparece de modo mais dramático nos países como o Reino Unido e os EUA, onde as políticas neoliberais começaram a ser aplicadas mais cedo, foram mais longe e os modelos de relações de trabalho ofereciam menos proteção legal para os sindicatos do que os da Europa continental. São esses desdobramentos de natureza institucional e política que procuraremos examinar no próximo capítulo.

empresas familiares. Agora, Trata-se dos executivos profissionais das multinacionais e das grandes corporações. Por isso, parece-nos mais correto referir-se ao "poder empresarial" do que ao "poder burguês", no sentido marxista tradicional.

\section{Capítulo 7 \\ As mudanças nos sistemas de relações de trabalho}

A mudanças no sistema produtivo e na organização das empresas A atuaram no sentido de alterar os padrões anteriormente estabelecidos de relações de trabalho entre as empresas e seus empregados e com os sindicatos. Mas as transformações induzidas pela situação de mercado e pelas novas tecnologias passam por um filtro institucional constituído pelas tradições, por uma cultura, por práticas e prescrição de condutas, fortemente enraizadas na sociedade e, amiúde, formalizadas em legislações ou contratos mais ou menos extensos que se conectam com estruturas especializadas que têm seus próprios interesses, tal como os sindicatos, as associações patronais, os partidos e os organismos governamentais. As particularidades dos sistemas de relações de trabalho nacionais são, portanto, variáveis importantes a ser consideradas nas explicações das causas da dessindicalização.

Dois pares opostos de relações entre empresas e sindicatos e de estruturação sindical merecem ser examinados em razão de seus efeitos sobre o sindicalismo:

a) negociações centralizadas vs. negociações fragmentadas, ou seja, modelos corporativos e modelos liberais e pluralistas; e

b) estruturas sindicais com forte implantação no interior das empresas (comissões sindicais ou conselhos de empregados) e estruturas sindicais fracamente implantadas nos locais de trabalho.

Esses pares alternativos de práticas de negociação e organização dos trabalhadores têm relação com outras características do sindicalismo que não serão, contudo, examinadas aqui, como as divisões ideológicas internas, as estratégias sindicais, o grau de intervencionismo governamental e a própria centralização das associações patronais.

Negociações centralizadas e negociações descentralizadas

O modelo de negociação centralizada, nos quadros de um "corporativismo social" (ou neocorporatismo), tende a vigorar nos "países social democratas" da Europa do Norte, em particular os países 
escandinavos $^{1}$. Tal como será tratado aqui, o neocorporativismo, que utilizaremos como sinônimo de corporativismo social, indica uma forma de

${ }^{1}$ A literatura sobre o corporativismo é imensa. Não temos a intenção de entrar nessa área. Mas, apesar disso, convém esclarecer certos pontos, tendo em vista especialmente o modo (pejorativo) como o termo tem sido usado entre nós nesses últimos tempos, ou seja, como expressão de interesses particulares de categorias profissionais geralmente ilegítimos por se contraporem aos "superiores interesses" da nação ou da coletividade.

O conceito de corporativismo é entendido de muitas maneiras. Antes da Segunda Grande Guerra, esteve associado a regimes antiliberais e antidemocráticos e à cultura ibérica e ao catolicismo (cf., por exemplo, Wiarda, 1974) e entendido como formas autoritárias e conservadoras de dominação social, aí incluindo o controle sobre as relações entre o Capital e o Trabalho. As taxinomias foram variadas, do corporativismo tradicional católico ao corporativismo estatal, dirigista, revolucionário do fascismo italiano (ver, por exemplo, incisa, 1986)

No após-guerra, a problemática do corporativismo retornou sob a denominação de neocorporativismo, mais comumente designado de corporativismo social, sob as formas de mesocorporativismo, corporativismo setorial (Cawson, 1985). Na acepção de corporativismo social, o neocorporativismo resultaria menos da fraqueza da sociedade civil diante das estruturas burocráticas do Estado, mas da força dos grupos de interesse (basicamente, sindicatos e associações patronais) organizadas em poderosas estruturas centralizadas capazes de influenciar as decisões do Estado, às vezes tornando-se parte integrantes de organismos estatais ou paraestatais de natureza tripartite. [Cf., sobre o assunto, Pekkarinen, Pohjola \& Rowthorn (1992).10 adjetivo "social" desloca o foco para as organizações da sociedade civil. Mas, algumas vezes, se fala em "corporativismo liberal". A junção paradoxal dos dois termos, vistos antes da Segunda Grande Guerra como mutuamente excludentes, enfatiza o alto grau de autonomia e cooperação voluntária dos grupos de interesses nas políticas públicas (Lehmbruch, 1992a e 199b).

Portanto, a modalidade de corporativismo do após-guerra dos países capitalistas democráticos não deve ser confundido com o tipo de corporativismo criado pelo Estado e de inspiração fascista, como o que foi introduzido entre nós na década dos 30 na área trabalhista. Assim, Schmit ter (1974) distingue o corporativismo social, ou "societal" (societal corporatism) do corporativismo estatal (state corporalism). Os conceitos de Schmitter são geralmente conhecidos pelos cientistas políticos. Mas, para o grande público, conviria utilizar mais algumas linhas, explicitando a conceituação do autor.

Schmitter focaliza o corporativismo essencialmente como um modo de representação de interesses profissionais. No corporativismo social, as relações com o sistema político implicariam relativa autonomia das unidades constituintes (como os sindicatos e as associações patronais); no corporativismo estatal, as "unidades constituintes" estariam subordinadas ao poder de um Estado centralizado: "O corporativismo social parece ser um componente concomitante, se não inelutável, do Estado de Bem Estar democrático do capitalismo pós-liberal avançado; o corporativismo estatal parece ser um elemento definidor, ou uma necessidade estrutural, de uni Estado neomercantilista, antiliberal, autoritário e atrasado do ponto de vista capitalista" (p. 105). (Em outro trabalho, Schmitter prefere o termo "intermediação de interesses" ao de "representação de interesses", para sublinhar que intermediação e representação de interesses profissionais que se exerce no interior de economias capitalistas sob regimes políticos democráticos e pluralistas, mas com forte intervencionismo estatal e grande poder das organizações sindicais. Desse ângulo, nada tem a ver com as modalidades de corporativismo tradicional de sociedades católicas menos desenvolvidas que tende a se impor em países onde a organização sindical é fraca.

As seguintes características do corporativismo são habitualmente ressaltadas: negociação tripartite centralizada, forte intervenção governamental, altos índices de sindicalização e de cooperação entre associações patronais e sindicais. Entre as precondições institucionais para o corporativismo social estão não apenas a centralização das entidades dos trabalhadores e do patronato e o controle das entidades de cúpula sobre os sindicatos (tanto do lado dos trabalhadores como das empresas) mas também, como acentua Pekkarinen (1992), o alto grau de concentração entre as empresas, característica das economias de exportação dos países nórdicos (p. 302), o que significa, no plano econômico, que a negociação salarial é dominada por um pequeno número de atores poderosos, com o Estado desempenhando muitas vezes um papel relevante por meio da imposição compulsória de políticas de rendas, oferecendo compensações por congelamento ou redução de salários, tais como políticas sociais e eliminação

"as associações não apenas podem expressar interesses próprios, deixar de expressar, ou mesmo desconhecer os interesses de seus membros e/ou desempenhar um papel importante de ensinar a esses quais 'devem ser' seus interesses, como também podem frequentemente se ver obrigadas a assumir funções governamentais privadas de distribuição de recursos e controle social" [Schmitter, 1992, p. 77].)

$\mathrm{O}$ ponto que parece importante nos esquemas corporativos, entendidos como modos de intermediação e/ou representação de interesses e que têm relações com os índices de sindicalização e de conflito, é o da centralização das organizações dos trabalhadores e do patronato, centralização que leva a negociação trabalhista a ser efetuada em alto nível, às vezes em nível nacional. Um dos resultados é a redução da autonomia das "unidades constituintes" locais, às vezes, no caso dos sindicatos, mediante o controle dos fundos de greve pelas organizações de cúpula. Outra consequência é a redução dos níveis de conflito.

No caso do Brasil, a presença do "corporativismo estatal" - onde o Estado é o ator principal, embora não o único - contribuiu para impedir o surgimento de modalidades de "corporativismo social". Mas, na década dos 90, tivemos pelo menos duas experiências inéditas (mas de curta duração) desse tipo de corporativismo na indústria automobilística de São Paulo. Sobre o assunto, há o estudo de Arbix (1996), que investigou a história da câmara setorial da indústria automobilística (classificada pelo autor como um caso de mesocorporatismo tripartite), e o de Mello e Silva (1997), que estudou duas empresas do setor petroquímico. 
de impostos. Em outros casos, mesmo quando não intervém diretamente, o Estado pode atuar decisivamente, ameaçando intervir se o Capital e o Trabalho não chegarem a um acordo aceitável (Rowthorn, 1992, p. 84).

Os países de modelos pluralistas são tipicamente os de pequena intervenção governamental, negociações descentralizadas, frequentemente limitadas a empresas, nas quais as partes tentam maximizar vantagens levando em conta basicamente os interesses particulares dos grupos de trabalhadores envolvidos. Restrições salariais voluntárias, nesse contexto de fragmentação da barganha, encontram muita dificuldade para efetivar-se. Por isso, sistemas pluralistas tendem também a ser mais conflitivos. Os chamados "interesses gerais da economia nacional” não são levados em conta ${ }^{2}$.

Com variações entre países, o modelo Socialdemocrata identificou-se com negociações centralizadas, corporativismo social, baixos índices de conflito, política redistributivista, performance econômica elevada, Estado de Bem-Estar ${ }^{3}$. Considerando o êxito da socialdemocracia nos países do

\footnotetext{
${ }^{2}$ Schmitter (1974) definiu o conceito de pluralismo na área das relações de trabalho como um "sistema de representação de interesses no qual as unidades constitutivas estão organizadas num número não especificado de múltiplas categorias, voluntárias, competitivas, não ordenadas hierarquicamente e autodeterminadas (quanto ao tipo ou extensão dos interesses), categorias que não estão especialmente autorizadas, reconhecidas, subsidiadas, criadas ou controladas de algum modo pelo Estado no que diz respeito à seleção da liderança ou à articulação de seus interesses e que não têm o monopólio da atividade de representação dentro de suas respectivas categorias" (p. 96).

${ }^{3}$ Um dos problemas na discussão da relação entre centralização e sindicalização vem do fato de que centralização ou descentralização não é uma variável dicotômica, mas forma uma escala na qual a localização relativa de cada sistema sindical não é objeto de inteiro consenso entre os analistas. Calmfors e Driffill (1988), considerando índices que levam em conta a estrutura da negociação (nação, indústria, empresa, número das organizações centrais de trabalhadores e empregadores), classificaram os países segundo o grau de centralização das negociações. Entre os sistemas centralizados incluíram a Áustria, a Noruega, a Suécia, a Dinamarca e a Finlândia. Entre os intermediários colocaram a Alemanha, a Holanda, a Austrália, a Bélgica e a Nova Zelândia. Entre os descentralizados ficaram a França, a Itália, o Reino Unido, o Japão, a Suíça e o Canadá (apud Pohjola, 1992, p. 50).

Wallerstein (1985), ordenando o grau de centralização sindical de vários países a partir da classificação de vários autores, incluiu entre os sistemas descentralizados os seguintes países (sempre, dentro de cada classe, em ordem decrescente de centralização): Austrália, Canadá, França, Alemanha, Irlanda, Itália, Japão, Nova Zelândia, Reino Unido e Estados Unidos. Entre os moderadamente centralizados: Dinamarca e Suíça; e entre os altamente centralizados: Áustria, Bélgica, Finlândia, Israel, Holanda, Noruega e Suécia (p. 42). Nesse esquema, na época, a Suécia teria o sindicalismo mais centralizado e os EUA, o menos.
}

norte da Europa, neocorporativismo e socialdemocracia aparecem frequentemente associados. Crouch observa que, em grande parte da literatura, é difícil determinar quando temos um mecanismo corporativo ou simplesmente o êxito da socialdemocracia na conquista de uma sociedade na qual os operários obtiveram suficientes vantagens sociais que tornaram desnecessárias ações conflitivas (Crouch, 1993, p. 15) ${ }^{4}$.

Wallerstein defende a tese de que os países com sistemas altamente centralizados tendem a ser países pequenos e muito dependentes de exportações industriais, ao passo que, nos países grandes ou nos países especializados na exportação de produtos agrícolas, as organizações sindicais tendem a ter baixo grau de centralização. Um mercado interno pequeno e a especialização em alguns produtos industriais reduziriam o leque das estratégias sindicais, aproximando sindicatos e empresários na defesa da capacidade competitiva externa da indústria nacional. Na Suécia, o famoso Acordo Básico (1938), assinado entre a federação patronal (SAF) e a central sindical (LO), implicou a aceitação dos direitos das empresas de só assinar acordos coletivos com sindicatos que reconhecessem explicitamente os direitos da companhia de contratar e despedir trabalhadores. As políticas implementadas pelo Partido Social-Democrata estiveram orientadas para o fortalecimento das grandes empresas voltadas para a exportação, nos quadros de uma economia concentrada e internacionalizada, dependente de mercados externos (Pontusson, 1996; Rjellberg, 1993).

${ }^{4} \mathrm{O}$ malogro das experiências corporativas em países como França, EUA e mesmo GrãBretanha e Itália em contraste com Alemanha, Áustria, Bélgica, Holanda e países escandinavos, é tratado por Maier (1985). Arriscando-nos a empobrecer o pensamento do autor, transcrevemos alguns pontos salientados por Maier. No após-guerra, os esforços "protocorporativos" de negociação salarial consensual foram facilitados pela necessidade de reconstrução econômica, pela tradição marxista reformista de intervencionismo e regulação econômica e social, pela unificação e centralização do movimento sindical, pelo desenvolvimento paralelo dos partidos e sindicatos socialdemocratas. A necessidade da reconstrução, a economia de exportação e a forte dependência dos mercados internacionais teriam facilitado políticas de cooperação e de barganha consensual entre o Capital e o Trabalho e o abandono de uma "visão exclusiva do poder operário". Na França e na Itália, a divisão ideológica, a concepção de luta de classes do sindicalismo comunista não teria dado condições para uma política de negociações consensuais centralizada, que está na base do corporativismo socialdemocrata. No caso do Reino Unido, a tradição de acordos fragmentados (apesar da filiação da maioria dos sindicatos ao TUC) levou o reformismo trabalhista para a direção de mudanças gerais na sociedade, que não implicaram a contenção) das demandas salariais que levassem à colaboração de classes (ver especialmente pp. 50-56). A aplicação dos esquemas corporativos requer, como uma das suas precondições, forte autoridade das organizações de cúpula sobre as organizações locais. A Itália, durante o período da solidarietà nazionale (19771979), e o Reino Unido, durante o período do social conluia (19741979), países que não tinham tradição corporativa, tiveram, contudo, experiência de "concertação social" (cf. Regini, 1985). (Sobre o assunto, ver também Wilson, 1992.) A importância do fator ideológico é ressaltada por Panitch (1992) mas num sentido diferente de Maier. Segundo Panitch, numa linha de argumentação marxista, as 
O ponto que me parece importante nos esquemas corporativos, tal como está sendo entendido aqui, e que tem relações com os índices de sindicalização e de conflito é a centralização das organizações dos trabalhadores e do patronato, que leva a negociação trabalhista a ser efetuada em alto nível. Um dos resultados é a redução da autonomia das "unidades constituintes" locais, às vezes, no caso dos sindicatos, mediante o controle dos fundos de greve pelas organizações de cúpula e, correlata mente, a redução dos níveis de conflito.

Estudando o processo de descentralização das negociações em seis países, anteriormente muito diferenciados quanto ao seu âmbito e nível de centralização (Suécia, Austrália, Alemanha Federal, antes da absorção da RDA, Itália, Reino Unido e EUA), Katz (1993) notou a crescente similaridade entre eles. Três hipóteses, para o autor, explicariam a evolução na direção da descentralização: mudanças no poder de barganha dos sindicatos; expansão de novas formas de organização que premiam a flexibilidade e a participação do empregado e diversificação das preferências dos trabalhadores.

Mas houve também mudanças nas políticas das companhias, como salientamos no capítulo anterior. A transnacionalização das suas estratégias de produção e venda não trouxe maior centralização dos acordos coletivos, mesmo em âmbito nacional. Se isso tivesse ocorrido, seria mais fácil para os sindicatos nacionais, federações e centrais unir os trabalhadores em torno de grandes plataformas gerais e avançar em direção a entidades sindicais transnacionais. Diante da competição mais acirrada, as companhias orientaram-se no sentido de maior flexibilidade operacional mediante "unidades estratégicas de negócios", com maior autonomia de atuação operacional e fixação de objetivos (Ferner \& Hyman, 1993a). As grandes empresas começaram simultaneamente a centralizar e a descentralizar seus sistemas de decisão. Decisões estratégicas, como novos investimentos, estão sendo centralizadas, enquanto decisões específicas dos locais de

afinidades ideológicas entre o corporativismo e a socialdemocracia são menos evidentes. Os dois movimentos evoluíram a partir de bases sociais, filosofia e práticas diferentes. Mas um fator, ao lado de outros, que facilitou a aproximação entre o corporativismo e a socialdemocracia teria sido a predominância, dentro dos partidos socialdemocratas, "das correntes que repudiam a luta de classes como a dinâmica da mudança social” (pp. 153-154). trabalho estão sendo descentralizadas de modo a envolver níveis gerenciais mais baixos nas instâncias de decisão (Baethge \& Wolf, 1995, p. 245).

O resultado foi cada vez mais a busca de acordos por locais de trabalho. No conjunto, três processos parecem nitidamente associados às mudanças em curso nos países desenvolvidos: descentralização da barganha; aumento das negociações por local de trabalho e flexibilização (Locke \& Kochan, 1995). Esse desenvolvimento complicou a ação sindical, especialmente porque atuou no sentido de enfraquecer o alcance das negociações de nível mais elevado. Mais do que nunca, os sindicatos necessitam de atuação flexível, a fim de coordenar diferentes níveis de negociação. De um lado, o sindicalismo tem de ser forte no plano político, para negociações centralizadas; de outro, necessita estar bem implantado nas empresas - nos locais de trabalho mais exatamente - para negociar questões que decorrem das especificidades de cada situação de trabalho e de emprego e que não mais podem ser padronizadas. Como veremos, Trata-se de uma nova e difícil tarefa dos sindicatos diante das estratégias mercadológicas e práticas gerenciais das grandes empresas, especialmente das multinacionais.

No enfoque institucional e na ênfase sobre os efeitos dos modelos de relações de trabalho sobre o poder sindical, frequentemente há a valorização dos modelos neocorporativos do norte da Europa5. A ideia é que a resistência

\footnotetext{
${ }^{5}$ A inclusão dos sistemas de relações de trabalho dos países na classe dos "corporativos" ou "pluralistas" varia segundo Os critérios adotados pelos autores e o período. Lehmbruch (1985) elaborou, na primeira metade da década dos 80, uma escala que ia de pluralismo (EUA, Canadá, Austrália, Nova Zelândia), corporativismo .frágil (Reino Unido e Itália), corporativismo médio (Irlanda, Bélgica, República Federal Alemã, Dinamarca e Finlândia e Suíça, como caso-limite) a lime corporativismo (Áustria, Suécia, Noruega e Holanda). Não incluídos na escala estavam a França e o Japão, entendidos como casos de "concertação sem participação dos trabalhadores". O pluralismo foi definido pela predominância de grupos de pressão política e pela atuação dos lobbies das agências governamentais e parlamentares, pela competição fragmentada dos grupos de interesses e por um baixo grau de participação dos sindicatos nas tomadas de decisão; o corporativismo frágil, pela participação institucionalizada dos sindicatos na formação e implementação de políticas somente em certos aspectos da política ou por sua participação apenas em níveis específicos do processo político - por exemplo, consulta ou implementação. Tanto no caso do pluralismo como no do corporativismo frágil, os objetivos da negociação coletiva seriam limitados. A negociação em nível nacional não seria importante e, portanto, políticas de renda concertadas seriam difíceis de aplicar. O corporativismo médio caracterizou-se por uma participação setorial do sindicalismo semelhante à do corporativismo frágil, mas o objetivo da negociação coletiva seria mais amplo e as tentativas de concertação de políticas alcançariam mais sucesso. No
} 
patronal ao sindicalismo tenderia a ser mais baixa nos sistemas em que vantagens outorgadas para os sindicalizados, por meio de negociações centralizadas entre federações patronais e sindicais, ou legislação governamental, são estendidas a todos os empregados, sindicalizados ou não. A intervenção governamental direta e/ou acordos centralizados entre confederações patronais, centrais sindicais e governo tendem a generalizar vantagens, tornando-as de aplicação obrigatórias para todos os empregadores. Por essa razão, "socializam" os prejuízos das empresas e "igualizam" as condições da competição entre as firmas no mercado nacional. Com isso, cada empresa individualmente teria menos motivos para não querer negociar ou pôr o sindicato para fora de suas instalações.

Tratar-se-ia de um sistema que estaria mais adequado a países de governos socialdemocratas, pequenos e desenvolvidos, e que operaria, não para introduzir protecionismo e preços competitivos, mas preços livres aliados à necessidade de manutenção da capacidade de competição externa. $\mathrm{Na}$ Noruega, na Suécia e na Dinamarca, os primeiros defensores da barganha centralizada não seriam os sindicatos mas os empresários, o que não significaria dizer que o apoio sindical seria irrelevante. Se a barganha fosse descentralizada, os custos da queda de eventuais declínios da demanda externa seriam pagos (pelo menos inicialmente) pelas empresas e trabalhadores desse setor. Mediante o chamado "salário solidário", a centralização das negociações reduziria a níveis muito pequenos as diferenças entre os trabalhadores altamente qualificados e os demais.

caso do corporativismo forte, haveria uma efetiva participação dos sindicatos e associações empresariais na formação e implementação de políticas em áreas fundamentais para a administração da economia (pp. 65-66). O artigo de Lehmbruch é da década dos 80. Depois disso, como vimos (nota 4), o corporativismo frágil da Itália e da Grã-Bretanha desapareceu. Schmitter (1974) entende que, em começos da década dos 70, empiricamente, os melhores casos de corporativismo social seriam exemplificados pela Suécia, Suíça, Holanda, Noruega e Dinamarca (p. 104).

Outra escala classificatória estabeleceu três níveis de "graus de corporativismo": a) alto: Áustria, Alemanha, Japão, Dinamarca, Noruega, Suécia; b) intermediário: Austrália, Finlândia, Holanda, Bélgica, Canadá, Estados Unidos; c) baixo: Nova Zelândia, França, Reino Unido e Itália (Tarantelli, 1986, apud Pohjola, 1992, p. 59).

Outras classificações de países segundo graus de neocorporativismo poderiam ser citadas. Elas indicariam pequenas alterações no ranking das nações. Mas essa análise nos desviaria muito do objetivo central deste trabalho. Queremos ressaltar apenas que, apesar das variações que possam ser encontradas, os países nórdicos, seguidos da Áustria e da Alemanha, estão sempre nos primeiros graus das escalas.
Notam Moene e Wallerstein (1995) que a negociação centralizada distribuiu os custos da manutenção da competitividade do setor exportador para toda a economia, beneficiando especialmente os trabalhadores do setor metalmecânico. Mas o resultado não deixa de ser a redução do conflito e o favorecimento do crescimento das taxas de sindicalização.

Mas acontece que os modelos neocorporativos de negociações centralizadas estão cada vez mais submetidos às tensões das novas condições de produção, inclusive nos países onde tinham oferecido bons resultados do ponto de vista da defesa dos salários, baixa inflação, níveis mínimos de desemprego e políticas sociais. Na Suécia, depois de 27 anos consecutivos, a negociação centralizada chegou ao fim depois de um acordo separado no setor metal-mecânico. Foi reinstaurada no ano seguinte mas permaneceu sob constante pressão. Por sua vez, a defesa do emprego, que era um dos pontos fortes do modelo socialdemocrático, também não conseguiu resistir às pressões das transformações mundiais e à abertura da economia. Os níveis de desemprego não distinguem, hoje, os países nórdicos do resto da Europa; as centrais sindicais têm dificuldade de controlar os sindicatos locais e, especialmente, de impor restrições salariais voluntárias (Martin, 1995; Moene \& Wallerstein, 1995; Sivesind; Kalleberg; Hovde \& Fennefoss, 1995; Clement, 1994, Rehn \& Viklund, 1992; Pekkarine, 1992).

A continuidade das transformações econômicas e seus efeitos sobre sistemas sindicais anteriormente sólidos obrigam hoje a repensar em que medida a muralha neocorporativa, especificamente o sistema centralizado de negociações e a política intervencionista socialdemocrática de "salários solidários" e igualitarismo, serão capazes de resistir às pressões desestabilizadoras que se acentuaram na década dos 90 diante da exposição dessas economias ao mercado internacional. Acontece que, no contexto da globalização, a boa integração entre negociações locais e as centralizadas vai se fazendo mais difícil diante das transformações nas novas técnicas de gestão. As grandes empresas estão utilizando simultaneamente estruturas decisórias centralizadas e descentralizadas. Decisões estratégicas, observam Baethge e Wolf (1995), como locação de produtos, decisões de investimentos, estão sendo centralizadas, enquanto decisões que tratam de arranjos particulares nas fábricas individuais estão sendo descentralizadas para incluir mais empregados nos níveis mais baixos da administração e da tomada de decisões. Os administradores de nível local, assim, não têm mais 
poder decisório para tratar das "grandes questões". Essas acabam por ficar fora do alcance das organizações locais dos trabalhadores, o que faz com que muitos temas importantes acabem desaparecendo das listas de negociação (pp. 245-246) ${ }^{6}$. É nesse ponto que ganha relevância a organização dos trabalhadores por local de trabalho, especialmente se forem capazes de atuar em conexão com entidades sindicais, como federações e centrais, capazes de atingir patamares mais elevados de negociação.

\section{A importância dos conselhos e empresa}

Teria sido precisamente a força das organizações locais que teria evitado, em alguns países europeus, quedas mais agudas nas taxas desindicalização. É no fortalecimento e desenvolvimento de conselhos de empresas que Freeman (1995) (assim como outros autores americanos) deposita alguma esperança de recuperação do sindicalismo dos EUA. Freeman acredita que seria inteiramente equivocado entender que os empregadores norte-americanos seriam intransigentemente contrários a que os empregados tenham uma voz independente sobre as decisões nas fábricas. Os próprios interesses empresariais, segundo as novas técnicas de relações humanas de integração dos empregados, iriam na direção da maior participação dos trabalhadores. No caso, tratar-se-ia da criação de conselhos de trabalhadores dentro das empresas, independentes dos sindicatos, os

${ }^{6}$ Uma sintética descrição das alterações no sistema belga de negociações encontra-se em Hancke (1991). Além da queda nos níveis de sindicalização, o autor assinala as dificuldades de manutenção do sistema anterior, pelo qual negociações de empresa suplementavam acordos nacionais. A partir de meados de 1970, cada vez mais os acordos por companhia começaram a crescer enquanto decaíam os acordos nacionais e setoriais. Entre 1974 e 1979, os acordos nacionais assinados caíram de 729 para 400 (p. 470). Por outro lado, em razão dessa tendência, os sindicatos encontram mais dificuldade para representar camadas mais heterogêneas de empregados, aspecto já apontado. As novas tecnologias não mais obedecem às rígidas áreas de competência profissional originadas de procedimentos e modos de organização do trabalho vindas do após-guerra. "As reordenações estratégicas das empresas não mais se limitam às suas fronteiras e cada vez mais se estendem além delas para atingir a todos os empregados da produção de outras firmas envolvidas..." (p. 476). Essas reorientações estratégicas substituem gradualmente a estrutura "vertical" clássica da indústria por novas relações "horizontais", que abrangem, por exemplo, todas as companhias que produzem peças para veículos. Isso supõe a crescente cooperação tecnológica entre muitas indústrias, o que afeta os sindicatos que tinham estruturas baseadas em firmas e setores relativamente fechados. Nesse novo contexto, em que a pressão das empresas por contratos flexíveis é cada vez maior, as negociações locais adquirem grande importância. O problema para os sindicatos é como coordenar os acordos por local de trabalho com as negociações centralizadas. quais, segundo um survey analisado pelo autor, encontrariam forte apoio do trabalhadores e baixa oposição dos empregadores ${ }^{7}$.

Nessa linha, Kochan e Wever (1990) entendem que os sindicatos americanos, para fugir do declínio irreversível, teriam de combinar várias formas de atuação que ampliassem o envolvimento dos sindicatos em dois níveis, "acima" e "abaixo" do patamar atual da negociação coletiva praticada nos EUA. Os autores enfatizam que muitas das decisões estratégicas importantes das empresas se fazem num nível muito acima das negociações coletivas dos locais de trabalho e, portanto, não são atingidas pela ação sindical nas fábricas. As organizações sindicais necessitariam tentar afetar essas estratégias que passam longe do "chão da fábrica".

${ }^{7}$ O survey, realizado em 1994 pelo próprio Freeman e por J. Rogers (1995) sobre participação dos trabalhadores nos locais do trabalho, não parece oferecer resultados conclusivos. Cerca de 113 dos empregados declararam que votariam por uma representação sindical, embora $41 \%$ dissessem que gostariam que houvesse sindicato em seus locais de trabalho. $\mathrm{O}$ resultado da pesquisa que reforçaria a tese de Freeman baseia-se nas respostas dos empregados que declararam preferir, a sindicatos, comitês conjuntos de cooperação (joinl cooperative commillees), reunindo trabalhadores e pessoal da chefia. Mas Trata-se apenas de preferências manifestadas em sondagens de opinião. Comitês conjuntos não são conselhos de trabalhadores nem comitês sindicais de empresa. Deery (1995), comentando as colocações de Freeman, indaga se os empregadores norte-americanos iriam aceitar voluntariamente formas de representação operária, tais como conselhos de trabalhadores, os quais incorporariam princípios de cogestão e de partilha de informações e consulta. Deery observa que esses conselhos só têm efetividade [do ponto de vista do trabalhador] quando os sindicatos estão presentes e não ausentes (p. 539), posição, como veremos, compartilhada por muitos outros autores.

${ }^{8} \mathrm{Um}$ dos exemplos citados de êxito da atuação sindical em nível mais elevado e diferente da simples reivindicação foi a pressão do sindicato dos trabalhadores da indústria automobilística sobre a General Motors para a "sindicalização" da GM:Foyota joini venture e, posteriormente, o trabalho conjunto realizado pelo sindicato com a GM para planejai; desenhar e administrar a formação da Saturn Corporation. Houve muitos outros casos de participação dos sindicatos nas decisões estratégicas das empresas, com êxito variável e muitos problemas, como na Chrysler, PanAm, Eastern Airlines, Western Airlines, Wheeling-Pittsburgh Steel Corporation, Weirton Steel, Rath MeatPacking. Em todos os casos, os sindicatos obtiveram vários lugares na ,junta de direção em troca de concessões nos salários e nas chamadas "regras de trabalho". Os êxitos foram variados e muitos problemas surgiram, inclusive com os próprios sindicatos nacionais. Sobre o assunto, ver Kochan; Katz \& McKersie (1994). De outro ângulo, Heckscher (1996) tem uma visão muito crítica desse tipo de parceria empresa-sindicato. No caso da fábrica do projeto Saturno da General Motors, o acordo estabeleceu uma categoria de "membro associado", que poderia abranger até $20 \%$ dos empregados. Diferentemente dos demais filiados, eles poderiam ser despedidos sem maiores dificuldades. Nesses acordos, companhias e sindicatos estabelecem uma linha de separação entre um núcleo de empregados protegidos, "de dentro", e os demais. Além disso, empresas e sindicatos tenderiam a atuar conjuntamente a fim 
os sindicatos deveriam também atuar num nível mais "baixo" do que o dos acordos coletivos de empresa, de modo a aumentar a sua influência (e a dos trabalhadores) nos pontos de produção, isto é, nos locais de trabalho. Seria necessário um papel mais ativo das organizações sindicais na representação dos novos interesses dos empregados. Especialmente, diante de progressos tecnológicos previsíveis, seria preciso que os sindicatos antecipassem programas de retreinamento (Kochan \& Wever, 1990, p. 376).

A importância da organização por local de trabalho é reforçada por uma pesquisa de Hancké (1993). O autor comparou a situação sindical de seis países europeus e correlacionou os índices de sindicalização com os da força das organizações sindicais por fábrica. A conclusão foi que, nos países onde as organizações sindicais estavam bem implantadas nos locais de trabalho, as quedas nas taxas de sindicalização foram significativamente menores. $\mathrm{O}$ autor classificou sete países em três faixas: a) de baixa sindicalização (Holanda e França); b) de média sindicalização (Reino Unido e Itália); e c) de alta sindicalização (Alemanha, Bélgica e Suécia). (Desempregados e aposentados foram excluídos dos cálculos de sindicalizados.) Na França e na Holanda, os sindicatos têm organizações locais fracas. No primeiro país, especialmente, apesar da institucionalização dos conselhos de empresa e de as leis Auroux tentarem fortalecer os sindicatos nos locais de trabalho, as divisões do sindicalismo reduziram os efeitos dessas medidas. Na Holanda, às organizações locais faltariam estruturas mais fortes. Nos casos "intermediários" da Itália e do Reino Unido, os sindicatos sempre operaram a nível local, mas o pluralismo ideológico, na Itália, e as divisões entre sindicatos, no Reino Unido, teriam feito com que as organizações de local de trabalho tivessem pouco efeito no sentido de barrar a queda na sindicalização ${ }^{9}$. A Bélgica, a Alemanha e a

de passar para o restante da sociedade os custos das oscilações do mercado e de medidas de proteção solicitadas ao governo (p. 126).

${ }^{9}$ No Reino Unido, uma pesquisa no setor metal-mecânico, de 1980, indicou que as empresas com mais de mil empregados, em média, negociavam com cinco sindicatos. Mas a existência de vários sindicatos não significa pluralismo sindical porque cada um deles representa segmentos profissionais diferentes e não necessariamente competem entre si, ou seja, não são ideológica e politicamente rivais (Marsh, 1984, p. 32). Trata-se, pois, de uma situação diferente da que existe nos países da Europa latina onde há centrais rivais (geralmente, socialistas, comunistas e democratas-cristãs, ou católicas). Em 1992, o TUC abrangia aproximadamente 70 sindicatos, que representam $80 \%$ do total de trabalhadores sindicalizados no país. Mas o
Suécia seriam os casos bem-sucedidos de integração entre organizações locais atuantes (conselhos de empresas e representação sindical) com organizações centralizadas, ou seja, um sistema de representação dual.

Hancké pretendeu demonstrar que a força das organizações locais explica não só as diferenças nas taxas nacionais de sindicalização como também a extensão da dessindicalização. Desse ângulo, a importância do sistema neocorporativo é relativizada. O caso da Holanda seria um bom exemplo. Segundo Hancké, os arranjos neocorporativos não impediram o declínio do sindicalismo holandês pela ausência de organizações sindicais sólidas no interior das empresas.

A pesquisa de Hancké reforçou uma tese de Visser (1988) sobre as razões das diferenças nas taxas de sindicalização de vários países. Segundo o autor, quanto mais a barganha empregado-empregador tem lugar no âmbito das empresas e envolve a participação de trabalhadores não funcionários dos sindicatos, maior a probabilidade de que benefícios adquiridos sejam relacionados com o apoio dos empregados à ação sindical. Mas, ressalta Visser, é necessário que a representação nos locais de trabalho (conselhos de trabalhadores) esteja influenciada pelo sindicato, ainda que possa ser formalmente autônoma. Se o conselho de trabalhadores estiver fora do controle do sindicato, sua existência contribuiria pouco para a elevação dos níveis de sindicalização, considerados aqui como indicação de poder sindical. "Uma relação parece particularmente clara: onde as taxas de sindicalização são baixas, a representação de local de trabalho é tipicamente autônoma perante o sindicato" (p. 152). No caso da Suécia, não há organização de local de trabalho independente do sindicato. "O modelo implica sindicatos fortes tanto a nível local como central [...]. Os sindicatos suecos sempre foram céticos com relação a conselhos... Organizações similares a conselhos existem mas não são independentes dos sindicatos" (Brulin, 1995, p. 189).

A presença dos sindicatos nas empresas e sua posição dominante diante dos conselhos de trabalhadores parece ser uma condição necessária para a força do sindicalismo. Mas não é suficiente. A unidade (ou divisão) do movimento sindical é outra variável a ser levada em conta. Visser

número de sindicalizados no TUC caiu de aproximadamente 12 milhões de membros em 1979 para 7.780 mil em 1992 (Lecher \& Naumann, 1994, pp. 35-36) 
constatou que sistemas sindicais não competitivos (quer dizer, monopolistas e unificados) estão associados com índices maiores e mais estáveis de sindicalização (p. 151), além de obterem resultados melhores no que diz respeito ao crescimento econômico, à inflação e ao desemprego ${ }^{10}$.

Em outro estudo, Visser (1993b) considera que uma das vias mais promissoras para explicar as diferenças nas taxas de sindicalização seria relacionar características institucionais (relações "políticas" e "relações industriais") com as diferentes condutas do patronato, dos sindicatos e dos trabalhadores envolvidos na decisão da sindicalização. Aqui, especial atenção é dada novamente ao local de trabalho e à abrangência do contrato coletivo. O local de trabalho seria importante porque apenas aí se encontrariam "pessoas para punir os arrivistas" (free riders) [que se beneficiariam com as vantagens obtidas por outros sem pagar os custos da participação sindical] e garantir a solidariedade do grupo operário. Mas apenas no caso de o sindicato já existir na empresa e ser reconhecido pelo empregador (p. 210).

Como outros autores, Visser entende que a extensão obrigatória de vantagens trabalhistas a empregados de todas as empresas, por sua vez, faria os empregadores individualmente menos hostis ao sindicalismo. Em lugar de enfrentar sozinhos os sindicatos, os empregadores teriam maior incentivo para filiar-se a associações patronais, uma vez que, de todo modo, teriam de arcar com os custos das vantagens dadas aos trabalhadores. "A centralização da negociação coletiva em entidades que reúnam muitos empregadores tende a diminuir a diferença de salários entre as firmas e a ajudar os sindicatos a ganhar uma base nas pequenas firmas do setor" (p. 213). (A tese, a nosso ver, suporta interpretações contrárias: poder-se-ia levantar a hipótese de que sistemas extensivos de cobertura sindical a empresas e a trabalhadores não sindicalizados podem aumentar a

\footnotetext{
${ }^{10}$ Uma frase citada por três autores franceses, comparando o sistema alemão com o de seu país, sintetiza as diferenças que podem existir entre sistemas de relações de trabalho nos quais a situação das organizações patronais devem também ser consideradas: "Centralizada e centrada sobre a situação econômica da indústria, o sistema alemão apoia-se sobre a forte homogeneidade setorial e sobre a autoridade que as organizações patronais e sindicais têm sobre seus membros. Descentralizado e centrado sobre as lutas do mercado de trabalho nas empresas, o sistema francês corresponde à heterogeneidade do tecido industrial e à fraqueza estrutural das organizações sindicais e patronais" (Maurice; Sellier \& Silvestre, 1982, p. 214, apud Crouch, 1993, p. 3)
}

hostilidade coletiva das empresas ao sindicalismo em geral $^{11}$.) A combinação ideal, do ponto de vista do aumento do poder sindical, parece ser organizações sindicais centralizadas e unificadas, com organizações bem implantadas nos locais de trabalho, com vínculos fortes com partidos políticos (de preferência um só partido), com estratégias de atuação que não levem à redução da capacidade de competição das empresas e, consequentemente, não exacerbem a resistência patronal ao sindicalismo.

Do ângulo da combinação de organizações centrais fortes, negociações centralizadas articuladas com organizações por empresa e negociações locais, a Alemanha aparecia como o modelo ideal para aumentar o poder sindical, especialmente quando esse modelo é cotejado com o norte-americano. No sistema alemão, a cogestão, nas empresas médias e grandes, efetua-se por intermédio de conselhos de trabalhadores eleitos a cada três anos pelos empregados, com representação proporcional do pessoal de escritório e trabalhadores da produção. Esse modelo teria a capacidade de forçar a empresa a procurar uma "reconciliação de interesses" com seus empregados na eventualidade de qualquer mudança, inclusive nos casos de vendas de ações e mudanças tecnológicas ${ }^{12}$.

${ }^{11}$ Em estudo posterior, diante da continuidade da diminuição geral das taxas de sindicalização, Visser parece menos confiante em que as organizações sindicais mais abrangentes, como as que existiram desde o século passado na parte democrática da Europa, consigam sobreviver no século XXI, fato que autor deplora, pois entende que, "sem um forte contrapoder sindical, ao Capital é dado o poder de abusar de sua força e liberdade" (Visser, 1994a, p. 43).

12 Os conselhos de trabalhadores das empresas não devem ser entendidos num sentido revolucionário. Tal como definem Rogers e Streeck (1995, pp. 610), “conselhos operários são organismos institucionalizados para a comunicação representativa entre um único empregador ('a administração') e os empregados ('força de trabalho') de uma única fábrica ou empresa (local de trabalho')". Os autores destacam as seguintes características dos conselhos de trabalhadores nas empresas: a) representam os trabalhadores num dado local de trabalho, independentemente de sua posição como membro do sindicato; b) representam a força de trabalho de uma fábrica ou de uma empresa específica e não de um setor industrial ou de uma área territorial, o que significa dizer que a parte contrária é um empregador individual e não uma associação de empregadores; c) os conselhos não são "sindicatos de companhia" (company unions), no sentido de organizações criadas ou controladas pelos empregadores; d) sendo organismos de representação, os conselhos de empresa diferem das organizações ou políticas empresariais destinadas a incrementar a participação dos empregados nas suas funções, tais "como grupos de trabalho", "círculos de qualidade" etc.; e) a comunicação entre empregadores e trabalhadores pode ser de diferente natureza e pode vir da iniciativa de qualquer das partes; f) mais comumente, os conselhos têm status legal; g) as estruturas dos conselhos variam bastante interpaíses e intrapaíses; h) conselhos de trabalhadores não são a 
Esse sistema dual, que articula vários níveis de representação dos empregados dentro das empresas com o movimento sindical fora delas, poderia prover uma boa integração do sistema de barganha por indústria e por região, com acordos por empresas governados pelas diretrizes estabelecidas no contrato regional ou setorial, às vezes com a participação de representantes dos trabalhadores em instituições relacionadas com políticas sociais de intervenção no mercado de trabalho. Regras gerais, que regulamentem, por exemplo, o tempo de trabalho, os programas de treinamento ou o tipo de determinação das escalas de salário numa indústria, são negociadas em intervalos irregulares, enquanto os salários são negociados anualmente. Esse sistema de negociação é complementado, na base, por acordos de firma ou de fábrica, que estendem o mínimo estabelecido nos contratos regionais (Kern \& Sabel, 1994, pp. 217-218).

Os sindicatos têm seus próprios representantes, os "delegados sindicais", que habitualmente representam entre trinta e cinquenta trabalhadores. Têm papel limitado, de distribuição de material sindical e de apoio aos conselhos das empresas. Os delegados sindicais devem antes apoiar do que controlar os conselhos, embora às vezes possam ocorrer conflitos entre eles. Mas podem, em conjunto, tomar decisões que envolvam, por exemplo, questão de emprego, sem necessidade formal de antes procurar a aprovação do sindicato. Os conselhos de empresa têm legalmente direito a informação fornecida pela empresa, a consulta e codeterminação em certas questões. A negociação coletiva propriamente dita, conduzida no nível de indústria, cabe aos sindicatos enquanto acordos individuais cabem aos conselhos (Visser \& Ruysseveldt, 1996b; MüllerJentsch, 1995; Lecher \& Naumann, 1994; Jacobi; Keller \& Müller-Jentsch, 1993). (No Cap. 9, voltaremos a tratar dos conselhos de empresas, tal como são apresentados por vários autores como uma via de superação dos problemas atuais do sindicalismo.)

Considerando as formas de negociação centralizada, as relações com partidos políticos e governos, isto é, os modelos da Europa do Norte, a ideia da salvação do sindicalismo, especialmente do norte-americano, pela combinação de comissões de local de trabalho com um sindicalismo forte

mesma coisa que a representação de empregados nos organismos de direção das companhias. É nesse sentido que o termo "conselho operário", "conselho de trabalhadores" ou "conselho de empresa" aparece neste trabalho. negociando a nível nacional, ou de ramo, quer dizer, com maior grau de centralização, faz o modelo dual de representação alemão parecer bastante atraente para autores que enfatizam mais os motivos institucionais e motivacionais do declínio do sindicalismo do que as transformações estruturais da economia e da sociedade. Em comparação com o sistema de negociação coletiva norte-americano, de modo geral, o modelo neocorporativo altamente centralizado e unificado dos países da Europa do Norte teria produzido melhores resultados no passado, ao favorecer a sindicalização e agora, nesses tempos difíceis para o movimento sindical, no sentido de evitar quedas tão acentuadas como na França, nos EUA, no Japão e na Holanda ${ }^{13}$.

$\mathrm{Na}$ verdade, o sistema de negociação dual não é exclusivo da Alemanha e de países neocorporativos. A negociação sindical em âmbito de empresas existe na Escandinávia, na Bélgica, no Reino Unido e na Itália (a partir dos anos 60) combinada com negociações centralizadas, na França, na Itália (desde os anos 60), na Holanda e na Áustria. Mas há diferenças nesses casos nacionais com relação ao fato de os sindicatos conquistarem" os conselhos operários "por dentro" ou "por fora" e ao fato de se tratar de sindicalismo unificado ou dividido ideologicamente. Na Alemanha e na Áustria, os conselhos operários, embora formalmente independentes, são de fato uma extensão do sindicato. Nos dois países, todos os componentes do conselho são membros de apenas um sindicato, que representa empregados manuais e empregados de escritório. Já na França, na Holanda e na Suíça, as rivalidades entre correntes sindicais estendem-se para dentro dos conselhos (Visser, 1988, pp. 152 153), o que ajuda a explicar os níveis de sindicalização significativamente mais baixos desses últimos países.

\footnotetext{
${ }^{13}$ Naturalmente, o julgamento das qualidades do modelo é influenciado pelas posições ideológicas do autor. Analisando as relações de trabalho e a atuação da socialdemocracia na Dinamarca e na Suécia, Swenson (1991) é extremamente crítico diante do uso de esquemas interpretativos de tipo corporativo ("que ignoram o setor empresarial") e das consequências da centralização. Para o autor, a "centralização" das negociações foi em larga medida o resultado da força dos empregadores e não de sua fraqueza, tese que encontra apoio em
} Moene e Wallerstein (1995) e em Streeck (1985) 


\section{A CRESCENTE HOSTILIDADE DAS EMPRESAS AO SINDICALISMO}

Submetidas a um ambiente mais turbulento, a busca por maior flexibilidade e desregulamentação das normas de utilização da mão de obra, juntamente com os esforços por redução de custos, vem levando à crescente oposição dos empresários aos sindicatos. A ela muitos autores creditam a redução das taxas de sindicalização e o recuo do sindicalismo em geral. Essa oposição tem se manifestado inclusive em países onde as relações entre empresas e sindicatos eram de tipo cooperativo, como na Suécia e na Alemanha. A dimensão da hostilidade ao sindicalismo depende de múltiplas situações nacionais específicas: poderio das organizações sindicais; sindicalismo mais radical ou mais cooperativo; negociações mais centralizadas ou mais fragmentadas; maior ou menor intervencionismo governamental e proteção legal ao sindicalismo; relacionamento dos sindicatos com partidos políticos, e outras características nacionais. Apesar das diferenças entre países, um fator principal tem comandado a conduta dos empresários perante o sindicalismo e a sua disposição de enfrentar o poder dos dirigentes sindicais: o grau de exposição das empresas à competição, aspecto dependente cada vez mais da profundidade da abertura da economia nacional ao mercado internacional e da remoção de barreiras protecionistas.

Nesse quadro de uma economia cada vez mais globalizada e sujeita a mudanças rápidas, o patronato foi se tornando menos propenso a aceitar as normas restritivas e os aumentos dos custos da mão de obra impostos pela sindicalização. A rejeição ao sindicalismo aliou-se ao esforço das empresas para melhorar as relações individuais com os próprios empregados, de modo a fazer com que o sindicato não lhes pareça necessário e os trabalhadores, dirigindo-se diretamente às gerências, possam "resolver seus problemas". Às políticas mais duras de enfrenta mento com poder sindical, de "pagar para ver", no estilo macho management, juntaram-se, pois, medidas de valorização e integração dos empregados, programas "participativos" e "integrativos"14.

${ }^{14}$ Esse tipo de política foi aplicado especialmente pelas multinacionais ,japonesas no Ocidente. Nos EUA, até a chegada delas, existiam sindicatos em todas as fábricas de automóveis e em quase todas as de autopeças da CM, Ford e Chrysler. Em 1992, o mesmo já não acontecia em várias fábricas, todas japonesas: quatro da Honda, uma da Nissan, três da Toyota e uma da Subaru-Isuzu (Unterweger, 1988, p. 18).
Para os autores que colocam mais ênfase nas hipóteses institucionais, em oposição às teses estruturalistas, que ressaltam as mudanças na economia e no mercado de trabalho, a hostilidade patronal estaria entre o principal fator de declínio das taxas de sindicalização. Se os motivos das quedas nos índices de sindicalização fossem estruturais, macroeconômicos, escrevem Freeman e Medoff (1987), a proporção de trabalhadores sindicalizados cairia em todos os países, mas, "em vez disso, fora dos Estados Unidos, a sindicalização vem aumentando em toda a parte, frequentemente em grande número" (Freeman \& Medoff, 1987, p. 274). (Os autores estão escrevendo em fins da década dos 70.) Para eles, os "fatores estruturais aumentam ou diminuem a dificuldade de organização mas não determinam a sindicalização"(p. 276).

Freeman e Medoff estimam que de um quarto à metade das derrotas dos sindicatos nas eleições para aceitação ou não do sindicato nas empresas vêm da oposição patronal e do uso de "práticas desleais" por parte dos empregadores (pp. 277 e 287). Naquele momento, os EUA pareciam efetivamente ser um "caso singular", talvez único, de declínio do sindicalismo, embora em outros países, como a França e a Holanda, as taxas de sindicalização já tivessem começado a declinar. Posteriormente, Freeman (1995) volta a enfatizar os fatores institucionais diante dos econômicos. O autor entende que mudanças na composição do emprego não explicam diferenças nas taxas de sindicalização, porque elas ocorreram de modo similar em todos os países. No caso norte-americano, o fator principal das décadas seria a hostilidade empresarial ao sindicalismo e à negociação coletiva "num grau nunca visto em outro lugar do mundo livre"(p. 313).

No mesmo sentido, Farber (1990, apud Kochan \& Weinstein, 1994, p. 487) argumenta que alterações na composição da força do trabalho, mudanças demográficas e ocupacionais responderiam por apenas $20 \%$ do total do declínio das taxas de sindicalização dos EUA. Como uma das evidências do peso da ação antissindical do patronato, Kochan e Weinstein (1994, p. 487) afirmam que $70 \%$ dos empregadores do setor privado contratam consultorias externas para atuar contra as campanhas de sindicalização organizadas pelos sindicatos, enquanto $40 \%$ dos locais de trabalho não obtêm um acordo coletivo com os empregadores, mesmo depois de terem ganho as eleições para a representação. 
Para Kochan (1988), cerca da metade das perdas de associados dos sindicatos norte-americanos seria devida a alterações estruturais na economia entre 1977 e 1984. As perdas restantes viriam de outros elementos de natureza institucional.

Ocorre que o desafio patronal ao sindicalismo não se limitou a recusar reivindicações trabalhistas (na verdade, cada vez menores) mas também a não reconhecer as organizações sindicais (onde a legislação possibilitava essa prática). Os sindicalismos dos países de relações de trabalho pluralistas, em comparação com os "neocorporativos", foram os mais afetados. Tal é o caso especialmente do Reino Unido e dos EUA. No primeiro país, até pelo menos a década dos 70 , as relações de trabalho eram denominadas de "voluntaristas", quer dizer, fundadas na aceitação voluntária dos resultados das negociações pelas partes (sindicatos e empresas). A intervenção governamental era mínima. Nenhuma legislação tornava obrigatórios os acordos. Os contratos bilaterais não tinham força de lei. Como o reconhecimento do sindicato por parte do patronato é voluntário e pode ser retirado, de acordo com a maior ou menor predisposição das empresas, a existência do sindicato como interlocutor e representante dos empregados depende da relação de forças entre as partes dentro da empresa, que determinará os custos e as vantagens para o patronato de tentar retirar o sindicato de dentro dos locais de trabalho. Mesmo onde anteriormente havia negociações, ou seja, o sindicato ou os sindicatos eram aceitos, e as companhias negociavam e fechavam acordos com eles, é possível seu desreconhecimento por ocasião do término do contrato e negociação de outro ${ }^{15}$.

\footnotetext{
${ }^{15}$ No modelo de relações descentralizadas e voluntárias de relações industriais, em que as negociações nos locais de trabalho são predominantes, as oscilações do mercado de trabalho e dos ciclos de negócio tenderiam a ter forte repercussão sobre o sindicalismo. O poder sindical estaria mais dentro das firmas do que fora delas. Essa seria a explicação da escola liberal-pluralista para as características e para a crise atual do sindicalismo britânico. O leitor encontrará uma crítica radical dessa concepção em Howell (1995): "Para os pluralistas, o crescente poder dos trabalhadores refletiu mudanças nas condições de trabalho e não recursos organizatórios ou estratégicos derivados dos sindicatos ou recursos políticos derivados do Estado" (p. 157). Segundo Howell (e outros), o poder sindical britânico derivou amplamente de razões políticas e da intervenção estatal favorável aos sindicatos e relacionados com os períodos em que o Partido Trabalhista esteve no governo. Para McIlroy, o voluntarismo, por sua ênfase na barganha coletiva e na valorização da ausência de lei, obscurece a questão do poder, despolitiza a atuação sindical e desvia a atenção das estruturas
}

Especialmente depois da série de leis do governo Thatcher, aumentou o número de empresas que deixaram de reconhecer o sindicato, que significa o fim dos contratos coletivos e também da obrigação dos empregados de se filiar aos sindicatos com os quais a empresa fechava um acordo (closed shop) ${ }^{16}$. No setor privado, o reconhecimento de sindicatos

de poder e de dominação "que poderiam produzir mudanças mais fundamentais" (McIlroy, pp. 236237). (Urna análise sintética das mudanças no sindicalismo britânico, de fácil acesso pp. 236237). (Urna análise sintética das mudanças no si
pelo público brasileiro, encontra-se em McIlroy, 1997.)

${ }^{16}$ Literalmente, a "oficina fechada". Segundo o sistema, todos os trabalhadores, sob pena de perda de emprego, estão obrigados a se filiar aos sindicatos com os quais a empresa negocia um contrato coletivo. Algumas vezes, o trabalhador já deve estar sindicalizado para obter o emprego (pre-entry shop); em outras, precisa sindicalizar se para continuar empregado (postentry shop). Antes das leis do governo Thatcher, calcula-se que, em 1978, cerca de 5,2 milhões de empregados na indústria britânica (um em cada quatro) estavam no sistema de "oficina fechada" (closed shop), dos quais cinco entre seis na situação de post-entry, quer dizer, devendo aderir ao sindicato depois de obter o emprego (Marsh, 1984, p. 43). Mas há diferença no sentido do termo closed shop no Reino Unido e nos EUA. Os americanos denominam de "oficina fechada" (closed shop) o que corresponde ao pre-entry shop dos ingleses. Já a cláusula da "oficina sindicalizada" (union shop) nos EUA assemelha-se à post-entry shop britânica. Nos EUA, a cláusula da "oficina fechada" (closed shop) foi tornada ilegal pela lei Taft-Hartley de 1947 e depois permitida apenas para a indústria da construção civil. A "oficina sindicalizada" (union shop) é permitida e legal em $60 \%$ dos estados americanos. O requisito de ser membro do sindicato para conseguir emprego não significa que a filiação ao sindicato esteja aberta a quem quiser aderir. É necessário que o pedido de sindicalização seja aceito pelo sindicato. Em certos ofícios, muitas barreiras discriminatórias existiam expressamente. Até a Lei dos Direitos Civis, de 1964, muitos sindicatos, notadamente sindicatos de ofício, não aceitavam a filiação por motivos de sexo, raça, religião ou nacionalidade. Alguns sindicatos, como o dos Carpinteiros, eram sindicatos de pai-para-filho, para usarmos um termo de Merkel (1983): "Urna pessoa só era admitida como aprendiz ou membro se seu pai fosse do sindicato. Todos os demais, em particular negros e mulheres, eram mantidos de fora" (p. 136). Com isso, mediante a cláusula da "oficina fechada", ao controlar a filiação, o sindicato pretendia controlar a oferta de mão de obra, com a intenção de elevar seu preço no mercado de trabalho. A "oficina fechada" foi defendida - e aplicada quando possível - principalmente pela AFL, que reunia sindicatos de ofício. A cláusula da "oficina sindicalizada" (union shop) não encontrava tanta resistência da parte dos empregadores, porque a empresa era livre para contratar empregados. A obrigação de filiar-se ao sindicato com o qual existia acordo vinha posteriormente. O prazo mínimo para sindicalização geralmente é de trinta dias, embora possa ser ultrapassado. Se o trabalhador não se sindicalizar, o sindicato pode exigir do empregador que ele seja despedido. Do ponto de vista do empregado, a filiação não está ligada apenas à ideia de fortalecer o sindicato com vistas à obtenção de melhores salários e outras vantagens. A sindicalização serve também como um elemento de proteção contra dispensas e punições consideradas injustas, uma vez que o empregado pode recorrer ao representante local do sindicato e o assunto ser levado a discussão, dependendo do acordo coletivo específico. "Numa empresa não sindicalizada, um 
de trabalhadores manuais para fins de negociação coletiva por parte de empresas caiu de 70,3\%, em 1984, para 56,2\%, em 1990. Para empregados não manuais, a queda foi de $48,7 \%$ para $41,0 \%$ nos mesmos anos (Beaumont \& Harris, 1995, p. 389). Entre 1988-1994, ocorreram 391 "desreconhecimentos" de sindicatos no Reino Unido, mas apenas 87620 trabalhadores foram afetados por "desreconhecimentos" entre 1988 e 1994 (Gall \& McKay, 1994, p. 436). A conclusão dos autores é que, "apesar dos novos desenvolvimentos na área das relações trabalhistas, os desreconhecimentos permaneceram insignificantes e marginais fora de alguns poucos setores" (p. 443).

$\mathrm{Na}$ verdade, Gall e McKay entendem que os desreconhecimentos "não devem ser vistos como o grande problema para a maioria dos sindicatos e que seria errado atribuir a eles muita significação, particularmente quando o número de casos é ainda pequeno" (p. 434). Várias pesquisas indicaram que o patronato britânico não fez muito uso da nova legislação dos Conservadores, especialmente quanto à cláusula da closed shop. Mais comum foi o recurso à Suprema Corte para a obtenção de decisões que prejudicaram os sindicatos (injunctions). As novas leis trabalhistas foram usadas especialmente no setor tipográfico e naval e nas pequenas empresas, Com base num conjunto de pesquisas, Marsh (1992) julga que as leis criminais desempenharam um papel mais importante nos resultados das disputas trabalhistas. Na greve dos mineiros de 1984 1985, na Inglaterra e no País de Gales, a polícia estava melhor preparada para enfrentar os piquetes de greve. Numerosas prisões $(7$ 917) foram feitas sob acusação de perturbação da ordem pública e processos foram abertos. Muitas acusações foram feitas com base na Lei de Conspiração e Proteção da Propriedade. Mas a maioria das acusações não foram muito graves e disseram respeito a perturbação da ordem pública pelos piquetes de greves (Marsh, 1992, pp. 102-103).

Talvez mais grave para o futuro do sindicalismo britânico tenha sido o encolhimento, na década dos 90 , da proporção de trabalhadores

empregado pode ser despedido por vontade ou capricho. O empregador não tem de dar uma boa razão para a dispensa. De fato, nenhuma razão é necessária." A restrição que existe vem de violação de leis federais ou estaduais por parte do empregador, como, por exemplo, atualmente, discriminação racial (Merkel, 1983, p. 130). Diante das dificuldades de encontrar um termo em português equivalente, decidimos manter os termos em inglês: closed shop e .union shop. representados por acordos coletivos, especialmente no setor privado: somente 38\% dos empregados (num total de 21,9 milhões) estão cobertos por acordos coletivos, mais da metade no setor público (Milward; Stevens; Smart \& Hawes, 1992, apud Howell, 1995, p. 153). (Dados da Employment Gazette, $\mathrm{n}^{\circ}$ 5, May 1995, apud OIT 1997-1998, baseados num survey domiciliar, davam $25,6 \%$ de trabalhadores cobertos por acordos coletivos no Reino Unido em 1994.)

A crítica ao modelo pluralista

Nos EUA, o modelo pluralista, de negociações fragmentadas e de eleições nos locais de trabalho para a aceitação da representação através do sindicato votado pelos empregados, é criticado por grande número de autores. Várias propostas - como as da Comissão Dunlop, em 1995 - têm sido feitas para alterá-lo mas sem êxito (cf., entre outros, Heckscher, 1996; Freeman, 1995; Strauss, 1995; Kochan; Katz \& McKersie, 1994; Craver, 1993; Freeman \& Pelletier, 1990; Moody, 1989; Kochan, 1988; Freeman \& Medoff, 1987; Lipset, 1986b). No passado, o sistema institucionalizado em 1936 na Junta Nacional de Relações Industriais (INRI) teria ajudado a implantação de sindicatos nos locais de trabalho e protegido os empregados das retaliações patronais. Hoje, agiria em sentido contrário ao obrigar, numa situação politicamente adversa, os empregados a decidir, em cada local de trabalho ("unidade de barganha"), se querem ou não ser representados por sindicato, votação que deve ser renovada ao final de cada contrato. A votação favorável ao sindicato não significa necessariamente que todos os empregados passem a ser sindicalizados, porque muitos contratos não incluem cláusulas de union shop que obriguem os trabalhadores a se filiar sob pena de perda de emprego. Ademais, a votação favorável ao sindicato não significa que haverá negociação com a empresa. Em 1983, em 37\% das "unidades de local de trabalho" em que haviam ganho as eleições para obtenção do certificado de representação, os sindicatos não lograram assinar contratos com as empresas. A proporção de unidades de local de trabalho que não conseguiram negociar um contrato ou renovar contratos que se extinguiram é estimada em 44\% (Dickens \& Leonard, 1985, p. 328).

$\mathrm{Na}$ base do modelo norte-americano estaria a concepção de que os proprietários têm o direito de administrar suas empresas enquanto os representantes dos sindicatos teriam o direito de discutir os impactos das decisões gerenciais sobre os trabalhadores. Nos locais de trabalho, a 
orientação para o controle do emprego e tarefas (job control) teria sido outro dos princípios da JNRI. Tratava-se de uma concepção guiada pelo princípio de obter uma "luta leal", destinada a estabelecer regras do jogo justas que capacitassem os sindicatos a enfrentar os empregadores em pé de igualdade (Heckscher, 1996, p. 43). Mas o modelo ter-se-ia tornado crescentemente inadequado. Ele não mais permitiria aos sindicatos boas regras do jogo para enfrentar as empresas diante das mudanças ambientais. Notadamente nos locais de trabalho, o sindicalismo americano teria poucos recursos para enfrentar as novas políticas patronais caracterizadas, de um lado, por uma atuação dirigida ao empregado individual, como programas de Trabalho Participativo, Círculos de Qualidade, Qualidade de Vida Operária e, de outro, por uma crescente oposição aos sindicatos (Kochan; Katz \& McKersie, 1994, especialmente cap. 6; Heckscher, 1996).

Segundo os críticos do modelo americano, as autoridades governamentais estar-se-iam tornando tolerantes com os empresários que burlam as regras eleitorais nas empresas em que os empregados devem votar para decidir se querem ou não ser representados por um sindicato (certification elections) e utilizam "práticas desleais", em princípio, proibidas pela Junta Nacional de Relações Industriais ${ }^{17}$. O esquema explicativo que enfatiza o papel da JNRI poderia ser resumido da seguinte maneira: nos EUA (e em países de negociação descentralizada, ou mesmo fragmentada, por empresa ou local de trabalho como no Reino Unido), a globalização estaria expondo mais fortemente as empresas à competição e à necessidade de rebaixamento de custos. Desse modo, os empresários tornarse-iam mais resistentes aos sindicatos. A ênfase na "hostilidade empresarial" apoia-se em dados que mostram que os sindicatos, de fato, obtêm vantagens para seus membros, tanto do ponto de vista salarial como de benefícios. Com isso, tornariam as "empresas sindicalizadas" (que negociam com sindicatos) menos competitivas diante das que não o são (quer dizer, onde não há contratos coletivos). Em comparação com outras

${ }^{17}$ Um pequeno número de eleições para a obtenção de certificados de representação é conduzido por juntas de relações de trabalho estaduais ou pela Junta Nacional de Mediação. Para estados da federação em que informações puderam ser coletadas, Dickens e Leonard (1985) estimaram que, em 1980, a média de trabalhadores em eleições supervisionadas pela JNRI era mais de quatro vezes superior à das supervisionadas por entidades estaduais. No caso da aquisição de novos sindicalizados mediante eleições nos locais de trabalho, provavelmente menos de $8 \%$ vinham de eleições supervisionadas por entidades de governos estaduais (p. 325). na mesma situação, as empresas "não sindicalizadas" receberiam um "prêmio", que seria custos menos elevados com a mão de obra, para não falar da liberdade de atuação decorrente da inexistência de acordo coletivo.

A influência da ação sindical sobre as empresas é mais forte e mais facilmente medida em países como os EUA e o Reino Unido, onde as negociações são descentralizadas e as vantagens obtidas pelos empregados podem ficar restritas a uma dada firma, ou unidade de trabalho, numa proporção muito mais elevada do que nos países de barganha nacional que envolvem organizações de cúpula dos empresários e dos trabalhadores. Nesses sistemas pluralistas, os contratos de trabalho, quando existem, são minuciosos e abrangentes. Mas há a possibilidade da existência de empresas que não reconhecem o sindicato e, assim, não há contrato coletivo. Por isso, nos EUA e no Reino Unido, os custos da sindicalização são mais elevados e visíveis, comparando-se, de um lado, os salários e benefícios dos empregados em empresas (ou unidades de trabalho) que negociam com os sindicatos e, de outro, os benefícios dos empregados em empresas que não negociam.

No cotejo entre "empresas sindicalizadas" e "não sindicalizadas", Freeman e Medoff (1987) estimam que a força de trabalho sindicalizada "é substancialmente mais bem paga" e que a diferença média, nos anos 70 , entre sindicalizados e não sindicalizados foi da ordem de 20\% a 30\%" (p. $62)^{18}$. Entretanto, para os autores, os efeitos sobre o PNB dos EUA dos "salários sindicais monopolistas", quer dizer, salários que não são determinados pelo jogo do mercado mas impostos pelos sindicatos, seriam pequenos: da ordem de $0,2 \%$ a $0,4 \%$ (em 1980).

Os custos econômicos, extremamente baixos, dos efeitos da ação sindical na economia nacional, tal como calculados por Freeman e Medoff (analistas simpáticos aos sindicatos), minimizam as dimensões das críticas liberais mais fortes ao sindicalismo, como as de Reynolds (1986). Para esse autor, "os sindicatos reduzem a renda nacional pela mesma razão que outros cartéis e monopólios o fazem: restringem a produção, deformam a estrutura relativa dos preços e levam à má distribuição dos recursos. Preços determinados pelos sindicatos (union pricing) desviam a força de trabalho dos empregos de alta produtividade para os de baixa. Além disso, os

${ }^{18}$ Um resumo do livro de Freeman e Medoff, tratando do mesmo assunto, encontra-se em Freeman (1986). 
sindicatos diminuem a produtividade no trabalho ao limitar a flexibilidade empresarial, opor-se às novas tecnologias, forçar o emprego de trabalhadores além do necessário (featherbedding), impor regras de trabalho restritivas e perturbar a produção através de greves, ameaças de greves e outras táticas de confronto (adversarial tactics) (p. 235)"”.

Mas, no estudo dos efeitos da ação sindical sobre os lucros e produtividade das empresas, talvez conviesse separar as duas faces de atuação sindicais que Freeman e Medoff distinguem, inspirados no conhecido trabalho de Hirschman (Exit, Voice, and Loyalty): a) a face sindical "monopolista", resultante de obtenção de vantagens excessivas para os trabalhadores sindicalizados, que teria efeitos negativos sobre a economia e os trabalhadores em geral e b) a face de "voz" (protesto, reação coletiva) dos sindicatos que teria efeitos positivos sobre o desempenho das empresas e sobre o conjunto dos trabalhadores. O efeito "voz" predominaria sobre o efeito "monopolista" e, no final, "pesadas as coisas, o sindicalismo parece melhorar em vez de prejudicar o sistema social e econômico" (Freeman \& Medoff, 1987, p. 32. Para mais detalhes, ver especialmente, cap. 1, "Uma Nova Imagem do Sindicalismo dos Estados Unidos"). Os cálculos dos efeitos gerais da sindicalização sobre a economia nacional, de todo modo, são bastante complicados, porque há um efeito menos detectável: o que vem da tendência à equiparação dos salários e benefícios do setor empresarial que negocia com sindicatos para empresas que não negociam, ou seja, um efeito de difusão de vantagens (Freeman \& Medoff, 1987, Cap. 3: “O Efeito Salarial Sindical”).

Em 1997, os salários semanais médios dos trabalhadores sindicalizados seriam $34 \%$ mais elevados do que os dos não sindicalizados, ou seja, 640 dólares semanais contra 478 para os não sindicalizados. Os maiores benefícios da sindicalização seriam auferidos pelas mulheres e pelas minorias. As mulheres sindicalizadas ganhariam $40 \%$ a mais, em média, dos que as não sindicalizadas; os "afro-americanos" sindicalizados, $44 \%$, e os "latinos", 53\%. As porcentagens acima referem-se às médias e envolvem muitos tipos de atividades. Os benefícios salariais da sindicalização são, no entanto, altamente variáveis e tendem a ser tanto mais elevados quanto mais baixas são as qualificações e os salários, o que explica as vantagens que "afro-americanos" e "latinos" receberiam. Por exemplo: operadores de máquinas sindicalizados teriam salários semanais de 724 dólares contra 501 dos não sindicalizados. Para trabalhadores do setor agrícola, florestal e da pesca, seria de 74\% (505 dólares para sindicalizados e 290 para não sindicalizados). Em compensação, para profissionais liberais e pessoal administrativo de qualificação mais elevada, seria de apenas 5\% (Employment and Earnings, Departamento do Trabalho e Emprego dos EUA, janeiro de 1998, site da AFL-CIO, 22.6.98). Em outros termos: a sindicalização seria mais vantajosa para os negros e latinos do que para os brancos; para as mulheres do que para os homens; para os não qualificados do que para os qualificados; para os deficientes físicos do que para os não deficientes (Freeman \& Medoff, 1987; Metcalf, 1990).

Os benefícios para os empregados sindicalizados, em comparação com os não sindicalizados, variam segundo as conjunturas do mercado.Com relação a períodos, Benjamin (1986) escreve que, durante a Grande Depressão dos anos 30, os trabalhadores sindicalizados tinham salários, em média, $40 \%$ maiores do que os dos não sindicalizados. Durante os últimos anos da década de 30 e os primeiros da década de 40, as condições econômicas melhoraram, os salários subiram e as diferenças diminuíram. Ao final da Segunda Grande Guerra, os trabalhadores sindicalizados estavam ganhando, em média, apenas $5 \%$ a mais do que os não sindicalizados. Depois disso, nas duas décadas seguintes, os sindicatos foram capazes de aumentar a diferença para uma média entre $15 \%$ e $20 \%$. Durante os anos 70, o "prêmio" para empresas não sindicalizadas estaria em torno de $30 \%$ e, para inícios da década dos 80, Benjamin estima que, apesar das perdas sindicais, a diferença entre empresas nas duas situações seria em média de $25 \%$. O efeito mais imediato dessa diferença teria sido a redução do montante de força de trabalho empregada nas "empresas sindicalizadas". De modo mais preciso: considerando $25 \%$ a mais de benefícios, a redução média do emprego seria provavelmente de $16 \%$ a $18 \%$, "embora alguns estimem que seria maior do que 20\%" (p. 211-212).

Vão na mesma direção outras pesquisas sobre as consequências da sindicalização sobre salários e níveis de emprego e seus efeitos mais fortes nos EUA do que em outros países. Para Blanchflower e Freeman (1992) que compararam os EUA com cinco outros países desenvolvidos no período entre 1985 e 1987 (Reino Unido, Alemanha Ocidental, Áustria, Austrália e Suíça) - os efeitos da sindicalização sobre salários e benefícios seriam maiores do que em outros países desenvolvidos mas não no tocante a outros benefícios. A pesquisa de Blanchflower e Freeman (1992) confirma resultados de outras investigações, que estimam os "prêmios" para as 
empresas advindos da inexistência de sindicatos em aproximadamente $15 \%$ nos anos 60, tendo subido para $20 \%$ a $25 \%$ nos anos 80 (p. 71).

No caso do Reino Unido, onde também as negociações são fragmentadas, Metcalf (1990), com base num conjunto de dados e estudos de outros autores, relata que, para os empregados, o "prêmio" médio da sindicalização estaria em torno de $10 \%$ de aumento de salário. No entanto, há muitas situações que devem ser tidas em conta. No Reino Unido, além da mera existência de sindicato, seria preciso distinguir as unidades de trabalho onde existe o pre-entry closed shop e onde existe o post-entry closed shop. Para trabalhadores semiqualificados, os salários, quando existe pre-entry closed shop, seriam 14\% mais elevados e $9 \%$ quando existe postentry closed shop. A média de aumento para todos os empregados seria de $8 \%$. Baixaria para $6 \%$ quando existem apenas sindicatos, mas não closed shop (p. 291). O pre-entry closed shop, para o empregador, seria, assim, a pior situação. Mas os custos da sindicalização, para as empresas, não devem ser calculados apenas do ângulo salarial. Em comparação com trabalhadores não sindicalizados, os membros dos sindicatos têm maiores probabilidades de receber mais vantagens por motivos de doença, vales para refeições, pagamento de aposentadoria profissional e férias mais longas (Blanchflower \& Oswald, 1988 apud Metcalf, 1990, p. 291).

Para a AFL-CIO, as probabilidades de trabalhadores americanos sindicalizados receberem benefícios médicos e aposentadorias seriam, nas grandes empresas, significativamente mais elevadas. Em 1995, 85\% dos trabalhadores sindicalizados receberiam assistência médica contra $74 \%$ dos não sindicalizados (US Dept. of Labor Employee Benefits Survey, site da AFL-CIO de 8.8.98).

Tal como nos EUA, as camadas de trabalhadores britânicos mais pobres e as minorias étnicas tendem a obter maiores benefícios com a sindicalização. No caso do Reino Unido, em comparação com a média salarial dos trabalhadores manuais brancos (em 1982), os antilhanos sindicalizados ganhavam $11 \%$ menos, enquanto os não sindicalizados ganhavam $19 \%$ menos. No caso dos asiáticos, os sindicalizados ganhavam $16 \%$ menos e os não sindicalizados, $19 \%$. Em média, comparando com os antilhanos, os salários dos operários brancos eram 14\% mais altos (Metcalf, 1990, p. 298). Em outros termos: a sindicalização não igualava os salários entre brancos e não brancos (e isso talvez fosse impossível em razão das diferenças de qualificação) mas reduzia as diferenças.

Esses efeitos positivos da sindicalização referem-se aos empregados. Para as companhias, a pressão sindical por salários e outros benefícios tenderia a diminuir a produtividade e a rebaixar a oferta de emprego. No Reino Unido, as pesquisas teriam comprovado que, em média, as empresas não sindicalizadas tinham produtividade mais elevada e que os locais de trabalho não sindicalizados tendiam a ter mais trabalhadores do que os sindicalizados. Entre 1980 e 1984, nas empresas com closed shop, havia quatro vezes mais probabilidade de ocorrer diminuição de emprego. Mas novamente cumpre considerar os contextos em que operam as companhias. Nas empresas em situação de monopólio, os sindicatos têm maiores chances de elevar os salários sem correr o risco de os empregos diminuírem. Em situações de concorrência, os efeitos das pressões sindicais podem ser mais negativos para os empresários porque a elevação dos preços encontra mais dificuldade para ser transferida para os consumidores e as empresas podem perder capacidade de competição e os trabalhadores, o emprego. Ademais, para utilizar as palavras de Metcalf, "a habilidade do sindicato de capturar excesso de lucro das empresas é maior quando o próprio estabelecimento ocupa uma posição forte no mercado" (p. 293).

A tese das vantagens obtidas pelos sindicatos a favor dos empregados, e a subsequente hostilidade patronal, usada especialmente para explicar o declínio da sindicalização nos EUA, permite uma indagação: se os sindicatos são suficientemente poderosos no sentido de elevar significativamente as vantagens concedidas aos seus membros e tornar as empresas sindicalizadas menos competitivas, por que o desejo dos trabalhadores de ser representados por sindicatos não é reforçado, assim como a disposição de enfrentar o patronato votando a favor da aceitação do sindicato? Por que os sindicatos que têm força suficiente para aumentar os benefícios dos empregados e redividir lucros não conseguem enfrentar as empresas? Uma resposta mais ampla, e de mais difícil verificação empírica seria que há limites para a obtenção de vantagens por parte dos sindicatos. A resistência patronal tornar-se-ia mais vigorosa quando as concessões (salários e benefícios) aos empregados começam a pôr em risco a sobrevivência da companhia. Estamos pensando em empresas privadas em situações de competição, em que a transferência de custo para os produtos e 
para os consumidores mais dificilmente acontece. A partir de um dado teto (que pode variar bastante) a ação sindical não consegue avançar porque determinaria a falência da empresa e a perda de empregos.

Nessa linha de raciocínio, Blanchflower e Freeman (1992) consideram que o estímulo que os empregadores têm de opor-se aos sindicatos é relativamente maior do que o dos empregados de lutar pelo reconhecimento da representação sindical porque sabem que os sindicatos não podem elevar demais as suas vantagens para não favorecer os competidores e arriscar o emprego (p.71). Já para as empresas, num mercado competitivo e cada vez mais exposto, em que têm de enfrentar competidores internacionais de custos mais baixos, o estímulo a resistir à presença de sindicato seria mais forte. A disposição para a resistência viria não somente das diferenças nos custos relacionados com salários mas também da necessidade de maior flexibilização e liberdade de organização que certas "práticas sindicais restritivas" impõem, dificultando o progresso tecnológico e mudanças organizacionais internas. Exemplos dessas práticas restritivas que reduziriam a flexibilidade seriam a impossibilidade de permuta de tarefas entre trabalhadores e a obrigatoriedade de utilizar mais empregados do que o necessário para realização de uma dada tarefa (feather-bedding).

No sistema americano, nota Strauss (1995), a negociação coletiva efetivamente reduz a flexibilidade, embora não a elimine inteiramente. Uma vez "sindicalizada", isto é, uma vez firmado o contrato com o sindicato, a empresa tem menos liberdade para tomar decisões, ao contrário do que acontece no continente europeu (p. 342).

As observações acima conduzem a uma avaliação negativa do papel dos sindicatos no desempenho das empresas e na expansão ou manutenção dos empregos e a uma avaliação positiva da atuação dos sindicatos na defesa dos interesses dos sindicalizados, especialmente dos mais desprotegidos (o que não significa dizer de todos trabalhadores). Mas os especialistas dos estudos das relações de trabalho, em razão da variedade de situações, geralmente concordam quanto às dificuldades de interpretar os efeitos da ação sindical sobre as companhias. Em certos casos, notadamente sob o modelo taylorista-fordista, os sindicatos atuam no sentido de "disciplinar" os trabalhadores, evitar "greves selvagens", quer dizer, não decretadas pelo sindicato, melhorar a comunicação entre a gerência e os empregados, moderar os aumentos de salário que uma conjuntura de alta demanda de mão de obra (provocada por mercado aquecido) poderia propiciar. Os contratos coletivos, válidos geralmente por dois ou três anos, estabelecem as condições e o momento em que haverá aumento salarial e/ou concessão de outros benefícios, o que facilita o planejamento de custo das firmas e outras medidas de racionalização e planejamento estratégico.

A Ação sindical pode ainda servir de estímulo para o progresso tecnológico e de melhoria da qualidade do produto. Mas, na época atual, a maioria das empresas (notadamente nos EUA) entendem que os sindicatos, precisamente por trazerem benefícios para os empregados, dificultam os avanços tecnológicos, reduzem sua agilidade e as tornam menos capazes de enfrentar as alterações mercadológicas bruscas trazidas por um ambiente mais turbulento. No final, reduziriam os lucros e a capacidade de novos investimentos. Assim, as vantagens que os sindicatos afirmam trazer para o desempenho das empresas não são vistas pelo patronato como capazes de compensar as desvantagens, especialmente em mercados altamente competitivos. Portanto, seria melhor não ter de barganhar com sindicatos e firmar contratos coletivos.

Mas a hipótese que atribui forte responsabilidade pelas quedas da sindicalização à hostilidade patronal, especialmente a atuação desleal da administração das empresas quando de eleições nos locais de trabalho para a atribuição do certificado de representação, fica enfraquecida (embora não rejeitada) pelos resultados da pesquisa de Dickens e Leonard (1985). Os autores mostram que, no período 1955-1980, embora a "descertificação" possa ter sido prejudicial para os sindicatos, ela não teria sido a principal causadora do declínio das taxas de sindicalização norte americanas, porque há muitos fatores intervenientes, que são difíceis de mensurar. Além da influência da atuação antissindical das empresas, Dickens e Leonard apontam a fraca atuação dos sindicatos no sentido de organizar novos sindicais em locais de trabalho e a diminuição da vontade dos empregados de enfrentar a administração das empresas (p. 333), quer dizer, de se filiarem a sindicatos e de entregarem a eles a responsabilidade de negociar suas condições de trabalho.

Mas entendemos que a fraqueza da hipótese da "hostilidade patronal" deve-se ao fato de que ela apenas explicaria o declínio do sindicalismo nos países de negociação fragmentada num contexto de ausência de legislação social ampla, como os EUA e o Reino Unido. Desse modo, ela não poderia 
explicar as perdas dos sindicatos em países de negociação centralizada, com legislação de proteção aos empregados e/ou forte intervencionismo governamental na área trabalhista. Assim, a variável "hostilidade patronal" parece só adquirir mais relevância quando considerada no âmbito do modelo de relações de trabalho "pluralista" e conflitivos, mas não em modelos intervencionistas ou neocorporatismo ${ }^{19}$.

\section{Os custos financeiros da sindicalização}

O modelo de relações de trabalho criado pela JNRI e mais as tradições do sindicalismo norte-americano, orientado para a barganha acentuada geralmente a nível de empresa ou de local de trabalho, dificultam aos sindicatos encontrar respostas, mesmo que apenas parcialmente satisfatórias, para estancar a perda de associados e aumentar a sindicalização. Em razão do modo como se procede a obtenção de novos membros, o sindicalismo americano conhece certos problemas que são inexistentes em outros lugares, especialmente para os países de negociação centralizada, de extensa legislação trabalhista e/ou alto intervencionismo do governo. Ocorre que, no caso norte-americano, os custos marginais da elevação da taxa nacional de sindicalização são muito elevados pelo fato de a filiação se realizar por meio da sindicalização do conjunto de empregados de um "local" (que pode ser uma fábrica ou uma empresa, ou seja, uma unidade de trabalho). Não há, a não ser excepcionalmente, filiação individual $^{20}$. Para isso, os sindicatos habitualmente contratam

\footnotetext{
${ }^{19}$ De acordo com Strauss (1995), três razões explicariam a maior hostilidade dos empresários norte-americanos ante os sindicatos. A primeira seria muito simples. As empresas podem evitálos porque as penalidades para ações antissindicais são baixas e as repercussões negativas na opinião pública são mínimas. A segunda seria de natureza econômica. Ironicamente, os sindicatos teriam tido muito êxito na defesa dos interesses dos trabalhadores sindicalizados e as diferenças de benefícios entre sindicalizados e não sindicalizados teriam aumentado bastante e superado as de Outros países. A terceira razão estaria relacionada com a ausência de um sindicalismo e de partidos socialistas nos EUA (pp. 333-334).

${ }^{20}$ Muitos "locais" estão filiados a sindicatos internacionais, quer dizer, a sindicatos nacionais norte-americanos e canadenses (o designativo "internacional" é utilizado quando a organização americana tem sindicatos canadenses filiados). Outros locais filiam-se diretamente à central e outros permanecem independentes. As tarefas principais dos locais são negociar contratos, zelar pela correta aplicação do acordo coletivo e, eventualmente, organizar greves, realizar atividades educacionais, sociais, treinamento profissional, cursos etc. Nos sindicatos organizados por indústria (industrial unions) todos os trabalhadores, qualquer que seja sua qualificação, pertencem ao sindicato. O local é dirigido por
}

"sindicalizadores" profissionais. O trabalho voluntário não é utilizado ou o é em pequena escala. Além disso, as motivações ideológicas ou partidárias que levam à realização de atividades voluntárias para o sindicato existem em grau consideravelmente inferior às que existem na Europa.

Esse traço do sindicalismo nos EUA é apontado, por Freeman e Medoff e outros, como uma das principais causas das quedas nas taxas de sindicalização americanas. Reelaborando dados levantados por Paula Voos (1982), os autores estimam que, nos anos de 1950 e 1960, os gastos feitos pelos sindicatos para filiar cada trabalhador não sindicalizado caíram acentuadamente. "Em 1953, os sindicatos gastaram 1,03 dólar (em dólares constantes deflacionados pelos salários) por membro não sindicalizado para fins de organização; em 1963, gastaram 0,91 dólares; em 1974, 0,71 dólares, com um declínio geral de $30 \%$. Usando esses números, estimamos que o declínio no esforço de organização sindical contribuiu substancialmente para a queda, no último quarto de século, da porcentagem dos trabalhadores não agrícolas recém-organizados por meio de eleições promovidas pela Junta Nacional de Relações Industriais" (Freeman \& Medoff, 1987, p. 277).

A tese do alto custo da sindicalização nos EUA é defendida também por Kochan e Wever (1991). As lideranças sindicais comumente estimariam o custo de cada novo membro em torno de mil dólares. Em 1990, calculando em $12 \%$ o índice nacional de sindicalização do setor privado e considerando as perdas de emprego nos ramos em que a sindicalização tradicionalmente era elevada, os sindicatos, para recrutar anualmente 320 mil novos membros, teriam de gastar 300 milhões de dólares apenas para manter a mesma taxa de $12 \%$, quer dizer, para ficar onde estavam. Esse valor estaria muito acima das possibilidades organizatórias e financeiras dos sindicatos (Chaison \& Dhavale, 1990, apud Kochan \& Wever, 1991, p. 371, e Rogers, 1995, p. 380). Cálculos como esses levaram Freeman e Medoff a concluir que, "no

funcionários eleitos. Muitos têm presidente, vice-presidente, secretário-tesoureiro e, dependendo do seu tamanho, podem ter funcionários remunerados. Nos sindicatos organizados por ofício, como entre Os carpinteiros, o local pode ter uma base geográfica, que organiza todos Os trabalhadores da mesma profissão, mesmo que estejam sob diferentes empregadores. Pode existir ainda um local agregado ou conjunto (amalgamated local), que é um local mais amplo, filiando trabalhadores de numerosos estabelecimentos numa mesma cidade ou indústria. Esse tipo de local pode ter várias filiais (branch) (Merkel, 1983, especialmente o capítulo "Estrutura e Funcionamento do Sindicato"). 
todo, a redução da atividade de organização parece ter contribuído para o declínio na representação sindical" (Freeman \& Medoff, 1987, p. 278).

Mas essa explicação perde força à luz de outras pesquisas. Nos EUA, o custo marginal mais baixo por sindicalizado, segundo cálculos de Paula B. Voos (citados por Freeman \& Medoff), estaria entre US\$152 e US\$ 500 dólares (em dólares de 1967). Em 1980, o custo marginal da extensão de mais um trabalhador abrangido por acordos (mas não necessariamente sindicalizado) estaria entre 375 e 1.235 dólares. O valor médio teria passado de 185 para 729 dólares (Voos, 1983, pp. 582-583). Mais elevado do que conseguir a filiação de um trabalhador "potencialmente sindicalizável" seria o custo da extensão da representação (union contract coverage) que teria passado a custar, para o sindicato, de 176 a 579 dólares per capita em 1967, para algo entre 434 a 1.429 em 1980 (Voos, 1983, p. 584).

Pelos cálculos de Voos (1984b), entre 1953 e 1978 a proporção de trabalhadores que eram membros de sindicatos declinou a uma taxa de $0,3 \%$ anuais. Se os sindicatos tivessem tentado estancar a sangria por meio de programas de sindicalização, teriam de gastar entre 163 milhões e 442 milhões de dólares (p. 44). Até aqui não há muita 'diferença com relação à tese do alto custo marginal da sindicalização nos EUA. Mas ocorre que Voos não endossa inteiramente as conclusões que Freeman e Medoff extraem de sua própria pesquisa (apresentada como tese de doutoramento em Harvard) (Voos, 1982).

A partir da amostra dos maiores 27 sindicatos americanos do setor privado, Voos encontrou que os gastos para sindicalização, entre 1957 e 1974, aumentaram apesar de pequeno declínio entre os anos 1958-1959 e 1979-1981. "Os programas de sindicalização atingiam 21,6\% dos orçamento dos sindicatos em 1953; subiram para $22 \%$ e $23 \%$ em 1956-1958 e declinaram para 19\% em 1973-1974 depois de terem afundado para cerca de $18 \%$ em 1972." A conclusão é que, durante o período, os sindicatos valorizaram outras atividades mais do que a de sindicalização (Voos, 1984a, p. 58). Em outras palavras: os gastos com a aquisição de novos membros teriam aumentado, porém menos do que outros gastos do orçamento dos sindicatos. De todo jeito, como acentua Voos, cálculos precisos são difíceis de efetuar. Se os sindicatos têm um custo sindicalizando, têm também um custo não sindicalizando. A relação custo/benefício com salários e despesas dos "organizadores sindicais" profissionais - contrapostos às compensações extras resultantes do aumento do poder de barganha que vêm da extensão da representação sindical e da redução da competição entre empresas não sindicalizadas - envolve muitos elementos, entre os quais o benefício do aumento geral do poder sindical nos estados e no país, benefício difícil de quantificar.

$\mathrm{O}$ balanço entre custos e benefícios marginais resultantes da adição de "mais um trabalhador sindicalizado ${ }^{21}$ varia bastante entre os sindicatos considerados individualmente'. Assim, é possível que, a partir de certo número de trabalhadores sindicalizados, diante da relação custo-benefício pouco vantajosa, os sindicatos tenham tido um interesse decrescente pela sindicalização, especialmente quando as dificuldades (e custos) aumentam, como é o caso dos EUA. O benefício marginal médio de uma sindicalização para o sindicato (entre 1969 e 1971) seria de menos de 18 dólares (Raisin, 1983, apud Voos, 1983, p. 578).

Ocorre, independentemente das divergências com relação aos custos e aos esforços despendidos pelos sindicatos, que o modelo americano da sindicalização por meio das eleições nos locais de trabalho sob supervisão da JNRI aumenta extraordinariamente os custos da sindicalização. Em 1992, o assistente da secretaria de finanças da AFL-CIO, Charles McDonald, apresentou os seguintes cálculos para mostrar a magnitude das dificuldades que enfrentam os sindicatos. Para manter a taxa de sindicalização do setor privado no índice de 12,4\%, seria necessário um ganho líquido de 136 mil novos membros anuais. Mas seria o oposto que estaria ocorrendo. Os sindicatos estariam sindicalizando 90 mil empregados através das eleições da JNRI. Considerando perdas anuais de 10 mil membros por desreconhecimento do sindicato e outras devido a fechamento de empresas e a outras fontes de perda de associados, McDonald calcula que, para alcançar o ganho líquido de 132 mil, seria necessário acrescentar 360 mil novos sindicalizados pelos procedimentos da JNRI. Considerando a descoberta da AFL-CIO de que, em 1985, a média de sindicalizados por organizador sindical era de 60, os sindicatos necessitariam de seis mil organizadores em tempo integral para conseguir sindicalizar 360 mil trabalhadores, apenas para

${ }^{21}$ Voos trabalhou, como dissemos, com uma amostra de 27 dos mais importantes sindicatos norte-americanos do setor privado. Os cálculos implicaram várias simulações. No caso dos custos marginais do aumento da representação sindical de mais um trabalhador, os benefícios para os sindicatos tendem a ser menores porque, em muitas empresas, os sindicatos não conseguem impor a cláusula da union shop e, consequentemente, o empregado beneficiado pelo acordo não se sindicaliza, ou seja, não contribui para o sindicato. 
ficar nos $12,6 \%$ da proporção de sindicalizados do setor privado. Os sindicatos não poderiam arcar com esses custos, ainda que fosse possível elevar o número de organizadores (McDonald, 1992, p. 22).

É claro que, aqui, se consideram apenas cálculos financeiros de vantagens e desvantagens da sindicalização. Esse tipo de cálculo não pode ser transposto sem adaptações para o sindicalismo europeu, onde o uso de "sindicalizadores profissionais" não existe, a burocracia sindical é menor, como Lipset já salientou há certo tempo (Lipset, 1961) e onde prevalecem mecanismos de tipo neocorporativo em sindicalismos unificados ou onde, mesmo nos países de sindicalismo dividido, a motivação ideológica (socialista, comunista, católica) é mais forte do que entre os trabalhadores norte-americanos. Trata-se, de fato, de um sindicalismo mais orientado para a classe no seu conjunto do que para um grupo específico de trabalhadores, como nos EUA.

\section{Capítulo 8 Os efeitos das mudanças políticas}

A leis trabalhistas e sindicais, de proteção ao trabalho e ao Asindicalismo, o modo pelo qual essa proteção (ou controle) se efetua, têm complicadas relações com o tipo de partido no governo. Partidos de esquerda tendem a promover legislações que favorecem os sindicatos; partidos de direita tendem a baixar leis que reduzem o poder sindical. Mas Trata-se de tendências que só se efetivam se todos os demais fatores forem iguais. Na prática, há tipos diferentes de partidos de direita e de esquerda, de vínculos diferenciados dos partidos com as organizações sindicais, além, obviamente, dos efeitos de outros elementos do meio social, econômico, tecnológico e cultural que afetam as políticas governamentais diante das organizações sindicais. Apesar dessas ressalvas, parece intuitivo que os sistemas de relações de trabalho não são independentes do jogo político nacional e das características do sistema político em geral. Trata-se, porém, de uma proposição muito vaga da qual ninguém discordaria. O modo específico de relacionamento entre os sistemas é que cumpre captar. No caso do presente trabalho, interessam-nos especificamente os efeitos dessa relação sobre as taxas nacionais de sindicalização. $O$ fim do socialismo e as derrotas da esquerda. O deslocamento da iniciativa econômica em benefício das empresas, o fortalecimento do poder empresarial, de um lado, a diminuição do poder do Estado e o enfraquecimento do sindicalismo, de outro lado (que em muitos países influenciavam fortemente as decisões governamentais), coincidiram, na década dos 80, com o fim dos regimes socialistas do Leste europeu e com vitórias de partidos conservadores e derrotas da esquerda no Ocidente. No conjunto, houve o deslocamento das preferências políticas do eleitorado, deslocamento que foi, segundo os conceitos tradicionais, da esquerda para o centro ou para a direita, ou, se quisermos, do socialismo para o liberalismo.

Desse ângulo, no rol dos fatores políticos que prejudicaram o sindicalismo na década dos 80 poder-se-ia incluir o colapso dos regimes comunistas da Europa Oriental. Mas é difícil estimar quanto o fím dos regimes socialistas do Leste europeu teria influído no recuo do sindicalismo e especialmente na queda das taxas de sindicalização. Em princípio, seus 
efeitos, no rol dos elementos desfavoráveis para o sindicalismo, deveriam ser reduzidos. A grande maioria dos sindicatos da Europa Ocidental, para não falar do caso do sindicalismo dos EUA, não estava sob controle de partidos comunistas. A socialdemocracia e o trabalhismo há muito tinham se colocado no campo do respeito às regras do jogo parlamentar e tinham programas políticos e econômicos que os diferenciavam muito dos existentes nos regimes comunistas. Por isso, é provável que, diretamente (se assim se pode dizer), o impacto negativo da súbita decomposição dos regimes comunistas deva ocupar posição secundária na lista dos motivos que, no Ocidente, pressionaram para baixo o sindicalismo. Todavia, invertendo o raciocínio, se o desaparecimento dos regimes comunistas não prejudicou muito o movimento sindical, parece pouco provável que possa ser incluído entre os eventos que lhe foram favoráveis. O sindicalismo é basicamente uma instituição que repousa sobre bases coletivas; por sua vez, a socialdemocracia e o trabalhismo podem ser incluídos na ampla família dos sistemas anti-individualistas e antiliberais. A hegemonia do individualismo a partir dos anos 80 dificilmente poderia estimular atitudes e valores simpáticos às organizações sindicais.

Por isso, pode-se considerar que as repercussões do desaparecimento da URSS e das Democracias Populares podem ter atingido o sindicalismo do Ocidente por vias indiretas, ou seja, pela preferência da maioria do eleitorado pelos partidos democrata-cristãos, liberais e conservadores que estariam ainda mais distantes do comunismo do que o socialismo ocidental. A hipótese aqui é que a derrocada da URSS e dos regimes da Europa Oriental favoreceu a ascensão ao poder de governos adversários do poder sindical e do sindicalismo em geral, mesmo quando os sindicatos não se identificavam com os regimes comunistas. Assim, enfrentar os dirigentes sindicais e o poder dos grandes sindicatos (como fizeram Thatcher e Reagan, especialmente) começou a render votos diante de um eleitorado mais influenciado por valores individualistas e liberais, inclusive entre os trabalhadores ${ }^{1}$. Desse ângulo, as várias medidas tomadas contra os

\footnotetext{
${ }^{1}$ Apesar da hostilidade de Reagan contra os sindicatos, e da intensa campanha da AFL-CIO a favor de Mondale nas eleições de 1984, levantamento realizado por essa central revelou que 46\% dos membros de sindicatos com menos de 35 anos e $52 \%$ dos sindicalizados brancos do sexo masculino votaram em Reagan. "A grande maioria de votos de sindicalizados a favor de Mondale foi atribuída a idosos do sexo masculino, a mulheres e a minorias raciais" (Galenson, 1986, p. 65). De modo geral, os sindicatos americanos inclinam-se para o Partido Democrata. A
}

sindicatos não seriam apenas, ou principalmente, resultado de uma ofensiva antissindical orquestrada pelo Capital mas de uma atuação que parece eleitoralmente lucrativa da parte de facções da classe política e que encontra respaldo em segmentos ponderáveis da própria classe trabalhadora, hostis à organização sindical e ao poder e privilégios de seus dirigentes, uma “oposição operária aos sindicatos", no dizer de Troy (1986, p. 101).

Desse modo, o desaparecimento do comunismo no Leste europeu provavelmente reforçou a maré individualista e liberal que deslegitimou todos os tipos de concepções holísticas, das mais radicais, como o comunismo, às mais moderadas, como a socialdemocracia e o trabalhismo.

Esquematicamente, a deslegitimação das concepções socialistas e o deslocamento das preferências eleitorais para o neoliberalismo, na Europa do Norte, prejudicaram os socialdemocratas em benefício de partidos da direita

aliança entre os democratas e os sindicatos vem de longa data. Por outra parte, alguns estudos mostram que a ação política dos sindicatos não é desprezível, especialmente quando se trata do apoio a candidatos à Câmara de Deputados. Em 1988, a AFL-CIO apoiou 379 candidatos à Câmara Federal. Os Comitês de Ação Política, patrocinados pelos sindicatos, nas eleições de 1987-1988, contribuíram com 36 milhões de dólares por candidato e também apoiaram candidatos nas eleições estaduais e na disputa por cargos municipais. Além da contribuição financeira, os sindicatos oferecem outras formas de apoio, como equipamentos, envio de correspondência, telefones, uso das malas diretas dos sindicatos etc. Nas eleições de 1976, mais de 120 mil voluntários deram mais de dez milhões de telefonemas em favor de candidatos apoiados pela central AFL-CIO. Muitos resultados favoráveis foram obtidos. Entre 1978 e 1988, mais de $50 \%$ dos deputados e senadores eleitos foram apoiados pela AFL-CIO. No período, cerca de $2 / 3$ dos candidatos apoiados por essa central foram vitoriosos, mas esse número não inclui os candidatos apoiados pelos sindicatos que não conseguiram se eleger. No período, alguns conhecidos candidatos ao Senado, como George McGovern, Birsch Mayh e Frank Church, foram derrotados nos seus esforços de reeleição. Além das modalidades citadas, os sindicatos costumam empregar lobistas para uma ação política indireta. Em 1982, os sindicatos empregavam 287 lobistas $(2,4 \%)$ do total registrado de aproximadamente $12 \mathrm{mil}$. Em contrapartida, dados da revista Fortune registravam, em 1981, 1 90(1 lobistas trabalhando para as empresas (Delaney, 1991, pp. 374-375). A ideia de que os sindicatos americanos são alheios à atuação política não corresponde à realidade. Mas, diferentemente da Europa, o que não existe no sindicalismo dos EUA é uma ligação estreita com um partido de tipo socialdemocrata, socialista, trabalhista, comunista ou democrata-cristão . Além disso, a massa de trabalhadores com frequência não acompanha a posição da liderança sindical, embora os sindicalizados tendam a ser mais fiéis às posições eleitorais adotadas pelos sindicatos e geralmente rejeitem os candidatos republicanos. Mas, ao que parece, as disposições eleitorais dos trabalhadores manuais sindicalizados e não sindicalizados variam de eleição para eleição. Dados comparativos sobre o assunto encontram-se em Galenson e Smith (1978). 
tradicional ou de novos partidos de centro ou liberais, ou de uma "nova direita"; na Europa do Sul, não só fortaleceram os partidos de direita como levaram a uma reinversão da relação de força entre socialistas e comunistas existente desde o fim da Segunda Guerra. Aqui, foram os partidos comunistas os que mais sofreram perdas. Do ponto de vista dos partidos socialdemocratas, socialistas, trabalhistas e especialmente comunistas, as derrotas sofridas foram ideologicamente tanto mais graves quanto decorreram de mudanças das preferências do eleitorado e não de golpes militares.

Esses acontecimentos transformaram inteiramente o contexto político anterior, especialmente o da Europa do Norte. Em meados da década dos 70 , período em que as taxas de sindicalização cresciam em toda a parte e o poder sindical aumentava, pela primeira e única vez na história do apósguerra havia primeiros-ministros socialdemocratas em todos os Estados da região: Reino Unido, Alemanha Ocidental, Áustria, Bélgica, Holanda, Noruega, Dinamarca, Suécia e Finlândia (Anderson \& Camiller, p. 10)².

Depois dessa década, num movimento complexo e com altos e baixos, em que um padrão Socialdemocrata da Europa do Norte (esquerda unida) e um padrão comunista/socialista (esquerda dividida) da Europa do Sul devem ser diferenciados na sua evolução, os partidos de esquerda, ou de centro-esquerda, começaram a perder votos e, depois, a ser alijados dos governos. Embora indicações da ascensão dos partidos neoliberais, conservadores ou democrata-cristãos já estivessem visíveis em alguns países, o marco principal para a série de derrotas da social democracia europeia foi a vitória de Margareth Thatcher, no Reino Unido, em 1979. Na Alemanha, em 1982, a socialdemocracia, depois de governar desde 1966, entregou o poder à democracia-cristã, que começou um reinado que só terminaria em fins de 1998. O período da hegemonia da socialdemocracia no Norte da Europa foi abalado.

\footnotetext{
${ }^{2}$ Uma avaliação da situação da esquerda europeia na década dos 70 e dos 80 acessível ao público brasileiro encontra-se na coletânea organizada por Anderson e Camiller, com artigos de vários autores sobre o recuo eleitoral dos partidos socialdemocratas, trabalhistas e comunistas na França, na Itália, na Espanha, na Alemanha, na Inglaterra, na Suécia, na Dinamarca e na Noruega. A situação sindical não é avaliada, mas o conjunto dos artigos mostra, de modo geral, as perdas de votos da esquerda aproximadamente no mesmo período em que as taxas de sindicalização declinavam.
}

Não foi um movimento que atingiu os vários países no mesmo momento e na mesma intensidade. Na Suécia, depois de um interlúdio de governo de coalizão (19761982), os socialdemocratas obtiveram três vitórias sucessivas na década dos 80 , mas sofreram uma derrota de “proporções históricas" em 1991 (Pontusson, 1994). Na Noruega, em 1981, o Partido Trabalhista foi derrotado pelo Partido Conservador (cf., para mais detalhes, Mjoset; Cappelen; Fagerberg \& Tranoy, 1994). Na Dinamarca, um governo conservador-liberal foi formado em 1982 (cf. Christiansen, 1994). Essas derrotas da socialdemocracia e os novos realinhamentos eleitorais estiveram relacionados com a crise do modelo do Estado de Bem-estar Social, que favoreceu as propostas alternativas de reformas neoliberais, e com as dificuldades da socialdemocracia de encontrar respostas aos desafios trazidos pela globalização.

Contudo, enquanto a socialdemocracia sofria perdas no Norte, os socialistas registraram avanços no Sul da Europa, superando em quase toda a parte a direita e... os partidos comunistas. Na França, em 1981, os socialistas ganharam as eleições presidenciais e obtiveram, logo depois, ampla maioria nas eleições legislativas. Na Espanha, em outubro de 1982, os socialistas do PSOE venceram as eleições, obtendo 48,4\% do total dos votos, mais do dobro do seu rival mais próximo, a Aliança Popular (Camiller, 1994). Na Itália, a desestruturação do quadro político surgido no após-guerra foi mais complexo em virtude do pluripartidarismo polarizado, da necessidade de coligações e do surgimento de novas formações partidárias ou mudanças de nomes de antigos partidos ${ }^{3}$. Mas também aí os socialistas ganharam votos na década dos 70. Nas eleições de 1983, com Bettino Craxi como primeiro-ministro, os socialistas ocuparam pela primeira vez uma posição importante no gabinete. Em 1994, porém, uma coligação neoliberal denominada "Polo da Liberdade", formada por partidos recém-criados (Liga Norte, Força Itália e Aliança Nacional), venceu as eleições. Na Espanha, a derrota da esquerda veio mais tarde, já na segunda metade dos anos 90, em março de 1996, quando o Partido Popular

${ }^{3}$ O PCI, em começos da década dos 90, mudou o nome de PCI para Partido da Esquerda Democrática, enquanto outra tendência comunista, mais ortodoxa, criou a Refundação Comunista em 1992; o Partido Democrata-cristão transformou-se no Partido Popular Italiano; o Movimento Social Italiano (ex-fascista), na Aliança Nacional. Surgiram a Liga Lombarda (posteriormente Liga Norte) e a Força Itália. 
(fusão da antiga Aliança Popular com liberais e democrata-cristãos), sob a liderança de José Maria Aznar, derrotou os socialistas do PSOE.

Esses exemplos serviram para indicar que as derrotas da esquerda, ou centro-esquerda, espalharam-se ao longo dos anos 70 e 80, e em alguns casos entraram pela década dos 90. De modo geral, iniciaram-se no Norte da Europa e atingiram primeiro os partidos socialdemocratas e trabalhistas e, mais tarde, a esquerda dos países latinos e, aí, afetaram mais fortemente os partidos comunistas do que os partidos socialistas.

Mas, no conjunto dos países europeus, especialmente a partir da segunda metade da década dos 90 , os ventos começaram a soprar para outro lado. Os socialdemocratas suecos voltaram ao governo em 1994. Na Itália, em abril de 1996, uma coligação de centro-esquerda obteve maioria no Parlamento. Em maio de 1997, os socialistas venceram na França e, em maio, os trabalhistas voltaram ao poder no Reino Unido; em outubro do ano seguinte, na Alemanha, a socialdemocracia derrotou a democracia cristã. Em fins de 1998, os quatro mais importantes países da Europa Ocidental estavam sob governos de centro-esquerda: Alemanha, França, Itália e Reino Unido. Entre os quinze países da União Europeia, onze estavam sob governos socialdemocratas e somente na Espanha e na Irlanda os socialdemocratas não tinham participação no governo.

Durante todo o período das vitórias dos partidos tradicionais de direita, ou de centro-direita, ou das novas formações de orientação neoliberal, as taxas de sindicalização tenderam a declinar. Parece, pois, pertinente a indagação: Quais os efeitos do declínio dos partidos de esquerda, ou de centro-esquerda, no recuo do sindicalismo?

De um ponto de vista acadêmico, com o retorno dos partidos socialdemocratas, socialistas e trabalhistas ao podei; tem-se a oportunidade de avaliar mais adequadamente a influência desse fator - "existência de governos amigos" - nas taxas de sindicalização. Contudo, a avaliação é, de certo modo, prejudicada porque há muitas indicações de que a esquerda, ou centro-esquerda, que volta a governar, depois de longos anos de hegemonia dos partidos de direita ou centro-direita, não é mais a mesma que deixou o poder, especialmente no sentido de tentar retomar antigos projetos e bandeiras socialistas ou mesmo, mais modestamente, reformistas, ou neocorporativos. Uma razão é que os partidos não são meros reflexos de grupos de interesses. São organizações complexas, com projetos próprios, dos quais o mais importante é alcançar o poder e conservá-lo. A adaptação às novas tendências do eleitorado - que não ocorre sem problemas - visa mantê-los politicamente competitivos. Desse modo, os velhos "partidos da classe operária" buscam novos segmentos do eleitorado, transformando-se em catch-all parties, para usar o conhecido conceito de Kirchheimer (1966), quer dizer, no caso, pôr de lado os vínculos preferenciais com a classe operária, procurando apoio nos novos segmentos assalariados da classe média ou, mais recentemente, adotando estratégias eleitorais de ampliação máxima do eleitorado. As reorientações das estratégias socialdemocratas não foram as mesmas interpaíses e também variou no tempo dentro de um mesmo país, entre outras coisas porque os efeitos da reestruturação pós-industrial foram variadas (Esping-Andersen, 1991). De modo geral, os partidos socialdemocratas, ante os desafios trazidos pela globalização e mudanças na estrutura social, adotaram uma estratégia de "partido de governo" que variou segundo os países, foi influenciada pelos grupos e facções no interior de cada partido e produziu resultados eleitorais também diferentes (Koeble, 1992).

Talvez por essa capacidade de readaptação a mudanças ambientais os votos da esquerda europeia tenham se mantido notavelmente estáveis a partir do fim da Segunda Guerra, apesar da redução da classe operária tradicional, sua principal base eleitoral. Assim, na comparação entre o total da soma dos votos dos partidos de esquerda (especialmente socialdemocratas e comunistas) nos períodos de 1944-1978 e 1979-1988, a esquerda perdeu apenas $2,0 \%$, isto é, caiu de $39,6 \%$ para 37,6\% no total de votos em 23 democracias europeias (Crewe, 1991, p. 20). No conjunto dos partidos de esquerda, em 1917-1944 e em 1945-1978, antes da tempestade da globalização, apenas na Bélgica houve perdas de votos $(2,1 \%)$. Num grupo pequeno de países (Suíça, Irlanda e Alemanha), houve estabilização ou pequeno aumento $(0,8 \%)$; crescimento médio na Suécia, na Finlândia, na Áustria e na Dinamarca $(6,4 \%)$ e forte aumento na França, na Itália, na Islândia, em Luxemburgo, no Reino Unido, na Holanda e na Noruega $(12,2 \%)$ (Bartolini, 1983, p. 157).

Nesse quadro, o Reino Unido constitui uma exceção e os prejuízos eleitorais do Partido Trabalhista não guardam proporção com o declínio numérico da classe operária. As perdas do Partido Trabalhista ocorreram de modo muito mais fundo e rapidamente do que o declínio da classe 
trabalhadora, afirma Crewe $(1991, \text { p. } 25)^{4}$. No caso inglês - o único na Europa Ocidental em que o voto de esquerda é monopolizado por apenas um partido - o sistema eleitoral de voto distrital de maioria simples em um turno (plurality) não apenas distorce a vontade do eleitorado como impede, no campo da esquerda, o aparecimento de outro partido, como acentua Mair (1996). Nunca os comunistas ou os verdes conseguiram mais de $1 \%$. O resultado do monopólio da esquerda, desfrutado pelo Partido Trabalhista, acentua Mair, significa que qualquer desilusão com o trabalhismo como partido se refletirá no desencanto com a esquerda em geral (p. 181).

A política de adaptação dos partidos às tendências dominantes do eleitorado e também a necessidade dos partidos de esquerda, quando no governo, de responder a novas mudanças na economia, pressionam os partidos a se descolar de suas antigas bases eleitorais de modo a não serem, como tentaram ser no passado, partidos de uma só classe social. Com isso, é mais difícil de medir os efeitos das mudanças governamentais sobre o poder sindical porque os partidos de centro-esquerda tendem a incorporar, quando voltam ao governo, pontos das políticas neoliberais. Apesar disso, a hipótese que defendemos é que a existência de partidos de esquerda, ou centro-esquerda, no governo tende a favorecer o sindicalismo, enquanto a existência de governos de direita tende a lhe ser prejudicial. É difícil encontrar argumentos convincentes de que, em regimes democráticos, para o sindicalismo é melhor um governo conservador do que de esquerda. Mas a questão não é somente que, para o sindicalismo, é melhor partidos socialistas, socialdemocratas ou trabalhistas no governo, especialmente quando esses partidos estão profundamente ligados aos sindicatos e frequentemente deles dependem financeiramente. $\mathrm{O}$ ponto relevante da discussão sobre as causas do declínio da sindicalização é quanto o recuo do

${ }^{4}$ As eleições de maio de 1997 não confirmaram as previsões pessimistas de Crewe de que o declínio do Partido Trabalhista poderia não ser reversível (1991, p. 23). Nas eleições de 1997, os trabalhistas obtiveram $45 \%$ dos votos e 419 cadeiras, impondo aos conservadores (165 cadeiras e $31 \%$ dos votos) sua pior derrota desde 1906. Os liberais-democratas, com 46 cadeiras e $17 \%$ dos votos, conseguiram, como terceiro partido, seu melhor resultado desde 1929 (Financial Times, 34 May 1997). Mas a favor das previsões de Crewe, os $45 \%$ dos votos trabalhistas não superaram as votações de 1945, 1950, 1951 e especialmente a de 1966, quando o Partido Trabalhista chegou a 48,1\% dos votos (Crewe, 1991, p. 22). Deve-se notar, no entanto, que esses números se referem à proporção de votantes e não à de eleitores registrados. Nesse caso, a porcentagem dos votos trabalhistas é bastante menor, entre $20 \%$ e 25\% nas eleições de 1983 e de 1987, números sugestivos do desgaste do Partido Trabalhista. sindicalismo se deveu às vitórias de partidos conservadores e às derrotas de partidos de esquerda ou, inversamente, quanto o crescimento do sindicalismo é favorecido pela existência de governos social democratas, socialistas ou trabalhistas. Vejamos mais detalhadamente esse ponto que tem sido investigado por alguns autores.

\section{O SINDICALISMO E "GOVERNOS AMIGOS"}

A variável "governo socialdemocrata" está especialmente associada a altas taxas de sindicalização. A relação foi testada estatisticamente, entre outros, por Wallerstein (1989). A variável independente foi o tempo de permanência de partidos trabalhistas, socialdemocratas ou socialistas no governo e a variável dependente, os níveis nacionais de sindicalização. A partir desses indicadores, Wallerstein encontrou que um ano de maioria governamental Socialdemocrata aumentava, na média, a taxa de sindicalização em aproximadamente $1 \%$. Governos de esquerda seriam importantes para o sindicalismo não apenas pelo apoio político mas também pelas leis que fazem votar nos parlamentos de maioria Socialdemocrata ou socialista a favor dos sindicatos. "Governos controlados por partidos socialistas, trabalhistas ou de esquerda são o melhor caminho para a ampliação da proteção legal das organizações sindicais", diz Visser, lembrando, por outro lado, que os governos de esquerda estão relacionados com a dimensão do setor público, o que, por sua vez, contribui para aumentar os níveis de sindicalização (1993b, p. 213).

A perda do governo por partidos socialistas, isto é, por partidos "mais amigos dos sindicatos", parece, assim, por várias análises comparativas, um fator correlacionado com quedas nos níveis nacionais de sindicalização. Nos cálculos de Wallerstein, no índice da variável "governos de esquerda", o valor atribuído aos EUA foi de 0,00, o mais baixo (dados até 1978), juntamente com os do Canadá e da Irlanda. No outro polo, em "índice de esquerdismo", estava, em primeiro lugar, a Suécia (dados até 1980), seguida da Dinamarca (dados até 1980) e da Noruega (dados até 1979).

Mas apenas esse fator seria insuficiente para explicar índices nacionais de sindicalização. Wallerstein examina outros fatores importantes e chega à conclusão de que a "dimensão da força de trabalho" nacional (que está ligada à dimensão da população) seria outra variável de alta correlação com as taxas de sindicalização. Esse aspecto relaciona-se com o custo 
marginal para o sindicato da filiação de cada novo associado. Esse custo aumentaria significativamente nos países de grande população. Em tais países, os sindicatos estariam mais propensos a se conformar com níveis mais baixos de adesão porque os custos para atingir o "ponto de saturação" da sindicalização seriam muito elevados, como já vimos para os euA. Segundo Wallerstein, países de pequena população podem atingir altos índices de filiação com menores custos marginais. Além disso, como já notamos, pequenos países industrializados, com limitado mercado interno, necessitam ser externamente competitivos para manter salários e empregos. Portanto, os níveis de conflito tenderiam a ser relativamente menores: trabalhadores e empresas mais facilmente se poriam de acordo e os obstáculos para a sindicalização levantados pelo patronato e/ou pelos governos não seriam muito fortes.

De modo mais específico: Wallerstein (1989) buscou relações entre nível de sindicalização (variável dependente) e as seguintes variáveis independentes habitualmente usadas para explicar diferenças nas taxas nacionais de sindicalização : a) tamanho da força de trabalho; b) governos de esquerda; c) proporção da força de trabalho em minas, manufaturas, serviços públicos e construção civil; d) proporção de trabalhadores manuais fabris (blue-collar workers). Está suposta nos cálculos de Wallerstein a hipótese de que a adesão ao sindicato é livre e a organização sindical não é perseguida pelos governos. Mas sindicalização livre teria um custo mais elevado nos grandes países do que nos pequenos.

De modo resumido: o autor encontrou que, ao lado da "importância de governos de esquerda", a única variável significativa para explicar as discrepâncias nacionais nos índices de adesão a sindicatos seria o tamanho da força de trabalho potencialmente sindicalizável em cada país. Já a composição da força de trabalho, o peso de trabalhadores industriais na força de trabalho nacional, especificamente na indústria, na mineração e na construção (que são habitualmente mais propensos à sindicalização nos países desenvolvidos), não acrescentariam muita coisa à análise comparativa dos diferenciais das taxas nacionais. Aqui, teríamos a combinação dos efeitos de dois tipos de variáveis: uma de natureza estrutural, socioeconômica (tamanho da força de trabalho) e outra de tipo político (governos "amigos" ou "adversários").
Mas outras pesquisas enfraquecem, ou rejeitam, a hipótese de uma relação estatisticamente comprovada da influência positiva de governos de esquerda sobre os sindicatos e, consequentemente, de sua capacidade preditiva sobre a evolução das taxas de sindicalização. Num esforço similar de medir os efeitos da variável proximidade/hostilidade dos governos diante dos sindicatos, Galenson (1994) classificou os governos numa escala de 5 a 1 pontos, ou seja, indo de governos mais identificados com as organizações sindicais a menos identificados. Os regimes autoritários, sob os quais sindicatos são reprimidos, ou que só permitem seu funcionamento sob controle, receberam valor 1 . Na "categoria 5" (máximo de proximidade governo/sindicato) estaria a Austrália, com o Partido Trabalhista no poder.

O primeiro-ministro Bob Hawke havia sido o presidente da central sindical australiana (ACTU) e o Partido Trabalhista Australiano havia estado no poder de 1983 até o resto da década. Para que se tenha uma ideia da identificação do governo com os sindicatos, nota Galenson que o ramo ocidental da central sindical entendia taxativamente que os sindicatos filiados à central eram parte integral do Partido Trabalhista (que estava no governo) e que as cotizações dos trabalhadores para os sindicatos serviam para garantir uma parte substancial das finanças do partido. Mesmo assim, apesar do ambiente político favorável, a taxa de sindicalização declinou 14\% durante a década dos 80 (Galenson, 1994, pp. 30 31). Do mesmo modo, ela caiu também em outros países sob governos socialistas, como na França. Inversamente, ela se manteve estável sob governos que não eram de esquerda e não tinham ligações com os sindicatos e, provavelmente, não declinaram nessas circunstâncias politicamente adversas precisamente pela força do sindicalismo, como na Dinamarca. Portanto, cabe também a hipótese de que governos de esquerda, especialmente socialdemocratas, têm mais probabilidades de ganhar eleições e permanecer no poder quanto mais forte for o sindicalismo. Aqui, parecem pertinentes os resultados da pesquisa mencionada de Cameron (1985), na qual o autor encontrou forte correlação entre a existência de governos controlados por partidos de esquerda e a força organizatória do sindicalismo: "Onde o movimento sindical é altamente inclusivo no sistema de filiação, altamente unificado no sentido de possuir pequeno número de sindicatos nacionais de trabalhadores industriais, capazes de outorgar considerável poder à confederação (como na Suécia, na Noruega, na Áustria e, numa extensão menor, na Finlândia, na Bélgica e na Dinamarca), os partidos ligados ao movimento sindical são 
capazes de controlar o governo a maior parte do tempo (apesar de perdas ocasionais como aconteceu na Noruega em 1965-1971 e desde 1981 e na Suécia em 1976-1982)" (p. 167).

$\mathrm{Na}$ Dinamarca, país em que a esquerda ficou muito tempo no governo e o sindicalismo era poderoso, depois de 1982 o governo esteve em mãos de uma coligação não socialista, mas a tradição de fazer os sindicatos participarem de decisões econômicas não mudou (Galenson, 1994, p. 32). Há, por outro lado, situações mais complexas e variadas. Na Suécia, entre 1976 e 1982, o governo esteve em mãos de uma colisão "burguesa", como são comumente denominados os partidos que não são de esquerda. Depois, em 1991, a socialdemocracia perdeu as eleições e pela primeira vez, desde 1928, o líder do partido conservador foi primeiro-ministro. De 1982 a 1991, os socialdemocratas voltaram ao governo. Entre 1991 e 1994, novo governo de coalizão do Partido Conservador com o Novo Partido Democrata. A socialdemocracia retornou ao poder depois das eleições de outubro de 1994, com mais de $40 \%$ dos votos. Durante todo o período, o declínio das taxas de sindicalização suecas foi mínimo. Provavelmente, no caso sueco (como também no de outros países onde a socialdemocracia foi afastada do poder), não houve tentativas mais agressivas dos governos conservadores e das empresas de golpear o poder sindical, ao contrário do que aconteceu em outros países, como nos EUA, sob os governos republicanos, ou no Reino Unido, sob o governo dos conservadores.

\section{O governo Thatcher e o sindicalismo}

A vitória do Partido Conservador, sob a liderança de Margareth Thatcher, em 1979, no Reino Unido, constitui um paradigma dos efeitos negativos da ascensão de um governo hostil ao sindicalismo. No caso, Tratase dos efeitos de uma variável de natureza política. De modo geral, é consensual que a conduta do novo governo para com os sindicatos responde por parte do declínio sofrido na década dos 80 . Sob o longo período de hegemonia conservadora, o sindicalismo britânico teve grandes perdas de associados, sofreu graves derrotas nas principais batalhas em que se engajou ou que se viu forçado a se engajar (como no setor mineiro e tipográfico) e conheceu um recuo generalizado. Ao final dos governos conservadores, o sindicalismo estava reduzido a um ator de segundo plano na política britânica. Todavia, não há consenso quanto à parcela de responsabilidade das perdas sindicais que podem ser atribuídas à política dos conservadores, mais especificamente às novas leis trabalhistas votadas pelo Parlamento.

Sobre o assunto, o polêmico artigo de Freeman e Pelletier (1990) vale a pena de ser analisado mais detidamente. No caso, além de descrever um exemplo específico, o trabalho é particularmente representativo de um tipo de metodologia e de explicação sobre os motivos do retrocesso do sindicalismo. Em outros termos: o artigo traz para a discussão a questão das relações entre as variáveis políticas e o declínio do sindicalismo e, por outro, situa de modo explícito as divergências entre as hipóteses estruturalistas e as institucionais, ou entre as socioeconômicas e as políticas.

O objetivo de Freeman e Pelletier foi verificar com mais exatidão quais as razões das perdas do sindicalismo britânico na década dos 80. Por meio de um "índice de leis favoráveis ao sindicalismo" (index of the favourableness of labour laws to unionism) e de um conjunto de testes de regressão, aplicados ao Reino Unido e também à Irlanda (que serviu de grupo de controle), os autores concluíram que as leis sobre o sindicalismo, o emprego e as relações de trabalho baixadas pelo governo Thatcher - em comparação com outros fatores macroeconômicos negativos relacionados com a composição do emprego - respondem pela maior porcentagem de perdas nas taxas de sindicalização. Freeman e Pelletier rejeitam a tese de que as alterações da estrutura do emprego, de declínio de setores de atividade em que as taxas de sindicalização eram elevadas, para outros menos propensos à sindicalização teriam sido a maior causa das perdas sindicais britânicas. Pelos cálculos dos autores, as alterações no mercado de trabalho favorecendo os empregados não manuais em prejuízo dos trabalhadores manuais e as mudanças de gênero (aumento do emprego feminino) implicariam a perda de 3,1 pontos percentuais na sindicalização (entre 1980 e 1986).

Mas ocorre que as quedas nas taxas de sindicalização, no período, teriam sido de 8,6\%. Sobrariam, assim, 5,5\% para "outros fatores" (p. 145). Esses "outros fatores" seriam basicamente os efeitos das leis sindicais e trabalhistas aprovadas pelo Parlamento durante o governo conservador. Por meio de vários modelos de simulação destinados a avaliar o impacto dessa legislação, Freeman e Pelletier estimam que a queda da taxa de sindicalização britânica seria de apenas $1 \%$ a $2 \%$, na hipótese de que as leis do período Thatcher não tivessem existido. 
A cadeia de raciocínio pode ser exposta da seguinte maneira: a) a sindicalização eleva os salários dos empregados e reduz os lucros das empresas; b) os empresários podem afetar significativamente a capacidade dos sindicatos de filiar trabalhadores; e c) a legislação relativa aos direitos dos sindicatos tem um papel relevante na capacidade de filiação de novos membros. Se, entre 1946 e 1973 (quando o Partido Trabalhista esteve no governo durante a maior parte do período), as leis trabalhistas fortaleceram os sindicatos, as leis do governo Thatcher atuaram em sentido contrário. Seria de sua responsabilidade a maior porcentagem das quedas nas taxas de sindicalização por aumentar a capacidade dos empresários de resistir às pressões dos sindicatos e impedir, ou dificultar, a sindicalização.

Dada a ligação profunda entre o Partido Trabalhista e o sindicalismo, as vitórias dos conservadores, talvez mais do que em outra parte, tiveram implicação direta sobre o espaço ocupado pelos sindicatos no sistema político e econômico. É possível que, em países onde a dependência do partido diante dos grandes sindicatos fosse menor, as alternâncias dos partidos no governo não produzissem o mesmo efeito. No caso britânico, o sistema bipartidário (onde desde a Segunda Guerra apenas trabalhistas e conservadores se alternam no poder) provavelmente acirrou ainda mais a política antissindical dos conservadores. O enfraquecimento do poder sindical implicava, na ocasião, atingir diretamente os rivais trabalhistas e aumentar as chances eleitorais do Partido Conservador. Os sindicatos controlam as principais estruturas do partido ou têm forte influência sobre elas. Na Conferência Anual do Partido Trabalhista, os cinco maiores sindicatos tinham cerca da metade do total de votos e o conjunto do movimento sindical, 90\% (Marsch, 1992, p. 149). As contribuições dos sindicatos para o partido, desde 1979, têm oscilado em torno de $80 \%$ do orçamento partidário, vindo a metade de apenas quatro grandes sindicatos (Fatchett, 1987, pp. 4647, apud Marsch, 1992, p. 147). Em 1987, do total dos 229 deputados do Partido Trabalhista, 104 tinham sido eleitos com apoio dos sindicatos.

Entre 1974 e 1979, os trabalhistas no governo fizeram aprovar no Parlamento um conjunto de leis que beneficiaram as lideranças e as atividades sindicais: garantia de tempo livre para militância sindical, ampliação dos direitos dos sindicatos ao acesso à informação nas empresas, criação de um serviço de conciliação e arbitragem, entre outras medidas. A situação reinverteu-se com a vitória dos conservadores. Uma série de leis particularmente duras foi votada no Parlamento de maioria conservadora.
Não caberia aqui uma descrição detalhada dessas medidas, mas, para os que não estão familiarizados com o assunto possam avaliá-las um pouco melhor, descreveremos - sem preocupação de detalhes - algumas das medidas mais prejudiciais para o poder sindical. As leis foram sendo votadas pelo Parlamento aos poucos e estenderam-se de 1980 a 1993. Assim, em 1980, foi votada a Lei sobre o Emprego; em 1982, nova lei sobre o mesmo assunto; em 1984, a Lei sobre os Sindicatos; em 1986, a Lei sobre os Salários; em 1988, 1989 e 1990, novas leis sobre o emprego e, em 1993, a Lei sobre a Reforma Sindical e sobre os Direitos de Emprego. Cada uma delas significou novo golpe sobre o poder das lideranças sindicais.

Sem preocupação de ordem cronológica, eis as principais leis: a) restrições à cláusula da "oficina fechada" (closed shop) e depois sua completa eliminação; b) restrição aos piquetes, que só passaram a ser admitidos se realizados no próprio local de trabalho em greves legais; c) eliminação das imunidades dos sindicatos de modo a permitir que sejam processados em caso de greve ou de "ação sindical ilegal"; d) definição mais restrita do conceito de "disputa sindical", tornando mais difíceis greves de solidariedade; e) obrigatoriedade de eleição para os principais cargos de direção dos sindicatos por voto secreto a cada cinco anos ;f) necessidade, para a realização de uma "ação sindical", como uma greve, da aprovação por votação secreta realizada pelo correio, com participação de pelo menos $80 \%$ dos qualificados a votar e com a apuração realizada por um "corpo independente"; g) obrigação, por parte dos sindicatos, no caso de a maioria dos associados votar a favor da "ação sindical", de comunicar à empresa (ou às empresas) os resultados da votação com sete dias de antecedência, com detalhes do resultado, além de um adicional de mais sete dias de aviso para informar sobre o começo do movimento, apresentar informações sobre sua natureza, com detalhes sobre quantos trabalhadores estarão envolvidos (em alguns casos, dando nomes); qualquer desobediência a esses procedimentos permite que o empregador, outra companhia atingida, um trabalhador sindicalizado ou mesmo um cidadão requeiram que o movimento cesse imediatamente; h) sindicatos com fundos políticos devem ter eleição dos membros que controlam essas verbas, realizada a cada dez anos pelo correio; i) trabalhadores sindicalizados que ultrapassarem piquetes de greves não

${ }^{5}$ Os secretários-gerais dos sindicatos eram designados ou eleitos vitaliciamente. Como nota Marsch (1984, pp. 3031) com uma pitada de ironia, tal como os juízes de Sua Majestade, raramente eles abandonam o cargo antes da aposentadoria. 
podem ser punidos pelos sindicatos; j) direito dos trabalhadores sindicalizados de inspecionar os livros dos sindicatos; 1) a recusa das empresas (geralmente sob pressão sindical) de empregar trabalhadores não sindicalizados foi tornada ilegal; m) ampliação dos direitos dos empregadores de despedir empregados que tomem parte em ações sindicais ilegais; $n$ ) eliminação da imunidade dos delegados de pessoal (shop stewards) que organizem ações de solidariedade a empregados punidos por terem participado de greves ilegais; o) proibição do desconto em folha das cotizações sindicais (check-off) a não ser com consentimento escrito dos filiados, consentimento a ser renovado a cada três anos ${ }^{6}$; p) liberdade dos trabalhadores de se filiar aos sindicatos de sua escolha; q) direito dos empregadores de oferecer estímulos monetários para trabalhadores sindicalizados abandonarem o sindicato $^{7}$; r) direito dos usuários de serviços públicos, no caso de greves ilegais, de processar sindicatos.

Segundo Mcllroy, "os sindicatos britânicos tornaram-se a instituição independente mais regulada do mundo" (1995, p. 250). De modo geral, o governo conservador atuou pragmaticamente, avançando passo a passo. Inicialmente, a Lei do Emprego, de 1982, não proibiu a prática da closed shop, mas colocou muitos obstáculos à sua aplicação, tal como a obrigação de ser votada a cláusula por maioria dos $80 \%$ dos trabalhadores com direito de voto (no caso de novos acordos que instituíssem cláusulas de closed shop). Posteriormente, outra Lei sobre o Emprego, de 1982, tornou obrigatório, para a continuidade de uma cláusula de closed shop já existente, o voto favorável de $85 \%$ dos empregados. Em 1988, ações sindicais destinadas a impor a postentry closed shop foram tornadas ilegais. Em 1990, outra lei sobre o emprego atingiu a cláusula da pre-entry closed shop, proibindo os sindicatos de exigir

${ }^{6}$ A tarefa de recolher assinaturas de membros do sindicato para reautorizar o desconto em folha da autorização sindical ocupa muito tempo de atividade dos funcionários sindicais e representantes do pessoal. No entanto, considera-se que essa tarefa tem o lado positivo de aproximar dos trabalhadores os funcionários e dirigentes sindicais locais e possibilitar estatísticas mais atualizadas sobre quem são os sindicalizados (IRS - Employment Revim, 1996, p. 3).

7 Em janeiro de 1994, reagindo à constituição de um conselho de trabalhadores em sua empresa, a fábrica britânica da Caterpillar, em Leicester, propôs a seus empregados a soma de 500 libras para que abandonassem o sindicato em que estavam filiados, aderissem a outro sindicato "da casa" e renunciassem a seu direito de negociação coletiva. "Esta oferta, qualificada de 'elemento de uma estratégia destinada a levar o pessoal a participar do planejamento e da tomada de decisão', foi aceita por $80 \%$ dos trabalhadores da empresa, membros até então de um dos mais importantes sindicatos britânicos" (Jefferys, 1996b, p. 270). dos trabalhadores prévia filiação sindical para obter emprego. A estratégia do Partido Conservador consistiu em levantar a bandeira do direito do trabalhador individual contra a "tirania das lideranças sindicais",

A legislação votada pela maioria conservadora no Parlamento visou enfraquecer o poder sindical mediante o aumento dos direitos individuais dos empregados diante das lideranças sindicais. Outras leis destinadas a diminuir a intervenção governamental no mercado atingiram os empregados individualmente, como a eliminação (em 1986) do salário mínimo para menores de 21 anos, os quais deixaram de contar com a proteção dos Conselhos Salariais de cunho corporativo, abolidos, afinal, em 1993. No conjunto, houve uma destruição dos organismos tripartites, alguns de grande importância para os sindicatos, como a Comissão dos Serviços de Energia e do Conselho Nacional de Desenvolvimento Econômico (Howell, 1995). Com isso, o pouco que havia de corporativismo na Grã-Bretanha foi destruído.

Porém até que ponto estariam corretas as conclusões de Freeman e Pelletier de que a legislação antissindical teve a principal parcela da responsabilidade na queda dos índices de sindicalização no Reino Unido9? É certo que ambos utilizam um conjunto de correlações e tentam, com auxílio de cálculos estatísticos, dar base mais sólida e maior precisão à investigação de fatores que, intuitivamente, parecem negativos para os níveis de sindicalização. Acontece que outros estudos, utilizando também dados detalhados sobre a evolução da sindicalização no período considerado, reduzem o peso da legislação e, indiretamente, enfraquecem as teses que acentuam o efeito de "governos hostis", e consequentemente das variáveis institucionais, na decadência dos sindicatos britânicos.

Howell, por exemplo, relativiza a importância da legislação. Para ele, os ciclos econômicos e as transformações na composição da força de trabalho "foram esmagadoramente importantes de 1979 a 1983 (um período de

\footnotetext{
${ }^{8}$ Como é fácil de imaginar, muita coisa se escreveu sobre a legislação que mudou o perfil "voluntarista" das relações de trabalho britânicas. Para Os propósitos desse livro, entendemos que bastavam as informações retiradas de alguns trabalhos de caráter mais geral sobre o sindicalismo britânico. Assim, foram usados: Visser \& Ruysseveldt (1996a); Ackers; Smith \& Smith (1996); Mcllroy (1993); Dorey (1993); Marsch (1992); e Freeman \& Pelletier (1990) (esses últimos, no entanto, não trazem as leis posteriores a 1988).

${ }^{9}$ É preciso dizer que Freeman e Pelletier não negam inteiramente a ação de outros fatores, tais como as mudanças no mercado de trabalho, a ampliação da participação feminina etc. Apenas valorizam mais a influência das novas leis.
} 
profunda recessão e de desindustrialização), mas de 1983 para a frente (quando a economia se recuperou e os sindicatos continuaram a declinar) o impacto da legislação tornou-se mais importante" (Howell, 1995, p. 168). Para o autor, ao contrário de uma opinião corrente e da de outros analistas, o Estado britânico sempre teria desempenhado papel importante no sistema de relações de trabalho britânico: "Os maiores ganhos na filiação sindical nos anos 70 foram nas áreas da economia em que a influência do Estado era importante e o poder sindical de mercado era fraco. Isso sugere que a política governamental foi uma determinante crucial para a força do sindicalismo" (p. 166).

Disney (1990), por sua vez, chama atenção para o fato de que as estatísticas vinham apontando, até 1964, um declínio secular, ainda que lento, das taxas de sindicalização do Reino Unido. Porém, depois desse ano, até 1968, elas voltaram a ter um crescimento pequeno para, finalmente, conhecerem forte expansão na década dos 70. A partir de 1980 houve uma queda abrupta. Em 1965, a proporção de sindicalizados na força de trabalho nacional potencialmente sindicalizável era de $43,2 \%$ (depois de ter chegado a 45,2\% em 1948); passou a 47,7\% em 1970 e continuou subindo para chegar a 50,4\% em 1974 (Price \& Bain, 1976, p. 340). Quando, em 1980, a sindicalização despencou, cerca de $58 \%$ da força de trabalho estavam sindicalizadas no Reino Unido.

Esses dados, à primeira vista, fortalecem a tese da influência que governos de esquerda têm no fortalecimento do sindicalismo. Mas Disney considera que cerca de $90 \%$ do declínio das taxas de sindicalização britânicas podem ser explicados pela estrutura macroeconômica (Disney, 1990, pp. 166-167). A legislação sobre as relações de trabalho do período não teria tido um efeito direto. Disney alerta para o fato de que os períodos de novas legislações estão geralmente relacionados com situações de mudança macroeconômica. Além disso, dificilmente, no curto prazo analisado por Freeman e Pelletier, as novas leis teriam tido tempo de produzir impacto catastrófico sobre os níveis de sindicalização ${ }^{10}$.

${ }^{10}$ Parece-nos importante, na análise de Disney, a separação entre ciclos e tendências. Modelos cíclicos podem esclarecer variações em torno de uma "média" estabelecida, mas que deve ser explicada, por sua vez, por fatores muitos diferentes. Tendências referem-se a movimentos mais profundos de longa duração. $\mathrm{O}$ que teria enfraquecido as análises em termos macroeconômicos seria a confusão com os "ciclos de negócios", em que as taxas agregadas de sindicalização seriam erroneamente explicadas por um conjunto de variáveis
Disney, assim como outros, inverte a relação de causa e efeito: teria sido a fraqueza do movimento sindical e sua incapacidade de reação diante das ações governamentais que teriam permitido que o governo Thatcher fosse conseguindo aprovar e aplicar, passo a passo, medidas antissindicais cada vez mais ousadas. As leis do período Thatcher não teriam caído num vazio político. Haveria um "clima" político e ideológico que favoreceu os conservadores, como provam as vitórias eleitorais do Partido Conservador, sinal de que a maioria do eleitorado aprovava a política conservadora ou, pelo menos, não avaliava negativamente as medidas contra as lideranças sindicais ${ }^{11}$. O governo teria usado esse clima ideológico liberal antissindical

como preços, inflação e desemprego (p. 167) e não por outros fatores macroeconômicos. Por exemplo, no curto prazo, mudanças na filiação a sindicatos são afetadas positivamente pelos níveis de emprego e inflação de preço e negativamente por inflação de salários e desemprego. Algumas dessas relações seriam não lineares. Entretanto, de acordo com Disney, nenhuma dessas variáveis teria efeitos de longo prazo a não ser que se transformem em tendências (p. 168). (No caso, está embutida uma polêmica com outros autores britânicos dos efeitos sobre o sindicalismo de "ciclos econômicos", discussão que não interessa aqui.)

${ }^{11}$ Os conservadores voltaram ao governo no momento de baixo prestígio dos sindicatos. Segundo indicam algumas pesquisas, a maioria do eleitorado apoiou as reformas do governo conservador (Marsch, 1992, especialmente cap. 3, "Origens, Desenvolvimento e Conteúdo da Legislação Conservadora").

A hostilidade da opinião pública aos sindicatos ou, mais precisamente, às lideranças sindicais tem sido salientada como parte de um clima político geral que teria favorecido os partidos conservadores e rendido dividendos eleitorais aos governos que adotavam medidas contra os sindicatos. Não foi algo que teria acontecido apenas no Reino Unido. Nos EUA, Lipset (1985a) entende que a perda de prestígio das lideranças sindicais - mais do que da instituição sindical propriamente dita - ante os trabalhadores e o público em geral foi um dos fatores que contribuíram para a fraqueza do sindicalismo americano.

De acordo com Bowden (1989), o temor com relação ao sindicalismo existiria também no Canadá: "O medo do poder sindical constitui a maior objeção ao sindicalismo entre os canadenses" (Bowden, 1989, p. 729). Nesse país, a série de pesquisas conduzidas pelo Gallup entre 1979 e 1984 teria mostrado que de $62 \%$ a $68 \%$ da população canadense entendem que os sindicatos estão se tornando muito poderosos, enquanto somente $6 \%$ a $7 \%$ acham que eles [os sindicatos] não são suficientemente poderosos (p. 729). Outro especialista dos estudos na área sindical, Walter Galenson, vai mais longe ao considerar; com base numa série de pesquisas, que os sindicatos canadenses são mesmo mais criticados pela opinião pública de seu país do que os sindicatos americanos nos EUA (Galenson, 1994, pp. 114-117).

Mas as posições dos vários autores e as evidências oferecidas pelas pesquisas parecem não permitir conclusões sólidas. Freeman, por exemplo, entende que a hipótese (da relação entre declínio da sindicalização e mudanças da opinião pública com relação ao sindicalismo) não encontra evidências em pesquisas comparativas entre países. Segundo Freeman (1990), no Reino Unido, os levantamentos de opinião pública mostrariam que as atitudes para com os sindicatos tornaram-se mais favoráveis na década de 80 , justamente nos anos de declínio das 
de modo pragmático, procurando estabelecer uma separação entre dirigentes sindicais, de um lado, e simples trabalhadores e membros dos sindicatos, de outro. Dorey (1993) observa que, na questão relacionada com o voto para a eleição da direção dos sindicatos, se os dirigentes sindicais tentassem se opor à votação, "o governo poderia tranquilamente apresentar o fato como outro exemplo de quão autocráticos alguns dirigentes sindicais tinham se tornado e como estavam distanciados da base" (p. 30).

taxas de sindicalização (p. 310). É possível, aqui, que as variações conjunturais de opinião sejam fortes e que as atitudes da opinião pública flutuem segundo as circunstâncias. Um exemplo foi a posição do público americano quando da greve da empresa privada de entrega de correio, United Parcel Services (UPS). A greve foi organizada pelo sindicato dos caminhoneiros, o International Brotherhood of Teamsters, e durou 16 dias. Segundo a pesquisa realizada pelo Instituto Gallup e patrocinada pelo jornal USA Today e pela rede CNN, os grevistas tiveram apoio de $55 \%$ dos americanos contra $27 \%$ dados à UPS (Arbix, 1998). A hipótese levantada por Edwards e Bain (1988) dá uma pista para o entendimento das variações da população na avaliação do sindicalismo. Diante da contradição encontrada em parcelas da opinião pública, de apoio à política dos conservadores e de simpatia pelos sindicatos, os autores sugerem que, "quando a taxa de sindicalização sobe, a popularidade sindical decresce e quando a taxa de sindicalização cai, a popularidade dos sindicatos sobe". Nenhuma conexão direta entre os dois fatos necessita existir (p. 316). A explicação aventada, no caso, seria que inflação e greves seriam associadas pelos eleitores ao poder sindical e a popularidade dos sindicatos, como resultado, declinaria. Seria, portanto, o declínio da inflação e das greves, e não a hostilidade ao governo Thatcher, que explicaria o aumento da popularidade sindical depois de 1979 (p. 323).

A pesquisa de Jarley e Kuruvilla (1994), que trata das variações da opinião pública norteamericana a favorável ou contrária aos sindicatos entre 1936 e 1991, chama a atenção para fatores conjunturais. Segundo os autores, mais de $50 \%$ da variação líquida (relação entre aprovação e desaprovação) pode ser explicada por apenas dois fatores: mudanças nos preços de consumo e número de dias perdidos por greves. Nenhuma outra variável seria estatisticamente significante. Mas, apesar das oscilações de conjuntura, a pesquisa de Jarley e Kuruvilla conclui que houve "um forte declínio linear de apoio aos sindicatos no período estudado" (p. 110). No entanto, entre 1936 e 1991, surpreendentemente, a porcentagem de desaprovação raramente foi além dos $30 \%$ dos entrevistados, tendo atingido seu pico em 1981, com 35\%. Por outro lado, a porcentagem de aprovação nunca caiu abaixo de $55 \%$. Assim, as porcentagens nas variações de aprovação ou desaprovação devem ter vindo das oscilações dos que não tinham opinião (variação de $4 \%$ a $18 \%$ no período em estudo) (p. 102). Outro estudo, comparando as atitudes da opinião pública do Reino Unido e da Dinamarca sobre o poder sindical, introduz outro aspecto importante a ser considerado que diz respeito à avaliação popular do sindicalismo: segundo Nielsen (1987), a oposição maior da população não se refere aos sindicatos enquanto instituição mas à sua atuação no campo político, especialmente quando as suas lideranças tentam impor decisões ao parlamento.
As novas leis do governo Thatcher foram apresentadas como parte da campanha "Devolver os Sindicatos aos Trabalhadores", baseada na percepção do Partido Conservador de que as lideranças sindicais estavam distanciadas de seus liderados. Ao lado dessas leis, foram votadas outras destinadas a beneficiar diretamente os empregados, como a extensão da licença-maternidade e a proteção das mulheres grávidas contra demissões arbitrárias, proteção aos trabalhadores com problemas de saúde e de acidentes de trabalho (Visser \& Ruysseveldt, 1996a, p. 54).

Nessa mesma linha de argumentação, outros autores (por exemplo, McIlroy, 1995, p. 265; Howell, 1995, p. 168; Marsch, 1992, passim) entendem que as leis antissindicais efetivamente atingiram os sindicatos mas como parte de um contexto econômico e político, como o desemprego ascendente e contínuo, que já tinha enfraquecido a resistência do sindicalismo. Consequentemente, os efeitos das leis votadas pelo Parlamento precisariam ser vistos como inseparáveis de mutações mais amplas na política, na economia e na sociedade britânica de modo geral. O impacto da nova legislação deveria ser relativizado e analisado em correlação com outras variáveis sociais e econômicas. As leis aprovadas pelos conservadores estariam relacionadas com uma economia em transição que pressionava em direção a mudanças institucionais que, por sua vez, estavam vinculadas a um jogo de forças políticas no qual as lideranças sindicais eram colocadas na defensiva e sentiam que suas demandas perdiam legitimidade. Talvez por isso os sindicatos tivessem oposto tão fraca resistência à ação do governo conservador. Já na década dos 70, governos trabalhistas tinham procurado aplicar políticas anti-inflacionárias que visavam restaurar a competitividade das indústrias britânicas mediante contenções salariais e outras medidas destinadas a evitar uma crise financeira. Com isso, as relações entre o Partido Trabalhista e os sindicatos vinham se deteriorando já na década dos 70 (Ward, 1988, pp. 72-73; Marsch, 1992, especialmente o cap. "Os Sindicatos e o Partido Trabalhista").

Além disso, para que se possa aferir com mais exatidão os efeitos da legislação antissindical sobre os níveis de sindicalização, seria necessário verificar em que medida ela foi efetivamente levada à prática pelos empresários e como afetou concretamente as relações entre os sindicatos e as empresas. Esse aspecto não aparece no artigo de Freeman e Pelletier (e nem poderia, porque seria preciso deixar passar certo tempo para examinar os efeitos da nova legislação sobre a sindicalização e também porque novas 
leis, depois da publicação do artigo, foram votadas pelo Parlamento). No entanto, essa questão foi posteriormente pesquisada mediante exame dos acordos coletivos firmados na "era Thatcher".

Assim, Dunn e Wright (1994) examinaram uma amostra de cem acordos coletivos de 50 "unidades de negociação" (bargaining units) entre 1979 e 1990. A conclusão dos autores é que as cláusulas de reconhecimento de sindicatos permaneceram amplamente intocadas e o sistema de desconto em folha das cotizações sindicais (check-off) não sofreu alterações de monta na comparação entre 1979 e 1990. Do mesmo modo, a pesquisa não encontrou um único caso de "desreconhecimento" de sindicato. Outras normas existentes anteriormente também não foram alteradas, tal como as facilidades de atuação dos delegados sindicais (shop-stewards), os quais teriam mesmo aumentado em número.

Porém algumas consequências importantes decorreram das novas leis. Na pesquisa, das 50 "unidades de negociação", em 1979, a cláusula da closed shop constava dos acordos em 21 "unidades de negociação", três das quais obrigando a sindicalização prévia para a obtenção do emprego. Em 1990, foram encontradas apenas 16 "unidades de negociação" em que a cláusula da closed shop fora incluída no contrato. No entanto, nesses casos, a retirada da cláusula dizia respeito aos empregados de escritório e não aos operários da produção. Segundo Dunn e Wright, as maiores mudanças nos acordos foram a introdução de cláusulas que aumentavam a flexibilidade na organização do trabalho (acompanhadas em vários casos de uma norma de compensação para os empregados, como, por exemplo, garantias de salário e emprego), a inclusão de declarações ressaltando o caráter cooperativo das relações entre a empresa e o sindicato e, em alguns casos, declarando que ambos tinham "substanciais interesses mútuos" e que "relações harmoniosas trazem mútuos benefícios para ambas as partes". Essa cláusula tendeu a substituir, no "novo estilo de acordo", a declaração anterior de que a administração (da empresa) reconhecia o direito do sindicato de negociar. Segundo os autores, seria indicativo do novo padrão o acordo com a Shell em que o sindicato reconhecia explicitamente à administração da companhia "a responsabilidade pelo planejamento, organização e execução final de suas operações" (p. 40).

Como conclusão, Dunn e Wright ressaltam a crescente formalização das relações no ambiente de trabalho, combinada, em alguns casos, com o aumento das prerrogativas empresariais, embora pouca mudança tivesse ocorrido no que tange ao reconhecimento do sindicato propriamente dito.

Demoramo-nos na citação da pesquisa de Dunn e Wright porque ela exemplifica as dificuldades de respostas simples para o problema das quedas de sindicalização e o para o recuo do sindicalismo e, consequentemente, para localizar a dimensão dos efeitos de políticas antissindicais relacionadas com a ascensão de governos conservadores. Quando se examinam as razões por que declinam as taxas de sindicalização, muitos aspectos estão envolvidos. Mesmo quando o foco da análise se limita à legislação, é necessário ver como e em que amplitude medidas legais são levadas à prática e em que escala afetam o poder sindical, ainda quando são formalmente dirigidas contra o sindicalismo. No final, o esforço de Freeman e Pelletier de conseguir cifras mais exatas para as consequências da legislação conservadora sobre as perdas do sindicalismo britânico e, portanto, de deslocar o peso da explicação para os motivos de natureza institucional não parece ter conseguido colocar em segundo plano as hipóteses macroeconômicas.

Cumpre ver que, no caso britânico (e dos países nórdicos) as situações partidárias, em comparação com as da Europa latina, são relativamente bem definidas e estáveis. Os efeitos dos governos socialistas sobre o sindicalismo, comparativamente, podem ser detectados com mais facilidade: de um lado, o número de partidos é pequeno e, de outro, há um sindicalismo unificado ideologicamente com vínculos fortes com um só partido. Em outros termos: o perfil da divisão das forças políticas é ideológica e organizatoriamente nítido. Em situações de pluripartidarismo, em países federativos, com sindicalismo dividido, nem sempre se têm resultados eleitorais límpidos que tornem muito visíveis seus efeitos sobre o sindicalismo. Por exemplo: há vitórias esmagadoras de um só partido; há vitórias apertadas que reforçam ou enfraquecem uma de suas alas; há vitórias obtidas em coligações; há vitórias regionais num quadro em que pode ser difícil concluir quem venceu e quem perdeu. Em cada uma dessas situações, a construção da variável "governo de esquerda" apresenta muitas dificuldades, mesmo quando se consegue medir a dimensão das vitórias (ou derrotas) dos partidos.

No tocante à influência de governos conservadores, cumpre também destacar que há graus diferentes de conservadorismo; as relações entre os 
governos de "direita" e os setores empresariais podem variar; a força do sindicalismo pode ser grande em países em que a direita, ou o centrodireita, vai ao poder, de modo que os custos do confronto com o poder sindical podem ser elevados, fazendo com que o novo governo julgue mais prudente não provocá-lo; o grau de radicalismo do movimento sindical varia em cada país e no tempo, o que pode fazer com que a hostilidade do governo e dos empresários aos sindicatos possa também variar. Ademais, na hipótese da existência de pluralidade ideológica dentro do sindicalismo, o quadro torna-se mais complexo porque provavelmente haverá condutas variadas do governo para com facções sindicais diferentes. Considerações equivalentes podem ser estendidas a governos de esquerda. Esses podem ser mais radicais ou menos radicais, podem ter maior ou menor sustentação parlamentar e podem, também, não querer pagar os custos econômicos e políticos em confrontos com o setor empresarial e, assim, prejudicar a economia nacional para atender a certas demandas do movimento sindical ${ }^{12}$.

$\mathrm{Na}$ Alemanha, por exemplo, o comportamento do governo da democracia-cristã diante dos sindicatos foi notavelmente diferente da que teve o governo Thatcher no Reino Unido. Dentro da DGB alemã existe um facção minoritária de sindicalistas ligados à democracia-cristã. Importantes políticos alemães possuíam uma "forte identidade sindical" e estavam organizados num "comitê social" dentro do partido. Esse grupo opôs-se fortemente às medidas de desregulamentação pretendidas pela chefia da democracia-cristã (Jacobi; Keller \& Müller-Jentsch, 1993, p. 241). Ademais, os partidos democrata-cristãos, em razão da doutrina social católica, não são hostis ao sindicalismo, embora o catolicismo em si mesmo pareça não favorecer a adesão sindical ${ }^{13}$.

${ }^{12}$ Deixamos de lado as dificuldades relacionadas com a definição do que é um governo de direita (ou de esquerda), aspecto que se presta a controvérsias. Abdicamos também da tentativa de transferir essa problemática para a América Latina e para outras regiões do Terceiro Mundo. Formas de "autoritarismo popular", como o peronismo ou o getulismo (que foram "amigos dos sindicatos"), deveriam ser incluídas na categoria de governos de "esquerda" ou de "direita"? Poderíamos, no caso, dizer que eram "governos amigos" mas que mantinham os sindicatos sob forte controle, o que, na pontuação de Galenson, significa que deveriam receber nota 1 .

${ }^{13}$ A pesquisa de Misra e Hicks (1994) em 18 democracias ricas do após-guerra oferece subsídios relevantes para a avaliação das relações entre catolicismo e sindicalização. Segundo os autores, o catolicismo em si mesmo é um fator inibidor da sindicalização, o que significa dizer que, quanto maior o peso da população católica num dado país, menor a propensão para a
Talvez por isso a desregulamentação e flexibilização da economia e das relações de trabalho na Alemanha foram moderadas sob o governo da CDUCSU em aliança com o FDP (liberais): "A exigência ideológica de 'fazer recuar' o Estado foi sempre parte da retórica conservadora, mas dificilmente da realidade política" (Jacobi; Keller \& Müller-Jentsch, 1993, p. 260). Os autores chamam a atenção para o fato de que, em contraste com o Reino Unido, era impossível para o governo democrata-cristão alemão impor uma política geral de privatizações porque a Constituição Federal concede forte autonomia aos länders (estados), muitos dos quais são controlados pela socialdemocracia. $\mathrm{O}$ resultado foi que o impacto no campo trabalhista da derrota de um "governo amigo" foi muito menor na Alemanha (depois que os socialdemocratas perderam para os democratacristãos) do que em outros países europeus, de dimensões econômicas e tradição industrial próximas, como o Reino Unido (Lane, 1994). Por outro lado, no modelo neocorporativo alemão, de negociações centralizadas, os sindicatos tendem a ser bastante moderados e, por isso, despertam menos hostilidade entre os empresários e segmentos das classes médias.

Para complicar o esforço de avaliação da relação "partidos de esquerda/poder sindical", cumpre atentar para o fato de que a intensidade e profundidade dessa relação varia nos diferentes países e em diferentes épocas. Podem existir governos socialistas com ligações fortes com um sindicalismo unificado neocorporativo (Áustria, países escandinavos, por exemplo), ou unificado pluralista (do tipo britânico) e governos socialistas mas com vínculos fracos com o movimento sindical. Esse é o caso da França. A divisão do sindicalismo e a existência de uma central ligada ao Partido Comunista enfraquecem os laços entre o "governo socialista amigo" e o sindicalismo. Na França, as taxas de sindicalização, que já eram baixas, continuaram a declinar durante todo o governo socialista, apesar de se tratar de um governo que realizou o mais audacioso programa de nacionalizações do pós-guerra e, por esse ângulo, fortemente esquerdista. Em geral, as estatizações tendem a aumentar o poder do Estado, da tecnocracia estatal e dos partidos políticos que controlam o governo ante o patronato privado. Porém, se, nos partidos de esquerda no governo, os sindicalistas não

sindicalização. Porém, essa correlação só se sustenta quando não existe um partido democratacristão. A existência de uma forte proporção de católicos na população não pressupõe necessariamente a existência de partidos democrata-cristãos fortes, mas, quando esses partidos surgem, a correlação com os níveis elevados de sindicalização é significativa. 
ocuparem lugar importante, não tiverem alguma influência sobre o sistema decisório e, direta ou indiretamente, sobre as empresas estatizadas e os organismos de planejamento e intervenção, a ampliação do setor público ou estatal pode apenas criar um ambiente mais favorável para a sindicalização mas não aumenta o poder dos dirigentes sindicais na mesma proporção que nos países onde os partidos e os sindicatos socialdemocratas estão unidos.

Também a conduta do "governo amigo" diante do sindicalismo deve ser vista mais de perto. No caso francês, diz Howell (1992), os socialistas atuaram no sentido de favorecer a flexibilização e desregulamentar as relações de trabalho: a introdução dos conselhos sindicais de empresa e a obrigatoriedade de negociação não reforçaram as centrais sindicais. Chamando a atenção para o fato de que a França possuía um dos mais rígidos sistemas de relações de trabalho dos países industrializados, Howell entende que os socialistas no governo, talvez por isso, não aplicaram, na área trabalhista, o que proclamavam na oposição - conduta que, na verdade, não chega a ser uma peculiaridade dos socialistas franceses. O PS, inicialmente contrário à flexibilização, e apesar de suas ambiguidades a respeito, mudou rapidamente de posição. O sistema de relações de trabalho francês, altamente centralizado e influenciado pelo Estado, foi enfraquecido pelas leis do socialista Auroux, que estimularam as negociações por empresa. "Entre 1982 e 1986, os acordos no nível de ramo industrial caíram mais da metade e, fato ainda mais notável, os acordos por empresas aumentaram duas vezes e meia" (p. 86).

O caso francês reforça, pois, as teses que atribuem maior peso, nos estudos sobre a dessindicalização, a fatores de natureza estrutural, mesmo quando a existência de "governos amigos" é uma variável que não deve ser desprezada. De todo jeito, a avaliação desse efeito político, mesmo que façamos abstração de razões de ordem econômica, necessita levar em conta a natureza do "governo de esquerda" bem como as características específicas do contexto sindical, notadamente a existência de sindicalismo unificado ou dividido.

\section{EUA VS. CANADÁ}

A comparação entre o sindicalismo canadense e o norte-americano possibilita acrescentar outros elementos para avaliar as mútuas e complexas interações entre as variáveis de tipo socioeconômico com as político- institucionais. Nas disputas entre "estruturalistas" e "institucionalistas", a situação cômoda do sindicalismo no Canadá, na década dos 80, em comparação com o calvário do sindicalismo norte-americano, era frequentemente citada pelas teorias institucionalistas para mostrar a importância primeira do sistema de relações de trabalho, especialmente a legislação relativa ao sindicalismo e a maior disposição dos dirigentes sindicais e dos trabalhadores a enfrentar as pressões empresariais. No contexto, esse tipo de abordagem possibilitava previsões mais otimistas sobre o futuro do sindicalismo. Em outras palavras: mudanças na legislação, nas estratégias sindicais, nas disposições dos trabalhadores poderiam salvar os sindicatos cujo fim não estaria fatalmente inscrito nas transformações de natureza macroeconômicas e técnicas da sociedade contemporânea globalizada, na sociedade de serviços "desindustrializada". $\mathrm{O}$ avanço, ou estabilidade, do sindicalismo canadense, contraposto ao declínio do norte-americano, parecia, para muitos, uma evidência de que, finalmente, não haveria motivos estruturais que comprometessem o futuro da instituição sindical no mundo ocidental. A melhor prova estaria ali, do outro lado da fronteira. Não era mais necessário evocar o exemplo dos países nórdicos, de tradições tão diferentes, para demonstrar como o movimento sindical norte-americano seria capaz de encarar o fenômeno das mudanças na economia, no mercado de trabalho, na tecnologia, nas novas estratégias empresariais e outros eventos desse final de século.

Por múltiplos prismas, a evocação do caso canadense fazia sentido. Nos últimos setenta anos, as taxas de sindicalização dos dois países tinham tido crescimento relativamente semelhante. Antes de 1920, nos dois lados da fronteira, a proporção de trabalhadores sindicalizados esteve abaixo de $20 \%$. A partir de meados da década de 30, o New Deal e a criação do CIO elevaram os níveis americanos de sindicalização, que passaram a ser ligeiramente superiores aos canadenses. Contudo, a partir de meados de 1950, a sindicalização dos EUA começou a declinar, enquanto, no Canadá, apesar de pequenas perdas em alguns anos, o sindicalismo cresceu e acabou por superar, em termos da proporção de sindicalizados, o dos EUA. De 1956 a 1993, o número canadense de sindicalizados aumentou em quase $200 \%$ (um aumento líquido de 2,7 milhões de membros) e os ganhos obtidos excederam o crescimento da força de trabalho. As taxas de sindicalização, nesses anos, passaram de 33,3\% para 37,6\% (Rose \& Chaison, 1996, p. 81). 
Uma vez que a economia canadense parecia, à primeira vista, muito semelhante à dos EUA, o caso do Canadá favorecia as explicações "culturalistas" e institucionais. Lipset (1986b), por exemplo, entendia que a principal razão, durante a década dos 80 , da situação cômoda do sindicalismo no Canadá, em comparação com a dos EUA, vinha da grande proteção legal oferecida aos sindicatos. Essa proteção estaria relacionada com as atitudes da população diante do poder sindical. Lipset, com utilização de pesquisas relativas à aprovação/desaprovação do sindicalismo, notou uma correlação positiva entre a curva de declínio da aprovação do sindicalismo pela opinião pública e a derrota dos sindicatos entre os empregados nas eleições nos locais de trabalho para a aceitação ou não dos sindicatos (certification elections): “... o fator principal, se não o maior, que afeta o crescimento ou declínio dos sindicatos e a capacidade de vencer as eleições para a obtenção do certificado de representação, é a variação da apreciação que o público tem dos sindicatos" (p. 440). Lipset não rejeita os efeitos de variações estruturais sobre os sindicatos, mas insiste em que "eles são mediados pela diversidade de valores nacionais" (p. 442). Ora, a cultura nacional canadense (que, segundo o autor, ficaria entre a cultura britânica e a norte-americana, um pouco mais próxima da segunda) seria "mais elitista, comunitária, estatista e particularista (grupalmente orientada) do que a dos EUA" (p. 442). Resultaria daí que não teria ocorrido no Canadá, nos tempos mais recentes, um retorno aos valores clássicos do liberalismo, tal como nos EUA, porque esses nunca teriam feito parte das tradições canadenses. A maior força do sindicalismo canadense estaria ligada a um "ambiente legal amistoso, politicamente mais cooperativo, a empregadores menos hostis e, mais importante do que tudo, à maior propensão dos trabalhadores canadenses a se filiar a sindicatos" (p. 451).

O que entra em discussão aqui é o sistema de relações de trabalho em vigor nos dois países e, especificamente, o modo de reconhecimento do sindicato. No Canadá, como nos EUA, os empregados da empresa devem decidir se querem ou não o sindicato. É aí que entra uma variável política relacionada com a cultura nacional e com a influência sobre o sistema de relações de trabalho. De modo mais direto, esse aspecto envolve a conduta das autoridades governamentais diante do sindicalismo. Nos EUA, as petições para a criação de um sindicato no local de trabalho, geralmente dirigidas à JNRI, solicitando a autorização (authorization cards), exigem a assinatura de pelo menos $30 \%$ dos empregados do local de trabalho. Em meados de 1980, os sindicatos norte-americanos estavam ganhando menos de $45 \%$ das votações.

Já no Canadá, os sindicatos obtêm reconhecimento se demonstrarem que filiam a maioria dos trabalhadores que cotizam os sindicatos $(50 \%$ a $60 \%$, dependendo da jurisdição). "Mais comumente, pelos regulamentos canadenses, há concessão automática do certificado de representação quando $55 \%$ a $60 \%$ dos empregados da 'unidade de barganha' demonstram sua adesão a um sindicato assinando a carta de filiação e o pagamento nominal das cotizações" (Huxley; Kettler \& Struthers, 1986, p. 130). Onde eleições são exigidas, como na Colúmbia britânica e na Nova Escócia, elas são quase sempre realizadas em duas semanas. A extensão do prazo, como já fizemos notar, é um dado importante porque reduz o tempo de que dispõem os empregadores para influenciar seus empregados no sentido de votarem contra a representação sindical. Não há necessidade de que os certificados sindicais que não são voluntariamente aceitos pelos empregadores sejam submetidos a referendo em votação secreta, como acontece nos EUA, onde no "período eleitoral" os empregadores têm, também, o direito de dirigir a palavra aos empregados. Nos EUA, portanto, as empresas disporiam de amplo espaço de tempo para campanhas antissindicais antes da realização das eleições.

Lipset parte, assim, da existência de um clima desfavorável aos sindicatos na opinião pública dos EUA que influenciaria as autoridades públicas na adoção de medidas destinadas a enfraquecer o poder sindical. No Canadá, em virtude de padrões culturais menos individualistas e antissindicais, inclusive da parte de partidos conservadores, a hostilidade seria significativamente menor.

Nos estudos sobre o desenvolvimento diferenciado do sindicalismo dos dois países, uma entre as várias interpretações que dirigem o foco da análise para a ação dos próprios sindicatos (nesse sentido, similar às interpretações de Kochan; Freeman, Medoff et alii) é a de dois autores também simpáticos ao sindicalismo: Joseph Rose e Gary Chaison (1996). As taxas nacionais de sindicalização mais elevadas do lado canadense seriam resultado fundamentalmente da atuação dos próprios sindicatos auxiliados por uma legislação mais favorável (esse último aspecto também ressaltado por Lipset). A tese de Rose e Chaison é a de que sindicatos canadenses teriam sido particularmente ativos no esforço para a obtenção 
de "certificados de representação" nas áreas em que o emprego estava em ascensão, quer dizer, no setor de serviços e entre os empregados de escritório (white-collar), técnicos e profissionais (p. 86). Além disso, os sindicatos do Canadá teriam estado menos dispostos do que os dos EUA a fazer concessão aos empregadores, apesar de as dificuldades enfrentadas terem sido aproximadamente as mesmas. Um exemplo seria o acordo do sindicato dos trabalhadores das indústrias automobilísticas nos EUA e no Canadá com a Ford e a General Motors. Em 1982, ambas as companhias solicitaram ao sindicato reabertura de negociações nas quais o sindicato concordou com o congelamento de salários e de pensões, a perda de pagamento dos dias feriados e o adiamento dos reajustes de compensação pelo aumento do custo de vida, em troca de promessas de maiores garantias de emprego e de renda. No caso canadense, os representantes sindicais recusaram inicialmente a reabertura de negociações e, em posteriores discussões, rejeitaram maiores concessões. $\mathrm{Na}$ indústria do aço, os sindicatos americanos, em 1984, concordaram com cortes de salários e de benefícios. Já os canadenses negociaram um acordo de três anos, que manteve os reajustes por aumento do custo de vida e aumentos salariais no segundo e no terceiro ano (Rose \& Chaison, 1996, p. 89).

Tomando como indicador as taxas de greves depois de 1980 até 1992, Rose e Chaison observam que, embora elas tenham declinado nos dois países, o declínio teria sido quatro vezes maior nos EUA. Segundo os autores, a queda no Canadá pode ser interpretada como "sinal de força comparável entre sindicatos e empresas e desejo de adaptação às mudanças econômicas negociada sem conflito", ao passo que, nos EUA, o declínio não seria decorrência de acordos com os sindicatos mas, antes, o reconhecimento pelo sindicalismo do aumento da disposição das empresas de substituir de forma permanente os grevistas (p. 91). Mas, aqui, é preciso reconhecer que a legislação do Canadá, que coloca muitas restrições à substituição de empregados que fazem greve, é bem mais favorável ao sindicalismo do que a dos EUA, o que aumenta a capacidade de resistência do sindicalismo canadense em comparação com o norte americano.

Finalmente, os dois autores aproximam-se de uma ideia antes avançada por Lipset: a importância da existência de partidos políticos ligados ou simpáticos aos sindicatos. A organização sindical, o êxito nas negociações coletivas e as influências políticas e sindicais devem ser consideradas tanto como determinantes quanto como consequências das taxas de sindicalização (p. 99). Mas essa colocação não elimina a ideia principal: a maior determinação dos sindicatos canadenses de agir, sindical e politicamente, no sentido de manter suas posições.

Mas é possível apresentar outro tipo de explicação. Exemplar nos termos de hipóteses estruturalistas é a posição de Leo Troy $(1986,1990)$. Avaliando o declínio das taxas de sindicalização nos EUA, o autor rejeita especialmente as teses de que a responsabilidade maior pelo declínio estaria na hostilidade dos empregadores norte-americanos. $\mathrm{O}$ recuo do sindicalismo, para Troy, dever-se-ia basicamente a fatores econômicos, às forças do mercado, à passagem da produção industrial para a de serviços, à substituição mais rápida das indústrias tradicionais pelas de high tech, alterando profundamente a importância relativa das camadas de trabalhadores na sociedade, isto é, reduzindo o volume dos trabalhadores manuais e aumentando o dos não manuais. Nesses setores de alta tecnologia, que envolvem equipamento, planejamento, pesquisas e produtos de alta sofisticação, os EUA estariam à frente do Canadá e da Europa Ocidental. O resultado seria a expansão de "empresas não sindicalizáveis". Viria daí, nos EUA, o aumento das derrotas sindicais nas eleições para obtenção de certificados, porque as novas camadas de empregados efetivamente não desejariam os sindicatos. Desse modo, a hostilidade patronal aos sindicatos não seria um ato que partiria apenas do lado das empresas, mas encontraria uma correspondência do lado dos empregados. A tese de Troy seria a de que os sindicatos dos EUA estariam condenados ao declínio. Mas declínio não significa extinção. $O$ sindicalismo americano continuaria a representar os trabalhadores nas empresas nas quais se entrincheiraram, mas as taxas nacionais de sindicalização continuariam a cair (Troy, 1986, p. 107). Só uma maciça intervenção governamental poderia reinverter a tendência, mas mesmo assim a curto prazo (p. 109).

Esse mesmo tipo de raciocínio "estruturalista" é utilizado pelo autor, na análise do caso canadense, para rebater as teses sobre o "caráter excepcional" do declínio dos sindicatos nos EUA. De acordo com Troy (1990), as taxas de sindicalização canadenses conseguiram manter-se estáveis (ou tiveram queda menos acentuada do que nos EUA) porque a economia canadense e a de outros países europeus se encontram atrasadas em comparação a processos que já estariam em curso nos EUA, isto é, basicamente, a transição da produção industrial para a de serviços. Ao contrário das afirmações de Freeman e de Chaison e Rose, as leis canadenses 
teriam sido, afirma Troy, favoráveis aos sindicatos porque as indústrias desse país estavam protegidas por altas tarifas. Os novos acordos comerciais com os EUA iriam expor as indústrias canadenses a uma competição feroz, que levaria ao declínio do sindicalismo. Os EUA não seriam um "caso único", uma exceção no mundo desenvolvido, mas, sim, o caso de um país em que as mudanças estruturais da economia estariam mais avançadas.

De acordo com Troy, a falha principal da análise de outros autores, Lipset inclusive, viria do fato de raciocinarem como se todos os países industrialmente avançados "tivessem essencialmente o mesmo mercado de trabalho", além de não distinguirem entre o sindicalismo do setor público e o do setor privado (Troy, 1990, p. 112). As altas taxas agregadas de sindicalização, no Canadá, dever-se-ia m especialmente ao setor público que teria (em 1985) 29,9\% do emprego contra $16,3 \%$ dos EUA.

Os avanços da privatização, vaticinou Troy, deverão produzir no Canadá (e em outros países) os mesmos efeitos negativos sobre o sindicalismo que produziram nos EUA.

$\mathrm{Na}$ realidade, não se trataria apenas do emprego do setor público stricto sensu, mas também do peso das empresas estatais nas economias nacionais. Um exemplo seria o das ferrovias. Em 1947, nas principais ferrovias americanas, o número de empregados era de 1,410 milhão com uma taxa de sindicalização de 76\%. Em 1990, segundo estimativa de Troy, o número de ferroviários seria de 225 mil com uma taxa de sindicalização de $90 \%$. No caso, a proporção de sindicalizados teria subido, mas o número de membros teria decrescido aproximadamente 830 mil em cerca de 40 anos e, consequentemente, ajudado a rebaixar os índices nacionais de sindicalização (Troy, 1990, p. 122).

O autor argumenta que é verdade que a taxa nacional de sindicalização no Canadá teria aumentado de 31,9\%, em 1975, para 33,9\% em 1985. Mas o crescimento teria decorrido em grande parte da sindicalização do setor público (notadamente saúde e educação), em que os índices teriam passado de 45,5\% nos serviços em 1975 para 67,7\% em $1985^{14}$. Considerando apenas

\footnotetext{
${ }^{14}$ Esses números são ligeiramente diferentes dos de outros autores. Meltz e Verma (1995, p. 104) estimam que a taxa de sindicalização, em 1990, teria permanecido em $21 \%$ no setor privado contra a os dados de Troy de $18 \%$. Mas os autores notam a ausência de estatísticas que possibilitem calcular com precisão as diferenças entre os níveis de sindicalização no setor privado e público.
}

o setor privado, alega Troy, a sindicalização encolheu de $25,7 \%$ para $20,7 \%$ entre 1975 e 1985 (pp. 126-127). Ora, uma vez que a economia norteamericana apoiava-se mais no setor de mercado do que no estatal, as taxas de sindicalização americanas tenderam a ser mais afetadas pelas alterações das últimas décadas do que as do lado canadense. Como conclusão, Troy considera que os mesmos desenvolvimentos que o sindicalismo norteamericano conheceu antecipadamente deverão ocorrer no Canadá, quando o setor público se encolher e a economia se vir exposta às mesmas pressões competitivas que a dos EUA. O resultado seria o reforço das tendências para retirar as proteções legais aos sindicatos a fim de atender às necessidades do mercado. Nesse momento, os índices de sindicalização canadense deverão também baixar, tal como aconteceu nos EUA.

Os desenvolvimentos posteriores parecem dar razão a Troy. As taxas de sindicalização canadense estabilizaram-se apesar de ter o número absoluto de sindicalizados crescido ligeiramente: em 1980, 3.397 mil trabalhadores estavam sindicalizados. Em 1994, eram 4.079 mil. Mas esse número está praticamente estabilizado desde 1990, quando 4031 mil empregados estavam sindicalizados. Em termos percentuais, em 1980, $37,0 \%$ do total da força de trabalho pertenciam a sindicatos. Em 1994, a proporção era de $37,5 \%$, com um pequeno aumento, portanto (Chaison, 1996, p. 53). Pelos dados da OIT (1997-1998), considerando o total da força de trabalho não agrícola, em 1993 31,0\% estariam sindicalizados e, considerando apenas trabalhadores, $36,7 \%$ (no caso, apontando declínio).

Diante da crise financeira das administrações públicas, os sindicatos foram obrigados a conformar-se com a renovação de piores contratos. Do lado político, houve as derrotas do Novo Partido Democrático, que a central sindical canadense havia ajudado a criar e com o qual mantinha fortes laços. Em muitas províncias, os governos conservadores retiraram muitas das vantagens legais que beneficiavam os sindicatos. Na província de Ontário, por exemplo, o novo governo conservador passou, em 1995, uma nova legislação que mudava o sistema de outorga de certificados para os sindicatos, que deixou de basear-se na apresentação de cartas de filiação. Tal como nos EUA, passaram a ser exigidas eleições nos locais de trabalho e houve fortes concessões aos empregadores no tocante à permissão para a substituição de trabalhadores em greve (Chaison, 1996, p. 57). A conclusão de Chaison é que, para o sindicalismo canadense, os tempos difíceis estão 
longe de terem passado e que os significativos ganhos na sindicalização do passado recente dificilmente serão mantidos (p. 53).

\section{CONCLUSÃO}

São muitas as dificuldades para dimensionar os efeitos da ação dos diferentes tipos de variáveis no declínio do sindicalismo, especialmente para estabelecer uma hierarquização entre variáveis de tipo socioeconômico, isto é, estruturais, e outras de tipo político-institucional. Aqui, os contextos nacionais e o período em foco desempenham importância particular. Há países, como foi o caso do Reino Unido, em que mudanças políticas levaram a alterações na legislação que tiveram forte impacto sobre o poder sindical e, ponto em que parece haver consenso, fizeram recuar as taxas de sindicalização. Mas, como já vimos, é difícil calcular a dimensão das perdas que se devem à ação das alterações na legislação porque outros processos de desindustrialização e de transição em direção a uma economia de serviços estavam em curso na Grã-Bretanha. Já em outros países, as perdas sindicais podem ter correlações mais fortes com mudanças na economia nacional, que se efetuam com relativa autonomia ante o tipo de governo e o sistema de relações de trabalho, tal como elevação do desemprego e alterações tecnológicas.

Outras vezes, o que aparece como a causa mais visível da queda da sindicalização pode ser, de fato, um epifenômeno. Esse pode ser o caso da variável "hostilidade patronal", possível de medir mas difícil de determinar quanto ela afeta as taxas de sindicalização. Mesmo que se consigam indicadores adequados da resistência patronal aos sindicatos (por exemplo, "uma escala de hostilidade ao sindicalismo"), restaria explicar por que os empresários, nessas últimas décadas, se teriam tornado mais "antissindicais" do que no passado, como se alguma vez os sindicatos norte-americanos (e os de muitos outros países) tivessem sido aceitos sem resistência. São conhecidos os violentos combates trabalhistas para a introdução dos sindicatos nas grandes empresas, quando os EUA estavam muito longe de enfrentar a concorrência asiática e não se falava em globalização. Seria preciso também explicar por que os sindicatos, hoje, não estão tendo a mesma capacidade de resistência do passado. Ademais, como isolar a variável "hostilidade patronal" do conjunto de outros elementos que também podem dificultar a sindicalização, como a maior antipatia (ou simpatia) da opinião pública para com os sindicatos, o aumento da proporção da mão de obra feminina, a influência das elites políticas, a desconcentração industrial, a fragmentação dos interesses das classes trabalhadoras, a expansão do setor de serviços, as privatizações e muitos outros fatores intervenientes.

Assim, a hipótese que valoriza as consequências de uma variável política - os efeitos de governos de esquerda sobre os índices de sindicalização - parece aceitável se colocada em termos de tendência, isto é, de que governos de esquerda tendem a aumentar as taxa de sindicalização... se todos os demais fatores forem iguais. Ambos os fenômenos (fortalecimento dos sindicatos e dos partidos de esquerda) estão relacionados porque geralmente têm as mesmas causas, tais como o aumento do peso político e social das camadas assalariadas, a urbanização, a expansão do sufrágio etc. Portanto, processos que favorecem o crescimento das taxas de sindicalização tendem correlatamente a favorecer partidos de esquerda. Por isso, a proposição pode ser invertida: a elevação das taxas de sindicalização, quer dizer, do aumento do poder sindical, ceteris paribus, tende a facilitar a eleição de governos de esquerda; e o crescimento nos índices de sindicalização tende a favorecer a continuidade de governos de esquerda. Por sua vez, a esquerda no poder tende a fazer leis que favorecem os sindicatos. Não se pretende, pois, negar a influência que tem sobre o sindicalismo a existência de "governos amigos", "governos neutros" e "governos adversários", com todas as gradações que possam ser incluídas nessas três classes. A dúvida não diz respeito à tendência geral mas às dificuldades de mensuração dos efeitos dessa variável, porque há, aqui, entre outras razões, uma relação de reforçamento mútuo entre fatores, na qual é difícil dizer o que é causa e o que é efeito.

No caso, estamos lidando com uma variável de tipo políticoinstitucional cuja quantificação apresenta dificuldades. Mas problemas existem também quando se buscam correlações entre taxas de sindicalização e fatores socioeconômicos, em que aparentemente estaríamos diante de fenômenos mais facilmente quantificáveis. Aceitemos, por exemplo, que a concentração e o crescimento industrial, especialmente se ambos aconteceram ao mesmo tempo, favorecem a expansão do sindicalismo. Pode se, além de medir o crescimento das camadas assalariadas, medir a concentração fabril por meio de certos indicadores. Assim, é possível operar com variáveis quantitativas que permitiriam maior 
precisão na avaliação dos seus efeitos sobre a força do sindicalismo. Mas as correlações da industrialização com as taxas de sindicalização e o sindicalismo nem por isso são simples e permitem predizer quando, como e quanto o crescimento industrial irá resultar no aumento do poder sindical.

Para o fortalecimento do sindicalismo conta não apenas o volume de trabalhadores e sua concentração, mas também a composição da força de trabalho (qualificação, proporção de mulheres e menores, fontes de recrutamento etc.), os ramos de indústria e outros elementos que, historicamente, sabemos que influenciaram a expansão do movimento operário. A expansão da grande indústria da produção em massa pode recorrer abundantemente a trabalhadores de origem agrícola, ou a trabalhadores imigrantes e, assim, enfraquecer os antigos sindicatos de ofício de trabalhadores qualificados. O resultado pode ser uma forte perturbação no sistema sindical estabelecido, o surgimento de novas correntes ideológicas, conflitos organizatórios, rivalidades sindicais cuja consequência seria eventuais quedas imediatas nas taxas globais de sindicalização. Mas pode acontecer também o contrário: levar à rápida expansão de correntes sindicais mais agressivas, sindicalmente mais inovadoras e mais motivadas a criar novas formas de organização, como aconteceu no Reino Unido em fins do século passado com o movimento do chamado "novo sindicalismo" e, nos EUA, com a formação do CIO. Não se pode predizer que a expansão da mão de obra e a concentração fabril eleva a sindicalização se não se tem em conta o contexto em que se dá o impulso industrial. De modo que apenas se pode concluir que, em principio, industrialização e concentração da mão de obra devem favorecer o crescimento do sindicalismo.

$\mathrm{Na}$ realidade, fatores de natureza econômica mais facilmente operacionalizados como variáveis quantitativas - como descentralização industrial, maior oferta de trabalho no setor de serviços, desemprego, inflação etc. - têm efeitos diferenciados sobre os movimentos sindicais. Na medida em que caem num campo de relações de trabalho e de forças políticas, são absorvidos através dos filtros de uma cultura, aceitos, rejeitados ou modificados segundo cada sociedade nacional.

É sobre um modelo específico de organização sindical, e também de relações de trabalho, que cada fator de natureza tecnológica, econômica e política incide. O resultado é um número muito grande de combinações e de resultados. A organização sindical, suas estratégias, suas tradições e valores constituem uma variável de tipo político-institucional que, à luz da história do sindicalismo e das teorias das organizações, não pode ser deixada de lado. As respostas do sindicalismo não são apenas reações determinadas automaticamente de mutações ambientais, mas decorrem também de transformações que se dão nos sindicatos enquanto organização e que passam, quase fatalmente, pelos interesses e valores das lideranças sindicais. As estratégias correspondentes a mudanças ambientais serão adotadas a partir dos sindicatos como estruturas organizatórias. Consequentemente, os interesses específicos e a cultura da liderança sindical são variáveis a ser introduzidas nas análises, embora sejam dificilmente apreendidas em termos estatísticos.

Deveríamos concluir, portanto, na comparação entre as múltiplas hipóteses relacionadas com o declínio da sindicalização, que nenhuma hierarquização de fatores causais poderia ser estabelecida? Especificamente quanto à discussão entre as explicações socioeconômicas e as explicações institucionais e políticas, seria impossível detectar as mais nocivas para o sindicalismo?

Na verdade, muitas pesquisas têm procurado, com auxílio de recursos metodológicos matemáticos mais sofisticados, testar hipóteses relacionadas com as diferenças nacionais nas quedas das taxas de sindicalização e explicar por que o sindicalismo declinou mais em alguns países do que em outros e por que os países altamente desenvolvidos e democráticos diferem tanto no que diz respeito aos níveis de sindicalização. Desse ponto de vista, essas pesquisas avançam no sentido de dar maior rigor aos escritos sobre o sindicalismo. No entanto, apesar dos cálculos estatísticos mais sofisticados, do uso de equações matemáticas e modelos econométricos, do controle mais rigoroso das variáveis (que marcha junto com o crescente abandono das referências históricas), geralmente os resultados a que chegam são contestados parcial ou totalmente por outras pesquisas, como vimos no caso do artigo de Freeman e Pelletier sobre o Reino Unido. Especialmente, não se revelam capazes de explicar os mesmos fenômenos em outros contextos nacionais ou mesmo setoriais. Ou seja, têm sua capacidade de predição reduzida e não chegam a modelos confiáveis capazes de explicações mais amplas, entre outras razões porque não conseguem controle estatístico de todas as variáveis relacionadas com as diferenças nacionais nos índices de sindicalização. 
Um dos obstáculos para a criação de um modelo explicativo, quer dizer para previsões, vem do fato de que, se a variável dependente "taxa de sindicalização" é relativamente fácil de ser medida (ainda que os significados da sindicalização possam variar e que dificuldades existam na comparação entre países), com relação aos fatores causais, que são utilizados nas equações como variáveis independentes, os problemas são incomparavelmente maiores. Alguns dos fatores são quantitativos e de mensuração relativamente fácil, tais como as taxas de desemprego, as mudanças no volume da força de trabalho, os aumentos ou quedas de produtividade, as médias salariais. Mas outros, que aparecem como variáveis independentes, estão de tal modo conectados e interdependentes que é difícil isolá-los e, amiúde, de distinguir o que é causa e o que é efeito, ou seja, quais seriam as variáveis dependentes e independentes.

No final, muitos dos esforços que marcam atualmente grande parte da produção dos pesquisadores na construção de modelos sociométricos, de cálculos mais sofisticados de covariância, análises multivariadas, cenários alternativos, poucas vezes conseguem dar maior rigor a achados que a história do sindicalismo já havia sugerido. Quando parecem comprovar empiricamente alguma relação, frequentemente ela é contrariada por novos cálculos ou desmentida por novos desdobramentos ${ }^{15}$.

\footnotetext{
${ }^{15}$ Um exemplo dessas dificuldades é ilustrado pelas discussões que visam saber se é a sindicalização que afeta os níveis de salário, ou se, ao contrário, são os níveis salariais que favorecem a sindicalização ou se ambas as variáveis são simultaneamente determinadas. Apesar de um pouco longo, citamos um trecho do artigo de Bain e Elias (1985) sobre o assunto: "Alguns economistas têm tentado responder a essa indagação usando dados americanos para estimar simultaneamente modelos de equação mas obtiveram resultados contraditórios. Pencavel (1970) e Altenfelder e Johnson (1972), para o setor industrial, concluíram que a direção da causação vem primariamente dos salários para a sindicalização. Schmidt e Strauss (1976), usando dados individuais de ocupações semiqualificadas, concluíram que a causalidade vem de ambas as direções e que o 'mais poderoso fator determinante da sindicalização é o diferencial [de salário] entre sindicalização/não sindicalização'. Mais tarde, Schmidt (1978, p. 461), numa reelaboração e reestimação de seus primeiros trabalhos, encontrou que a sindicalização tem um significativo efeito nos níveis salariais, mas, em contraste com Lee, achou que os diferenciais de ganhos entre sindicalização/não sindicalização `não têm nenhum eleito perceptível na probabilidade de sindicalização', o que significa dizer que não têm valor preditivo. Do mesmo modo, Hirsch e Berger (1984, p. 677) não encontraram nenhuma relação significante entre o prognosticado diferencial entre 'salário sindicalizado' e 'não sindicalizado' [quer dizer, de empresas ‘sindicalizadas' e "não sindicalizadas'] e a probabilidade de filiação sindical...” (pp. 82-83).
}

Por isso, se a separação entre classes de fenômenos relacionados com a dessindicalização parece útil para fins de exposição, as análises e os prognósticos sobre o futuro do sindicalismo precisam levar em conta a interação de um conjunto amplo e variado de desenvolvimentos que se dão em muitos campos da atividade social. Dessa perspectiva, parece produzir melhores resultados deixar de lado os esforços de mensuração de variáveis isoladas para captar, em conjunto e em interação, as transformações em curso nos países altamente desenvolvidos e tentar verificar para que tipo de sociedade essas transformações apontam e que lugar e papel nela poderá ter o sindicalismo.
[Uma vez que julgamos que não conviria incluir na relação bibliográfica os trabalhos citados (que não lemos) mas que as referências bibliográficas deveriam ser apresentadas, optamos por reproduzi-las abaixo para o caso de algum leitor se interessar pelo tema: Altenfelder, $\mathrm{O}$ \& Johnson, G.E. (1972), "Unionism, Relative Wages, and Labor Quality in U.S Manufacturing Industries", International Economic Review, 13, pp. 488-508, 147-161; Hirsch, B.T \& Berger, M.C. (1984), "Unions Membership Determination and Industry Characteristics", Southern Economic Journal, 50, pp. 665-679; Lee, Lung-Fei (1978), "Unionism and Wage Rates: A Simultaneous Equations Model with Qualitative and Limited Dependent Variables", International Economic Review, 19, pp. 415433; Pencavel, J. (1970), An Analysis of the Quit Rate in American Manufacturing Industry, Princeton, New York, Princeton University, Industrial Relations Section. Schmidt, P \& Strauss, R. P (1976), "The Effect of Unions on Earnings and Earnings on Unions: A Mixed Logic Approach", International Economic Review, , 27, pp. 203-212.] 


\section{Terceira Parte: \\ Perspectivas do Sindicalismo}

\section{Capítulo 9 \\ Respostas sindicais}

$\mathrm{O}_{\mathrm{s}}^{\mathrm{s}}$ dirigentes sindicais, obviamente, têm consciência da dimensão dos perigos que ameaçam a própria sobrevivência da organização sindical... e que põem em risco também seus empregos, pois a dessindicalização reduz fortemente as finanças dos sindicatos. Esse último aspecto é especialmente dramático nos países em que os sindicatos dependem amplamente das cotizações dos associados.

No Reino Unido, cerca de $80 \%$ das rendas dos sindicatos vêm das contribuições dos associados, $7 \%$ de investimentos e o restante de outras fontes. Em 1991, oito dos vinte maiores sindicatos britânicos estavam operando com déficit. Para os grandes sindicatos, 81,5\% dos gastos são com administração. $\mathrm{O}$ valor das cotizações dos associados, no Reino Unido, é baixa: $0,38 \%$ dos rendimentos médios em 1990, contra mais de $1 \%$ nos países escandinavos e $1 \%$ na Alemanha. As variações, no entanto, são fortes de acordo com a categoria profissional. A inscrição, no caso britânico, para a filiação no sindicato dos professores do ensino básico era de apenas 28,23 libras, mas chegava a 100,69 libras no sindicato dos gráficos, sendo de 54,85 libras a média calculada para o conjunto dos sindicatos. McIlroy alerta que há indícios de "significativo aumento" nessa média nos anos 90 (McIlroy, 1995, pp. 44-45). Mas nem todos os sindicalismos são tão dependentes das cotizações dos sindicalizados. Na França, apenas $10 \%$ dos gastos dos sindicatos vêm de cotizações de associados e os sindicatos necessitam pesadamente dos subsídios governamentais (Visser \& Ruysseveldt, 1996, p. 105; Rosanvallon, 1988, pp. 92). Talvez por isso o número de funcionários em tempo integral dos sindicatos franceses seja muito baixo em comparação com o de outros países ${ }^{1}$.

Na difícil situação atual, os sindicatos hoje limitam-se basicamente a reagir às iniciativas das empresas, tentando evitar a perda de vantagens anteriores (em particular benefícios médicos, garantia do emprego, limitação das subcontratações), deixando de lado iniciativas para a obtenção de novos ganhos. As reivindicações de aumentos salariais, por exemplo, tornaram-se raras (Chaison, 1996, p. 23). Dessa observação não se deve deduzir a ausência de algumas grandes mobilizações de trabalhadores e de empregados. A grande greve dos funcionários públicos da França de dezembro de 1995 e outros movimentos importantes em vários países mostrou que certa capacidade de reação continua existindo ${ }^{2}$, embora sejam quase sempre reações defensivas, destinadas a barrar a aplicação de

\footnotetext{
${ }^{1}$ De acordo com Wright (1994, apud Ruysseveldt \& Visser, 1996b, p. 105), haveria duas vezes mais funcionários sindicais na Dinamarca do que na França, embora a força de trabalho dinamarquesa seja dez vezes menor.

${ }^{2}$ Pode-se discutir o caráter ofensivo e "progressista" do movimento de dezembro. Referindose à greve, dirá Touraine: "Forte pelo que recusava, ela foi fraca pelo que não propunha". O sociólogo francês vê a sociedade francesa da atualidade dividida em três grandes setores: o primeiro seria formado das categorias profissionais ou grupos sociais que teriam oportunidades boas ou razoáveis de encontrar seu lugar nos mercados nacionais ou internacionais. O segundo seria o dos marginalizados, dos quais muitos recebem um auxílio do Estado ou das instituições de proteção social. Um terço da população francesa estaria nesse setor (tanto os que perderam emprego como os que não conseguem entrar no mercado de trabalho). O terceiro seria o das atividades protegidas ou subvencionadas pelo Estado, quer se trate de funcionários ou de assalariados de empresas públicas (dos quais uma parte, no entanto, pertenceria ao primeiro setor) e uma parte importante de agricultores e trabalhadores de atividades que necessitam da ajuda do Estado. As lideranças do movimento de 1995 teriam sido dos segmentos mais protegidos (Touraine et alii, 1996). A greve de novembro-dezembro teve como centro da disputa a oposição dos empregados do setor público à eliminação de vantagens, especialmente o aumento das cotizações dos anciãos e das contribuições para saúde dos aposentados, proposta pelo governo. A duração das cotizações dos funcionários seria aumentada de 37,5 anos para 40, a fim de ficar equiparada às de outros assalariados. As primeiras manifestações começaram por volta de 10 de novembro. Foram particularmente ativos os funcionários dos correios, da empresa França Telécom, os ferroviários, os empregados do metrô etc. A paralisação teve o apoio do movimento estudantil e de muitos intelectuais, dos quais cerca de 200 assinaram um manifesto de apoio aos grevistas publicado no jornal Le Monde (15.12.95). As mobilizações grevistas, nesse movimento, foram mais fortes nas províncias do que em Paris, ao contrário do que habitualmente acontece.
} 
mudanças que as lideranças sindicais ou os trabalhadores consideram que lhes são prejudiciais.

Mas, ao lado das ações tradicionais do sindicalismo, respostas mais inovadoras têm sido postas em prática. Entre elas, seria possível separar: a) as respostas de natureza coletiva, dirigidas para os trabalhadores enquanto grupo e que, consequentemente, envolvem as estratégias sindicais clássicas de mobilização (mais agressivas ou menos agressivas, dependendo do contexto) e que, às vezes, têm um componente político quando implicam a busca de apoio em partidos ou governo; b) as respostas orientadas para o trabalhador individual; e c) as respostas organizatórias referentes a modificações na própria estrutura sindical.

\section{A) respostas coletivas}

São as que se aproximam das atividades tradicionais dos sindicatos. Elas se destinam a aumentar os níveis de sindicalização entre categorias já sindicalizadas, trazer novos segmentos profissionais para os sindicatos, organizar grupos de trabalhadores de categorias já existentes mas ainda fora dos sindicatos, ou evitar novas perdas onde o sindicalismo já esteve bem implantado.

Nessa linha de respostas coletivas, os sindicatos têm procurado voltar-se para novos grupos de trabalhadores, especialmente jovens, mulheres e migrantes. De modo geral, essas iniciativas sindicais renderam poucos frutos. No caso dos jovens que estão entrando no mercado de trabalho, os empregos mais atraentes estão em setores de atividades (serviços pessoais, comércio, atividades por conta própria, informática, lazer etc.) nos quais, na relação custo-benefício, a sindicalização é pouco compensatória para o empregado. A taxa de sindicalização entre os trabalhadores jovens tende a ser muito baixa, tendência que, se continuar, deverá trazer ainda mais prejuízos para o sindicalismo ${ }^{3}$. No caso das mulheres, os sindicatos conseguiram mais êxito, especialmente nas áreas da educação e da saúde pública. Mas encontraram maiores barreiras quando quiseram organizar as mulheres do segmento privado, tanto no caso dos empregos e atividades estáveis e "nobres" quanto no caso de atividades de baixa qualificação. A sindicalização foi também difícil nos ramos de ${ }^{3}$ No caso do TUC britânica, a média de idade dos filiados aos seus sindicatos é de 46 anos.
Entre os menores de 20 anos, somente 5\% estão sindicalizados (Waddington, 1998, p. 164). atividade em que grande parte da mão de obra está em trabalho temporário ou em tempo parcial. No caso dos migrantes, o apelo do sindicalismo é mais difícil de encontrar eco em virtude de lealdades maiores com a própria etnia e/ou pelo fato de, às vezes, para os migrantes, seus maiores problemas parecerem decorrentes mais da situação de estrangeiros, ou de filhos de estrangeiros, do que de assalariados. "Em que pese o êxito de algumas dessas iniciativas", conclui relatório da Organização Internacional do Trabalho, "é preciso reconhecer que, até agora, os resultados são muito modestos" (OIT, 1997-1998, p. 37).

Ironicamente para o sindicalismo, para muitos empregados, as vantagens da filiação podem ter diminuído em razão, muitas vezes, do êxito de pressões sindicais anteriores, que serviram para obter e consolidar um conjunto de vantagens que tornam, hoje, a organização sindical menos necessária do que no passado: salário mínimo, direitos trabalhistas, saúde e ensino públicos, seguros contra o desemprego e pensões para aposentados, benefícios que levam Galenson a indagar se os sindicatos são ainda necessários (1994, p. 135). A esses pontos poder-se-iam ainda acrescentar as novas políticas de relações humanas das grandes empresas, destinadas a melhorar as relações com os empregados, e as estratégias "integrativas" e de administração mais democráticas das grandes empresas modernas.

\section{B) respostas "individualistas"}

Numa linha de atuação destinada a servir não aos trabalhadores enquanto coletividade mas ao trabalhador enquanto indivíduo, os sindicatos procuraram aprofundar e diversificar serviços oferecidos a preços especiais, tais como: cursos, empréstimos, cartões de crédito, consultorias em assuntos profissionais sobre direitos dos empregados à seguridade social, imposto de renda, negociação do contrato individual de trabalho e outros assuntos equivalentes. Nessa linha, algumas vezes, os sindicatos acabam concorrendo com empresas e outras entidades de prestação dos mesmos serviços. Alguns sindicatos britânicos dão aos seus membros descontos em empréstimos, prêmios de seguros ou têm uma agência de viagens ou de obtenção da casa própria. A central norte-americana AFL-CIO empreendeu um programa chamado Union Privilege Benefits que oferece vantagens desse tipo. No Japão, o movimento de "identidade social" montou um programa de "bem-estar total" (OIT, 1997-1998). 
O engajamento nesse tipo de atividade não está isento de certos riscos: primeiro, os sindicatos podem afastar-se de suas funções de negociação e pressão e, segundo, podem passar a competir com outras empresas especializadas num campo de atividade para os quais não estão suficientemente preparados e, desse modo, arriscam-se a prejuízos financeiros.

\section{C) respostas organizatórias}

Nessa classe poderíamos incluir as respostas que incidem sobre mudanças na instituição sindical propriamente dita. Os "tempos difíceis" (para utilizar uma expressão do título da obra de Chaison) levaram a um grande aumento das fusões de sindicatos em muitos países. Como resultado desse movimento, no Reino Unido, o número de sindicatos baixou de 453 para 268 em 1992 (McIlroy, 1995, p. 19). Em fins de 1994, eram 243 (IRS Employnzent Review, April 1996). Entre os sindicatos filiados ao TUC, a redução foi muito acentuada: de 170, em 1970, para 74 em 1996 (Waddington, 1998, p. 164)

O movimento em direção a fusões, no caso do Reino Unido, sempre foi elevado. Os sindicatos surgiram, nesse país de antiga industrialização, como sindicatos de trabalhadores qualificados que tinham um ofício, fechados para os braçais sem qualificação. Mais tarde, a expansão da mecanização e a existência de grandes unidades de produção - que punham empresas poderosas diante de vários sindicatos de ofício relativamente pequenos estimulou a fusão de sindicatos e/ou a transformação das organizações por ofício em entidades de operários industriais. De 1911 a 1993, ocorreram no Reino Unido 1093 fusões de sindicatos (Chaison, 1966, p. 93).

As fusões de sindicatos foram estimuladas pelas dificuldades do sindicalismo nos últimos anos. Nos EUA, entre 1980 e 1994, a taxa média de fusão subiu $41 \%$ em comparação com os anos precedentes, com uma fusão por ano. Nos anos referidos, a maior parte dos casos de fusão (merger) foram antes processos de absorção (absorption) do que de unificação (amalgamation) (52 contra 5). No caso de absorção, um sindicato mais forte simplesmente incorpora um sindicato pequeno ${ }^{4}$.

\footnotetext{
${ }^{4}$ Essa forma de fusão é denominada por Visser e Waddington (1996) de "aquisição" para significar a absorção por um sindicato grande de outro menor que, consequentemente, desaparece. $\mathrm{O}$ maior continua a existir. No caso da unificação (amalgamalion) tem-se o acordo de dois ou mais sindicatos para criar um novo (p. 41). Os autores, em sua pesquisa comparada
}

Um caso clássico (relatado por Chaison, de onde retiramos as informações subsequentes) foi, nos EUA, o da absorção do Sindicato dos Trabalhadores do Vidro, da Cerâmica e dos Plásticos. Esse sindicato havia perdido um 1/4 de seus membros em razão principalmente do fechamento de fábricas. Nessa precária situação, o sindicato não teria recursos nem mesmo para efetuar seu congresso anual sem elevar as cotizações dos membros. A saída foi a absorção da entidade pelo Sindicato dos Moldadores e Trabalhadores em Atividades Conectas. Outro exemplo, entre muitos, foi a absorção, em 1995, do Sindicato dos Trabalhadores da Borracha. Não se tratava, nesse caso, de um sindicato pequeno mas de uma organização com 98 mil membros. Acontece que, desde 1980, o sindicato tinha perdido a metade de seus filiados e estava muito debilitado após uma greve iniciada em 1994 contra a companhia Bridge/Firestone, que durou dez meses e fracassou. Essa ação esvaziou os fundos de greve do sindicato e elevou suas dívidas para três milhões de dólares. Sua absorção pelo Sindicato dos Trabalhadores do Aço deu ao Sindicato dos Trabalhadores da Borracha acesso a um fundo de greve de mais de 160 milhões de dólares (pp. 26-27).

Normalmente, essas fusões apresentam dificuldades relacionadas com a distribuição de postos de comando na futura organização e ao destino dos funcionários sindicais. Chaison, no entanto, relata casos de fusão em que pequenos sindicatos aceitaram a integração em razão das condições vantajosas oferecidas pelos sindicatos mais poderosos, como a manutenção dos funcionários da organização menor e certo grau de autonomia pós-fusão.

Em muitos casos, surgem "problemas de jurisdição" relacionados com os sindicatos que representarão grupos profissionais e segmentos da classe trabalhadora depois da fusão. Um desses casos, que vale a pena reproduzir, envolveu o Sindicato Internacional dos Tipógrafos, o mais antigo dos EUA ainda existente. Em 1977, as mutações na área da impressão e da edição levaram empregados que estavam sob a jurisdição do sindicato dos tipógrafos para tarefas nas redações. O sindicato começou, então, a entabular

das estruturas sindicais da Suécia, da Holanda e do Reino Unido, notam que, no polo oposto das fusões, há a dissolução de sindicatos que ocorre quando os seus membros decidem pelo fim da organização. Esse caso deveria ser considerado como algo distinto do de fusão. Visser e Waddington, no estudo do sindicalismo dos três países considerados, encontraram que a mortalidade de sindicatos tende a ocorrer por ondas. Como regra geral, até a tempestade dos tempos atuais, os sindicatos, como organização, tenderam a tornar-se mais estáveis passada a fase de sua institucionalização e aceitação pela ordem capitalista democrática. 
negociações para a fusão com o Sindicato (Guilda) dos Jornalistas. As novas tecnologias tinham enfraquecido o poder de barganha dos tipógrafos e reforçado o dos empregadores porque as greves passaram a ser facilmente derrotadas quando as tarefas poderiam ser efetuadas facilmente fora da "unidade de barganha" dos impressores. Uma fusão informal ocorreu entre o Sindicato dos Tipógrafos, com 75 mil membros, e o dos jornalistas, com 32 mil. Mas foi rompida em 1981 em razão de divergências sobre mensalidades e autonomia local das duas organizações e porque os jornalistas temeram que seus interesses passassem a plano secundário. Apesar dos problemas, os funcionários de ambas as organizações prosseguiram as negociações e criaram, em setembro de 1982, o Sindicato Internacional da Mídia. As propostas foram levadas à apreciação dos membros e aprovadas em 1983. O sindicato dos Teamsters interveio. Uma fusão foi tentada e fracassada com essa entidade. (Um dos argumentos dos Teamsters era que, uma vez que seu sindicato controlava os motoristas dos caminhões de entrega dos jornais, o sindicato dos tipógrafos teria seu poder de pressão aumentado.) $\mathrm{O}$ acordo com os Teamsters, que não estavam filiados à AFL-CIO, não se realizou. Finalmente, em 1987, os tipógrafos fecharam um acordo com o Sindicato dos Trabalhadores da Comunicação da América, criando uma divisão semi autônoma dentro dele, denominada Trabalhadores do Setor de Impressão, Edição e Mídia (pp. 32-38).

No Canadá, as fusões prosseguiram mais rapidamente do que nos EUA. De uma média de 1,5 fusão por ano na década de 60, de 2,6 na dos 70, elas passaram para 2,9 em 1980 e subiram para 4,8 nos primeiros anos de 1990. Na grande maioria dos casos, Trata-se de absorções de pequenos sindicatos por grandes. O campeão foi o Sindicato dos Trabalhadores da Indústria Automobilística do Canadá, que realizou nove absorções de outros sindicatos. O segundo lugar coube ao Sindicato dos Empregados Públicos do Canadá (Chaison, 1996, pp. 55-57).

Os resultados da pesquisa de Chaison são pessimistas: "Em cada país estudado (EUA, Canadá, Grã-Bretanha, Austrália e Nova Zelândia), as fusões foram tipicamente incapazes de resolver os problemas fundamentais que elas mesmas criaram" (p. 165). Acontece que uma das consequências das fusões tem sido a criação de "sindicatos gerais", multiprofissionais, distantes da jurisdição sindical anterior. No final, como conclui outro pesquisador, Kim Moody (1989), em suas ácidas, pessimistas e radicais observações sobre o futuro do sindicalismo americano, esses sindicatos estão se tornando "organizações multijurisdicionais", negociando em muitas indústrias, mas sem força real em qualquer delas, a não ser, talvez, na sua base tradicional. Em alguns casos, essa política de crescimento ao acaso, na verdade, teria aumentado a desunião dos empregados dentro da indústria (p. 197). A essa mesma conclusão amarga chega Waddington (1998) para o Reino Unido. No caso, o autor salienta mais o aumento da heterogeneidade da composição da massa de sindicalizados que resulta de cada fusão. A consequência é "a criação de numerosas subseções representativas de interesses particulares. A heterogeneidade da representação coloca também o problema da coesão sindical numa escala inteiramente nova" (p. 165), ponto que se relaciona com o da fragmentação dos interesses das classes trabalhadoras tratado anteriormente.

Quadro 9.1

Número de sindicatos em alguns países

\begin{tabular}{|l|c|c|c|c|}
\hline & 1980 & 1985 & 1990 & 1995 \\
\hline Alemanha & - & - & $17^{(1991)}$ & $16^{(1990)}$ \\
Austrália & 325 & 323 & 295 & 142 \\
Dinamarca & - & $138^{(1987)}$ & 131 & 95 \\
EUA & $304^{\mathrm{a}}$ & - & - & - \\
Holanda & - & - & 37 & - \\
Irlanda & - & $100^{(1998)}$ & 95 & $73^{(1984)}$ \\
Japão & 72693 & 74499 & 72202 & $71674^{(1994)}$ \\
Nova Zelândia & $265^{\mathrm{a}}$ & 259 & $66^{(1991)}$ & $82^{(1994)}$ \\
Reino Unido & 438 & 370 & 287 & $243^{(1994)}$ \\
Suécia & - & - & $68^{(1991)}$ & $67^{(1994)}$ \\
Suíça & 25 & 24 & 23 & $26^{(1994)}$ \\
\hline
\end{tabular}

${ }^{\mathrm{a}}$ Chaison, 1996, p. 4

Fontes: Statistics of Trade Union Membership, OIT, July, 1997

No Quadro 9.1 está uma relação do número de sindicatos por país. Na maioria dos casos, pode-se notar o constante declínio da quantidade de sindicatos. Mas a extensão do fenômeno depende da natureza da estrutura do sindicalismo em cada país. No caso do Japão, em que vigora o sindicalismo por empresa (e que não fez parte deste estudo), o número de sindicatos é extremamente elevado e sofreu pouca variação. A Alemanha encontra-se na situação oposta, com um número muito baixo de sindicatos (somente 16), os quais representam setores econômicos tais como metalurgia, construção, serviços públicos, têxtil e vestuário, agricultura, polícia etc. 
As fusões das últimas décadas têm sido respostas defensivas do sindicalismo que, como se notou, decorrem do declínio do número de associados e/ou de mudanças no mercado de trabalho e na tecnologia da produção. De modo geral, como os dados sobre as taxas de sindicalização indicam, não conseguem evitar posteriores perdas. Mas é preciso notar que fusões ocorreram sempre no sindicalismo, especialmente na sua fase de consolidação. Nem sempre fusões ou, ao contrário, multiplicação do número de sindicatos foram respostas a um ambiente hostil ou a uma conjuntura particularmente desfavorável para o sindicalismo. Introdução de novas tecnologias, conflitos políticos internos no movimento sindical (disputas ideológicas e/ou lutas pelo poder dentro de sindicatos, federações ou centrais) podem ter efeitos no aumento ou na redução do número de sindicatos. Por outro lado, fusões, absorções ou eliminação de sindicatos não necessariamente significam aumento ou diminuição das taxas nacionais de sindicalização, cuja variação, como já foi visto, depende de muitas outras razões.

\section{O FUTURO DO SINDICALISMO NA VISÃO DOS PESQUISADORES}

As observações anteriores referem-se mais à medida que os sindicatos, tal como existem hoje, estão pondo em prática ou tentando aplicar em maior ou menor escala. Outra questão diz respeito às sugestões decorrentes dos estudos e pesquisas dos analistas do sindicalismo, quer dizer, de propostas externas ao sindicalismo, as quais tendem a apontar alternativas mais amplas que atingem, às vezes, a própria natureza da instituição sindical. As sugestões alternativas geralmente refletem o estado do sindicalismo no país do pesquisador, aspecto que se relaciona com o sistema de relações de trabalho em vigor. Por exemplo, nos EUA, como já vimos, há forte ênfase na necessidade de alterações na Lei Nacional de Relações Industriais. Nos últimos tempos, muitos de seus dispositivos têm sido burlados pelos empregadores ou simplesmente deixados de lado enquanto outras alterações na legislação reduzem a força do sindicalismo e sua importância para os trabalhadores 5 .

${ }^{5}$ Uma avaliação da Lei Nacional de Relações Industriais e das propostas de reforma escaparia de nossa competência e provavelmente não teria interesse para a maioria dos leitores. Porém, citamos alguns pontos que estão sendo questionados pelos analistas e algumas das propostas de alteração sugeridas a fim de dar uma ideia mais precisa de certas características do modelo norte-americano, especialmente do tipo da influência da legislação no sistema de relações de trabalho dos EUA. Ao contrário da legislação brasileira, a norteamericana intervém pouco em questões de conteúdo, mas intervém muito no que diz respeito ao estabelecimento das regras do conflito e, desse modo, influi sobre seus resultados, quer dizer; sobre questões substantivas. A maioria dos exemplos que se seguem foram retirados do livro de Craver (1993, cap. 6, "Necessidade de Reforma da Lei Nacional de Relações do Trabalho"), um forte crítico do modelo americano e defensor de uma revisão na legislação. Vejamos alguns itens que, na opinião de Craver (compartilhada, em geral, por outros pesquisadores simpáticos ao sindicalismo), deveriam ser objeto de alteração em benefício dos sindicatos: a) Ampliação dos direitos de controle dos sindicatos sobre o ambiente de trabalho. Este ponto ganhou relevância depois que a Suprema Corte entendeu que a decisão de uma empresa de fechar uma de suas unidades não constituía matéria de negociação com o sindicato. O pronunciamento da Suprema Corte foi sobre um conflito entre uma empresa e um sindicato mas criou jurisprudência para aumentar a liberdade das companhias sobre um conjunto de assuntos que, por lei, estavam antes submetidos à negociação com o sindicato; b) Direitos de punição de empregados pelos sindicatos. Esses direitos foram reduzidos por decisão da Suprema Corte, que estabeleceu que os sindicatos não poderiam mais punir empregados que furassem um piquete de greve legal, caso esse trabalhador tivesse se "dessindicalizado" antes do início do movimento; c) Eleições para implantação do sindicato. As eleições para "sindicalização da empresa" deveriam ser efetuadas no prazo máximo de duas semanas depois que a petição para a sua realização (dirigida à JNRI) tivesse sido apresentada. Os sindicatos entendem que um prazo curto para a realização das eleições é importante para ganhar a votação na empresa. Prazos longos ampliam o período de tempo à disposição dos empregadores para influenciar os trabalhadores e, portanto, aumentam a probabilidade de a proposta de formação do sindicato ser rejeitada pelos empregados; d) Substituição de grevistas. Deveria ser eliminado o direito de os empregadores substituírem empregados em greve, de modo temporário ou permanente. A jurisprudência para a permissão da contratação permanente de furadores de greve veio depois que o presidente Reagan decidiu, em 1981, terminar com a paralisação dos II mil controladores de voo que, ilegalmente, haviam entrado em greve contra o governo federal. Um estudo da AFL-CIO revelou que, durante o ano de 1990, 11\% dos 243300 trabalhadores que entraram em greve naquele ano foram substituídos; e) Atividades "secundárias". Dever-se-ia permitir aos sindicatos efetuarem "atividades secundárias" (de busca de solidariedade), quer dizer, tentar convencer empregados de outras firmas, que abastecem ou retiram produtos de estabelecimentos afetados por movimentos grevistas, a suspender essas operações; f) Pressão sobre outras empresas e empregados não envolvidos no conflito. Os sindicatos deveriam ter o direito de pressionar ou coagir fornecedores ou compradores da empresa sob greve a cessar seus negócios com ela. Além disso, os grevistas deveriam poder usar cartazes e distribuir panfletos para convencer fregueses de lojas que continuam a vender produtos de uma firma com a qual estão em disputa a não adquirir mercadorias produzidas por ela ("the primary business"); g) Garantias a não sindicalizados. Os empregados não sindicalizados que levantem questões de "óbvio interesse de outros empregados" deveriam ser considerados como engajados em "atividade conjunta construtiva" (de solidariedade) e colocados sobre a proteção da LNRI e, consequentemente, não poderiam ser punidos pelas empresas; h) Atividades de lobby. Aos sindicatos deveria ser dada permissão para utilizarem recursos das cotizações sindicais em atividades de lobby a fim de estender os direitos dos empregados 
Especialmente nos Estados Unidos, alguns autores entendem necessária, para revitalizar o sindicalismo, a criação de organizações de local de trabalho, quer dizer, de conselhos operários. Como mencionamos antes, o modelo dual da Alemanha, onde nos anos 80 o sindicalismo enfrentou razoavelmente bem as pressões decorrentes das mudanças na economia e na política, pareceu uma alternativa para barrar a decadência do sindicalismo no setor privado norte-americano. A existência de um partido político ligado aos sindicatos, dessa perspectiva, aparece citado algumas vezes como algo importante. As lideranças dos grandes sindicatos, a "burocracia do sindicalismo de negócio", como as denomina Moody pejorativamente, sua incapacidade de inovar e disposição para ceder são vistas frequentemente como um fator relacionado com a decadência do sindicalismo no setor privado. Em outros termos: seria necessária a formação de outro tipo de movimento sindical, mais democrático, menos burocratizado, mais dinâmico, mais capaz de atrair as minorias étnicas, os trabalhadores marginalizados e os não organizados. Tentativas nessa direção são mencionadas por vários autores. Os mais "à esquerda" sugerem que os sindicatos sejam mais duros na resistência às pressões das empresas e as lideranças sindicais mais empenhadas no esforço de levar o sindicato para novos segmentos das classes trabalhadoras, além da clientela habitual do sindicato. Nesse tipo de ampliação da atuação é enfatizada a necessidade de os sindicatos darem mais atenção para problemas que afetam os trabalhadores como cidadãos. Entram nessa classe as reivindicações que interessam às minorias étnicas, a atenção a questões que se referem

(sindicalizados) a todos os trabalhadores; i) Dispensa de empregados. Medidas que impeçam a dispensa de empregados que lideram movimentos para a criação de um sindicato na empresa deveriam ser adotadas.

A legislação de relações de trabalho dos EUA especifica vários atos dos empregadores que são considerados ilegais (unfair practices). Mas acontece que vários desses "procedimentos desleais", proibidos pela lei, têm custo baixo (quando acontece de o sindicato conseguir prová-los), sendo as multas consideradas muito pequenas comparadas com as vantagens de não haver sindicato na empresa. As multas, portanto, não serviriam para barrar ações antissindicais das companhias. Empregados despedidos, se comprovada conduta desleal da empresa, devem ser readmitidos e receber uma indenização. Mas as ordens da Junta para readmissão, na maioria dos casos, são tidas pelos sindicatos como inúteis. Frequentemente, enquanto aguarda o julgamento, o trabalhador despedido é obrigado a procurar outro emprego. Além disso, pesquisas indicam que indenizações das empresas aos empregados, quando comprovada "conduta desleal", atingem somente $35 \%$ a $40 \%$ dos casos. especificamente às mulheres, aos aposentados, à defesa do meio ambiente, às reivindicações democráticas, de modo geral.

Essas opções e linhas de atuação referem-se a respostas sugeridas pelos pesquisadores nos diferentes países e setores econômicos, algumas das quais estão sendo efetivamente tentadas pelos sindicatos. As estratégias a ser adotadas, dependendo do lugar que venham a ocupar no conjunto da atuação sindical, podem provocar alterações na própria natureza do sindicalismo, que poderia transformar-se, no próximo século, em algo diferente do que foi no século XX. Novas identidades e funções poderiam ser assumidas. Mas o que poderia ser esse novo sindicalismo não parece muito claro.

As avaliações dos pesquisadores sobre as estratégias e desdobramentos futuros são influenciadas pela situação do sindicalismo de seus próprios países e pelas suas próprias posições políticas e ideológicas. Os autores mais simpáticos ao sindicalismo são mais propensos a acreditar que seria possível à organização sindical superar os anos difíceis mediante novas formas de atuação, além de conservar as posições obtidas anteriormente nos anos de vacas gordas. As soluções aventadas são frequentemente contraditórias. Assim, para citar um exemplo: no caso dos EUA, é habitual a crítica à passividade dos dirigentes sindicais, ao seu desinteresse em aumentar os gastos com a ampliação da filiação, em tentar incorporar novos segmentos, em levantar novas bandeiras e em desenvolver outras ações inovadoras. Strauss (1995), por exemplo, salienta que os sindicatos americanos têm estado afastados das grandes questões sociais e políticas, como os direitos femininos, os das minorias, a proteção aos deficientes físicos; o direito de aborto, as questões ecológicas. Nessa área, no melhor dos casos, teriam sido parceiros secundários. "Mais frequentemente, foram seguidores neutros ou (como no caso da guerra do Vietnã) opuseram-se às posições progressistas [...]. Mesmo na área do emprego, foram os grupos de defesa de interesses específicos (como no caso dos direitos dos gays) que assumiram papéis que caberiam ao sindicalismo. Os sindicatos tornaram-se burocráticos, mais interessados na defesa de seu pedaço do que expandir-se para novas áreas" (p. 344).

Notadamente para autores mais "à esquerda", uma dose maior de militância e de atuação solidária seria necessária. Uma transformação no caráter do sindicalismo poderia vir com a mudança de seu hábitat. Para Moody, se os sindicatos se abrissem em direção aos novos segmentos 
marginalizados e de baixa qualificação da classe trabalhadora, o sindicato acentuaria o seu caráter de movimento social: "Como a composição e a natureza da classe trabalhadora e do trabalho que ela realiza mudam, o sindicalismo precisa também mudar" (Moody, 1989, p. 341). Isso implicaria retomar as tradições militantes do sindicalismo de indústria (para os EUA), estender a democracia para a base, aumentar a solidariedade dos empregados para mais além das segmentações das categorias e dos locais de trabalho, incorporando reivindicações que ultrapassem as demandas profissionais tradicionais de modo a atrair os "hispânicos", os negros e as mulheres e criar um "novo sindicalismo" mais combatente (Moody, 1989, especialmente o cap. 14, "Refazer a Classe Operária Norte-americana").

Tal tipo de crítica adquire sentido em se tratando de um sindicalismo altamente profissionalizado e orientado para a defesa dos interesses dos trabalhadores sindicalizados e não do conjunto da classe. Mas, enquanto alguns pesquisadores americanos criticam a "profissionalização" do tipo "sindicalismo de negócio" de seu país, o sindicalismo francês, a julgar por certas análises, parece sofrer de um mal inverso: ausência de estruturas mais sólidas, de melhor organização, de mais controle das cúpulas sobre as bases. Em outras palavras: precisaria de mais profissionalismo. Desse modo, Durand (1996), refletindo sobre a situação presente de um sindicalismo que, no passado, sempre confiou na capacidade da liderança de sindicatos minoritários e nas grandes mobilizações dos trabalhadores, entende que, na hora atual, a saída para a legitimação do sindicalismo junto aos trabalhadores seria justamente "a profissionalização dos sindicalistas no mesmo nível dos especialistas empregados pelas direções das empresas...". Se a profissionalização não mais pode conduzir às grandes mobilizações do passado, "baseadas no desinteresse militante", ela permitiria ao menos "produzir um discurso e uma prática quotidiana receptiva pelos assalariados, portanto legitimadora do sindicato" (p. 51).

Também para Rosanvallon (1988), o declínio do sindicalismo francês, que julga irreversível na sua forma atual, viria da "redução de sua capacidade de representação social. Os sindicatos estariam muito afastados de sua base, distantes das preocupações terrenas, insuficientemente atentos aos movimentos da sociedade" (p. 199). Considerando a decadência acentuada do sindicalismo na França, Rosanvallon entende que uma taxa de $2 \%$ de sindicalização nos próximos anos não deve ser excluída. Mas o autor julga que um tal desenvolvimento não eliminaria necessariamente a representatividade sindical, pois ela poderia mudar de forma: "A legitimidade sindical seria como a dos partidos, de essência puramente eleitoral. O partido político não é um movimento social. Funcionalmente, não tem necessidade de aderentes. Esses são constituídos por um pequeno núcleo de ativistas em torno dos eleitos. Ninguém sonharia em fazer do número de filiados a um partido o critério de sua representatividade. Só os resultados eleitorais contariam" (p. 91). O autor julga que um tal desenvolvimento implicaria um "problema de financiamento" dos sindicatos, mas isso poderia ser contornado mediante contribuições públicas, tal como os partidos (e mesmo os sindicatos) já recebem. Nessa visão, o sindicalismo manteria um papel (necessário) de agência social, com tarefas de representação dos empregados nas empresas e em muitas outras instituições do Estado 6 . Já existiriam nas empresas francesas cerca de 400 mil pessoas em funções de delegado do pessoal, delegado sindical, membro dos comitês de empresa, dos comitês de higiene e de segurança. Além disso, existiriam ainda 12 mil administradores sindicais nas caixas de auxílio-doença e de seguro-família. Desse modo, os sindicatos já teriam um papel de agências sociais e desempenhariam funções de autoridades governamentais, espécie de "funcionários do social", sendo uma instituição semipública.

Trata-se de uma tese que implica a eliminação, ou redução, do papel de pressão do sindicato enquanto movimento social, pois, sem aderentes, a força do sindicalismo teria de ser garantida pela lei. Entendemos que está implícita nas teses de Rosanvallon o fim do sindicalismo nos termos em que existiu como movimento social e político. Na realidade, Rosanvallon considera que esse papel de "agência social", entre as múltiplas funções do sindicalismo, foi o único que se teria desenvolvido enquanto os demais, inclusive a de movimento social, estariam estagnados ${ }^{7}$. Está suposta, aqui, também a transformação da instituição sindical e não apenas de suas formas de atuação.

\footnotetext{
${ }^{6}$ Rosanvallon define como agência social "o conjunto das funções sindicais que estão ligadas a um papel institucional: participação na gestão de instituições sociais e semipúblicas; participação em Instituições econômicas ou sociais do Estado; função de representação em organismos como Conselho Econômico e Social etc. Na qualidade de agência social, o sindicato é uma espécie de 'funcionário do social', um organismo quase público. Esse aspecto distingue-se do de sua dimensão de movimento social (força de reivindicação e de negociação)" (p. 24)

${ }^{7}$ Rosanvallon acentua que o sindicato está muito longe de ser uma forma unificada e coerente de representação social, mas, ao contrário, integraria, no seu interior, um conjunto
} 
Especificamente para o Reino Unido, Visser (1994c) é pessimista ao avaliar os possíveis êxitos das estratégias sugeridas por Towers (1989) para a recuperação do sindicalismo britânico: a) trabalhar para eleger um governo trabalhista e obter leis favoráveis; b) aumentar as fusões sindicais; c) recrutar em novos segmentos; d) melhorar a oferta de serviços para seus membros e e) revisar as estratégias sindicais. Apesar de afirmar que, no conjunto, todas provavelmente podem ajudar, o pesquisador holandês entende que, mesmo que um governo trabalhista possa eliminar as medidas mais prejudiciais impostas pelos conservadores, não haveria retorno para o ambiente legal e político da década dos 70. As fusões podem concentrar recursos dos sindicatos e estruturar as atividades de modo mais eficiente, mas elas têm sido medidas defensivas oportunistas que têm feito a estrutura sindical britânica mais complexa do que nunca. O recrutamento de novos segmentos profissionais poderia ser uma saída, mas Visser entende - com outros pesquisadores, aliás - que a baixa da popularidade do sindicalismo entre os jovens, não só na Grã-Bretanha mas em vários países, é um dos aspectos mais alarmantes e que parece altamente improvável de que a atual geração chegue a alcançar os mesmos níveis de mobilização coletivas das gerações passadas. A tentativa de melhorar a oferta de serviços para os associados, que é uma estratégia de tipo empresarial, tenderia a fazer com o que o "status de consumidor" garanta mais benefícios do que o de sindicalizado.

A mudança de objetivos, por sua vez, no caso do Reino Unido, tem ido mais na direção da redução das táticas de confronto (Visser, 1994c, pp. 100-101). A cooperação com os empresários estaria ligada ao esforço dos sindicatos de impedir a continuidade na queda do número de sindicalizados. Waddington (1998) classifica esse tipo de orientação, procurada por alguns sindicatos britânicos, com o nome de "parceria social". A cooperação poderia estabelecer-se em nome de interesses comuns dos trabalhadores e empresários, tais como: segurança no emprego, formação profissional; informação, consulta e negociação; elevação da produtividade; saúde e segurança (p. 161). Essa seria uma das respostas que os sindicatos

de funções ligadas às necessidades e à situação de uma dada população: "O sindicato acumula as funções de advogado (defesa dos interesses individuais dos assalariados), de representante eleito localmente e de deputado nacional (função de representação), de mediador e negociador, de jornalista e de pesquisador, de animador social, de especialista, de juiz. É ao mesmo tempo um movimento social, uma associação, uma instituição semipública, uma sociedade de prestação de serviços" (p. 42). britânicos procuraram aplicar diante das políticas neoliberais. Ela constituiria uma entre três tipos principais de respostas tentadas pelo sindicalismo. Os outros dois seriam, tal como já foi salientado, reforçar os laços com o Partido Trabalhista para, na eventualidade de vir esse partido a formar o gabinete, alterar pelo menos parte da legislação do período thatcherista. A outra seria a reforma da estrutura sindical do Reino Unido, extremamente complicada, marcada, atualmente, pela baixíssima participação dos trabalhadores nas assembleias locais (apenas de $4 \%$ a $7 \%$ dos membros). De modo geral, a conclusão do autor, simpático ao sindicalismo, é pessimista. No caso das tentativas de parceria social, poucas experiências foram levadas à prática. Waddington nota que o novo governo trabalhista mostrou pouco interesse no reforço dos vínculos tradicionais com os sindicatos, ainda que esses retirassem recursos de seus fundos para financiar as campanhas dos trabalhistas.

Já na visão de Hyman (1994c) quatro "emergentes identidades" (que corresponderiam a estratégias diferenciadas) abrem-se para os sindicatos hoje:

a)A decorrente do deslocamento da ênfase da ação sindical do coletivismo para o individualismo, na qual os sindicatos orientar-se-iam especialmente no sentido de oferecer serviços para os trabalhadores enquanto indivíduos (que já mencionamos). Nesse caso, o sindicato transformar-sei-a numa espécie de sociedade de auxílio mútuo e pouca coisa teria em comum com um sindicato nos termos atuais.

b)Uma segunda alternativa seria a acentuação da dimensão cooperativa, na qual o sindicato faria parte da "coalizão produtiva", colaborando com a direção das empresas para elevar sua capacidade produtiva e concorrencial. Essa orientação não é nova. Segundo Hyman, na Alemanha, o "egoísmo de companhia" tem sido frequentemente reconhecido como um contrapoder ante os esforços dos sindicatos para aumentar a solidariedade dos trabalhadores além das fronteiras de uma empresa. O tipo ideal desse tipo de sindicato seria o "sindicato de empresa" (company union), ou seja, sindicatos dirigidos, influenciados ou criados pelos empregadores para colaborar com o patronato e impedir a existência de sindicatos autônomos de orientação mais conflitiva. A lógica desse modelo conduziria o sindicalismo a um desenvolvimento segundo o modelo japonês.

c)A terceira alternativa seria o sindicato como "parceiro social", um interlocutor do governo. Essa linha teria uma base sólida em países onde os 
benefícios governamentais para o desemprego, doenças e aposentadoria são considerados explicitamente como parte do "salário social", na determinação do qual os sindicatos teriam um legítimo papel representativo. Tal alternativa imporia fortes dilemas para o sindicalismo, tanto a nível macro, das políticas nacionais, como a nível micro, das empresas e locais de trabalho: os sindicatos só poderiam manter ou aumentar seu status representativo externo (reconhecimento pelo governo e empregadores) às custas de sua representatividade interna diante dos trabalhadores, legitimando orientações governamentais e empresariais sem obter garantias e proteção para seus representados.

d)A última alternativa seria o que traduzimos, na falta de melhor termo, por "sindicalismo como uma organização de movimento popular"8. O autor considera que a organização de interesses econômicos e a atuação como movimento social têm sido dois polos opostos de análise da natureza do sindicalismo. Durante as últimas décadas, a orientação "economicista", voltada para a defesa de interesses profissionais particulares de grupos de trabalhadores, teria dominado o sindicalismo na maioria dos países da Europa, mas, hoje, haveria a reabilitação do sindicalismo como movimento social. O modelo de movimento social ou de classe estaria sendo recuperado especialmente pelos sindicatos cuja base tradicional se torna muito frágil. Esses sindicatos estariam sendo pressionados a incorporar pelo menos alguns elementos do modelo de movimento social. Mas a tensão entre o modelo tradicional do sindicato, como organização de interesses e como movimento social, não poderia ser ignorada porque, em muitas questões importantes, haveria conflito entre o sindicato como organização de defesa de interesses de um dado grupo e o sindicato como movimento social, com metas mais amplas, tais como no caso de políticas de restrições a empresas poluidoras do ambiente, ou seja, orientações dirigidas ao trabalhador e ao cidadão.

Como conclusão, Hyman entende que nenhum sindicato poderia assumir inteiramente qualquer dos quatros modelos expostos. Mas, nesses tempos difíceis, os sindicatos teriam de dar prioridade a um dos modelos apresentados. As escolhas dependeriam das tradições específicas do sindicalismo de cada país e dos contextos nacionais. Hyman não acredita

${ }^{8} \mathrm{O}$ termo inglês é "trade unions as populist compaining organizations", de difícil tradução em português, especialmente porque o termo "populista", em português, tem sentido pejorativo. Optamos, sem muita convicção, pela tradução acima. que, neste fim de milênio, haveria razão para esperar o aparecimento de um padrão euro-sindical para o conjunto dos países da União Europeia (Hyman, pp. 133-136). Acordos coletivos multinacionais, de âmbito continental, seriam especialmente difíceis em razão: a) das diferenças na legislação dos vários países, diferenças relacionadas com greves, direitos sociais, escala de salários, benefícios e outras cláusulas trabalhistas; b) da resistência dos sindicatos devido a diferenças ideológicas internas; c) da competição entre eles para atrair investimentos internacionais; d) das oposições patronais; e) da falta de apoio dos governos e partidos nacionais (Visser, 1996a).

As pressões em direção a negociações por companhia ou por local de trabalho, a descentralização da barganha, juntamente com esforços no sentido da incorporação de novos grupos de trabalhadores, poderiam ser um meio de renovação do sindicalismo. Nesse caso, as tendências de reestruturação das empresas poderiam ser uma oportunidade para a recuperação do movimento sindical mediante, especialmente, o reforçamento das organizações de local de trabalho, dos conselhos de trabalhadores, tanto no setor público como no privado, solução aventada por numerosos autores e referida no Cap. 6 (cf., por exemplo, Ackers; Smith \& Smith, 1996; Jefferys, 1996b; Kern \& Sabel, 1994; Regini, 1994; Hancké, 1993; Blanchflower \& Freeman, 1992; Crouch, 1994).

A importância dos acordos locais é acentuada inclusive para o setor público. No que diz respeito a esse setor, Fairbrother (1996) acredita que os sindicatos britânicos estariam em condições de começar a desenvolver formas mais ativas de sindicalismo de local de trabalho do que o fizeram no passado (p. 111). Na medida em que a administração muda para formas mais descentralizadas, cresceriam as possibilidades para um sindicalismo mais implantado nos locais de trabalho. Esse deslocamento teria reflexos positivos na própria organização sindical. Ele implicaria a ênfase na descentralização mais do que na centralização, em formas igualitárias de organização, atuação e participação sindical dos trabalhadores, menos passividade e distanciamento de parte das lideranças. No conjunto, o autor, ao contrário de outros, vê otimisticamente, na reestruturação do Estado, possibilidades para o surgimento de "formas participativas de sindicalismo", embora esse desenvolvimento lhe pareça mais difícil nos locais onde existe uma longa história de formas centralizadas e hierárquicas de sindicalismo (p. 112). A expectativa otimista de Fairbrother é que, quando os sindicatos enfrentam 
crise de representação, há indicações de que formas mais inovatórias e imaginativas de organização e atuação podem surgir (p. 115).

Mas a maioria dos autores entende que, apesar da crescente importância do local de trabalho como unidade de negociação, os sindicatos, para conservarem força política, como já foi dito, precisariam fazer com que negociações locais estejam integradas, ou respaldadas, por negociações nacionais, o que aponta para a tentativa de manutenção de esquemas neocorporativos, mais difíceis de subsistir na época atual. Um dos problemas, reconhecido também por Fairbrother, vem do fato de que a predominância das negociações por locais de trabalho e a tentativa de renovação do sindicalismo a partir da empresa, ou das unidades de trabalho, podem trazer consigo a limitação das preocupações dos trabalhadores e do sindicalismo com as questões locais, estimulando um "sindicalismo de empresa" (mas num sentido diferente do "company union") no qual os empregados se preocupam com seus interesses mais próximos, indiferentes aos dos seus companheiros de outros ramos e locais de trabalho. Outra dificuldade residiria em como conseguir uma rede mais ampla de unidades de locais de trabalho em lugar de lideranças e ativistas isolados (pp. 142-143).

Mais agressividade ou mais cooperação?

No entanto, ainda que a salvação do sindicalismo por meio da ampliação e reforçamento da ação mais militante e agressiva possa aparecer como uma via de renovação, essa linha nem sempre é considerada como a melhor alternativa. Outros pesquisadores preferem acentuar a necessidade de novas orientações adaptadas à época da produção flexível, isto é, a relações menos conflitivas, o que não significa dizer de cooperação subalterna. Um exemplo é encontrado na ideia do "sindicalismo associativo" (associonational unionism), desenvolvida por Heckscher tendo os EUA como referência. A ideia parte da crescente inadequação do modelo sindical e de relações de trabalho criado durante o New Deal. O tipo de trabalhador então existente estaria em fase de diminuição e de confinamento em ramos decadentes da produção. Nas novas indústrias, a linha que separa, de um lado, os trabalhadores de macacão das oficinas e, de outro, os técnicos e pessoal especializado de escritório tenderia a tornarse mais indistinta e confusa. O sindicalismo deveria tentar incorporar esses segmentos profissionais altamente qualificados em funções que oscilam entre as atividades nos escritórios e na produção, atividades cada vez menos diferenciadas à medida que aumentam a automatização e a informatização.

O "sindicalismo associativo", de acordo com Heckscher, no tocante às suas formas de ação, não seria de colaboração de classes. $\mathrm{O}$ conflito não diminuiria necessariamente mas mudaria de forma, deixando a greve de ser o principal instrumento de pressão sobre as empresas. Movimentos grevistas, na época atual, acredita Heckscher, tenderiam a produzir cada vez menos resultados positivos. Outras táticas, como denúncias públicas de atos desleais e contrários aos empregados de parte de empresas, a atuação junto a organismos legislativos e governos, o uso intenso da publicidade, deveriam ser mais constantemente utilizadas. Nos quadros do "sindicalismo associativo", a Lei Nacional de Relações Industriais dos EUA deveria ser inteiramente reformada. Para substituir o modelo de tipo "adversário", que vigoraria nos EUA, Heckscher imagina formas duráveis de cooperação dos sindicatos com a administração das empresas cujo desdobramento natural seria a co gestão, que o autor, contudo, acredita muito difícil de vigorar nos Estados Unidos (Hecksher, 1996).

Tal orientação estaria num meio-termo, se assim se pode dizer, entre as estratégias conflitivas e as de cooperação. Um dos dilemas que os movimentos sindicais encontram hoje viria do fato de que, quanto mais êxito obtêm as ações sindicais de confronto, destinadas, por exemplo, a bloquear a flexibilização das normas de trabalho, a reorganização empresarial e outras medidas consideradas prejudiciais aos empregados, mais as companhias são tentadas à terceirização, à fragmentação das unidades produtivas, às transferências de locais de produção e outras medidas de represália.

No caso da indústria automobilística alemã, Kern e Sabei (1994) entendem que as táticas sindicais que oferecem mais resultados diante das ofensivas empresariais são as que chamaríamos de "intermediárias". Tratase de estratégias que conseguem apresentar às gerências contrapropostas que, ao mesmo tempo, servem de defesa para grupos de trabalhadores prejudicados por ações empresariais e oferecem ao patronato alternativas capazes de melhorar a capacidade de competição da companhia e, assim, encontram menos resistência das administrações.

Mas essa orientação implicaria uma mudança profunda na tradição sindical dos países desenvolvidos. O sindicalismo, nas democracias capitalistas, esteve habitualmente voltado para a obtenção de políticas 
redistributivas em benefício dos sindicalizados ou dos trabalhadores no seu conjunto. A gestão da produção (pelo menos dentro do sistema capitalista) não preocupou especialmente os sindicatos, a não ser em ocasiões excepcionais. Nos países onde o movimento sindical, ou parte dele, era movido por fortes sentimentos de oposição social e de rejeição da ordem econômica capitalista, a preocupação com a produtividade (notadamente a nível da empresa) poderia parecer "colaboração de classe". As estratégias de confronto não precisam estar motivadas necessariamente por ideologias socialistas ou de luta de classes. Os sindicatos americanos, que estão muito longe de partilhar qualquer tipo de ideologia socialista, nem por isso deixam de ser muito refratários a propostas que os levem a assumir responsabilidades de tipo empresarial, inclusive no que diz respeito à criação de comissões de representantes de trabalhadores na empresa ou a quaisquer outras iniciativas que pudessem ser consideradas como coparticipação e que levassem à representação dual dos empregados, quer dizer, à representação do sindicato ao lado de outra forma de representação dos trabalhadores escolhida diretamente pelos empregados das empresas e fora do controle sindical. Nesses casos, os sindicatos precisariam harmonizar suas demandas com as políticas das empresas e se arriscariam a se transformar em "sócios do capital".

Consequentemente, nos países onde predominaram orientações de confronto, os sindicatos não se preocuparam com os problemas da saúde das empresas e da economia. Essa afirmação não valeria para o sindicalismo dos países nórdicos, da Alemanha ou da Áustria do após guerra, onde vigoraram (e em certa medida ainda vigoram) sistemas neocorporativos. Mas, de todo jeito, na época das políticas keynesianas, argumenta Streeck (1994), os sindicatos podiam permanecer confortavelmente orientados para a ampliação do consumo e para a conquista de novas vantagens para os assalariados. No final, a defesa de demandas corporativas conjugava-se com os interesses gerais da produção. $\mathrm{O}$ modelo alemão de relações entre o Capital e o Trabalho parecia especialmente apropriado para o modo fordista de produção em massa e para o modo keynesiano de regulamentação do consumo (Baethge \& Wolf, 1995, p. 238). No entanto, à medida que a mola da economia se desloca do Estado para as empresas, o sindicalismo estaria encontrando dificuldade para encontrar seu novo papel: "Produção requer acima de tudo cooperação e complacência, não conflito e resistência" (Streeck, 1994, p. 253). O problema, como o autor observa, é que frequentemente os sindicatos não são recompensados pelas posturas "cooperativas". Por isso, uma "cooperação passiva" não seria a que daria melhores resultados. Os sindicatos necessitariam de atuações agressivas, inclusive de natureza política, de controle do comportamento empresarial a fim de poderem alcançar uma participação mais efetiva na área produtiva (p. 254).

Desse ângulo, os sindicatos poderiam ter um papel importante em assuntos de treinamento vocacional, o que significaria, na visão do autor, o retorno a certas práticas e tradições do sindicalismo de ofício, de treinamento e controle das atividades profissionais que teriam sido aniquiladas pelo modelo taylorista-fordista ${ }^{9}$.

Essas e outras recomendações relativas às estratégias e respostas sindicais, no entanto, chocam-se com a realidade industrial, social, política e cultural dos tempos de globalização. Não basta a vontade das lideranças sindicais. Existem também as disposições e tendências que estão fora do controle do sindicato, como os interesses das administrações das empresas, a evolução da tecnologia, os imperativos do mercado e, também, dependendo das circunstâncias, a atuação dos governos. Ocorre, como se observou ao longo deste trabalho, que as empresas estão numa posição confortável para enfrentar as organizações sindicais, o que significa dizer que uma estratégia sindical não vem apenas da vontade dos sindicatos, mas depende também do tipo de política adotada pelas empresas, as quais, nessas últimas décadas, têm tido a iniciativa das mudanças ${ }^{10}$. Para ter maior acesso e controle das decisões, se não existem disposições favoráveis dos empresários, os sindicatos precisam ter certo poder de pressão para forçar a negociação no sentido de uma "cooperação não subalterna". Como estão enfraquecidos, suas ações são antes reações defensivas no sentido de manutenção do status quo do que ações em direção a novas conquistas. $\mathrm{O}$ sindicato acaba por ser um sócio menor... quando é aceito como tal.

\footnotetext{
${ }^{9}$ Cf. também, sobre a importância da introdução de políticas vocacionais na pauta sindical como uma das saídas do sindicalismo para tentar evitar novas perdas de associados, Rainbird e Vincent (1996).

${ }^{10}$ Uma opinião heterodoxa sobre o futuro do sindicalismo é defendida por I,uca Lanzalaco e Philippe Schmitter (1994). Os autores argumentam que as respostas dos trabalhadores sempre serão reativas às ações das empresas que se encontram em situação mais vantajosa do que os sindicatos para a escolha de estratégias.
} 


\section{CONCLUSÃo}

$\mathrm{A}^{\mathrm{s}}$ páginas precedentes levam-nos a encerrar essa avaliação da rganização sindical em alguns países desenvolvidos com uma questão que inevitavelmente se coloca: Qual o futuro do sindicalismo? Existirão sindicatos no século XXI? Se sim, qual será seu papel? Essas indagações impõem-se diante do declínio persistente do sindicalismo nos países analisados. Elas, na realidade, estiveram explícitas ou implícitas em praticamente todos os autores citados neste trabalho embora as abordagens e as explicações para a redução das taxas de sindicalização possam ter variado ${ }^{1}$.

Já mencionamos que o tipo de prognóstico sobre o futuro do sindicalismo tende a ser influenciado pelas convicções políticas e ideológicas e pelo país a partir do qual os autores focalizam o sindicalismo. Não seria preciso ressaltar que os pesquisadores mais favoráveis aos sindicatos inclinam-se a vislumbrar saídas para o movimento sindical, enquanto os mais hostis acham que os sindicatos terão muita dificuldade para sobreviver no tipo de hábitat que se delineia para o século XXI. A influência do fator ideológico é, por si mesma, indicativa de que o destino

\footnotetext{
${ }^{1}$ Por exemplo, escreve Boyer (1995): "É possível que os sindicatos do período fordista possam, de fato, tornar-se obsoletos e, consequentemente, decaírem. Mas, ao mesmo tempo, novos sindicatos podem surgir nas próximas décadas" (p. 555). De sua parte, diz Crouch (1992a): "Não há nenhuma eliminação do papel dos empregados à vista", o que pode sempre gerar uma "demanda por representação" (p. 359). Mas, no mesmo texto, o autor admite que "as relações industriais no momento são capazes de uma variedade de destinos. Alguns deles, efetivamente, incluem a possibilidade de um contínuo e irreversível declínio do sindicalismo e do conflito: onde os empregadores do setor privado utilizam amplamente empregados white-collars e empenham-se a fundo no sentido de aplicar políticas de participação que excluam os sindicatos; onde os sindicatos não encontram nenhuma estratégia para contrabalançar essas políticas; onde Os governos tornam a política de exclusão dos sindicatos legal e factível. Esse desenvolvimento poderia acontecer em empresas individuais, talvez ramos inteiros da economia e até mesmo em países inteiros, se as tendências estruturais da década dos 80 persistirem. Esses casos tornam possível que, eventualmente, uma extrapolação das tendências de 1980 seja válida”. Mas o autor acredita que outros contextos, diferentes do anterior, podem surgir de modo a tornar possível a representação autônoma dos interesses dos trabalhadores. Nesse caso, tais situações possibilitariam que as greves e os lockouts continuassem seu padrão de ocorrência num ciclo há muito estabelecido (pp. 361-362).
}

do sindicalismo na sociedade contemporânea é de difícil apreensão e que as mais sofisticadas análises não são capazes de oferecer resultados mais conclusivos, menos sujeitos a interpretações ideologicamente enviesadas. Assim, sobra espaço para prognósticos fundados em convicções e esperanças políticas. As conclusões das pesquisas e dos subsequentes diagnósticos retornam ao campo das lutas políticas e influenciam, direta ou indiretamente, os resultados das disputas entre partidos e grupos de interesses. Por exemplo: a afirmação de que o sindicalismo é uma instituição ultrapassada pela história (certa ou errada) enfraquece o campo socialista e as esquerdas em geral e beneficia seus adversários. Em alguns países, essa conclusão dá legitimidade a políticas neoliberais e a medidas destinadas a limitar o poder sindical. Inversamente, pesquisas que reduzem a extensão das perdas sindicais ou que, mesmo reconhecendo o declínio do sindicalismo, localizam suas causas em determinados fatores políticoinstitucionais de natureza conjuntural (por exemplo, políticas governamentais, novas legislações etc.) tendem a beneficiar os partidos e correntes socialistas e facções políticas antiliberais e abrem espaço para medidas legais de proteção à instituição sindical.

Mas o reconhecimento da presença de fatores ideológicos, especialmente a simpatia (ou a antipatia) pelo poder sindical ou pelo sindicalismo tout court, não impede necessariamente que algumas inferências das estatísticas e pesquisas, menos sujeitas à interpelação ideológica, possam ser apresentadas e que não haja espaço para uma avaliação mais objetiva. De modo geral, algumas conclusões são menos discutíveis e refutáveis enquanto outras já não o são. A tese que defendemos é a de que, no estudo do sindicalismo, há áreas em que os contornos são mais claros e se prestam menos à tergiversação, enquanto em outras são mais obscuros, sobrando, portanto, mais espaço para preferências subjetivas. Para tentar reduzir o viés e evitar generalizações ou prognósticos precipitados, conviria fixar brevemente alguns pontos já tratados ao longo desse trabalho.

O primeiro consiste em reafirmar que, por sindicatos, estamos entendendo organizações permanentes de trabalhadores assalariados formalmente destinadas a tentar obter vantagens para seus associados ou para o conjunto dos trabalhadores mediante negociações com as empresas e com o Estado, pressões políticas e outros meios de atuação. Nessa acepção ampla, o sindicalismo pode assumir várias faces. $\mathrm{Na}$ realidade, tem sido assim na história do movimento sindical. O sindicalismo transforma-se com 
o tempo e possui feições diferentes segundo os meios nacionais. Mas algumas alternativas de mudança devem ser excluídas para que o termo "sindicato" continue válido. Em outras palavras: a metamorfose dos sindicatos atuais em cooperativas, em sociedades de auxílio mútuo ou mesmo em company unions, descaracterizaria o sindicalismo tal como existe atualmente em qualquer de suas formas. Essa afirmação não implica descartar essas possibilidades, mas considerar que, mesmo que o sindicalismo possa ter várias faces, o abandono definitivo da face oposicionista e reivindicatória significaria uma mutação tão profunda que não mais se poderia falar em sindicalismo ${ }^{2}$.

Do mesmo modo, não julgamos que caiba separar o futuro do sindicalismo como instituição e o futuro do sindicalismo como movimento e considerar que a primeira forma teria maiores probabilidades de sobrevivência do que a segunda. Parece difícil que, sem alguma dose de movimento social, de oposição, de potencial conflitivo - que pode ser mais forte ou mais fraca o sindicalismo, tal como o estivemos analisando, possa sobreviver. Entendemos que, a fim de que uma associação possa ser classificada como um sindicato, é essencial algum componente de oposição aos que estão em situação de comando numa relação de emprego, mesmo que as características desse componente possam variar nacionalmente, que o coeficiente oposicionista seja fraco, que o conteúdo e a dimensão da oposição sejam nacionalmente diferentes e que estejam sujeitos a variação, inclusive dentro de correntes sindicais no interior de um mesmo país. Está suposta aqui a ideia de que existe alguma divergência de interesses entre, de um lado, a administração das empresas, na forma da propriedade por ações, na de propriedade familiar ou na de propriedade estatal, e, de outro lado, os empregados.

Não vai nessa afirmação a tese da incompatibilidade total e irreversível entre o Capital e o Trabalho, entre o lucro e o salário, ou qualquer outro componente do esquema marxista de luta de classes. A tese que defendemos é de que o sindicalismo é algo diferente de uma sociedade de auxílio mútuo, de uma cooperativa ou de uma entidade auxiliar da administração das

${ }^{2}$ Lembremos que Hyman (1994) entende que o sindicalismo, ante os desafios contemporâneos, não poderia assumir inteiramente as quatro principais identidades já referidas: sociedade de socorro mútuo; sindicato de companhia; parceiro social e movimento social. Na busca por novas identidades, segundo o autor, o sindicalismo daria prioridade a cada uma delas, devendo a escolha refletir as especificidades nacionais de cada sindicalismo (p. 136). empresas ou do Estado, como nos ex-países socialistas. Esse pressuposto não exclui a possibilidade de mudanças de estratégias, de aparecimento de novas táticas, de colocação de novos objetivos. Mas consideramos que deve estar sempre pressuposto que tais alterações táticas e estratégicas devem ser fixadas visando a obtenção de vantagens para os trabalhadores numa complicada relação de conflito e cooperação com os empregadores, mesmo que esse objetivo, na relação empregatícia, não consiga ser alcançado ou se revele equivocado e o sindicato, buscando o bem, cause o mal.

O "mal" pode vir de um excesso de reivindicações, de elevação dos coeficientes de conflito incapaz de ser absorvida pelo regime democrático, de obtenção de benefícios imediatos que, depois, enfraqueçam a capacidade de competição das empresas, levem à diminuição de investimentos, à fuga de capitais, à desorganização da economia e ao rebaixamento geral do padrão de vida dos assalariados. O "mal" pode vir também de uma exacerbação do radicalismo que resulte na destruição da democracia e na instalação de regimes autoritários. O "mal" pode introduzir se, ainda e de modo mais sub-reptício, quando a obtenção de vantagens para categorias profissionais específicas se faz às custas de outras, geralmente menos organizadas sindicalmente ou com menos capacidade de mobilização.

Essas observações, de caráter geral, parecem-nos necessárias para que, nas especulações sobre o destino do sindicalismo, estejamos nos referindo a um mesmo tipo de instituição. Na hipótese de que os atuais sindicatos assumam predominantemente funções que hoje são preenchidas por entidades que organizam segmentos populacionais não assalariados, como ordens de profissionais autônomos (médicos, advogados e outras profissões liberais), cooperativas, movimentos sociais policlassistas, sociedades de amigos de bairro, ONGs de defesa ecológica ou de outra natureza, sociedades de auxílio mútuo, o próprio fundamento da representação sindical estaria transformado. Assim, uma mutação do sindicalismo na direção de entidades como as mencionadas deveria ser entendida como uma modalidade de declínio do sindicalismo tal como ele existiu, com suas várias faces, no mundo ocidental.

Outro ponto a ser fixado é o da existência de uma variedade de situações sindicais, como procuramos mostrar ao longo desse trabalho. A força do sindicalismo não é e nunca foi a mesma no interior de sociedades industriais concretas. A Suécia e os EUA, por exemplo, dificilmente 
poderiam ser excluídos da categoria de sociedades desenvolvidas avançadas. No entanto, a natureza de seus sistemas de relações de trabalho e do papel desempenhado pelos sindicatos nos dois países é significativamente diferente. Essas considerações visam servir de alerta para os problemas contidos em prognósticos relacionados com o futuro do poder sindical nas sociedades pós-industriais consideradas abstratamente. Sabemos que, mesmo antes da tempestade trazida pela globalização, em países que eram notavelmente semelhantes em termos de renda per capita, urbanização, educação da mão de obra e outras macrovariáveis, as funções e importância da instituição sindical não eram equivalentes.

Desse modo, é razoável a expectativa de que, para os próximos anos, apesar de pressão uniformizadora das forças tecnológicas, das alterações no mercado de trabalho, da organização da produção e de outros fatores estruturais, o peso e a função do sindicalismo continuem muito variados em cada país. Acontece que processos estruturais de mudança incidem sobre sistemas de relações de trabalho já instituídos, cuja continuidade se liga a interesses de atores importantes e a uma cultura estabelecida, quer dizer, se entrelaçam com fatores de natureza institucional.

Num balanço geral das mudanças ocorridas nesses últimos anos nas sociedades desenvolvidas, nota Crouch (1996) que, "apesar de que desregulamentação, flexibilização e descentralização tenham sido a senha para a mudança em virtualmente todos os países da Europa Ocidental há muitos anos, isso não envolveu necessariamente um conflito com sistemas neocorporativos dessas nações nas quais esses sistemas estiveram funcionando relativamente bem" (p. 358). Segundo o autor, teria havido, antes, uma nova síntese de pressões por coordenação e por descentralização. Vem daí a conclusão de que, "quando diferentes sistemas encontram desafios comuns, o mais provável é uma revisão da diversidade do que uma convergência" (p. 358). O ponto que nos parece importante reter é de que, considerando a diversidade das pressões, parecem mais prováveis movimentos em direção a um pequeno número de tipos de sistemas do que apenas $\mathrm{um}^{3}$.

\footnotetext{
3 São esses os quatro tipos percebidos por Crouch: Grupo 1, caracterizado por corporativismo relativamente descentralizado, com liderança dos empregadores (Alemanha, Áustria, Suíça, Holanda, Bélgica e partes do norte da Itália); Grupo 2, caracterizado pelo corporativismo centralizado e por um movimento sindical forte (Suécia, Noruega,
}

No mesmo sentido vão as conclusões de Locke e Kochan (1995) sobre as transformações nos sistemas de relações de trabalho, valorizando os fatores institucionais e talvez atribuindo-lhes excessivo peso: “... relações de emprego são moldadas de modo sistemático e previsível pelas instituições que filtram as pressões externas [do mercado e das reestruturações econômicas] e pelas estratégias dos principais atores". A tese dos autores é a de que, nos países que têm uma história de instituições de relações de trabalho fortemente centralizadas, o ajustamento tende a seguir um padrão negociado que equilibra diferentes interesses sociais e econômicos. Em países de negociações fragmentadas, como os EUA e a Grã-Bretanha, os ajustamentos seriam impostos de modo mais unilateral, quer dizer, pelas empresas (p. 382).

Entretanto, ainda que aceitemos a persistência de tipos diversos de sindicalismo e da resistência de tradições nacionais inseridas nos modelos de relações de trabalho, resta o fato indiscutível de que as transformações trazidas pela globalização pressionaram numa mesma direção todos os modelos, inclusive os corporativos do Norte da Europa. A diferença, com relação a outros países, está no ritmo da mudança, e não na sua direção. Não há movimentos a favor de maior centralização da barganha e de fortalecimento dos sindicatos, para tomarmos dois exemplos. As tradições e particularidades nacionais servem, desse modo, para retardar e ajustar certos desenvolvimentos, mas não para alterar seus rumos. Essas observações de cunho geral visaram salientar que, nos prognósticos relativos ao futuro do sindicalismo, cumpre considerar múltiplos cenários, que devem variar segundo as taxas atuais de sindicalização de cada país, o grau de exposição das economias às novas forças da globalização e outras variáveis. A hipótese, no caso, seria de que, nos países onde o sindicalismo é mais forte e se encontra implantado há mais tempo, é mais provável que a instituição sindical possa persistir como um ator político e social de algum relevo. A suposição é a que movimentos sindicais mais poderosos se relacionam com tradições associativas nacionais e com valores coletivos e de democracia social mais arraigados.

Dinamarca e Finlândia); Grupo 3, caracterizado por relações frágeis e negociação coletiva descentralizada (França, Reino Unido, Irlanda, Espanha e partes do sul da Itália); Grupo 4, caracterizado por um sistema rústico de relações de trabalho, fracamente regulamentado, com supremacia dos empregadores (Grécia, Portugal, partes da Itália e da Espanha e uma franja de setores pobres de todos os países) (Crouch, 1996, p. 372). 
Está suposto igualmente, convém repisar, que o sindicalismo não é apenas o resultado de processos econômicos e tecnológicos. Esses fornecem apenas as condições sociais básicas que abrem maiores possibilidades para a emergência do fenômeno sindical. A extensão do poder sindical e suas características vinculam-se a outros componentes do sistema político e cultural, a certas predisposições dos agentes sociais que dimensionam o espaço e as singularidades dos sindicalismos nacionais. Aqui, as disposições da opinião pública ante o poder sindical e o sindicalismo desempenharão papel importante, porque elas afetam a conduta do governo (e do patronato) diante dos sindicatos. Não seria preciso ressaltar que também a conduta das empresas é uma variável importante para o sindicalismo. Mas, muito provavelmente, não se terão, nesses campos mencionados, desenvolvimentos nacionais semelhantes.

No limite, a ênfase sobre os aspectos da cultura e tradições nacionais, sobre a relevância dos sistemas de relações de trabalho de cada país pode levar a considerar inúteis as previsões relativas ao destino do sindicalismo na sociedade pós-industrial considerada abstratamente. Desse prisma, os desenvolvimentos de natureza econômica e tecnológica que tenderiam a se universalizar com a globalização seriam vistos como menos relevantes. Mas, sem negar que os fatores econômicos e técnicos passam pelo filtro das estruturas institucionais e valores culturais e políticos nacionais, consideramos que é possível destacar um conjunto de processos que são, em si mesmos, prejudiciais ao sindicalismo e que estão acontecendo em toda a parte, tais como a automação, o desemprego, a estabilidade monetária, a terceirização, o trabalho em tempo parcial, a informatização, a diminuição ou o desaparecimento de áreas de atividades e ocupações em que os sindicatos eram fortes, a fragmentação dos interesses das classes trabalhadoras e outros fenômenos que apontamos anteriormente.

A tese aqui é que esses fatores podem ter efeitos maiores ou menores sobre a organização sindical, embora tendam a ser, em geral, negativos. A partir daí é possível um prognóstico sobre o destino do sindicalismo como instituição no interior da sociedade de serviços, considerando ambas as instituições abstratamente. Desse ângulo - especialmente quando enfatizamos os elementos de mudanças estruturais na economia e seus reflexos no mercado de trabalho e no sistema de estratificação social - o sindicalismo aparece como uma instituição condenada a ocupar uma posição subalterna na sociedade pós-industrial, porque todos os fatores que favoreceram sua expansão passada não mais existem ou se reduziram significativamente: grandes concentrações de trabalhadores em áreas geográficas e indústrias; produção em série; más condições de trabalho e baixos salários; homogeneidade da força de trabalho; peso da classe operária no interior da estrutura social; forte diferenciação entre as camadas sociais; existência de mecanismos de exclusão política e social das classes assalariadas; estilo autoritário de gerência; etc. Desse modo, nossa tese é que as características gerais da sociedade pós-industrial abrem pouco espaço para a organização sindical, embora a extensão desse espaço possa ser diferente quando se avaliam sociedades nacionais específicas. A conclusão vai, portanto, a favor da ideia do recuo do sindicalismo à medida que avança a desindustrialização. Não seria preciso salientar que nos inclinamos, sem negar a influência das variáveis políticas e institucionais, a dar mais valor às mutações estruturais que levam para sociedades de serviços. Em nenhuma parte essas mudanças favoreceram os sindicatos e não há sinais de que isso possa vir a acontecer no futuro.

Mas isso não significa necessariamente o desaparecimento do sindicalismo. Pode-se imaginar algumas possibilidades de continuidade da organização sindical. Tipicamente, três alternativas, que não se excluem, podem ser consideradas. A primeira, que poderia abrir para o sindicalismo perspectivas futuras, seria o surgimento de novos grupos profissionais nas áreas do mercado que mais se têm expandido, quer dizer, de assalariados suscetíveis de sindicalização nos setores mais modernos da economia. Trata-se de uma alternativa que suporia a persistência do sindicalismo como uma instituição de relevo no interior de uma sociedade pós-industrial. Mas não há indicações nessa direção. Pelo contrário. Nas novas profissões e atividades que aparecem com as mudanças em curso, que espelham o futuro e em que o emprego mais cresce, a organização sindical tem mostrado pouca capacidade de implantação, tais como: serviços pessoais, comunicações, lazer, atividades culturais, turismo. Nada indica, atualmente, que a expansão dessas áreas de atividades deva contribuir significativamente para fornecer novos campos de atuação sindical e de recrutamento de novos associados. Se suas chances de sobrevivência dependerem da sindicalização desses novos grupos profissionais, o sindicalismo pode se considerar como uma espécie ameaçada de extinção em virtude da destruição do seu hábitat sem que nenhuma possibilidade de proteção ambiental exista ou alguma ONG possa vir a salvá-lo. 
A segunda possibilidade de sobrevivência do sindicalismo estaria ligada à permanência do passado. Não está excluído, como amiúde aconteceu ao longo das transformações nos sistemas de produção e de trabalho, que no século XXI coexistam, tal como hoje, tipos variados de tecnologia, de modos de produção, de organização do trabalho e de relacionamento entre empregados e empregadores. Nesse caso, seria possível a persistência de organizações sindicais nos lugares em que as técnicas de fabricação e as vias de obtenção de vantagens salariais e de benefícios sofrerem poucas alterações com relação às que existem atualmente. $\mathrm{O}$ sindicalismo, portanto, manter-se-ia nos setores produtivos mais arcaicos. Se, em termos abstratos, nas sociedades pós-industriais, os sindicatos, como existem hoje, parecem ter pouco espaço e funções, não está escrito que em sistemas econômicos concretos persistam situações em que a instituição sindical, e mesmo o movimento de trabalhadores, não possam ter continuidade. Fábricas de chaminé podem continuar a existir ao lado das fábricas automatizadas. Grupos de operários de macacão podem persistir num mar de empregados de escritório, de técnicos, de autônomos, de trabalhadores de emprego precário. Mas, nessa alternativa, o dado essencial é que os sindicatos ficariam confinados às atividades produtivas que representariam o século XX dentro do século XXI. Se assim for, o sindicalismo não seria uma força que tenderia a crescer com o progresso da tecnologia. Não teria o futuro a seu favor.

Finalmente, uma terceira possibilidade que não pode ser descartada, ao menos teoricamente, seria os sindicatos conservarem posições fortes em segmentos de atividades econômicas reorganizados e reformados, em empresas e fábricas já "modernizadas", em setores da administração pública reformados onde o sindicalismo estava bem implantado e uma tradição associativa existe. Pensamos em atividades industriais, mas também em setores de serviços públicos e privados "racionalizados" depois da introdução de novas tecnologias e de novas formas de administração. Em muitos desses locais informatizados e remodelados, nos quais a relação empregatícia persiste, os grupos de empregados remanescentes (os "núcleos estáveis") poderiam conservar ou mesmo aumentar seu poder de pressão em condições de ocasionar fortes prejuízos para os empregadores e, consequentemente, manter a força de negociação.

Se tal acontecer, a taxa de sindicalização nacional se estabilizaria em níveis baixos, mas o sindicalismo se manteria como uma instituição moderna, adaptada ao novo ambiente. A sindicalização ficaria localizada em alguns setores de atividade, nos quais poderia até mesmo crescer. ( $\mathrm{Na}$ verdade, essa expansão desigual do sindicalismo sempre aconteceu, mesmo nas suas fases de ouro.) Contudo, não mais estaríamos diante do sindicalismo como fenômeno de massas, como na fase do fordismo, da produção em série, parcelada e padronizada. Em lugar de grandes organizações, dominadas numericamente por trabalhadores de média ou baixa qualificação, os sindicatos agrupariam minorias de empregados de qualificação elevada, salários mais altos e maior capacidade de organização. Tratar-se-ia de organizações sindicais e de trabalhadores em condições de dominar os procedimentos técnicos, de participar de níveis decisórios mais elevados e de participar da gestão das empresas e organizações do setor privado e público. Mutatis mutandis, haveria alguma similitude com os antigos sindicatos de ofício, dos manuais qualificados. Na medida em que seria um sindicalismo de minorias, as tendências à burocratização tenderiam também a ser menos intensas.

Nessa terceira alternativa, os sindicatos continuariam importantes, mas apenas no plano econômico. A força política nacional do sindicalismo diminuiria em virtude da redução do número relativo e absoluto de filiados, do declínio financeiro das grandes centrais e organizações sindicais, da redução da proporção de eleitores sindicalizados. Das três possibilidades visualizadas, essa é a mais otimista. A primeira supõe praticamente a liquidação do sindicalismo pela impossibilidade de sua penetração entre as novas profissões emergentes e atividades econômicas que tendem a tornar-se majoritárias e mais importantes. A segunda prevê a possibilidade da persistência do sindicalismo, mas com pouca força de pressão sobre os empregadores e com capacidade de atuação política cada vez mais limitada, agarrado a um sistema produtivo superado do qual o sindicalismo poderá se tornar um defensor. A terceira prevê a possibilidade da continuidade e da renovação do sindicalismo adaptado às novas modalidades de produção e de atividades econômicas. Essa alternativa poderia ser favorecida em razão da elevação da qualificação profissional e educacional dos trabalhadores trazida pela automação, pelas necessidades gerenciais de participação dos empregados, pelas tendências de aumento das negociações de local de trabalho, pela força que adquirem pequenos grupos de empregados que controlam posições estratégicas nas empresas. Mas estamos entrando no domínio da futurologia. A formação de um "novo sindicalismo" adaptado à 
era pós-industrial não depende apenas de mudanças no sistema produtivo mas de muitas outras, difíceis de antever.

Para os anos próximos, tudo indica que os sindicatos terão de combater a partir dos terrenos nos quais eles se implantaram nas décadas passadas e sobre os quais se consolidaram. São essas estruturas que estão sendo atacadas pelas forças da mudança. O conflito trabalhista da atualidade não coloca como antagonistas as "velhas empresas" da era fordista e do Estado paternalista versus o "velho sindicalismo" dos operários e dos funcionários. De certo modo, o combate que ora se trava é desigual porque os adversários principais são as novas empresas da era da informatização, da produção flexível e do novo "Estado modernizado" contra o velho sindicalismo que surgiu, em períodos anteriores, de um meio ao qual estava adaptado. Não há, hoje, um conflito que anteponha, de um lado, um novo sindicalismo surgido de um mundo pós-industrial e, de outro, empregadores privados e públicos da sociedade de serviços. Por isso, o destino do velho sindicalismo não é risonho porque o hábitat da sociedade pós-industrial e do mundo globalizado lhe é muito desfavorável.

\section{Anexos Metodológicos E Estatísticas}

\section{Anexo 1}

Taxas de sindicalização e número de trabalhadores sindicalizados Metodologia

Os dados da OIT englobam filiados a todos os tipos de sindicatos, sejam eles interprofissionais, setoriais, de ofício ou profissão ou de empresa assim como as associações profissionais cujas atividades consistam em negociações coletivas, campanhas dirigidas a órgãos legislativos e autoridades governamentais, greves, petições, manifestações ou ações judiciais. Não estão compreendidos membros de associações: a) que dependem dos empregadores; b) que recusam a representação coletiva e preferem a individual; c) que não negociam; d) que são compostas principalmente por trabalhadores por conta própria. Também não estão incluídos membros de: e) conselhos de empresa, estabelecidos pela legislação ou criados voluntariamente pelos trabalhadores; f) sindicatos "domesticados" ou company unions, cuja sobrevivência ou orçamento depende do empregador; g) sociedades que se dedicam principalmente à educação; h) sindicatos de agricultores, de comerciantes ou de pessoas cuja atividade principal é de caráter autônomo.

As taxas referentes a trabalhadores incluem trabalhadores do setor privado e público. Estão excluídos do número de sindicalizados os trabalhadores por conta própria, os desempregados e os aposentados.

As taxas referentes à mão de obra não agrícola incluem todos os trabalhadores urbanos, do setor público ou privado: assalariados, autônomos e familiares não remunerados, incluindo desempregados da indústria e dos serviços A OIT esclarece que, quando se usa esse indicador, a vantagem é de dispor de dados para quase todos os países, inclusive para os não desenvolvidos. A desvantagem é que muitas categorias em que a sindicalização tende a ser baixa (por exemplo, trabalhadores por conta própria e os familiares não remunerados, em particular no ramo da construção e nos serviços comerciais, pessoais e domésticos) estão presentes na mão de obra não agrícola. Para os países desenvolvidos, esse 
fato não altera significativamente os resultados porque a proporção da força de trabalho na agricultura é muito pequena (OIT, 1997-1998,"Notas técnicas", pp. 287-288).

\section{Anexo 1.1}

Taxas de sindicalização (1985 a 1995)

\begin{tabular}{|l|c|c|c|c|c|c|}
\hline País & Ano & $\begin{array}{c}\text { Mão de } \\
\text { obra } \\
\text { não } \\
\text { agrícola }\end{array}$ & Trabalhadores & Ano & $\begin{array}{c}\text { Mão de } \\
\text { obra } \\
\text { não } \\
\text { agrícola }\end{array}$ & Trabalhadores \\
\hline Alemanha & 1995 & 19,6 & 28,9 & 1991 & 30,7 & 35,0 \\
Ex-RDA & 1993 & 34,1 & 42,4 & 1991 & 41,1 & 46,2 \\
Ex-RFA & 1993 & 24,5 & 29,1 & 1985 & 29,5 & 35,3 \\
Austrália & 1995 & 28,6 & 35,2 & 1985 & 40,6 & 50,0 \\
Áustria & 1995 & 36,6 & 41,2 & 1985 & 51,7 & 51,0 \\
Bélgica & 1995 & 38,1 & 51,9 & 1985 & 42,0 & 52,0 \\
Canadá & 1993 & 31,0 & 37,4 & 1985 & 31,2 & 36,7 \\
Dinamarca & 1994 & 68,2 & 80,1 & 1985 & 67,4 & 78,3 \\
Espanha & 1994 & 11,4 & 18,6 & 1985 & 7,3 & 11,5 \\
EUA & 1995 & 12,7 & 14,2 & 1985 & 15,0 & 18,0 \\
Finlândia & 1995 & 59,7 & 79,3 & 1985 & 61,4 & 68,3 \\
França & 1995 & 6,1 & 9,1 & 1985 & 11,6 & 14,5 \\
Holanda & 1995 & 21,8 & 25,6 & 1985 & 23,3 & 28,7 \\
Itália & 1994 & 30,6 & 44,1 & 1985 & 32,9 & 47,6 \\
Japão & 1995 & 18,6 & 24,0 & 1985 & 22,6 & 28,8 \\
Noruega & 1995 & 51,7 & 57,7 & 1985 & 50,7 & 55,7 \\
Nova & 1995 & 23,2 & 24,3 & 1986 & 47,1 & 54,1 \\
Zelândia & 1995 & 18,8 & 25,6 & 1986 & 40,6 & 51,4 \\
Portugal & 1995 & 32,9 & 1985 & 36,0 & 45,5 \\
Reino & 1995 & 26,2 & 31,1 & 1985 & 79,3 & 83,8 \\
Unido & 1994 & 77,2 & 92,6 & 1985 & 25,4 & 28,8 \\
Suécia & 1994 & 20,0 & 22,5 & & \\
Suíça &
\end{tabular}

Fonte: El Trabajo en el Mundo 1997-1998, OIT, Genebra.
Anexo 1.2

Variação nas Taxas de Sindicalização (1985 a 1995)

\begin{tabular}{|l|c|c|c|}
\hline País & Período & Mão de obra não agrícola & Trabalhadores \\
\hline Alemanha & $1991-1995$ & $-1,1$ & $-6,1$ \\
Ex-RDA & $1991-1993$ & $-7,1$ & $-3,8$ \\
Ex-RFA & $1991-1993$ & $-4,9$ & $-6,2$ \\
Austrália & $1985-1995$ & $-12,0$ & $-14,8$ \\
Áustria & $1985-1995$ & $-15,1$ & $-9,8$ \\
Canadá & $1985-1993$ & $-0,2$ & 0,7 \\
Dinamarca & $1985-1994$ & 0,8 & 1,8 \\
Espanha & $1985-1994$ & 4,1 & 7,1 \\
EUA & $1985-1995$ & $-2,3$ & $-3,8$ \\
Finlândia & $1985-1995$ & $-1,7$ & 11,0 \\
França & $1985-1995$ & $-5,5$ & $-5,4$ \\
Holanda & $1985-1995$ & $-1,6$ & $-3,2$ \\
Itália & $1985-1994$ & $-2,3$ & $-3,5$ \\
Japão & $1985-1995$ & $-4,0$ & $-4,8$ \\
Noruega & $1985-1995$ & 1,0 & 2,0 \\
N. Zelândia & $1986-1995$ & $-23,9$ & $-29,8$ \\
Portugal & $1986-1995$ & $-21,8$ & $-25,8$ \\
Reino Unido & $1985-1995$ & $-9,8$ & $-12,6$ \\
Suécia & $1985-1994$ & $-2,1$ & 7,3 \\
Suíça & $1985-1994$ & $-5,4$ & $-6,2$ \\
\hline
\end{tabular}

Fonte: El Trabalo en el Mundo 19971998, OIT, Genebra. 
Anexo 1.3

Número de Sindicalizados (em milhares)

\begin{tabular}{|l|c|c|c|c|c|}
\hline País & Ano & $\begin{array}{c}\text { Total de } \\
\text { sindicalizados }\end{array}$ & Ano & $\begin{array}{c}\text { Total de } \\
\text { sindicalizados }\end{array}$ & $\begin{array}{c}\text { Variação } \\
\%\end{array}$ \\
\hline Alemanha & 1995 & 9300 & 1991 & 30,7 & $-20,3$ \\
Ex-RDA & 1993 & 2681 & 1991 & 3428 & $-21,8$ \\
Ex-RFA & 1993 & 7654 & 1985 & 8127 & $-5,8$ \\
Austrália & 1995 & 2440 & 1985 & 2793 & $-12,6$ \\
Áustria & 1995 & 1287 & 1985 & 1404 & $-8,3$ \\
Canadá & 1993 & 4128 & 1985 & 3730 & 10,7 \\
Dinamarca & 1994 & 1808 & 1985 & 1730 & 4,5 \\
Espanha & 1994 & 1606 & 1985 & 835 & 92,3 \\
Estados Unidos & 1995 & 16360 & 1985 & 16996 & $-3,7$ \\
Finlândia & 1995 & 1377 & 1985 & 1411 & $-2,4$ \\
França & 1995 & 1758 & 1985 & 2555 & $-31,2$ \\
Holanda & 1995 & 1540 & 1985 & 1290 & 19,3 \\
Itália & 1994 & 6392 & 1985 & 6860 & $-6,8$ \\
Japão & 1995 & 12410 & 1985 & 12418 & $-0,1$ \\
Noruega & 1995 & 1068 & 1985 & 971 & 10,0 \\
Nova Zelândia & 1995 & 362 & 1986 & 680 & $-46,7$ \\
Portugal & 1995 & 800 & 1986 & 1434 & $-44,2$ \\
Reino Unido & 1995 & 7280 & 1985 & 9739 & $-25,2$ \\
Suécia & 1994 & 3180 & 1985 & 3341 & $-4,8$ \\
Suíça & 1994 & 740 & 1985 & 806 & $-8,2$ \\
\hline
\end{tabular}

Fonte: El Trabajo em el Mundo 19971998, OIT, Genebra.
Anexo 2

Conflitos Trabalhistas

\section{Metodologia}

Os critérios adotados pelos vários países para medir a ocorrência de lockouts e greves variam. A OIT organiza os dados segundo as metodologias nacionais, como já indicamos. Não caberia reproduzir aqui mais detalhadamente os critérios utilizados por cada país. Assinalamos alguns exemplos para conhecimento dos leitores das diferenças existentes do que corresponde, em alguns dos principais países, a uma paralisação (requisitos mínimos para a paralisação ser incluída na estatística):

1.Alemanha. Não está incluída a administração pública. Estão incluídas as interrupcões de trabalho que duraram menos de um dia se o número de jornadas não trabalhadas for superior a cem. A partir de 1993, as estatísticas abrangem toda a República Federal Alemã.

2.Áustria. Sem restrição de número. Jornada de trabalho de oito horas.

3.Bélgica. Sem restrição de número, mas o setor público está proibido de fazer greve.

4.Canadá. Greves de pelo menos meio jornada de paralisação e que acarretem a perda de mais de dez jornadas de trabalho.

5.Dinamarca. Só estão incluídas as paralisações que duraram mais de cem jornadas não trabalhadas.

6.Espanha. Antes de 1990: somente greves, excluído o País Basco; 1980 e 1985: excluídos o País Basco e a Catalunha; antes de 1986: se nenhuma restrição estiver indicada, os dados relativos à Catalunha e ao País Basco figuram nos totais. No Quadro 5.3 (no corpo do texto, Cap. 5), os dados indicam média dos trabalhadores em greve cada mês. Lockouts excluídos.

7.Finlândia. Só paralisações de mais de uma hora de duração.

8.França. Pelo menos uma jornada não trabalhada. Setor público e agrícola estão excluídos.

9.Holanda. Nenhuma restrição em tamanho. Toma-se como base jornada de trabalho de sete horas. 
10.Itália. Nenhuma restrição em tamanho da paralisação.

11.Noruega. Pelo menos um dia de duração.

12.Portugal. Somente greves. Antes de 1985: nenhuma restrição quanto ao número de trabalhadores envolvidos. Estão excluídas as greves gerais de nível nacional e do setor público.

13.Reino Unido. Greves políticas excluídas. Incluídas greves de dez ou mais trabalhadores ou as que tiveram menos de um dia de duração, se o número de jornadas não trabalhadas for superior a cem.

14.Suécia. Só paralisações que duraram pelo menos oito horas.

15.Suíça. Pelo menos um dia de duração.

16.Estados Unidos. Não estão incluídas as interrupções de trabalho por locais com menos de mil trabalhadores envolvidos.

Informações elaboradas a partir das publicações: OIT; Elt irabajo en el Mundo - 1997/ 1998, Genebra, e Labour Market Trends, April 1996, construída a partir da ILO Sources and Methods. Labour Statitlic, vol. 17, "Greves e Lockouls".

\section{Anexo 2.1}

Número de Conflitos

\begin{tabular}{|l|c|c|c|c|c|c|c|c|c|c|c|}
\hline País & 1986 & 1987 & 1988 & 1989 & 1990 & 1991 & 1992 & 1993 & 1994 & 1995 & 1996 \\
\hline Áustria & 11 & 6 & 5 & 7 & 9 & 9 & 3 & 3 & 0 & 1 & 0 \\
Bélgica & - & - & 64 & 81 & 33 & 62 & 49 & 28 & 30 & 46 & - \\
Canadá & 748 & 668 & 548 & 627 & 579 & 463 & 404 & 381 & 374 & 328 & 327 \\
Dinamarca & 215 & 202 & 157 & 132 & 232 & 203 & 151 & 218 & 240 & 424 & $930^{c}$ \\
Espanha & 914 & 1497 & 1193 & 1047 & 1312 & 1645 & 1360 & 1209 & 908 & 883 & 830 \\
EUA & 69 & 46 & 40 & 51 & 44 & 40 & 35 & 35 & 45 & 31 & 37 \\
Finlândia & 1236 & 791 & 1327 & 606 & 450 & 270 & 165 & 125 & 171 & 112 & 94 \\
França a & 78 & 66 & 46 & 38 & 29 & 12 & 15 & 10 & - & - & - \\
Françab & 1329 & 1391 & 1852 & 1743 & 1529 & 1318 & 1382 & 1351 & 1671 & - & - \\
Grécia & 213 & 381 & 532 & 312 & 480 & 161 & 824 & 596 & 215 & 110 & - \\
Holanda & 35 & 28 & 38 & 27 & 29 & 28 & 23 & 12 & 17 & 14 & 12 \\
Irlanda & 102 & 80 & 65 & 38 & 49 & 54 & 38 & 46 & 28 & 34 & 32 \\
Itália & 1469 & 1149 & 1769 & 1297 & 1094 & 791 & 903 & 1054 & 861 & 545 & 791 \\
Noruega & 16 & 10 & 15 & 14 & 15 & 4 & 16 & 12 & 20 & 11 & 18 \\
Portugal & 363 & 213 & 181 & 307 & 271 & 262 & 409 & 230 & 300 & 282 & 274 \\
Reino Unido & 1074 & 1016 & 781 & 701 & 630 & 369 & 253 & 211 & 205 & 235 & 244 \\
Suécia & 75 & 72 & 144 & 139 & 126 & 23 & 20 & 33 & 13 & 36 & 9 \\
Suíça & 1 & 0 & 4 & 2 & 2 & 1 & 3 & 0 & 8 & 2 & - \\
\hline
\end{tabular}

a Inclui greves localizadas (a ordem de greve é interna a um estabelecimento); média mensal de trabalhadores envolvidos em greve em curso em cada mês. As paralisações na agricultura e administração pública não estão registradas.

${ }^{b}$ Greves generalizadas (a ordem de greve se estende a várias empresas); agricultura e administração pública não incluídas.

c. Para este ano todas as greves e lockouts, sem nenhum limite de tamanho. Para 1996: OIT, Anuário de Estatística del nabajo, 19971998.

Fonte: ILO, 1996

Anexo 2.2

Número de Conflitos (1986 e 1995)

\begin{tabular}{|l|c|c|c|c|c|c|c|c|c|c|}
\hline País & 1986 & 1987 & 1988 & 1989 & 1990 & 1991 & 1992 & 1993 & 1994 & 1995 \\
\hline Áustria & 11 & 6 & 5 & 7 & 9 & 9 & 3 & 3 & 0 & 1 \\
Bélgica & - & - & 64 & 81 & 33 & 62 & 49 & 28 & 30 & 46 \\
Canadá & 748 & 668 & 548 & 627 & 579 & 463 & 404 & 381 & 375 & 326 \\
Dinamarca & 215 & 202 & 157 & 132 & 232 & 203 & 151 & 218 & 240 & 424 \\
Espanha & 914 & 1497 & 1193 & 1047 & 1312 & 1645 & 1360 & 1209 & 908 & 883 \\
EUA & 69 & 46 & 40 & 51 & 44 & 40 & 35 & 35 & 45 & 31 \\
Finlândia & 1236 & 791 & 1327 & 606 & 450 & 270 & 165 & 125 & 171 & 112 \\
França & 78 & 66 & 46 & 38 & 29 & 12 & 15 & 10 & - & - \\
França & 1391 & 1391 & 1852 & 1743 & 1529 & 1318 & 1382 & 1351 & 1671 & - \\
Grécia & 213 & 381 & 532 & 312 & 480 & 161 & 824 & 596 & 215 & 110 \\
Holanda & 35 & 28 & 38 & 27 & 29 & 28 & 23 & 12 & 17 & 14 \\
Irlanda & 102 & 80 & 65 & 38 & 49 & 54 & 38 & 46 & 28 & 34 \\
Itália & 1469 & 1149 & 1769 & 1297 & 1094 & 791 & 903 & 1054 & 861 & 545 \\
Noruega & 16 & 10 & 15 & 14 & 15 & 4 & 16 & 12 & 20 & 11 \\
Portugal & 363 & 213 & 181 & 307 & 271 & 262 & 409 & 230 & 300 & - \\
Reino Unido & 1074 & 1016 & 781 & 701 & 630 & 369 & 253 & 211 & 205 & 235 \\
Suíça & 1 & 0 & 4 & 2 & 2 & 1 & 3 & 0 & 8 & 2 \\
Suécia & 75 & 72 & 144 & 139 & 126 & 23 & 20 & 33 & 13 & 36 \\
\hline
\end{tabular}

Para a França, as mesmas observações do Anexo 2.1.

Fonte: ILO, 1996 
Anexo 2.3

Greves por Milhão de Empregados (1950-1954 a 1990-1991)

\begin{tabular}{|c|c|c|c|c|c|c|c|c|c|c|}
\hline & & 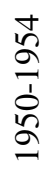 & $\begin{array}{l}\stackrel{2}{2} \\
\stackrel{1}{n} \\
2 \\
2\end{array}$ & 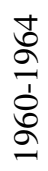 & $\begin{array}{l}\stackrel{\circ}{\circ} \\
\stackrel{1}{b} \\
\stackrel{2}{0}\end{array}$ & $\begin{array}{l}\frac{1}{5} \\
\frac{1}{2} \\
\vdots \\
\vdots\end{array}$ & $\frac{\stackrel{2}{a}}{a}$ & 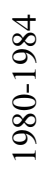 & 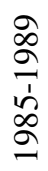 & $\begin{array}{l}\bar{\sigma} \\
\frac{\delta}{2} \\
\text { ळ }\end{array}$ \\
\hline 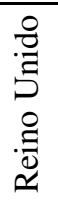 & 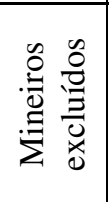 & $\vec{d}$ & $\vec{\infty}$ & $\begin{array}{l}n \\
\hat{n} \\
n\end{array}$ & مै & $\stackrel{0}{\Theta}$ & $\begin{array}{c}m \\
+ \\
\infty\end{array}$ & 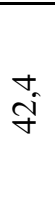 & $\stackrel{\infty}{\stackrel{\sim}{\sim}}$ & ?ִ \\
\hline 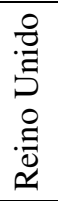 & $\begin{array}{l}0 \\
0 \\
0 \\
0\end{array}$ & $\vec{m}$ & ڤ̊ & $\begin{array}{l}0 \\
\stackrel{+}{0}\end{array}$ & $\begin{array}{l}\stackrel{0}{+} \\
\dot{H}\end{array}$ & $\begin{array}{l}0 \\
\infty \\
=\end{array}$ & fi & $\stackrel{m}{n}$ & $\begin{array}{l}0 \\
\stackrel{0}{0}\end{array}$ & $\begin{array}{l}0 \\
\infty \\
\infty\end{array}$ \\
\hline 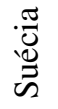 & & $\hat{a}$ & $\stackrel{+}{+}$ & $\stackrel{m}{n}$ & $\stackrel{m}{\rightarrow}$ & $\Omega^{2}$ & $\begin{array}{l}\text { id } \\
\text {. }\end{array}$ & ते & $\stackrel{+}{\stackrel{\sim}{N}}$ & $\underbrace{}_{0}$ \\
\hline 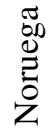 & & 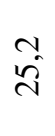 & $\stackrel{\text { I }}{ \pm}$ & के & $\stackrel{+}{+}$ & 2 & $=$ & $\stackrel{\infty}{\sigma}$ & $\stackrel{0}{0}_{0}^{0}$ & F \\
\hline 蔦 & & $\begin{array}{l}m_{0} \\
\infty\end{array}$ & $\stackrel{0}{0}$ & $\stackrel{2}{\Xi}$ & $\begin{array}{l}\infty \\
i n\end{array}$ & $\stackrel{m}{r}$ & to & $\hat{i}$ & $\sigma_{0}^{\circ}$ & F \\
\hline 焉 & & ஸీ & $\stackrel{0}{\stackrel{0}{0}}$ & $\stackrel{\circ}{i}$ & $\begin{array}{l}0 \\
\hat{\delta}\end{array}$ & $\frac{0}{\sqrt{n}}$ & $\begin{array}{l}\stackrel{0}{\circ} \\
\stackrel{n}{n}\end{array}$ & $\begin{array}{l}b \\
\text { a }\end{array}$ & $\frac{\pi}{6}$ & ڤू. \\
\hline
\end{tabular}

\begin{tabular}{|c|c|c|c|c|c|c|c|c|c|}
\hline $\begin{array}{l}\frac{\pi}{\Xi} \\
\frac{\Xi}{\Xi}\end{array}$ & $\tilde{\infty}$ & $\overrightarrow{6}$ & Oें & $\begin{array}{l}0 \\
\text { di } \\
\text { o }\end{array}$ & $\begin{array}{l}0 \\
\text { ñ } \\
-1\end{array}$ & 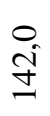 & $\begin{array}{l}\stackrel{ }{N} \\
\text { In }\end{array}$ & $\stackrel{m}{\mathbb{f}}$ & f \\
\hline 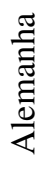 & ' & ' & ' & ' & ' & ' & ' & 1 & ' \\
\hline 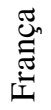 & $\begin{array}{l}0 \\
\text { I }\end{array}$ & $\begin{array}{l}0 \\
\pm \\
\Xi\end{array}$ & $\stackrel{0}{\hat{\sigma}}$ & t̃ & $\begin{array}{l}\circ \\
\stackrel{2}{2}\end{array}$ & $\stackrel{0}{i}$ & $\stackrel{0}{=}$ & $\widetilde{D}^{+}$ & ti \\
\hline 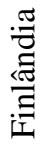 & $\frac{n}{m}$ & $\tilde{\curvearrowright}$ & $\begin{array}{l}0 \\
\hat{N}\end{array}$ & $\stackrel{?}{\underset{\gamma}{\gamma}}$ & $\begin{array}{l}0 \\
\text { in }\end{array}$ & $\begin{array}{l}0 \\
\infty \\
\infty \\
\infty\end{array}$ & 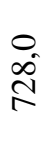 & $\stackrel{0}{m}$ & 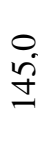 \\
\hline 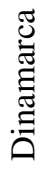 & $\stackrel{m}{r}$ & $\hat{I}$ & $\begin{array}{l}\infty \\
\infty \\
-1\end{array}$ & $\stackrel{0}{\stackrel{0}{n}}$ & $\frac{0}{j}$ & $\begin{array}{l}n \\
\hat{n}\end{array}$ & ô & $\begin{array}{l}0 \\
=\end{array}$ & $\frac{n}{\infty}$ \\
\hline 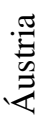 & ' & ' & ' & ' & 1 & ' & ' & ' & \\
\hline
\end{tabular}


Anexo 2.4

Grevistas por Mil Empregados (1950-1954 a 1990-1991)

\begin{tabular}{|c|c|c|c|c|c|c|c|c|c|c|}
\hline & & 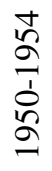 & 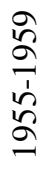 & 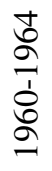 & 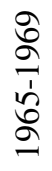 & $\begin{array}{l}\frac{1}{2} \\
\frac{1}{2} \\
\frac{1}{2}\end{array}$ & $\frac{\stackrel{2}{a}}{\frac{1}{2}} \frac{1}{2}$ & 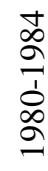 & 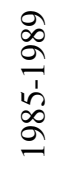 & $\begin{array}{l}\bar{a} \\
\bar{\delta} \\
\vdots\end{array}$ \\
\hline 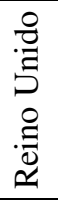 & 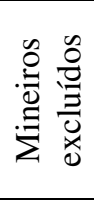 & 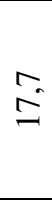 & ¿े & $\begin{array}{l}0 \\
\text { in } \\
\text { in }\end{array}$ & $\overrightarrow{6}$ & $\begin{array}{l}\hat{\infty} \\
i n\end{array}$ & $\overline{8}$ & $\stackrel{m}{i}$ & $\stackrel{+}{\stackrel{d}{\sim}}$ & $n$ \\
\hline 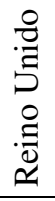 & 总 & $\begin{array}{l}0 \\
\text { in }\end{array}$ & $\begin{array}{l}n \\
\text { के } \\
\text { non }\end{array}$ & $\stackrel{\infty}{6}$ & $\begin{array}{l}0 \\
\stackrel{0}{+}\end{array}$ & $\begin{array}{l}0 \\
\dot{f}\end{array}$ & $\underset{\sigma}{*}$ & $\frac{n}{n}$ & î & $\vec{\infty}$ \\
\hline 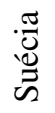 & & $\ddot{m}$ & ${ }^{n}$ & $0^{0}$ & $\vec{i}$ & $\overline{0}$ & $\stackrel{\sim}{f}$ & î & $\hat{n}^{2}$ & $\stackrel{+}{\infty}$ \\
\hline $\begin{array}{l}\text { D. } \\
\stackrel{0}{0} \\
\overline{0} \\
z\end{array}$ & & $\stackrel{\sim}{m}$ & $\stackrel{\infty}{=}$ & $\vec{n}$ & n' & $\stackrel{\sim}{f}$ & $\stackrel{\circ}{\circ}$ & $m_{\infty}^{m}$ & $\stackrel{+}{\sigma_{-}}$ & $\begin{array}{l}0 \\
i\end{array}$ \\
\hline $\begin{array}{l}\frac{\pi}{0} \\
\frac{\pi}{0} \\
\frac{\pi}{I}\end{array}$ & & $\stackrel{\vec{m}}{m}$ & $\hat{m}$ & o. & $\stackrel{+}{i}$ & $\stackrel{\vec{r}}{r}$ & $\stackrel{b}{*}$ & $\hat{n}$ & $\stackrel{\infty}{i}$ & $\stackrel{m}{n}$ \\
\hline 覀 & & $\begin{array}{l}\text { : } \\
\stackrel{+}{n}\end{array}$ & $\stackrel{\infty}{\infty}$ & $\stackrel{\substack{\infty \\
\pm}}{\stackrel{0}{+}}$ & $\stackrel{0}{\mathscr{O}^{-}}$ & $\frac{\infty}{\stackrel{0}{\sim}}$ & $\frac{0}{i n}$ & $\begin{array}{l}0 \\
\text { if } \\
\text { f }\end{array}$ & $\stackrel{\circ}{\circ}$ & 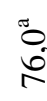 \\
\hline
\end{tabular}

\begin{tabular}{|c|c|c|c|c|c|c|c|c|c|}
\hline $\begin{array}{l}\text { 㞼 } \\
\text { I }\end{array}$ & $\stackrel{\circ}{=}$ & $\stackrel{+}{\sim}$ & $\stackrel{0}{0}$ & $\stackrel{\circ}{\dot{q}}$ & di & $\vec{m}$ & $\overrightarrow{\vec{d}}$ & 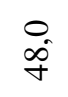 & $\begin{array}{l}n \\
\stackrel{i}{I}\end{array}$ \\
\hline 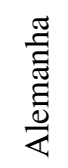 & $\stackrel{\infty}{+}$ & $\stackrel{3}{\pi}$ & $\stackrel{+}{m}$ & 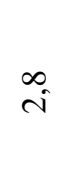 & 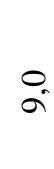 & గु. & $\stackrel{2}{\approx}$ & $\stackrel{n}{n}$ & $\therefore$ \\
\hline 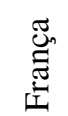 & $\begin{array}{l}\infty \\
\infty\end{array}$ & $\begin{array}{l}0^{\circ} \\
\therefore\end{array}$ & $\stackrel{\circ}{\Xi}$ & $\begin{array}{l}0 \\
\stackrel{\mathbb{I}}{0}\end{array}$ & $\begin{array}{l}0 \\
\stackrel{0}{0}\end{array}$ & $\vec{F}$ & वे & 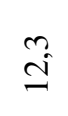 & $\stackrel{\overbrace{}}{\varrho}$ \\
\hline $\begin{array}{l}\text { 㺃 } \\
\text { 䔍 }\end{array}$ & $\underline{6}$ & $\underset{i}{\vec{n}}$ & $\stackrel{+}{\Xi}$ & $\stackrel{\vec{g}}{g}$ & $\begin{array}{l}0 \\
\stackrel{\infty}{=}\end{array}$ & ف요 & $\stackrel{8}{\Omega}$ & कू & $\frac{m}{\delta}$ \\
\hline 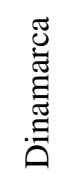 & $\stackrel{\circ}{\circ}$ & $\stackrel{\infty}{\infty}^{\infty}$ & $\stackrel{+}{+\infty}$ & $\begin{array}{l}\infty \\
\infty\end{array}$ & fó & $\stackrel{f}{f}$ & $\bar{d}$ & n' & $\overline{ \pm}$ \\
\hline 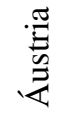 & & & $\vec{a}$ & $\tilde{a}^{2}$ & ô & ${ }_{0}^{0}$ & iे & $\bar{m}$ & $\stackrel{2}{ \pm}$ \\
\hline
\end{tabular}


Anexo 2.5

Médias de Dias Perdidos por Mil Empregados (1950-1954 a 1990-1991)

\begin{tabular}{|c|c|c|c|c|c|c|c|c|c|c|}
\hline & & $\begin{array}{l}\stackrel{+}{2} \\
\stackrel{1}{1} \\
\stackrel{n}{2}\end{array}$ & $\begin{array}{l}\hat{a} \\
\hat{a} \\
\dot{n} \\
\tilde{a}\end{array}$ & 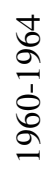 & 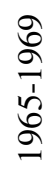 & $\begin{array}{l}\frac{1}{5} \\
\frac{1}{2} \\
\vdots \\
\vdots\end{array}$ & $\begin{array}{l}\frac{a}{a} \\
\frac{1}{2} \\
\stackrel{2}{a}\end{array}$ & 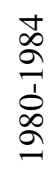 & $\begin{array}{l}\stackrel{a}{\circ} \\
\frac{1}{2} \\
\stackrel{2}{\sigma}\end{array}$ & $\begin{array}{l}\bar{a} \\
\frac{1}{2} \\
\circ\end{array}$ \\
\hline 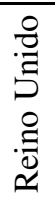 & 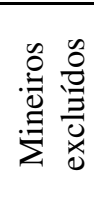 & $\overrightarrow{f t}$ & $\stackrel{0}{i}$ & $\stackrel{\circ}{\stackrel{0}{\Xi}}$ & $\begin{array}{l}\stackrel{0}{y} \\
\dot{y}\end{array}$ & $\frac{0}{\frac{j}{y}}$ & $\stackrel{0}{\stackrel{0}{\stackrel{5}{\gamma}}}$ & $\underset{\underset{\sim}{+}}{\stackrel{0}{f}}$ & 히 & $\stackrel{\substack{\infty \\
+\infty}}{ }$ \\
\hline 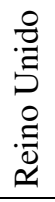 & $\underbrace{0}_{0}$ & $\stackrel{\vec{\infty}}{\hat{\infty}}$ & @ & $\frac{0}{m}$ & $\begin{array}{l}0 \\
\stackrel{n}{n}\end{array}$ & $\begin{array}{l}0 \\
\infty \\
i \\
i\end{array}$ & $\begin{array}{l}\stackrel{\circ}{+} \\
\stackrel{+}{+}\end{array}$ & $\stackrel{\circ}{\underset{f}{f}}$ & $\stackrel{0}{\underline{0}}$ & $\begin{array}{l}n \\
\stackrel{\infty}{+}\end{array}$ \\
\hline 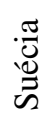 & & $\begin{array}{c}0 \\
\text { in }\end{array}$ & $\tilde{n}$ & $\hat{f}$ & $\hat{a}$ & $\begin{array}{l}\infty \\
\hat{n}\end{array}$ & $\begin{array}{l}\infty \\
\dot{0}\end{array}$ & ڤે & $\stackrel{0}{\mathrm{I}}$ & $\underset{\infty}{\infty}$ \\
\hline $\begin{array}{l}\text { D. } \\
\stackrel{0}{0} \\
\overline{0} \\
z\end{array}$ & & $\begin{array}{l}b^{\circ} \\
\stackrel{0}{f}\end{array}$ & $\stackrel{0}{8}$ & \& & $\underset{r}{0}$ & $\stackrel{\dot{n}}{n}$ & $\hat{i}$ & $\begin{array}{l}\infty \\
\dot{i}\end{array}$ & $\stackrel{0}{\varrho}$ & $\begin{array}{c}0 \\
m\end{array}$ \\
\hline $\begin{array}{l}\frac{\pi}{0} \\
\frac{\pi}{\tilde{I}} \\
0 \\
1\end{array}$ & & $\begin{array}{l}0 \\
\infty \\
\infty\end{array}$ & $\stackrel{\infty}{\stackrel{i}{0}}$ & ลे & in & $\stackrel{\vec{f}}{f}$ & $\begin{array}{l}\infty \\
\stackrel{d}{d}\end{array}$ & $\stackrel{\infty}{\simeq}$ & $\stackrel{n}{\infty}$ & $\stackrel{\infty}{\tilde{\lambda}^{\infty}}$ \\
\hline 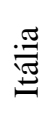 & & O্ं & î & $\begin{array}{l}0 \\
\text { î }\end{array}$ & $\frac{0}{\infty}$ & $\begin{array}{l}0 . \\
\text { oे } \\
0\end{array}$ & $\stackrel{\text { ó }}{=}$ & ले & $\begin{array}{l}0 \\
\infty \\
\infty \\
0\end{array}$ & $\stackrel{0}{\vec{D}}$ \\
\hline
\end{tabular}

\begin{tabular}{|c|c|c|c|c|c|c|c|c|c|}
\hline $\begin{array}{l}\frac{\tilde{J}}{\Xi} \\
\stackrel{\Xi}{\Xi}\end{array}$ & $\begin{array}{l}\stackrel{0}{N} \\
\stackrel{N}{N}\end{array}$ & $\begin{array}{l}0 \\
\equiv\end{array}$ & $\begin{array}{l}0 \\
i n \\
n\end{array}$ & $\begin{array}{l}0 \\
\text { i⿱ } \\
\text { in }\end{array}$ & $\begin{array}{l}\stackrel{0}{\infty} \\
\stackrel{\infty}{+}\end{array}$ & $\frac{0}{\infty}$ & $\begin{array}{c}0 \\
\infty \\
m \\
m\end{array}$ & $\frac{0}{a}$ & $\begin{array}{l}0 \\
0 \\
n \\
n\end{array}$ \\
\hline 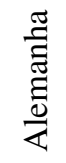 & $\hat{8}$ & $\vec{m}$ & $\begin{array}{l}0 \\
\infty \\
\infty\end{array}$ & $n$ & $\stackrel{\infty}{\sim}$ & $\underset{\sim}{\dot{\sigma}}$ & $\stackrel{\sigma}{\dot{\gamma}}$ & $\stackrel{\infty}{-}$ & $\infty_{\infty}^{\infty}$ \\
\hline 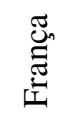 & $\stackrel{0}{0}$ & $\begin{array}{l}0 \\
0 \\
0\end{array}$ & $\begin{array}{l}0 \\
\stackrel{n}{2} \\
\end{array}$ & $\stackrel{ }{\text { N}}$ & $\stackrel{0}{0}$ & $\begin{array}{l}\text { 을 } \\
\text { N }\end{array}$ & $\stackrel{n}{n}$ & $\begin{array}{l}\vec{f} \\
\text { mे }\end{array}$ & $\stackrel{n}{\tilde{N}}$ \\
\hline 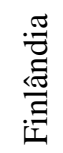 & $\begin{array}{l}0 \\
\dot{8} \\
\text { in }\end{array}$ & 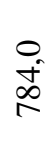 & $\begin{array}{l}0 \\
\stackrel{f}{n}\end{array}$ & $\vec{\infty}$ & $\begin{array}{l}0 \\
\hat{a} \\
\text { ñ }\end{array}$ & $\begin{array}{l}0 \\
n \\
\infty \\
n\end{array}$ & $\stackrel{0}{8}$ & $\begin{array}{l}0 \\
\text { i } \\
\text { d }\end{array}$ & $\begin{array}{l}0 \\
\stackrel{0}{0} \\
\stackrel{\infty}{0}\end{array}$ \\
\hline 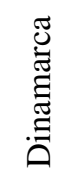 & $\stackrel{\infty}{m}$ & $\begin{array}{l}0 \\
\text { in }\end{array}$ & $\stackrel{0}{\stackrel{0}{N}}$ & $\vec{m}$ & $\begin{array}{l}0 \\
8 \\
0 \\
0\end{array}$ & ה̃ & $\begin{array}{l}0 \\
0 \\
0\end{array}$ & $\begin{array}{l}0 \\
\text { ¿ }\end{array}$ & $\frac{\sigma_{n}}{m}$ \\
\hline 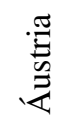 & $\begin{array}{l}\stackrel{0}{d} \\
\stackrel{+}{n}\end{array}$ & $\vec{n}$ & $\hat{\infty}$ & $\hat{\tilde{a}}$ & $\stackrel{\sim}{ \pm}$ & $\stackrel{9}{-}$ & $\stackrel{0}{=}$ & $\vec{i}$ & $\stackrel{\infty}{\infty}$ \\
\hline
\end{tabular}




\section{Autores Citados}

AARON, Benjamin; GRODIN, Joseph R. \& STERN, James L. (ed.). (1979) Public Sector Bargaining. Washington D.C., of National Affairs, apud HERMAN \& KUHN (1981).

ACCORNERO, Aris; BIBES, Geneviève \& GROPPO, Bruno. (1990) "Les Formes de La Syndicalisation en Italie". In: BIBES, Geneviève \& MOURIAUX, René (ed.). Les Syndicats européens à l'épreuve. Paris, Presses de la Fondation Nationale des Sciences Politiques.

ACKERS, Peter; SMITH, Chris \& SMITH, Paul. (1996) “Against All Odds? British Trade Unions in the New Workplace". In: ACKERS, Peter, SMITH, Chris \& SMITH, Paul (ed.). The New Workplace and Trade Unionism. London, Routledge.

ALLEN, V. L. (1971) The Sociology of Industrial Relations. London, Longman.

AMOROSO, Bruno. (1992) "Development and Crisis of the Scandinavian Model of Labour Relations in Denmark". In: BAGLIONI, Guido \& CROUCH, Colin (ed.). European Industrial Relations. The Challenge of Flexibility London, Sage.

ANDERSON, Perry. (1966) "Introdução". In: ANDERSON, Perry \& CAMILLER, Patrick (ed.). Um Mapa da Esquerda na Europa. Rio de Janeiro, Contraponto.

ARBIX, Glauco. (1998) "Falsos Passaportes para a Modernidade: O Governo e as Relações de Trabalho", Debates, n 10, São Paulo, Fundação Konrad Adenauer.

(1996) Uma Aposta no Futuro. Os Primeiros Anos da Câmara Setorial da Indústria Automobilística. São Paulo, Scritta.

ARONSON, Robert L. (1985) "Unionism Among Professional Employees in the Private Sector", Industrial and Labor Review, vol. 38, $\mathrm{n}^{\circ} 3$, April.
BAETHGE, Martin, \& WOLF, Harald. (1995) "Continuity and Change in the 'German Model' of Industrial Relations". In LOCKE, Richard, KOCHAN, Thomas \& PIORE Michael (ed.). Employment Relations in a Changing World Economy. Cambridge, The MIT Press.

BAGLIONI, Guido. (1992) "Industrial Relations in Europe in the 1980s". In: BAGLIONI, Guido \& CROUCH, Colin (ed.). European Industrial Relations. The Challenge of Flexibility. London, Sage. (Há tradução brasileira sob o título: "As Relações de Trabalho na Europa nos Anos 80". In: COMIN, Álvaro Augusto et al. (orgs.). O Mundo do Trabalho. Crise e Mudança no Final do Século. São Paulo, CESIT/Scritta, 1994.)

\& CROUCH, Colin (ed.). (1992) European Industrial Relations. The Challenge of Flexibility. London, Sage.

BAIN, G.S. \& ELIAS, P (1985) "Trade Union Membership in Great Britain: An Individual-Level Analysis", British Journal of Industrial Relations, vol. 22, $\mathrm{n}^{\circ}$ 1, March.

BARISI, Giusto. (1989) "La Vitalité du Syndicalisme Italien”, Problèmes Économiques, apud Notes de Conjoncture Sociales, 30.8.1989.

BARRETO, José. (1993) "Portugal: Industrial Relations under Democracy". In: FERNER, Anthony \& HYMAN, Richard (ed.). Industrial Relations in the New Europe. Oxford, Blackwell. BARTOLINI, Stefano. (1983) "The European Left Since World War I: Size, Composition and Patterns of Electoral Development". In: DAALER, Hans \& MAIR, Peter (ed.). Western European Party System. Continuity \& Change. London, Sage.

BEHRMANN, Suzan L. (1994) "Union Members in 1993”, Compensation and Working Conditions, 46, February 914, apud CHAISON (1996).

BENJAMIN, Daniel K. (1986) “Combinations of Workmen: Trade Unions in the American Economy". In: LIPSET, Seymour Martin (ed.). Unions in Transition. Entering the Second Century. San Francisco, ICS Press.

BENSON, Herman. (1986) "The Fight for Union Democracy". In: LIPSET; Seymour Martin (ed.). Unions in Transition. Entering the Second Century. San Francisco, Institute for Contemporary Studies. 
BERSTEIN, Aaron. “Sweeney's Blitz”, Business Week, 17 February 1997.

BEYNON, Huw. (1975) Working for Ford. EP Publishing, 1979\& 1980. (A primeira edição é de 1973. Há edição brasileira: Trabalhando para Ford. Trabalhadores e Sindicalistas na Indústria Automobilística. São Paulo, Paz e Terra, 1995.)

(1995) “A Destruição da Classe Operária Inglesa?”, Revista Brasileira de Ciências Sociais, $\mathrm{n}^{\circ}$ 27, ano 10, fevereiro.

BIRD, Derek, \& CORCORAN, Louise. (1994) "Trade Union Membership and Density 1992 1993", Employment Gazette, vol. 10, n 6, June.

; BEATSON, Mark \& BUTCHER, Shaun. (1993) Employment Gazette, Centenary Issue, May.

BLANCHFLOWER, David G., \& FREEMAN, Richard B. (1992) "Unionism in the United States and Other Advanced OECD Countries", Industrial Relations, vol. 31, $\mathrm{n}^{\circ} 1$, Winter.

\& OSWALD, A. (1988) The Economic Effects of Britain's Trade Unions, Employment Institute, apud METCALF (1990).

BOLETIM 2409. (1992) Departamento do Trabalho dos EUA, "Technological Changes and its Impact on Labor in Four Industries", apud RIFKIN (1996).

BOSCH, Gerhard. (1985) "West Germany". In: CROSS, M. (ed.). Managing Workforce an Reduction. An International Survey. I,ondon, Croom Helm, apud VISSER (1988).

; DAWKINS, Peter \& MICHON, François. (1994) "Working Time in 14 Industrialized Countries: An Overview". In: BOSCH, Gerhard; DAWKINS, Peter \& MICHON, François (eds.). Times are Changing. Genève, International Institute of Labour Studies.

BOWDEN, Gary. (1989) "Labor Unions in the Public Mind: the Canadian Case", The Canadian Review of Sociology and Anthropology / La Revue Canadienne de Sociologie et d'Anthropologie, vol. 26, $\mathrm{n}^{\circ} 55$, November.

BOYER, Robert. (1988) "Wage/Labour Relations, Growth, and Crisis: a Hiden Dialetic". In: BOYER, Robert (ed.). The Search for Labour
Market Flexibility. The European Economies in Transition. Oxford, Clarendon Press.

.(1995) "The Future of Unions: Is the Anglo-Saxon Model a Fatality, or Will Contrasting National Trajectories Persist?", British Journal of Industrial Relations, vol. 33, n 4, December.

BRANCIARD, Michel. (1982) Syndicats et partis. Autonomie ou dépendence, 1879-1947. Paris, Éd. Syros, tomo I.

BRONFENBRENNER, Kate. (1997) "U.S. Labor/Suppressed study says NAFTA used against workers", Inter Press Service, 27 January, comunicado de imprensa apud OIT, 1997-1998, p. 80.

BRULIN, Göran. (1995) "Sweden: Joint Councils under Strong Unionism". In: ROGERS, Joel \& STREECK, Wolfgang (eds.). Works Councils. Consultation, Representation and Cooperation in Industrial Relations. Chicago, The University of Chicago Press.

BURGI, Noëlle. (1990) "Grande-Bretagne: Une Conféderation: Trois Stratégies". In: BIBES, Geneviève \& MOURIAUX, René (eds.). Les syndicats européens à l'épreuve. Paris, Fondation National des Sciences Politiques.

CALMFORS, L. \& DRIFFILL, J. (1988) "Bargaining structure, Corporatism and Macro-Economic Performance", Economic policy, n ${ }^{\circ}$ 6, apud POHJOLA, 1992.

CAMERON, David. (1984) "Social Democracy, Corporatism, Labour Quiescence, and the Representation of Economic Interest in Advanced Capitalist Society". In: GOLDTHORPE, John H. (ed.). Order and Conflict in Contemporary Capitalism. Studies in the Political Economy Western European Nation. Oxford, Oxford University Press.

CAMILLER, Patrick. (1994) "Sobrevivência do Socialismo?". In: ANDERSON, P \& CAMILLER, (eds.). (1994) Uma Mapa da Esquerda na Europa Ocidental. Rio, Contraponto.

CARTER, Bob. (1985) Capitalism, Class Conflict and the New Middle Class. London, Routledge \& Kegan Paul. 
CARVALHO, José Murilo de. (1987) Os Bestializados. O Rio de janeiro e a República que não Foi. São Paulo, Companhia das Letras.

CASTANHEIRA, José Pedro. (1983) A História dos Bancários do Sul e Ilhas (1910-1969): Os Sindicatos e o Salazarismo. Lisboa, Ed. S.B.S.I.

CAWSON, Alan. (1985) "Varieties of corporatism: the importance of the meso-level of interest intermediation". In: CAWSON, Alan (ed.). Organized Interest and the State. Studies in Meso-Corporatism. London, Sage.

CÉZARD, Michel; MALAN, Anna \& BEZANÇON, Thomaz. (1995) "Le Rôle des Répresentants du personnel: révendications collectives et reclamations individuelles", Premiers Syntèses, août 1981, apud JEFFERYS, Steve (1996).

CHAISON, Gary N. (1996) Union Mergers in Hard Times. The View from Five Countries. ILR Press, Cornell University Press.

\& DHAVALE, Dileep G. (1990) "A Note on the the Severity of the Decline in Union Organizing Activity", Industrial and Labor Relations Review, vol. 43, apud KOCHAN \& WEVER (1995). p. 371

CHANG, Clara \& SORRENTINO, Constance. (1991) "Union Membership Statistics in 12 Countries", Monthly Labor Review, vol. 114, n ${ }^{\circ} 12$.

CHINOY, Ely. (1955) Automobile Worker and the American Dream. Boston, Random House.

CHRISTIANSEN, Niels Finn. (1996) "Dinamarca: O Fim de um Edílio?". In: ANDERSON, Perry \& CAMILLER, Patrick (orgs.). Um Mapa da Esquerda na Europa. Rio de Janeiro, Contraponto.

CHURCH, Roy; OUTRAM, Quentin \& SMITH, David N. (1991a) "The 'Isolated Mass' Revisited: Strikes in British Coal Mining", The Sociological Review, vol. 39, $\mathrm{n}^{\circ}$ 1, February.

(1991b) "The Militancy of British Miners, 18931986: Interdisciplinary Problems and Perspectives", The Journal of Interdisciplinary History, vol. 22, $\mathrm{n}^{\circ} 1$, Summer.
CLEMENT, Wallace. (1994) "Exploring the Limits of Social Democracy: Regime Change in Sweden”, Studies in Political Economy, vol. 44, Summer.

CODARA, Lino. (1997) Rapporto Annuale sulle Relazione Sindicali. Roma, CESOS, junio.

COBBLE, Dorothy. (1994) "Making Postindustrial Unionism Possible". In: FRIEDMAN, Sheldon; HURD, Richard; OSWALD, Rudolf \& SEEBER, Ronald (eds.). Restoring the Promise of American Labor Law. Ithaca, I\&L, Press, apud STRAUSS, 1995.

CORIAT; Benjamin. (1992) El Taller y el Robot. Ensayos sobre el Fordismo y la Producción en Masa en la Era de la Electrónica Madrid, Siglo Veintiuno Editores.

COUFFIGNAL., Georges. (1982) "Les Syndicats espagnols: Priorité au politique". In: ARMINGEON, K.; COUFFIGNAL, G.; COX, A.; LABBÉ, D.; MOURIAUX R. \& REVELEI, M. (eds.). Les Syndicats européens et la crise. Grenoble, Presses Universitaires de Grenoble.

CRAVER, Charles B. (1993) Can Union.s Survive? New York, New York University Press.

CREWE, Ivor. (1991) "Labor Force Changes, Working Class Decline, and the Labour Vote: Social and Electoral Trends in Postwar Britain". In: PIVEN, Frances Fox (ed.). (1991) Labor Parties in Postindustrial Societies. Cambridge, Blackwell.

(1996) "Revised Diversity: from the Neo-Liberal Decade to Beyond Maastricht" In: VAN RUYSSEVELDT; Joris \& VISSER, Jelle (eds.). Industrial Relations in Europe. Tradition and Transitions. London, Sage.

.(1994) "The Fate of Articulated Industrial Relations Systems: a Stock-taking after the 'Neo-liberal' Decade". In: REGINI, Marino (ed.). The Future of Labour Movements. London, Sage.

.(1993) Industrial Relations and European Mates Traditions. Oxford, Clarendon Paperback. 
.(1992a) "Afterword". In: BAGLIONI, Guido \& CROUCH, Colin (eds.). European Industrial Relations. The Challenge of Flexibility London, Sage.

.(1992b) "United Kingdom: The Rejection of Compromise". In: BAGLIONE Guido \& CROUCH, Colin (eds.). European Industrial Relations. The Challenge Flexibility. London, Sage.

CROZIER, Michel. (1962) "Sociologie du syndicalisme". In: FRIEDMANN, G. \& NAVILLE, E (eds.). Traité $d u$ Sociologie $d u$ Travail. Paris, Armand Colin, $2^{\circ}$ vol. (Tradução brasileira em RODRIGUES, Leôncio Martins (org.). Sindicalismo e Sociedade. São Paulo, Difusão Européia do Livro, 1968.)

CURME, Michael A.; HIRSCH, Barry T \& MACPHERSON, David A. (1990) "Union Membership and Contract Coverage in the United State, 19831988”, Industrial and Labor Review, vol. 44, n. 1, October.

CURRENT Population Survey, 5/1977, apud. FREEMAN, Richard B. \& MEDOFF James L. (1987). p. 41.

DIBDEN, Jennifer \& MII.LWARD, Neil. (1991) “Trade Union Membership: Developments and Prospects", Policy Studies, vol. 12, no 4.

DEERY, Stephen. (1995) "The Demise of the Trade Union as a Representative Body?", British Journal of Industrial Relations, vol. 33, $n^{\circ} 4$, December.

DELANEY, John Thomas. (1991) "The Future of Unions as Political Organizations", journal of Labor Research, vol. 12, n4, Autumn.

DICKENS, William T \& LEONARD, Jonathan S. (1985) "Accounting for the Decline in Union Membership, 19501980”, Industrial and Labor Relations Review, vol. 38, $\mathrm{n}^{\circ} 3$, April.

DIEESE, Boletim do Dieese, janeiro de 1997, ano XVI, n 190, “Aspectos do Sindicalismo Italiano", dados a UIL., central sindical italiana.

DILTS, David A. \& DEITSCH, Clarence R. (1983)Labor Relations. New York/London, MacMillan: Publishing Company/ Collier Macmillan Publisher.
DISNEY, Richard. (1990) "Explanation of the Decline in Trade Union Density in Britain: an Appraisal”, British Journal of Industrial Relations, vol. 28, $\mathrm{n}^{\circ} 2$, July.

DOLLÉANS, Édouard \& CROZIER, Michel. (1950) Mouvements ouvriers et socialistes. Chronologie et bibliographie. Paris, Les Éditions Ouvrières.

DOLVIK, Jon Erik \& STOKLAND, Dag. (1993) "Norway: 'The Norwegian Model' in Transition". In: FERNER, A. \& HYMAN Richard (eds.). Industrial Relations in the New Europe. Oxford, Blackwell.

DOREY, Peter. (1993) "One Step at a Time: the Conservative Government's Approach to the Reform of Industrial Relations Since 1979", The Political Quartely, vol. 64, n¹, January-March.

DRUCKER, Peter. (1993) Sociedade Pós-Capitalista. 3. ed. São Paulo, Pioneira.

DUNN, Stephen \& WRIGHT, Martin. (1994) "Maintaining the Status Quo'? An Analysis of the Contents of British Collective Agreements, 1979-1990”, British Journal of Industrial Relations, vol. 32, n 1 , March.

DURAND, Jean-Pierre. (1996) "Le Compromis productif change de nature!". In: DURAND, Jean-Pierre (ed.). Le Syndicalisme au futur. Paris, Syros.

EBBINGHAUS, Bernhard. (1995) "The Development of Trade Unions in Western Europe: Global Convergence or Cross-national Diversity?", Eurodata Newsletter, ${ }^{\circ} 2$, Autumn, Research Archive of the National Centre for European Social Research.

EDWARDS, P K., \& BAIN, George Sayer. (1988) "Why Are Trade Unions Becoming More Popular? Unions and Public Opinion in Britain", British Journal of Industrial Relations, vol. 26, $\mathrm{n}^{\circ} 1$, November

EDWARDS, Paul. (1995) "The Employment Relationship". In: EDWARDS, Paul (ed.) Industrial Relations. Theory \& Practice in Britain. Oxford, Blackwell. 
\& HYMAN, Richard. (1994) "Strikes and Industrial Conflict: Peace in Europe?”. In: FERNER, A. \& HYMAN, Richard (ed.). Industrial Relations in the New Europe. Oxford, Blackwell.

; HALL, Mark; HYMAN, Richard; MARGINSON, Paul; SISSON, Keith; WADDINGTON, Jeremy \& WINCHESTER, David. (1993) "Great Britain: Still Muddling Through". In: FERNER, A. \& HYMAN, Richard (eds.). Industrial Relations in the New Europe. Oxford, Blackwell.

EMPLOYMENT Gazette, 5/95, apud WADDINGTON, Jeremy \& WHITSTON, Colin. "Trade Unions: Growth, Structure and Policy". In: EDWARDS, Paul, 1995.

ESCOBAR, Modesto. (1995) "Spain: Work Councils or Unions?" In: ROGERS, Joel \& STREECK, Wolfgang (eds.). Works Councils. Consultation, Representation and Cooperation in Industrial Relations. Chicago, The University of Chicago Press.

ESPING-ANDERSEN, Gosta. (1994) "The Emerging Realignment Between Labour Movements and Welfare States". In: REGINI, Marino (ed.). The Future of Labour Movements. london, Sage.

.(1991) "Postindustrial Cleavage Structures: A Comparison of Evolving Patterns of Social Stratification in Germany, Sweden, and the United States". In: PIVEN, Frances Fox (ed.). Labor Parties in Postindustrial Societies, Cambridge, Polity Press/Blackwell Publishers.

ESTIVILL, Jordi \& HOZ, Joseph de la. (1992) -“Transition and Crisis: The Complexity of Spanish Industrial Relations". In: BAGLIONI, Cuido \& CROUCH, Colin (eds.). The Challenge of Flexibility. London, Sage.

FAIRBROTHER, Peter. (1996) "Workplace Trade Unionism in the State Sector”. In: ACKERS, Peter; SMITH, Chris \& SMITH, Paul (ed.). The New Workplace and Trade Unionism. London, Routledge.

FARBER, H. (1990) "The Decline of Unionization in the USA: What Can Be Learned From Recente Experience", Journal of Labor Economics, vol. 18, $\mathrm{n}^{\circ}$ 1, apud KOCHAN, Thomas \& WEINSTEIN, Marc (1994).
FATCHETT; D. (1997) Trade Unions and Politics in the 1980s: The 1984 Act and Political Fund Ballots. London, Croom Helm, apud MARSH, 1992.

FAUSTO, Bóris. (1976) Trabalho Urbano e Conflito Social (18901920). São Paulo, Difel.

FERNANDES, Antônio Monteiro. (1985) "Portogallo". In: BELLARDI, Lauralba (ed.). Dallo Stato Corporativo alla Libertà Sindacale. Esperienze Comparativa. Milano, Franco Angeli.

FERNER, Anthony. (1994) "The State as Employer". In: HYMAN, Richard \& FERNER, Anthony. New Frontiers in European Industrial Relations. Oxford, Blackwell.

\& HYMAN, Richard. (1993a) "Industrial Relations in the New Europe: Seventeen Types of Ambiguity”. In: FERNER, Anthony \& HYMAN, Richard (eds.). Industrial Relations in the New Europe. Oxford, Blackwell.

$\&$ (1993b) "Italy: Between Political Exchange and MicroCorporatism". In: FERNER, Anthony \& HYMAN, Richard (eds.). Industrial Relations in the New Europe. Oxford, Blackwell.

FEUILLE, Peter. (1991), "Unionism in the Public Sector. The Joy of Protected Markets", Journal of Labour Research, vol. 12, $\mathrm{n}^{\circ} 4$, Autumn.

FREEMAN, Richard B. (1995) "The Future of Unions in Decentralized Collective Bargaining Systems: US and UK in an Era of Crisis", British Journal of Industrial Relations, vol. 33, $\mathrm{n}^{\circ}$ 4, December.

.(1990) "On Divergence of Unionism among Developed Countries". In: BRUNETT, Renato \& DELL'ARINGA, Carlos. Labour Relations and Economic Performance. MacMillan-International Economic Association.

\& MEDOFF, James L,. (1987) O Papel dos Sindicatos nas Sociedades Modernas. Rio de Janeiro, Forense Universitária. (Tratase da tradução do conhecido livro What Do Unions Do?, de 1984.) 
\& PELLETIER, Jeffrey. (1990) "The Impact of Industrial Relations Legislation on British Union Density”, British Journal of Industrial Relations, vol. $28, \mathrm{n}^{\circ} 2$, July.

FRIEDMANN, Georges. (1964) O Trabalho em Migalhas. São Paulo, Perspectiva.

GALENSON, Walter. (1994) Trade Union Growth and Decline. An International Study. Praeger.

.(1986) "The Historical Role of the American Trade Unionism". In: LIPSET; Seymour Martin (ed.). Unions in Transition. Entering the Second Century. San Francisco, ICS Press.

\& SMITH, Robert S. (1978) “The United States". In: DUNLOP, John \& GALENSON, Walter (eds.). Labor in the Twentieth Century. Cambridge, Academic Press. Gregor. (1995) "The Comitati di Base in the Italian Workers' Movement”, Capital \& Class, n55, Spring.

\& McKAY, Sonia. (1994) "Trade Union Derecognition in Britain, 1988-1994”, British Journal of Industrial Relations, ${ }^{\circ} 32$, September.

GALLIE, Duncan. (1978) In Search of the New Working Class. Automation and Social Integration within the Capitalist Enterprise. Cambridge, Cambridge University Press.

GOETSCHY, Janine. (1990) "Le Confort suédois". In: BIBES, Geneviève \& MOURIAUX, René (eds.). Le.s Syndicats européens à l'épreuve. Paris, Presses de la Fondation Nationale des Sciences Politiques.

\& ROZENBLAIT, Patrick. (1993) "France: The Industrial Relations Systems at a Turning Point?" In: FERNER, Anthony \& HYMAN, Richard (eds.). Industrial Relations in the New Europe. Oxford, Blackwell

GOLDTHORPE, John; LOCKWOOD, David; BECHHOFFER, Hank \& PLATT; Jennifer. (1970) The Affluent Worker: Industrial Altitudes and Behaviour. Cambridge, Cambridge University Press. (O estudo é mais amplo e envolve outros volumes sobre atitudes e comportamento político, a estrutura de classe etc. Estamos citando apenas a pesquisa relacionada diretamente com as atitudes ante o trabalho.)

GOVERNMENT Union Review. (1996) vol. 17, $\mathrm{n}^{\circ} 2$.
GREEN, Francis. (1992) "Recent Trends in British Trade Unions Density: How Much of a Compositional Effect?", British Journal of Industrial Relations, vol. 30, $\mathrm{n}^{\circ} 3$, September.

GROUX, Guy \& MOURIAUX, René. (1990) "Le Cas français". In. BIBES, Geneviève e MOURIAUX, René (eds.). Les Syndicats européens à l'épreuve. Paris, Presses de la Fondation des Sciences Politiques.

HANCKE, Bob. (1991) "The Crisis of National Unions: Belgian Labor in Decline", Politics \& Society, vol. 19, n 4, December.

HANCKÉ, Bob. (1993) “Trade union Membership in Europe, 1960-1990: Rediscovering Local Unions", British Journal of Industrial Relations, vol. 34, $\mathrm{n}^{\circ} 4$, December ${ }^{*}$.

HECKSCHER, Charles C. (1996) The New Unionism. Employee Involvement in the Changing Corporation. Ithaca, Cornell University Press.

HERMAN, Edward \& KUHN, Alfred. (1981) Collective Bargaining and Labor Relations. New Jersey, Prentice-Hall.

HOBSBAWM, Eric J. (1987) Mundos do Trabalho. São Paulo, Paz e Terra. . (1981) Os Trabalhadores. São Paulo, Paz e Terra.

HOTZ-HART Beat. (1993) "Switzerland: Still as Smooth as Clockwork?' In: FERNER, A. \& HYMAN, R. (eds.). Industrial Relations in the New Europe. Oxford, Blackwell.

HOWELL, Chris. (1995) "Trade Unions and the State: A Critique of British Industrial Relations", Politics \& Society, vol. 23, n² 2 , June.

.(1992) "The Dilemmas of Post-Fordism: Socialists, Flexibility, and Labor Market Deregulation in France”, Politics \& Society, vol. 20, $\mathrm{n}^{\circ} 1$, March.

HUXLEY, Christopher; KETTLER, David, \& STRUTHERS, James. (1986) "Is Canada's Experience Especially Instructive"? (1986) in: LIPSET, Seymour Martin (ed.). Unions in Transition. Entering the Second Century. San Francisco, ICS Press.

* O nome Hancké, segundo a publicação, apareceu como Hancke ou Hancké. Optamos, em cada caso, por seguir a grafia que aparece em cada revista. 
HYMAN, Richard. (1998) "La Répresentation Syndicale des Intérêts dans une Europe en Mutation", Sociologie du Travail, $\mathrm{n}^{\circ} 2$,

.(1996a) "Changing Union Identities in Europe". In: LEISINK, Peter; VAN LEEMPUT \& VILROKX, Jacques (eds.). The Challenges to Trade Unions in Europe. Chetelham, Edward Elgar Publishing.

(1996b)"'Institutional Transfer: Industrial Relations in Eastern Germany", Work, Employment \& Society, vol. 10, n 4, December.

.(1996c) "Los Sindicatos y la Desarticulación de la Clase Obrera", Relaciones de Trabajo en America Latina, Revista latino-americana de Estadias del Trabajo, ano 2, $\mathrm{n}^{\circ} 4$.

(1994a) "Introduction: Economic Restructuring, Market Liberalism and the Future of National Industrial Relations Systems". In: HYMAN, Richard \& FERNER, Anthony (eds.). New Frontiers in European Industrial Relations. Oxford, Blackwell.

(1994b) "Trade Unions and the Disaggregation of the Working Class". In: REGINI, Marino (ed.). The Future Labour Movements. London, Sage.

.(1994c) "Changing Trade Unions Identities and Strategies". In: HYMAN, Richard \& FERNER, Anthony (eds.). New Frontiers in European Industrial Relations. Oxford, Blackwell.

\& EDWARDS, P K., (1994) "Strikes and Industrial Conflict: Peace in Europe". In: HYMAN, Richard \& FERN ER, Anthony, New Frontiers in European Industrial Relations. Oxford, Blackwell.

INCISA，Ludovico. (1986) In: BOBBIO， N.; MATTEUCCI， N. \& PASQUINO, G. Dicionário de Política. Brasília, Editora Universidade de Brasília.

IRS Employment Reviera, April 1996.

IWD - Institut der Deutschen Wirtschafi. (1997 a) "Der Osten bricht weg", 10 April.

JACOBI, Otto \& MÜLLER-JENTSCH, Walter. (1993) "West Germany: Continuity and Structural Change". In: BAGLIONI, Guido \&
CROUCH, Collin (eds.)., European Industrial Relations. The Challenge of Flexibility. London, Sage.

; KELLER, Berndt, \& MÜLLER-JENTSCH, Walther. (1993) "Germany: Codetermining the Future?". In: FERNER, A. \& HYMAN, R. (eds.). Industrial Relations in the New Europe. Oxford, Blackwell.

JARLEY, Paul, \& KURUVILLA, Sarosh. (1994) "American Trade Unions and Public Approval: Can Unions Please All of. the People All the Time?", Journal of Labor Research, vol. XV, $\mathrm{n}^{\circ}$ 2, Spring.

JEFFERYS, Steve. (1996a) "Down But Not Out: French Unions After Chirac", Work, Employment \& Society, vol. 10, n³, September.

.(1996b) "Stratégies de survie: les syndicats ont-ils le choix?" In: DURAND Jean-Pierre (ed.). Le syndicalisme au futur. Paris, Syros.

JOHNSTON, William B., \& PACKER, Arnold E..(1987) Workforce 2000. Indianapolis, Hudson Institute, apud KOCHAN \& WEVER (1990).

KANE, Elimane, \& MARSDEN, David. (1988) "The Future of Trade Unionism in Industrialized Market Economies", Labour and Society, vol. 13, $\mathrm{n}^{\circ}$ 2, April.

KASSALOW, Everett. (1969) Trade Unions and Industrial Relations: an International Comparison. New York, Random House.

KATZ, Harry. (1993) "The Decentralization of Collective Bargaining: A Literature Review and Comparative Analysis", Industrial and Labor Relations Review, vol. 47, $\mathrm{n}^{\circ} 1$, October.

KERMAN, E. Edward \& KUHN, Alfred. (1981) Collective Bargaining and Labor Relations. New Jersey, Prentice-Hall.

KERN, Horst \& SABEL, Charles E (1994) "Trade Unions and Decentralized Production: a Sketch of Strategic Problems in the German Labour Movement". REGINI, Marino (ed.). The Future of Labour Movements. London, Sage.

KERR, Clark \& SIEGEL, Abraham. (1954) "The Inter-Industry Propensity to Strike - An International Comparison". In: DUBIN, Robert; KORNHAUSER, Arthur \& ROSS, Arthur (eds.). Industrial Conflit. New York, McGraw Hill. 
KHOSROKHAVAR, Farhad. (1996) "Les nouvellles formes de mobilisation sociale". In: TOURAINE, A.; DUBET; E, LAPEYRONNIE, D.; KHOSROKHAVAR, E \& WIEVIORKA, M. Le Grand Refus. Réflexion sur la grève de décembre 1995. Paris, Fayard, 1996.

KIRCHHEIMER, Otto. (1966) "The Transformation of the Western European Party Systems". In: LAPALOMBARA, Joseph \& WEINER, Myron (eds.). Political Parties and Political Development. Princeton, Princeton University Press.

KJELLBERG, Anders. (1993) "Sweden: Can the Model Survive?" In: FERNER, Anthony \& HYMAN, Richard (eds.). Industrial Relations in the New Europe. London, Blackwell.

KNOWLES, K. G. C. J. (1952) Strikes, a Study in Industrial Conflict. New York, Philosophical Library.

KOCHAN, Thomas A. (1988) "The Future of Worker Representation: an American Perspective", Labour and Society, vol. 13, n 2, April.

\& WEVER, Kirsten. (1991) "American Unions and the Future of Worker Representation". In: STRAUSS, George; GALLAGHER, Daniel G. \& FIORITO, Jack (eds.). The State of the Unions. Madison (Wisconsin), Industrial Relations Research Association Series.

KATZ, Harry C., \& McKERSIE, Robert B. (1994) The Transformation of American Industrial Relations. New York, IRS Press.

\& WEINSTEIN, Marc. (1994) "Recent Development in US Industrial Relations", British Journal of Industrial Relations, vol. 32, $\mathrm{n}^{\circ} 4$, December.

KOEBLE, Thomas. (1992) "Recasting Social Democracy in Europe: A Nested Games Explanation of Strategic Adjustment in Political Parties", Politics \& Society, vol. 20, $\mathrm{n}^{\circ}$ 1, March. LABOR Press Service, $2 / 17 / 92$.

LABOUR Research. (1994a) "Unions in New Membership Alert", vol. 83, $\mathrm{n}^{\circ} 5$, May

.(1994b) "Lies, Damned Lies and Union Density!", vol. 83, n 6, June.
LANE, Christel. (1994) "Industrial Order and the Transformation of Industrial Relations: Britain, Germany and France Compared". In: HYMAN, Richard \& FERNER, Anthony (eds.). New Frontiers in European Industrial Relations. Oxford, Blackwell.

LANZALACO, Luca \& SCHMITTER, Philippe. (1994) "Europe's Internal Market, Business Associability and the Labour Movement". In: REGINI, Marino (ed.). The Future of Labours Movements. London, Sage.

LASSERRE, Henri. (1986) "La Crise du syndicalisme aujourd'hui", Les Temps Modernes, $n^{\circ}$ 476, Mars.

LECHER, Wolfgang \& NAUMANN, Reinhard. (1994) "The Current State of Trade Unions in the EU Member States". In: LECHER, Wolfgang (ed.). Trade Unions in the European Union. A Handbook. London, Lawrence \& Wishart.

LEHMBRUCH, Gerhard. (1992a) "Democracia Consorcional, Conflicto de Clases y Neocorporativismo". In: SCHMITTER, Philippe \& LEHMBRUCH, Gerhard (ed.). Neocorporativismo I. Más Allá del Estado y el Mercado. México, Alianza Editorial. (A primeira edição em inglês é de 1979.)

.(1992b) "Corporativismo Liberal y Gobierno de Partidos". In: SCHMITTER, Philippe \& LEHMBRUCH, Gerhard (eds.) Neocorporativismo I. Más Allá del Estado y el Mercado. México, Alianza Editorial.

.(1985) "Concertation and the Structure of Corporatist Networks". In: GOLDTHORPE, John H. (ed.). Order and Conflict in Contemporary Capitalism. Studies in the Political Economy of Western European Nation. Oxford, Clarendon Press.

LEVINE, Marvin J., \& HAGBURG, Eugene C. (1979) Public Sector Labor Relations. St Paul/ Los Angeles, West Publishing Company.

LEWIN, David. (1986) "Public Employee Unionism in the 1980s: An Analysis of Transformation". In: LIPSET, Seymour Martin (ed.). Unions in Transition. Entering the Second Century. San Francisco, ICS Press. 
LILJA, Kari. (1993) "Finland: No Longer the Nordic Exception". In: FERNER, Anthony \& HYMAN, Richard (eds.). Industrial Relations in the New Europe. Oxford, Blackwell.

LIMA, Marinús Pires. (1991) "Relações de Trabalho, Estratégias Sindicais e Emprego (1974-1990)", Análise Social, vol. 26, n 5.

LIPSET, Seymour Martin. (1986a) "Labour Unions in the Public Mind". In: LIPSET Seymour Martin (ed.). Unions in Transition. Entering the Second Century. San Francisco, ICS Press.

.(1986b) "North American Labor Movements: A Comparative Perspective". In: LIPSET, Seymour Martin (ed.). Unions in Transition. Entering the Second Century. San Francisco, ICS Press.

.(1961) "Trade Union and Social Structure", Industrial Relations, vol. 1, $\mathrm{n}^{\circ}$ 1, October. (Tradução em português em RODRIGUES, Leôncio Martins (org.). Sindicalismo e Sociedade. São Paulo, Difusão Europeia do Livro, 1968.)

LOCKE, Richard \& KOCHAN, Thomas. (1995) "Conclusion: a CrossNational Review of the Evidence". In: LOCKE, Richard; KOCHAN, Thomas \& PIORE, Michael (eds.). Employment Relations in a Changing World Economy. Cambridge, the MIT Press.

, \& PIORE, Michael. (1995) "Introduction". In: LOCKE, Richard; KOCHAN, Thomas \& PIORE, Michael (eds.). Employment Relations in a Changing World Economy. Cambridge, the MIT Press.

LOCKWOOD, David. (1962) El Trabajador de la Clase Media, Madrid, Aguilar.

LOJKINE, Jean. (1990)A Classe Operária em Mutação. Belo Horizonte, Oficina de Livros.

LUCIO, Miguel Martínez. (1993) "Spain: Constructing Institutions and Actors in a Context of Change". In: FERNER, Anthony \& HYMAN, Richard (eds.). Industrial Relations in the New Europe. London, Blackwell.

McDONALD, Charles. (1992) "U.S. Union Membership in Future Decades: A Trade Unionist's Perspective", Industrial Relations, vol. 31, $\mathrm{n}^{\circ} 1$, Winter.
MACSHANE, Denis. (1994) "Trade Unionism in Eastern Europe". In HYMAN, Richard \& FERNER, Anthony (eds.). New Frontiers in European Industrial Relations. Cambridge, Blackwell.

MAIER, Charles. (1985) "Precondition for Corporatism”. In: GOLDTHORPE John H. (ed.). Order and Conflict in Contemporary Capitalism. Studies in the Political Economy of Western European Nations. Oxford, Clarendon Press.

MAIR, Peter. (1996) “Grã-Bretanha . Trabalhismo e Reforma Eleitoral”. In: ANDERSON, Perry \& CAMILLER, Patrick (org.). Um Mapa da Esquerda na Europa. Rio de Janeiro, Contraponto.

MARGINSON, Paul \& SISSON, Keith. (1994) "The Structure of Transnational Capital in Europe: The Emerging Euro-company and its Implications for Industrial Relations". In: HYMAN, Richard \& FERNER, Anthony (eds.). New Frontiers in European Industrial Relations. Oxford, Blackwell.

MARSH, Arthur. (1984) Trade Union Handbook. Hampshire, Gower.

MARSH, David. (1992) The New Politics of British Trade Unionism. Ithaca, ILR Press.

MARTIN, Andrew. (1995) "The Swedish Model: Demise or Reconfiguration?". In: LOCKE, Richard; KOCHAN, Thomas \& PIORE, Michael (eds.). Employment Relations in a Changing World Economy. Cambridge, The MIT Press.

MARTIN, Dominique. (1976) "Le système de négociation et de répresentation dans l'éntreprise", Droit Social, vol. 3, apud TCHOBANIAN, 1995.

MAURICE, M.; SELLIER, E \& SILVESTRE, J.J. (1982) Politique d'éducation et organisasion industrielle en France et en Allemagne. Paris, Presses Universitaires de France apud CROUCH, 1993.

McILROY, John. (1995) Trade Unions in Britain Today. Manchester, Manchester University Press.

.(1997) "O Inverno do Sindicalismo". In: ANTUNES, Ricardo (org.). Neoliberalismo, Trabalho e Sindicato. São Paulo, Boitempo Editorial. 
MELlO E SILVA, Leonardo. (1997). A Generalização Difícil. A Vida Breve da Câmara Setorial do Complexo Químico Seguida do Estudo de seus Impactos em Duas Grandes Empresas do Ramo em São Paulo. Tese de doutoramento, Departamento de Sociologia da USP, São Paulo (mim.).

MELTZ, Noah \& VERMA, Anil. (1995) "Developments in Industrial Relations and Human Resource Practices in Canada: An Update from the 1980s". In: LOCKE, Richard; KOCHAN, Thomas \& PIORE, Michael (eds.). Employment Relations in a Changing World Economy. Cambridge, The MIT Press.

MERKEL, Muriel. (1983) The Labor Union Handbook. New York, Beaufort Books, Inc.

METCALF, David. (1989) "Can Unions Survive in the Private Sector?" Comunicação apresentada no seminário "Employment Institute/TUC Seminar": "Trade Unions and the Economy in the Late 1990s", March, apud DISNEY, 1990.

(1990) "Trade Union and Economic Performance: the British Evidence". In: BRUNETTA, Renato \& DELL'ARINGA, Carlo (eds.). Labour Relations and Economic Performance. London, The MacMillan Press.

MEYER, David \& BAIN, Trevor (1994) "Union Decertification Election Outcomes: Bargaining Unit Characteristic and Union Resources", Journal of Labor Research, vol. 15, $\mathrm{n}^{\circ} 2$.

MEYER, David G., \& COOKE, William N. (1993) "US Labor Relations in transition: Emerging Strategies and Company Performance", British Journal of Industrial Relations, vol. 4, $\mathrm{n}^{\circ} 31$.

MIELKE, Sigfried; RÜTTERS, Peter, \& TUDYKA, Kurt. (1994) -“Trade Union Organization and Employee Representation". In: LECHER, Wolfgang (ed.). "Trade Unions in the European Union. A Handbook. London, Lawrence \& Wishart.

MILWARD, Neil; STEVENS, Mark; SMART David \& HAWES, W.R. (1992) Workplaces Industrial Relations in Transition, Aldershot, Dartmouth, apud HOWELL, Chris (1995).
MISRA, Joya, \& HICKS, Alexander. (1994) "Catholicism and Unionization in Affluent Postwar Democracies: Catholicism, Culture, Party, and Unionization", American Sociological Review, vol. 59, n² 2, April.

MJOSET; Lars; CAPPELEN, Adne; FAGERBERG, Jan \& TRANOY, Bent Sofus. (1996) “Noruega: Mudança de Modelo". In: ANDERSON, Perry \& CAMILLER, Patrick (ed.). Um Mapa da Esquerda na Europa Ocidental. Rio de Janeiro, Contraponto.

MOENE, Karl Ove \& WALLERSTEIN, Michael, (1995) "How SocialDemocracy Worked: Labor-Market Institutions", Politics \& Society, vol. $23, \mathrm{n}^{\circ} 2$, June.

MONTHLY Labor Review, May 1996.

MOODY, Kim. (1995) "Estados Unidos. O Declínio dos Sindicatos", Interação, $\mathrm{n}^{\circ} 15$, mar-abr.

.(1989) An Injury to All. The Decline of American Unionism. New York, Verso.

MORCILLO, Fernando Almendros, JIMÉNEZ-ASENJO, Henrique; AMORÓS, Francisco Pérez \& TORRECILLA, Eduardo Rojo. (1978) El Sindicalismo de Clase en España (1939-1977). Barcelona, Ediciones Península.

MOURIAUX, René. (1986) Le syndicalisme face à la crise. Paris, Ed. La Découverte.

(1983) Les syndicats dans la société fiançaise. Paris, Presses de Ia Fondation Nationale des Sciences Politiques.

(1982) La CGT. Paris, Seuil.

MÜLLER-JENTSCH, Walter. (1995) "Germany: From Collective Voice to Co-Management”. In: ROGERS, Joel \& STREECK, Wolfgang (eds.). Works Councils. Consultation, Representation and Cooperation in Industrial Relations. Chicago, The University of Chicago Press.

NEGRELLI, Serafino \& SANTI, Ettore. (1992) "Industrial Relations in Italy". In: BAGLIONI, Guido \& CROUCH, Colin (eds.). European Industrial Relations. The Challenge of Flexibility London, Sage. 
NIELSEN, Hans Jorgen. (1987) "Unions in Politics: Public Opinion in the United Kingdom and Denmark", European Journal of Political Research, vol. 15 .

NISBET, R. (1978) "Public Union and the Decline of Social Trust". In: CHICKERING, A. L. (ed.). Public Employee Unions. Lexington, Lexington Books.

OIT (19971998) El Trabajo en el Mundo. Relaciones Laborales, Democracia y Cohesión Social, 1997-1998. Genève.

(1996) ILO Yearbook of Labour Statistic, Strikes and Lockouts. Genève.

(1994) Informe I, "Las Indústrias Mecánicas en la Economia Mundial”, Situación Reciente en las Industrias Mecánicas. Genève.

(1985) Situación Sindical y Relaciones Laborales en España. Genève.

OLNEY, Shauna L. (1996) Unions in a Changing World. Problems and Prospects in Selected Industrialized Countries. Genève, OIT

OXLEY, H., \& MARTIN, J. (1991) "Controlling Government Spending and Deficits; Trends in the 1980s and Prospects for the 1990s", OECD Economic Studies, 17, Autumn, apud FERNER (1994), p. 57.

PANITCH, Leo. (1992) "El Desarrollo del Corporativismo en las Democracias Liberales". In: SCHMITTER, Philippe C. \& LEHMBRUCH, Gehard (eds.). Neocorporativismo I. Más allá del Estado y el Mercado. México, Alianza Editorial.

PANEBIANCO, Angelo. (1992) Modelos de Partidos. Madrid, Alianza Universidad.

PASCHKES, Maria Luiza de Almeida. (1985). A Ditadura Salazarista. São Paulo, Brasiliense.

PEKKARINEN, Jukka. (1992) "Corporatism and Economic Performance in Sweden, Norway, and Finland". In: PEKKARINEN, Jukka; POHJOLA, Matti \& ROWTHORN, Bob (eds.). Social Corporatism: A Superior Economic System? Oxford, Clarendon Press.
; POHJOLA, Matti, \& ROWTHORN, Bob (eds.). (1992) Social Corporatism: A Superior Economic System? Oxford, Clarendon Press.

PINTO, Mário. (1993) "Frade Union Action and Industrial Relations in Portugal". In: BAGLIONI, G. \& CROUCH, C. (eds.). European Industrial Relations. The Challenge of Flexibility. London, Sage.

PIORE, Michael J. \& SABEL, Charles F. (1984) Second Industrial Revolution Divide. Possibilities for Prosperity. New York, Basic Books.

POHJOLA, Matti. (1992) "Corporatism and Wage Bargaining". In: PEKKARINEN, Jukka; POHJOLA, Matti \& ROWTHORN, Bob (eds.). (1992) Social Corporatism: A Superior Economic System? Oxford, Clarendon Press.

PONTUSSON, Jonas. (1996) "Suécia. Depois da Idade de Ouro". In: ANDERSON, Perry \& CAMILLER, Patrick (orgs.). Um Mapa da Esquerda na Europa Ocidental. Rio de Janeiro, Contraponto.

PRICE, Robert \& BAIN, George Sayer. (1976) "Union Growth Revisited: 19481974 in Perspective", British Journal of Industrial Relations, vol. $14, \mathrm{n}^{\circ} 3$, November.

RAINBIRD, Helen \& VINCENT Catherine. (1996) "Training: a New Agenda on the Bargaining Agenda". In: LEISINK, Parar; VAN LEEMPUT Jim \& VILROKX, Jacques (eds.). The Challenges to Trade Unions in Europe . Edward Elgar Publishing.

RAISIN, John. (1983) "Union Dues and Wage Premiums", Journal of Labor Research, vol. 14, $\mathrm{n}^{\circ} 1$, Winter, apud VOOS, 1983.

REGINI, Marino. (1994) "Introduction: the Past and Future of Social Studies of Labour Movements". In: REGINI, Marino (ed.). The Future of Labour Movements. London, Sage.

.(1985) “The Condition for Political Exchange: How Concertation Emerged and Collapsed in Italy and Great Britain". In: GOLDTHORPE, Alan (ed.). Order and Conflict in Contemporary Capitalism. Oxford, Clarendon Press. 
REHN, Gösta \& VIKLUND, Birger (1994) “Changes in the Swedish Model In: BAGLIONI, Guido \& CROUCH, Colin (eds.). European Industrial Relations. The Challenge of Flexibility. London, Sage.

REICH, Robert B. (1998) "Como Clinton Criou 13 Milhões de Empregos”, O Estado de São Paulo, 2 de fevereiro.

REICH, Robert B. (1994) O Trabalho das Nações, 2, ed, São Paulo, Educator.

REYNAUD, JeanDaniel. (1975) Les Syndicats en France. Paris, Seuil.

.(1984) 'Trance: La Rigueur des Temps” (mimeogr.).

REYNOLDS, Morgan. (1986) "The Case for Ending the Legal Privileges and Immunities of Trade Unions". In: LIPSET, Seymour Martin (ed.). Unions in Transition. Entering the Second Century. San Francisco, ICS Press.

RIFKIN, Jeremy. (1995) O Fim dos Empregos. São Paulo, Makron Books.

RODRIGUES, Leôncio Martins. (1991) "As tendências Políticas na Formação das Centrais Sindicais”. In: BOITO JR., Armando (org.). O Sindicalismo Brasileiro nos Anos 80. São Paulo, Paz e Terra.

(1992a) "As Transformações da Sociedade Contemporânea e o Futuro do Sindicalismo". In: REIS VELLOSO, João Paulo dos \& RODRIGUES, Leôncio Martins (orgs.). O Futuro do Sindicalismo. São Paulo, Nobel.

.(1992B) "A Crise do Sindicalismo no Primeiro Mundo", Folha de São Paulo, 22 de março.

(1992c) "A Sindicalização da Classe Média", Folha de São Paulo, 24 de maio.

.(1990) CUT. Os Militantes e a Ideologia. São Paulo, Paz e Terra.

(1970) Industrialização e Atitudes Operárias. São Paulo, Brasiliense.

ROGERS, Joel. (1995) "United States: Lessons from Abroad". In: ROGERS, Joel, \& STREECK, Wolfgang (eds.). Works Councils. Consultation, Representation and Cooperation in Industrial Relations. Chicago, The University of Chicago Press.
(1995) "The Study of Works Councils: Concepts and Problems". In:-\&-.(eds.). Works Councils. Consultation, Representation and Cooperation in Industrial Relations. Chicago, The University of Chicago Press.

ROSANVALLON, Pierre. (1988) La Question syndicale. Paris, Hachette.

ROSE, Joseph B. \& CHAISON, Gary. (1996) "Linking Union Density and Union Effectiveness: The North American Experience", Industrial Relations, vol. $35, \mathrm{n}^{\circ} 1$, January.

ROWTHORN, Bob. (1992) "Corporatism and Labour Market Performance". In: PEKKARINEN, Jukka; POHJOLA, Matti, \& ROWTHORN, Bob. Social Corporatism: A Superior Economic System? Oxford, Clarendon Press.

RUBERY, Jill \& FAGAN, Colette. (1994) "Does Feminization Mean a Flexible Labour Force?". In: HYMAN, Richard \& FERNER, Anthony (eds.). New Frontiers in European Industrial Relations. London, Blackwell.

RUYSSEVELDT, Joris van \& VISSER, Jelle. (1996) "Contestation and State Intervention Forever? Industrial Relations in France". In: RUYSSEVELDT Joris van \& VISSER, Jelle (eds.). Industrial Relations in Europe. Tradition and Transitions. London, Sage.

SARFATI, Hedva \& KOBRIN, Catherine. (1987) La Flexibilité du marché de l'emploi: un enjeu économique et social. Genève, OIT

SCHEUER, Steen. (1993) "Denmark: Return to Decentralization". In: FERNER, Anthony \& HYMAN, Richard (eds.). Industrial Relations in the New Europe. Oxford, Blackwell.

SCHMIDT, Manfred G. (1995) Estudo Comparativo da Taxa de Participação Ocupacional de Homens e Mulheres nos Países Industrializados. São Paulo, ILDESFES.

SCHMITTER, Philippe. (1992) "Modos de Intermediación de Intereses y Modelos de Cambio Social en Europa Occidental". In: SCHMITTER, Philippe C. \& LEHMBRUCH, Gerhard (eds.). Neocorporativismo I. Más allá del Estado y el Mercado. México, Alianza Editorial. 
(1974) "Still the Century of Corporatism?" In: SPIKE, Frederick B. \& STRITCH, Thomas (eds.). The New Corporatism. Notre Dame, University of Notre Dame Press.

SEGRESTIN, Denis. (1992) "Recent Changes in France". In: BAGLIONI, Guido \& CROUCH, Colin (eds.). European Industrial Relations. The Challenge of Flexibility. London, Sage.

SHALEV, Michael. (1994) "The Resurgence of Labour Quiescence". In: REGINI, Marino(eds.). The Future of Labour Movements. London, Sage.

SIVESIND, Karl; KALLEBERG, Ragnvald; HOVDE, Svein \& FENNEFOSS, Arvid. (1995) "Social-Democratic Order Under Pressure: Norwegian Employment Relations in the Eighties". In: LOCKE, Richard; KOCHAN, Thomas \& PIORE, Michael (eds.). Employment Relations in a Changing World Economy. Cambridge, The MIT Press.

STOLEROFF, Alan \& NAUMANN, Reinhard. (1996) "Unions and the Restructuring of the Public Sector in Portugal". In: LEISINK, Peter; VAN LEEMPUT, Jim \& VILROKX, Jacques (eds.). The Challenges to Trade Unions in Europe. Edward Elgar Publishing.

STRAUSS, George. (1995) "Is the New Deal System Collapsing? With What Might It Be Replaced?", Industrial Relations, vol. 32, $\mathrm{n}^{\circ} 3$, July.

STREECK, Wolfgang. (1994) "Training and the New Industrial Relations: a Strategic Role for Unions?". In: REGINI, Marino (eds.). The Future of Labour Movements. London, Sage.

(1994) "NeoCorporatist Industrial Relations and the Economic Crisis in Western Germany". In: GOLDTHORPE, John H. (ed.). Order and Conflict in Contemporary Capitalism. Oxford. Oxford University Press.

SWEENEY, Kate \& DAVIES, Jackies. (1996) "International Comparisons of Labour Disputes in 1994", Labour Market Trends, April.

SWENSON, Peter. (1991) "Bringing Capital Back in, or Social Democracy Reconsidered: Employer Power, Cross-Class Alliances, and
Centralization of Industrial Relations in Denmark and Sweden", World Politics, vol. 43, $\mathrm{n}^{\circ}$ 4, July.

TARANTELLI, E. (1986) "The Regulation of Inflation and Unemployment", Industrial Relations, vol. 25, apud POHJOLA, 1992.

TCHOBANIAN, Robert. (1955) "France: From Conflict to Social Dialogue?". In: ROGERS, Joel, \& STREECK, Wolfgang (eds.). Works Councils. Consultation, Representation and Cooperation in Industrial Relations. Chicago, The University of Chicago Press.

THUROW, Lester C. (1997) O Futuro do Capitalismo. Rio de Janeiro, Rocco.

TOURAINE, Alain; DUBET François; LAPEYRONNIE, Didier; KHOSROKHAVAR, Farhad, \& WIEVIORKA, Michel. (1996) Le Grand Refus. Réflexions sur la gréve de décembre de 1995. Paris, Fayard.

TOWERS, B. (1989) "Running the Gauntlet: British Trade Unions Under Thatcher, 1979-1988", Industrial and Labor Relations Review, vol. 42, apud VISSER (1994b).

TROY, Leo. (1996) "Has Public Sector Labor Topped Out?", Government Union Review, vol. $17, \mathrm{n}^{\circ} 2$.

.(1994) The New Unionism in the New Society. Public Sector Unions in the Redistributive Mate. Faixfax, George Mason University Press.

(1990) "Is the U.S. Unique in the Decline of Private Sector Unionism?", Journal of Labor Research, vol. 11, n 2.

.(1986) "The Rise and Fall of American Trade Unions: the Labor Movement from FDR to RR". In: LIPSET, Seymour Martin (ed.). Unions in Transition. Entering the Second Century. San Francisco, ICS Press.

TURNBULL, Peter. (1992) "Dock Strikes and the Demise of the Dockers' 'Occupational Culture'”, The Sociological Review, vol., 40, n 2, May. 
MORRIS, Julia, \& SAPSFORD. (1996) "Persistent Militants and Quiescent Comrades: Intra-Industry Activity on the Docks", The Sociological Review, vol. 44, n 4 , November.

TUSELL, Javier. (1988) La Ditadura de Franco. lii Parte: "El Franquismo y Ias Ditaduras Contemporáneas". Madrid, Alianza Editorial.

UNTERWEGER, P (1988) "Lean Production: Myth and Reality". Documento preparado para uma conferência organizada pelo Instituto Internacional de Estudos do Trabalho, OIT, Genève, Spring de 1988, apud Situación Reciente en las Indústrias Mecánicas, p. 113.

VILROKX, Jacques, \& LEEMPUT, Jim Van. (1993) "Belgium: A New Stability in Industrial Relations?" In: FERNER, Anthony \& HYMAN, Richard (eds.). Industrial Relations in the New Europe. Oxford, Blackwell.

VISSER, Jelle. (1996a) "Traditions and Transitions in Industrial Relations: a European View”. In: RUYSSEVELDT; Joris Van \& VISSER, Jelle (eds.). Industrial Relations in Europe. Tradition and Transitions. London, Sage.

(1996b) "Corporatism Beyond Repair? Industrial Relations in Sweden". In: RUYSSEVELDT, Joris Van \& VISSER, Jelle (eds.). Industrial Relations in Europe. Tradition and Transitions. London, Sage.

(1996c) "A Truly Mixed Case: Industrial Relations In: RUYSSEVELDT, Joris Van \& VISSER, Jelle (eds.). Industrial Relations in Europe. Tradition and Transitions. London, Sage.

\& VAN RUYSSEVELDT, Joris. (1996a) "From Pluralism to... Where? Industrial Relations in Great Britain". In: VAN RUYSSEVEIDT Joris \& VISSER, Jelle (eds.). Industrial Relations in Europe. Traditions and Transitions. London, Sage.

\& ___ (1996b) "Robust Corporatism, Still? Industrial Relations in Germany". In: VAN RUYSSEVELDT Joris \& VISSER, Jelle (eds.). Industrial Relations in Europe. Traditions and Transitions. London, Sage.
\& WADDINGTON, Jeremy. (1996) "Industrialization and Politics: a Century of Union Structural Developments in Three European Countries", European Journal of Industrial Relations, vol. 2, $\mathrm{n}^{\circ} 1$, March

.(1994a) "The Strenght of Union Movements in Advanced Capitalist Democracies: Social and Organizational Variations". In: REGINI, Marino (eds.). The Future of Labour Movements. London, Sage.

.(1994b) "European Trade Unions: the Transitions Years". In: HYMAN, Richard \& FERNER, Anthony (eds.). New Frontiers in European Industrial Relations. Oxford, Blackwell.

.(1993a) "The Netherlands: The End of an Era and the End of a System". In: FERNER, Anthony \& HYMAN, Richard (eds.). Industrial Relations in the New Europe. Oxford, Blackwell.

.(1993b) "Union Organisation. Why Countries Differ", The International journal of Comparative Labour Law and Industrial Relations, Autumn.

.(1992) "Continuity and Change in Dutch Industrial Relations". In: BAGLIONI, G. \& CROUCH, C. (eds.). European Industrial Relations. London, Sage.

.(1991) “Trends in Trade Unions Membership", Employment Outlook, Genève, OECD.

.(1989) "Les Syndicats européens: la grande mutation”, Problèmes Économiques, juillet.

.(1988) "Trade Unionism in Western Europe: Present Situation and Prospects", Labor and Society, vol. 13, n², April.

VOOS, Paula. (1984a) "Trends in Union Organizing Expenditures, 19531977”, Industrial and Labor Relations Review, vol. 38, ${ }^{\circ} 1$, October.

.(1984b) "Does it Pay to Organize? Estimating the Cost to Unions", Monthly Labor Review, vol. 107, ${ }^{\circ}$ 6, June.

.(1983) "Union Organizing: Costs and Benefits", Industrial and Labor Relations Review, vol. 36, $\mathrm{n}^{\circ} 4$, July. 
(1982) Labor Union Organizing Programs 19541977. Tese de doutorado, Harvard University, May de 1982, apud FREEMAN \& MEDOFF (1987).

WADDINGTON, Jeremy. (1998) "Les Syndicats au Royame-Uni face ao néo-libéralisme”. Sociologia du Travail vol. 40, n², Février.

\& WHITSTON, Colin. (1995) "Trade Unions: Growth, Structure and Policy". In: EDWARDS, Paul (eds.). Industrial Relations. Theory \& Practice in Britain. Oxford, Blackwell.

$\&$ (1994) Employment Gazette, June.

WALKER, Charles, \& GUEST Robert H. (1952) The Man on the Assembly Line. Cambridge, Harvard University Press.

WALLERSTEIN, Michael. (1989) "Union Organization in Advanced Industrial Democracies", American Political Science Review, vol. 83, $\mathrm{n}^{\circ} 2$, June.

.(1985) Working Class Solitarily and Rational Behavior. Chicago (tese de doutoramento apresentada no Departamento de Ciência Política da Universidade de Chicago).

WARD, Terry. (1988) "From Mounting Tension to Open Confrontation: The Case of the UK". In: BOYER, Charles (eds). The Search for Labour Markel Flexibility. The European Economies in Transition. Oxford, Clarendon Press.

WESTERN, Bruce. (1994) "Institutional Mechanisms for Unionization in Sixteen OECD Countries: An Analysis of Social Survey Data", Social Forces, vol. 7, $\mathrm{n}^{\circ}$ 2, December.

WIARDA, HOWARD J. (1974) "Corporatism and Development in the Iberic-Latin World: Persistent Strains and New Variations". In: PIKE, Frederick \& STRITCH, Thomas (eds.). The New Corporatism. University of Notre Dame.

WILSON, Graham. (1992) "Por que no Hay Corporativismo en Estados Unidos?”. In: SCHMITTER, Philippe C.; STREECK, Wolfgang \& LEHMBRUCH, Gerhard (eds.). Neocorporativismo II. México, Alianza Editorial.
WRENCH, John \& VIRDEE, Satnam. (1996) "Organising the Unorganised. 'Race', Poor Work and Trade Unions”. In: ACKERS, Peter; SMITH, Chris \& SMITH, Paul (eds.). The New Work Place and Trade Unionism. London, Routledge.

WRIGHT, V. (1994) The Government and Politics in France. London, Routledge, apud RUYSSEVELDT \& VISSER (1996b). 